\title{
A Study of Royal Female Power and Political Influence in Ancient Egypt: Contextualizing Queenship in the Twelfth Dynasty
}

\author{
Hill, Brandi D.
}

How to cite:

Hill, Brandi D. (2019) A Study of Royal Female Power and Political Influence in Ancient Egypt: Contextualizing Queenship in the Twelfth Dynasty. Doctoral thesis, Swansea University.

http://cronfa.swan.ac.uk/Record/cronfa51920

Use policy:

This item is brought to you by Swansea University. Any person downloading material is agreeing to abide by the terms of the repository licence: copies of full text items may be used or reproduced in any format or medium, without prior permission for personal research or study, educational or non-commercial purposes only. The copyright for any work remains with the original author unless otherwise specified. The full-text must not be sold in any format or medium without the formal permission of the copyright holder. Permission for multiple reproductions should be obtained from the original author.

Authors are personally responsible for adhering to copyright and publisher restrictions when uploading content to the repository.

Please link to the metadata record in the Swansea University repository, Cronfa (link given in the citation reference above.)

http://www.swansea.ac.uk/library/researchsupport/ris-support/ 
A Study of Royal Female Power and Political Influence in Ancient Egypt:

Contextualizing Queenship in the Twelfth Dynasty

Volume 1 of 2

Brandi Denise Hill

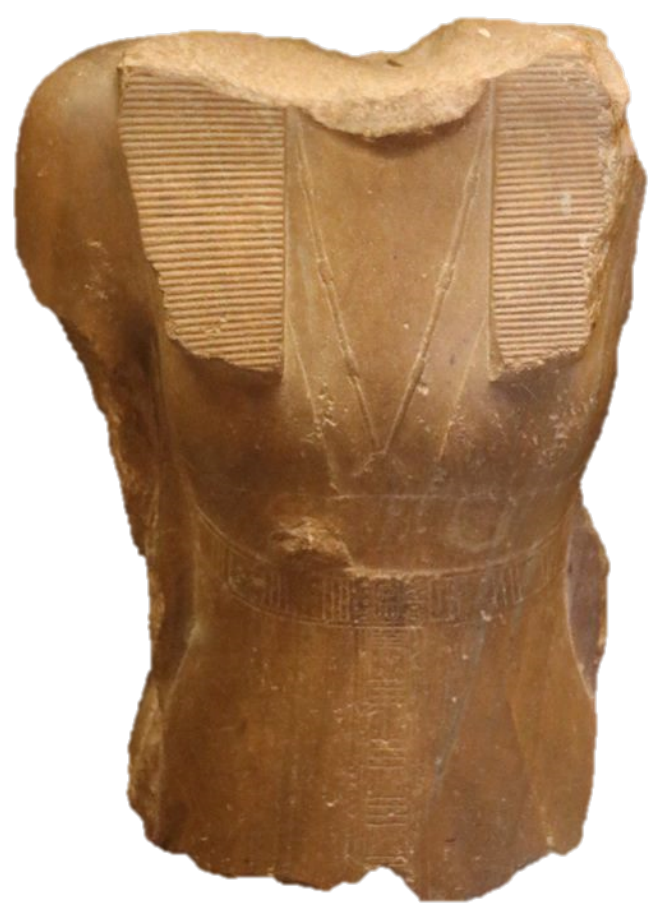

Submitted to Swansea University in fulfillment of the requirements for the

Degree of Doctor of Philosophy

Swansea University

2019 


\section{Summary}

Hill, Brandi Denise. A Study of Royal Female Power and Political Influence in Ancient Egypt: Contextualizing Queenship in the Twelfth Dynasty

The Twelfth Dynasty was a time for iconographic expression, new architectural designs, and titular expansion. During the dynasty, royal women began sharing iconographic attributes with ruling monarchs and for the first time the uraeus and sphinx pose became standardized for royal women. Women in the queenship position were buried similar to the pharaonic style and used cenotaph type burials. Princess Neferuptah became the first royal woman to have her name encircled within a cartouche and Sobekneferu was the first female ruler of Egypt to have full pharaonic titulary.

This thesis explores the political power of Twelfth Dynasty royal women by aiming to redefine queenship to better understand the ancient Egyptian concept, analyze the iconography, as well as clarify the tenure and reign of Princess Neferuptah and Sobekneferu. The iconographic study discusses specific attributes that include the poses, the severity of their facial characteristics, surviving uraei, wig type, headgear worn, style of ears, cosmetic or natural eyes, dress, jewelry, and if represented independently or paired. Using an art historical analysis this study interprets the surviving representations of Twelfth Dynasty royal women as elevations of their royal statuses in governmental positions. It also compares their iconography to royal women of other time periods, such as the Old Kingdom through the beginning of the Eighteenth Dynasty, and with male monarchs of the Twelfth Dynasty. This project formulates ideas on the events of the late Twelfth Dynasty by describing the power exhibited by the royal women Neferuptah and Sobekneferu. It examines Neferuptah and Sobekneferu in an art historical and archaeological context by their art works, (possible) burial complexes, building projects, titled burial goods, and representations with Amenemhat III. This study includes a complete familial lineage with artifacts and the first catalogue of surviving representations of all known Twelfth Dynasty royal women. 
Copyright (C Brandi Denise Hill 2019 


\section{DECLARATION}

This work has not previously been accepted in substance for any degree and is not being concurrently submitted in candidature for any degree.

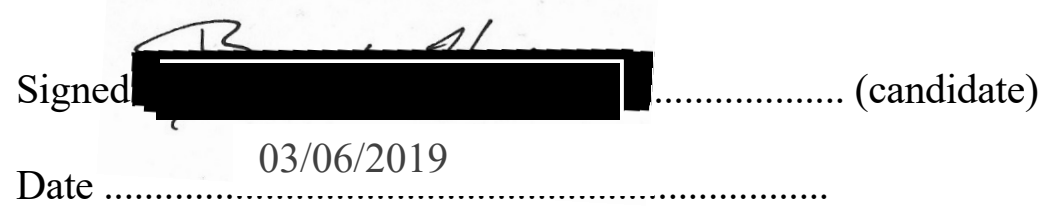

\section{STATEMENT 1}

This thesis is the result of my own investigations, except where otherwise stated.

Other sources are acknowledged by footnotes giving explicit references. A bibliography is appended.

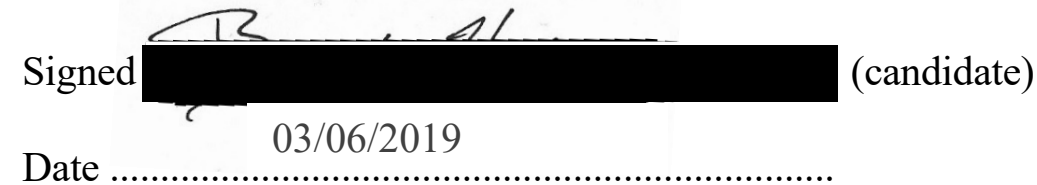

\section{STATEMENT 2}

I hereby give consent for my thesis, if accepted, to be available for photocopying and for inter-library loan, and for the title and summary to be made available to outside organisations.

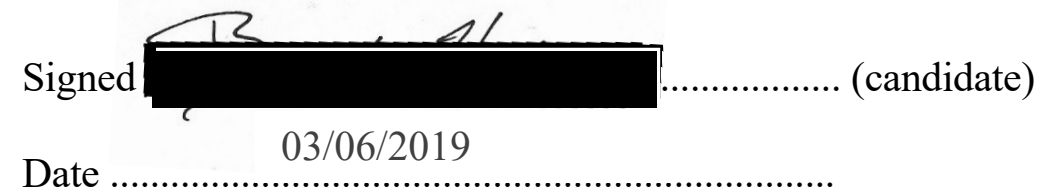

NB: Candidates on whose behalf a bar on access has been approved by the University (see Note 7), should use the following version of Statement 2:

I hereby give consent for my thesis, if accepted, to be available for photocopying and for inter-library loans after expiry of a bar on access approved by the Swansea University.

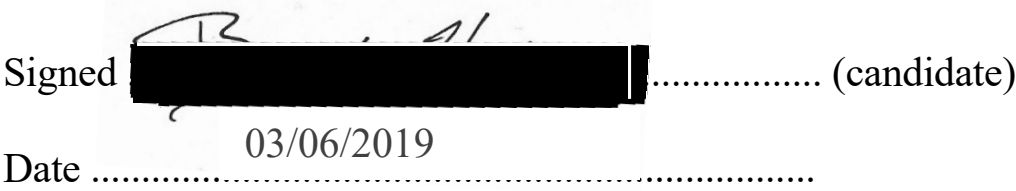




\section{Table of Contents}

\section{Volume 1}

Acknowledgments and Dedication $\quad x i$

List of Figures $\quad$ xii

List of Charts and Tables $\quad$ XxV

Relevant Chronology xxvi

List of Abbreviations $\quad$ xxvii

Chapter 1: Introduction 1

1.1 Introduction 1

1.2 Methodology

1.3 The data 4

1.3.1 Twelfth Dynasty royal women 5

1.3.2 Catalogue of all known representations of Twelfth Dynasty 6

1.4 The criteria of Twelfth Dynasty female representation $\quad 7$

1.5 Context of the Twelfth Dynasty 11

$\begin{array}{lll}1.5 .1 & \text { Iconography } & 11\end{array}$

$\begin{array}{ll}\text { 1.5.2 Locations associated with royalty } & 12\end{array}$

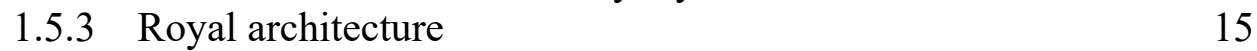

$\begin{array}{lc}1.6 \text { Twelfth Dynasty royal women } & 18\end{array}$

1.7 Contributions made by this thesis 23

$\begin{array}{ll}1.8 \text { Structure of discussion } & 23\end{array}$

Chapter 2: Review of Previous Scholarship 27

2.1 Introduction $\quad 27$

2.2 Gender and political power 27

2.2.1 Gender studies in Archaeology 31

2.2.2 Women in Ancient Egypt 33

2.2.2.1 Women's political role in the Ancient Egyptian government 37

2.3 Publications that consider the political presence of Twelfth Dynasty royal women $\quad 40$

2.4 Overview of evidence $\quad 46$

$\begin{array}{lr}2.5 \text { Titles } & 50 \\ 2.6 \text { Mortuary } & 50 \text { mplexes }\end{array}$

2.6 Mortuary complexes $\quad 52$

2.7 Discussion $\quad 56$

Chapter 3: Framework of Queens, Queenship, and Female Rulership 59

3.1 Introduction $\quad 59$

3.2 Definitions of Queenship ideology and the Queen 61

3.3 Gender and Power 64

3.3.1 Women in ancient Egyptian Twelfth Dynasty 66

3.4 An etymological approach to the term 'Female Horus' 69

3.5 Female Monarchs and royal women exercising political power $\quad 72$

$\begin{array}{ll}3.5 .1 \text { Meretneith } & 73\end{array}$

$\begin{array}{ll}\text { 3.5.2 Khentkaus I and II } & 77\end{array}$

3.5.3 Neithikrety/Nitocris $\quad 80$ 
3.5.4 Ahhotep $\quad 81$

3.5.5 Hatshepsut $\quad 85$

3.5.5.1 Hatshepsut's connection with the Middle Kingdom and Sobekneferu $\quad 88$

3.5.6 Nefertiti, Meritaten, and Neferneferuaten 91

3.5.6.1 Ankhesenamun's letter to Šuppiluliumaš I, the Hittite king

3.5.7 Tausret

96

3.7 Discussions

98

103

\section{Chapter 4: Iconographic Representations of Twelfth Dynasty}

\section{Royal Women}

4.1 Introduction 105

$\begin{array}{lr}4.2 \text { Poses } & 112\end{array}$

\begin{tabular}{ll} 
4.2.1 Standing & 112 \\
\hline & 115
\end{tabular}

$\begin{array}{ll}\text { 4.2.2 Seated } & 115\end{array}$

4.2.3 The sphinx pose $\quad 117$

4.2.4 The human-headed bird $\quad 119$

$\begin{array}{ll}\text { 4.3 Severe Facial Characteristics } & 121\end{array}$

4.3.1 Round and pentagon faces with shape cheekbones and nasolabial folds 122

4.3.2 Heavy eyelids, eyebrows, and supraorbital ridges 124

4.3.3 Hybrid forms $\quad 125$

$\begin{array}{lr}\text { 4.4 Surviving Uraei } & 126\end{array}$

$\begin{array}{ll}\text { 4.4.1 Uraei designs } & 127\end{array}$

$\begin{array}{ll}\text { 4.4.2 Tail curves } & 128\end{array}$

$\begin{array}{lr}4.5 \text { Wig Type } & 129\end{array}$

4.5.1 Tripartite 129

4.5.2 The Hathoric style 129

$\begin{array}{ll}4.5 .3 \text { Rounded style } & 130\end{array}$

4.5.4 Blunt style $\quad 131$

4.6 Headgear 131

4.6.1 Vulture headdress $\quad 131$

4.6.2 Diadem type crown 133

$\begin{array}{ll}4.7 \text { Ears } & 134\end{array}$

$\begin{array}{lr}4.8 \text { Eyes } & 135\end{array}$

4.9 Dress 135

4.10 Jewelry 136

4.11 The royal beard 137

4.12 Overview of the iconography of Twelfth Dynasty royal men $\quad 140$

4.12.1 Amenemhat I, Senwosret I, Amenemhat II, and Senwosret II 141

4.12.2 Senwosret III, Amenemhat III, and Amenemhat IV 149

4.13 The iconography of Twelfth Dynasty royal women compared to

royal women of the Old Kingdom, Middle Kingdom, and early New

$\begin{array}{ll}\text { Kingdom } & 158\end{array}$

4.13.1 Old Kingdom through the Eleventh Dynasty 158

4.13.2 Thirteenth Dynasty through the Eighteenth Dynasty ending
with Hatshepsut

$\begin{array}{ll}\text { 4.14 Discussions } & 167\end{array}$ 
$\begin{array}{lr}\text { Chapter 5: Neferuptah } & 173\end{array}$

5.1 Introduction 173

5.2 Relief from the Temple of Medinet Madi (Cat. 55) 174

$\begin{array}{ll}5.3 \text { Feet from a seated statue (Cat. 13) } & 179\end{array}$

$\begin{array}{ll}\text { 5.4 Sphinx (Cat. 69) } & 183\end{array}$

$\begin{array}{lr}5.5 \text { Block of granite } & 186\end{array}$

$\begin{array}{ll}\text { 5.6 Papyrus sheet } & 187\end{array}$

5.7 Amenemhat III in a Sed-festival cloak, flanked by two royal women

(Cat. 29) 190

5.8 Neferuptah's double burial 193

5.8.1 Burial equipment from the pyramid of Amenemhat III 196

5.8.2 Burial equipment from the pyramid of Neferuptah 199

$\begin{array}{ll}5.9 \text { Neferuptah's political tenure and familial connections } & 208\end{array}$

$\begin{array}{ll}5.10 \text { Discussions } & 214\end{array}$

$\begin{array}{lr}\text { Chapter 6: Sobekneferu } & 219\end{array}$

$\begin{array}{ll}6.1 \text { Introduction } & 219\end{array}$

6.2 Torso of Sobekneferu Musée du Louvre E27135 (Cat. 58) 221

6.3 Statues from Tell el-Dab'a (Cat. 59, 60, 61, 62) 223

6.4 Inscriptions from Amenemhat III's mortuary complex and Labyrinth at Hawara

6.5 Surviving architraves from Herakleopolis Magna (Ihnasya el Madina and the Temple of Kom el-Aqarib) 235

6.6 Karnak and Saqqara king lists, the Turin Canon, and Manetho 236

6.7 Glazed blue cylinder seal BM 16581 and cylinder seal Cairo JE $72663 \quad 240$

6.8 Papyrus from Harageh 243

6.9 Bead with an inscription for Sobekneferu 245

6.10 Green pottery scarab and an ivory-colored scarab BM C66159 246

6.11 Nile level reading at the Second Cataract from Kumma, Nubia 247

6.12 Statue base inscribed for Amenemhat III and Sobekneferu (Cat. 57) 249

$\begin{array}{ll}\text { 6.13 Stela inscribed with Sobekneferu's name } & 249\end{array}$

6.14 Possible statue found at Gezer (Cat. 14) 251

6.15 Possible statuette of a late Middle Kingdom queen (Cat. 10) 253

6.16 Possible head of a sphinx (Cat. 67) 258

6.17 Possible shrines depicting two pharaohs 262

6.18 A seated statue joined from two parts - Berlin and Boston (Cat. 62) 267

6.19 Sobekneferu's sole reign and familial connections 273

$\begin{array}{ll}6.20 \text { Discussions } & 282\end{array}$

Chapter 7: Discussions and Conclusions 285

$\begin{array}{ll}\text { 7.1 Redefining female rulership } & 286\end{array}$

7.2 The political image of royal women in the Twelfth Dynasty: summaries $\begin{array}{ll}\text { and findings from the catalogue } & 288\end{array}$

$\begin{array}{ll}\text { 7.3 Tenure and possible reign of Neferuptah } & 293\end{array}$

7.4 Clarification of the sole reign of Sobekneferu 294

$\begin{array}{ll}7.5 \text { Impact of research } & 296\end{array}$

$\begin{array}{ll}7.6 \text { Future research } & 297\end{array}$

$\begin{array}{ll}\text { Bibliography } & 299\end{array}$ 


\section{Volume 2}

Appendix 1 List of Twelfth Dynasty locations associated with royalty Appendix 2 Genealogy and list of Twelfth Dynasty royal women with associated artifacts

Catalogue of surviving representations for Twelfth Dynasty royal women 


\section{Acknowledgements and Dedication}

I would like to thank my Ph.D. supervisor Dr. Kasia Szpakowska for whom I am forever indebted to for her guidance and support. I also wish to thank my former supervisors Dr. Martina Minas-Nerpel and Dr. Kenneth Griffin for their assistance and valuable feedback.

I would like to thank the Egyptian Exploration Society for their professional and financial support by being a part of their first Familiarization tour. An extended thank you to the Egypt Centre, the Gwent Glamorgan Archeological Trust, the British Federation of Women Graduates, and the Women Graduates Swansea University Society.

I also express my gratitude for the support and time of my fellow postgraduate students at Swansea University and beyond. I would like to thank Izold Gwegan, Amber Furmage, Andee Middleton, and Amr Shahat for their expertise and knowledge. During my Ph.D. journey I have made many lifelong friendships and am excited to see how we change the future together.

I am especially grateful to Rio Althagafy who has been my strength throughout the Ph.D. process. I sincerely thank my parents along with all of my family and friends for their patience, encouragement, and for believing in me all these years. A special thank you to Tomica Melton who welcomed me into her home and I hope one day James, Emmett, and Corey find this inspiring. May you always find your true selves in this life and remember to never give up on your dreams.

This work is dedicated to Maggie Hill who taught me that my best is good enough.

"Nevertheless, she persisted"1

\footnotetext{
${ }^{1}$ Senator Mitch McConnell about Senator Elizabeth Warren, 07 February 2017.
} 


\section{List of Figures}

Front cover of Volume 1, Torso of Sobekneferu Musée du Louvre, Paris E27135 (C) Brandi Hill 2015.

Front cover of Volume 2, A royal woman Metropolitan Museum of Art, New York MMA 08.202.7 (C) Brandi Hill 2015.

Fig. 1.1 Weavers from the tomb of Khnumhotep, Metropolitan Museum of Art, New York MMA 33.8.16 (C) The Metropolitan Museum of Art.

Fig. 1.2 Face of a Twelfth Dynasty royal woman (C Christie's Sale Catalogue, September 23, 1998.

Fig. 1.3 Face of Senwosret III, Metropolitan Museum of Art, New York MMA 26.7.1394 (C) The Metropolitan Museum of Art.

Fig. 1.4 Map of Lower Egypt, Upper Egypt, and Lower Nubia (C) Bourriau 1988: 167.

Fig. 3.1 Drawing of column fragment for Sobekneferu (C) Habachi 1954: pl. XVb.

Fig. 3.2 Original Abydos seal of Meretneith's time by Kaiser (C) Callender 2011a: 31.

Fig. 3.3 Altered Abydos seal from Den's time by Dreyer (C) Callender 2011a: 32.

Fig. 3.4 Stela of Meretneith (C) Petrie 1900: Front piece.

Fig. 3.5 Seal of $t p i-t-w$ (C) Petrie 1900: pl. XXI 22/23.

Fig. 3.6 Seal of $h r-t p i-h \underline{t}$ (C) Petrie 1900: pl. XXI 22/23.

Fig. 3.7 Photograph of Khentkaus I on the southern doorjamb of the granite gate (C) Verner 2015: fig 2.

Fig. 3.8 Ruler list from the tomb of Kha'bekhnet (C) Lepsius, Public Domain, Wikipedia Commons.

Fig. 3.9 Gilded coffin inscribed for Ahhotep I (C) Winlock 1924: pl. XVI.

Fig. 3.10 Wooden coffin inscribed for Ahhotep I C Daressy 1909: pl. IX.

Fig. 3.11 Stela of Ahmose from Karnak (C) Lacau 1926: pl. 1.

Fig. 3.12 Comparison of Sobekneferu and Hatshepsut in the kneeling pose, (C) Habachi 2001: Cat. 9; Large kneeling statue of Hatshepsut, Metropolitan Museum of Art, New York MMA 29.3.1 (C) The Metropolitan Museum of Art.

Fig. 3.13 Comparison seated states of Sobekneferu and Hatshepsut, (C) Habachi 2001: Cat. 11; The Female Pharaoh Hatshepsut, Metropolitan Museum of Art, New York 29.3.3 (C) The Metropolitan Museum of Art. 
Fig. 3.14 The Royal Family. Ägyptisches Museum und Papyrussammlung, Berlin ÄM 14145 C Seyfried 2012: Fig. 2.

Fig. 3.15 Bust of Queen Nefertiti, Ägyptisches Museum und Papyrussammlung, Berlin ÄM 21300 (C) Ägyptisches Museum und Papyrussammlung.

Fig. 3.16 River scene with royal barges and tow boats, The Museum of Fine Arts Boston 63.260 (C) The Museum of Fine Arts, Boston.

Fig. 3.17 Nefertiti and the royal family driving chariots, (C) author's photograph 2016.

Fig. 3.18 Votive stela with two monarchs, Ägyptisches Museum und Papyrussammlung, Berlin ÄM 17813 C Ägyptisches Museum und Papyrussammlung.

Fig. 3.19 Princess Fresco, The Ashmoleon Museum Oxford AN1893.1-41.267 (C) The Ashmoleon Museum Oxford.

Fig. 3.20 Headless seated statue of Tausret (C) Bassir 2013: 74.

Fig. 3.21 Headless seated statue of Tausret (C) Bassir 2013: 72.

Fig. 3.22 Possible ostrakon of Tausret, Egyptian Museum, Cairo CG 25125 C Wildung 1984b: 181.

Fig. 4.1 Statue of Senwosret I, The British Museum, London BM EA 44 (C) The British Museum.

Fig 4.2 Statue of Senwosret III, The British Museum, London BM EA 686 C) The British Museum.

Fig. 4.3 Standing statue of Amenemhat III, Egyptian Museum, Cairo JE 37400 (C) The Global Egyptian Museum Online.

Fig. 4.4 Female figure with basket of loaves and meat on head, The British Museum, London BM EA 30716 (C) The British Museum.

Fig. 4.5 Statue of nurse Sitsneferu, The Metropolitan Museum of Art, New York MMA I18.2.2 (C) The Metropolitan Museum of Art.

Fig. 4.6 Female member of Djedefre's family, Musée du Louvre, Paris E12627 (C) Fay 1998: 125.

Fig. 4.7 Senwosret III with Khenemetneferhejet I and Khenemetneferhejet II, The British Museum, London BM EA 1069 (C) The British Museum.

Fig. 4.8 Senwosret III with Khenemetneferhejet I and Khenemetneferhejet II, The British Museum, London BM EA 1145 (C) The British Museum. 
Fig. 4.9 Seated statue of Queen Khenemetneferhedjet I, Musée du Louvre, Paris E32564 (C) Musée du Louvre.

Fig. 4.10 Seated statue of Nofret, The Egyptian Museum, Cairo CG 381 (JE 37487) (C) author's photograph 2016.

Fig. 4.11 Female human-headed bird, The Grand Egyptian Museum, Cairo 14506 C The Grand Egyptian Museum.

Fig. 4.12 Common round face shape, author's labelling, Statuette of a late Middle Kingdom queen (Cat. 10) The Metropolitan Museum of Art, New York MMA 65.59.1 (c) The Metropolitan Museum of Art.

Fig. 4.13 Pentagonal shaped face, author's labelling, bust statue of a queen (Cat. 1) Staatliche Museen Berlin ÄM 14475 C Staatliche Museen zu Berlin.

Fig. 4.14 Nasolabial fold, author's labelling, bust of a queen (Cat. 4) The Egyptian Museum, Cairo JE 39741 (C) The Egyptian Museum.

Fig. 4.15 Supraorbital ridge, author's labelling, bust statue of a queen (Cat. 1) Staatliche Museen ÄM 14475 C Fechheimer 1923: 57.

Fig. 4.16 Fragment of a magic knife inscribed for Menkaura's mother Khamerernebty I, Museum of Fine Arts, Boston MFA 11.766 (C) The Museum of Fine Arts, Boston.

Fig. 4.17 Seven tail curves, author's labelling, head of a female sphinx (Cat. 64) Museum of Fine Arts, Boston MFA 2002.609 (C) The Museum of Fine Arts, Boston.

Fig. 4.18 Two-Feather diadems from the rock tomb of Ukhhotep (C) Blackman, Litt, and Apted 1953: plate X.

Fig. 4.19 Parts of the ear, author's labelling, head of a female sphinx (Cat. 64) The Museum of Fine Arts, Boston MFA 2002.609 (C) The Museum of Fine Arts, Boston.

Fig. 4.20, Relief of Queen Hetepi and Amenemhat IV from Medinet Madi (C) Bresciani and Giammarusti 2012: 74.

Fig. 4.21 Relief of Queen Hetepi and Amenemhat IV from Medinet Madi (C) Bresciani and Giammarusti 2012: 85.

Fig. 4.22 Drawing of Queen Hetepi and Amenemhat IV (C) Amber Furmage 2016.

Fig. 4.23 Close up of original relief for Queen Hetepi from Medinet Madi (C) Bresciani, and Giammarusti 2012: 85.

Fig. 4.24 Seated statue of Amenemhat I, The Egyptian Museum, Cairo 60520 C Arnold 1991: 31. 
Fig. 4.25 Head of a statue of an early Middle Kingdom king attributed to Mentuhotep III, Antikenmuseum Basel und Sammlung Ludwig BSAe III 8397 (C) The Metropolitan Museum of Art 2015.

Fig. 4.26 Royal head, The Garstang Museum of Archaeology at the University of Liverpool E.2811.

Fig. 4.27 Senwosret I Fayum school, The Egyptian Museum, Cairo CG 411 C Lorand 2012: pl. 10.1

Fig. 4.28 Senwosret I Delta school, The Egyptian Museum, Cairo CG 38230 C Lorand 2012: pl. 11.1.

Fig. 4.29 Kneeling statue of Senwosret I Memphite school, Staatliche Museen zu Berlin, Ägyptisches Museum und Papyrussammlung ÄM 1205 (C) The Metropolitan Museum of Art 2015.

Fig. 4.30 Head of a colossal statue of Senwosret I Southern school, Medelhavsmuseet, Stockholm MME 1972:017 (C) The Metropolitan Museum of Art 2015: 73 .

Fig. 4.31Attributed Statuette of Amenemhat II, The Museum of Fine Arts, Boston MFA 29.1332 (C) The Museum of Fine Arts.

Fig. 4.32 Great Sphinx of Tanis, Musée du Louvre, Paris A 23 (C) Musée du Louvre.

Fig. 4.33 Colossal seated statue of Amenemhat II, The Metropolitan Museum of Art, New York MMA L.2011.42 (C) The Metropolitan Museum of Art.

Fig. 4.34 Statue Senwosret II, Ny Carlsberg Glyptotek, Copenhagen AEIN 659 (C) The Ny Carlsberg Glyptotek.

Fig. 4.35 Senwosret as a juvenile, Musée du Louvre, Paris E12960 (C Musée du Louvre.

Fig. 4.36 Head of a colossal statue of Senwosret III, The Nelson-Atkins Museum of Art 62-1 (C) The Nelson-Atkins Museum of Art.

Fig. 4.37 Statue of Senwosret III as a sphinx, The Metropolitan Museum of Art, New York MMA 17.9.2 (C) The Metropolitan Museum of Art.

Fig. 4.38 Bust of Amenemhat III, The Metropolitan Museum of Art, New York MMA 45.2.6 (C) The Metropolitan Museum of Art.

Fig. 4.39 Seated statue of Amenemhat III, The Egyptian Museum, Cairo CG 385 C Wildung 1984a: 206.

Fig. 4.40 Head of Amenemhat III, The Fitzwilliam Museum E.2.1946 (C) The Fitzwilliam Museum. 
Fig. 4.41 Statue of Amenemhat III as a priest, The Egyptian Museum, Cairo JE 20001 C Arnold 2015b: 68.

Fig. 4.42 Dyad statue of Amenemhat III, The Egyptian Museum, Cairo CG 392 (JE 18221) (C) The Metropolitan Museum of Art 2015: 297.

Fig. 4.43 Sphinx of Amenemhat IV, The British Museum, London BM EA 58892 (C) The British Museum.

Fig. 4.44 Head of a king, possibly Amenemhat IV, The Metropolitan Museum of Art, New York MMA 08.200.2 (C) The Metropolitan Museum of Art.

Fig. 4.45 Head of possible queen with vulture crown, Ägyptisches Museum, Universität Leipzig 1965 (C) The Metropolitan Museum of Art 1999: 262.

Fig. 4.46 Drawing of Khentkaus I on southern doorjamb of the gate in her tomb (C) Verner 2001: 174, pl. 85 a,b.

Fig. 4.47 Mother of a king, The Egyptian Museum, Cairo CG 255 (C) Fay 1999: 129.

Fig. 4.48 Drawing of the false door of Princess Nebet, present location unknown (C) Habachi 1983: 208-11.

Fig. 4.49 Stela of Queen Iuhetibu XV and Dedusobek, the parents of a king, The Egyptian Museum, Cairo C Dodson 2004: 113.

Fig. 4.50 Drawing of Princesses Iuhetibu II and Dedetanuq standing before Min, Musée du Louvre, Paris C8 (C) Dodson 2004: 109.

Fig. 4.51 Princess Sobeknakht suckling a prince, The Brooklyn Museum, New York 43.137 (C) The Brooklyn Museum.

Fig. 4.52 Upper part of the seated statue of a queen, The Metropolitan Museum of Art, New York MMA 16.10.244 (C) The Metropolitan Museum of Art.

Fig. 4.53 Statue fragment of Hatshepsut, The Museum of Fine Arts, Boston MFA 52.347 (C) The Museum of Fine Arts, Boston.

Fig. 5.1 Reconstruction of the relief of Princess Neferuptah (Cat. 55) (C) Bresciani and Giammarust 2012: 86.

Fig. 5.2 Princess Neferuptah (C) Brandi Hill 2016.

Fig. 5.3 Reconstructions of Princess Neferuptah, Front cover (C) Sidky 1971.

Fig. 5.4 Reconstructions of Princess Neferuptah (C) Bresciani and Giammarust 2012: 86.

Fig. 5.5 Unknown royal woman, The Egyptian Museum, Cairo JE 39741 (C) The Egyptian Museum Cairo. 
Fig. 5.6 Unknown royal woman left side, The Egyptian Museum, Cairo JE 3974 C The Egyptian Museum Cairo.

Fig. 5.7 Seated statue of Amenemhat III, The Egyptian Museum, Cairo 385 C Oppenheim, Arnold, Arnold, Yamamoto 2015: Fig. 27.

Fig. 5.8 Headless sphinx, Kunsthistorisches Museum, Vienna AS 5753 (C) Fay, B. 1996.

Fig. 5.9 Headless sphinx, Kunsthistorisches Museum, Vienna AS 5753 C) Fay, B. 1996.

Fig. 5.10 Papyrus: The Petrie Museum, London UC32212 (C) Collier and Quirke 2002: 138, 140.

Fig. 5.11 Imperfect sheet of Papyrus: The Petrie Museum, London UC32212 (C) The Petrie Museum.

Fig. 5.12 Amenemhat III in a Sed-festival cloak flanked by two women, The Egyptian Museum, Cairo JE 43104 (c) Stünkel 2015: 95.

Fig. 5.13 The two sarcophagi in the burial chamber of Amenemhat III (C) Petrie: 1890: 17 .

Fig. 5.14 The cenotaphs of queens Hedjet I and Hedjet II and burial of Queen Hedjet II, illustrations by author (C) Arnold 2002: Plan 1.

Fig. 5.15 Offering table found in the well chamber (C) Farag and Iskander 1971: VIIIa.

Fig. 5.16 Offering table found in the well chamber along with vase fragments from Hawara (C) Farag and Iskander 1971: pl. VIIIb.

Fig. 5.17 Alabaster offering table with list of offerings (C) Farag and Iskander 1971: 9.

Fig. 5.18 Black granite offering table found in Neferuptah's pyramid (C) Farag and Iskander 1971: pl. VIa.

Fig. 5.19 Black granite offering table found in Neferuptah's pyramid (C) Farag and Iskander 1971: pl. VIb.

Fig. 5.20 Pottery types of Queen Khenemetneferhedjet I (C) Allen 1998: 45.

Fig. 5.21 Queens' ware from the tomb of Queen Khenemetneferhedjet I C Allen 2009: 326 .

Fig. 5.22 Neferuptah's granite sarcophagus, The Egyptian Museum, Cairo (C) Dodson 2004: 98 
Fig. 5.23 Kilt of Senebtisi, The Metropolitan Museum of Art, New York MMA08.200.29 (C) The Metropolitan Museum of Art.

Fig. 5.24 Canopic jar fragment of Hathorhotep (C) De Morgan 1903: 105.

Fig. 5.25 Stone fragments with the name Sobek, probably Sobekneferu (C) Arnold 1992: pl. 71a, 23.

Fig. 5.26 Line drawing of the stone fragment with the name Sobek, probably Sobekneferu (C) Arnold 1992: pl. 71a, 23.

Fig. 5.27 Plan of Amenemhat III's and Princess Neferuptah's pyramids (C) Grajetzki 2014a: 62 .

Fig. 5.28 Prince Ramesses II in front of Seti I at Abydos (C) Dodson 2004: 168.

Fig. 5.29 Prince Khaemwaset in front of Pharaoh Ramesses II, Queen Isetneferet, and Princess Bintanath (C) Dodson 2004: 168.

Fig. 6.1 Torso of Sobekneferu (Cat. 58), Musée du Louvre, Paris E27135 (C) Musée du Louvre.

Fig. 6.2 Map of Sobekneferu's statues found at Tell el-Dab'a, illustration by author (C) Habachi 2001: 154.

Fig. 6.3 Inscription from the headless sphinx of Sobekneferu (Cat. 62) (C) Naville 1885: 21 .

Fig. 6.4 Kneeling statue of Sobekneferu (Cat. 61) (C) Habachi 2001: pl. 13.

Fig. 6.5 Seated statue of Sobekneferu (Cat. 59) (C) Habachi 2001: pl. 15b.

Fig. 6.6 Seated statue of Sobekneferu (Cat. 60) (C) Habachi 2001: pl. 14a.

Fig. 6.7 Column fragment for Sobekneferu, The Egyptian Museum, Cairo C Habachi 1954: pl. XVa.

Fig. 6.8 Drawing of column fragment for Sobekneferu, The Egyptian Museum, Cairo (C) Habachi 1954: pl. XVb.

Fig. 6.9 Plaque with inscriptions of Sobekneferu, Amenemhat III and Dehdehet, The Petrie Museum, London UC 14337 (C) The Petrie Museum.

Fig. 6.10 Surviving blocks from the Kom el-Aqareb Temple at Herakleopolis Magana (C) Perez-Die 2017: 481.

Fig. 6.11 Sobekneferu located on the Karnak ruler list, Musée du Louvre, Paris E 13481 (C) Musée du Louvre. 
Fig. 6.12 Sobekneferu located on the Saqqara ruler list (C) Mariette 1864: 169.

Fig. 6.13 Sobekneferu located on the Turin Canon (C) Museo Egizio di Torino 1874.

Fig. 6.14 Glazed blue cylinder seal, The British Museum, London BM EA 16581 C The British Museum.

Fig. 6.15 Drawing of glazed blue cylinder seal, The British Museum, London BM EA 16581 C The British Museum.

Fig. 6.16 Fragmented papyrus for Sekhem Sobeknferu, The Petrie Museum, London UC32778 (C) The Petrie Museum.

Fig. 6.17 Fragmented papyrus for Sekhem Sobeknferu, The Petrie Museum, London UC32778 (C) The Petrie Museum.

Fig. 6.18 Bead inscription for Sobekneferu (C) Habachi 1954: 463.

Fig. 6.19 Green pottery scarab (C) Callender 1998: 231.

Fig. 6.20 Scarab inscribed for Sobekneferu, The British Museum, London BM EA 66159 (C) The British Museum.

Fig. 6.21 Nile level reading for Sobekneferu located at the Second Cataract from Kumma Nubia (C) Habachi 1954: Pl. XIII C.

Fig. 6.22 Fragment of statue base inscribed for Sobekneferu (Cat. 57) (C) Kaiser 1967: pl. 428.

Fig. 6.23 Thirteenth Dynasty Stela with Sobekneferu's name, (c) Marselles Château Borély 223.

Fig. 6.24 Lower part of Princess Sobekneferu's statue (C) Weinstein 1974: 49.

Fig. 6.25 Drawing of the lower part of Princess Sobekneferu's statue (C) Weinstein 1974: 50 .

Fig. 6.26 Statuette of a late Middle Kingdom Queen (Cat. 10), The Metropolitan Museum of Art, New York MMA 65.59.1 (C) The Metropolitan Museum of Art.

Fig. 6.27 Fragment from the head of Queen's statue, The Metropolitan Museum of Art, New York MMA 2001.585 (C) The Metropolitan Museum of Art.

Fig. 6.28 Fragment from the head of Queen's statue, The Metropolitan Museum of Art, New York MMA 2001.585 C Brandi Hill 2016.

Fig. 6.29 Statuette of a late Middle Kingdom Queen, The Metropolitan Museum of Art, New York MMA 65.59.1 (c) The Metropolitan Museum of Art. 
Fig. 6.30 Fragment from the head of Queen's statue, The Metropolitan Museum of Art, New York MMA 2001.585 (C) The Metropolitan Museum of Art.

Fig. 6.31 Queen Khenemetneferhedjet I's top of the head decoration, Musée du Louvre, Paris E32564 (C) Musée du Louvre.

Fig. 6.32 Head of a sphinx (Cat. 67), Bibliothèque Nationale, Paris 53-607 (C) Bibliothèque Nationale.

Fig. 6.33 Head of a sphinx, right side (Cat. 67), Bibliothèque Nationale, Paris 53-607 (C) Bibliothèque Nationale.

Fig. 6.34 Human-headed bird representing a royal woman (Cat. 38), The Grand Egyptian Museum, Cairo 14506 (C) The Grand Egyptian Museum.

Fig. 6.35 Bust of an unknown royal woman (Cat. 11) (C) Sotheby's sales catalogue December 5, 1987.

Fig. 6.36 Shrine with two pharaohs, The Egyptian Museum, Cairo JE 43289 (C) Bagh 2011: 102-103.

Fig. 6.37 Shrine with two pharaohs, Ny Carlsberg Glyptotek, AEIN 1482 (C) Bagh 2011: 102 .

Fig. 6.38 Comparison of column fragment and Cairo shrine, The Egyptian Museum, Cairo; JE 43289 (c) Bagh 2011: 102.

Fig. 6.39 Bust of a royal woman, Staatliche Museen, Berlin ÄM 14475 C) Fechheimer 1923: 57.

Fig. 6.40 Lower body fragment of a female statue seated on a throne, The Museum of Fine Arts, Boston MFA 24.742 (C) Museum of Fine Arts Boston.

Fig. 6.41 A seated statue of Sobekneferu joined by two parts (C) Fay, Freed, Schelper, and Seyfried 2015: 91.

Fig. 6.42 Seated royal woman, right side, The Egypt Centre Swansea W848 (c) The Egypt Centre.

Fig. 6.43 Seated royal woman, front, The Egypt Centre Swansea W848 (C) The Egypt Centre.

Fig. 6.44 Temple building programme of Sobekneferu (C) Hirsch 2004: Karte 8.

Fig. 6.45 Inscription for seated statue of Princess Neithikerty, The Oriental Institute, Chicago 8663 (C) Gardiner and Peet 1955: XXXIII.

Fig. 6.46 Seated statue of Queen Senet, The Egyptian Museum, Cairo CG424 (C) Borchardt 1925: 201 
Fig. 6.47 Inscription from seated statue of Queen Senet found at Tell Abu el-Filus (C) Roth 2001: 582.

Fig. A.1 Offering table from Lisht (C) Mace 1922: 12.

Fig. A.2 Drawing of offering table from Lisht (C Roth Fig. 99.

Fig. A.3 Statuette taken to the Musée du Louvre, Paris but has been lost since the year 1830 (C) Champollion 1828: 248-249.

Fig. A.4 Fragment of a weight, The Metropolitan Museum of Art, New York MMA 22.1.785 (C) The Metropolitan Museum of Art.

Fig. A.5 Relief of Princess Kayet (Cat. 52) (C Simpson 1954: 267, pl XXa.

Fig. A.6 Relief drawing of Princess Kayet (Cat. 52) (C) Simpson 1954: 267, pl. XXb.

Fig. A.7 Large slab of stone from the shrine of Senwosret I at Serabit el-Khadim inscribed for Queen Neferu and Princess Sebat (C) Gardiner and Peet 1955: pl. XXI.

Fig. A.8 Basin fragment (C) Roth 2001: fig. 100.

Fig. A.9 Fragment of a seated statue (C) Roth 2001: fig. 101.

Fig. A.10 Remains of Pyramid I during 1906 excavations (C) Arnold 1992: pl. 14a.

Fig. A.11 Large slab of stone from shrine of Senwosret I at Serabit el-Khadim inscribed for Queen Neferu and Princess Sebat (C) Gardiner and Peet 1955: pl. XXI 71.

Fig. A.12 Inscribed column fragment (C) Arnold 1992: pl 17c.

Fig. A.13 Inscribed fragments of a false door (C) Arnold 1992: pl. 20d.

Fig. A.14 Pyramid II area during 1933-34 excavations (C) Arnold 1992: pl. 22a.

Fig. A.15 Wooden coffin fragments from Dahshur (C) De Morgan 1903: 70.

Fig. A.16 Princess Ita’s middle coffin (C) De Morgan 1903: 50.

Fig. A.17 Inscribed sphinx for Princess Ita (Cat. 68) Musee du Louvre, Paris AO 13075 C Fay, B. 1996.

Fig. A.18 Intact burial at the complex of Amenemhat II C De Morgan 1903: 46.

Fig. A.19 Diadem type crowns of Princess Khenmet C Ziegler 2008: Fig. 51.

Fig. A.20 Tombs of Itaweret and Sathathromeryt (C De Morgan 1903: 69.

Fig. A.21 Tombs of Itaweret and Sathathromeryt (C) De Morgan 1903: 69. 
Fig. A.22 Cylinder seal impression of Princess Itakayet, The Brooklyn Museum, New York 44.123.74 (C) Brooklyn Museum.

Fig. A.23 Cylinder seal of Princess Itakayet, The Brooklyn Museum New York 44.123.74 C Brooklyn Museum.

Fig. A.24 Statue of Queen Nofret (Cat. 15), The Egyptian Museum, Cairo CG 381 (JE 37487) (C) Brandi Hill 2016.

Fig. A.25 Statue of Queen Nofret (Cat. 16), The Egyptian Museum, Cairo CG 382 C) Brandi Hill 2016.

Fig. A.26 Seated state of Queen Khenemetneferhedjet "The Great" (Cat. 18), Musée du Louvre, Paris E32564 (C) Musée du Louvre.

Fig. A.27 Lower half of the seated statue of Queen Khenemetneferhedjet "The Great" (Cat. 31), Elephantine Museum, Elephantine 101 (C) Habachi 1985: 193-194.

Fig. A.28 Lower half of a seated statue of Senwosret III with two royal females (Cat. 32), The British Museum, London EA1069 (C) The British Museum.

Fig. A.29 Lower half of a seated statue of Senwosret III with two royal females (Cat. 33), The British Museum, London EA1145 (C) The British Museum.

Fig. A.30 Lower half of a seated statue of Senwosret III with two royal females (Cat. 34), The British Museum, London EA1146 (C) The British Museum.

Fig. A.31 Relief fragment of Queen Hedjet from Lahun (Cat. 53) (C) Stünkel 2006: 154.

Fig. A.32 List of family members on Kahun papyrus Queen Khenemetneferhedjet Weret (C) Borchardt 1899: 91.

Fig. A.33 Wooden statue of Queen Khenemetneferhedjet Weret Kahun papyrus (Cat. 39) (C) Borchardt 1899: 96.

Fig. A.34 Standing stone statue of Queen Khenemetneferhedjet Weret Kahun papyrus (Cat. 40) C Borchardt 1899: 96.

Fig. A.35 Fragment of a false door inscribed for Queen Khenemetneferhedjet from Bubastis (C) Lange 2007: 91-93.

Fig. A.36 List of family members on Kahun papyrus Princes Itakayet (C) Borchardt 1899: 91.

Fig. A.37 Sarcophagus of Princess Itakayet (C) Arnold 2002: pl. 76.d.

Fig. A.38 List of family members on Kahun papyrus Princes Neferet (C) Borchardt 1899: 91. 
Fig. A.39 Crown of Sithathoryunit (C) Ziegler 2008: Fig. 43.

Fig. A.40 Pectorals of Senwosret II and Amenemhat III (C) Winlock 1934: pl. VII.

Fig. A.41 Plan of Tomb 8 burial of Sit-Hathor-yunit (C) Bruton 1920: pl. XXII.

Fig. A.42 Canopic jar inscriptions and surviving title wife of the monarch from a block of granite (C) Brunton 1920: pl. XV.

Fig. A.43 Rounded limestone stela of Princess Hatshepsut, The Egyptian Museum, Cairo CG 20394 (C) Lange and Schäfer 1902: 390.

Fig. A.44 Inscription (E. 1 and 2) for Princess Hatshepsut and Queen Nofret $\mathbb{C}$ Langer and Schäfer 1902: 391.

Fig. A.45 Lower half of a seated statue of Senwosret III with two royal females (Cat. 32), The British Museum, London BM EA 1069 (C) The British Museum.

Fig. A.46 Lower half of a seated statue of Senwosret III with two royal females (Cat. 33), The British Museum, London BM EA 1145 (C) The British Museum.

Fig. A.47 Lower half of a seated statue of Senwosret III with two royal females (Cat. 34), The British Museum, London BM EA 1146 (C) The British Museum.

Fig. A.48 Wooden statue Queen Khenemetneferhedjet Sheryt Kahun papyrus (Cat. 41) (C) Borchardt 1899: 96.

Fig. A.49 Standing granite statue of Queen Khenemetneferhedjet Sheryt Kahun papyrus (Cat. 42) C) Borchardt 1899: 96.

Fig. A.50 Tomb and sarcophagus of Queen Neferthenut C Arnold 2002: pl. 78b.

Fig. A.51 Sarcophagus inscription of Queen Neferthenut (C) Arnold 2002: pl. 119.

Fig. A.52 Eighteenth Dynasty stela of Senwosret III and Queen Meretseger, The British Museum, London BM EA 846 (C) The British Museum.

Fig. A.53 Tomb of unnamed Princess of Queen (C) Arnold 2002: pl. 74c.

Fig. A.54 Tomb of Princess Mereret (C) Arnold 2002: pl. 83c.

Fig. A.55 Tomb of Princess Senetsenbetes (C) Arnold 2002: pl. 84a.

Fig. A.56 Sarcophagus inscription of Princess Senetsenbetes (C) Arnold 2002: pl. 119.

Fig. A.57 Tomb of Princess Menet (C) Arnold 2002: pl. 84b.

Fig. A.58 Sarcophagus inscription of Princess Menet (C) Arnold 2002: pl. 119.

Fig. A.59 Tomb of Princess Sithathor (C) Arnold 2002: pl. 84c. 
Fig. A.60 Scarab ring of Princess Sithathor (C De Morgan 1895: 62.

Fig. A.61 Relief fragment from the pyramid complex of Senwosret III (C De Morgan 1895: 77.

Fig. A.62 Tomb of unnamed Princess or Queen (C) Arnold 2002: pl. 85a.

Fig. A.63 Tomb of Princess Sit[...] C Arnold 2002: pl. 84b.

Fig. A.64 False door of Queen Aat (Cat. 54) (C) Roth 2001: 581.

Fig. A.65 Offering table of Queen Aat (C) De Morgan 1903: 101.

Fig. A.66 Skull remains of Queen Aat C Strouhal 2006: 137.

Fig. A.67 Skull remains of anonymous Queen or Queen Khenmetneferhedjet (C) Strouhal 2006: 136.

Fig. A.68 Relief of Queen Hetepi (Cat. 56) (C) Bresciani and Giammarusti 2012: 74.

Fig. A.69 Seated statue of Queen Senet (Cat. 17) Royal Collection Trust London (C) Royal Collection Trust.

Fig. A.70 Lower half of a seated statue of Queen Senet (Cat. 28) The Egyptian Museum, Cairo CG 424 (C) Borchardt 1925: 201.

Fig. A.71 Lower half of the seated statue of Queen Senet (Cat. 36) (C) Roth 2001: 582.

Fig. A.72 Canopic jar fragment of Hathorhotep (C De Morgan 1903: 105

Fig. A.73 Seated statue of Princess Neithikerty (Cat. 30) (C) Gardiner and Peet 1955: pl. XXXIII.

Fig. A.74 Relief fragments from the temple of Amenemhat III and Senwosret III (C) Petrie 1905: pl. 14.

Fig. A.75 Rounded limestone stela of Princess Sobeknakht, The Egyptian Museum, Cairo CG 20537 C Lange and Schäfer 1908: 144.

Fig. A.76 Inscription (C) for Princess Sobeknakht (C) Langer and Schäfer 1908: 145.

Fig. A.77 Princess Sobeknakht suckling a Prince, The Brooklyn Museum, New York 43.137 (C) Brooklyn Museum. 


\section{List of Charts and Tables}

Chart 1.1 Provenances chart.

Chart 4.1 Find spots of Twelfth Dynasty royal female representations.

Table 3.1 Queenship ideology and the Queen.

Table 4.1 Provenances for the sphinxes of Twelfth Dynasty royal women.

Table 5.1 Cenotaphs and burials of the late Twelfth Dynasty.

Table 5.2 Inventory of items found in Neferuptah's sarcophagus, table by author based after Farag and Iskander 1971.

Table 5.3 Measurements of the sarcophagi of Neferuptah and Amenemhat III by author based after Farag and Iskander 1971: 17 and Petrie 1890: 17. 


\section{Relevant Chronology ${ }^{2}$}

Twelfth Dynasty

1981-1802

Amenemhat I

1981-1952

Senwosret I

1961-1917

Amenemhat II

1919-1885

Senwosret II

1887-1878

Senwosret III

1878-1840

Amenemhat III

1859-1813

Amenemhat IV

1814-1805

Sobekneferu

1805-1802

${ }^{2}$ Oppenheim, Arnold, Arnold, and Yamamoto 2015: XIX. 


\section{List of Abbreviations}

\begin{tabular}{|c|c|}
\hline AAMT & Advances in Archaeological Method and Theory \\
\hline AAR & African Archaeological Review \\
\hline AeUL & Ägypten und Levante \\
\hline ASAE & Annales du Service des Antiquités de l'Egypte \\
\hline AJSL & American Journal of Semitic Languages and Literatures \\
\hline APAW & Abhandlungen der Preussischen Akademie der Wissenschaften \\
\hline ArOr & Archiv Orientální \\
\hline $\mathrm{BA}$ & Biblical Archaeologist \\
\hline BES & Bulletin of the Egyptological Seminar \\
\hline ASJ & Aesthetic Surgery Journal \\
\hline $\mathrm{BACE}$ & Bulletin of the Australian Centre for Egyptology \\
\hline BAR & Biblical Archaeology Review \\
\hline BASOR & Bulletin of the American Schools of Oriental Research \\
\hline $\mathrm{BCM}$ & Bulletin of the Cleveland Museum of Art \\
\hline BEM & Bulletin of the Egyptian Museum (Cairo) \\
\hline BES & Bulletin of the Egyptological Seminar \\
\hline $\mathrm{BiOr}$ & Bibliotheca Orientalia \\
\hline BIFAO & Bulletin de l'Institut Français d'Archéologie Orientale \\
\hline BMFA & Bulletin of the Museum of Fine Arts, Boston \\
\hline BMMA & Bulletin of the Metropolitan Museum of Art, New York \\
\hline BSFE & Bulletin de la Société française d'Égyptologie \\
\hline $\mathrm{CCdE}$ & Les Cahiers Caribéens d'Égyptologie \\
\hline $\mathrm{CdE}$ & Chronique d'Égypte \\
\hline CHANE & Culture and History of the Ancient Near East \\
\hline Chungará & Chungara Revista de Antropología Chilena \\
\hline CRAIBL & $\begin{array}{l}\text { Comptes rendus des séances de l'Académie des Inscriptions et Belles- } \\
\text { lettres }\end{array}$ \\
\hline CRIPEL & $\begin{array}{l}\text { Cahier de Recherches de l'Institut de Papyrologie et d'Égyptologie de } \\
\text { Lille }\end{array}$ \\
\hline $\mathrm{DE}$ & Discussions in Egyptology \\
\hline E\&L & The Journal Egypt and the Levant \\
\hline $\mathrm{EAO}$ & Égypte, Afrique et Oriente (Paris \\
\hline ESS & Egyptian Study Society \\
\hline GM & Göttinger Miszellen \\
\hline JAAC & The Journal of Aesthetics and Art Criticism \\
\hline JAOS & Journal of the American Oriental Society \\
\hline JAMT & Journal of Archaeological Method and Theory \\
\hline JARCE & Journal of the American Research Center in Egypt \\
\hline JEA & Journal of Egyptian Archaeology \\
\hline JEOL & $\begin{array}{l}\text { Jaarbericht van het Vooraziatisch—Egyptisch Genootschap 'Ex } \\
\text { Oriente Lux' }\end{array}$ \\
\hline JNES & Journal of Near Eastern Studies \\
\hline JSSEA & Journal of the Society for the Study of Egyptian Antiquities \\
\hline KMT & KMT: A Modern Journal of Ancient Egypt \\
\hline MAFS & Mission Archéologique de Saqqarah \\
\hline MAN & The Journal of the Royal Anthropologial Institute \\
\hline MDAIK & $\begin{array}{l}\text { Mitteilungen des Deutschen Archäologischen Instituts, Abteilung } \\
\text { Kairo }\end{array}$ \\
\hline
\end{tabular}


MMJ Metropolitan Museum Journal

NIN Journal of Gender Studies in Antiquity

OLA Orientalia Lovaniensia Analecta

OrNS Orientalia Nova Series

PSBA Proceedings of the Society of Biblical Archaeology

PES

RAr

Prazských egyptologických studií

$\mathrm{RC}$

Revue archéologique (Paris)

$\mathrm{RdE}$

Revue du Caire (Cairo)

Revue d'Egyptologie

RSO Rivista degli Studi Orientali

RT

Recueil de traveaux relatifs à la philologie et à l'archéologie égyptiennes et assyriennes

SAK Studien zur Altägyptischen Kultur

Syria Syria: Revue d'art orientale et d'archéologie (Paris)

TdE Trabajos de Egiptología - Papers on Ancient Egypt

WorldArch World Archaeology

ZAeS Zeitschrift für Ägyptische Sprache und Altertumskunde

ZDMG Zeitschrift der Deutschen Morgenländischen Geseltschaft 


\section{Chapter 1: Introduction}

\subsection{Introduction}

This thesis examines the political power and influence of royal women from the ancient Egyptian Twelfth Dynasty. This study further analyses royal women's surviving representations and explores previous ideologies of queenship. When comparing them to women of other time periods, the art and artifacts of Twelfth Dynasty royal women have been less studied. To present a diverse prespective, this thesis argues for the power of Twelfth Dynasty royal women and introduces their political presence for future Middle Kingdom scholarship. The significance of Twelfth Dynasty royal women and their importance as ancient Egyptian politicians are demonstrated through their art works, associated texts, temple presence, and burials. Their proficiency in government extends beyond the position of queenship and into the pharaonic office and this study on Twelfth Dynasty royal women can be used to interpret how this administration was perceived in ancient Egypt.

\subsection{Methodology}

Ancient Egyptian royal women expressed diverse types of power and because of this understanding their place in politics is essential to Egyptology. This thesis interprets Twelfth Dynasty royal women through their iconography, and surviving artifacts, along with their roles in the queenship position and their reigns as female monarchs. Three main research questions are addressed in this study:

1. What are the iconographic regularities and irregularities of the surviving artworks of Twelfth Dynasty royal women and how do these artistic features represent their official positions?

2. What evidence is there to support the hypothesis that Princess Neferuptah was the intended heir to Amenemhat III, and how does this affect the roles and representations of Twelfth Dynasty royal women?

3. There is more surviving evidence from Sobekneferu's reign than is regularly presumed. How do these artifacts demonstrate her political power and how can her sole reign in the dynastic succession of Amenemhat III and Amenemhat IV be interpreted?

This study uses the surviving iconography of Twelfth Dynasty royal women, along with textual evidence on their mortuary complexes and artifacts, to establish a new 
understanding of how gender and power interacted with Twelfth Dynasty politics. In this thesis an art historical analysis is used since there are numerous surviving representations of Twelfth Dynasty royal women in which the majority of the artworks have not yet been studied. A further feminist iconographic analysis is employed for this thesis to examine the implications that the images of royal women had during the Twelfth Dynasty. This includes exploring the iconography that symbolizes both governmental positions for royal women and examining how political power was exhibited through their artworks such as during the tenure and reign of Princess Neferuptah and Sobekneferu. Within these iconographic analyses three main approaches are considered:

- Stylistic analysis of the formal elements, including the material, size, and preservation status ${ }^{3}$

- Who the woman is being represented and how she is shown, such as being depicted as a queen or monarch

- The artwork's context within the ancient Egyptian political history

Subject matters such as royal regalia and elements symbolizing the political office of queen or pharaoh are stylistically analyzed to interpret the political application and reception by ancient audiences. If the depiction of the Twelfth Dynasty royal woman has surviving texts, the representation is examined independently from the text to discover any iconographic regularities. Other surviving artifacts, such as papyri and funeral objects, are included in this thesis's collection to help establish a correct historical context ${ }^{4}$ for the Twelfth Dynasty. An art historical analysis is applied to this thesis in order to comprehensively examine Twelfth Dynasty royal women. This is significant because this study is the first successful attempt at assembling all known surviving representations of Twelfth Dynasty royal women. Additionally, this thesis serves as the first analysis to establish the regularities and irregularities for the iconographic features of royal women during the time period. Understanding the

\footnotetext{
3 "In brief, stylistic analysis concerns the examination of form and its linear and proportional characteristics, as well as subject matter, color palette, the organization of pictorial composition and space, and the rendering of individual forms and their connection to each other." Hartwig 201: 313. 4 "The theory of iconography holds that art is influenced by its historical context, becoming a type of document of a civilization and its different historical or societal conditions." Hartwig 2011: 319.
} 
iconography of the Twelfth Dynasty also bridges the new definitions presented in Chapter 3 with the representations of royal women which continuously developed in order to reflect the definition of queenship ideology and the queen. In this thesis, iconography is used as a vessel to accumulate the underlying connotations that are found in royal women's artworks which importantly allows for their historical and political contexts to be perceived through the artistic details (see below).

\section{Work of representational art}<smiles>CCCCCCCC</smiles>

Pre-iconographic Description Enumerating everything that can be seen in a representation without establishing any relationships or interpretations: Identifying the formal elements.

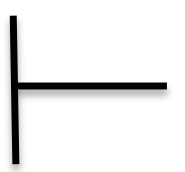

Knowledge of themes and subject matter in ancient Egyptian art, as well as their modes of representation over the history; knowledge of the artist's direct and indirect sources

Iconographic Description Relating the elements of representation with one another and formulating the theme or subject without attempting to discover the deeper meaning: How the royal woman is being shown - as a Princess, Queen, or Monarch

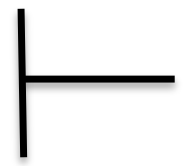

Profound knowledge of the time period's cultural historical character, e.g., politics, religious practices, literature, everyday life, and state of modern scholarship etc.

Interpretation Identifying the deeper content of a work of art explicitly or not explicitly intended by the artist incorporated in their work: Context of representations for Twelfth Dynasty royal women in the political history of ancient Egypt $^{5}$

Throughout this thesis key terms and phrases are used to express the multiple positions of Twelfth Dynasty royal women. Interpretations of the words are listed below to help clarify how they are uniquely applied to the research in this study. The operant definitions of Queenship ideology and the Queen can be found in Chapter 3.2 .

\footnotetext{
${ }^{5}$ Adapted from Van Straten 1994: 16, "The Phases of Iconography and Iconology"; See also "history of style", "history of types" and "the unifying principals which reveal the basic attitude of a nation, period, class, religious or philosophical" Hartwig 2015: 47 and Panofsky 1939; Müller 2015: 78-97.
} 
- Power - The capacity to control or directly influence something or someone

- Political power - The capacity to control or directly influence the government

- Politician - A single individual that is part of the personnel, processes, relationships, institutions, and procedures that make authoritative public decisions

- Government - The political unit of the royal family and elite persons led by the pharaoh who exercises control over Egypt

- Government representative - A single individual who represents the government, especially daughters of the pharaoh

- Female ruler - A biological female that exercises power while either holding the pharaonic office or a royal tenure

- Reign - The period of time a single individual is in the pharaonic office

- Rule - The period of time a single individual is in one of the offices of regent, co-regent, or queenship.

- Tenure - The fact or supported action for a single individual to hold a politically inclined position in the royal family or government

- The Pharaonic Office - The androgynous manifestation of divine rulership, which is comprised of the offices of kingship and queenship

- Obtainable politics - The political positions of the pharaonic office, regency, and co-regency that royal women could securely acquire

- Sustainable politics - The political position of queenship that is continually designated for royal women

\subsection{The data}

The data analyzed in this thesis consists of the surviving representations and the previously recorded artifacts for Twelfth Dynasty royal women. This data collection is employed to generate the first completed catalogue for Twelfth Dynasty royal women, an updated genealogy, an iconographic analysis, and revised examinations of the tenure of Princess Neferuptah and reign of Sobekneferu. Data has been collected from online and published museum catalogues, reference lists, general publications, and manually through the author's visits to museums and Egyptian archaeological sites. The representations are analyzed individually to interpret a set of evidence for female political power during the Twelfth Dynasty. The iconographic 
protocols or decorum ${ }^{6}$ are optimized and used to ensure the representations are consistently examined.

\subsubsection{Twelfth Dynasty royal women}

The information for the updated genealogy of Twelfth Dynasty royal women and the list of their known artifacts has been collected through previous genealogies, published excavation reports, Egyptian papyri, along with sculptures and reliefs. The genealogy found below (Chapter 1.6) and in Appendix 2 gathers all known names and familial ties of Twelfth Dynasty royal women. They are also listed numerically, which corresponds with the list of Twelfth Dynasty royal women in Appendix 2 and the numbering system used throughout this thesis. Within the genealogy the relationships of royal women are shown as maternal, marital, and sororal. All known Twelfth Dynasty royal women are placed within the families, except for six due to the availability of information regarding their relatives. These include Anonymous Princesses or Queens (RW28, RW29, RW35, RW37), Shedetetef (RW48), and Sobeknakht (RW49).

The data collected for the list of Twelfth Dynasty royal women in Appendix 2 consists of all known women and their artifacts, while also including the aforementioned six not covered in the updated genealogy. Each royal woman is firstly listed by name then followed by their relationships to other family members, such as grandmother, mother, wife, sister, and daughter. If the royal woman is mentioned within a papyrus, the English translation is provided immediately below her familial ties. The archaeological evidence composed in the appendix includes previously recorded excavations and artifacts for the royal women listed. When available, photographs and line drawings are shown as figures. The artifacts collected consist of mummies and skeletal remains, offering tables, statues, reliefs, stelae, false doors, cylinder seals, papyri, burials with equipment including sarcophagi and jewelry, as well as fragments of weights, basins, and columns.

\footnotetext{
6 "Decorum is a set of rules and practices defining what may be represented pictorially with captions, displayed, and possibly written down, in which context and in what form." Baines 1990: 20.
} 


\subsubsection{Catalogue of all known representations of Twelfth Dynasty royal women}

The catalogue of all known representations of Twelfth Dynasty royal women prominently displays the data collected for the art historical analysis. The data includes statues and reliefs with photographs and line drawings, representations without photographs are classified as no image. The representations of Twelfth Dynasty royal women are organized into nine different alphabetical categories based on the preservations status, style, and who is being represented. The nine categories include busts, feet, fully intact, heads, lower halves, other, reliefs, Sobekneferu, and sphinxes. The representations are then alphabetically categorized by current location, such as Berlin, Boston, Brussels, etc.

The data for every entry in the catalogue is labeled as catalogue number, collection, name, material, height, provenance, date, preservation status, description, and bibliography. If the information is unavailable the data is left as unknown. The name is either a description of the object itself, for example 'bust of', or names the royal woman being depicted. Twelfth Dynasty royal women were represented in at least fifteen different types of material with granite as the prevailing stone used and range in size from small statuette to over life-size. The provenances, which include at least twenty-two locations (Chart 1.1) include all recorded information about the artwork, including place of discovery, credited organizations from museums, and selling information. This fundamental information is followed by the date in which each entry is attributed to one or two reigns of pharaohs from the Twelfth Dynasty. The preservations status and descriptions of each object exhaustibly detail their appearances and includes any previous data that has been collected for the iconographic analysis. Furthermore, if the artwork has been previously recorded in a publication, this information is noted in the bibliography. 


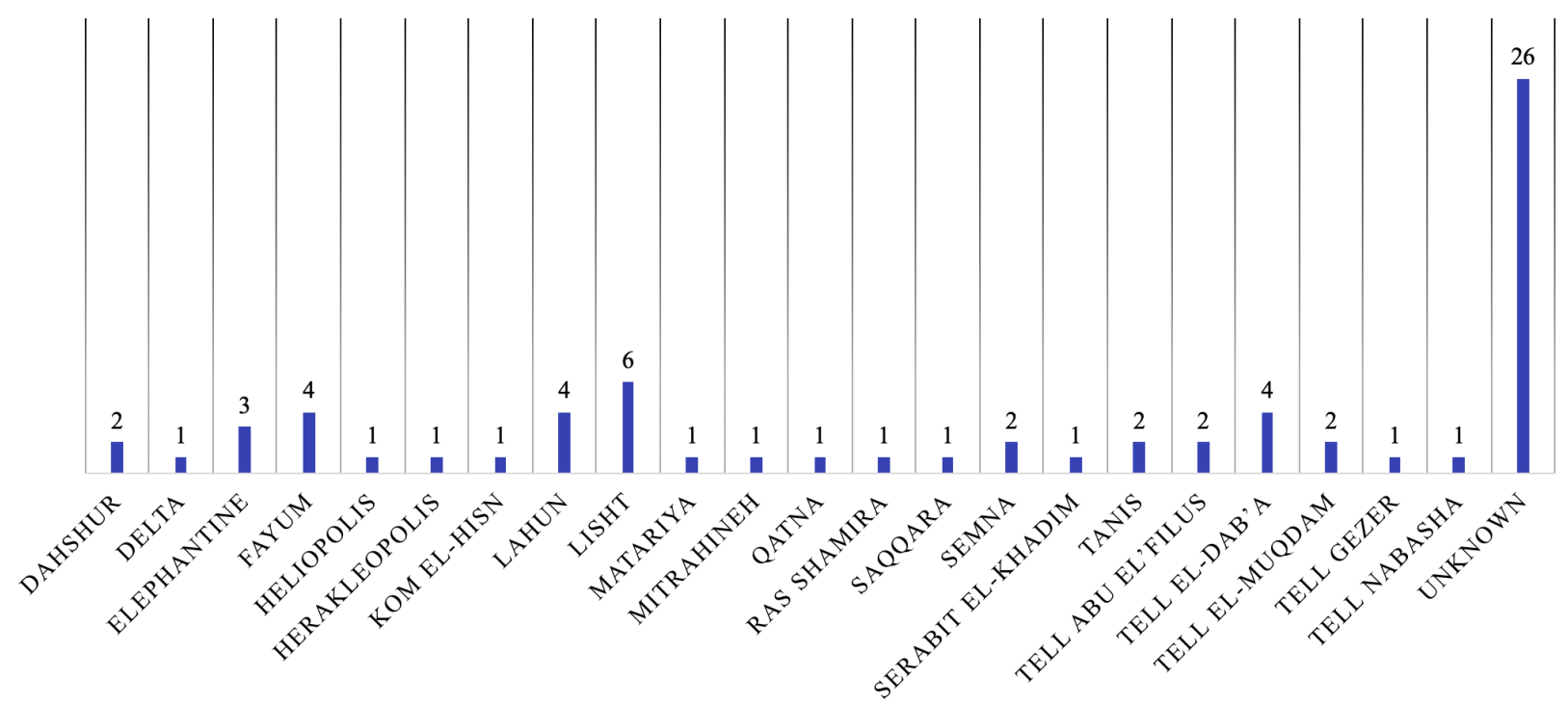

Chart 1.1 Provenances chart, by author.

\subsection{The criteria of Twelfth Dynasty royal female representation}

Observed from their surviving representations, Twelfth Dynasty royal women shared many physical characteristics with royal men. These aspects include cylindrical limbs, large feet, oversized ears, and facial characteristics. The royal women's front upper body or breasts are the singular physical characteristic that is not shared. However, breast emphasis was not exclusively female because enlarged breasts are also seen on ancient Egyptian non-royal men, possibly depicting them with the condition gynaecomastia. ${ }^{7}$ Considering the style, Twelfth Dynasty royal women's breasts are not depicted as enlarged breast tissue but rather their natural size when compared to the body type. Although the art of royal women was restricted to depicting smaller breasts, this was not the case for non-royal women, as seen in the relief of female weavers from the tomb of Khnumhotep at Beni Hasan (Fig. 1.1). ${ }^{8}$ The female overseer standing is depicted with breast ptosis, ${ }^{9}$ or low hanging breasts, which was most likely caused by weight gain, pregnancy, or ageing. While breasts can be used as a defining physical criterion for royal women, this one relief of five

\footnotetext{
7 "The condition that cause men's breasts to swell and become larger than normal. It is most common in teenage boys and older men.” For information see the National Health Service website: https://www.nhs.uk/chq/Pages/885.aspx?CategoryID=61.

${ }^{8}$ Newberry 1893: pl. 29.

${ }^{9}$ The sagging or abnormally lower position of the breasts. "Artistic representations of the ptotic breast in which the breast has lost volume and is supported by the chest wall are synonymous with ageing, infirmity, and loss of attractiveness." Kirwan 2002: 355, see figure 1: Classification of ptosis.
} 
female weavers depicts five different breast types, ${ }^{10}$ which is an important example in analyzing women from the Twelfth Dynasty since one characteristic can be depicted in multiple styles.

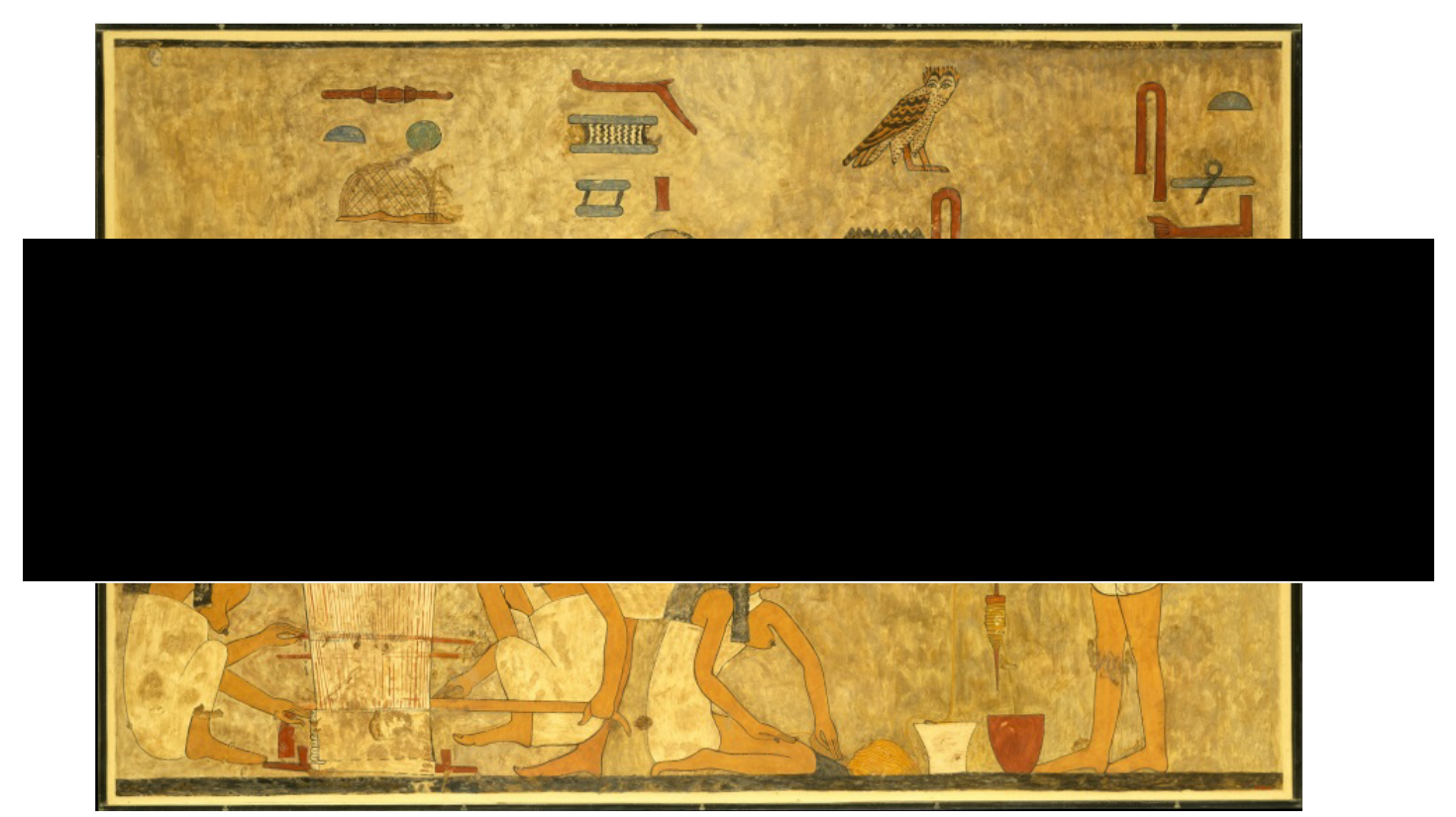

Fig. 1.1 Weavers from the tomb of Khnumhotep, The Metropolitan Museum of Art, New York 33.8.16.

It is also apparent that the faces of both royal women and men are remarkably similar and that without the addition of wigs and headgear their gender cannot always be correctly assigned (Figs. 1.2, 1.3). The fact that the physical characteristics of royal women and men are exceedingly similar during the dynasty supports their equality in the iconographic development of the period and demonstrates that the art works of both sexes presented similar statements to the viewer. Recognizing the representation of physical similarities between Twelfth Dynasty royal women and men further minimizes the contrast that has often been assumed for their iconography and roles in the government. Royal women were meant to be viewed as women who were in the royal family and also politicians.

\footnotetext{
10 The types of breasts depicted can be an indication of their different ages, Roehrig 1996: 20.
} 


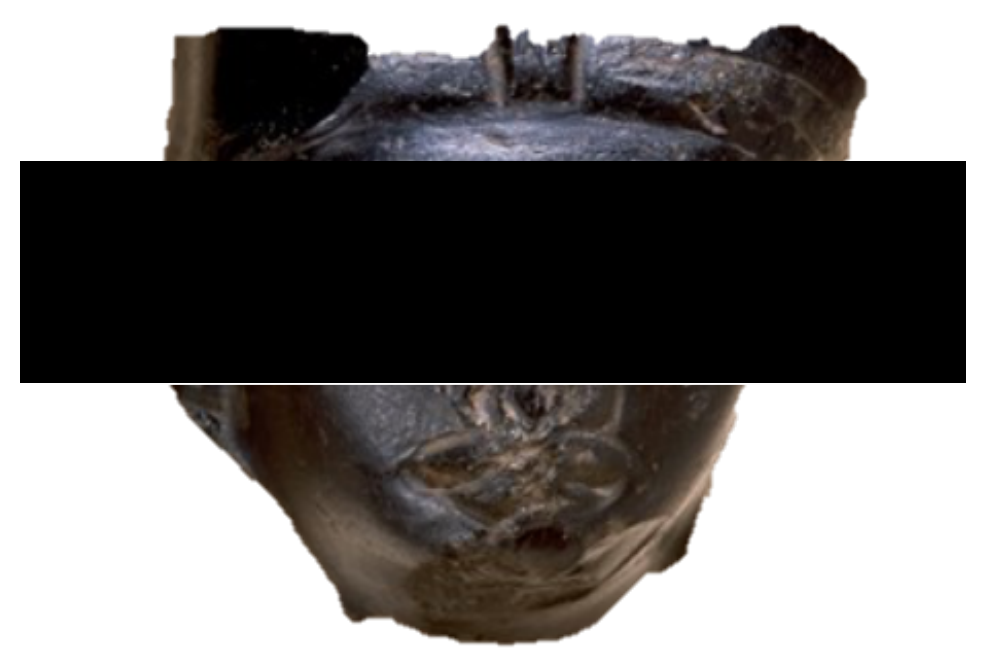

Fig. 1.2 Face of a Twelfth Dynasty royal woman, Christie's Sale Catalogue, September 23, 1998.

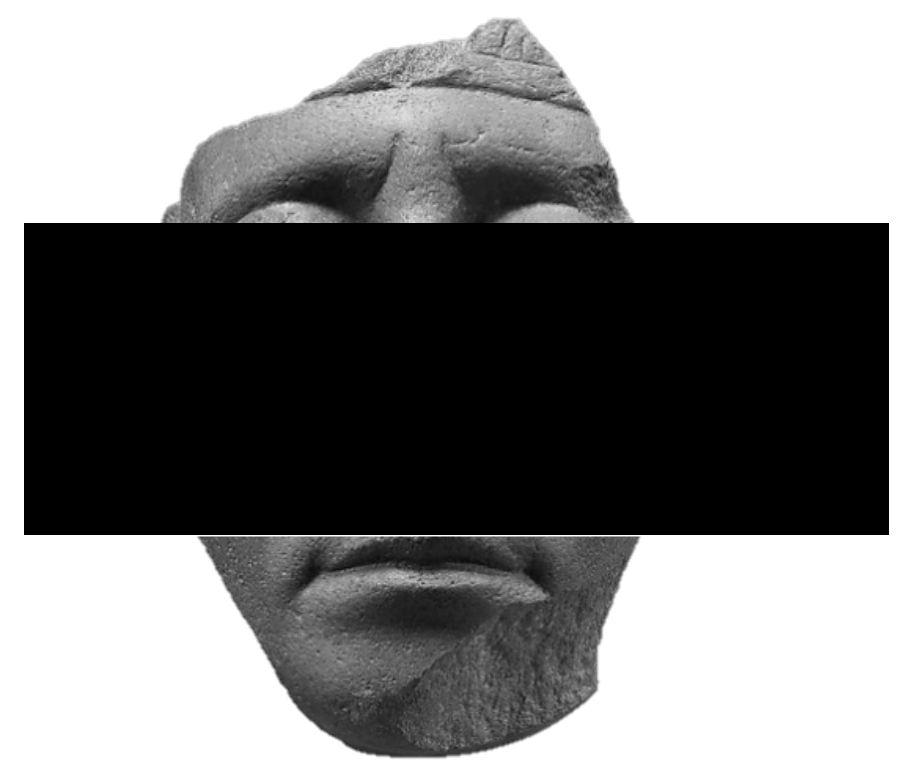

Fig. 1.3 Face of Senwosret III, The Metropolitan Museum of Art, New York 26.7.1394.

Twelfth Dynasty royal women were represented in four poses, including standing, seated, sphinx, and human-headed bird (see Chapter 4.2). When Sobekneferu was in the pharaonic office, she was also depicted kneeling while offering. All five poses listed here were shared among royal women and men, which confirms no form was restricted to a certain sex. Similar to the facial characteristics, without additional attire the physical characteristics in the poses of royal women and men are depicted the same. However, during this time the kneeling while offering pose was restricted to the person in the pharaonic office allowing for both male and female rulers to be 
depicted in the posture. The Twelfth Dynasty was the earliest period in Egypt for all royal women to be commonly shown wearing the uraei in art (see Chapter 4.4). This standardization of the cobra emblem reinforces their status as part of the royal family and is the best definitive way to declare if the woman is royal or not. The sharing of royal uraei during the Twelfth Dynasty proves that this iconographic characteristic was also not restricted to a certain sex, similar to the previously mentioned poses, and the uraeus was no longer only worn by the ruling monarch. Twelfth Dynasty royal women were depicted in a style further affirming their equal iconographic opportunities that represented political status which coincided with the genderneutrality of poses, uraei, and severe facial characteristics.

Considering Twelfth Dynasty royal women were represented in all five of the gender-neutral poses, along with royal uraei and severe facial characteristics, it was often their dress and hairstyles that made them distinctive from royal men. Excluding Sobekneferu's pharaonic regalia, Twelfth Dynasty royal women are only seen in two types of dress (see Chapter 4.9). The sheath dress was the leading female apparel type that was used in royal female representations of the dynasty. Similar to the aforementioned styles of representing breasts, the surviving depictions of non-royal women during the Twelfth Dynasty seem to not be constricted to sheath dresses. Non-royal women are seen wearing kilts, cloaks (see Fig. 4.5), and dresses with alternating straps (see Fig. 4.4). There are currently two surviving representations of Twelfth Dynasty royal women wearing a cloak or robe type garment, making the sheath dress the dominant signifier for accessing the clothing of royal women during this time.

When Twelfth Dynasty royal women are compared to non-royal women, they were also represented in a smaller number of varying types of wigs, which include the tripartite, Hathoric, rounded, and blunt (see Chapter 4.5). The tripartite wig exposing the ears and aiding in displaying the facial characteristics is the most popular type used by royal women of the dynasty. The second prominent wig style, the Hathoric, was distinctive of only women. Both royal and non-royal women were commonly depicted with this style, but royal or non-royal men were not. It seems that during the Twelfth Dynasty the combination of the sheath dress and Hathoric style wig were exclusive to women and combined with a uraeus, was a prevailing method to represent royal women. 


\subsection{Context of the Twelfth Dynasty}

At the end of the Eleventh Dynasty a large political shift occurred, giving rise to one of the most stable succession lines in pharaonic Egypt. Beginning with Amenemhat I, the Twelfth Dynasty monarchs controlled Egypt for nearly 200 years. Using the strategy of co-regency, these Twelfth Dynasty rulers were able to secure the transfer of the pharaonic office to the next heir, as a result of this, there were only eight rulers. ${ }^{11}$ The rulers include Amenemhat I, Senwosret I, Amenemhat II, Senwosret II, Senwosret III, Amenemhat III, Amenemhat IV, and Sobekneferu. In addition to the Twelfth Dynasty being historically known for its stability and successful reigns, it is also the time of Egypt's first well-documented female monarch, Sobekneferu.

\subsubsection{Iconography}

The iconography of the Twelfth Dynasty is distinct within ancient Egyptian art history and shows advancement in multiple representational types. The iconography of Twelfth Dynasty royal women has not been fully explored, although there are more surviving examples of statues and reliefs than royal texts. Artworks from the late Twelfth Dynasty are best known for their facial features. In this thesis, these prominent features are termed as 'severe' facial characteristics (Figs. 1.2, 1.3; see Chapter 4.3). The word severe is used to define the features as 'extremely intense' and this study includes these characteristics as unique impressions of the person being represented. From this definition, the images of Twelfth Dynasty royal and non-royal people who have the severe facial characteristics can be considered a type of reflective portraiture but not realistic portrayals of the person. As described in Chapter 4, royal women were often depicted with the severe facial characteristics and each face was constructed differently. The fact that these faces are all unique opens questions about the sculptor's creativity and the represented person's choice of expressiveness. Similar to Amenemhat III, who is known for having multiple face types, ${ }^{12}$ Twelfth Dynasty royal women were also represented with different and unique reflective portraiture that was expressed through the severe characteristics.

Although Twelfth Dynasty royal female art is understudied, the dynasty's iconographic experimentation is one of the most noticeable changes in ancient Egyptian art history. Sculpture from the Twelfth Dynasty includes all sizes from under miniature to colossal, with the larger artworks most likely being permanently

\footnotetext{
${ }^{11}$ Bourriau 1988: 4.

12 Oppenheim 2015: 23.
} 
set up within visible sections of temples. ${ }^{13}$ Each depiction of the severe facial characteristics for royal and non-royal people was unique and not every artist or person being represented took part in this style. Wigs and jewelry combinations shifted and are often shown differently between royal women. Certain poses were shared among royal and non-royal people, including striding, standing, and seated. Non-royal individuals were also shown in block form and with the person's legs to the side and cross-legged. Furthermore, royal women were frequently shown in the sphinx pose and introduced during the dynasty was the royal female-headed bird. Sobekneferu was also depicted in the devotional stance and kneeling while offering.

\subsubsection{Locations associated with royalty}

Middle Kingdom sites have been discovered throughout Egypt, from the northern Delta site of Buto to the military fortresses of Kumma in Nubia (Fig. 1.4). Surviving from the Twelfth Dynasty are royal structures such as pyramids and temples along with non-royal settlements and cemeteries. The Twelfth Dynasty was domestically stable and there are thirty-six known nomes from the time period (see Appendix 1). ${ }^{14}$ Some predominately non-royal sites include Kon Rabia at Memphis ${ }^{15}$ as well as the pyramid town of el-Lahun, ${ }^{16}$ Herakleopolis, and Sidmant el-Gebel located in the Fayum. ${ }^{17}$ Surviving from Middle Egypt are numerous cemeteries including Meir, ${ }^{18}$ Qaw el-Kebir, el-Rifa, Asyut, Deir el-Bersha, and Beni Hasan. ${ }^{19}$ Additionally, more Twelfth Dynasty non-royal tombs are located in western Thebes ${ }^{20}$ and at Khelua in the Fayum. ${ }^{21}$

Including structures for royal women, men, and anonymous owners there are twenty-five surviving pyramids dating to the Twelfth Dynasty. ${ }^{22}$ Eight securely known pyramids belong to royal women, which accounts for approximately a third. Since multiple owners of pyramids are not known, it is strongly assumed that this percentage is higher. Among Twelfth Dynasty tombs and pyramids there are thirty-

\footnotetext{
13 Arnold 2015a: 20.

${ }^{14}$ Arnold and Jánosi 2015: 57; Grajetzki 2006: 77-133.

${ }^{15}$ Giddy 2015: 323.

${ }^{16}$ Petrie, Burton, and Murray 1923; For a plan of the town see: http://www.ucl.ac.uk/museumsstatic/digitalegypt/lahun/townplan.gif.

${ }^{17}$ Arnold 2015c: 321.

${ }^{18}$ Blackman 1914; 1915a; 1915b; 1924; Blackman and Apted 1953.

${ }^{19}$ Kamrin 2015: 319.

${ }^{20}$ Arnold 2015b: 317; Grajetzki 2006: 91.

${ }^{21}$ Arnold 2015c: 321.

22 For overviews see Lehner 1997; Verner 1997; Verner 2002.
} 
five known funerary burials for royal women, the largest cemetery being at Dahshur. Twenty tombs and five pyramids for Twelfth Dynasty royal women are located at Dahshur, followed by five burials and one pyramid in the Fayum, along with two tombs and two pyramids located at Lisht. Twelfth Dynasty royal women are securely associated with seven of the twelve royal building locations listed in Appendix 1, which include Abydos, Dahshur, the Delta, Elephantine, the Fayum, Lisht, and the Sinai (see Fig. 1.4). The locations further listed in Appendix 1 encompass sites with royal building activities such as funerary complexes, temples, royal towns, and military fortresses. 


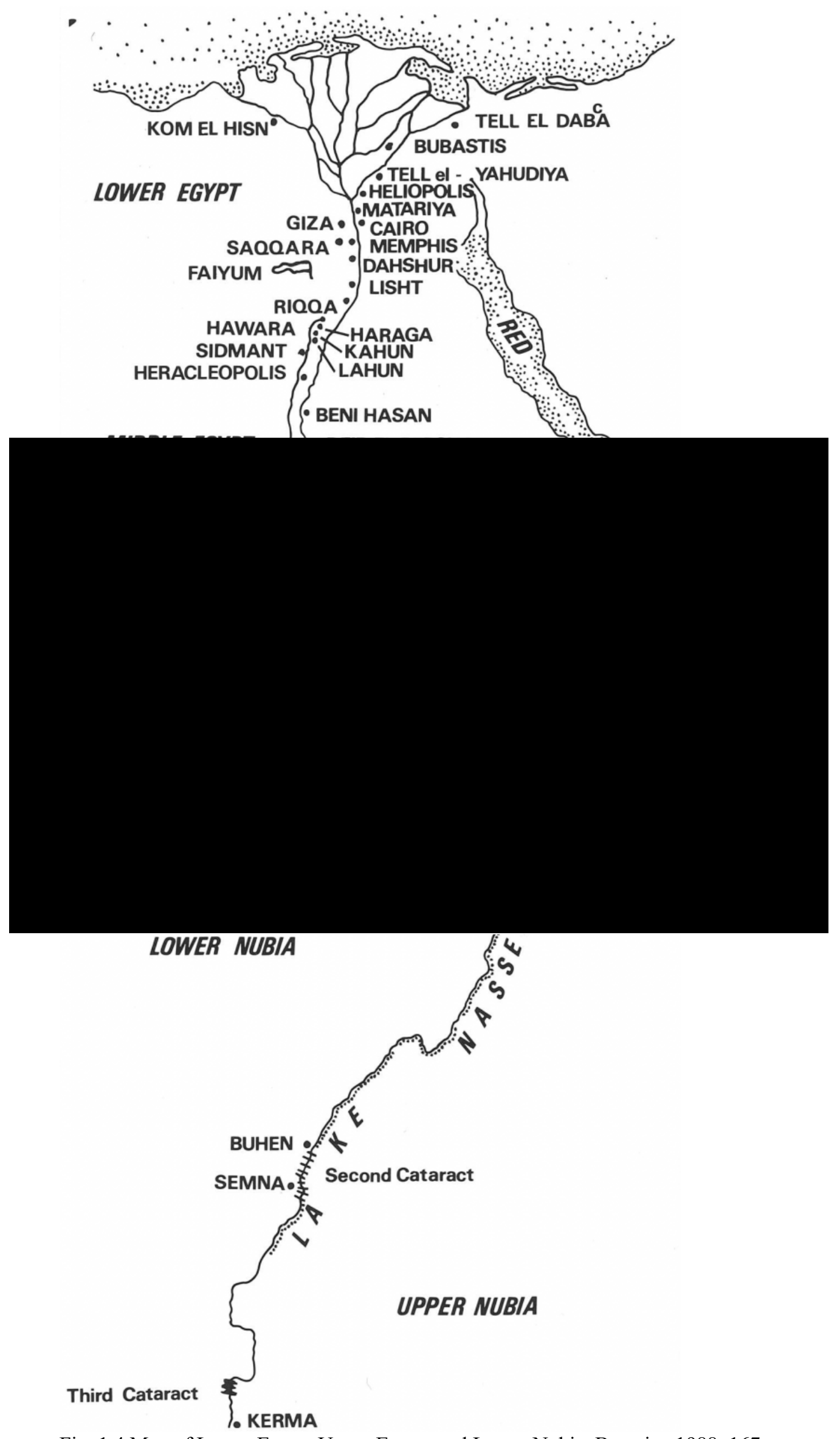

Fig. 1.4 Map of Lower Egypt, Upper Egypt, and Lower Nubia, Bourriau 1988: 167. 


\subsubsection{Royal Architecture}

As stated above (see Chapter 1.5.2), there is surviving evidence for Twelfth Dynasty royal women from mortuary complexes and temples throughout Egypt. The majority of royal women are known from their burials and funeral equipment. This includes evidence ranging from the surviving body of the woman herself to small goods with titles. The burial style of Twelfth Dynasty royal women was not stagnant throughout the entire dynasty and seems to have changed with each reign. Royal women were mostly buried in the same mortuary complex with the pharaoh, but the tomb style varied from pyramids, mastabas, and shaft tombs. ${ }^{23}$ Princess Neferuptah had her own pyramid complex and this would have been the same for Sobekneferu. Introduced during the Twelfth Dynasty, queens Khenemetneferhedjet II (RW25), Aat (RW38), and Khenemetneferhedjet III (RW39) not only shared the funerary complex but also the same pyramid as the pharaoh. In the cases of queens Khenemetneferhedjet II, Aat, and Khenemetneferhedjet III, Senwosret III and Amenemhat III may have used the pyramid as a cenotaph type burial possibly establishing the ownership of those pyramids to the royal women (see Fig. 5.14 and Table 5.1). By the late Twelfth Dynasty cenotaph type burials were common for ruler monarch s and royal women in the queenship position (see Chapter 5.8), while gallery style tombs along with pyramids were prevalent for other royal women.

Similar to Twelfth Dynasty artworks, temple blocks and burial complexes were heavily reused and relocated during later times. Due to natural damage and repurposing, the Temple of Medinet Madi commissioned by Amenemhat III and Amenemhat IV is the only surviving original and completed Twelfth Dynasty temple. This temple gives an insight into the most common type of temple architecture from the dynasty, which is supported by the surviving remains of other damaged or incomplete Twelfth Dynasty temples. It consists of an entrance room before the offering room that has three statue chambers. ${ }^{24}$ The White Chapel of Senwosret I, located at Karnak, is also an example of temple architecture. ${ }^{25}$ Beginning with Senwosret I, colossal statues became regular architecture elements for temples. Described by Arnold as "a new frontality in temple design" 26 the

\footnotetext{
${ }^{23}$ For an overview of the tombs of the royal women see Dodson 2016: 47-52; Grajetzki 2014a.

${ }^{24}$ Bresciani and Giammarusti 2012; Arnold 2015a: 14. A temple built by Senwosret II or Senwosret III located in Qasr el-Sagha has a similar style with seven statue chambers, although it was never completed.

${ }^{25}$ For reports see Lacau and Chevrier 1956; Lacua and Chevrier 1969.

${ }^{26}$ Arnold 2015a: 14.
} 
Twelfth Dynasty introduced a row of monolithic Osiride pillars standing $4.7 \mathrm{~m}$ (15 ft) tall. Senwosret III and Amenemhat III also introduced multiple sanctuaries at their Abydos and Hawara funerary complexes. ${ }^{27}$ Although slightly different from each other, all funerary complexes of Twelfth Dynasty monarchs included pyramids mostly made of limestone and mudbrick, with some containing cenotaph type burials.

Amenemhat I constructed the first pyramid of the Twelfth Dynasty at Lisht. Arranged parallel to the west enclosure wall are two rows of eleven tombs that are possibly for royal women, two burials include that of Queen Neferet I (RW 1) and Queen Neferitatjenen (RW 2). ${ }^{28}$ Also located at Lisht is the pyramid complex of Senwosret I. The complex has nine separate enclosed pyramids for royal women. Only two pyramid owners are securely known, Queen Neferu (RW 7) and Princess Itakayet I (RW 9). ${ }^{29}$ Seven of the pyramids have their own enclosure walls with the last two sharing a singular wall. Each pyramid has two chapels, one on the north and one on the east side, with complexes that have subsidiary burials and a boat pit is located outside the fifth complex.

Diverging from his predecessor, Amenemhat II built his pyramid at Dahshur. The pyramid complex has not been completely excavated, but jewelry and undisturbed burials have been discovered..$^{30}$ Although the tombs of the royal women located within the pyramid complex have not been adequately recorded, one queen and four princesses are known. These include Queen Keminub (RW 12), Princess Ita (RW 13), Princess Khunmet (RW 14), Princess Itaweret (RW 15), and Princess Sithathormeryt (RW 16). Also known for the surviving jewelry, the el-Lahun funerary complex belonging to Senwosret II includes one queen's pyramid and eight mastabas for royal women or relatives. A significant change in Twelfth Dynasty funerary complex architecture can be seen from the entrance of Senwosret II's pyramid, which was discovered under the burial of Princess Sithathoryunit (RW 23). ${ }^{31}$

\footnotetext{
27 Arnold 2015a: 14-16.

${ }^{28}$ Lythgoe 1907: 113-117; 1909: 119-123; 1915: 5-22; Mace: 1914: 207-222 1921 5-19; Verner

2002: 396-398.

${ }^{29}$ Arnold 1992.

${ }^{30}$ Arnold 2015d: 321-322.

${ }^{31}$ Petrie 1891.
} 
Senwosret III and Amenemhat III constructed their cenotaph pyramid complexes at Dahshur. ${ }^{32}$ Senwosret III's complex consists of seven small pyramids, four situated on the north and three on the south side. Queen Nefrethenut (RW 26) securely owns pyramid 2 and Princess Itakayet III (RW 21) is the owner of pyramid 3. Pyramid 4 is owned by an anonymous princess or queen (RW 28) and has a passage leading underground to a gallery of burials for eight more queens and princesses who were related to both Senwosret III and Amenemhat III. Within the eight additional burials, six are on the north side of the chamber and two are on the south side. The owners of the underground gallery tombs include an anonymous princess (RW 29), Princess Mereret (RW 30), Princess Senetsenbetes (RW 31), Princess Menet (RW 32), Princess Sithathor I (RW 33), Princess Khnemet[...] (RW 34), an anonymous princess or queen (RW 35), Princess Sit[...] (RW 36), and another anonymous princess or queen (RW 37). Located on the south side of the complex are three pyramids in which two belong to Queen Khenemetneferhedjet I (RW 20) and Queen Khenemetneferhedjet II (RW 25). Both queens Khenemetneferhedjet I and Khenemetneferhedjet II have cenotaph type burials underneath their personal pyramids (see Fig. 5.15). Khenemetneferhedjet II's actual burial is located through an underground vaulted corridor leading to her chamber, which is underneath the cenotaph pyramid of Senwosret III. ${ }^{33}$

Amenemhat III's Dahshur complex includs the burials of Queen Aat (RW 38) and an anonymous queen or Queen Khenemetneferhedjet III (RW 39), underneath the southwestern part of the main pyramid. ${ }^{34}$ Underground corridors originally connected all three of the burial chambers. Roughly a third of the way through his reign, Amenemhat III began a second pyramid at Hawara, which would be his final burial place along with Princess Neferuptah's cenotaph burial. The independent funerary complex of Princess Neferuptah (see Chapter 5.8.2) is located just southeast of Amenemhat III's Hawara pyramid. The location and architecture style of tombs of Amenemhat IV and Sobekneferu are currently unknown, although

\footnotetext{
${ }^{32}$ For Senwosret III see Arnold 2002; De Morgan 1903. For Amenemhat III see Arnold 1987; De Morgan 1895; De Morgan 1903.

${ }^{33}$ Arnold 2002.

${ }^{34}$ For ground plan of the pyramid of Amenemaht III and examination of the skeletons of queens Aat and Khenemetneferhedjet III see Stouhal 2006: 134. For excavation reports see Arnold 1987: 43-45, 50-52; De Morgan 1903: 100-101.
} 
it is expected that they would have been buried in pyramid complexes with Sobekneferu's possibly in Hawara.

\subsection{Twelfth Dynasty royal women}

The earliest list of Twelfth Dynasty royal women is found in Sabbahy's unpublished thesis Titulary and Iconography of the Ancient Egyptian Queen. ${ }^{35}$ Because

Sabbahy's is the first list, it is not complete and includes twenty-three royal women. The second and more thorough can be found in Troy's 1986 publication Patterns of Queenship,${ }^{36}$ which includes forty-one royal women. The third list and first produced genealogy of Twelfth Dynasty royal women is located in Dodson's Complete Royal Families ${ }^{37}$ which lists forty royal women. The most recent list was published in 2014 by Grajetzki in Tomb Treasures of the Late Middle Kingdom, ${ }^{38}$ but only includes thirty Twelfth Dynasty royal women. The current study has created a more exhaustive list of Twelfth Dynasty royal women by integrating the four lists of Sabbahy, Troy, Dodson, and Grajetzki. The forty-eight Twelfth Dynasty royal women listed in Appendix 2 are in chronological order and are shown with a T, D, or G if they are listed by another name in either Troy's, Dodson's, or Grajetzki's lists. The genealogy found below includes the royal woman's name and corresponding number without T or D. Additionally, hyphens are not used in the women's names and Hedjet is used as an abbreviation for the name Khenemetneferhedjet.

The list in this thesis is the first to include photographs, detailed information, and current locations of royal women's artifacts. From the list there are restrictions such as finding correct sources and some royal women are still known as anonymous. As a result of this, there can never be a true number of how many Twelfth Dynasty queens and princesses were present in the dynasty. Among the forty-eight royal women listed, there are sixteen queens, twenty-seven princesses, four anonymous royal women, and one ruling monarch. Daughters of the pharaohs are the most numerous at just over half the known women. From the Twelfth Dynasty there are three known sons of the pharaoh excluding those who ruled, princes Amenemhatankh, Khentyechtay, and Senwosretsoneb. Twenty-seven princesses are known versus only three princes, meaning the daughters were more

\footnotetext{
${ }^{35}$ Sabbahy 1982.

36 Troy 1986.

${ }^{37}$ Dodson 2004.

${ }^{38}$ Grajetzki 2014a.
} 
often included in royal inscriptions and most likely were regular governmental representatives to the public. The majority of the Twelfth Dynasty queens were originally daughters of the pharaohs and as their political position changed so did their titles. It should also be noted that multiple princesses outlived their parents by some time and were often buried in their nephew's or niece's as well as their brother's or sister's reign. While there is no surviving knowledge about their personal lives, these royal women were buried with the title $s 3 t n s w t$, emphasizing the high political position of pharaoh's daughter.

The following genealogy is a complete account of Twelfth Dynasty royal women. Chapters 5 and 6 fully examine the tenure of Princess Neferuptah and reign of Sobekneferu and acknowledging the royal women that ruled before them is fundamental to this study. The information collected in the following genealogy and list located in Appendix 2 is much more complex than previously thought or recorded and allows for a better awareness of the surviving artifacts for Twelfth Dynasty royal women. It also serves as a continuation of steps towards completing research on ancient Egyptian royal women and their place in politics, society, art, literature, and architecture. For ease of use the genealogy can be found in this chapter as well as Appendix 2. Throughout this thesis royal women are referred to by the following numbering system RW1-49, which is found on both the genealogy and list. A full table providing the genealogical information along with a list recording all known artifacts in concordance with Troy and Dodson's naming system is provided in Appendix 2. 


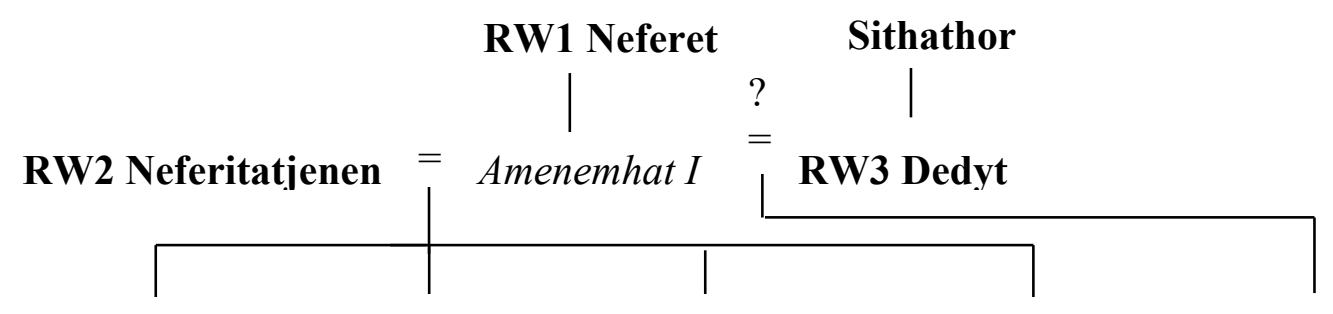
Senwosret $I=$ RW7 Neferu
RW5 Neferusheri RW6 Kayet
RW4 Neferet

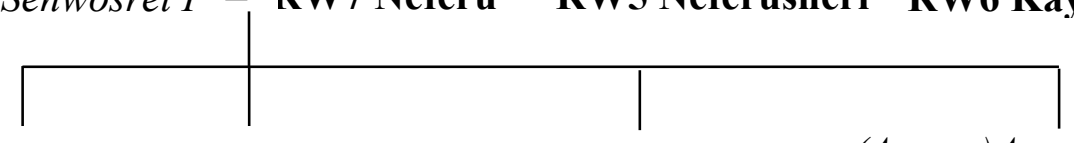

RW8 Sebat RW9 Itakayet I RW10 Nensed.. (Ameny)Amenemhat II = RW12 Keminub $=$ RW11 Kanefe

RW14 Khenmet RW15 Itaweret
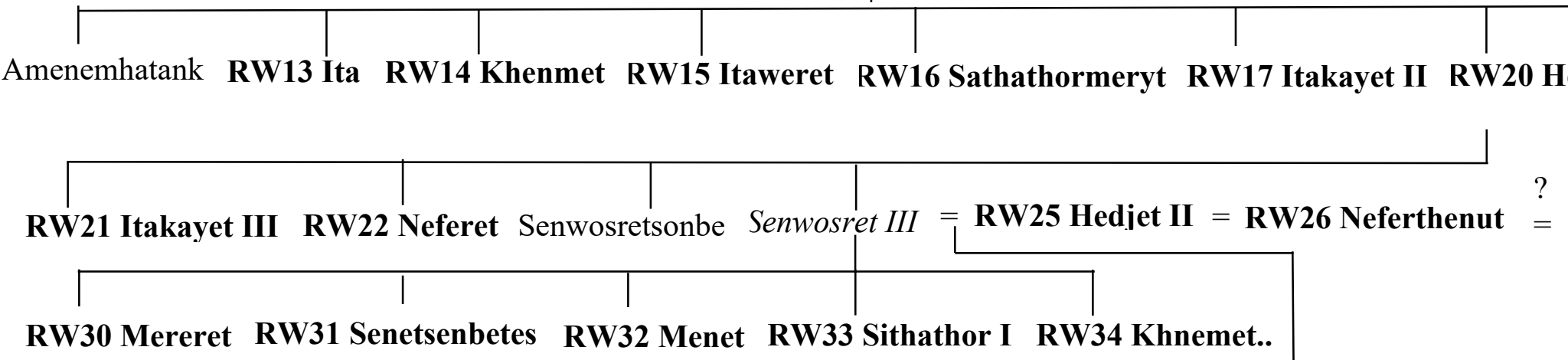

Not included:

RW28 Anonymous Princess or Queen RW29 Anonymous Princess or Queen RW35 Anonymous Princess or Queen RW37 Anonymous Princess or Queen RW48 Shedetetef RW49 Sobeknakht

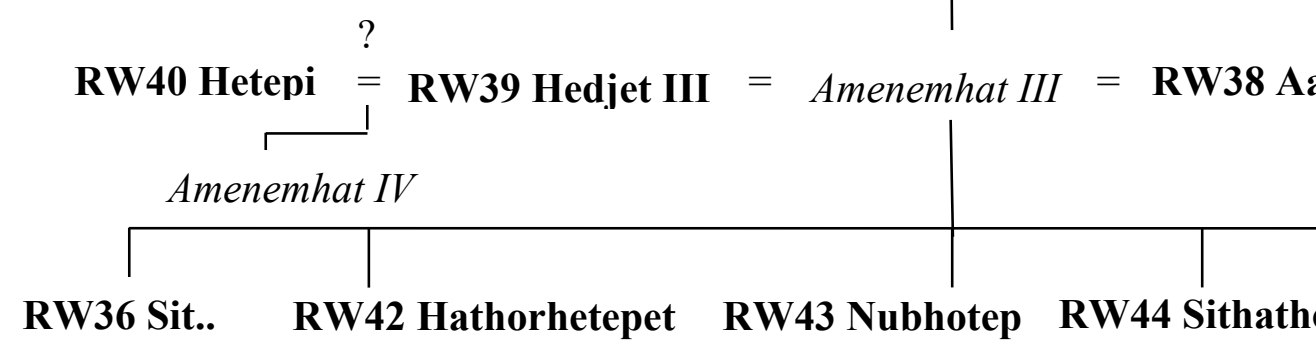




\subsection{Contributions made by the thesis}

This thesis aims to provide multiple contributions to the field of Egyptology and Gender Studies. Through this research the power of Twelfth Dynasty royal women as female politicians is further understood. Each known royal woman, including Princess Neferuptah (see Chapter 5) and Sobekneferu (see Chapter 6), are reintroduced and for the first time listed alongside their surviving artifacts (see Appendix 2). The artifacts of royal women demonstrate how the intersection of gender and power was presented to the ancient Egyptian viewers. This can be seen in the reign of Sobekneferu which has previously been understudied. Therefore, Chapter 6 of this thesis presents the first full analysis of Sobekneferu and her role as a woman in the pharaonic office.

The catalogue accompanying this study contributes to Egyptology as the first document archiving all known representations of Twelfth Dynasty royal women. This study also re-interprets former ideas of queenship and female rulership while creating new definitions for the Twelfth Dynasty royal women's political power. Although these definitions are customized for the Twelfth Dynasty, they can be applied to royal women in political positions during other time periods. The information collected in this thesis along with its examinations of Twelfth Dynasty royal women could potentially have major impact on Middle Kingdom scholarship. Furthermore, this study could also contribute to identity studies, which reflects how social categories such as gender, class, and qualifications affected Twelfth Dynasty politics.

\subsection{Structure of discussion}

This thesis comprises two volumes. Volume 1 includes the main text of the thesis, which is composed of seven chapters, and Volume 2 which consists of the appendices and catalogue for the surviving depictions of Twelfth Dynasty royal women.

Chapter 1 is an introduction to the thesis and serves as a preface for the later referenced data, iconographic styles, and royal building locations. It introduces Twelfth Dynasty royal women and presents an updated genealogy of the dynasty. The genealogy is also located in Appendix 2 along with the Twelfth Dynasty royal 
women's surviving artifacts and associations with the queenship and pharaonic political positions.

Chapter 2 provides a review of previous scholarship of Twelfth Dynasty royal women. The chapter has five sections, including scholarship for gender and power, publications that discuss the political presence of Twelfth Dynasty royal women, an overview of all known evidence for Twelfth Dynasty royal women, publications that have recorded their surviving titles, and a brief survey of mortuary complex scholarship.

Chapter 3 examines the framework of Twelfth Dynasty queens, queenship, and ancient Egyptian female rulership. The definitions of Queenship ideology and the Queen is presented in this chapter. The following two sections include discussions of gender and power along with an etymological approach to the term 'Female Horus'. Ten female rulers, in addition to Sobekneferu, are identified in this chapter in order to discuss the frequency and diverse types of women in power. These female rulers are Meretneith, Khentkaus I, Nitocris, Ahhotep, Hatshepsut, Nefertiti, Meritaten, Neferneferuaten, Ankhesenamun, and Tausret.

Chapter 4 categorizes the iconographic elements for Twelfth Dynasty royal women to determine their art historical context. A full analysis of the iconographic features of Twelfth Dynasty royal women mirroring the catalogue located in Volume 2 is found here. The characteristics are classified into nine subsections including the poses, severe facial characteristics, surviving uraei, wig type, headgear, ears, eyes, dress, and jewelry. Additionally, comparisons and overviews of Twelfth Dynasty male monarchs and royal women from the Old Kingdom through the Eighteenth Dynasty ending with Hatshepsut are included. The features of Sobekneferu are examined and discussed more prominently in Chapter 6 (see below).

Chapter 5 serves as the primary discussion on the Twelfth Dynasty royal woman Princess Neferuptah's tenure aside from her mortuary complex excavated by Farag and Iskander. This chapter draws together the information collected for Neferuptah, including all of her surviving representations and inscriptions. Neferuptah's double burial or cenotaph type burial and pyramid complex are also reviewed. Furthermore, 
this chapter addresses the argument of whether Neferuptah was the intended heir to the throne or was the actual co-regent of Amenemhat III.

Chapter 6 is the first study dedicated to Sobekneferu and is the most recent revision to the list of all of her known material. This chapter analyses the reign of Sobekneferu in relation to the royal female family members of the late Twelfth Dynasty. The chapter lists and examines all of the surviving material for her, which includes at least twenty-five artifacts and inscriptions. Each surviving representation and artifact is analyzed separately to create an updated examination of her role in the pharaonic office. Additionally, statues that possibly represent Sobekneferu are also addressed.

Chapter 7 concludes the summaries and findings of each previous chapter while highlighting new information that was produced from the research. The impact and possibilities for future research are addressed in this chapter.

Volume 2 provides two appendices and the catalogue of surviving representations of Twelfth Dynasty royal women. Appendix 1 includes the list of royal building locations and Middle Kingdom nomes. Appendix 2 is comprised of the genealogy introduced in Chapter 1 and a list all known artifacts and associations for Twelfth Dynasty royal women. The catalogue of known representations is the first for royal women of the Twelfth Dynasty and is essential for this thesis and any future research. The catalogue is organized into nine sections in the order of busts, feet, fully intact statues, heads, lower halves, other, reliefs, Sobekneferu's images, and sphinxes. The entries are further sorted alphabetically by the city the representations are now located in and depictions with no surviving images are also included. 


\section{Chapter 2: Review of Previous Scholarship}

\subsection{Introduction}

Several scholars have published their ideas on different aspects of queenship during the Twelfth Dynasty. The majority of theories set forth by previous Egyptologists are brief or describe in little detail the political position of Twelfth Dynasty royal women. In general textbooks related to ancient Egyptian history, ${ }^{39}$ minimal attention has been brought to the political status of royal women and often the reign of Egypt's first documented female monarch Sobekneferu is barely mentioned or omitted. Within Middle Kingdom scholarship ${ }^{40}$ there is little in-depth study on the topic of Twelfth Dynasty royal women, especially beyond their titulary. This review of previous literature explores the few publications that argue for the concept of Twelfth Dynasty royal women having political power or influence.

The information in each section is ordered by publication date, with the exception of those scholars who have written multiple works on Twelfth Dynasty royal women for whom their later publications are listed after their earlier ones. This review also includes publications of collections of evidence consisting of descriptions of statues and titulary, along with a brief overview of the scholarship relating to the titles amd mortuary complexes of Twelfth Dynasty royal women. These publications are necessary to this study because most of the evidence for royal women comes from their burial sites and surviving artifacts.

\subsection{Gender and political power}

For the majority of modern history, politics has been considered an opportunity almost exclusively for men. ${ }^{41}$ This has carried over into the field of political science where women are a minority as university staff. ${ }^{42}$ Lovenduski's 1981 chapter "Toward the Emasculation of Political Science: the Impact of Feminism"43 brings attention to the shortcomings of feminist theory in the study of political science. She acknowledges the contribution feminism has made towards the exposure of sexist

\footnotetext{
${ }^{39}$ This is particularly noticeable in general overviews of the Twelfth Dynasty. Gardiner 1961; Hayes 1978, Grimal 1992; Tyldesley 2006.

${ }^{40}$ Some sample publications include: Arnold 1979; Arnold 1987; Arnold 1988; Arnold 1991; Bourriau 1988; Brunton 1920; Callender 2000; Hayes 1953; Petrie, Brunton, Murray: 1923; Ryholt 1997; Schneider 2006. For a comprehensive bibliography on the Middle Kingdom scholarship see the references listed in Oppenheim, Arnold, Arnold, Yamamoto 2015: 337-367.

${ }^{41}$ Squires 1999: 1.

${ }^{42}$ Ritter and Mellow 2000: 122.

${ }^{43}$ Lovenduski 1981: 83-97.
} 
biases found in political sciences and states:

The way in which Political Science reacts to such a turn [a genuinely feminist turn] will depend upon four factors: (1) openness and responsiveness; (2) developments in the object; (3) on internal professional political developments; (4) the quality of the new scholarship itself. ${ }^{44}$

Since 1981, Lovenduski has contributed multiple publications towards the scholarship of women in politics, including her 2005 book Feminizing Politics. ${ }^{45}$ She dedicates a chapter to the ideas of feminism and political representations defining politics as the "personnel, processes, relationships, institutions and procedures that make authoritative public decisions. ${ }^{" 46}$ Lovenduski further states that the roles of women and men in politics rely on each other and also how their specific institutions describe political representation. ${ }^{47}$ She categorizes political institutions as the "organizations, formal and informal rules, processes and procedures through which politics is done" 48 and it is through the power of these institutions that masculinity and femininity are shaped. ${ }^{49}$

Judith Squires's 1999 publication Gender in Political Theory ${ }^{50}$ examines the relationship between gender, modern political theory, and power. Squires introduces feminist theory and its relations with the discipline of politics by further building upon Lovenduski's previous arguments on how feminism theory has contributed to political science, including publicizing sexist biases, collecting new research material, and recognizing published works that challenge political studies. ${ }^{51}$ Squires states that feminist political theories have evolved from "adding women into the existing framework" to revealing the extent that the conceptions of gender actually structure politics. She describes the aims as a transformative project and how "adding women in" focuses on the ways politics structures gender relations while the latter displays how gender structures politics itself. ${ }^{52}$ Further into her introduction, Squires significantly explains the argument that gender is not a variable that can simply be added, concluding that gender is central to understanding the distribution

\footnotetext{
${ }^{44}$ Lovenduski 1981: 95.

${ }^{45}$ Lovenduski 2005.

${ }^{46}$ Lovenduski 2005: 13.

${ }^{47}$ Lovenduski 2005: 13-14.

${ }^{48}$ Lovenduski 2005: 26.

${ }^{49}$ Lovenduski 2005: 21, This is if sex and gender are understood as performances.

${ }^{50}$ Squires 1999.

51 Squires 1999: 17.

52 Squires 1999: 17.
} 
of power. ${ }^{53}$ This idea can be seen in the reigns and tenures of female rulers from ancient Egypt. This thesis does not add these women into the existing framework for kingship but demonstrates how the political office for the pharaoh was actually structured by both male and female components.

Similar to Squires's less detailed inclusion of Stephen Lukes's threedimensional definition of power, ${ }^{54}$ Pamela Paxton and Melanie M. Hughes's 2014 book Women, Politics, and Power: A Global Perspective ${ }^{55}$ introduces Lukes's definitions along with a comprehensive general example of the three different types of power. The three-dimensions are listed as:

Dimension 1: prevailing in a conflict over overt political preference Dimension 2: preventing the preferences of others from reaching the agenda Dimension 3: shaping the preferences of others to match yours ${ }^{56}$

Although the three dimensions are for modern political science, they can each be marginally applied to the ancient Egyptian government. For example, dimension one encompasses the pharaohs' political dominance and force. An artistic example of this is Sobekneferu's depiction crushing the nine bows beneath her feet as seen on her seated statues (Cat. 59, 60; Fig. 6.5, 6.6). Twelfth Dynasty military power is also exhibited from the numerous fortresses built by Senwosret III in Nubia (see Appendix I) that were in operation through Sobekneferu's reign. Dimension two can be applied to the absolute monarchy of ancient Egypt and the divine role of the pharaoh. Although there is no existing evidence to prove the ruling pharaoh personally prevented the preferences of others from reaching their agenda; the Loyalist Instruction from the Twelfth Dynasty describes how the ruler should be perceived by others as having the ultimate power. For example, the Loyalist Instruction from the Sehetepibre Stela states "He [monarch] is Ra, by whose rays one sees, for he is one who illuminates the Two Lands more than the sun disk" and explains that the monarch is all the gods and goddesses Khnum, Bastest, and Sakhmet ${ }^{57}$ which shows the ruler's ability to identify with any deity regardless of their gender (for further discussion see Chapter 3.4). Dimension three is the propaganda used by the ancient Egyptian rulers and encompasses the largest variety

\footnotetext{
53 Squires 1999: 19.

54 Squires 1999: 33.

55 Paxton and Hughes 2014.

${ }^{56}$ Paxton and Hughes 2014: 21.

${ }^{57}$ Simpson 2003: 173.
} 
of examples. Twelfth Dynasty specific cases include the dynamic changes in iconography for both royal women and men such as the severe facial characteristics, along with the standardization of the uraeus and sphinx form (see Chapter 4).

Furthermore, Sobekneferu's use of pharaonic regalia to display a sole female ruler as seen on her torso (Cat. 58; Fig. 6.1) presents the message or statement about the ideology of the pharaonic office that was accepted during her reign and subsequently all female rulers' times.

Paxton and Hughes further explain the difference between sex and gender stating that gender is practiced on a daily basis by people who are active agents who perform the gender. They also cite Lorber who describes a woman as a creature that civilization as a whole produces and characterizes as feminine. ${ }^{58}$ Within their "Women Struggle for Representation: Accessing Positions of Power" and "Explaining the Political Representation of Women-Culture" chapters, Paxton and Hughes observe multiple key points, including two problems with women accessing political power. They reference the previous label by D'Amico, which is the "widow's walk to power", ${ }^{59}$ discussing how multiple women in modern Asia have held power through the death of a male family member. Although their accession is no different than another male family member, they are able to legitimize their positions through the relationship they had with the deceased. ${ }^{60}$ Secondly, Paxton and Hughes address the two main historical arguments of why women have not regularly been in positions of political power. The two arguments being that:

1. Women naturally do not have the temperament of capabilities necessary for political participation.

2. Politics are simply out of a women's proper sphere. ${ }^{61}$

These two perspectives on the accession and place of women in government and holding political power can again respectively be adapted to royal women in ancient Egypt. As discussed in Chapter 3 of this thesis, royal mothers often ruled as regents for their son, although the term "widow's walk to power" cannot be directly applied. As mentioned earlier, royal women have also been categorized as having little or no

\footnotetext{
${ }^{58}$ Paxton and Hughes 2014: 25.

${ }^{59}$ D'Amico 1995:18.

${ }^{60}$ Paxton and Hughes 2014: 87.

${ }^{61}$ Paxton and Hughes 2014: 103.
} 
governmental participation due to their gender or simply because political power was routinely controlled by men.

\subsubsection{Gender studies in Archaeology}

Gender and Archaeology is recently a strongly discussed subject that has produced numerous publications. For this thesis, there are four key publications for the discussion of gender studies in Archaeology and Egyptology: Engendering Archaeology: Women and Prehistory; ${ }^{62}$ Gender in Archaeology: Analyzing Power and Prestige; ${ }^{63}$ Archaeologies of Social Life: Age, Sex, Class et cetera in Ancient Egypt; ${ }^{64}$ and Gender Archaeology ${ }^{65}$ Lynn Meskell's 1999 publication Archaeologies of Social Life is the only one of the four that specifically addresses issues in Egyptian archaeology. She discusses her theoretical concepts and further demonstrates her theories by using the New Kingdom village of Deir el-Medina as a framework to understand how individuals dealt with their social relations.

Published in 1991, Joan Gero and Margaret Conkey’s edited volume Engendering Archaeology: Women in Prehistory is an early attempt at addressing gender and archaeology. The book is composed of fourteen chapters by different authors highlighting problems and solutions in understanding women through the archaeological record. Within the authors' lead article "Tensions, Pluralities, and Engendering Archaeology: An Introduction of Women in Prehistory" they address the androcentric past that has been claimed as gender-neutral. They define the productions of gender through history as "a constitutive element of human social relations, based on culturally perceived and culturally inscribed difference and similarities between and among males and females." ${ }^{\prime 66}$ Gero and Conkey criticize the idea of women being unchanging throughout history and that gender biases can be corrected simply by adding new information about women. In discussing the invisibility of women in archaeology they question an important point: Why is there a need to find women in the past but not men? They note that simply adding women into the past will not answer why we need to find them ${ }^{67}$ This is a similar point

\footnotetext{
${ }^{62}$ Gero and Conkey 1991.

${ }^{63}$ Nelson 1997.

${ }^{64}$ Meskell 1999.

${ }^{65}$ Sørensen 2000.

${ }^{66}$ Gero and Conkey 1991: 8.

${ }^{67}$ Gero and Conkey 1991: 12-13.
} 
Wylie makes in the proceeding chapter "Gender Theory and the Archaeological Record: Why is there no Archaeology in Gender?"68 as well as an idea Squires discusses in the aforementioned book Gender in Political Theory.

In Gender in Archaeology: Analyzing Power and Prestige, Sarah Nelson mentions Egypt twice in reference to DNA sex analysis in mummies ${ }^{69}$ and how the royal succession line descended through the female members. ${ }^{70}$ Nelson highlights the double standard for recognizing powerful women through archaeology and notes that when a woman's burial is discovered with riches, possibly richer than other males, the woman is labelled as the ruler's wife or is rich only due to her male relative's status. ${ }^{71}$ She further examines the perceptions of women's public roles and how gender can be incorrectly assigned based on the archaeologist's bias of power. Nelson's concept and suggestion of women's archeological representation of public power is used throughout this thesis. She states,

The awareness that women hold various kinds of public positions is the beginning of "finding" gender in the political interpretations of archaeological sites. Further steps involve looking at public roles more in terms of negotiation and less in terms of dominance and raw power. ${ }^{72}$

Meskell begins her book Archaeologies of Social Life: Age, Sex, Class et cetera in Ancient Egypt by examining individuals and bodies. She discusses the individual, person, identity, and self, commenting that the individual is the physical "skin bound" human and personhood is the social being that culturally enhances the individual. ${ }^{73}$ The author also makes two compelling statements in regard to the concepts of beauty and sexuality. She notes that men were often the main wearers of different types of jewelry, including earrings, bracelets, necklaces, and rings. ${ }^{74}$ She further states that as a result of modern perceptions, women are repeatedly assumed to be sexualized objects in a society and differences between individuals and past societies are not identified. ${ }^{75}$

Meskell criticizes Egyptologists' constant misreading of ancient Egyptian female bodies and sexualities, expressing that the body and sexuality are taken

\footnotetext{
${ }^{68}$ Wylie 1991: 31-49.

${ }^{69}$ Nelson 1997: 59.

70 Nelson 1997: 127.

${ }^{71}$ Nelson 1997: 133.

72 Nelson 1997: 148-149.

${ }^{73}$ Meskell 1999: 32.

${ }^{74}$ Meskell 1999: 63.

${ }^{75}$ Meskell 1999: 64.
} 
directly from iconographic sources with little consideration to social constructs. She states that "woman is reduced to a visual spectacle." "76 Using the village of Deir elMedina as a case study, Meskell concludes that gender is not the primary difference. Her statements coincide with third-wave feminism, suggesting that multiple factors should be taken into account, such as rank, status, tomb types, and restrictions of ethnicity. ${ }^{77}$ Within her final chapter "Accessing Individuals at Deir el Medina" Meskell uses burial data to detail the life experiences of individuals from the village. She examines the content of multiple tombs at Deir el-Medina and lists what the burial goods monetary worth are, which gives the reader a useful understanding of gender and corresponding object value.

Similar to Nelson's suggestions of negotiation of raw power and dominance, Marie L.S. Sørensen densely discusses the negotiation of gender in her publication Gender Archaeology. She defines negotiation as "the continuous maintenance of, or attempts at maintaining, an agreed view of rights and obligations" ${ }^{\prime 78}$ and that negotiation of gender studies not only intertwines male and female but also it affects political and economic practices. Within her description Sørensen states that when gender arises from many dimensions it becomes fluid and this "stretchable identity" has to be agreed upon socially and this agreement further becomes the cultural construct. ${ }^{79}$ This idea is respectively paired with Nelson's aforementioned statement throughout the thesis. Both concepts are used in understanding the ancient Egyptian royal succession line, which was systematic and also negotiable in terms of sex and gender.

\subsubsection{Women in Ancient Egypt}

Women have generally been included in histories of ancient Egypt and multiple publications have been devoted to highlighting the place of women in society. ${ }^{80}$ Barbara S. Lesko's The Remarkable Women of Ancient Egypt ${ }^{81}$ is one of the first

\footnotetext{
${ }^{76}$ Meskell 1999: 97.

${ }^{77}$ Meskell 1999: 141, 152, 175.

${ }^{78}$ Sørensen 2000: 61.

${ }^{79}$ Sørensen 2000: 61.

${ }^{80}$ Allam 1989; Blackman 1921; Bryan 1996; Callender 1992a; Callender 1992b, Callender 2011a; Capel and Markoe 1996; Eldamaty, Hoffmann, and Minas-Nerpel 2015; Fay, B. 1991; Grajetzki 2009; Lesko 1991; Lohwasser 2001; Quirke 2007; Robins 2002; Roehrig 1996; Sabbahy 1982; Szpakowska 2008; Wilfong 1997.

${ }^{81}$ Lesko 1978.
} 
publications featuring an enthusiastic perspective in regard to the status of women. Lesko notes that it was known that royal women could be regents, briefly mentioning that Sobekneferu was a female monarch during the Twelfth Dynasty and

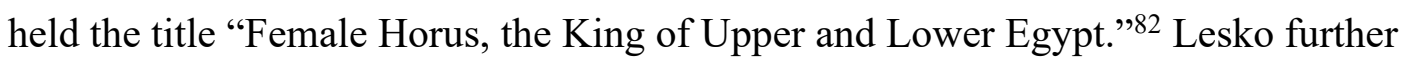
discusses the tenures of multiple New Kingdom queens and later presents the significant aspects of non-royal women, including their legal equality along with their work as laborers and priestesses.

One of the most significant and referenced general publications on ancient Egyptian women is Gay Robins's Women in Ancient Egypt. ${ }^{83}$ The publication is dedicated to the study of women from ancient Egypt and is presented as a survey over ten chapters. The first two chapters discuss royal women and queenship, which is followed by three chapters dealing with the lives of women, such as marriage, pregnancy, and family. The next two chapters are a review of ancient Egyptian women's occupations along with their economic and legal statuses. The final three chapters deal with the position of women in temple rituals, their death and afterlife, along with a discussion on the surviving images of women found in art. The book as a whole serves as a significant and useful tool for women studies, with the first two chapters "Royal Women and Queenship" 84 and "Queens, Power, and the Assumption of Kingship" ${ }^{85}$ relating to this thesis on royal women. In the first chapter, Robins begins by stating that "Royal women in ancient Egypt derived their importance from their relationship to the king, who was always, apart from a very few exceptions, male." 86 As discussed in Chapter 3.2 of this thesis, during the Twelfth Dynasty royal women emphasized their relationship with divine office of pharaoh rather than with the physical person holding the position. The usage of the word "importance" in Robins' opening sentence is also vague and does not clarify what part of the life of the royal woman is important. Nevertheless, Robins is successful in creating a detailed narrative for the different subsections of the chapter and presenting information about the lives of royal women including divine and physical.

Robins's second chapter "Queens, Power and the Assumption of Kingship" addresses the existence of female rulers and is often referenced in regard to powerful

\footnotetext{
${ }^{82}$ Lesko 1978: 3.

${ }^{83}$ Robins 1993.

${ }^{84}$ Robins 1993: 21-41.

${ }^{85}$ Robins 1993: 42-55.

${ }^{86}$ Robins 1993: 30.
} 
women. Within the chapter Robins discusses the surviving evidence for five royal women from the Eighteenth Dynasty: Ahhotep II, Ahmosenefertari, Hatshepsut, Tiy, and Nefertiti. The author rightfully notes that researchers can never really know the personal stories of royal women and the interconnection of Egyptian kingship and queenship meant one could not exist without the other. ${ }^{87}$ She also acknowledges that queenship has to be understood in order to comprehend the ideology of kingship. ${ }^{88}$ Robins concludes that "kingship itself was not an office open to women on normal terms" 89 which is in contrary to this thesis's explanations of the pharaonic office, kingship, and queenship. Although more men ruled in the pharaonic office than women, the office continually allowed for women to rule (see Chapter 3.2).

The first American museum exhibition dedicated to women in ancient Egypt was in 1996 by the Cincinnati Art Museum. The accompanying catalogue Mistress of the House Mistress of Heaven: Women in ancient Egypt was edited by Anne Capel and Glenn Markoe. ${ }^{90}$ The three main essays, written by Catharine Roehrig, Betsy Bryan, and Janet Johnson address the occupations, roles, and legal statuses of Egyptian women. The catalogue of the exhibition composes the majority of the publication and highlights the lives of Egyptian women on all levels, including motherhood, royalty, and the afterlife. Two Twelfth Dynasty female sphinxes are included in the "Female Royalty" section of the catalogue. The catalogue also includes the head of a queen or princess in the Brooklyn Museum (Cat. 65) ${ }^{91}$ and the head of a female sphinx in the Museum of Fine Arts, Boston (Cat. 64). ${ }^{92}$

While Twelfth Dynasty royal women are not specifically mentioned, in her essay "In women good and bad fortune are on earth: Statue and roles of women in Egyptian culture" Bryan briefly discusses Sobekneferu under the Women as Rulers subsection. Bryan includes Sobekneferu's pharaonic titulary, her familial relationship with Amenemhat III and Amenemhat IV, as well as a discussion on her multiple inscriptions. She also addresses the fact that Sobekneferu was legitimized as pharaoh and uses her torso now located in the Louvre (Cat. 58) as evidence of Sobekneferu's evolution of rulership from earlier time periods. Bryan further

\footnotetext{
${ }^{87}$ Robins 1993: 42.

88 Robins 1993: 55.

${ }^{89}$ Robins 1993: 55.

${ }^{90}$ Capel and Markeo 1996.

${ }^{91}$ Capel and Markoe 1996 106-107.

${ }^{92}$ Capel and Markoe 1996 107-108.
} 
questions if any royal family member could rule Egypt regardless of their gender, although she departs from this idea and cautions that Sobekneferu's reign may have ended in unfortunate terms along with her name being included in the ruler list under "grudging" circumstances. ${ }^{93}$

In the following year the second American exhibition centered on ancient Egyptian women was located at Kelsey Museum of Archaeology. Similar to the Mistress of the House Mistress of Heaven ${ }^{94}$ exhibition catalogue, Women and Gender in Ancient Egypt: From Prehistory to late Antiquity written by Terry Wilfong concentrates on the life experiences of ancient Egyptian women. It also examines the relationships of women and gender, along with sexuality, class, ethnicity, and status. By using the artifacts in the exhibition, the work accompanying the catalogue seeks to understand the gender roles in ancient Egypt. ${ }^{95}$

Wilfong significantly highlights the gender ambiguity of some ancient Egyptian objects. He notes they often have biological traits to accentuate the sex of the person being represented. Gender could also be displayed in multiple ways, such as the figure's sizes and color. Importantly, he notes some ancient Egyptian objects were originally made to indicate no particular gender and that assigning gender can become blurry because women and men often had similar clothes and body types. ${ }^{96}$ In a later chapter "Gender and Power" Wilfong acknowledges the ruling ability of royal women, and while referring to the work of Lana Troy, Queenship (see below) states that kingship ideology was comprised of a blend of male and female elements. ${ }^{97}$

Originally conducted as the third annual conference organized by the Egypt Centre, the proceedings were published by Carolyn Graves-Brown in 2008 as Sex and Gender in ancient Egypt: Don your wig for a joyful hour..$^{98}$ This volume incorporates contributions from multiple Egyptologists discussing conflicts in understanding gender and sex in ancient Egypt. In her chapter "Rules of Decorum and Expressions of Gender Fluidity in Tawosret's Tomb"99 Heather McCarthy examines the changing decoration in the Tausret's tomb located in the Valley of the

\footnotetext{
93 Bryan 1996: 29-30.

94 Wilfong 1997.

${ }^{95}$ Wilfong 1997: 9, 11.

${ }^{96}$ Wilfong 1997: 17-19.

97 Wilfong 1997: 36.

98 Graves-Brown 2008.

${ }^{99}$ McCarthy 2008 83-113.
} 
Kings (Tausret see Chapter 3.5.6). Similar to Sobekneferu, Tausret expressed gender fluidity in her iconography that corresponded with her time in the pharaonic office. McCarthy concludes that from the beginning of Tausret's tomb construction, it was planned to be different than others located in the valley. Additionally, before becoming regent and pharaoh, Tawosret may have even been Sety II's co-regent. ${ }^{100}$

Within her chapter "The Problem of Female Rebirth in New Kingdom Egypt" Kathlyn Cooney discusses the woman's afterlife transition from female to the male Osiris and back to female. She notes that gender is often mixed and coffins could be androgynous, leaving the gender signifiers to be displayed by the burial goods. ${ }^{101}$ Cooney also states that the adaptation of gender when becoming Osiris is restricted to elite burials. ${ }^{102}$ Within her contribution "The Bearded Woman and the Queen" Racheli Shalomi-Hen analyzes how the seated bearded man became a signifier for both divine and ordinary women. She explains that during the Old and Middle Kingdoms female divine names are often followed by the seated bearded man instead of the ordinary women and that male divine names are followed by the ordinary women instead of the seated bearded man. ${ }^{103}$ This type of interchangeability shows a type of gender identification but more importantly that the divinity of the women should be shown. ${ }^{104}$

\subsubsection{Women's political role in the ancient Egyptian government}

Despite the increase of publications discussing queenship in ancient Egypt, there is still no one study that addresses the political-historical role of royal women. Scholarly research has been limited to understanding the status of royal women by their relationships with men and discussion has been restricted to the legitimacy of the women's rules, regardless of the work. In contrast, there have been numerous publications solely dedicated to the role of the king and the ideals of kingship, such as Ancient Egyptian Kingship ${ }^{105}$ edited by David O'Connnor and David Silverman, and the recent British Museum catalogue Pharaoh: King of Ancient Egypt ${ }^{106}$ by Marie Vandenbeusch, Aude Semat, and Margaret Maitland.

The 2016 catalogue Pharaoh: King of Ancient Egypt serves as an engaging

\footnotetext{
${ }^{100}$ McCarthy 2008104.

${ }^{101}$ Cooney 2008: 6, 13 .

102 Cooney 2008: 15.

103 Shalomi-Hen 2008: 184.

104 Shalomi-Hen 2008: 186.

105 O'Conner and Silverman 1995.

106 Vandenbeusch, Semat, and Maitland: 2016.
} 
example of how ideas of the pharaonic office are still approached in comparison to earlier publications such as Ancient Egyptian Kingship. The catalogue includes a valuable description about the pharaonic office and many exquisite photographs of artworks depicting different pharaohs along with the items associated with them. It also mentions that not all pharaohs were male but includes the reigns of female pharaohs as not conforming to the ideal. ${ }^{107}$ Sobekneferu is not mentioned throughout the entire catalogue and is not even included in the incomplete chronology of rulers. While informative, these types of publications remind the reader that the knowledge of women in the ancient Egyptian government is still at surface level and needs to be further explored.

The operant definitions offered in this thesis for Queenship ideology and the Queen (see Chapter 3.2) are based on three main publications. The earliest is Lana Troy's Patterns of Queenship in Ancient Egyptian Myth and History, ${ }^{108}$ which is discussed below in section 2.3. Additionally, the publications by Baines and Yoffee, "Order, Legitimacy, and Wealth in Ancient Egypt and Mesopotamia", ${ }^{109}$ along with Ellen Morris's "The Pharaoh and the Pharaonic Office"110 are also used. Baines and Yoffee's “Order, Legitimacy, and Wealth" is located in Archaic States, an edited volume by Gary Feinman and Joyce Marcus. ${ }^{111}$ Baines and Yoffee's contribution concentrates on the power of kingship in both ancient Egypt and Mesopotamia while using the concepts of order, legitimacy, and wealth as the comparison terms. ${ }^{112}$ They define kingship as,

Among forms of political structure, kingship can be defined, rather inexactly, as rulership by a single individual holding a supreme office in a lifelong tenure, most often succeeding on a hereditary principle and wielding-or-not, as the case may be-great personal power. ${ }^{13}$

The authors also note that while kingship is the most common form of government, it is not the only one. They further explain that the king of Egypt was the sole intermediary between humans and the divine, along with his role being more about legitimacy rather than military force. The king or pharaoh ruled as an absolute

\footnotetext{
${ }^{107}$ Mailand 2016: 18.

108 Troy 1986.

${ }^{109}$ Baines and Yoffee 1998.

${ }^{110}$ Morris 2010.

${ }^{111}$ Feinman and Marcus 1998.

112 Baines and Yoffee 1998: 199-260.

113 Baines and Yoffee 1998: 205.
} 
monarchy and had dominant influence over the elite. ${ }^{114}$ Baines and Yoffee's definition of kingship is remodeled in this thesis as the legitimate definition of the physical person in the pharaonic position as well as the king (biological male) and queen (biological female).

This separation of the office and the person can be found in the Morris's article "The Pharaoh and the Pharaonic Office" within Alan Lloyds's edited book $A$ Companion to Ancient Egypt. Morris begins by citing Kantorowitz and delineating ancient Egyptian kingship by stating that "Egyptian kingship was that the body politic was unequivocally divine but was by necessity filled by a body natural."115 This statement, combined with Baines and Yoffee's interpretation of kingship, allows for the definitions found in chapter 3.2 of this thesis. Baines and Yoffee's "rulership by great personal power" and "single individual" correlates with Morris's "body politic" and "body natural". Morris includes an analysis about royal eligibility and accession rights. She briefly mentions daughters could rule, although she does not consider them when discussing the occupations and public life of the king's children. ${ }^{116}$ Morris further describes the divine role of the king along with the duties of pharaoh, including religious activities in temples, being the sole military representative for all Egyptians, and conducting government orders. ${ }^{117}$ Although never addressing female rulership, in her conclusion she raises important points. She notes that because the kingship of ancient Egypt depended on the ruler's relationship with the deities, anyone (body natural) through their devotion to the gods could rule over Egypt. She also states that in many periods the institution of kingship allowed for "greater power-sharing and negotiation than is commonly thought." 118 These concluding statements are successful in opening questions for future research regarding regency, co-regency, and female rulership, some of which are addressed in this thesis.

\footnotetext{
114 Baines and Yoffee 1998: 206-207.

115 Morris 2010:

${ }^{116}$ Morris 2010: 202-207.

${ }^{117}$ Morris 2010: 207-214.

${ }^{118}$ Morris 2010: 216.
} 


\subsection{Publications that consider the political presence of Twelfth Dynasty royal women}

With the smaller inclusions of two royal women from the time of Senwosret II (Nefert and Sithathoryunit), Flinders Petrie's A history of Egypt ${ }^{119}$ is the first publication to cover royal women in the Twelfth Dynasty, including the reign of the female monarch Sobekneferu. Petrie mentioned that her name is found as often as her father's Amenemhat III at Hawara and is certainly associated with him more than his son Amenemhat IV. ${ }^{120}$ Unlike later general history books on ancient Egypt, Petrie commented on the exquisite craftsmanship of the Twelfth Dynasty. Although his observations are relatively early, he did not suggest that Sobekneferu began the decline of the Twelfth Dynasty and instead compared the long reign of Amenemhat III to Pepi II's of the Sixth Dynasty, which had eventually led to disorganization. ${ }^{121}$ As mentioned in the introduction, succeeding authors of ancient Egyptian history did not generally follow Petrie's view. It was not until ninety years later that Lana Troy $^{122}$ again directly commented on the high status of Twelfth Dynasty royal women.

Lisa Sabbahy's unpublished dissertation, The Development of the Titulary and Iconography of the Ancient Egyptian Queen from Dynasty One to Early Dynasty Eighteen $^{123}$ is the first study to thoroughly investigate the complexity of royal female titles and iconography of the Twelfth Dynasty. She divides the royal women into two groups, queens and princess, and references the objects on which their titles are found. Sabbahy does not comment precisely on the status of royal women during the Twelfth Dynasty, but she makes comments stating that certain aspects of the royal women had undergone changes, such as "without a doubt, however, the nature of the queen's titulary has dramatically changed" 124 and "the sharing of certain titles of the queen with princesses $[\ldots]$ did not occur in the Old Kingdom or even during the First Intermediate Period." 125

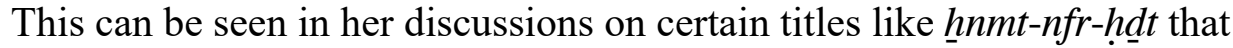
directly connects queens and princess with the politically associated white crown of

\footnotetext{
119 Petrie 1894.

120 Petrie 1894: 197-198

${ }^{121}$ Petrie 1894: 198-199.

122 Troy 1986.

123 Sabbahy 1982.

124 Sabbahy 1982: 181.

125 Sabbahy 1982: 217.
} 
Upper Egypt. Sabbahy also writes that Neferuptah's name was the "first known instance of a female name in a cartouche" and that this type of honor was extraordinary. ${ }^{126}$ This is because the cartouche shows the high political status of royal women during this time.

Sabbahy's publication "The female family of Amenemhat II: A review of the evidence" 127 examines the conclusions made by Biri Fay ${ }^{128}$ in regard to the women associated with Amenemhat II. Similar to the ideas presented in her dissertation, Sabbahy concentrates on the titulary and iconography of the Twelfth Dynasty royal women, stating that

The inability to distinguish between a queen and a princess by titulary is a major problem in dealing with the titles of royal women in the Twelfth Dynasty. These queens and princesses share the same royal insignia as well, and the lack of distinct symbols belonging just to the queen is the most dramatic change seen in royal female status since the Old Kingdom. ${ }^{129}$

Sabbahy specifically discusses nine royal women and their familial relationships with Amenemhat II: Keminub, Neferu, Kaneferu, Sithathormeryt, Itaweret, Khenemetneferhedjet I, Khnemet, Ita, and Nefert. Her examination of the royal women and their chronology is significant because it aids in understanding their political positions and relationships with the pharaoh. Sabbahy's concluding theories suggest there are four daughters of Amenemhat II $^{130}$ and that Khenemetneferhedjet is a title and not a name, which is accepted by Biri Fay, ${ }^{131}$ Lana Troy, ${ }^{132}$ Vivienne Callender, ${ }^{133}$ Silke Roth, ${ }^{134}$ Aidan Dodson, ${ }^{135}$ and Stefania Pignattari. ${ }^{136}$ Additionally, the royal woman Nefert has 'mixed titulary'137 because she was the daughter of a king and wife of a co-regent. ${ }^{138}$ The mixed titulary is important because Twelfth Dynasty royal women's titles shifted along with the political

\footnotetext{
126 Sabbahy 1982: 208.

127 Sabbahy 2003.

${ }^{128}$ Fay 1996.

${ }^{129}$ Sabbahy 2003: 243.

130 Sabbahy 2003: 244.

${ }^{131}$ Fay 1996.

132 Troy 1986.

133 Callender 1992.

${ }^{134}$ Roth 2001.

135 Dodson 2004.

${ }^{136}$ Pignattari 2008.

137 "The mixed titulary is a distinctive feature of the royal female titulary which appears only in the Twelfth Dynasty." Sabbahy 2003: 240.

138 Sabbahy 2003: 244.
} 
stability of the pharaohs.

Lana Troy's 1986 publication Patterns of Queenship in Ancient Egyptian Myth and History ${ }^{139}$ still stands as one of the most significant works on queenship. Within her book, she clarifies the role queens played within religion and the royal family. The appendix "Royal women, titles, and epithets" is also an important reference because the majority of the known titles for Twelfth Dynasty royal women are listed (see below Chapter 2.5). In her discussions of regency Troy concentrates on titles as well as the "feminine prototype" 140 and discusses the transition of titles and certain iconography from the Middle to the New Kingdom, stating that "the accumulation of these varying symbols of the authority of the kingship in the iconography of the royal women suggests a gradual elevation of the status of the feminine element." 141 Troy expands this theory and explores the ideology of queenship through her later articles, such as "The Ancient Egyptian Queenship as an Icon of the State"142 and "She for Whom All That is Said is Done: The Ancient Egyptian Queen." 143 Troy states that without the feminine authoritative element, kingship in ancient Egypt would not exist ${ }^{144}$ and that the ancient Egyptian kingship in myth and political aspects depended upon the feminine element. ${ }^{145}$ She also draws attention to the importance of Neferuptah and Sobekneferu during the Twelfth Dynasty, acknowledging the possible accession to the throne of Neferuptah and Sobekneferu's official political position as pharaoh. ${ }^{146}$ The theory that Neferuptah may have planned to ascend to the throne before Amenemhat IV and Sobekneferu marks a change in the understanding of the political presence and power already in place for the Twelfth Dynasty royal women. This idea is also further acknowledged by Vivienne Callendar, ${ }^{147}$ Stefania Pignattari, ${ }^{148}$ and Aidan Dodson. ${ }^{149}$

Vivienne Gae Callendar is a leading scholar in regard to examining royal

\footnotetext{
139 Troy 1986.

140 "One element in a system of complementary dualities [male and female], functioning in the context of androgyny of the primeval source, as a medium of transformation in the process of renewal and resurrection." Troy 1986: 53.

141 Troy 1986: 134.

142 Troy 2002.

143 Troy 2003.

144 Troy 2002: 24.

145 Troy 2003: 113.

146 Troy 2003: 95-96.

${ }^{147}$ Callender 1992.

148 Pignattari 2008.

${ }^{149}$ Dodson 2004.
} 
women in ancient Egypt and has written multiple works aimed at understanding queenship during the Twelfth Dynasty. Her contributions include her unpublished dissertation The Wives of the Egyptian Kings: Dynasties I-XVII, ${ }^{150}$ "Female Officials in Ancient Egypt and Egyptian Historians,"151 "A Review of All Known Material for Queen Sobekneferu of Dynasty 12,"152 "What Sex was Sobekneferu?,"153 and "The Middle Kingdom Renaissance (c. 2055-1650 BC)". ${ }^{154}$ While examining the same evidence previously published by Sabbahy, Callender's interpretations diverge by further theorizing about the high status of Twelfth Dynasty royal women. In The Wives of the Egyptian Kings, Callender directly addresses the status and position of the royal women in the Twelfth Dynasty. She states,

The status of the queen was not static: it underwent a slow, but continuous evolution throughout the pharaonic period. ${ }^{155}$ Thus, both the titulary and iconography of the wives of the kings show a progressive growth in the prestigious representation of the queen between Dynasties XI-XVII. ${ }^{156}$

The information Callendar uses for these statements includes comparisons to Old Kingdom royal women. She also states that "in the Middle Kingdom the position of the queens was more prominent in the monument records [and] sometimes the queens appear on other types of dedicatory stelae, and this phenomenon, too, represents a change of custom." ${ }^{157}$ Furthermore, her dissertation brings attention to the sphinx form, which was favored in representing Twelfth Dynasty royal women. This is the first time the sphinx became common for royal women, and in her brief discussion she describes the new style as "signaling some new religious interpretation of the role of royal women [also indicating] another form of religious elevation for royal women at that time." ${ }^{158}$

In "Female Officials" Callender dedicates a brief section of the chapter to the Middle Kingdom queens, mentioning their significant title 'Mistress of the Two Lands' and Sobekneferu's ability to exercise pharaonic power. ${ }^{159}$ Her published

\footnotetext{
150 Callender 1992a.

${ }^{151}$ Callender 1992b.

152 Callender 1998a.

${ }^{153}$ Callender 1998b.

154 Callender 2003.

155 Callender 1992a: 275-276.

156 Callender 1992: 277.

157 Callender 1992: 275.

${ }^{158}$ Callender 1992: 277.

${ }^{159}$ Callender 1992b: 29.
} 
conference paper "Material for Sobekneferu" is the only publication solely dedicated to the evidence for Sobekneferu's reign. Within this work, Callendar lists and discusses over seventeen items ${ }^{160}$ that are associated with her time on the Egyptian throne. She also brings attention to the high quality of workmanship during Sobekneferu's reign that coincides with her successful reign on the throne of Egypt. Significantly, but briefly, Callender mentions the theory that Hatshepsut drew inspiration from the works and actions of Sobekneferu to legitimize her position as pharaoh. ${ }^{161}$

Continuing with her discussions of Sobekneferu, Callender's article on the "Sex of Sobekneferu" includes an overview of the gender transitions during her reign, although no new theories are suggested. She discusses Sobekneferu's name, titulary, ${ }^{162}$ high standard of art, and her building projects. ${ }^{163}$ Within The Oxford History of Ancient Egypt, the chapter "Middle Kingdom Renaissance" keeps to the theme of the book and concentrates on the history of the Twelfth Dynasty. Callendar makes the brief but direct statement "the prominence of Neferuptah both during [Amenemhat III's] reign and after her death, together with the mortuary privileges provided for her and for the two queens at Dahshur, suggests the increased status of royal women in the late $12^{\text {th }}$ Dynasty." 164 This statement was not further developed until five years later in Stefania Pignattari's book Due donne per il trono d'Egitto: Neferuptah e Sobekneferu, ${ }^{165}$ which is discussed below in this thesis's review.

Silke Roth's publication Die Königsmütter des Alten Ägypten: von der Frühzeit bis zum Ende der 12. Dynastie ${ }^{166}$ is a detailed study of the role of the mother of the pharaoh from the First Dynasty to the end of the Twelfth Dynasty. Roth devotes her chapters to the chronology, titles, iconography, political position, and the cult of the pharaoh's mother. In regard to the Twelfth Dynasty, Roth includes descriptions of Neferet I, the mother of Amenemhat I; Nefertitannet, The mother of

\footnotetext{
${ }^{160}$ Callender 1998a: Sphinx; 230; Kneeling, and two seated statues from Tell el-Dab'a: 230; numerous columns, blocks, and plaques from Hawara: 230; Temple at Kom el-Aqarib: 230-231, inscription at the Labyrinth: 231, bead: 231; green pottery scarab: 231, cylinder seal from Cairo: 232; Nile graffito at the Second Cataract: 232; ivory scarab 232-233; glazed blue cylinder seal: 233 (BM EA 16581); column in Cairo museum: 233; torso statue in the Louvre: 233-234 (E 27135); and the possible statue at the MMA: 235 (MMA 65.59.1).

${ }^{161}$ Callender 1998a: 236.

162 Callender 1998b: 50.

163 Callender 1998b: 54.

164 Callender 2000: 158.

165 Pignattari 2008.

166 Roth 2001.
} 
Senwosret I; Neferu IV, the mother of Amenemhat II; Khenemetneferhedjet I, mother of Senwosret III; Hetepi, the mother of Amenemhat IV; and Senet, the suggested mother of Sobekneferu. ${ }^{167}$ Her description of Sobekneferu is significant because she is the first scholar to associate the king's mother Senet to Sobekneferu who was named ruler of Egypt. ${ }^{168}$ Furthermore, Roth gives an overview of the Twelfth Dynasty royal women's titles, iconography, and tombs ${ }^{169}$ stating that three quarters of the royal mothers from the Twelfth Dynasty are known because Senwosret II and Amenemhat III's mothers are still unknown. ${ }^{170}$ It can be debated that the mother of Senwosret II is Keminub because she is the only queen associated with Amenemhat II, ${ }^{171}$ and the possibilities for the mother of Amenemhat III are queens Neferhenut along with Khenemetneferhedjet II. ${ }^{172}$ Roth does not comment on the mother of Neferuptah; however her study is highly significant for understanding all other royal women in the Middle Kingdom. The publication is also essential for this thesis' research and reconstructing the royal female lineage.

The first publication explicitly addressing the status of Twelfth Dynasty royal women was Jack Josephson and Rita Freed's 2007 article “The Status of the Queen in Dynasty XII." 173 Within the publication Josephson and Freed compile evidence for the royal women's rise of status, concluding that during the Twelfth Dynasty the royal women's status dramatically rose. They state that,

The dramatic rise in the status of the queen at this time, demonstrated in part by her assumption of various aspects of the iconography of kingship, represented a major turning point in the role of the queen. The suddenness of this transition remains unexplained, but undoubtedly there was an extraordinary enhancement in the status of the royal female, who no longer functioned merely as a consort of the king but rose to occupy a vital position in the politics and religion of the nation. ${ }^{174}$

Josephson and Freed also include a catalogue for the artworks of Twelfth Dynasty royal women, which is the first to include references to twenty-one artworks of Twelfth Dynasty royal women and is fundamental to the more complete catalogue located in this thesis.

\footnotetext{
167 Roth 2001: 217-245.

168 Roth 2001: 242-245.

169 Roth 2001: 203-216.

170 Roth 2001: 203.

${ }^{171}$ Sabbahy 2003: 240.

172 Troy 1986: 158.

173 Josephson and Freed 2007.

174 Josephson and Freed 2007: 137.
} 
Recently published in 2008, Stefania Pignattari's book Due donne per il trono d'Egitto: Neferuptah e Sobekneferu ${ }^{175}$ is a publication that is devoted to discussing the tenure of Neferuptah and reign of Sobekneferu. Pignattari dedicates a chapter to the queens Aat, Hetepi, and Khenemetneferhedjet III, who are possibly the mothers of the sisters Neferuptah and Sobekneferu. She also has two separate chapters examining the independent lives of Neferuptah and Sobekneferu. She questions the theory that the Twelfth Dynasty ended because there was no suitable male heir, ${ }^{176}$ and similar to Troy and Callendar she emphasizes the importance of the political position of royal women during the reign of Amenemhat III $^{177}$ by stating that "perhaps during a period of prosperity and full of grand innovations, which was the Twelfth Dynasty, Amenemhat III contemplated the possibility of choosing a woman as his heir." 178

Pignattari describes Neferuptah as one of the most influential women of the Middle Kingdom because of her closeness with her father, mortuary complex, and being the first royal woman to have her name encircled within a cartouche. ${ }^{179}$ She also notes that the line of royal succession is often considered from Amenemhat III to Sobekneferu, ${ }^{180}$ generally including co-regency, making the reign legitimacy clearly connected to one if not both of the two princesses. ${ }^{181}$ In the same year Aidan Dodson mentioned the theory of Neferuptah being the intended heir, ${ }^{182}$ but Pignattari's book is the most recent detailed analysis of the possibility that the royal line was actually meant for Neferuptah and Sobekneferu.

\subsection{Overview of evidence}

Although Jacques Vandier did not express any opinion on the political position or status of Twelfth Dynasty royal women, his publication Manuel d'Archéologie Égyptienne: La Statuaire Égyptienne ${ }^{183}$ still remains an important source because of the evidence it records. Vandier included ten photographs of statues of Twelfth

\footnotetext{
175 Pignattari 2008.

176 Pignattari 2008: 44. For example, Gardiner 1961, Hayes 1973, and Grimal 1992.

${ }^{177}$ Pignattari 2008: 85.

178 Pignattari 2008: 86. translated by author.

179 Pignattari 2008: 67-68.

${ }^{180}$ As seen in Dodson 2004: 92.

181 Pignattari 2008: 70.

182 Ziegler 2008: 384.

183 Vandier 1958.
} 
Dynasty royal women, ${ }^{184}$ along with two further possibilities. ${ }^{185}$ Eight of these statues are located in the Egyptian Museum, Cairo, resulting in Vandier's publication being the first to record several images of Twelfth Dynasty royal women's statues still located in Egypt. Vandier's published photographs are significant because some of the statues have not been republished since and until this study they have not been published together. Accompanying his work, this research has presently added the seated statues of queens Senet and Khenemetneferhedjet I, which are currently located at the Egyptian Museum, Cairo (Cat. 28) and the Elephantine Museum, Aswan (Cat. 31).

Published in the 1986, Ingo Matzker's Die Letzten Könige der 12. Dynastie $^{186}$ is one of the more informative publications in regard to the documentation of Sobekneferu's reign. Similar to Petrie's A History of Egypt, ${ }^{187}$ which was published ninety years before, Matzker's theories on Sobekneferu's monumental titulary and inscriptions are restricted to her possible co-regency with Amenemhat III. ${ }^{188}$ Furthermore, he includes Sobekneferu's possible burial at Mazghuna, her contributions to Amenemhat III's Labyrinth at Hawara, and a temple at Herakleopolis Magna. ${ }^{189}$

In 1996, Biri Fay published The Louvre Sphinx and Royal Sculpture from the Reign of Amenemhat II, ${ }^{190}$ which includes the largest corpus of female sphinxes from the Twelfth Dynasty. Fay's collection is important because the Twelfth Dynasty is the first time in ancient Egypt royal women were depicted in the sphinx form since only the male ruler was normally depicted in this manner. As discussed in Chapter 4.2.3, the sphinx form was the third most common pose for Twelfth Dynasty royal women. Fay's analysis includes meticulous iconographic descriptions for the Twelfth Dynasty female sphinxes, with some photographed ${ }^{191}$ and others named in the catalogue. ${ }^{192}$ Within the publication Fay has two chapters discussing the

\footnotetext{
${ }^{184}$ Vandier 1958: LXVI: Cairo 43104; LXXIV: Cairo 381,382, Cairo M.E. VI, Paris B.N. 24, Berlin 14475, MMA 08.202.7; LXXV: Cairo 64770; LXXXI: Cairo 36359; LXXXIX: Cairo M.E. VII.

185 Vandier 1958: LXXI: MMA 29.100.150; Leiden D. 127.

${ }^{186}$ Matzker 1986.

187 Petrie 1894.

188 Matzker 1986: 95.

${ }^{189}$ Matzker 1986: 174-175.

${ }^{190}$ Fay 1996.

${ }^{191}$ Fay 1996: Plate 98c-d, Paris B.N. 24 Cat. 66; 58 Louvre AO 13075 Cat. 67; 93 Vienna ÄS1753 Cat 69; Brooklyn Museum 56.85, Cat. 63.

192 Sphinx Appendix 60: headless female sphinx; 50: fragmentary female sphinx.
} 
daughters and wives of Amenemhat II. ${ }^{193}$ Although she does not comment on the status of royal women within the royal family, she narrows down which royal women are actually associated with Amenemhat II. Fay does this by listing their names, monuments, titles, bibliography of previous scholarship, and her personal comments. She concludes that there are only four daughters of Amenemhat II and not enough evidence for a queen. Sabbahy later reviews Fay's conclusions, stating that there are four daughters of Amenemhat II but that Khenemetneferhedjet is a title and not a name, and Nefert has 'mixed titulary' because she was the daughter of a king and wife of a co-regent. ${ }^{194}$

Queens of Egypt: From Hetepheres to Cleopatra, ${ }^{195}$ is an exhibition and catalogue curated by Christiane Ziegler. The publication was created to explore queens throughout ancient Egyptian history and is the first exhibition devoted exclusively to queens. ${ }^{196}$ It has many contributing authors, including the previously mentioned scholar Lana Troy, and contains a list of Egyptian queens which includes royal women in chronological order, along with a brief description. The book contains more information on New Kingdom and later queens, but the catalogue includes four Twelfth Dynasty statues ${ }^{197}$ with short narrations of each photograph. Accompanying the catalogue is Aidan Dodson's "The book of Egyptian Queens", which consists of descriptions for only nine Twelfth dynasty royal women, although at least forty-one were known. Dodson mentions the theories that Neferuptah was the intended heir to the throne and was originally buried within her father's pyramid before being moved to her own. ${ }^{198}$ His information for Sobekneferu is less detailed but he states that she was another daughter of Amenemhat III and the first woman to have been appointed pharaoh of Egypt. ${ }^{199}$

Within the 2014 Palais des Beaux Arts de Lille exhibition Sésostris III: Pharaon de Légende, ${ }^{200}$ Grajetzki dedicates the chapter "La Place des Reines et des Princesses" to the royal women connected to Senwosret III's reign. ${ }^{201} \mathrm{He}$ includes brief discussions of the queens' statuses within the royal court and their tombs.

\footnotetext{
193 Fay 1996: 43-49.

194 Sabbahy 2003: 243-244.

195 Ziegler 2008.

196 Ziegler 2008: 18.

197 Ziegler 2008: 300, pl. 119; 301, pl. 120; 302, pl. 122; 317, pl. 146.

198 Dodson 2008: 384.

199 Ziegler 2008: 383-384.

200 Andreu-Lanoë and Morfoisse 2014.

${ }^{201}$ Grajetzki 2014b.
} 
Grajetzki further analyzes the sources mentioning the royal female family of Senwosret III including the seated statue of his mother Khenemetneferhedjet I now located in the Musée du Louvre (Cat. 18) along with an acknowledgment about the designation of Khenemetneferhedjet being used as a name. ${ }^{202}$ He also mentions Sobekneferu twice, stating who carried the titles daughter of $\mathrm{Ra}$ and the female Horus, as well as she fully reigned at the end of the Twelfth Dynasty. Additionally, she was the granddaughter of Senwosret III and includes a figure of her torso now in the Musée du Louvre (Cat. 58). ${ }^{203}$

The 2015 Metropolitan Museum of Art exhibition Ancient Egypt Transformed: The Middle Kingdom edited by Adela Oppenheim, Dorothea Arnold, Dieter Arnold, and Kei Yamamoto is the most recent and comprehensive catalogue of the Middle Kingdom. ${ }^{204}$ The publication is an exquisite overview of the Middle Kingdom and includes discussions on Middle Kingdom art, history, literature, and archaeology. Within the catalogue, Arnold's chapter "Pharaoh: Power and Performance" addresses the required performances of the pharaoh, including being the head of administration and the military, joining the two lands and erecting monuments to the deities. ${ }^{205}$ She also provides a discussion on the facial characteristics found on late Twelfth Dynasty artworks.

Directly following this chapter is Isabel Stünkel's contribution "Royal Women: Ladies of the Two Lands" where she examines the Middle Kingdom royal women's closeness with the ruling pharaoh. She lists the usual titles of the royal women, including king's mother, wife, sister, and daughter, stating that

The notable choice makes clear that the high position of the royal women was not determined by the relationship with the king as an individual but rather by their relationship to his divine aspect as ruler and to kingship in general. $^{206}$

Images of Queen Nofret (Cat. 14) and Amenemhat III in a Sed-festival cloak with two royal women (Cat. 28) are included and discussed in the text. Additionally, two Twelfth Dynasty sphinxes are also depicted in the catalogue. Sobekneferu is mentioned once in this section, in which Stünkel states Sobekneferu reigned at the end of the dynasty. Although the publication as a whole serves as an informative

\footnotetext{
202 Grajetzki 2014b: 50-57.

${ }^{203}$ Grajetzki 2014b: 48, 51-52, Fig. 8.

${ }^{204}$ Oppenheim, Arnold, Arnold, and Yamamoto 2015.

205 Arnold 2015b: 68-69.

206 Stünkel 2015: 92.
} 
reference, Sobekneferu is simply mentioned four times throughout. Each entry that Sobekneferu is specified in, she is directly associated with the last part of the time period and how the dynasty ended with her rule. Furthermore, her reign is not expanded upon and none of her objects are included within the publication.

The chapter "Neferusobek Project: Part 1" by Biri Fay, Rita Freed, Thomas Schelper, and Friederike Seyfried ${ }^{207}$ from The World of Middle Kingdom Egypt (2000-1550 BC $)^{208}$ identifies the bust now located in Berlin (Cat. 1) as Sobekneferu. The authors reunite the bust with the lower part that is located at the Museum of Fine Arts Boston (Cat. 27). They state that this "reconstruction is the first complete statue of this female pharaoh and finally provides a face that can with certainty be associated with her name." ${ }^{209}$ The goal of the project is to create an image from a three-dimensional scan and produce complete statues for both museums. The final report of the project will be completed at a later date. ${ }^{210} \mathrm{~A}$ discussion of this statue in this study can be found in Chapter 6.18 and is included as Cat. 62 .

\subsection{Titles}

Sabbahy's 1982 dissertation, The Development of the Titulary and Iconography of the Ancient Egyptian Queen ${ }^{211}$ was the first exploration on the titulary of royal women, with Chapter Five dedicated to the Twelfth Dynasty of the Middle Kingdom. Sabbahy states that "without a doubt the [Twelfth Dynasty] queen's titulary has dramatically changed." 212 She further notes that both Twelfth Dynasty

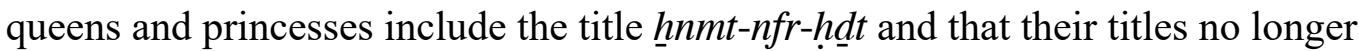
reflect their separate status as princess or queen. Sabbahy proposes that the "mixed titulary" of the royal women is due to the institution of co-regencies during Twelfth Dynasty. This would mean the royal woman who was the daughter and wife of the monarchs who were ruling would carry mixed titulary because she was both princess and queen. ${ }^{213}$ Within the chapter Sabbahy analyses the titulary of twenty-three royal women and included with first cumulative chart for the titles of these Twelfth

\footnotetext{
${ }^{207}$ Fay, Freed, Schelper, and Seyfried 2015.

${ }^{208}$ Miniaci and Grajetzki 2015.

${ }^{209}$ Fay, Freed, Schelper, and Seyfried 2015: 89.

${ }^{210}$ Fay, Freed, Schelper, and Seyfried 2015. 89.

211 Sabbahy 1982.

212 Sabbahy 1982: 181.

213 Sabbahy 1982: 218.
} 


\section{Dynasty figures. $^{214}$}

The appendix "Royal women, titles, and epithets" published in Troy's book Queenship is still the most comprehensive list of titles for Twelfth Dynasty royal women. Similar to Sabbahy, Troy notices a change in the titulary of Twelfth Dynasty royal women, stating that "the elevation of the ritual status of the royal women to an association with the sovereignty of the kingship also may be discretely discerned

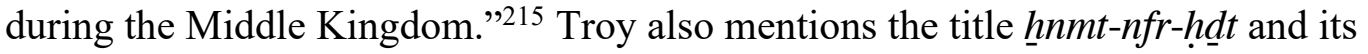
possible connection with the vulture crown of Nekhbet, although she does not address the same co-regency idea as Sabbahy. Within the appendix Troy lists the titles of forty-one royal women from the time period, noting where their titles are found. ${ }^{216}$ Her categorization of titles coincides with her second appendix "Titles and Epithets". Each title is shown in Egyptian hieroglyphs, followed by the transliteration and English translation.

The second chapter of Callender's dissertation The Wives of the Egyptian Kings examines the titulary of the queens from the Frist Dynasty through the Seventeenth Dynasty. Callender begins her discussion on the Twelfth Dynasty with the title $\underline{h} n m t-n f r-\underline{h} \underline{d} t$, also briefly mentioning its connection with the goddess Nekhbet, similar to Troy. Callender furthers her examination of the title and cites its usage by Hatshepsut, who most likely used it as an archaizing tool to associate herself with the Twelfth Dynasty. ${ }^{217}$ She also does not address Sabbahy's suggestion of the title being used for a co-regency. Callender analyzes ten titles and their different variations, addressing their meanings and usage. Similar to both Sabbahy and Troy, Callender notes the change for the titulary of royal women from the Old Kingdom, and attributes the development to their elevated place in the government. ${ }^{218}$

The most recent publication listing the titles of Twelfth Dynasty queens is Grajetzki's Ancient Queens: A hieroglyphic Dictionary. ${ }^{219}$ Each royal woman's name is printed in hieroglyphs with the transliteration and translation, along with a description. The dictionary only includes those who held the titles 'king's wife',

\footnotetext{
214 Sabbahy 1982: 214.

215 Troy 1986: 180.

216 Troy 1986: $157-159$.

${ }^{217}$ Callender 1992: 101.

218 Callender 1992: 112.

219 Grajetzki 2005a.
} 
which consists of eight Twelfth Dynasty royal women. Grajetzki also includes a genealogy of the Twelfth Dynasty royal family listing the women mentioned in the section. Similar to Roth, ${ }^{220}$ Grajetzki does not propose a mother for Amenemhat III. However, instead of agreeing with Roth's proposal that Queen Senet is the mother of Sobekneferu, Grajetzki suggests she is the wife of Amenemhat II and mother of Senwosret II $^{221}$ (for further discussion see Chapter 6.19).

\subsection{Mortuary complexes}

Petrie's book Illahun, Kahun and Gurob. 1889-90222 contains the first reports for the pyramid of Senwosret II which mentioned the possibility of a princess named Atumneferu. ${ }^{223}$ It was in 1913 that Petrie and Guy Brunton found the famous "Treasure of Illahun" which recorded the jewelry of royal women from the time of Senwosret II, including his daughter Princess Sithathoryunit. Brunton's 1914 publication Lahun I: The Treasure ${ }^{224}$ allowed for the first examination of Princess Sithathoryunit's tomb and exquisite jewelry.

The pyramid of Senwosret III at Dahshur was initially entered and excavated by Jacques de Morgan from 1894-1895.225 Additionally, since the 1990s the Metropolitan Museum of Art has continued to work at the pyramid complex, under the direction of Dieter Arnold who published The Pyramid Complex of Senwosret III at Dahshur: Architectural Studies. ${ }^{226}$ The excavations have resulted in the discovery of thirteen royal women from the late Twelfth Dynasty: queens Nefrethenut, Mereret, Senetsenebetes, Khenemetneferhedjet I, and Khenemetneferhedjet II, princesses Itakayet, Menet, and Sithathor, and five other anonymous royal women. ${ }^{227}$

The pyramid of Amenemhat III at Dahshur was also initially excavated by de Morgan in 1894-1895, ${ }^{228}$ and was likewise re-excavated by Arnold between 19761983. Arnold published his completed work Der Pyramidenbezirk des Königs Amenemhet III. in Dahschur. ${ }^{229}$ His reports of Amenemhat III's Dahshur pyramid

\footnotetext{
${ }^{220}$ Roth 2001.

${ }^{221}$ Grajetzki 2005a: 32. Within his description Grajetzki also notes the Queen Senet could possibly be the wife of Senwosret III.

222 Petrie 1891.

223 Petrie 1891: 5.

224 Brunton 1914.

225 De Morgan 1903.

${ }^{226}$ Arnold 2002.

227 Arnold 2002: 58-68, 70-74.

228 De Morgan 1895; De Morgan 1903.

${ }^{229}$ Arnold 1987.
} 
provide an insight into two queens who are buried underneath the pyramid as opposed to being buried outside the king's pyramid. The burials of Queen Aat and an anonymous queen or Khenemetneferhedjet III, both wives of Amenemhat III, are directly connected to his own burial chamber. However, he was buried in his second pyramid at Hawara, possibly because of construction faults or he used his Dahshur pyramid as a cenotaph type burial.

De Morgan was additionally responsible for excavating the pyramid of Amenemhat II at Dahshur during the $1894-1895$ season. ${ }^{230}$ Amenemhat II's pyramid complex has been described as "poorly investigated and documented." ${ }^{231}$ It is from de Morgan's excavations that we know of at least one unnamed queen and four princesses: Khnemet, Ita, Itaweret, and Sithathormeryt. His reports mainly concentrate on the jewelry of these princesses, although they do contain useful descriptions of the tombs and the royal women's personal items..$^{232}$

The pyramid complex of Senwosret I at Lisht was first excavated by Joseph Étienne Gautier and Gustave Jéquier ${ }^{233}$ who published Memoire sur les Fouilles de Lischt in 1902. Ninety years later, in 1992, the pyramid was further excavated by Arnold who published The South Cemeteries of Lisht III: The Pyramid Complex of Senwosret I. ${ }^{234}$ Arnold confirms that out of the nine subsidiary pyramids found in the enclosure, two may have belonged to royal women, Queen Neferu and Princess Itakayet. $^{235}$

Between April of 1907 and December of 1922, the Egyptian Exploration Society published several articles in The Metropolitan Museum of Art Bulletin detailing the excavations at Amenemhat I's pyramid at Lisht. ${ }^{236}$ These excavations are still significant in understanding the pyramid of Amenemhat I along with numerous tombs that are assumed to be for royal women. Three royal women have been identified from the pyramid complex: Queen Nefret, Princess Neferu, along with Amenemhat I's wife and the mother of Senwosret I, Queen Nefrytatenen.

Excavated by Labib Habachi in 1941 and 1942, ${ }^{237}$ the site of Tell el-Dab'a

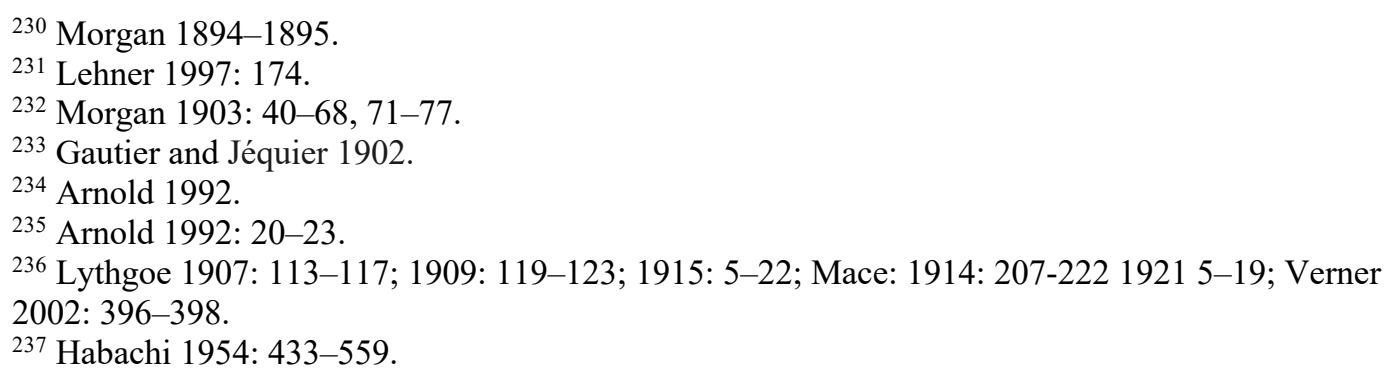


has produced a great deal of data, and possibly the most information for Sobekneferu than any other. From Tell el-Dab'a, Habachi documented three significant statues of Sobekenferu, one kneeling ${ }^{238}$ and two seated. ${ }^{239}$ His reports and photographs are important because Sobekneferu is represented wearing a traditional sheath dress with the inscriptions naming her the Female Horus and the Monarch of Upper and Lower Egypt. The statues show Sobekneferu's ability to mix feminine clothing with pharaonic titles. Before Habachi's photographs, the image of Sobekneferu was only known from her damaged statue now in the Louvre (Cat. 58). Still today the Tell elDab'a statues are the only other inscribed representations of Sobekneferu that have been found. Also found at Tell el-Dab'a was a sphinx inscribed for Sobekneferu, but the style and current locations for all of the statues are unknown. ${ }^{240}$

Published in 1971, Nagib Farag and Zaky Iskander's The Discovery of Neferwptah ${ }^{241}$ is today the largest corpus of information for Amenemhat III's daughter Neferuptah. Over time, Neferuptah's burial chambers filled with floodwater but her pyramid was never robbed. As a result, Farag and Iskander were able to find objects and small parts of her preserved skin. ${ }^{242}$ Inside her burial chamber numerous high status objects were found, such as a red granite sarcophagus, a mace-head, a flail, inscribed vases, an offering table, and pieces of silver with elegant jewelry. ${ }^{243}$ Most significant of the objects found are the vases, sarcophagus ${ }^{244}$ and offering table, ${ }^{245}$ which all include her name in a cartouche. Since Neferuptah is the first female to have her name written within a cartouche, these funerary objects show her special political status during the Twelfth Dynasty. Although Farag and Iskander's publication concentrates on the excavation of her pyramid, the book allows a slight insight into the historic place of the princess and possible future queen or female ruler. Farag and Iskander do not propose many theories except that after her death Neferuptah may have resided in her father's pyramid until her own could be finished. ${ }^{246}$

The most recent overview to the publications of mortuary complexes for the

\footnotetext{
${ }^{238}$ Habachi 2001: Cat. 9.

${ }^{239}$ Habachi 2001: Cat. 10 and 11.

240 Fay 1996: 69.

${ }^{241}$ Farag and Iskander 1971.

242 Farag and Iskander 1971: 5.

${ }^{243}$ Farag and Iskander 1971: 27-44.

${ }^{244}$ Farag and Iskander 1971: 14-15.

${ }^{245}$ Farag and Iskander 1971: Plate VII.

${ }^{246}$ Farag and Iskander 1971: 105-107.
} 
Twelfth Dynasty royal women is Wolfram Grajetzki's book Tomb Treasures of the Late Middle Kingdom. ${ }^{247}$ It consists of an overview of the female burial types during the Twelfth Dynasty and lists thirty queens and princesses in the "Royal Women of the Twelfth Dynasty" appendix. ${ }^{248}$ This appendix is a significant reference for quickly finding funerary objects that are associated with each woman, and Sobekneferu is excluded from this list due to her unknown burial site. Grajetzki explains that the amount of exquisite jewelry buried with royal women varies throughout the Twelfth Dynasty, but certain objects such as inscribed pectorals that were frequently worn by and buried with royal women are considered "objects of high prestige." 249 Within the burial types, Grajetzki includes detailed descriptions of ten royal female burials, including the pyramid of Neferuptah. His description concentrates on the specifics of Neferuptah's burial, and he states that she must have held a high status. ${ }^{250}$ Grajetzki also acknowledges her double burial, but contrary to earlier scholars, he theorizes that Amenemhat III actually planned to be buried with Neferuptah but died before her. This would have resulted in the permanent closing of the burial chamber and Neferuptah having to be buried in a separate pyramid. ${ }^{251}$

In Grajetzki's 2017 article The Two Burials of Neferuptah and other Second Burials for Royal Women, ${ }^{252}$ he again addresses Neferuptah's double burial. He provides a brief overview of the explanations by earlier Egyptologists including whether or not Neferuptah died first and when her body entered her own pyramid. Grajetzki offers a new interpretation and suggests Neferuptah's burial within Amenemhat III's at Hawara could be a cenotaph or a ritual burial and her own pyramid was her real burial. ${ }^{253} \mathrm{He}$ further states that cenotaph "dummy burials" are well attested in the Middle Kingdom and suggests the presence of royal females was importantly connect with rebirth and their burials close to the reigning monarch would have been significant to their transition into the afterlife. ${ }^{254} \mathrm{He}$ uses the burial of Khenmetneferhedjet I's at Dahshur as another example of a cenotaph for royal women. ${ }^{255}$ This example along with the double burial of Neferuptah is also further

\footnotetext{
${ }^{247}$ Grajetzki 2014a.

${ }^{248}$ Grajetzki 2014a: 189-194.

${ }^{249}$ Grajetzki 2014a: 160.

${ }^{250}$ Grajetzki 2014a: 70.

${ }^{251}$ Grajetzki 2014a: 69.

${ }^{252}$ Grajetzki 2017.

${ }^{253}$ Grajetzki 2017: 36.

${ }^{254}$ Grajetzki 2017: 41-42.

255 Grajetzki 2017: 36, 41.
} 
discussed in Chapter 5 of this study.

Isabel Stünkel's recently published dissertation, The Decoration of the North Chapel of Khenemetneferhedjet Weret I at Dahshur ${ }^{256}$ is the first full archeological examination for a chapel belonging to a Twelfth Dynasty royal woman and is the only in-depth study for Khenemetneferhedjet Weret I (Hedjet I). Within the study she includes an overview of the pyramid complex of Senwosret III and Khenemetneferhedjet I's pyramid, known as pyramid 8. She also dedicates a chapter to Khenemetneferhedjet Weret I and includes a list of her known objects. Stünkel states the north chapel of pyramid 8 is the best-preserved for any royal woman of the Middle Kingdom. ${ }^{257}$ She provides a detailed analysis of all of the surviving decorations for the chapel and creates reconstructions for numerous parts including the east and west walls which would have originally depicted Khenemetneferhedjet Weret seated on a throne. ${ }^{258}$ Similar to the scholars before her such as Sabbahy and Fay, Stünkel discusses the Twelfth Dynasty designation Khenemetneferhedjet. She includes an overview of its use during the dynasty and suggests that Khenemetneferhedjet could be a name that be a part of a double name or used together with an epithet. ${ }^{259}$

\subsection{Discussions}

This overview of previous scholarship from 1896 to 2016 focuses attention on the multiple publications that address gender studies, archaeology, and Twelfth Dynasty royal women. The chapter presents the complications and successes of studying royal women of the time period, while also highlighting the disparity in scholarship. As noted by scholars such as Callender, Twelfth Dynasty royal women are often under-emphasized and reduced to a footnote or simply omitted. ${ }^{260}$ Until Sabbahy's 1982 dissertation, the iconography of the princesses and queens had not been fully analyzed or even adequately discussed. Since then, other aspects of Twelfth Dynasty royal women, such as their representations, ideology, roles, and royal statuses have been studied and published. Although most of the recent theories have produced positive conclusions on the political presence of Twelfth Dynasty royal, there is still

\footnotetext{
256 Stünkel 2018.

${ }^{257}$ Stünkel 2018: 1.

${ }^{258}$ Stünkel 2018: 360-363.

259 Stünkel 2018: 402-430.

${ }^{260}$ Callender 1998b: 46.
} 
a need for further analysis to disassociate Sobekneferu's reign with the collapse of the Twelfth Dynasty.

This literature review also demonstrates the minimal amount of work published on Neferuptah and Sobekneferu, despite the former being the first royal woman to have her name encircled within a cartouche, and the latter being the first well-documented female monarch of ancient Egypt. While Sobekneferu's titulary has been studied to an extent, her iconography is rarely mentioned, although her images show the ability of the Egyptians to successfully depict a woman filling the office of pharaoh. Furthermore, seventy statues and reliefs are inscribed or attributed to Twelfth Dynasty royal women. Many of these representations have not been published, discussed, or mentioned by earlier Egyptologists. The aim of this study is to go beyond the previous 120 years of scholarship and meticulously examine royal women of the Twelfth Dynasty. In doing so, an extensive understanding of their iconography, political influence, as well as the tenure of Neferuptah and reign of Sobekneferu can be produced. 


\section{Chapter 3: Framework of Queens, Queenship, and Female Rulership}

\subsection{Introduction}

In all aspects from mythical to practical, queenship continuously shifted through

Egyptian history and no one theory can explain its complexity and significance.

Queenship in ancient Egypt has only been thoroughly studied since the 1980s. The understanding of queenship has often been treated as if it were an unchanging practice and concept throughout ancient Egyptian history, with studies centered on queenly titulary, iconography, and relationships to the ruling monarch. Queens have been studied as the essential feminine element of kingship and have been grouped by time periods such as the First to Sixth Dynasties and the New Kingdom through the Islamic period. There has not been a publication specifically dedicated to the queenship of the Twelfth Dynasty, although the titles of these royal women have often been examined. ${ }^{261}$ There are five publications that have discussed different aspects of queenship in detail (see Chapter 2: Literature Review): Sabbahy's Titulary and Iconography of the Ancient Egyptian Queen, ${ }^{262}$ Troy's Patterns of Queenship, 263 Callender's Wives of the Egyptian Kings, ${ }^{264}$ Roth's Königsmütter des Alten Ägypten, ${ }^{265}$ and Eldamaty, Hoffmann, and Minas-Nerpel's Ägyptische Königinnen. ${ }^{266}$

The lived experiences of non-royal and royal women would have been vastly different from each other due to their social and economic situations. ${ }^{267}$ As in any ancient culture, there was not just one type of woman or one type of power. Both royal and non-royal women should be discussed thoroughly and separately to fully understand their roles. While the places of women in all levels of ancient Egyptian society require further study, some activities were limited to royal women, such as filling the governmental offices of queenship and monarch. The theoretical framework of these royal women discussed in this chapter includes the queen herself and the political occupation of queenship. The political role of queenship would be filled by the biological female who could occupationally extend to the pharaonic

\footnotetext{
${ }^{261}$ Callender 1992; Sabbahy 1982, 2003; Troy 1986.

262 Sabbahy 1982.

263 Troy 1986.

${ }^{264}$ Callender 1992.

265 Roth 2001.

266 Eldamaty, Hoffmann, and Minas-Nerpel 2015.

${ }^{267}$ Meskell 1999: 55.
} 
office. This chapter attempts to further the study of the theoretical framework of queenship by providing an introductory understanding of the political office and role of royal women in positions such as regent and ruling monarch. It presents a definition of female rulership and examines the modern and ancient perceptions of gender and power. These constructs are described through the title 'Female Horus' and the reigns of Meretneith, Khentkaus I, Hatshepsut, and Tausret.

The study of queenship within this work focuses specifically on the female monarch, the royal mother, the royal wife, and royal daughter (see Chapter 1.3). The study of princesses is significant to this thesis because these young women often became queens, royal mothers, and rulers. Troy's Queenship and further works have set the pace for understanding queens as the feminine component in the Egyptian concept of rulership. ${ }^{268}$ She emphasizes that the mythological and physical presences of royal women were essential to the central being of the monarchy. Royal women complimented the ruler as a divine being, proved the legitimacy of the monarch's reign, and were directly connected with goddesses. ${ }^{269}$ Royal women of the Twelfth Dynasty were closely associated with the goddess Hathor, who was the daughter of $\mathrm{Ra}$ as well as mother of the god Horus, the earthly counterpart of the ruling monarch. ${ }^{270}$ Although the roles of the royal mother, wife, and daughter in Egyptian mythology have been discussed by Troy, there is still further research to be done on their political offices and female rulership.

While the personal lives of royal women are unknown, each individual's agency should not be discounted or combined with another woman's reign. Compared to other time periods, such as the New Kingdom, ${ }^{271}$ there is less remaining evidence for Twelfth Dynasty royal women, which has resulted in fewer studies. It has been suggested that royal women of the Twelfth Dynasty "had little impact on state affairs and all but vanished from royal monuments" 272 and that their progressive titulary and iconographic elements were only to show connection to the king. ${ }^{273}$ Although these examples have all but deleted Twelfth Dynasty royal women from ancient Egyptian history, ${ }^{274}$ understanding this time period is essential

\footnotetext{
268 Troy $1986 ; 2002 ; 2003 ; 2008$.

269 Troy 1986: 43-50.

270 Troy 2008: 156, 158.

271 Troy 1986: 161-168. Register A, The Royal Woman- Dynasty Eighteen.

272 Tyldesley 2012: 11.

273 Stünkel 2015: 94.

274 Gardiner 1961: 141; Grimal 1992: 171; Van de Mieroop 2011: 102-103, 107.
} 
to the study of queenship since they had a highly visible presence among the political and religious spheres. This dynasty is the earliest known time that political power and influence is regularly presented for Egyptian royal women.

\subsection{Definitions of Queenship ideology and the Queen}

The operant definitions for the political office and body for the Queen is significant in understanding the ancient Egyptian government and succession system. Within modern Egyptological scholarship there have been definitions put forth including Baines and Yoffee's definition of kingship: "Ruler holding supreme office in a lifetime tenure, most often succeeding on a hereditary principle and wielding - or not, as the case may be - great personal power". ${ }^{275}$ Their definition has been repurposed in this thesis to further emphasize the bodies who participated in official positions. With regard to Queenship, it has often been previously defined as simply "an aspect of kingship". ${ }^{276}$ While the daily lives of ancient Egyptian kings and queens were immensely integrated with each other, this thesis argues for the disconnection between the political occupations of kingship and queenship, which would mean queenship was not an aspect of kingship and was an independent position. The office of queenship is defined as the divine aspect and the queen as the body that fills the office. The main objective of these definitions of queenship presented in this thesis is to separate the political occupation from the individual that fills that office. This definition provides a new interpretation of the offices in which royal women had opportunities to continually and occasionally take part.

Traditionally in English, the Queen is defined as the sole ruler or as the wife or mother of the king and Queenship is the state of being a Queen. While $n s w t$ is commonly translated as King, ${ }^{277}$ in the case of female rulers, it can be adapated as Queen (the sole ruler). Throughout this thesis the Egyptian term $n s w t$ is translated as 'Monarch' to imply the office holder could be both male and female. During the Tweflth Dynasty, the Egyptian words that are regularly translated directly to Queen are $h m t ~ n s w t$ and $m w t$ nswt the wife and mother of the ruling monarch. As seen on the later Ramesside papyrus now in the British Museum ${ }^{278}$ and the Third

\footnotetext{
275 Baines and Yoffee 1998: 205.

276 Troy 1986: 2.

${ }^{277}$ Schneider 1993: 166-181; Wb 2, 325.1-329.10.

278 P. Chester Beatty 8 Papyrus, The British Museum, London EA10688,5; Wb 2, 332.8-11; Wilson, Ptol. Lexikon, 545; LGG IV, 346.
} 
Intermediate Period Onomasticon of Amenemipet ${ }^{279} n s w j t$ can also be translated as Queen although it is not used to refer to a particular royal woman. Furthermore $n s w . t$ is used as Queen for the goddess Isis on the Roman period papyrus of Tanaweruow that is in the Metropolitan Museum of Art. ${ }^{280}$ During the Ptolemiac period pre3.t, Female Monarch or Queen, is a title used for politically prominent royal women such as Arsinoe II, Berenike II, Cleopatra I, Cleopatra II, Cleopatra III, Berenice III, Cleopatra V, and Cleopatra VII who all at least jointly reigned during their life time. ${ }^{281}$ Although earlier female rulers such as Sobekneferu did not use pr $^{\text {? } 3 . t \text {, they }}$ did carry the title of $n s w t$ which indicated their legitimized reign over Egypt.

\begin{tabular}{|c|c|}
\hline The Office & The Person \\
\hline $\begin{array}{c}\text { The office of Queen (Queenship) } h m t \\
n s w t, m w t \text { nswt, snt } n s w t, \text { s3t } n s w t \text {, and } \\
n s w t\end{array}$ & $\begin{array}{c}\text { The body that fills the office } \\
\text { (Queen Mother and Wife } \\
\text { Princess Sister and Daughter) } \\
\text { A biological female ruler holding } \\
\text { The divine feminine manifestation of the } \\
\begin{array}{c}\text { Pharaonic office, which can incorporate } \\
\text { supreme office in a lifetime tenure, } \\
\text { person who carries the title } n s w t, \text { and the } \\
\text { woman who in the right circumstance can } \\
\text { become } n s w t\end{array}\end{array} \quad \begin{array}{c}\text { principle and wielding - or not, as the } \\
\text { case may be - great personal power }\end{array}$ \\
\hline
\end{tabular}

Table 3.1 Queenship ideology and Queen.

Defined as the divine feminine manifestation of the Pharaonic office, which incorporates the wife, mother, sister, or daughter of the person who carries the title $n s w t$, and the royal woman who can become $n s w t$, the office of queenship includes an abundance of positions and can incorporate many royal women. When discussing ancient Egypt, the Queen is still considered the hmt nswt or $m w t n s w t$, the wife or mother of the ruling person, however the office of queenship could be fulfilled by other royal women, including the ruler's sister or daughter. The royal woman did not

\footnotetext{
279 Gardiner 1947: pl. VII; Wb 2, 332.8-11; Wilson, Ptol. Lexikon, 545; LGG IV, 346.

${ }^{280}$ Religious text of Tanaweuow, daughter of Hartophnakhthes and Tatita (Papyrus Harkness), The Metropolitan Museum of Art, New York 31.9.7; Johnson 2004: 124.

${ }^{281}$ Erichsen, Glossar 133; Johnson 2010: 77-78; Leprohon 2013: 179-188; For Arsinoe II and Berenike II see Minas-Nerpel 2015: 87-114; For Arsinoe II see Nilsson 2010.
} 
have to be a queen to be in the queenship position and among multiple queens only one woman was in the office at a time. This encompasses royal women who had already held any, all or a combination of the positions hmt nswt, mwt nswt, snt nswt, or $s 3 t n s w t$. Additionally, among these positions, royal women could also be $n s w t$ or the ruling monarch. Significantly, a royal woman could be in one, multiple, or all of these official positions in her lifetime, while also having the opportunity, although less common, to become the ruling monarch.

The office of queenship was crucially important to the pharaonic office because it legitimized and regenerated the ruler. The earliest surviving representation of this regeneration of strength and power is from the Twelfth Dynasty as seen on the group statue of Amenemhat III with two royal women ${ }^{282}$ (Cat. 28). The royal woman taking part in the occupation of queenship were important in ritual activities, including pacifying the deities and actively participating in festivals. Royal women fulfilling this office could also take part in foreign affairs and correspondences (see below Chapter 3.5.6.1). ${ }^{283}$ Similar to their titles hmt nswt, $m w t$ t $n s w t$, snt $n s w t$, and $s 3 t$ nswt that were both position names and kinship terms, the queenship office was an overlap of political and religious duties. A royal woman as a wife of the ruling monarch or the mother of the next monarch would have political and religious roles which can be seen from their titles meaning both official and familial as well as fulfilling the place of the goddess Hathor. This type of doubling a name and title can further be seen with the Twelfth Dynasty designation for royal women Khenemetneferhedjet, The one who is united with the White Crown, which also emphasized their official and kinship relation to ruling monarch. ${ }^{284}$

As seen from their evolving iconography, titulary, and political positions such as their independent representations (see Chapter 4), Neferuptah's cartouche (Chapter 5) and Sobekneferu's reign (see Chapter 6); queenship for Twelfth Dynasty royal women was its own separate position. Statements inferring royal women did not hold active offices are a result of a misunderstanding of their roles. ${ }^{285}$ Their roles

\footnotetext{
${ }^{282}$ See Stünkel 2015: 95; Amenemhat III in a Sed-festival cloak, flanked by two royal women: Egyptian Museum Cairo, JE 43104.

${ }^{283}$ Such as Queen Tiye from the Eighteenth Dynasty as seen on the diplomatic correspondence rom King Tushratta to Queen Tiye: The British Museum London E 29794.

${ }^{284}$ For the most recent detailed discussion and list of royal women with the name/title Khenemetneferhedjt see Stünkel 2018: 402-430.

${ }^{285}$ For example, Roth states that "due to the fact that the majority of sources refer to the queens' role in the ideology of kingship, there is little evidence that queens held political influence" Roth 2009: 7.
} 
as royal women were performed in a separate position than that of kingship while simultaneously always being in relation to the monarch whether that be a title, government activity, or reigning as the ruler themselves. Throughout Egyptian history some queens were the hmt nswt or $m w t$ nswt but were never in the queenship position and majority of the monarch's daughters and sisters were also not in this political occupation. However, during a monarch's reign their mother, wife, daughter, or sister could be in the office of queenship and in certain situations these women could also be regent or co-regent to the reigning monarch while concurrently having the opportunity to be the reigning monarch.

\subsection{Gender and power}

Gender negotiation is intertwined with power and to understand their roles is to consider how political authority takes part in their meaning and value. ${ }^{286}$ Female rulership was an integral part of the Egyptian society, ${ }^{287}$ which resulted from the synthesized concepts of gender and power. The perceptions of "men" and "women" are not universal and modern definitions of gender do not span back to ancient Egypt. ${ }^{288}$ The roles and behavior expected from men and women are variable depending on many factors, including time period, age, and occupation. Gender was conceptually expansive in ancient Egypt and this extended to the royal family and their iconography. Gender is represented in Egyptian artwork through the use of the positions, sizes, and colors of figures. ${ }^{289}$ However, surviving artifacts suggest that iconography did not always follow certain types of gender rules and the decorum is occasionally inconsistent. For example, a Twelfth Dynasty relief of Amenemhat III, Neferuptah, and the goddess Renenutet (Cat. 55) depicts Amenemhat III and Renenutet as the same size, while also presenting Neferuptah in front of Amenemhat III and before the goddess. This is unusual because the princess is closer to the goddess than the Amenemhat III. ${ }^{290}$ While this particular order of figures does not break gender norms, it signifies the flexibility of gender roles and how they could be presented to the viewer.

\footnotetext{
286 Sørensen 2000: 62.

287 Bryan 1996: 25.

${ }^{288}$ Conkey and Gero 1991: 9; Nelson 1997: 22.

${ }^{289}$ Wilfong 1997: 17.

${ }^{290}$ Usually the pharaoh would be closest to the deity and shown without his family, such as the White Chapel of Senwosret I at Karnak. http://wayback.archiveit.org/7877/20160919152314/http://dlib.etc.ucla.edu/projects/Karnak/feature/WhiteChapel.
} 
Certain artifacts and elements in ancient Egypt were created for use by any individual regardless of sex, including, but not limited to, items such as jewelry, ${ }^{291}$ pottery, and home ware. ${ }^{292}$ There are also cases in which many objects are now too damaged to identify. ${ }^{293}$ Interpreting these damaged artifacts has caused a dependency on the modern understandings of gender, which is a prevailing issue where assumptions are made based on biases and experiences. Gender in Egyptian art has often been interpreted from the modern ideas of how gender should be and how it differentiates from sex. ${ }^{294}$ From a modern view point, ancient Egyptians used markers such as primary and secondary sexual characteristics along with features such as dress, hair, age, sex, and gender to indicate occupation. ${ }^{295}$ Royal and nonroyal women of the Twelfth Dynasty shared certain types of dress and hairstyles, such as kilts, sheath dresses, and wigs inspired by the goddess Hathor. This suggests that presenting certain elements of gender was not restricted socially and economically. As for the surviving works of Twelfth Dynasty royal women both gender and power were well represented, especially during the reign of Sobekneferu. Her reign demonstrates the flexible structures of the Egyptian language, iconography, and political positions.

Two notions by Nelson and Sørensen can be applied to better understand the power structure of ancient Egypt. Nelson's suggestion that the public roles of women should be viewed more as negotiations of power rather than attempts at dominance ${ }^{296}$ and Sørensen's claim that as the identification and interpretations of gender come from many dimensions, gender becomes fluid and its identity needs to be socially agreed upon. ${ }^{297}$ These concepts are perhaps most visible in the Egyptian succession line. Rulership was a negotiable shift of power that was systematically adaptable. Within the power structure of the political office in contrast to the physical body of the politician, it was socially agreed upon that the sex and gender for the office of pharaoh was negotiable and not fixed. An example of negotiation is being the living embodiment of Horus. Horus was fundamentally male, however ruling women could be the female version of the god (see below Chapter 3.4).

\footnotetext{
${ }^{291}$ Meskell 1999: 63.

292 Meskell 1999: 85.

293 Wilfong 1997: 18; Gilded Mask Fragment, Kelsey Museum, Ann Arbor 4651.

${ }^{294}$ Meskell 1999: 70; Nelson 1997: 21; Sørensen 2000: 42-59.

295 Cooney 2009: 99.

${ }^{296}$ Nelson 1997: 149.

${ }^{297}$ Sørensen 2000: 61.
} 
With the opportunity, royal women were able to rule Egypt without dominance or challenge from their contemporaries and a woman in the pharaonic office fully accorded with the fundamental principal of maat. For each new ruler, elements such as sex, identified gender, age, medical history, and sometimes familial relations were acceptably different for each individual. However, there were certain standard elements expected of each reigning monarch regardless of their sex, including their ritual activities such as erecting temples and their iconography for example wearing the nemes-headdress. This adaptability allowed for the succession line to not depend on an absolute birth sex and the office of pharaoh to be fulfilled by both genders. This pattern was even further flexible because although the ruler was chosen as male and the regent or co-regent as female, this could be changed and under certain circumstances any gender could take part in these positions.

\subsubsection{Women in the Twelfth Dynasty}

The professional roles of women in the ancient Egyptian society included businesswomen, brewers, textile workers, physicians, cosmetologists, managers of administrative districts, priestesses, viziers, regents, and reigning monarchs. Women were relatively equal under the law ${ }^{298}$ and controlled their own property. ${ }^{299}$ They were essential for the practice of ancient Egyptian religion and took part as religious practitioners, musicians, and for elite women the god's wives. A few roles were exclusively for royal women, ${ }^{300}$ including co-regent, regent, and ruler of Upper and Lower Egypt. These occupations demonstrate that women held and expressed power on all levels of Egyptian society. Different types of power are connected with the understanding of the society's labor, of which gender and craft are a significant part, ${ }^{301}$ and it is critical in this study to consider the existence of a gendered division of labor while recognizing that the involvement of women in public roles were not irregularities but highly visible activities. For this study, the employment and occupational duties of Twelfth Dynasty women will be considered as valid work, including monarchs that happen to be female.

The role of women in Egyptian society has been heavily questioned, while a

\footnotetext{
${ }^{298}$ Robins: 1993: 136; Johnson 1996: 175.

${ }^{299}$ Allam 1989: 133-134; Robins 1993: 127-129; Ziegler 2008: 20.

300 This included royal women who were of a non-royal birth.

${ }^{301}$ Costin 1996: 115.
} 
number of offices are assumed to have been restricted to men. ${ }^{302}$ Once preconceptions and assumptions are casted aside, surviving evidence indicates that both royal and non-royal women could control and administer a range of industries as well as estates without the need for a male manager. ${ }^{303}$ An additional argument is that women were excluded from administration mainly because they were not trained as scribes. ${ }^{304}$ Based on surviving artworks and inscriptions, the scribal profession seems to have been male dominated, although this does not mean that the actual processes of reading and writing were restricted to a certain sex. There were several levels of literacy ${ }^{305}$ and considering different comprehension methods the availability to learn to read and write would have been possible. At least four women from the Middle Kingdom held the position of scribe, which is clear evidence that women could be literate and had access to education. ${ }^{306}$ The goddess Seshat, patroness of writing and record keeping is depicted on a relief from the Twelfth Dynasty pyramid complex of Senwosret I at Lisht. ${ }^{307}$ The relief fragment now located in the Brooklyn Museum depicts Seshat recording captives and booty retrieved during the military campaigns of Senosret $\mathrm{I} .{ }^{308}$ It can be suggested that Seshat's presence as a divine female scribe was a representation of women being able to write within or outside of an occupation, however there is currently no sufficient evidence to connect Seshat's position with royal women. While the literacy rate is complex, it is likely the case that royal women had access to official literacy training, especially ones who reigned as regents and monarchs. It is most likely that ruling men were literate, ${ }^{309}$ which could thus mean the same for ruling women.

An example of both literacy and the ability to be in a sole managerial position of Twelfth Dynasty women is a surviving letter from one woman to another. ${ }^{310}$

\footnotetext{
302 Nelson 1997: 132; Millard 1976: 365.

${ }^{303}$ Millard 1976: 365; On the contrary, it has been assumed by some scholars that their duties remained unofficial, with a male ostensibly in charge as manager, Quirke 2007: 251-260.

${ }^{304}$ Wilfong 1997: 36; Quirke 2007: 260.

${ }^{305}$ Baines 1983: 584. Reading and the physical ability to write, reading and narrow composing ability, reading and the full ability to compose texts, carving signs with limited reading ability.

${ }^{306}$ A non-royal woman named Idwy is the earliest recorded female scribe, Callender 1992b: 17; Ward 1989: 35-36.

${ }^{307}$ Hayes 1978: 188; Markoe 1996: 142.

${ }^{308}$ Goddess Seshat, The Brooklyn Museum, New York, 52.129.

${ }^{309}$ Baines 1983: 580; Baines and Eyre 1983: 77-81.

${ }^{310}$ Griffith 1897: 78-79; Griffith 1898: XXXIV; Millard 1976: 366; Collier and Quirke 2002: 129 UC32209. It can be suggested that the letter was dictated by the women to a male scribe, however for business correspondences this seems unlikely as she was a trusted administrator.
} 
Within the heavily damaged letter the female administrator alerts most likely another female administrator that a serf or tiller named Sobekemheb has been apprehended. She also states that as a criminal she sent him to jail and is awaiting his hearing. Either the second administrator replies or the first then goes on to mention the movement of oil. The fact that this is not the only Twelfth Dynasty letter written by one woman to another suggests this practice is not an exception but rather surviving examples of women demonstrating their legal status and authoritative skills in Egypt. Other Middle Kingdom examples of businesswomen include the letter from a female weaving manager, ${ }^{311}$ multiple records addressing women as estate administrators, ${ }^{312}$ and a female titled as ruler $h k_{3} t .^{313}$ As this is the case for non-royal women, an established work force is expected for royal women. Although their public duties would have been different from non-royal women, including fulfilling the political offices of queenship and pharaoh, royal women would have expressed the same type of occupational power within the royal sphere of ancient Egypt.

The office of queenship in itself could be divine, comparable to that of deified kingship, and royal women were essential to the existence and renewal of rulership. Egyptian royal women held significant places in the religious sphere by being the mortal manifestations of the goddess Hathor as the mother, wife, and daughter of both Ra and Horus. Royal women were connected to other goddesses, including Neith, Maat, Sekhmet, Bastet, Wadjet, and Mut, and interchanged their own iconography with that of these goddesses. ${ }^{314}$ They were associated with the motif of the solar eye or solar daughter. ${ }^{315}$ This symbolism represented the royal women as the protector of the pharaoh and a military companion in scenes such as the pharaoh smiting enemies. ${ }^{316}$ Beginning in the Twelfth Dynasty, royal women were regularly portrayed with the cobra on their forehead, which legitimized their positions as monarchs and their connection with the divine protection of the cobra goddess. ${ }^{317}$ This connection with Wadjet solidified their placement as protectors and those who are protected. Based on the forehead position of the cobra, divine queens and royal women were both the protectors of the pharaonic office and queenship

\footnotetext{
${ }^{311}$ Collier and Quirke 2002: 114-117; Szpakowska 2008: 85; Nunn 1996: 196.

312 Millard 1976: 359-366.

313 Petrie 1901: 53 pl. XXVII.

314 Troy 1986: 53-54.

315 Troy 1986: 43-50.

316 Troy 1986: 64.

317 Johnson 1990: 6.
} 
position along with being under the protection of the goddess Wadjet. This duality benefited the religious and political role of the female monarch by complementing their divinity. Unlike kingship, which required a separate female component, a female monarch represented both the divine queenship and kingship, which resulted in their reign not needing the male counterpart to hold the position, as she incorporated both in one.

From the Early Dynastic Period through the Middle Kingdom, royal women had numerous roles in the governmental sphere. These include positions such as vizier, ${ }^{318}$ princess, queen, and reigning monarch (see above Chapter 3.2). In all periods, royal women could also hold multiple offices at the same time, for example queen mother and regent, or princess and God's Wife. ${ }^{319}$ The evidence for these has tended to focus on textual sources without taking into account the iconography, which in certain time periods, such as the Middle Kingdom's Twelfth Dynasty, has survived to a greater extent than textual accounts. Twelfth Dynasty royal women, including Sobekneferu, mainly used iconography to represent and express certain types of power. During this time, an equality in pharaonic titulary, including the female Horus, is seen (see Chapter 3.4), along with an equality in pharaonic regalia. Sobekneferu's torso (Cat. 58) shows a kilt and nemes-headdress overlaid upon a dress, which is the unmistakable outfit of a ruling female. This type of Egyptian iconography reflects the acceptability of a woman to reign as monarch.

\subsection{An etymological approach to the term 'Female Horus'}

The parameters of gender as a theoretical construct in ancient Egypt can be presented through the examination of the title "Female Horus". The female Horus as a construct is interesting because the pharaoh was the living embodiment of the god Horus who could be titled as male or female . This suggests that the rulership was a position shared by both sexes. In the same way that the male

\footnotetext{
318 Although their fulfillment of the occupation is unclear, the first recorded women who held the title vizier were Nebet and Queen Inenek-Inti, both during the reign of Pepy I of the Sixth Dynasty. For Nebet see Callender 1992a: 14-15, Callender 2011a: 254 in reference to the Abydos Stela CG1578 where vizier Nebet and her husband are shown with their children, see also Fischer 2000: 36-37 Fig. 27; For Queen Inenek-Inti see Callender 2011a: 238-241, Leclant and Labrousse 1998: 485 and the Mission Archéologique Franco-Suisse de Saqqara http://mafssaqqara.wixsite.com/mafs/necropole-depepy ier?fbclid=IwAR3OfqH4YD5nCZZZNJmj6c7G4tKnO1kLnFpFVe_eVqL3OtZ05fBQcVBSDm4. ${ }^{319}$ See Khentkaus I of the Fourth Dynasty (Chapter 3.5.2) and Princess Neferure of the Eighteenth Dynasty.
} 
monarch embodied the female goddess Bastet, the protector of the Two Lands, and Sekhmet, who shows extreme power against people who disobey the pharaoh's order, ${ }^{320}$ the female monarch is the embodiment of the male god Horus. The actions completed by the person holding the political position of pharaoh could be done by both women and men and this includes their acting as both gods and goddesses.

This title hrt has been transcribed and translated by Faulkner as meaning Horus of Queen, ${ }^{321}$ included in the Thesaurus Linguae Aegyptiae as $h r . w t$, the female Horus, ${ }^{322}$ and listed in the Ägyptisches Wörterbuch as hrt, the Horus Goddess, the living queen as well as the name of the reigning queen. ${ }^{323}$ It is not listed in the Egyptian grammars and dictionaries of Gardiner, ${ }^{324}$ Hoch, ${ }^{325}$ and Allen. ${ }^{326}$ For this thesis, the transcription hrt and English translation "female Horus" will be used. The female Horus is written with the falcon along with the flat loaf of bread $\triangle$,the phonogram for $t$. The writing of $h r t$, the female Horus, is first used during the reign of Sobekneferu. ${ }^{327}$ Sobekneferu regularly included $h r t$ within her titulary and it is found on over one-third of her surviving artifacts (Fig. 3.1; see Chapter 6). Her initial usage of the female ḥrt title was successful in representing a sole reigning female monarch and the term continued to be used onwards. Later female rulers such as Hatshepsut and Tausret also used this title. ${ }^{328}$ Beginning with Sobekneferu, pharaonic titulary was the same for both male and female rulers, and the title of hrt is an example of how women could rule without a complicated transition of titles.

\footnotetext{
${ }^{320}$ Roberts 1995: 10-13; Simpson 2003: 173.

${ }^{321}$ Faulkner 1962: 173.

${ }^{322}$ lemma-no. 107610; $W b 3,124.10-125.3 ; L G G \mathrm{~V}, 297 \mathrm{f}$.

${ }^{323}$ Hanning 2006: 1720, See also Hanning 1995: 544.

${ }^{324}$ Gardiner 1927.

${ }^{325}$ Hoch 1997.

${ }^{326}$ Allen 2014.

${ }^{327}$ Eldamaty 2015: 74; Troy 1986: 138; Hanning 2006.

${ }^{328}$ See Chapter 3.4 and 3.5 .
} 


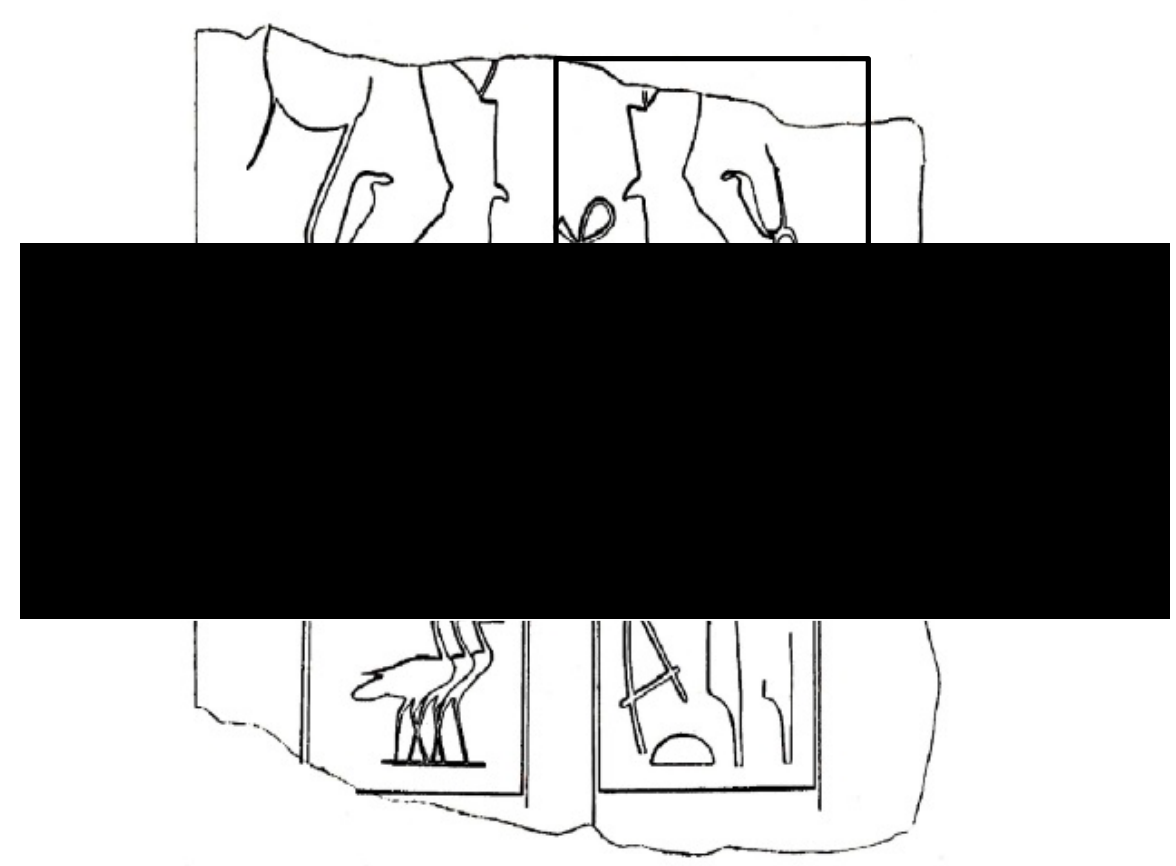

Fig. 3.1 Drawing of column fragment for Sobekneferu, Egyptian Museum Cairo.

The pharaohs would have been directly linked with all deities, which made them the "image of the gods." ${ }^{329}$ This type of identification would have been prevalent among both male and female monarchs since, as ultimate ruler, the pharaoh could be the image of a deity without regard to the assigned gender of the god or goddess. Having the title hrt meant that a monarch such as Sobekneferu was the living embodiment of Horus in female form. This suggests that certain aspects of the deity Horus expressed gender flexibility. This is also seen in circumstances when females adapt to becoming Osiris to obtain rebirth. ${ }^{330}$ In these cases, to become an image of the god, only gender bending or gender flexibility was needed ${ }^{331}$ and this could also be applied to monarchs who are female but are the manifestation of the god Horus.

As stated above, the succession line in ancient Egypt was systematic but not fixed, and the office of pharaoh was available to both women and men. Since the pharaoh was the living Horus on earth, then the aspect of Horus that was connected to rulership was gender fluid. Hornung states that:

\footnotetext{
${ }^{329}$ Hornung 1971: 139. Translated into English by Baines.

${ }^{330}$ Cooney 2008: 13; Smith 2017: 212.

${ }^{331}$ Cooney 2009: 104-105.
} 
The extensive textual evidence of the Middle and New Kingdoms suggests that at his accession the Pharaoh took on the role of Horus, and at his death he took on the role of Osiris, adopting the attributes of these gods without being identical to them. This form of divinity does not relate to him as an individual but to his office. ${ }^{332}$

The office of Egyptian rulership was available to different sexes and genders. This is also seen with the pharaoh's strong connection to the gods and goddesses, where a female holding the office of pharaoh would have equal opportunity to be the image of a certain god, such as Horus. The title $n s w t$ would have reflected the person in the office and this in turn would also be connected to the aspect of the living embodiment of Horus.

\subsection{Female Monarchs and royal women exercising political power}

Women ruled the country on multiple occasions in ancient Egypt, carrying the titles and iconography of $n s w t$ and $h r t$. Royal women were also regents and co-regents for numerous men, resulting in royal women making decisions on behalf of young male rulers. Publications about ancient Egyptian history from the Early Dynastic to the end of Pharaonic times have questioned, often negatively, the female ruler's ability to be ruling monarch and her actions while in office. For example, Sobekneferu's reign in the Twelfth Dynasty has been suggested to be the result of a royal line with no male heir ${ }^{333}$ and that she was able to rule only due to the victory of a family feud. ${ }^{334}$ While there is no evidence for these types of claims, they were the modern assumptions for her reign and are still continued to be used when describing her rulership.

From the Early Dynastic Period to the Nineteenth Dynasty there are at least seven other royal women who also held power in a tenure or pharaonic position: Meretneith, Khentkaus I, Neithikrety, Ahhotep, Neferneferuaten, Hatshepsut, and Tausret. ${ }^{335}$ The reigns of the earliest female rulers Meretneith, Khentkaus I, and Neithikrety present more questions than answers, and in the case of Neithikrety, her

\footnotetext{
332 Hornung 1971: 192. Translated into English by Baines.

${ }^{333}$ Hayes 1973: 43; Van de Mieroop 2011: 102-103, 107; Tyldesley 2012: 11.

334 Gardiner 1961: 141; Lesko 1989: 32.

${ }^{335}$ For more royal women who exemplified political power and influence see: Ankhnesmeryre II of the Sixth Dynasty; Ahmose-Nefertari of the Early Eighteenth Dynasty; Neferure of the Eighteenth Dynasty; Tiye of the Eighteenth Dynasty; Nefertiti of the Amarna Period; and Meritaten of the Amarna Period.
} 
actual existence. ${ }^{336}$ Both Meretneith and Khentkaus I showed exemplary status in their mortuary complexes and titles, but because of limited surviving material their reigns are yet fully understood. Hatshepsut of the Eighteenth Dynasty is the most well documented female ruler of the pre-Ptolemaic era. Multiple artistic depictions and building projects, including her mortuary temple at Deir el-Bahri have survived. These elements have aided in a more complete reconstruction of her reign than any other female monarch. The identity of the ruling Neferneferuaten of the Amarna Period during the Eighteenth Dynasty has been suggested to be multiple different women, including Nefertiti. The last female monarch described in this section is Tausret, who reigned during the Nineteenth Dynasty. Her reign as a female monarch was seen as legitimate through her constructions of a mortuary temple, tomb, and statues, yet similar to the earliest female rulers, her surviving material and modern scholarship has been limited until recently. There are certainly more royal women to be studied and it is hoped that further research on female rulership is undertaken in order to allow the prominence of these women to become visible.

\subsubsection{Meretneith}

Meretneith was a female ruler during Egypt's First Dynasty. Surviving information about Meretneith's life is limited to her mortuary complex, stelae, and important inscriptions. She was the mother of Den, as seen on an Abydos necropolis seal ${ }^{337}$ in which she is labelled as $m w t ~ n s w t$ mother of the king, which is the earliest known use of the title. ${ }^{338}$ Meretneith's name is also inscribed on the Palermo Stone, a royal annal that lists the rulers of the first five dynasties. ${ }^{339}$ Her name is located in the third register on the recto side (PS r.III). ${ }^{340}$ Meretneith is also included on seal listing rulers from Aha to Den (Figs. 3.2, 3.3). This supports that she was King Den's regent and ruled ancient Egypt on his behalf ${ }^{341}$ and possibily solely ruled after hs death. $^{342}$ Thus, Meretneith was perhaps the first recorded female monarch. ${ }^{343}$

\footnotetext{
${ }^{336}$ Coche-Zivie 1972: 115-138; Petrie 1894: 105; Goedicke 1962: 245-246; von Beckerath 1962: 144-145; Callender 2011a: 307-317.

${ }^{337}$ Dreyer 1986: 33-43; Kaiser 1986: 115-119.

${ }^{338}$ Callender 2011a: 34.

${ }^{339}$ For a recent comprehensive analysis see Wilkinson 2000.

340 Pätznick 2015: Figs. 170, 171; Wilkinson 2000: 103-105.

341 Wilkinson 2000: 103.

342 Pätznick 2015: 299, 303. Pätznick includes an ivory label now located in the Egyptian Museum Cairo as a possible representation of Meret-Neith behind her son's Horus, Fig. 172.

${ }^{343}$ Bryan 1996: 27, notes that although less is known, Neithhotep of the First Dynasty was mostly likely a regent for Djer. Emery 1961: 65, writes that "there is reason to suppose that she might be the
} 


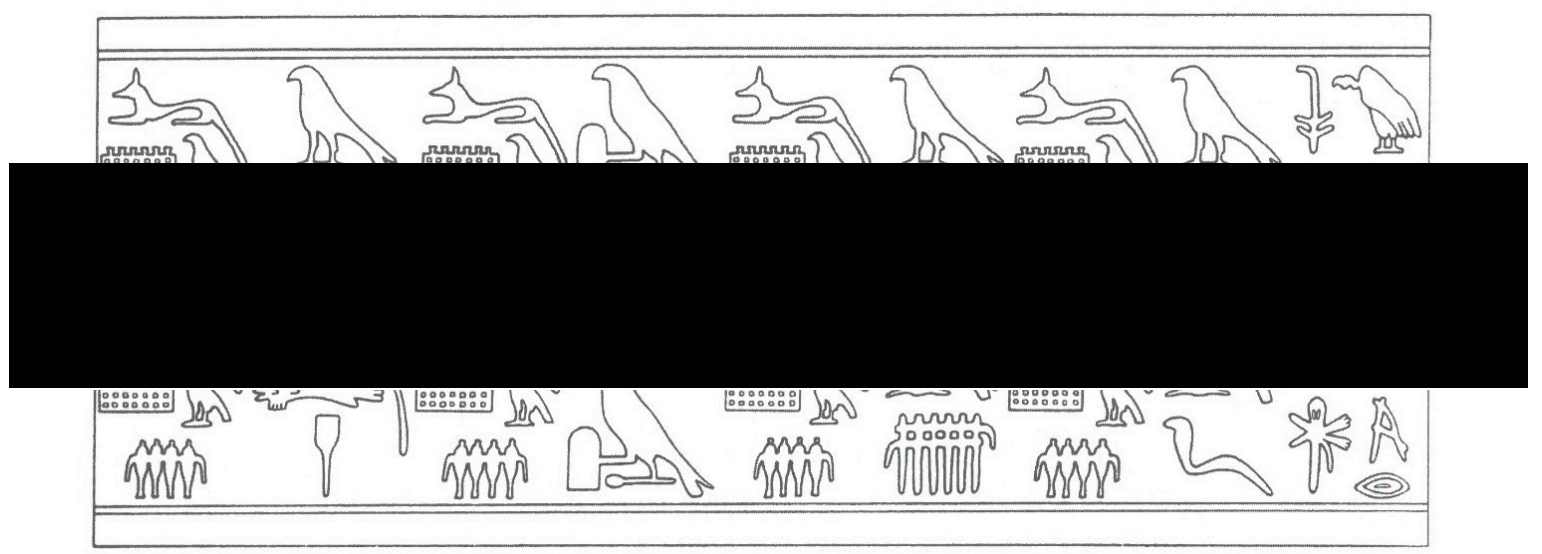

Fig. 3.2 Original Abydos seal of Meretneith's time by Kaiser, Callender 2011a: 31.

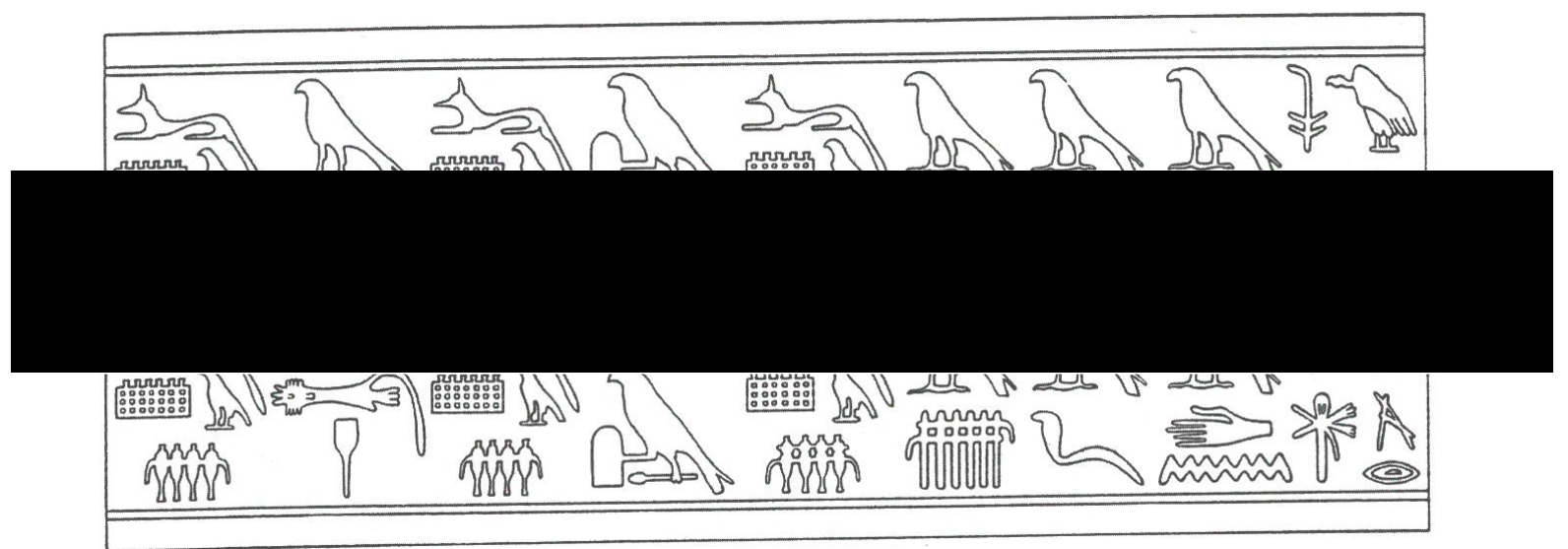

Fig. 3.3 Altered Abydos seal from Den's time by Dreyer, Callender 2011a: 32.

Meretneith's Abydos tomb was discovered by Petrie in 1900 and is now named as Abydos tomb Y.${ }^{344}$ When discovered, it was identified as Meretneith's tomb because of her inscribed stelae that stood in their original positions (Fig. 3.4). The well-built structure was wood lined with plastered floors. Within the central area there were eight rectangular storage rooms, in which only one was not robbed. Outside of Meretneith's tomb structure, forty-one subsidiary tombs were also found, which contained some intact burials of servants. ${ }^{345}$ Meretneith's tomb was indistinguishable from the tombs of the other rulers of the dynasty and she was included by Petrie as a king. From this, Wilkinson claims that "it can hardly be doubted that Meretneith was a king." 346 Like the majority of the other Abydos royal tombs excavated by Petrie, a burial was not found. Nevertheless, Meretneith's Abydos monument was of the

successor of Zer [Djer] and the third sovereign of the dynasty."; Pätznick 2015: 304, states it would be pointless to deny futher the place as the first woman pharaoh of Anceint Egypt to Metet-Neith. 344 Petrie 1900: 10-11.

345 Callender 2011a: 33; Pätznick 2015: 289-292, 294.

346 Emery 1961: 65; Wilkinson 1999: 74. 
status of a ruling monarch suggesting she reigned and was given the burial of a ruler.

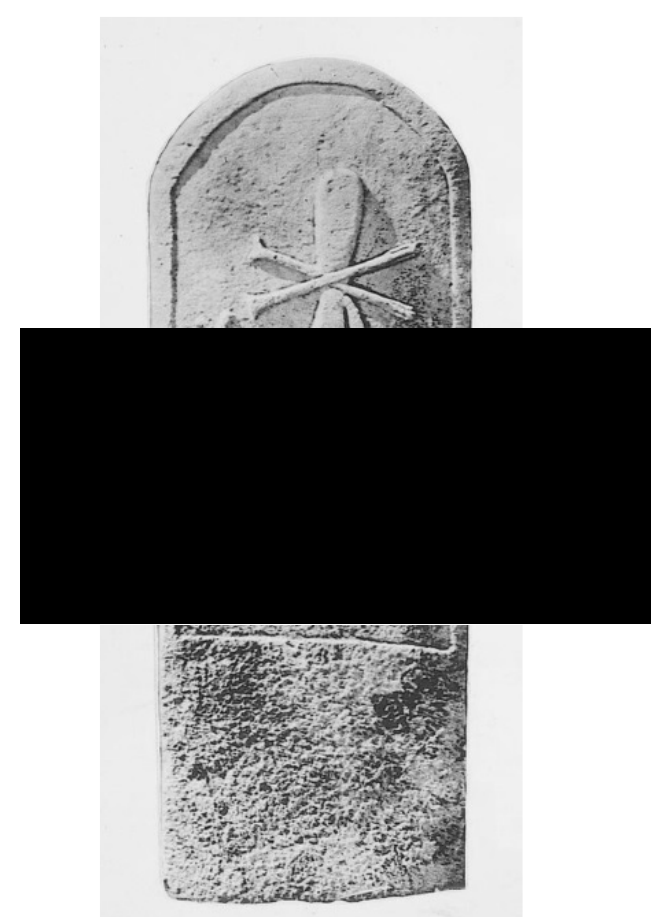

Fig. 3.4 Stela of Meretneith, Petrie 1900: Front piece.

Meretneith is also associated with an early Saqqara tomb (No. 3503) ${ }^{347}$ It is unknown if both of these tombs were securely owned by her, but the fact that two substantial monuments exist for Meretneith further supports that she was politically present during the dynasty. Since the tombs at Saqqara are suggested to be for officials, Meretneith may have had official status as well, although more evidence is needed to confirm this. Found within Saqqara No. 3503 were stone vessels and seal impressions with Meretneith's name, including two impressions of her serekh. ${ }^{348}$ Also found were groups containing a Horus serekh and a large number of impressions for Djer. The tomb had an original burial with a wooden sarcophagus, stone vessels, canopy poles, a few human bones, and a boat grave. ${ }^{349}$ Meretneith was one of a number of early rulers, such as Aha, ${ }^{350}$ and politically prominent Old Kingdom royal women, ${ }^{351}$ like Queen Neith of the Sixth Dynasty, who had substantial boat burials.

\footnotetext{
${ }^{347}$ Emery 1954: 128-170, pls. XL-LVI; Pätznick 2015: 293-294.

${ }^{348}$ Callender 2011a: 30 Fig. 16.

${ }^{349}$ Callender 2011a: 33-35.

${ }^{350}$ Emery 1949: pl. XL.

${ }^{351}$ Ward 2000: 39. Sixteen model boats buried in a row east of Queen Neith pyramid, one of the largest boat burials.
} 
It is certain Meretneith held an extraordinary status and place in the ancient Egyptian government. Her rule saw the building of the Abydos and Saqqara tombs and the foundation of two new domains, $t p \hat{i}-t-w$ and $h r-t p i ̉-h t$ (Fig. 3.5, 3.6), which continued to be in use through Den's reign. ${ }^{352}$ She may also have had an estate in the Western Delta $h w t i h w$, which was an important cattle producing site. ${ }^{353}$ The earliest known name for the treasury that performed taxation and collection was $p r-h d$ 'white house', which is mentioned on seal impressions in the tomb of Meretneith. ${ }^{354}$ Furthermore, the earliest known title for mayor $h 3 t i{ }^{-}{ }^{\top}$ is attested from the sealing of Meretneith's tomb and seems to have described the official Sekh-ka. ${ }^{355}$ This evidence from Meretneith's reign may be an example of early Egyptian bureaucracy. Meretneith ruled over domains, estates, and the earliest offices of taxation thus fulfilling the same functions that a ruler would.

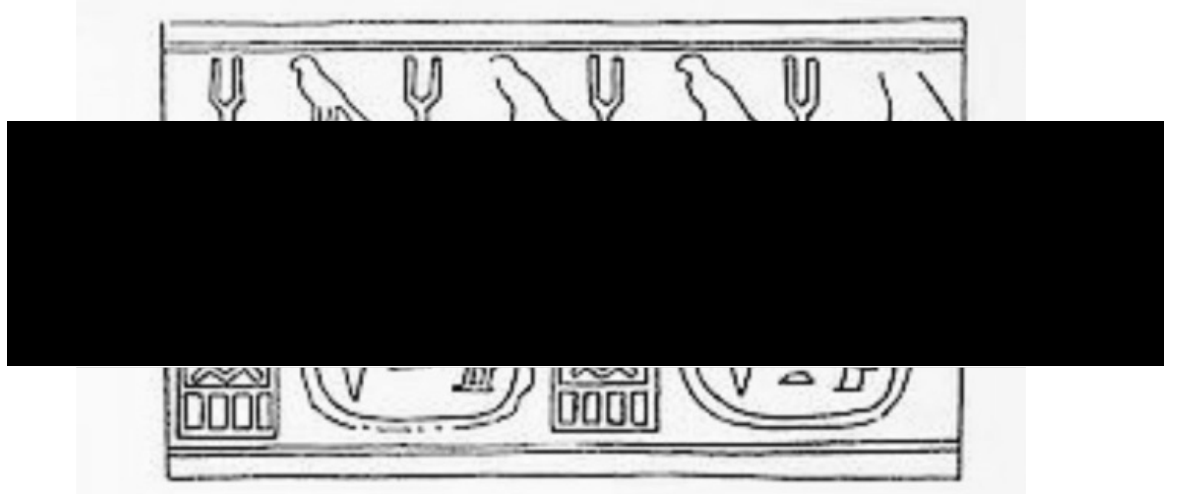

Fig. 3.5 Seal of tpi- $t-w$, Petrie 1900: pl. XXI 22/23.

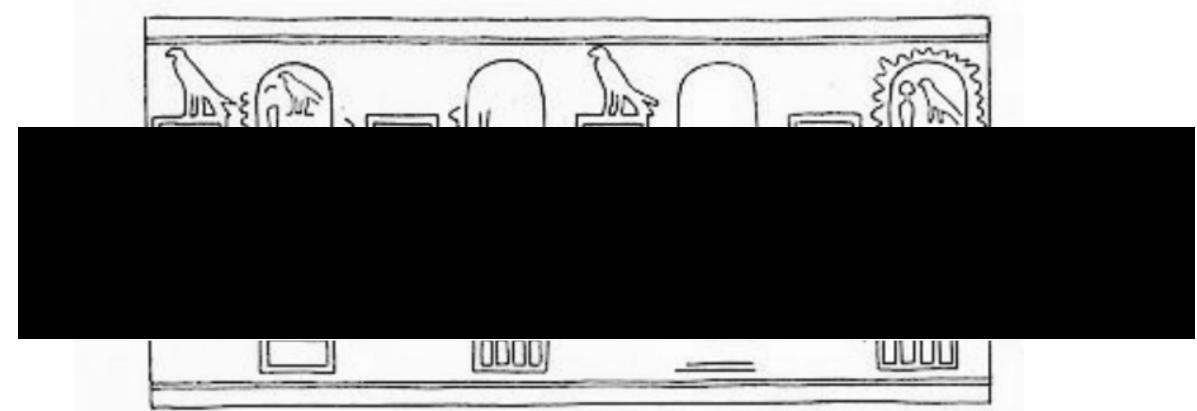

Fig. 3.6 Seal of $h r-t p i-h \underline{t}$, Petrie 1900: pl. XXI 22/23.

\footnotetext{
352 Petrie 1900: pls. XXI.22, XXI.23; Wilkinson 1999: 121

${ }^{353}$ Wilkinson 1999: 124.

354 Wilkinson 1999: 125.

355 Wilkinson 1999: 140.
} 


\subsubsection{Khentkaus I and II}

Khentkaus I ruled over Egypt during the Fourth Dynasty alone or as a royal mother on the behalf of her sons. ${ }^{356}$ Her exact familial relations are still unclear, but it is possible she was the daughter of Menkaure and the mother of Shepseskaf. ${ }^{357}$ Khentkaus I never held the title of hmt nswt, but she did have the title of $m w t$ nswt suggesting at least one of her children became pharaoh. The reign of Khentkaus I and her titles have been discussed among some scholars ${ }^{358}$ and the disagreement on the translation of her title $m w t$ nswt bjtj $n s w t$ bjtj is still on-going. The titles found at her mortuary complex can be translated in two ways "Mother of the monarch of Upper and Lower Egypt [as well as] the monarch of Upper and Lower Egypt" or "Mother of two monarchs of Upper and Lower Egypt". 359

The title "Mother of the monarch of Upper and Lower Egypt [as well as] the monarch of Upper and Lower Egypt" is supported by her iconography and grand mortuary complex, while the title "Mother of two monarchs of Upper and Lower Egypt" is supported by the existence of a second Khentkaus from the Fifth Dynasty who carried the same title. ${ }^{360}$ Callender argues that within Egyptian titulary, there was not a necessity for a specific regent title, which results in the dual $n s w t$ bitj title of Khenkaus I. ${ }^{361}$ Verner also suggests that since the title is used for both Khentkaus I and Khentkaus II that it means the two male rulers were twins. ${ }^{362}$ This further suggests that Khenkaus I was the mother of the possible twins Shepseskaf and Userkaf. ${ }^{363}$ At present, neither translation can be surely proven, although $m w t ~ n s w t$ bjtj nswt bjtj, translated as "Mother of the monarch of Upper and Lower Egypt [as well as] the monarch of Upper and Lower Egypt" can be argued to not be an isolated title for regency. It is more plausible the title was inscribed to reflect Khentkaus's

\footnotetext{
${ }^{356}$ Although it is still unknown what family generation Khentkaus I belongs to, she is placed in the Fourth Dynasty by Callender and Verner and in the beginning of the Fifth Dynasty by Dodson. Callender 2011a: 136; Dodson 2004: 64; Verner 2015: 87-88.

${ }^{357}$ Callender 2011a: 149.

${ }^{358}$ Callender 2011a: 148; Roth 2001: 90-104; Sabbahy 1982: 77-82; Troy 1986: 117; Verner 1999; Verner 2001: 175; Verner 2011: 778-784.

359 Translations: "Mother of the king of Upper and Lower Egypt [acting as] the king of Upper and Lower Egypt", "King of Upper and Lower Egypt and mother of the king of Upper and Lower Egypt", and "Mother of two kings of Upper and Lower Egypt." Verner 1997: 109; Verner 1999: 215; Verner 2001: 59; Verner 2015: 87.

${ }^{360}$ Recently the Czech Institute of Egyptology excavated the tomb Ac 30 which belongs to Khentkaus III. Krejči; Kytnarova, and Odler: 2015: 28-42; Verner 2015: 89.

${ }^{361}$ Callender 2011a: 148.

362 Verner 2011a: 783.

${ }^{363}$ Callender 2011a: 148; Verner 2011: 784, Verner 2015: 90.
} 
current political position. This would be similar to the later Queen Ankhnesmeryre II's pharaonic epithet mrrt ntrw nbw "Beloved of all gods" 364 which is used as an example for the regency with her son Pepi II. ${ }^{365}$ It is most likely the case that both Khentkaus I and Ankhnesmeryre II carried associated titles because they were conducting pharaonic type duties, which included regencies.

The iconography of Khentkaus I is significant because she is the first royal woman to be represented wearing pharaonic-type regalia, such as a uraeus, royal beard, and $h \underline{d}$-sceptre (Fig. 3.7; see also Chapter 4.13.1, Fig. 4.45). The type of image, along with the double $n s w t$ bjtj titles, can possibly be interpreted as the regalia for a female monarch or regent for another ruler. ${ }^{366}$

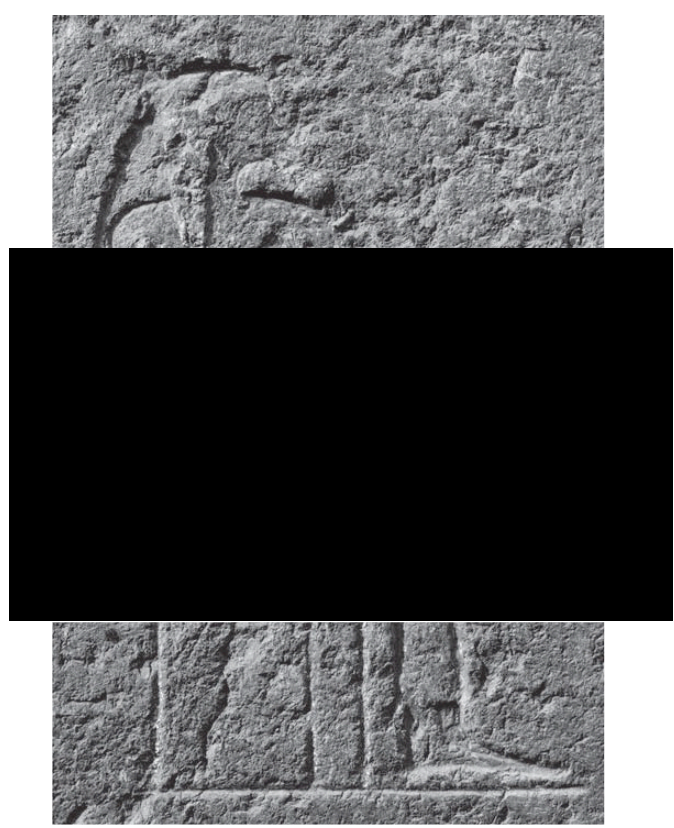

Fig. 3.7 Photograph of Khentkaus I on the southern doorjamb of the granite gate, Verner 2015: fig 2.

The images of Khentkaus I are located in her mortuary monument, which is an example of her extraordinary royal presence. Her large two-stepped mastaba LG 100 is located at Giza, just to the east of the pyramids of Khafre and Menkaure.

Originally thought to be a fourth pyramid, ${ }^{367}$ Khentkaus I's mastaba was constructed in two stages and encased with white limestone. ${ }^{368}$ The tomb is completely different

\footnotetext{
${ }^{364}$ Gardiner Peet, and Černý 1955: 64, pl. IX. A royal mission was sent to the Sinai by the queen regent. 
from other mortuary monuments of Fourth Dynasty royal women and displays royal status through its immense red granite false doors and gateways. Additionally, a temenos wall and a solar boat burial were found, further suggesting the heightened political status of Khentkaus I. ${ }^{369}$ This is because boat burials were important to rulership in the Old Kingdom and were considered symbols of royal power. ${ }^{370}$

During the Fifth Dynasty another royal woman, also named Khentkaus, held the title mwt nswt bjtj nswt bjtj. Khentkaus II was the wife of Neferirkare and the mother of two rulers Raneferef and Niuserre. ${ }^{371}$ Khentkaus II has been used as confirmation that the mwt nswt bjtj nswt bjtj addresses her as the mother of two monarchs and not a monarch herself. ${ }^{372}$ Including the double title, the surviving material for Khentkaus I and Khentkaus II is similar and the discussion in regards to their likeness has been termed the "Khentkaus problem." 373 Both queens also had divine temples $h w t n t r$, which were maintained through at least the Sixth Dynasty. ${ }^{374}$ The pyramid mortuary complex of Khentkaus II is located in Abusir, ${ }^{375}$ unlike that of her predecessor whose was located in Giza. Khentkaus II's complex was built before and after her receiving the title of monarch's mother. ${ }^{376}$ Since two sons are still not attested for Khentkaus I, Khentkaus II's role as a royal mother seems more unambiguous. However, this could support Khentkaus I as a sole ruler or regent with one son and while Khentkaus II was prominent during her dynasty, she mostly reproduced titles and iconography that began with Khentkaus I. Referring to the title mwt nswt bjtj nswt bjtj as a title for the mother of two kings, Verner states that both Khentkaus I and Khentkaus II played significant roles in "securing the legitimacy of succession to the throne" and their official position as the mother allowed the succession line to transfer from brother to brother. ${ }^{377}$ In this circumstance Khentkaus I could have still been a regent for at least one son to further legitimize and secure the pharaonic office.

\footnotetext{
369 Callender 2011a: 139.

370 Ward 2000: 2, 6.

${ }^{371}$ Callender 2011a: 177.

372 Callender 2011a: 177.

373 Verner 1997; Verner 2011.

${ }^{374}$ Callender 2011a: 177.

${ }^{375}$ For further reading, see Verner 1980; 2001.

376 Verner 2001: 47.

377 Verner 2015: 90.
} 
Whether Khentkaus I was a ruler, regent, or mother of two kings, she was a royal woman who exercised political power during the late Fourth Dynasty. ${ }^{378}$ It is possible that Khentkaus I as a royal woman included new elements into her mortuary complex that showed her status as a ruler or regent. ${ }^{379}$ Connected directly to her mortuary complex wall is a miniature town that housed the people who maintained her cult. ${ }^{380}$ Similar to the burial chambers of the rulers Menkaure and Shepseskaf, Khentkaus I's consisted of six deep niches. This pattern of niches is not seen in any other royal or non-royal burial chambers from this time. The titles, iconography, and mortuary complex of Khentkaus I was a large positive step for ancient Egyptian royal mothers. Her time as ruler stands as an example that political flexibility was available to royal women during the Old Kingdom and how it could be replicated by others.

\subsubsection{Neithikrety/Nitocris}

Neithikrety, who is more commonly known by the Greek name Nitocris, was once have thought to be a female ruler of the Sixth Dynasty. ${ }^{381}$ This ruler was given a twelve-year reign by Manetho and was claimed to have been the "loveliest of the women of her time, of fair complexion, the builder of the third pyramid." 382 Herodotus said that Nitocris succeeded her brother to the throne before ultimately committing suicide after avenging his death. ${ }^{383}$ The exact identity of Neithikrety has been the subject of great discussion amongst scholars. ${ }^{384}$ She would have been a member of the royal family, possibly a royal daughter, wife and/or mother. She may have even been related to Pepi II and his wife Neith, or even his regent mother Ankhnesmeryre II. ${ }^{385}$ It is also possible that the monarch Ibi usurped her pyramid complex, although the burial complex for Neithikrety has yet to be identified. ${ }^{386}$ The Turin Canon ${ }^{387}$ was originally thought to prove the existence of

\footnotetext{
378 "To her, rather than to one of the male representatives of the royal family, fell the task of securing the continuity of the monarchy." Verner 2015: 88.

${ }^{379}$ Callender 2011a: 142, 147.

${ }^{380}$ Maragioglio and Rinaldi 1967: 186.

${ }^{381}$ Callender 2011a: 307.

382 Manetho Africanus, Waddell 1940: 55.

${ }^{383}$ Herotodus Book II: 100, Godley 1920: 387-389; Lloyd 1993: 13-15.

${ }^{384}$ Baud 2010: 65-66; Bryan 1996: 29; Callender 2011a: 307-317; Coche-Zivie 1972: 115-138; Goedicke 1962: 245-246; Petrie 1894: 105; Ryholt 2000: 87-100; Troy 2003: 95; von Beckerath 1962: 144-145.

${ }^{385}$ Callender 2011a: 312.

${ }^{386}$ Callender 2011b: 258-259.

387 The Turin List: Museo Egizio di Torino 187; Gardiner 1959.
} 
Neithikrety as a female monarch, ${ }^{388}$ but Kim Ryholt's reconstruction of fragment 43 has led to the suggestion that Neithikrety was actually Netjerkare siptah. The name Siptah (literally, "son of Ptah") is masculine, thus meaning Neithikrety must be the name of a male monarch. From Ryholt's work, this female ruler of Egypt would have never existed but was mixed with the name of a lesser known king. ${ }^{389}$ More recently, Callender has questioned why a scribe would incorrectly copy hieroglyphs to create a female monarch many years before Herodotus. ${ }^{390}$ She also argues for the imbalance of the name Neithikrety-netjerkaresiptah because while Siptah (Sa Ptah) is considered masculine, Neithikrety is still feminine and has no male equivalent. ${ }^{391}$

The earlier royal women Neithhotep and Meretneith (see 3.5.1) include Neith in their names possibly suggesting a tradition for women ${ }^{392}$ as well as there is also a daughter of Amenemhat III of the Twelfth Dynasty with the same name, Princess Neithikrety (Cat. 30). ${ }^{393}$ Similar to later female monarch Sobekneferu, Hatshepsut, and Tausret who used $s 3$ and $s 3 t$ as titles within their titulary, Neithikrety's or Neithikrety-netjerkaresiptah's usage of $s 3$ in their titulary expressed their political occupation as pharaoh and could also coincide with the expanding titulary and iconography of a female monarch.

\subsubsection{Ahhotep}

Ahhotep's rule as queen and possible reigning monarch during the Seventeenth Dynasty bridges the Second Intermediate Period and the New Kingdom. She was the daughter of Ahmose I and Tetisherit, as well as the regent to her son Ahmose II and the mother of the prominent royal woman Ahmosenefertari. ${ }^{394}$ It is most likely during Ahhotep's regency with her son Ahmose that the Hyksos were expelled from Egypt and the country was under local rule once again. ${ }^{395}$ However, Ahhotep's political role has been considered minor based on the fact she was Ahmose's mother and did not carry full pharaonic titles. ${ }^{396}$ Similar to the earlier female rulers

\footnotetext{
${ }^{388}$ Coche-Zivie 1972: 125.

${ }^{389}$ Ryholt 2000: 92-93; For brief discussion on the Brovarski's suggestion that the name Siptah may refer to King Imhotep see Callender 2011b: 253, 256.

${ }^{390}$ Callender 2011b: 252.

${ }^{391}$ Callender 2011b: 254.

392 Callender 2011b: 255.

${ }^{393}$ Callender 2011b: 255; Gardiner, Peet, and Černý 1955: 104-15 pl. XXXIII.

${ }^{394}$ See the stelae of Ahmose II at Karnak, Egyptian Museum Cairo CG 34001 and Stele of Ahmose Abydos, Egyptian Museum Cairo CG 34002.

395 Guégan 2015: 194.

396 Troy 1986: 161.
} 
Meretneith and Khentkaus I, Ahhotep is primarily connected to the pharaonic office through the official position of $m w t$ nswt and her titles reflected this. Ahhotep's tenure was likely that of a pharaonic regent and co-regent to her son. Evidence for Ahhotep's role in Egyptian government has been solidified by forty-nine surviving artifacts and inscriptions. ${ }^{397}$

Ahhotep as a royal politician and ancestor is depicted in at least five ruler lists from later dates. She is clearly included as a ruler in the royal ancestor list discovered in the Nineteenth Dynasty Theban tomb of Kha'bekhnet (Fig. 3.8). ${ }^{398}$ Ahhotep is located on the top register in the fourth position behind Amenhotep I, Ahmosenefertari, and Seqenenre Taa. She is wrapped in an Osiris robe with a beard and nemes-headdress as well as holding a crook and flail. Ahhotep is represented identical to the other pharaohs including her husband Seqenenre Taa and son Ahmose II. This can be considered similar to Sobekneferu who is depicted identical to other rulers in the Karnak ruler list (see Fig. 6.11). Regardless of their sex, the rulers are represented as holders of the pharaonic office in separate attire from the royal women. This is because each political position of queen and monarch had distinctive iconography including regalia, clothing, and headgear that distinguished them from each other, and in the tomb of Kha'bekhnet Ahhotep is certainly depicted as a ruling monarch.

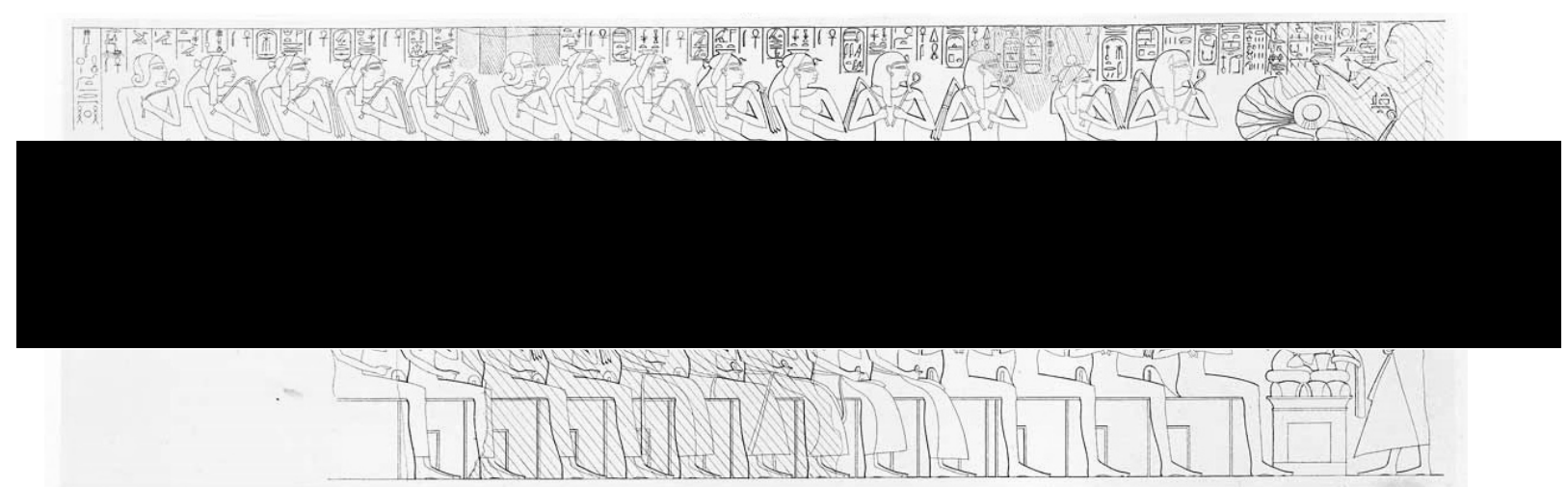

Fig. 3.8 Ruler list from the tomb of Kha'bekhnet, based after Lepsuis.

Two inscribed coffins have been discovered for Ahhotep, which have led to the debate as to how many royal women named Ahhotep lived during the Seventeenth

\footnotetext{
${ }^{397}$ For full analysis see Guégan 2015: 19-181.

398 "All deceased kings are depicted in mummiform guise, wearing the nemes headdress and uraeus and holding the crook and flail against their chests" El Shazly 2015: 44. Since Ahhotep is depicted in this style she can be considered a deceased king.
} 
Dynasty. ${ }^{399}$ The first was found at Dra Abu el Naga by Mariette in 1859 (Fig. 3.9) (00 $^{400}$ while the second was discovered by Brugsch in the Deir el-Bahri Cache (Fig 3.10). ${ }^{401}$ The first coffin (Cairo CG 28501) is gilded and when found contained silver and gold objects with the inscriptions of both Kamose and Ahmose II. ${ }^{402}$ The second coffin (Cairo CG 61006) is the largest of the two standing at a height of $3.12 \mathrm{~m}$ (10ft2in) and contained the mummy of a High priest and pharaoh Pinedjem I of the Twenty First Dynasty. Both coffins are possibly inscribed for the same Ahhotep but were made at different times during her reign. This is seen through the spelling of her name and her titles found on each coffin. The gilded coffin from Dra Abu el Naga identifies Ahhotep only as the wife of the monarch and depicted her name written in its early form. The larger coffin from Deir el-Bahri identifies Ahhotep as the daughter of the monarch, sister of the monarch, wife of the monarch, and mother of the monarch, while the writing of her name in the later form. ${ }^{403}$ The theory of two coffins for the same Ahhotep can be supported by the fact that her political status changed during her reign and this was expressed through her funerary objects. Since the placement of the mummy of Pinedjem I inside the coffin found in the Deir el-Bahri cache is an obvious case of reuse, it can also be suggested that one coffin was kept as a cenotaph type burial similar to the queens and monarchs of the Twelfth Dynasty (see Chapter 5.8).

\footnotetext{
${ }^{399}$ Eaton-Krauss 1990: 195-205; Roth 1999: 361-377; Guégan 2015; Robins 1982; Schmitz 1978; Troy 1979; Vandersleyen 1980.

${ }^{400}$ Desjardins 1860: 100; Winlock 1924: 252-253.

401 For background to Brugsch's discovery of the cache see Bickerstaffe 2010.

402 Roth 1999: 361-362.

${ }^{403}$ Eaton-Krauss 1990: 195-205; Eaton-Krauss 2003: 78-89; Roth 1999: 362; Vandersleyen 1971: 209.
} 

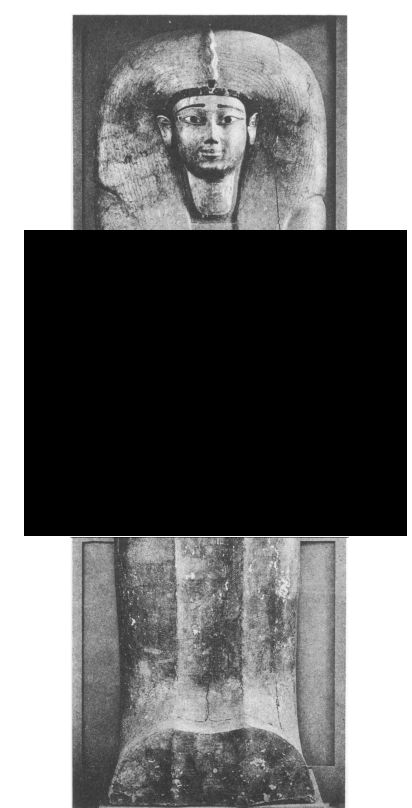

Fig. 3.9 Gilded coffin inscribed for Ahhotep, Winlock 1924: pl. XVI.

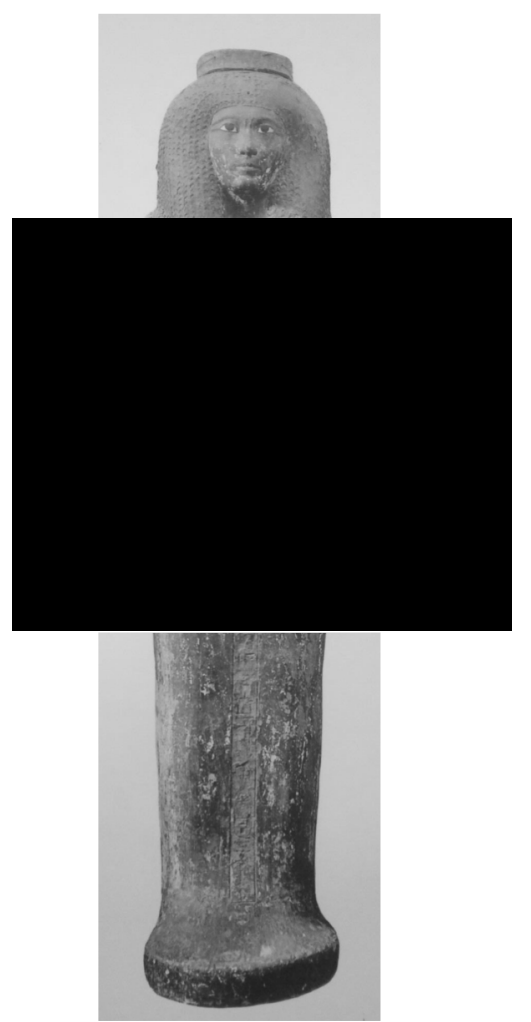

Fig. 3.10 Wooden coffin inscribed for Ahhotep, Daressy 1909: pl. IX.

In addition to acting as the regent to Ahmose II, Ahhotep was also described as a military general for the Egyptian domestic army. ${ }^{404}$ Arguably the most well-known inscription for Ahhotep is stela of Ahmose from Karnak (CG 34001), which was

${ }^{404}$ Roth 2005: 11; Schoske 2008: 193. 
dedicated by her son (Fig. 3.11). ${ }^{405}$ Ahhotep is once again described as the wife, sister, daughter, and mother of the ruling monarch. The stela is politically significant because it presents Ahhotep as the Lady of the Two Lands, ${ }^{406}$ the caretaker of Egypt, a military general who recruited soldiers and who fought to expel the rebels. ${ }^{407}$ One of the required functions of the pharaonic office was to be victorious over Egypt's enemies and prevail in conflict over overt political preference; this stela expresses Ahhotep's ability to fulfill this role. Ahhotep did not carry full pharaonic titulary; however as the hmt $n s w t$, snt $n s w t, s 3 t n s w t$ and especially $m w t n s w t$ she carried out the certain duties of a pharaonic office and her significance in the Egyptian government was recognized after her reign

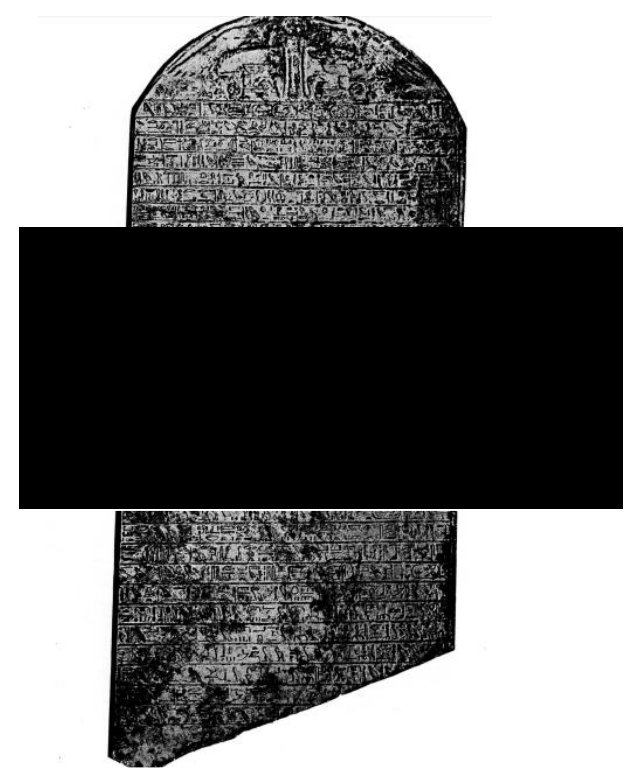

Fig. 3.11 Stela of Ahmose from Karnak, Lacau 1926: pl. 1.

\subsubsection{Hatshepsut}

Hatshepsut was a princess, queen, regent, and reigning monarch during the Eighteenth Dynasty. ${ }^{408}$ She was the daughter of Thutmose I, the wife and half-sister

\footnotetext{
405 Legrain 1903: 27-29.

${ }^{406}$ While the translation of $n b t$ is used throughout the thesis as Lady, it is noted in certain instances the updated phrase Female Manager is more applicable to better reflect the literal definition of the word- a woman in a position of authority or control. Stefanović and Satzinger describe a $n b t-p r$ as an "adult independent woman who was able to manage the economics of a house hold- with, or without a male owner, or to be enrolled in some other business enterprise" Stefanović and Satzinger 2015: 337. 407 Janosi 1991: 99.

${ }^{408}$ Brzostowski 1979; Callender 1995-1996; Callender 1988; Callender 2002; Cooney 2014; Galán, José, Bryan, and Dorman 2014; Krzyżanowski, 1980; Krzyżanowski, 1985; Krzyżanowski and Olbryś
} 
to Thutmose II, and stepmother and regent to Thutmose III. It can be suggested that Hatshepsut's political career began during her husband Thutmose II's reign, when she also held the office of God's Wife of Amun. ${ }^{409}$ However, upon the death of Thutmose II, Hatshepsut's governmental office as ruler was immediately recognized and recorded. ${ }^{410}$ During her regency with Thutmose III, Hatshepsut was crowned as ruler of Upper and Lower Egypt and stayed pharaoh until her death, with her rule lasting for nearly twenty-one years. ${ }^{411}$ During this time she commissioned building projects and has attestations throughout Egypt and Nubia ${ }^{412}$ with a significant emphasis on Thebes particularly Deir el-Bahri and Karnak. ${ }^{413}$ Hatshepsut's high number of surviving artifacts makes her the best documented female ruler included in this section.

Hatshepsut's iconography is significant in understanding her political presence in ancient Egypt. Her artwork followed the Thutmoside style that began in the early Eighteenth Dynasty. ${ }^{414}$ In the early years of her regency, Hatshepsut was depicted in regalia of the queenship office, such as sheath dresses and the double plumed crown. ${ }^{415}$ Through her transition of rulership, Hatshepsut blended queenly and pharaonic regalia to represent her position as ruler and eventually she was represented in full pharaonic regalia. When depicted together Hatshepsut and Thutmose III can only be distinguished by their physical positions and names while less often their regalia. ${ }^{416}$ Hatshepsut's iconographic change is well exhibited in her surviving statuary. ${ }^{417}$ Her statuary can be explained in three phases, which consist of

1991; Naville 1894-1908; Robins 1999b; Roehrig, Dreyfus, and Keller 2005; Tefnin 1979; For more information see the Polish-Egyptian Archaeological and Conservation Mission at the Temple of Hatshepsut Deir el-Bahari website: www.templeofhatshepsut.uw.edu.pl/en.

409 Troy 2003: 98.

${ }^{410}$ For the tomb biography of Ineni in Theban Tomb 81 see Dziobek 1992.

411 Roth 2005: 12-13.

412 Plans of the temples of Hatshepsut at Buhen and Elephantine in comparison with the Treasury of Thutmose I at Karnak, Bonnet 2014: 430, Fig. 18.4.; Schematic plan of Dukki Gel/Kerma under Hatshepsut, Bonnet 2014: 432, Fig. 18.7.

${ }^{413}$ For Hatshepsut's Mortuary Temple at Deir el Bahari see Naville 1894-1908.

${ }^{414}$ For an example of the style see The shabti of King Ahmose, The British Museum London, EA32191; Russmann 2005: 23-27; For an analysis of the sculpture and iconography of Hatshepsut see Tefnin 1979.

415 Dorman 2005: 88.

${ }^{416}$ Inscription fo Hatshepsut and Thutmose III, The Egyptian Museum Cairo, JE45493; Hatshepsut and Thutmose III shown as identical kings from the Chapelle Rouge, Keller 2005: 96, Fig. 41; Graffito of Hatshepsut and Thutmose III at Maghara, Sinai, Laboury 2014: 89, Fig. 5.30; Schulz 2015: 13-16.

417 Keller 2005: 158-164, Cat. 88-96; Laboury 2014 76-86; Tefnin 1979: 135-144, 162-170. Laboury describes Hatshepsut's iconography as "progressive masculinization" and includes four phases of her decoration process at the southern temple of Buhen, Laboury 2014: 76, Fig. 5.24. 
complete queenship guise, a mixture of female and pharaonic regalia, and complete pharaonic regalia. In full queenship dress Hatshepsut is shown wearing a sheath dress and usually headdresses such as the double feather crown. ${ }^{418}$ Similar to Sobekneferu of the Twelfth Dynasty, Hatshepsut's female pharaonic regalia consisted of a sheath dress and nemes-headdress. This type of combination showed Hatshepsut as a female monarch in control, and who ruled with great authority. ${ }^{419}$ Hatshepsut's final iconographic statement was her depictions as the canonical pharaoh of Egypt, which showed her with the nemes-headdress, uraeus, shendyt-kilt, and royal beard. ${ }^{420}$ With these images, Hatshepsut was able to strengthen her role in the pharaonic office and present this legitimization to the public.

Hatshepsut's most well-known building project is her mortuary temple at Deir el-Bahri. ${ }^{421}$ The iconography found throughout the temple depicts Hatshepsut's political life, including the transportation of her obelisks, her divine birth, during which time she was proclaimed ruler of Egypt. During her reign Hatshepsut led a successful trading expedition to the land of Punt, which is depicted on the walls of the middle terrace at the temple. ${ }^{422}$ Hatshepsut was the first New Kingdom pharaoh to initiate an expedition to Punt, which demonstrated her successful abilities as ruler. ${ }^{423}$ She was able to establish Egypt's trade with the south and exhibit her strong connection with the god Amun who legitimized her rulership. ${ }^{424}$ Also found within the temple are chapels for Hathor, Anubis, the cult of the royal family, and a sanctuary for the god Amun. From the temple's constructed style of vertical ramps, Hatshepsut was able to transform the public exposure of the priest's processions. Hatshepsut and the priests would have been visible to the public entering and exiting different parts of the temple, which allowed for Hatshepsut's reign as monarch to be

\footnotetext{
${ }^{418}$ Graffito at Aswan showing Senemut facing Hatshepsut, who wears queenly regalia; Hatshepsut wearing a plumed crown with ram's horns from the Chapelle Rouge, Dorman 2005: 87-88, Figs. $37-$ 38.

${ }^{419}$ The Female Pharaoh Hatshepsut, The Metropolitan Museum of Art, New York, 29.3.3; Keller 2005: 171.

${ }^{420}$ For examples see Hatshepsut in a devotional attitude, The Metropolitan Museum of Art, New York, 28.3.18; Large kneeling statue of Hatshepsut with the White Crown, The Metropolitan Museum of Art, New York, 30.3.1; Large kneeling state of Hathepsut, The Metropolitan Museum of Art, New York, 29.3.1; Head from a Osiride state of Hatshepsut, The Metropolitan Museum of Art, New York, 31.3.164.

${ }^{421}$ Naville 1894-1908.

${ }^{422}$ Naville 1894: 21-25; pl. VII, VIII. See also: Cast of Punt Reliefs, Temple of Hatshepsut at Deir el Bahri, Virginia Museum of Fine Arts, Richmond, L.5.52.48, lent by the Metropolitan Museum of Art. ${ }^{423}$ For a complete study on the land of Punt see Breyer 2016; Creasman 2014: 400-402.

${ }^{424}$ Creasman 2014: 399, 402.
} 
witnessed by the ordinary public. ${ }^{425}$ Her temple at Deir el-Bahri also served as the place for the Beautiful Festival of the Valley, where Amun-Ra's divine barque would be taken from Karnak to his shrine at Deir el-Bahri. ${ }^{426}$

At Karnak Temple, Hatshepsut commissioned the erection of obelisks for the Festival Hall, the Eastern Temple, and the Wadjet Hall. She also constructed all or part of the Palace of Maat, the Eighth Pylon, the Red Chapel, and the Pylon and Festival Court of Thutmose II. ${ }^{427}$ The Red Chapel is another example of how Hatshepsut's reign was legitimized by the divine sphere and Amun. ${ }^{428}$ Hatshepsut constructed extraordinary roads between the temples Luxor, Medinet Habu, and Deir el-Bahri to carry the sacred barque of Amun and these achievements helped reward her reign with prosperity and legitimacy. ${ }^{429}$ Because of these works, she was recognized as both ruler and regent by deities and the public.

\subsubsection{Hatshepsut's connections with the Middle Kingdom and Sobekneferu}

Hatshepsut's reign was filled with public displays of legitimization, including strongly connecting herself to the Middle Kingdom. Her approaches include her mortuary temple, titulary, and iconography. The temple of Mentuhotep II of the Eleventh Dynasty was the direct inspiration for Hatshepsut's mortuary temple at Deir el-Bahri, where she built her own monument in a similar style. ${ }^{430}$ Both temples were constructed with architectural components such as ramps and colonnades, but when finished Hatshepsut's temple would have been a unique structure displaying her political and religious office. ${ }^{431}$

On multiple iconographic and titular occasions Hatshepsut related herself to Sobekneferu of the Twelfth Dynasty, who she possibly used as a direct model. ${ }^{432}$

\footnotetext{
425 Warburton 2012: 241.

${ }^{426}$ Karkowski 1992: 155-166.

${ }^{427}$ For further information, photographs, and reconstruction model see Digital Karnak: http://wayback.archiveit.org/7877/20160919152257/http://dlib.etc.ucla.edu/projects/Karnak/feature/PalaceOfMaat; http://wayback.archiveit.org/7877/20160919152212/http://dlib.etc.ucla.edu/projects/Karnak/feature/P ylonVIII; http://dlib.etc.ucla.edu/projects/Karnak/feature/RedChapel; http://wayback.archiveit.org/7877/20160919152259/http://dlib.etc.ucla.edu/projects/Karnak/feature/PylonAndFestivalCourt OfThutmoseII.

428 Warburton 2012: 237.

${ }^{429}$ Arnold 2005: 135; See also; Map of Thebes showing the principal temples of the early $18^{\text {th }}$ Dynasty and the routes of festival processions, Roth 2005: 148, Fig. 63.

${ }^{430}$ Naville 1907-1913.

431 Warburton 2012: 240.

432 Callender 1998: 236; Laboury 2014: 86-87; Roth 2005: 12.
} 
The most important problem when comparing the two female rulers is the length of their reigns. Sobekneferu has a reign of around four years while Hatshepsut was regent and pharaoh for around twenty-one. Nevertheless, their titulary and iconography show many similarities, including the poses: devotional attitude (Cat. 57), ${ }^{433}$ kneeling (Cat. 60), ${ }^{434}$ and sphinx (Cat. 64). ${ }^{435}$ While ruling Egypt, both women directly associated themselves with their father and not the rulers who came before them. This association strategy was intended to strengthen the legitimacy of their reigns. Sobekneferu and Hatshepsut's titulary alternated between neutral, masculine, and feminine endings, such as being referred to as both the daughter and son of Ra. ${ }^{436}$

The iconography of Sobekneferu and Hatshepsut seems to be the most significant since all the surviving poses Sobekneferu is represented in, Hatshepsut is as well. Sobekneferu's statuary completes over one-third of her known artifacts. She is seen seated, in devotional attitude, in sphinx form, and kneeling (Fig. 3.12). Hatshepsut was also represented in these poses and is seen wearing a pierced double pouch pendent that was associated with Twelfth Dynasty rulers. It is unclear whether Hatshepsut was copying the iconography of Sobekneferu specifically, or simply depicting herself wearing regalia and jewelry typical of monarchs in general.

\footnotetext{
${ }^{433}$ Hatshepsut in a devotional attitude, The Metropolitan Museum of Art New York 28.3.18.

${ }^{434}$ Large kneeling statue of Hatshepsut, The Metropolitan Museum of New York Art 29.3.1.

${ }^{435}$ Sphinx of Hatshepsut, The Metropolitan Museum of Art New York 31.3.166.

${ }^{436}$ Callender 1998: 232, 236; Troy 1986: 142.
} 


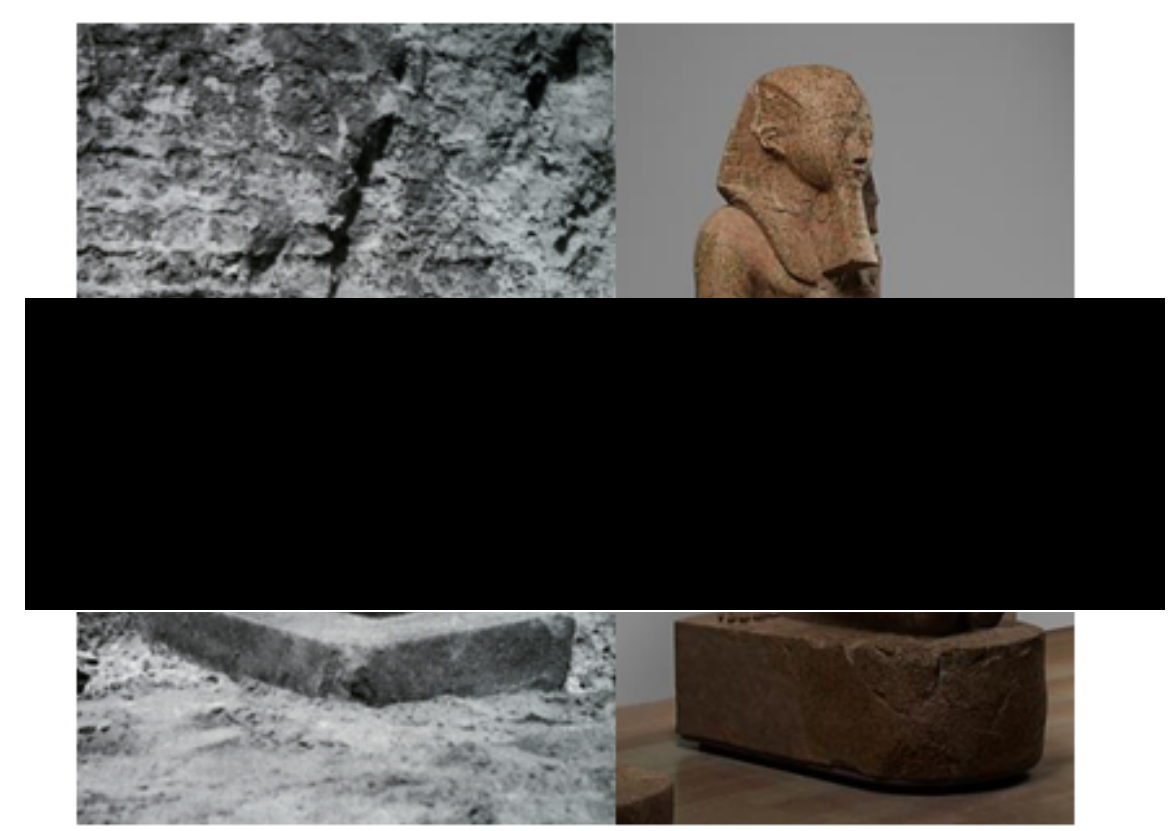

Fig. 3.12 Comparison of Sobekneferu and Hatshepsut in the kneeling pose, Habachi 2001: Cat. 9; Large kneeling statue of Hatshepsut, Metropolitan Museum of Art New York 29.3.1.

There are no known surviving heads for the statues of Sobekneferu's, but it is highly possible she wore the nemes-headdress or the White crown as seen on Hatshepsut ${ }^{437}$ to intentionally blend female and pharaonic regalia. As mentioned above, this is seen in Hatshepsut's iconography before she was represented as the canonical pharaoh (Fig. 3.13). Because Sobekneferu had a shorter reign, it is uncertain if her iconography would had transitioned similar to that of Hatshepsut's, but it could be possible it would have not needed to. Unlike Sobekneferu, Hatshepsut did not have a completely independent reign, which would have been a determining factor in Hatshepsut's iconographic transition. As Laboury states the masculinization of Hatshepsut's image "was not theoretically nor ideologically needed" it was directly related to the presence of Thutmose III. ${ }^{438}$ Sobekneferu was the first to blend female and pharaonic regalia, but because she was an independent ruler she may not have needed to show equivalency or her co-regency with another pharaoh, which may have been the case for Hatshepsut and Thutmose III. It is impossible to know Hatshepsut's exact motive, but she was likley inspired by Sobekneferu and used the Middle Kingdom as a legitimization tool during her reign.

\footnotetext{
${ }^{437}$ Large Kneeling Statue of Hatshepsut, The Metropolitan Museum of Art New York 30.3.1.

${ }^{438}$ Laboury 2014: 87.
} 


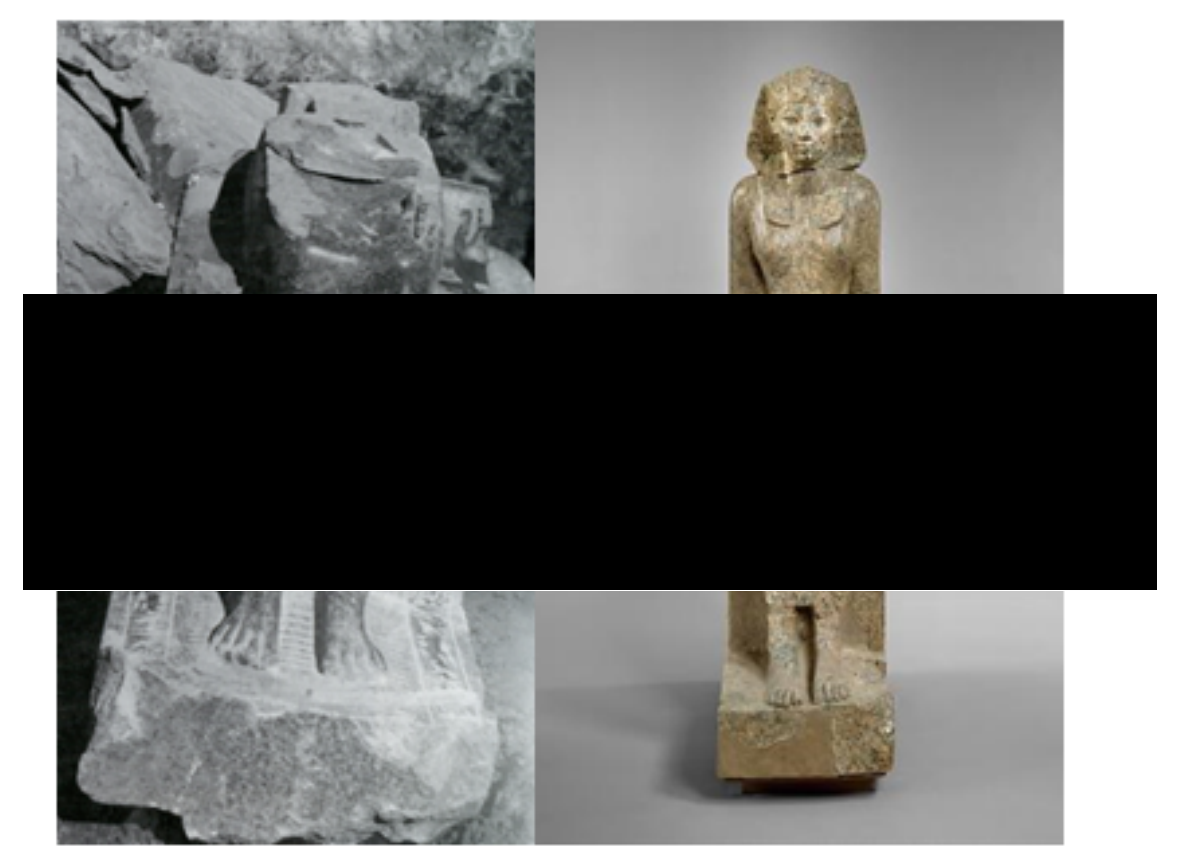

Fig. 3.13 Comparison seated states of Sobekneferu and Hatshepsut, Habachi 2001: Cat. 11; The female Pharaoh Hatshepsut, Metorpolitan Museum of Art New York, 29.3.3.

\subsubsection{Nefertiti, Meritaten, and Neferneferuaten}

Neferneferuaten Nefertiti was a queen along with a possible co-regent and ruler during the Amarna Period of the Eighteenth Dynasty. Her parents and original birthplace are unknown, but it is possible she was related to the later pharaoh Ay or his family. ${ }^{439}$ Nefertiti along with her husband, Akhenaten temporarily changed the religion, political capital, and iconography of ancient Egypt. Acting as one third of the triad made of Aten and Akhenaten, Nefertiti assisted in the religion of ancient Egypt shifting to a monotheistic belief worshipping the light. ${ }^{440}$ In year five of the Akhenaten's reign the capital was moved to the city of Tell el-Amarna. ${ }^{441}$ For the next twelve years Akhenaten, Nefertiti and their daughters would rule and worship from Amarna, however within twenty years of Akhenaten's death in year seventeen the city was abandoned. ${ }^{442}$ Accompanying the significant developments in religion and politics, the Amarna period produced momentous changes in iconography. Akhenaten and Nefertiti were depicted as equals and the royal family was now shown as intimate with new iconographic aspects as seen on the relief of Akhenaten holding Meritaten with Nefertiti holding Maketaten and Ankhesenpaaten (Fig. 3.14).

\footnotetext{
439 Green 1996: 10; Kemp 2012: 14.

440 Seyfried 2013: 190.

${ }^{441}$ Kemp 2013.

${ }^{442}$ Kemp 2012: 17.
} 


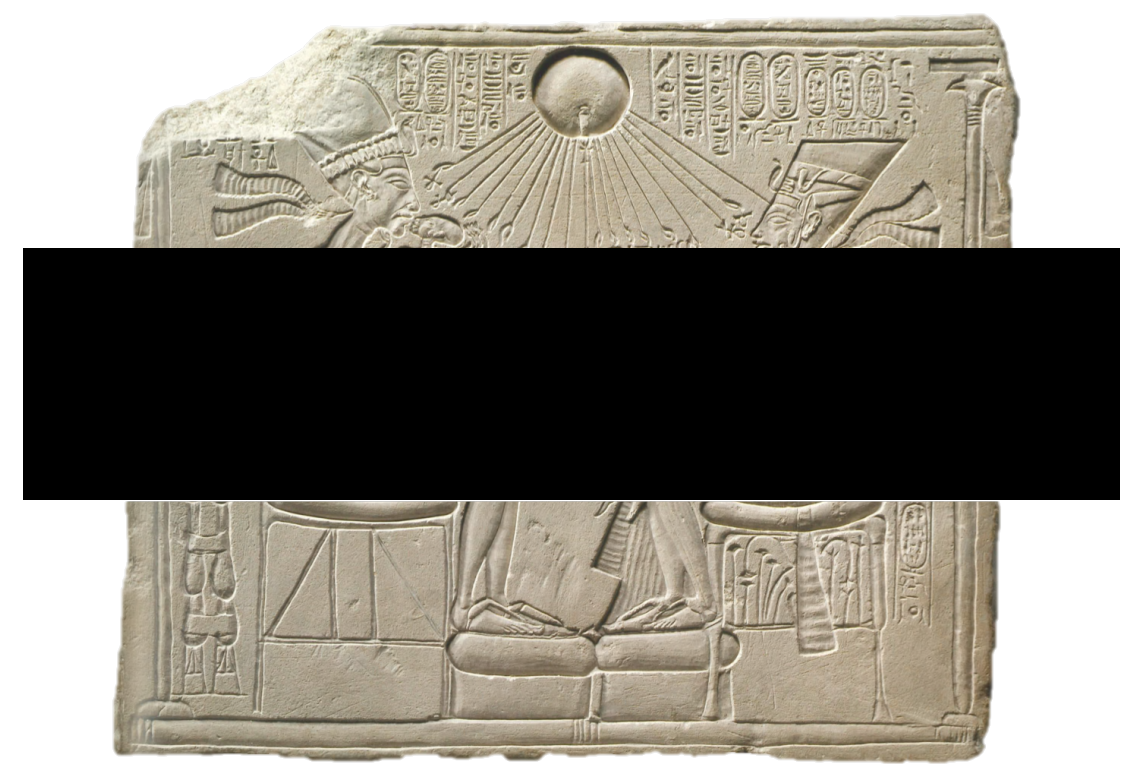

Fig. 3.14 The Royal Family. Ägyptisches Museum und Papyrussammlung, Berlin ÄM 14145.

Coinciding with Akhenaten's iconographic shifts as seen as on the colossal statue now located in the Egyptian Museum Cairo, ${ }^{443}$ Nefertiti was represented with new attributes including her characteristic crown shown most prominently on her surviving bust (Fig. 3.15), she was depicted in a river scene smiting a female enemy (Fig. 3.16), and also shown driving a chariot in a procession behind Akhenaten and in front of her daughters (Fig. 3.17). ${ }^{444}$ Similar to the earlier pharaoh Hatshepsut, Nefertiti was depicted worshipping the Aten by herself often being accompanied by a daughter. ${ }^{445}$ Unlike other female rulers before and after her, Nefertiti had a reigning husband; however she was shown ichnographically and religiously equal to him. Her prominence during this unique time period was so significant it has been suggested she was Akhenaten's co-regent during his last years and used the name Neferneferuaten (see further discussion below). Nefertiti's last known reference as Neferneferuaten Nefertiti is an inscription from Dayr Abu Hinnis that is dated to the third month of the fifteenth day of the sixteenth year of Akhenaten. Although it is unclear if she was his co-regent, this inscription securely dates her to the end of

\footnotetext{
${ }^{443}$ Colossal statue of Amenhotep IV/Akhenaten from Karnak, Egyptian Museum Cairo JE 49529. ${ }^{444}$ See also Akhénaton et Néfertiti, Musée du Louvre Paris E155593; Releif of Queen Nefertiti, The Metropolitian Museum of Art New York 47.57.1; Relief of Queen Nefertiti, The Metropolitian Museum of Art New York 61.117; Fragement of a relief showing Nefertiti, The Brooklyn Museum New York 71.89; Queen Nefertiti, The Brooklyn Museum New York 78.39; The Wilbour Plaque, The Brooklyn Museum New York 16.48; Queen Sculptor's model of Nefertiti's bust in profile, The Egyptian Museum Cairo JE59 296; Statuette of Nefertiti from the Thutmose workshop, Ägyptisches Museum und Papyrussammlung Berlin 21263.

${ }^{445}$ Arnold 1996: 85.
} 
Akhenaten's reign and helps dispel suggestions she disappeared during his thirteenth or fourteenth year after the funeral of their second oldest daughter Meketaten. ${ }^{446}$

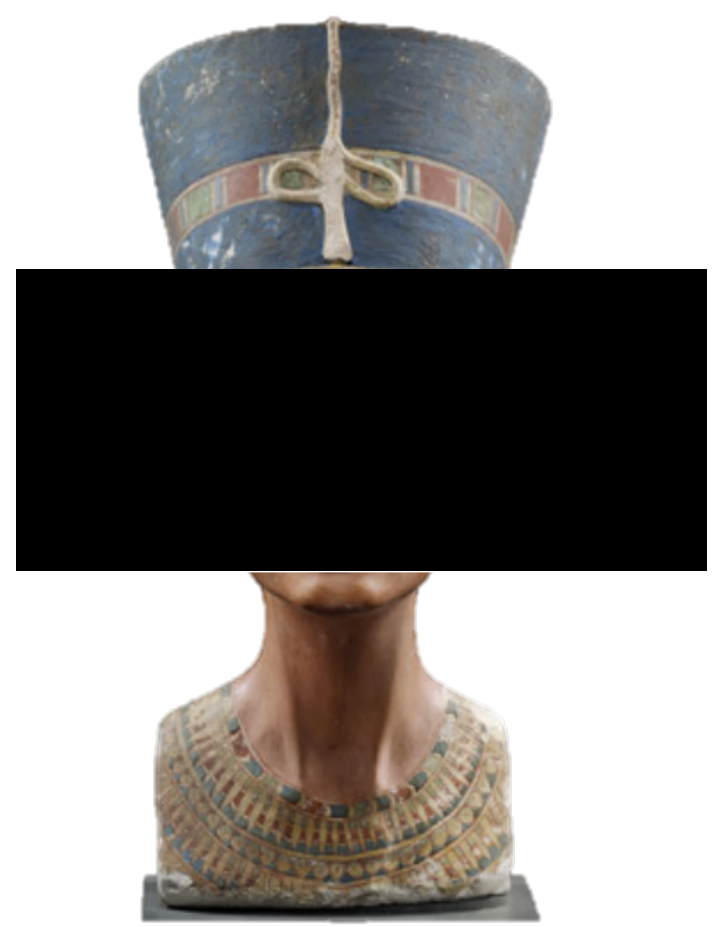

Fig. 3.15 Bust of Queen Nefertiti, Ägyptisches Museum und Papyrussammlung, Berlin ÄM 21300.

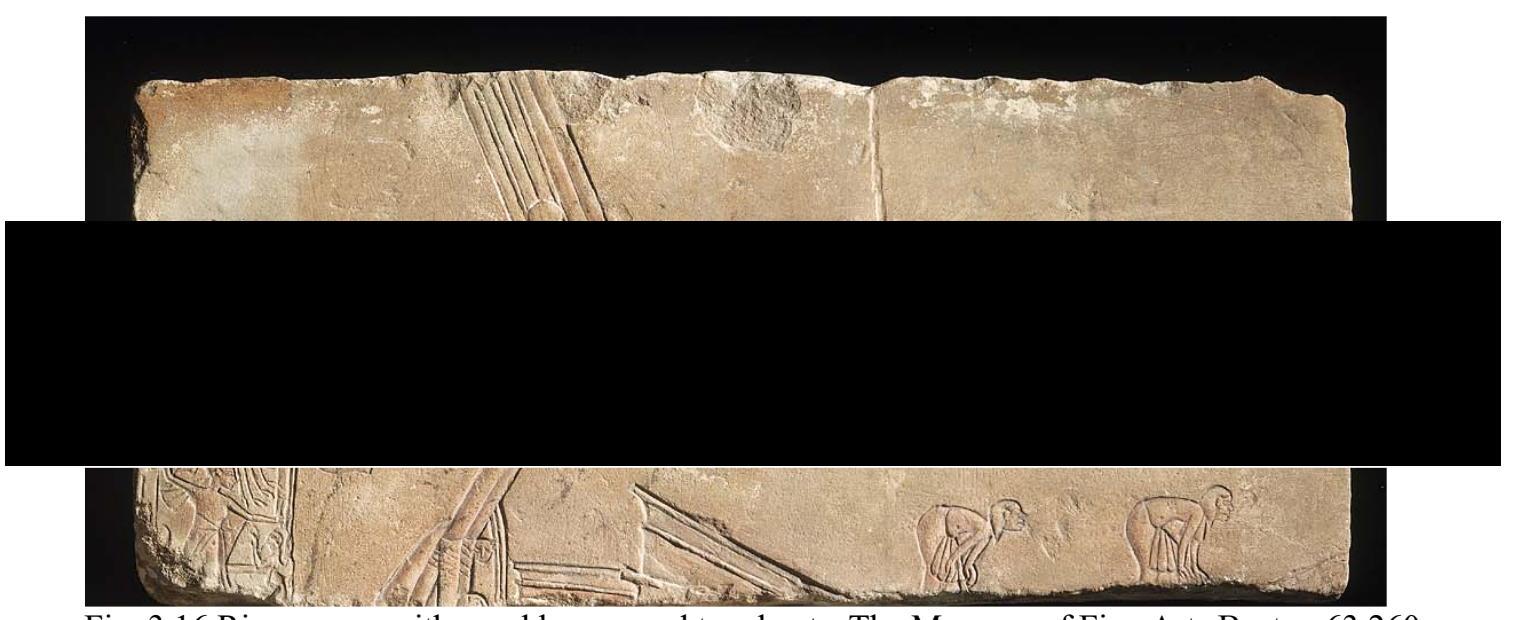

Fig. 3.16 River scene with royal barges and tow boats, The Museum of Fine Arts Boston 63.260.

${ }^{446}$ Van der Perre 2012: 195-197. 


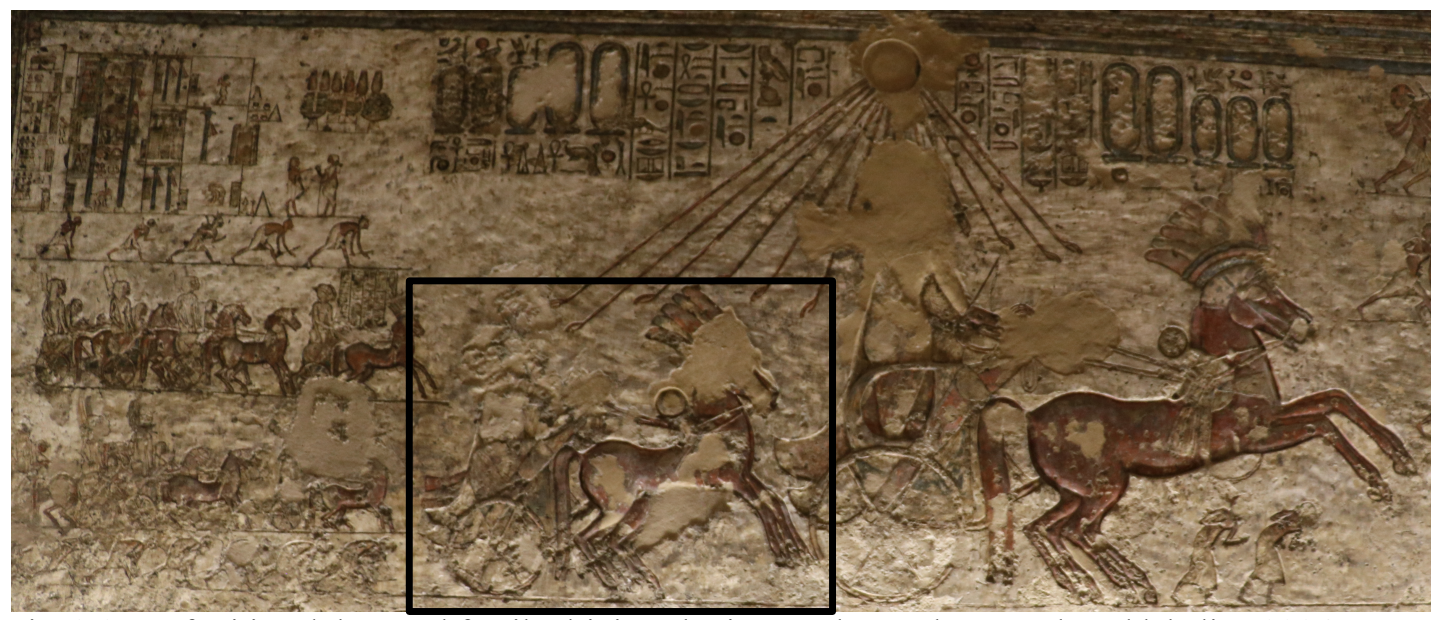

Fig. 3.17 Nefertiti and the royal family driving chariots, author's photograph and labeling 2016.

Nefertiti and Akhenaten had six daughters with Meritaten being the eldest and who was most likely born before Akhenaten's accession. Meritaten was often shown with her parents and the closest to Akhenaten as seen above on the royal family stela (Fig. 3.14). ${ }^{447}$ During her life time Meritaten's official positions changed including transferring from Akhenaten's daughter to his chief wife, which was also recognized by foreign rulers. ${ }^{448}$ In the later part of Akhenaten's reign, Meriaten was politically prominent and her images replaced those of her father's second wife Kiya. ${ }^{449}$ Meritaten is connected with two of Akhenaten's successors, Neferneferuaten ${ }^{450}$ and Smenkhkare. ${ }^{451}$ The discussions of who Neferneferuaten and Smenkhkare have encompassed multiple options including, them being the same person,

Neferneferuaten being Nefertiti, Meritaten, or Neferneferaten-Tasherit as well as Smenkhkare being Nefertiti, a son of Akhenaten, a brother of Akhenaton, the Hittite prince Zannanaza, the husband of Meritaten, or Meritaten herself. 452

\footnotetext{
${ }^{447}$ Green 1996: 10-11. Further depiciotns of Meritaten see Fragment of a column drum featuring the royal family worshipping, The Museum of Fine Arts Boston 67.637; Fragment of a column showing Nefertiti and Princess Meritaten offering to the Aten, Ashmolean Museum Oxford AN1893.1-41.71; Fragment of a column showing Akhenaten, Nefertiti, and Meritaten, Ashmolean Museum Oxford 1893.1-41.75; Stela showing Akhenaten giving earing to Princess Mereaten, Egyptian Museum Cairo JE44865; Princess Meritaten receiving an earring from Akhenaten, University Museum University of Pennsylvania Philadelphia E252; Fragment of a relief showing Akhenaten, Nefertiti, and Meritaten, The Petrie Museum London UC401; Sunshade block for Meriaten, Museum of the University of Pennsylvania E16230.

${ }^{448}$ For Amarna letters see Arnold 1996: 11; Kemp 2012: 15; Moran 1992; Wegner 2017: 152.

${ }^{449}$ Fragment fo the face of Kiya changed to Meritaten, Ny Carlsberg Glyptotek Copenhagen A.E.I.N. 1797; Relief Kiya's head changed to Meritation, Ny Carlsberg Glyptotek Copenhagen A.E.I.N 1776; Relief showing Kiya changed to Meritaten, Metropolitan Museum of Art New York 1985.328.8.

${ }^{450}$ For a list of Neferneferuaten's names and objects see Kawai 2005: 61-66.

${ }^{451}$ For a list of Smenkhkare's names and objects see Kawai 2005: 48-50.

452 For discussions see Angenot 2019; Allen 1994; Arnold 1996; Dodson 2015; Gabolde1998; Harris 1973, 1974; Kawai 2005: 48-92; Kemp 2012; Krauss 1978.
} 
Much debate has been around the modified 'co-regency stela' which originally depicted Akhenaten, Neferneferuaten, Meritaten, Ankhesenpaaten ${ }^{453}$ as well as an unfinished stela that depicts two Amarna pharaohs (Fig. 3.18). On the Berlin stelae ruler on the left has generally been accepted as Neferneferuaten, which could possibly be a depiction of Nefertiti with Meritaten or Smenkhkare as well as Meritaten with Smenkhkare. Similar to Neferneferuaten wearing the blue crown on the Berlin stela, a composite statue now in Hanover has a blue crown which most likely originally had a flat top crown which was only worn by Nefertiti. ${ }^{454}$ This would support Nefertiti's use of the blue crown after becoming ruler. Recently, Angenot has brought attention to the hand gesture made by the pharaoh in the front to the second monarch facing forward, that it is the same as seen in the princess fresco (Fig. 3.19), possibly suggesting the two rulers were princesses, one being Meritaten, who both became rulers. Whether believed to be the same person or two separate individuals, Neferneferuaten's female sex is secure meaning there was at least one female monarch during the Amarna Period. This female ruler, most likely Nefertiti or Meritaten would have reigned for around three years, solely as seen on an emended inscription that was changed from Akhenaten's year seventeen to Neferuneferuaten's year one ${ }^{455}$ or overlapping with the end of Akhenaten's and beginning of Tutankhaten's rule. ${ }^{456}$

\footnotetext{
453 The Amarna co-regency stela, The Petrie Museum University College London UC410. Kawai 2005: 72-76, Fig. 9.

${ }^{454}$ An Amarna Royal Head, Museum August Kestner Hanover 1970.49. Johnson 2015: 22-29.

455 Gabolde 2005: 89 cited in Williamson 2015: 9.

${ }^{456}$ Dodson 2015: 161.
} 


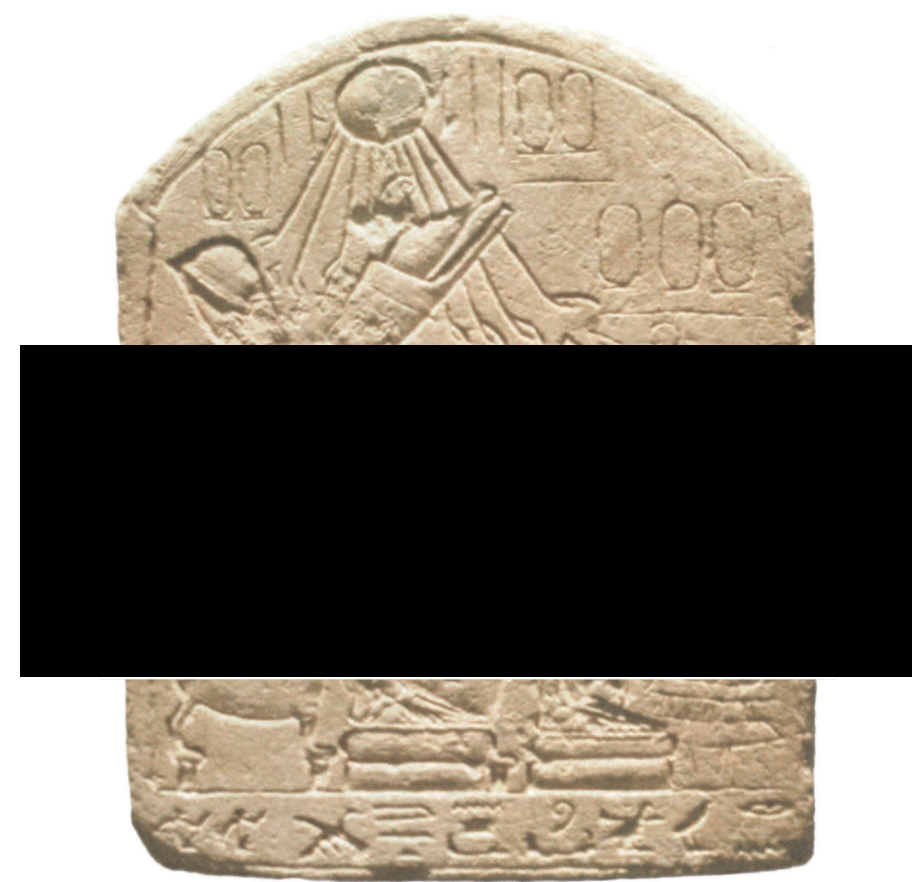

Fig. 3.18 Votive stela with two monarchs, Ägyptisches Museum und Papyrussammlung, Berlin ÄM 17813 .

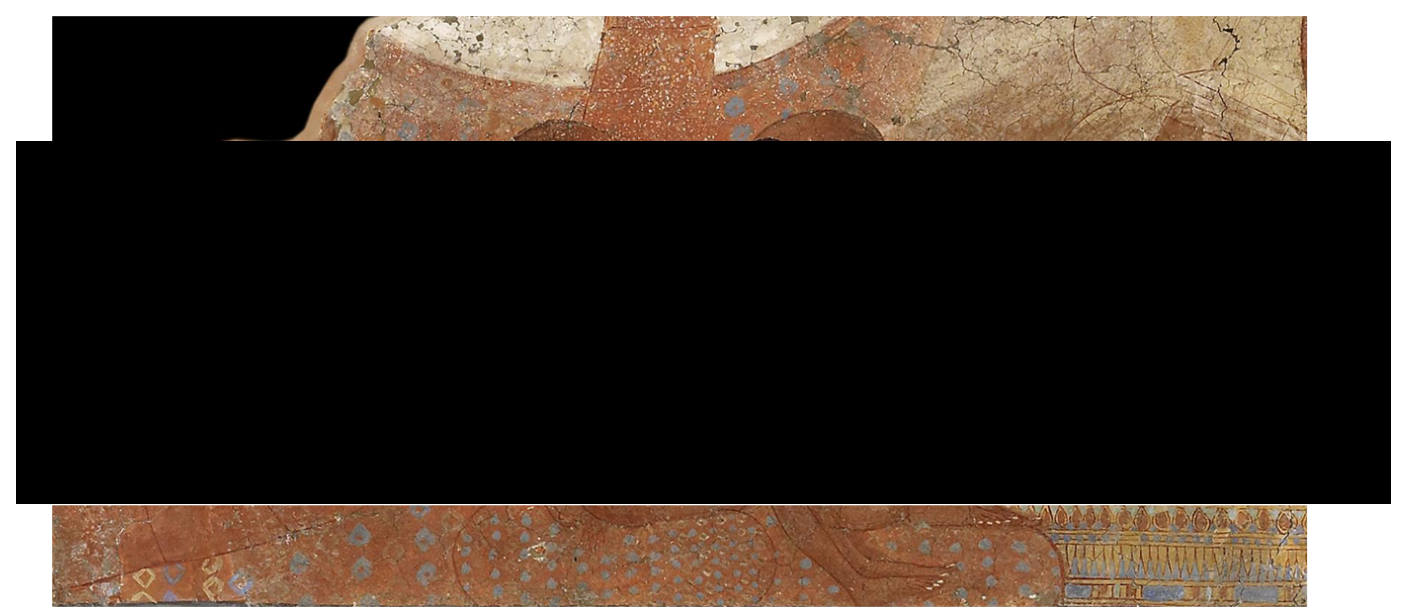

Fig. 3.19 Princess Fresco, The Ashmoleon Museum Oxford AN1893.1-41.267.

\subsubsection{Ankhesenamun's letter to Šuppiluliumaš I, the Hittite king}

Found on the Seventh Tablet in The Deeds of Šuppiluliumaš as told by his son

Musili II is the story of the letter sent from an Egyptian queen. ${ }^{457}$ Written in cuneiform, there is no Egyptian source for the letters sent from Queen Dahamunzu requesting a son to marry since her husband Nibhururiya was dead. ${ }^{458}$ It has mostly been accepted that the Egyptian queen is Akhesenamun, the third daughter of Akhenaten and Nefertiti, and her husband that died was Tutankhamun although

${ }^{457}$ Güterbock 1956a: 47-48; Güterbock 1956b: 94-97

${ }^{458}$ Bryce 2003: 178. 
Meritaten and Smenkhkare have been suggested. ${ }^{459}$ Translated by Güterbock the first letter sent by Akhesenamun stated:

My husband died. A son I have not. But to thee, they say, the sons are many. If thou wouldst give me one son of thine, he would become my (man) husband. Never shall I pick out a servant of mine and make him my husband!....I am afraid. ${ }^{460}$

Šuppiluliumaš does not believe the authenticity of the request and states "such a thing has never happened in my whole life". He further sent back the messenger Hattushaziti to confirm the credibility of the letter. Hattushaziti returns along with the Egyptian messenger Hani carrying Akhesenamun's reply. Dodson transcribes that letter as:

Why did you speak in this way, 'they deceive me'? If I had a son, would I have written about the shame of myself and of my land to another land? You did not trust me, and even spoke to me in that way! He who was my husband has died. I have no son. I do not want to take a servant of mine and make him my husband. I have not written to any other land, I wrote to you! They say you have many sons: give me one of your sons; to me he will be husband, but in the land of Egypt he will be king! ${ }^{461}$

The Egyptian messenger Hani echoes the queen's request and states it is a shame on their land and they "desire a son of our lord in the land of Egypt for kingship." Eventually Šuppiluliumaš’s son Zananzash was sent to Egypt but died in route by violence or sickness. ${ }^{463}$ In these letters to Šuppiluliumaš, Akhesenamun displays her political power by requesting the transfer of a foreign royal prince to her and initiates a diplomatic marriage, to the extent Šuppiluliumaš states because of this "Hatti and Egypt will be in eternal friendship with each other." 464 This also means Akhesenamun deliberately refused to marry anyone from the Egyptian royal or nonroyal spheres. It is also apparent Akhesenamun's main concern was having an offspring to be the next ruler and not the prince himself. This is seen by both Akhesenamun and Hani reiterating her need for a son in Egypt and they both requested any of Šuppiluliumaš's sons, not a specific one. Her demand for a husband could possibly suggest her plan to be co-regent and continue her family's royal line.

\footnotetext{
459 Dodson 2009: 89.

460 Güterbock 1956b: 94.

461 Dodson 2009: 91.

462 Dodson 2009: 91.

463 Dodson 2009: 91; Güterbock 1956b: 98.

${ }^{464}$ Doson 2009: 91; Güterbock 1956b: 98.
} 
Additionally, since it took two separate letters and multiple months for Zananzash to be sent to Egypt, Akhesenamun most likely would have been ruling in Tutankhamun's place after his death and before Ay's accession.

\subsubsection{Tausret}

Tausret ruled Egypt as a female monarch in the Nineteenth Dynasty. ${ }^{465}$ As seen through her iconography and titles, her political involvement shifted throughout her life. A royal family member, Tausret may have been a granddaughter of Ramses II. ${ }^{466}$ She married Sety II and held queenship titles such as Hereditary Princess, Lady of Upper and Lower Egypt, Monarch's Great Wife, and Lady of the Two Lands. ${ }^{467}$ It is uncertain if Tausret had any children, although there is a surviving relief of a son of Sety II and the burial of an unknown child in KV 56 who may have been related to her. ${ }^{468}$ After six years as pharaoh, Sety II died and was succeed by Merenptah siptah, the son of a Canaanite queen and possibly the son or grandson of Merenptah. ${ }^{469}$ As a result of Siptah's young age, Tausret ruled Egypt as his regent. After six years of regency, Siptah died leaving the throne to Tausret who ruled as a female monarch for three to five years. ${ }^{470}$ Combining her regency and sole reign, Tausret was on the throne of Egypt at least nine to ten years. ${ }^{471}$

Tausret's reign is presented on her headless seated statue (Figs. 3.20, 3.21). The statue was discovered in Medinet Nasr by Motawaa Belboush in 1971. 472 Without Tausret's head, the statue is $133 \mathrm{~cm}$, (4ft4in) in height and made from quartzite sandstone. Tausret is seen wearing a typical Nineteenth Dynasty pleated garment that ends above her ankles. Hanging from her belt, which contains her name, are six uraei with sun disks upon their heads. She wears the nemes-headdress and holds the $h k_{3}$ and $n h 3 h_{3}$ scepters in her right hand. Within the texts located on the base, sides, and back Tausret is named Monarch of Upper and Lower Egypt, Son

\footnotetext{
465 Bassir 2013; Callender 2004; Dodson 2010, Phelps and Creasman 2013; McCarthy 2008; McClain, Brett, Johnson 2013: 177-186; Wilkinson 2005; Wilkinson 2006; Wilkinson 2010; Wilkinson 2011a; Wilkinson 2012a; Wilkinson 2012b.

${ }^{466}$ Callender 2012: 28; Wilkinson 2012b: 2.

${ }^{467}$ Altenmüller 1983: 21; Troy 1986: 140, 171.

${ }^{468}$ Callender 2004: 85; Callender 2012: 31-32.

${ }^{469}$ Callender 2012: 29.

${ }^{470}$ Phelps and Creasman 2013: 55-56.

${ }^{471}$ Wilkinson 2011f: 8.

472 Bakry 1971: 17-26.
} 
of Ra, Beloved of Hathor, and Lady of the Red Mountain. ${ }^{473}$ Tausret's representation on her seated statue shows her as the female ruler through her pharaonic regalia and titulary. ${ }^{474}$ Similar to Sobekneferu's Twelfth Dynasty torso (Cat. 58), both women are presented in forms that unequivocally represent female monarchs.

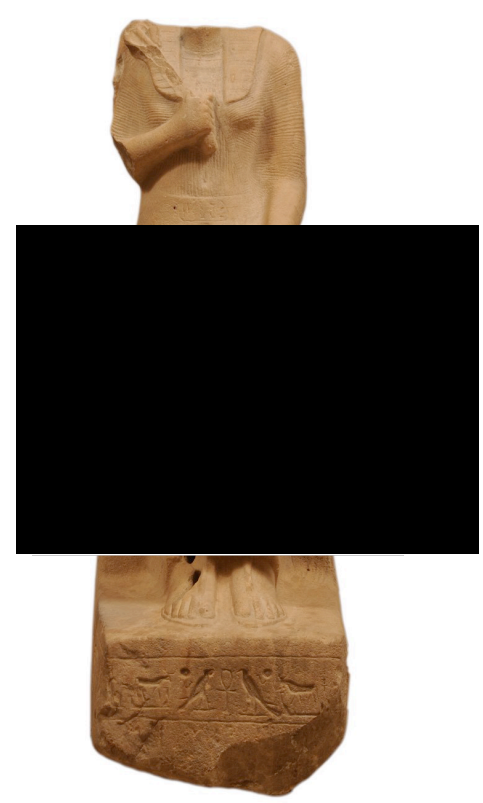

Fig. 3.20 Headless seated statue of Tausret. Bassir 2013: 74.

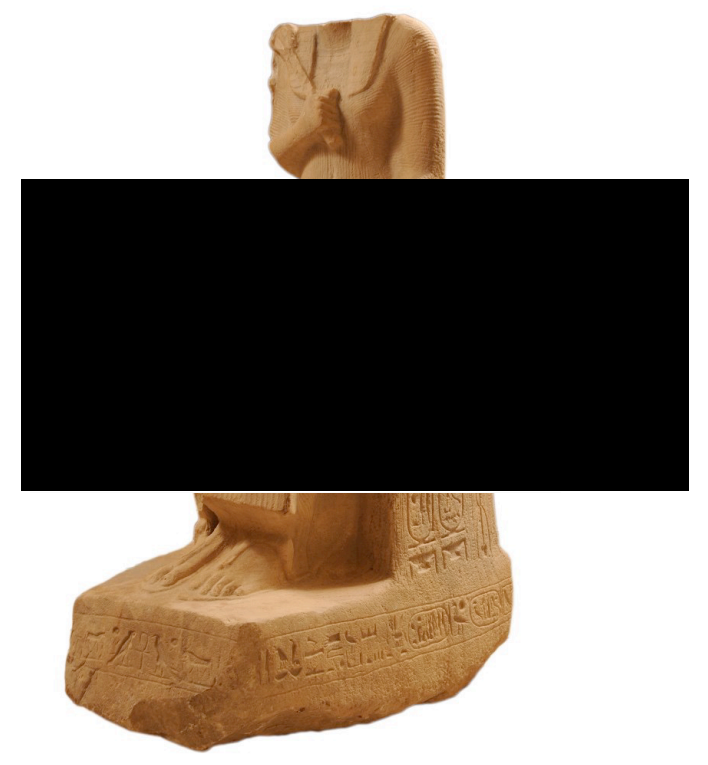

Fig. 3.21 Headless seated statue of Tausret. Bassir 2013: 72.

${ }^{473}$ Bassir 2013: 71-87.

${ }^{474}$ Bassir 2013: 77; Dodon 2010: 115; Roehrig 2012: 59. 
A second depiction that possibly represents Tausret occurs on an ostrakon now located in the Egyptian Museum Cairo (Fig. 3.22) that was discovered in the Valley of the Kings KV 9 and is dated to the Twentieth Dynasty. The suriving ostracon is $25 \mathrm{~cm}$ (10in) in height and $38 \mathrm{~cm}$ (1 $\mathrm{ft} 2 \mathrm{in})$ wide. ${ }^{475}$ It shows an Egyptian queen or female monarch mounted on a chariot and firing arrows at an opponent. The regalia, particularly the headgear, suggest that the woman driving the chariot must have been royal and the chariot-style suggests a dating of no earlier than mid-Eighteenth dynasty. ${ }^{476}$ There is no surviving inscription, but it is highly possible the female military leader represents Tausret. Earlier female monarch military commanders existed, as exhibited by the rules of Ahhotep and Hatshepsut ${ }^{477}$ as well as Sobekneferu's Nubian occupation during the Twelfth Dynasty (see Chapter 6). In addition, Meretneith of the First Dynasty was named Neith after the goddess of war and protection. ${ }^{478}$

Although found within the tomb of both Ramses V and VI it is unclear if the ostrakon depicts a formal royal event, a preliminary drawing, or a casual sketch. However, Reeves and Wilkinson note that ostraca from the Valley of the Kings is known for often being thoughts of the artists themselves and that in the tombs particularly of Ramses VI and IX ostraca are most often votive offerings and clear examples of preliminary drawings or occasionally depictions from assistants. ${ }^{479}$ Callender notes that there is not enough evidence to support if the ostrakon depicts a factual event; however she questions if the artist saw Tausret as a military leader before her death. ${ }^{480}$ Callender uses the Papyrus Harris I from the reign of Ramses IV and Setnakht's Elephantine stele as examples of the disorder of the country after Tausret's reign. ${ }^{481}$ While these texts are possibly propaganda pieces for the reign of Sethnakht, they mention the Asiatic leader Irsu who had control of Egypt between

\footnotetext{
${ }^{475}$ Callender 2012: 45; Callender 2004: 103; Wildung 1984b: 181, CG25125.

476 Partridge 2002: 65.

${ }^{477}$ Callender 2012: 45.

478 Tomashevich 1993: 385; Wilkinson 2003: 157; the woman represented on the ostrakon has also been suggested to be the goddess Astarte fighting symbolically in Egyptian queen's form, Wildung 1984b: 181 .

${ }^{479}$ Reeves and Wilkinson 1996: 32.

${ }^{480}$ Callender 2012: 46.

${ }^{481}$ See Papyrus Harris I: sections 398-399 and Elephantine stela lines 4, 7-11. Callender 2012: 4446; For further disccsin of Setnakht's Elephantine stela see Dodson 2010: 118-119 Fig. 113.
} 
Tausret and Setnakht. ${ }^{482}$ Considering these texts along with the ambiguous end of Tausret's reign, it is possible her rule ended with a military battle against the Asiatics and this is why an artist from the reign of Ramses $\mathrm{V}$ represented her as a military leader.

The ostrakon possibly shows a male monarch or a foreign military leader as an opponent, which could further suggest an invasion and war between Egypt and the Asiatics. Although it can be assumed from the kilt that the opponent is a man, there is no evidence to say it is not a depiction of a woman. Female monarchs such as Sobekneferu and Hatshepsut, as well as non-royal women, were often represented in art wearing kilts, ${ }^{483}$ which meant being depicted with the clothing garment does not restrict the sex of a person to male. If the queen or female monarch archer does not represent Tausret, this ostrakon can be used as an example of how women, at least royal, were active in military conflicts.

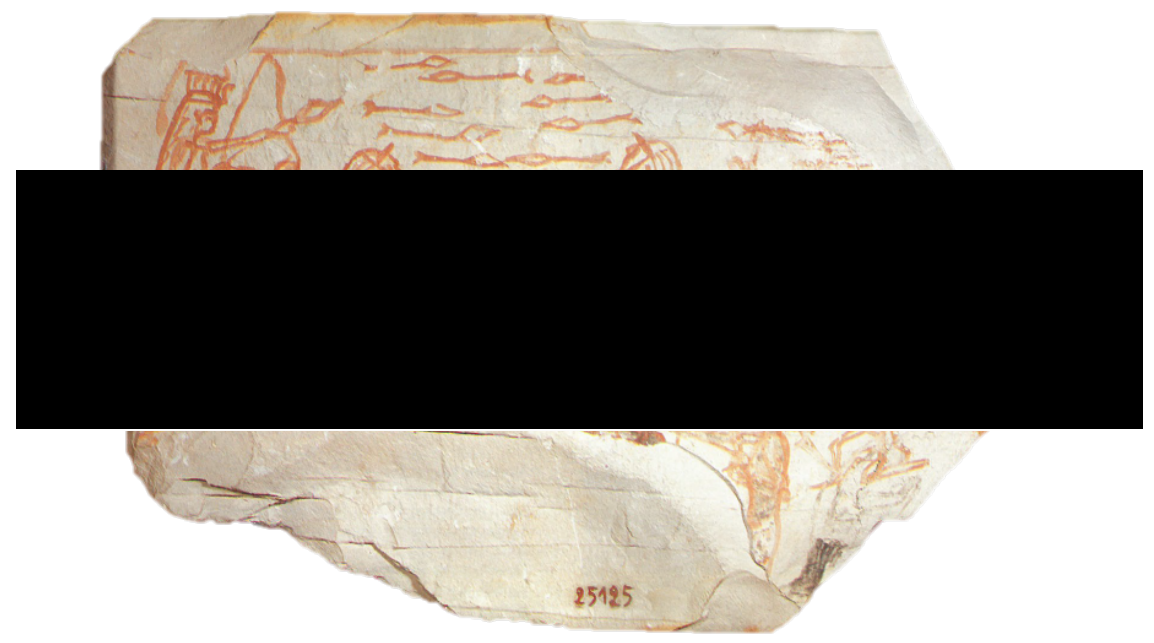

Fig. 3.22 Possible ostrakon of Tausret, Ostrakon Egyptian Museum Cairo CG 25125.

Similar to other New Kingdom rulers, Tausret had multiple building projects, including a tomb in the Valley of the Kings (KV 14) and a temple located in western Thebes. ${ }^{484}$ Tausret, along with Hatshepsut, were the only two female rulers buried within the Valley of the Kings. Tausret's tomb is labelled KV 14 and is one of the

\footnotetext{
${ }^{482}$ IFAO Ostracon 1864 states Chancellor Bay was killed by Siptah during his co-rengcy with Tausret, meaning the Asiatic was not Bay and a different invader who most likely came through the Delta.Callender $201043-44$.

483 Blackman and Apted 1953: pl. XVIII; Model group, The British Museum London EA 40915; Royal offering bearer Brooklyn Museum 53.178.

${ }^{484}$ Phelps and Creasman 2013: 55; For a complete summary of the results from the nine seasons of excavations see Wilkinson 2011.
} 
largest decorated tombs in the valley. ${ }^{485}$ Ramses III had his father Sethnakht, Tausret's successor, also buried inside tomb. While some representations have survived, her inscriptions and depictions were mostly replaced. Tausret's tomb iconography is significant to her rule because there are shifts in the reliefs that reflect her changing status from queen to regent to pharaoh. The sequence of depictions has been attributed to four phases: Tausret as queen, Tausret as regent, Tausret as sole ruler, and Sethnakht's replacement images.

Within the tomb, Tausret is seen wearing the blue crown while holding the flail, which was associated with great royal wives, and a lotus flower or piece of cloth. This depiction would have portrayed that Tausret was a legitimate and officially recognized female monarch. ${ }^{486}$ The iconography in her royal tomb is the only instance in which the transition from a royal family member to ruling monarch is shown. Tausret's tomb in the Valley of the Kings was begun near the end of Sety II's second year, which suggests Tausret was already politically present before becoming regent. ${ }^{487}$ To depict herself as regent, Tausret is shown with Siptah, which enforces both of their political offices. As ruler, Tausret is again represented with a slight but deliberate usage of female pharaonic regalia. Tausret's reign is an example of how royal women were often the preferred choice for regency and how they could conveniently transition to pharaoh.

Tausret would have ruled over Egypt as sole female monarch for at least three to five years and this would have been exhibited in her temple. The royal temple complex of Tausret is being excavated by the University of Arizona Egyptian Expedition. ${ }^{488}$ Originally visited and excavated by Petrie in 1895 to 1896 , the University of Arizona Egyptian Expedition have re-examined the temple finding significant remains. ${ }^{489}$ Tausret's temple is one of at least twelve "temples of millions of years $" 490$ located on the western banks of Luxor. From the recent excavations, over 3,000 artifacts have been discovered, including amulets, shabtis, statue fragments, pottery sherds, and later period burials. Several significant foundation

\footnotetext{
485 Altenmüller 2012: 67. The University of Hamburg led by Harwig Altenmüller conducted the most recent survey from 1983 to1989. For more information see the Theban Mapping Project website http://www.thebanmappingproject.com/sites/browse_tomb_828.html.

486 Altenmüller 2012: 78-80.

487 Altenmüller 2012: 90.

${ }^{488}$ Creasman, Caroli, Finlayson and Becktell 2014: 3.

${ }^{489}$ Kroenke 2011: 11-32; Moore 2011: 6-10; Wilkinson 2011: 33-52.

${ }^{490}$ Creasman, Johnson, Mclain, and Wilkinson 2014: 274-283; Wilkinson 2012: 92-106.
} 
stones were found indicating that Tausret reined for longer than originally assumed. ${ }^{491}$ Added to her six years with Siptah and two alone, would have been at least an additional one to two years, which suggests she reigned as pharaoh for at least eight years. However, it is likely that Tausret's successor Sethnakht or his son Ramesses III demolished her temple to use the material for their building projects. ${ }^{492}$

\subsection{Discussions}

Rulers in ancient Egypt took part in a succession line that was systematic but also adaptable. Because of this adaptability women ruling as sole monarchs was possible, although much less common than men. This flexibility allowed for the next monarch to proceed without the need for a certain birth sex-who could be presented as the ruling monarch. If necessary, titles could be re-gendered and iconography could be changed. This change of iconography is first seen with Sobekneferu, but the sharing of titles stretches from the early Dynastic times. In some cases, female monarchs are shown wearing false beards, or shendyt-kilts with bare chests. ${ }^{493}$ It should be noted that these items of pharaonic regalia are pieces of what is essentially a standardized uniform and are not used to indicate that a female was copying a male. ${ }^{494}$ Only the pharaoh wore the combination of a ceremonial beard and shendyt-kilt with a bare chest, as a result it should not have been different for a monarch that happened to be a female. It is not certain to say that royal women presented or gendered themselves as men. The sex or gender of the pharaoh were not the important factors, rather it was the way the ruler was represented that served to legitimize their reign.

Troy states that rulership in ancient Egypt was made of the combined roles of male and female that could be interpreted as two versions of the same phenomenon. ${ }^{495}$ When combined with the defintion of queenship, this suggests that the pharaonic office is comprised of both queenship and kingship and could be filled by either a male or female. Biological women and men were equivalent for the office and their symbolism could be shared. This type of duality is seen especially during the reigns of female rulers. ${ }^{496}$ The holder of the office of the monarch, or $n s w t$, could be female or male. The reigning monarch held political certainty, which can be

\footnotetext{
${ }^{491}$ Wilkinson 2011f: 8.

492 Phelps and Creasman 2013: 53-64; McClain, Brett, Johnson 2013: 177-186.

${ }^{493}$ Hatshepsut in devotional attitude, The Metropolitan Museum of Art New York 28.3.18.

494 Szpakowska 2012: 30.

495 Troy 1986: 136.

496 Troy 1986: 131, 136, 139.
} 
defined as ultimate power for a negotiable amount of time. The royal women of the family held political influence, which controlled the power of negotiation. Both royal men and women could rule over ancient Egypt alone or accompanied by a regentthey could be represented in androgynous iconography, which often made reference to multiple deities. Their titulary could be gendered or even re-gendered and both ruling women and men could be presented as Horus and Osiris. However, only royal women could produce the next ruler and be connected with certain goddesses that legitimized the reigning individual. As female monarchs, regents, and co-regents, royal women had opportunities to hold ultimate power for variable amounts of time while simultaneously controlling the extent of that time by legitimizing themselves or the corresponding ruler. These were capabilities royal men were unable to perform. This type of influence, along with the equality of male and female roles, set the foundation for the office of pharaoh. Females were more often than not accepted as having pharaonic equality in Egypt and this concept of rulership was never challenged by their contemporaries and was acceptable within Egyptian decorum.

Every aspect that has been discussed in this chapter, gender and power, royal and non-royal women, the female Horus, and female rulership needs further intensive study. Royal women played significant roles in Egyptian rulership and held the offices of pharaoh, regent, and co-regent. While this chapter has only introduced eight female rulers from Egypt: Meretneith, Khentkaus I, Neithikrety, Sobekneferu, Ahhotep, Hatshepsut, Neferneferuaten, and Tausret, it is essential to understand their reigns as successful events that were controlled by the women themselves.

Furthermore, Sobekneferu's use of female pharaonic regalia, equality among titulary, and building projects forms the evidence for this thesis's examination of queenship and female rulership. 


\section{Chapter 4: Iconographic Representations of Twelfth Dynasty royal women}

\subsection{Introduction}

The rulers of the Twelfth Dynasty began being depicted in a new iconographic style, which associated and simultaneously distanced their representational fashion from Old Kingdom artworks. Beginning during the reign of Senwosret I (Fig. 4.1), this new style transformed the facial characteristics into more deeply lined features, sharp cheeks, and oversized ears (see below Chapter 4.3). Described as being "from the hands of first class artists"497 "immediately recognizable"498 and "expressive, referring to the inward qualities and attitudes" ${ }^{\prime 49}$ the royal portraiture had undergone an unprecedented change from the Eleventh Dynasty. Significantly, this change is also seen in the art of the royal women. These shared features indicated the equal standardization of the iconographic style making these characteristics common during the dynasty.

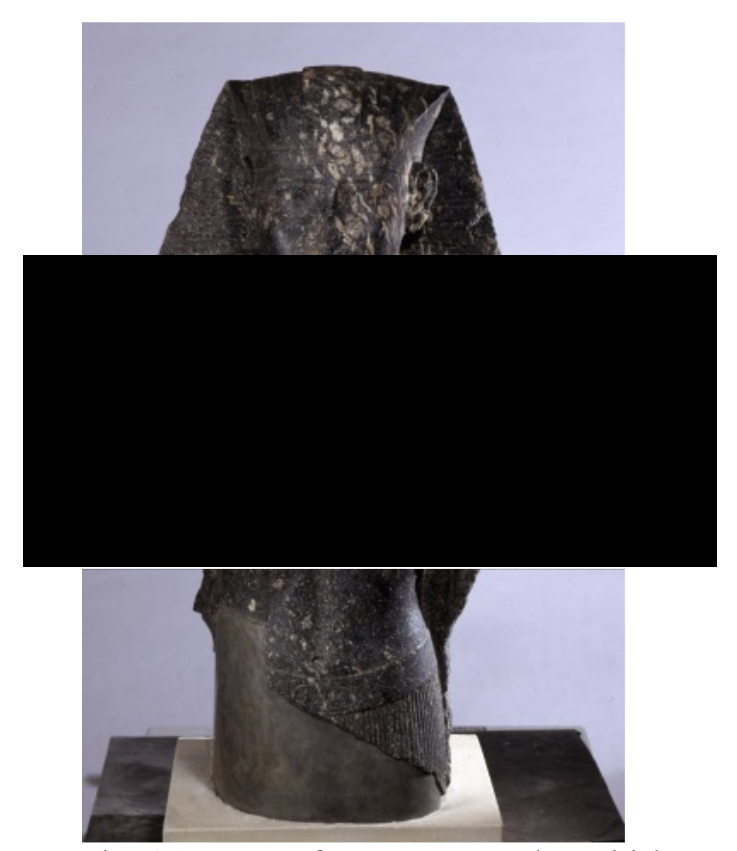

Fig. 4.1 Statue of Senwosret I, The British Museum London EA 44.

The Twelfth Dynasty is acclaimed for this unique iconographic expansion, which was equally open to both ruling men and women. The developments among royal women can be seen within the analysis of this chapter and accompanying catalogue.

\footnotetext{
497 Steindorff 1940: 45.

${ }^{498}$ Robins 2008: 113.

${ }^{499}$ Assmann 1996: 76.
} 
As Quirke demonstrates sculptures depend on the architectural program but can be examined separately to indicate royal power. ${ }^{500}$ In this dedicated art historical analysis of the iconography of Twelfth Dynasty royal women, their features are fragmented into nine different categories that reflect the political and artistic meaning of their characteristics. Each iconographic feature is accompanied by a detailed analysis and examples of surviving Twelfth Dynasty representations.

From the dozens of surviving works of Twelfth Dynasty royal women, nearly all of the representations are sculpture in the round. The other depictions are reliefs and currently only five have survived. They include the images of Queens Aat, Hetepi, Khenemetneferhedjet I, along with Princess Kayet and Neferuptah (Cat. 5256). Presently, there are no surviving stelae with images of Twelfth Dynasty royal women on them. Of the five reliefs, two are from the same temple in Medinet Madi (Cat. 55, 56), with both women being under life size. Due to lack of survival and destruction $^{501}$ (see Chapter 1.5 for discussion), evidence for Twelfth Dynasty temples is limited, but the fact that the depictions of Queen Hetepi and Princess Neferuptah are both found at Medinet Madi suggests that there may have been other temple depictions of royal women. ${ }^{502}$

Over half of the accounted artworks for Twelfth Dynasty royal women have no surviving inscription, which means dating these statues to this time period depends on iconographic examination. This could also further imply there are dozens more statues and reliefs of royal women not attributed to the time period. During the Twelfth Dynasty features become common creating a recognizable style. These include large ears, 'severe' facial characteristics, well-defined eyes, the Hathoric and tripartite wig styles, along with the standardization of the uraeus. A change in ancient Egyptian art that is first seen on the representations of Twelfth Dynasty royal women is the adoption of these severe facial characteristics. No two faces with the severe characteristics are exactly alike, ${ }^{503}$ making each similar to but unique from each other. The broad term 'severe' includes all variations of the deep-set eyes, heavy eyebrows and lids, sharp cheekbones, deep cut nasio-labial folds, and turned down mouths (see further discussion in Chapter 4.3). These facial features are also

\footnotetext{
${ }^{500}$ Quirke 2010: 59, Quirke looks at Thirteenth Dynasty three-dimensional sculpture in isolation from the "sacred, human-created landscape" to create an index of kingly power.

${ }^{501}$ Wilkinson 2000: 22.

${ }^{502}$ For example, see those of Montuhotep II, at Deir el-Bahari of the Eleventh Dynasty.

${ }^{503}$ Russmann 2001: 101.
} 
seen on the images of ruling pharaohs and are most common on Senwosret III (Fig. 4.2) and Amenemhat III (Fig. 4.3).

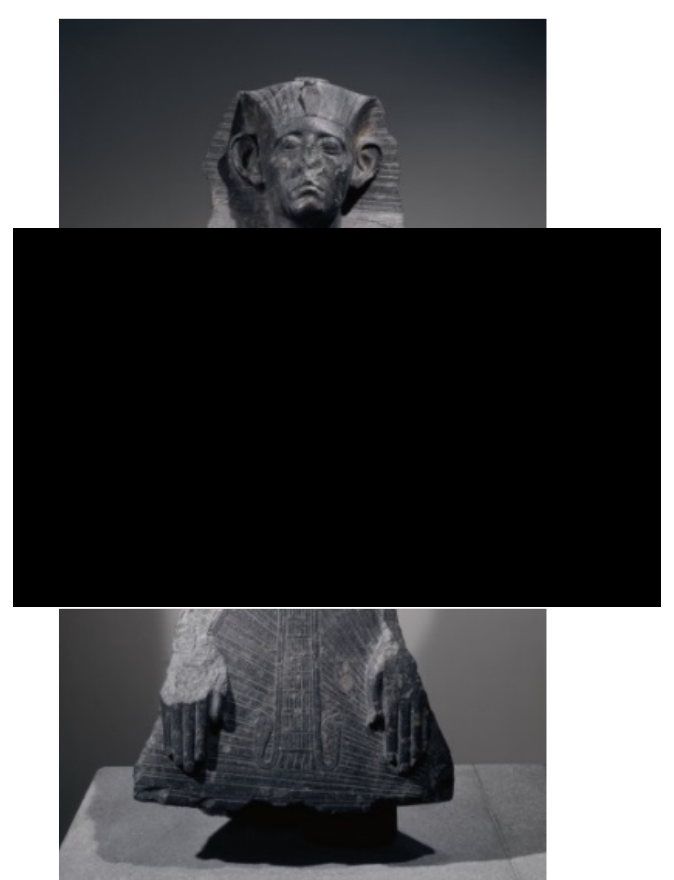

Fig. 4.2 Statue of Senwosret III, The British Museum London EA 686.

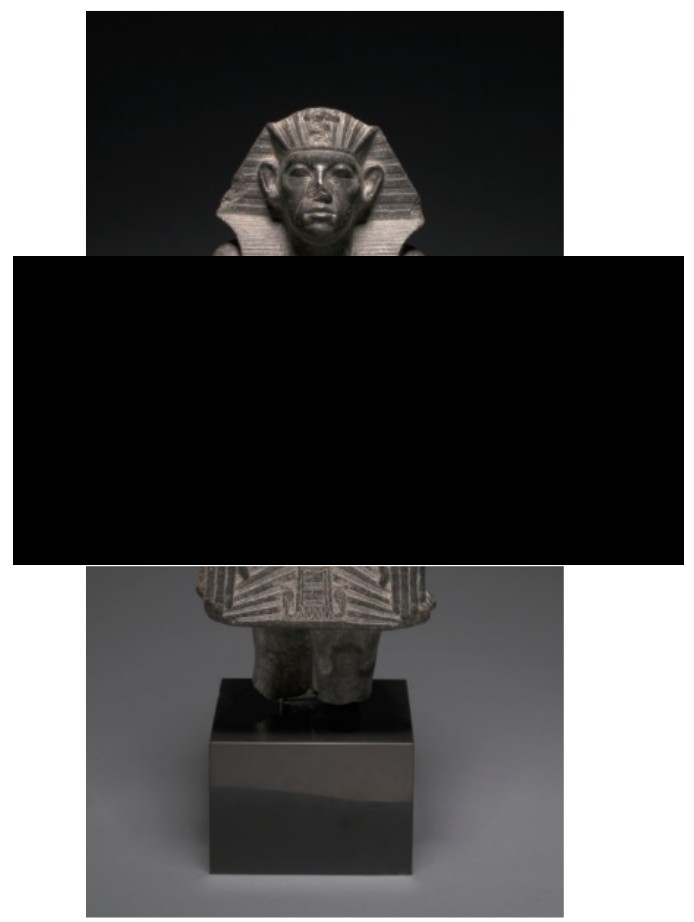

Fig. 4.3 Statue of Amenemhat III, The Cleveland Museum of Art 1960.56.

From the known materials used, royal women were represented in at least sixteen different types of stones and metals, the most common being granite followed by quartzite and basalt. This shows there was no specific restriction for representing 
royal women and quarried hard stones were favored. ${ }^{504}$ Their representations also vary in sizes, ranging from small standing poses - as seen on the group statues of two royal women with Senwosret III (Cat. 32, 33, 34) — to over life-size seated statues - such as the seated statues of Nofret (Cat. 15, 16). Statue workshops during the Twelfth Dynasty are largely unknown and no structure dedicated to sculpture activity has been discovered. ${ }^{505}$ Art work production likely involved numerous approaches and as a result of this, Oppenheim states that "Such interactions highlight the difficulties involved in defining regional styles in relation to workshops and instead suggest rich interconnections between different parts of the country." 506 There may have been workshops with statue models in certain areas as seen on a stela from the reign of Senwosret I now located in the Los Angeles County Museum of Art, which records the Overseer of Sculptors Shensetji's career relocation from Lisht to Abydos. ${ }^{507}$ As further discussed below (see Chapter 4.3 and 4.12.2) the facial characteristics of the dynasty are unique to each statue and rulers such as Senwosret III and Amenemhat III were depicted with noticeably different face and body features throughout their reigns. Because styles can be recognized, and not specific workshops, it is possible sculptors personally chose these specific features, or one artist created multiple styles, or even one model was made and copied by other artists. Although, it is known that during the Twelfth Dynasty art works and artists themselves moved around the country, such as the aforementioned stela and statues being transported to temples and funerary complexes, ${ }^{508}$ it is not necessarily clear what statues of royal women and men were made at certain locations.

The representations with known find spots mostly come from a funerary complex, as well as contemporary structures and temples; however, a large majority are unknown (Chart 4.1). From the nine representations that were securely found in or near a mortuary complex (Cat. 20, 26, 49, 50-54, 57) there is a head, a statue base, sections of possibly two colossi seated statues, and three reliefs; with most being discovered in Lisht. The three reliefs (Cat. 52, 53, 54) were found within pyramids

\footnotetext{
${ }^{504}$ Aston, Harrel, and Shaw 2000: 35-37.

505 Connor 2018: 21; For non-royal stela workshops of the early Tweflth Dynasty see Freed 1984, 1996; Ilin-Tomich 2011.

506 Oppenheim 2015: 26.

${ }^{507}$ Stela of the Overseer of Sculptors Shensetji (Funerary stela of Shen), The Los Angels County Museum of Art, William Randolf Collection 50.33.31; Oppenheim 2015: 153-154. For further references to sculptors connected with Lisht see Connor 2018: 21-22.

${ }^{508}$ As seen from the statues of Senwosret III, Connor 2018: 23-24; Fay 1996: 34.
} 
and would have not been on view, however the size and placement of the other statues suggest they could be seen by the public. At least one, possibly two colossi statues of a royal woman (Cat. 26, 49-51) stood near pyramid 6 in the mortuary complex of Senwosret I which suggests by their obvious size they could have been seen. Additionally, the statue for Sobekneferu and Amenemhat III (Cat. 57) originally could have been viewed, although possibly restricted, because it most likely came from Amenemhat III's complex or Labyrinth.

\section{FIND SPOT INSIDE OR NEAR A LOCATION}

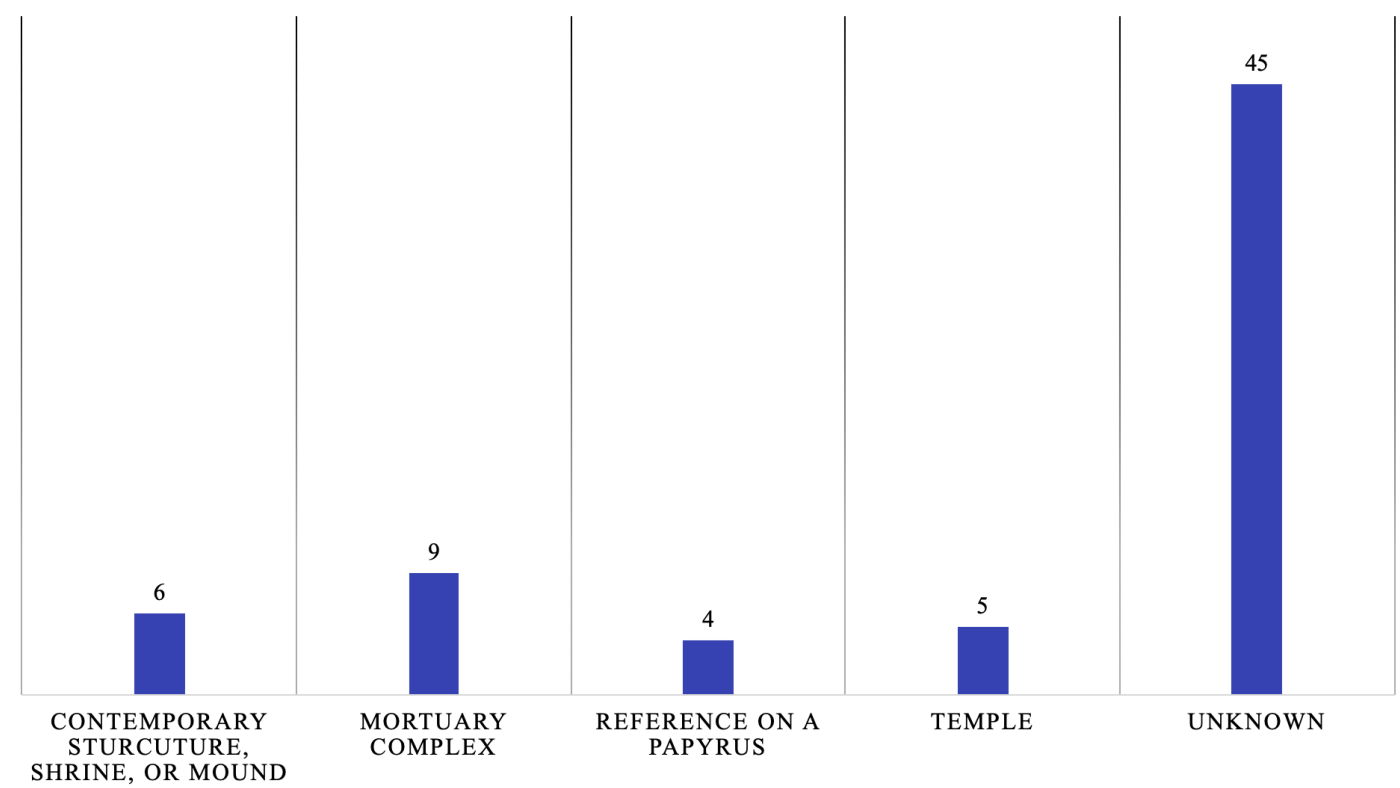

Chart 4.1 Find spots of Twelfth Dynasty royal female representations, by author.

While seated and standing poses are most common, Twelfth Dynasty royal women can also be shown as hybrid forms, such as sphinxes-for example the unknown royal woman (Cat. 64) - and as a human-headed bird - as seen on the statue now located in Cairo (Cat. 38). From the surviving representations the majority of the royal women are shown seated and independent from royal men, but if shown with the king, the women are standing. Twelfth Dynasty royal women are only seen standing when they are in association with another person, except for Sobekneferu who is in the independent devotional attitude as seen on the Louvre statue (Cat. 58) due to her pharaonic status (see discussion in Chapter 6.2).

Sobekneferu was a royal woman and a sole ruler, which resulted in her political status as pharaoh of Egypt changing her iconography (see Chapter 6). This is observed most prominently on her torso now located in the Louvre (Cat. 58) where 
she is seen wearing a feminine sheath dress under the pharaonic kilt, nemesheaddress, and pendent. There are five other statues securely inscribed for Sobekneferu: an inscribed base, two seated, one kneeling, and one in the sphinx pose (Cat. 57, 59, 60, 61, 62). All of her securely inscribed sculptures are headless and there are no remaining, or yet found, reliefs of Sobekneferu as a princess or pharaoh. In her seated and kneeling statues, she is seen wearing the feminine sheath dress while a nemes or another headdress can only be suggested.

The uraeus becomes standard in the iconography and is seen on every representation of royal women, except when the queen wears a vulture headdress. Even though uraei become prominent features, Twelfth Dynasty royal women are not depicted wearing crowns. Sobekneferu was the only royal woman depicted with the nemes-headdress, as seen on her Louvre torso (Cat. 58). Twelfth Dynasty male monarchs were also depicted with and without crowns (see below Chapter 4.12), such as Senwosret III and on the statue of Amenemhat III as a priest (Fig. 4.40, 4.41). As for the royal women who are not seen with crowns, uraei can be found joined with different styles of wigs, including tripartite, Hathoric, as well as rounded, and can be seen as damaged, removed, or fully intact. Except for one example, a wooden head now located in Cairo (Cat. 20), all surviving images of ears are shown being set in front of the woman's wig or headdress suggesting this was the standard style. This consistent style shows there was no difference among the ears of the royal women and men. In regard to the sizes, royal women follow the style of the Twelfth Dynasty and are always depicted with oversized ears.

With the exception of the two examples - the torso of Sobekneferu (Cat. 58) and Metropolitan Museum schist bust (Cat. 10) — the remaining illustrations of clothing for royal women is the sheath dresses. This is also mostly consistent with non-royal women, except for a few examples. Non-royal women could also be depicted wearing the sheath dress with one single strap, as demonstrated by a painted wooden figure in the British Museum (Fig. 4.4) and a fringed cloak only covering the left arm, as seen on nurse Sitsneferu (Fig. 4.5). There are no surviving representations of royal women wearing a single strap sheath dress or a fringed cloak (see Chapter 4.9). Painted details on the statues may have also not survived causing a discrepancy among the dress types. 


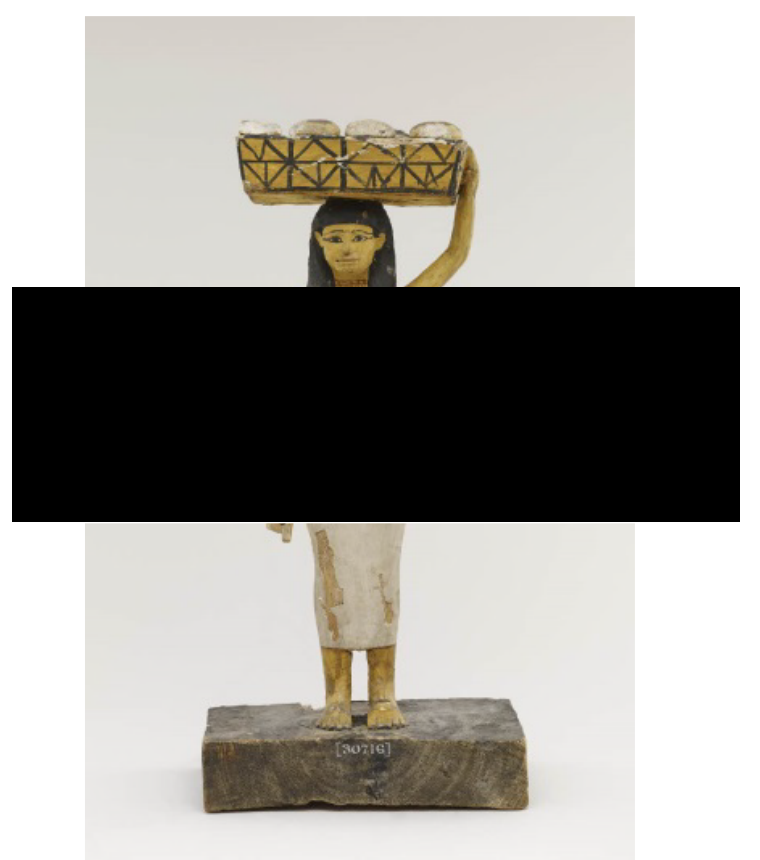

Fig. 4.4 Statue of a female figure with basket of loaves and meat on her head, The British Museum London 30716.

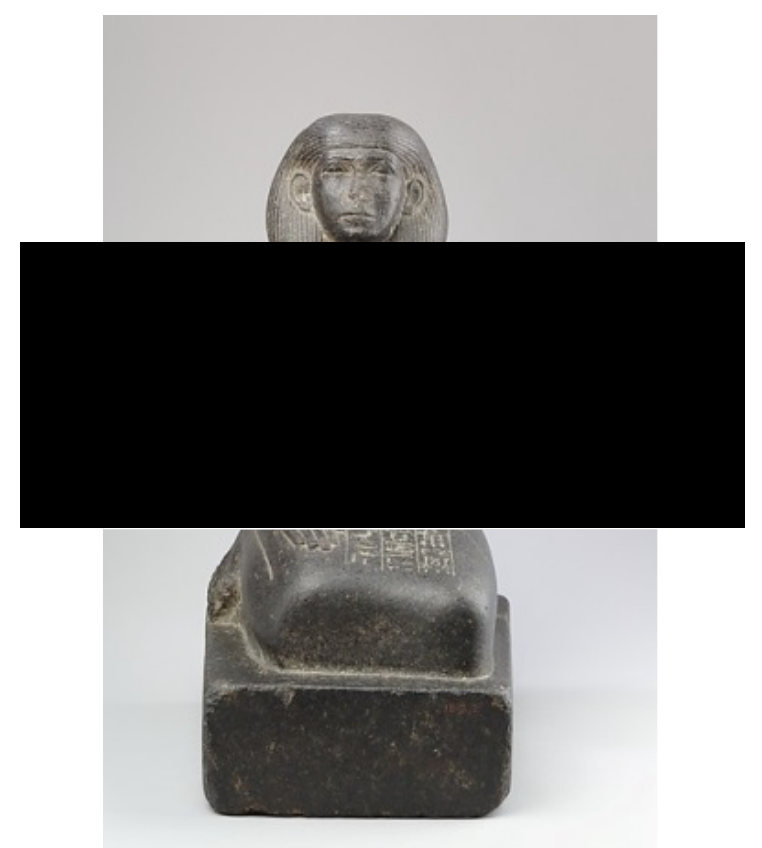

Fig. 4.5 Statue of Nurse Sitsneferu, The Metropolitan Museums of Art New York 18.2.2.

The sheath dress and jewelry are often portrayed as simplistic, with some embellishments of broad collars and bracelets. Although the majority of statues do not have incised jewelry, elaborate pectorals are presented in the art, for example a pectoral can be seen on a statue of Nofret (Cat. 15) and in grave goods at this time. ${ }^{509}$

${ }^{509}$ Grajetzki 2014a: 122. 
Representations of both royal females and males show slight differences among the jewelry, but all jewelry types are shared. This includes the pendant worn by Sobekneferu, as seen on her Louvre torso (Cat. 58), which the male monarchs also wore before her, such as Senwosret III (Fig. 4.2). Although Sobekneferu would have been depicted in the artistic style of a pharaoh, her iconography and that of earlier royal women display the equal expansion of the artistic features. They also present the connections for the developing iconography for the political offices of queenship and pharaoh, which are further discussed in the royal women and men ancillary sections 4.12 and 4.13 .

\subsection{Poses}

Surviving from the Twelfth Dynasty are five poses for royal women. These include: standing as shown by Queen Hetepi (Cat. 56), seated illustrated by Queen Khenemetneferhedjet (Cat. 18), the sphinx pose such as the body of an unknown royal woman (Cat. 70), a female-headed bird as seen on the unknown woman (Cat. 38), and kneeling as demonstrated by Sobekneferu (Cat. 61). Due to her pharaonic status Sobekneferu is the only Twelfth Dynasty royal woman to be depicted in the kneeling pose, as seen on her statue from Tell el-Dab'a (Cat. 61), which is further discussed in Chapter 6.3. The standing pose is where the women are in an upright position with both feet flat. Seated is the most common pose and can be described as the royal women's bodies resting upon a supporting surface, such as a throne or chair. The sphinx and female-headed bird are both types of hybrid forms. The sphinx consists of a female head or face combined with a lion's body while the other is a female head combined with the body of a bird. The last pose, kneeling, is where Sobekneferu's body is rested upon her knees.

\subsubsection{Standing}

In the seven surviving group representations the royal women are seen standing, such as the statue of Amenemhat III with two princesses (Cat. 29), the three group statues that include Queen Khenemetneferhedjet I and Khenemetneferhedjet II (Cat. $32,33,34)$, the copper statue of a royal woman (Cat. 48), and the reliefs of Queen Hetepi (Cat. 56) and Princess Neferuptah (Cat. 55). In the group statues of Amenemhat III and Senwosret III (Cat. 29, 32, 33, 34) two royal women are presented, situated on each side of the pharaoh. Although this style of representing the royal family with two royal women on both sides of the ruler is known from the 
Old Kingdom, ${ }^{510}$ there are no surviving Twelfth Dynasty group examples where the two royal women are seated at the pharaoh's ankles with their legs crossed underneath their body (Fig. 4.6).

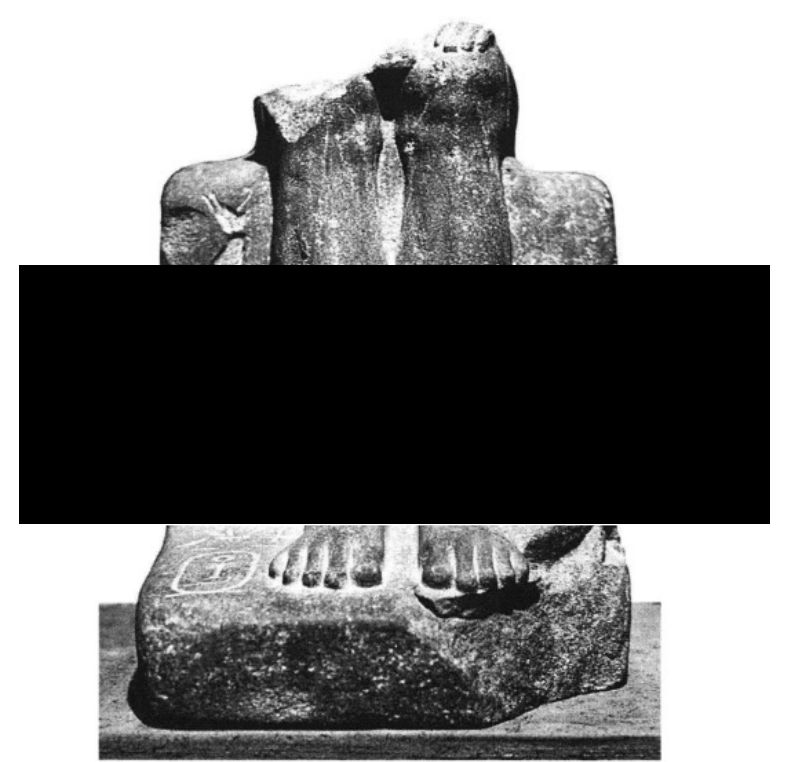

Fig. 4.6 Group statue of a female member of Djedefre's family, Musée du Louvre Paris E12627.

Furthermore, there are no surviving group statues of Twelfth Dynasty royal women embracing the pharaoh. The three almost identical group statues from the British Museum show a large seated Senwosret III with two small royal females, Khenemetneferhedjet I and II, standing and measuring up to his mid-calf (Cat. 32, 33, 34; Figs. 4.7, 4.8). These three are the only remaining statues from the Twelfth Dynasty that show royal women at this height. The royal women on the viewer's right of both statues have been attributed to Queen Khenemetneferhedjet I, wife of Senwosret II and mother of Senwosret III, due to the surviving titles of hmmt-nswt and $m w t-n s w t .{ }^{511}$ The royal woman on the viewer's left most likely represents Khenemetneferhedjet II who was Senwosret III's most well documented wife. ${ }^{512}$

\footnotetext{
${ }^{510}$ Princess Wemtetika: Present location unknown, Fay 1998: 172-173; Female member of Djedefre's family: Musée du Louvre E12627, Fay 1998: 175; Princess Nebibnebty and Seankhwptah: The Egyptian Museum Cairo CG 196, Fay 1998: 182; Roth 2006: 285; See also the triad statue of Menkaure, Hathor, and Bat: The Egyptian Museum Cairo JE 46499.

511 Sabbahy 1982: 191; Stünkel 2018: 25.

512 Stünkel 2018: 25.
} 


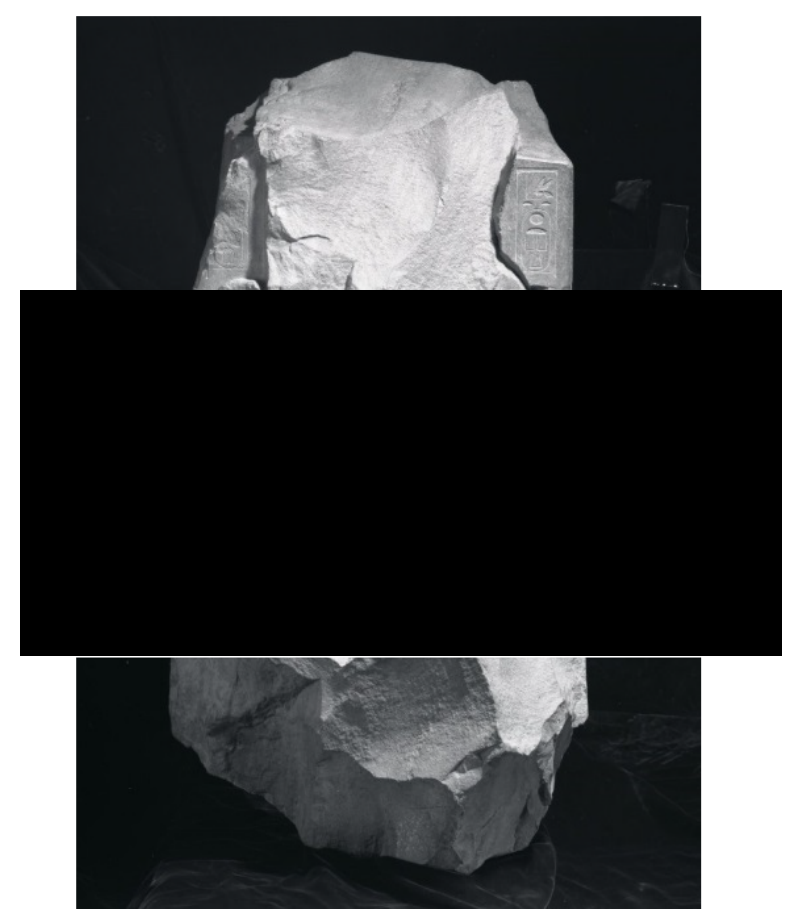

Fig. 4.7 Senwosret III with Khenemetneferhedjet I and Khenemetneferhedjet II, The British Museum London EA 1069.

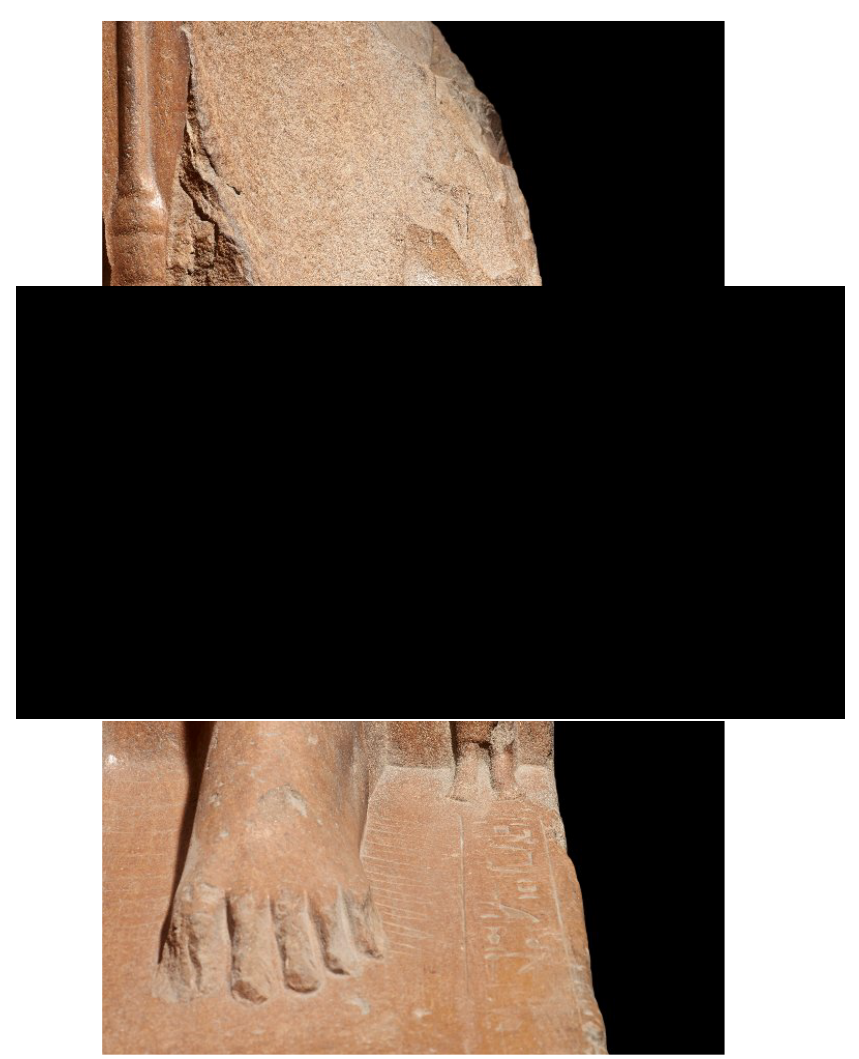

Fig. 4.8 Senwosret III with Khenemetneferhejet I and Khenemetneferhejet II, The British Museum London EA 1145. 
The third group statue shows two natural-sized royal women standing on each side of Amenemhat III who is seated in a Sed-festival cloak (Cat. 29). ${ }^{513}$ This representation is the earliest known statue of royal women participating in the rejuvenation of the pharaoh. ${ }^{514}$ Whether these two royal women are two princesses, two queens, or a queen and princess is unclear. Due to the fragmented titles on the right side it is possible both figures represent princesses. However, the closest parallel is the Senwosret III and Queen Khenemetneferhedjet group statues (Cat. 32, $33,34)$ that presumably represent the queen mother and queen wife. ${ }^{515}$ While there are four daughters attested to Amenemhat III, ${ }^{516}$ he only has three definite daughters, Neferuptah, Sobekneferu, and Neithikrety. It is possible that the two women depicted in the aforementioned group statue (Cat. 29) are princesses Neferuptah and Sobekneferu standing on either side of their father (for further discussion see Chapter 5.7).

Similar to group statues, the amount of surviving reliefs of royal women are very limited. Two of the surviving five reliefs are located within the Temple of Medinet Madi in the Fayum, which depict Amenemhat IV with his mother Hetepi (Cat. 56) and Amenemhat III with his daughter Neferuptah (Cat. 55). The royal mother Hetepi is seen standing behind her son Amenemhat IV while Neferuptah is depicted before the goddess Renenutet and in front of her father. Neither royal woman is life-size, but both are depicted in active roles. Queen Hetepi is entering the temple behind her son Amenemhat IV and Neferuptah is shaking a sistrum for the goddess Renenutet. The third existing relief is of Amenemhat III's wife Aat independently seated (Cat. 54), which is the only relief example of the most common sculpture pose of Twelfth Dynasty royal women.

\subsubsection{Seated}

Observed from the Middle Kingdom along with earlier and later time periods, the seated pose was regularly used for royal and non-royal people throughout ancient Egyptian history. The pose included the person's buttocks, thighs, and calves rested upon a throne seat. Although seated paired statues are frequently portrayed in art, out of all the surviving representations for royal women of the Twelfth Dynasty,

\footnotetext{
513 Evers 1929: pl. 99.

514 Stünkel 2015: 95.

515 Sabbahy 1982: 210-211.

516 Dodson 2004: 92.
} 
independently seated statues are the most common, for example the seated statue of Queen Khenemetneferhedjet (Cat. 18). There is currently no surviving statue of a Twelfth Dynasty royal women and man seated together. Twelfth Dynasty royal women were represented in two different seated poses, the first with both hands laid flat upon their thighs, such as Queen Khenemetneferhedjet I (Cat. 18, Fig. 4.9), or with their left arm across their body, as seen on the seated statue of Queen Nofret (Cat. 15, Fig. 4.10).

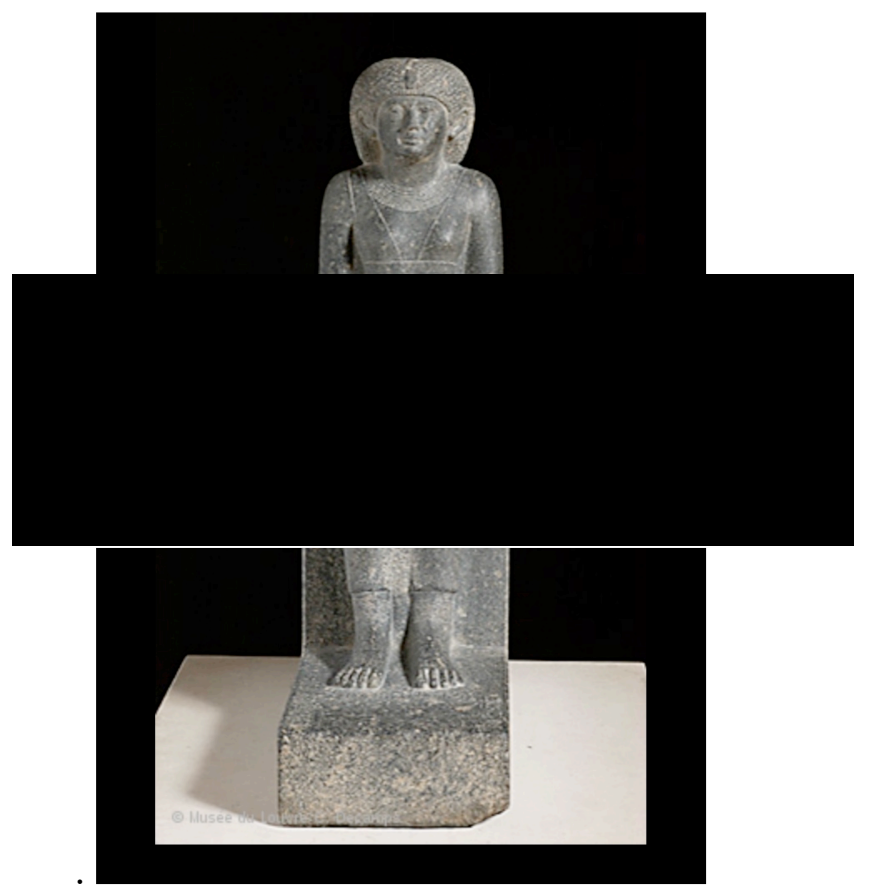

Fig. 4.9 Seated statue of Queen Khenemetneferhedjet I, Musée du Louvre E32564. 


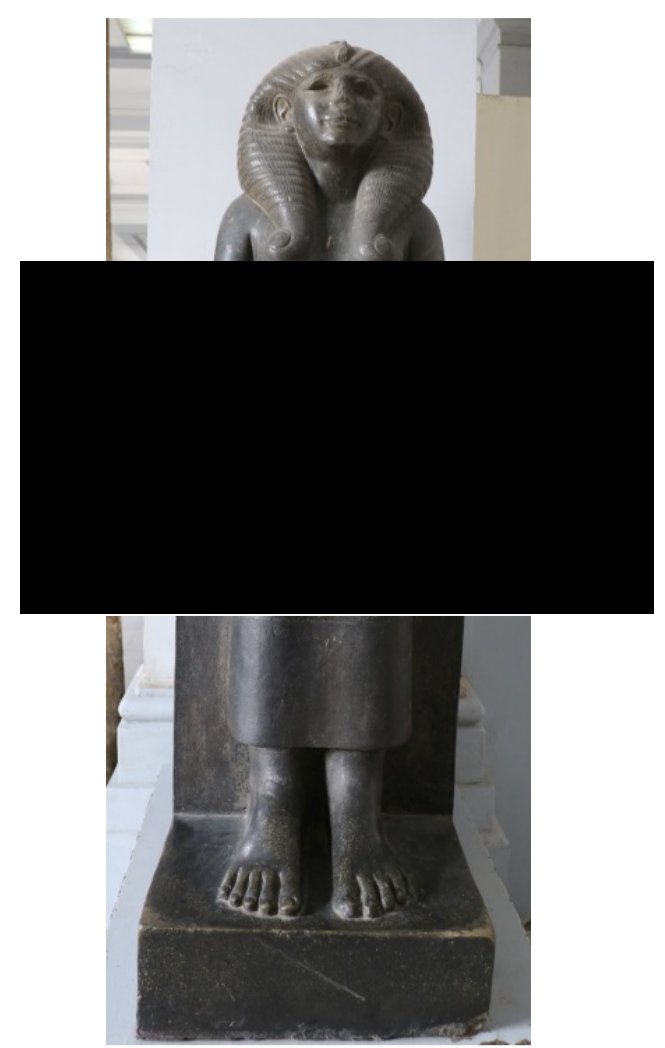

Fig. 4.10 Seated statue of Nofret, The Egyptian Museum Cairo, CG 381 (JE 37487).

Due to preservation many works are only busts or heads and cannot be truly categorized as seated or standing, as seen with a head of an unknown woman (Cat. 19). Neferuptah and Sobekneferu were represented in seated, standing, and sphinx poses (Cat. 55, 58-63), which means the same royal woman could have been represented in multiple different poses. These multiple types of depictions suggest there were no restrictions to the different poses Twelfth Dynasty royal women could be represented in.

\subsubsection{The sphinx pose}

The sphinx is defined as a human head with a lion body ${ }^{517}$ and is one of the most recognizable forms from ancient Egypt. The lion was a symbol of the ruler's strength and capability. ${ }^{518}$ Found at the funerary temple of Djedefre, the first example from ancient Egypt is possibly a female sphinx dated to the Fourth Dynasty. ${ }^{519}$ From what is attested, the Twelfth Dynasty is the first time in Egyptian art history that royal females were regularly portrayed as sphinxes, which are poses that presented royal

\footnotetext{
517 Jordan 1998: 183.

518 Robins 2001: 36; Teeter 2011: 223.

${ }^{519}$ Fay 1996: Appendix I.
} 
power $^{520}$ to the viewer. When represented in the sphinx pose, royal women were associated with the solar daughter and lioness goddess Sekhmet, whose name means "the female powerful one." 521 As the Eye of Ra, the goddess Hathor transformed into the fierce lioness goddess Sekhmet, ${ }^{522}$ which suggests the representations of the royal women in the sphinx pose with the Hathoric style wig, as seen on the two sphinxes (Cat. 67, 70), are associated with both of the goddesses. ${ }^{523}$

Including the two lost sphinxes of the politically notable Sobekneferu and Princess Neferuptah, the sphinx pose accounts for almost one third of all known royal female poses,${ }^{524}$ and is the third most common sculpture representation in the Twelfth Dynasty. Within the surviving representations there are four heads (Cat. 6467), three bodies (Cat. 62, 69, 70), and one fully restored sphinx (Cat. 68). The four remaining sphinx heads of unknown royal women (Cat. 64-67) wear damaged uraei and the Hathoric style wig can be found on two sphinxes of unknown royal women (Cat. 67, 70). The Bibliotheque Nationale sphinx (Cat. 67) is the only surviving head with the severe facial characteristics of the late Twelfth Dynasty along with a mane covering the surviving right shoulder. This frequency of the sphinx pose demonstrates that royal women during the Twelfth Dynasty had a considerable amount of political presence and their sculpture demonstrated it.

Five of the surviving eight sphinxes were discovered in Lower Egypt with two from the Heliopolis/Cairo region and two from Saqqara/Memphis. Additionally, two sphinxes have unknown provenances and one was discovered in Syria (Table 4.1). This could suggest that sphinxes for Twelfth Dynasty royal women were only set up in Lower Egypt, however it is also possible they were moved at later dates. This is seen with the head of female sphinx from Matariya (Cairo, Heliopolis) now in Boston (Cat. 64), whose head was probably broken off to make a building block from the body. ${ }^{525}$ Although broken and reused, the sphinx could have originally come from Heliopolis itself near the Twelfth Dynasty obelisk erected by Senwosret I or from another location such as a funerary complex or temple.

\footnotetext{
${ }^{520}$ Freed and Josephson 2009: 4-5; Josephson and Freed 2007: 135.

521 Troy 1986: 64.

522 Troy 1986: 64.

523 Ziegler 2008: 317.

524 This does not include the poses that are listed as non-applicable (N/A).

${ }^{525}$ Freed and Josephson 2009: 4.
} 


\begin{tabular}{|l|l|l|l|l|l|l|l|}
\hline Cat. 62 & Cat. 64 & Cat. 65 & Cat. 67 & Cat. 70 & Cat. 68 & Cat. 66 & Cat. 69 \\
\hline $\begin{array}{l}\text { Tell el } \\
\text { Dab'a }\end{array}$ & Matariya & Heliopolis & Saqqara & Mitrahineh & $\begin{array}{l}\text { Qatna, } \\
\text { Syria }\end{array}$ & Unknown & Unknown \\
\hline
\end{tabular}

Table 4.1 Provenances for the sphinxes of Twelfth Dynasty royal women.

The sphinx of Princess Ita (RW13) being discovered in Qatna, Syria is an example of Twelfth Dynasty objects being exported during the Second Intermediate Period. Ahrens states that since Ita's inscription is found between the forelegs, it indicates that the sphinx may have originally came from her burial complex at Dahshur. ${ }^{526}$ If this is the case, it could be that Neferuptah's sphinx (Cat. 69) and the headless Vienna sphinx (Cat. 70) also came from a burial complex, possibly Neferuptah's pyramid in Hawara (see Chapter 5.4). If both sphinxes originally stood at Neferuptah's pyramid complex and her securely inscribed sphinx was with a Luxor dealer along with the Vienna sphinx found in Metrahineh, it is highly possible the sphinxes were moved at later dates and possibly broken similar to the aforementioned Boston sphinx (Cat. 64). Sobekneferu's sphinx (Cat. 62) was discovered at the Tell el Dab'a/Khatana and may be the only sphinx of a Twelfth Dynasty royal woman that was found near its original placement (see Chapter 6.3), likely due to her building presence in the immediate area.

\subsubsection{The human-headed bird}

The second type of hybrid and fourth type of pose is that of a bird with a royal female head, as attested in the statue now located at the Egyptian Museum Cairo (Cat. 38; Fig. 4.11). The statue was found with a dealer in Cairo and proposedly came from the Delta. Although there is no other surviving parallel from the Twelfth Dynasty, due to its Hathoric style wig, diadem type uraeus, and facial characteristics, the statue is attributed to the late Twelfth Dynasty. This statue's fragmented body has been described as "probably a vulture" 527 but there is no evidence to support this type of hybrid. Because of the damage to the body, an actual bird species may be indistinguishable, but it is possible it represents a falcon. This royal female headed bird statue could possibly be an early representation of a $b a$-bird. If so, it would be the first human headed and falcon bodied statue that represents a deceased royal

\footnotetext{
${ }^{526}$ Ahrens 2011: 28-29.

${ }^{527}$ Fischer 1996: 116; Vandier 1958: 223.
} 
woman. Small wooden statues representing the $b a$ of deceased royal and non-royal people were more common during the New Kingdom through the Meroitic Period in Nubia, ${ }^{528}$ however, this statue could be a precursor to this style. This is highly significant because it once again shows the royal woman's closeness with the gods. Being represented in the $b a$-bird form gave the royal women's souls the ability to fly and accompany the sun god Ra on the daily cycle. ${ }^{529}$

Similarly, this Twelfth Dynasty bird with a royal female head could be the earliest surviving depiction of the pharaonic human-falcon image that was used during the Eighteenth Dynasty. During this time the form was developed to emphasis the pharaoh's closeness with the god Horus ${ }^{530}$ and is represented on nine statues and one relief which are connected with Eighteenth Dynasty pharaohs. ${ }^{531}$ One surviving head now located in the Brooklyn Museum ${ }^{532}$ most likely represents Hatshepsut which would further support that female monarchs were depicted in this style of expressing divine rulership. This Twelfth Dynasty example (Cat. 38; Fig. 4.11) is the only human-headed bird statue with no arms, which uses the wings as the upper limbs. Although there is no known bottom half to the statue, it is possible the royal woman would be striding with her human legs. If this statue securely depicts a female monarch of the Twelfth Dynasty in the divine human-falcon form, it can only be an image of Sobekneferu. During her reign, Sobekneferu commissioned other statues that were discovered in the Delta region (see Chapter 6.3) and was often connected with Horus being labelled as the female Horus ḥrt within her titulary (see Chapter 3.4). This statue could be an iconographic representation of the divine female Horus.

\footnotetext{
${ }^{528}$ Scalf 2012: 201.

${ }^{529}$ Scalf 2012: 202

${ }^{530}$ Hardwick and Riggs 2010: 117.

531 "The King as a falcon: corpus of images" A-G, Hardwick and Riggs 2010: 115-117.

532 Head of Hatshepsut of Thutmose III: The Brooklyn Museum 55.118.
} 


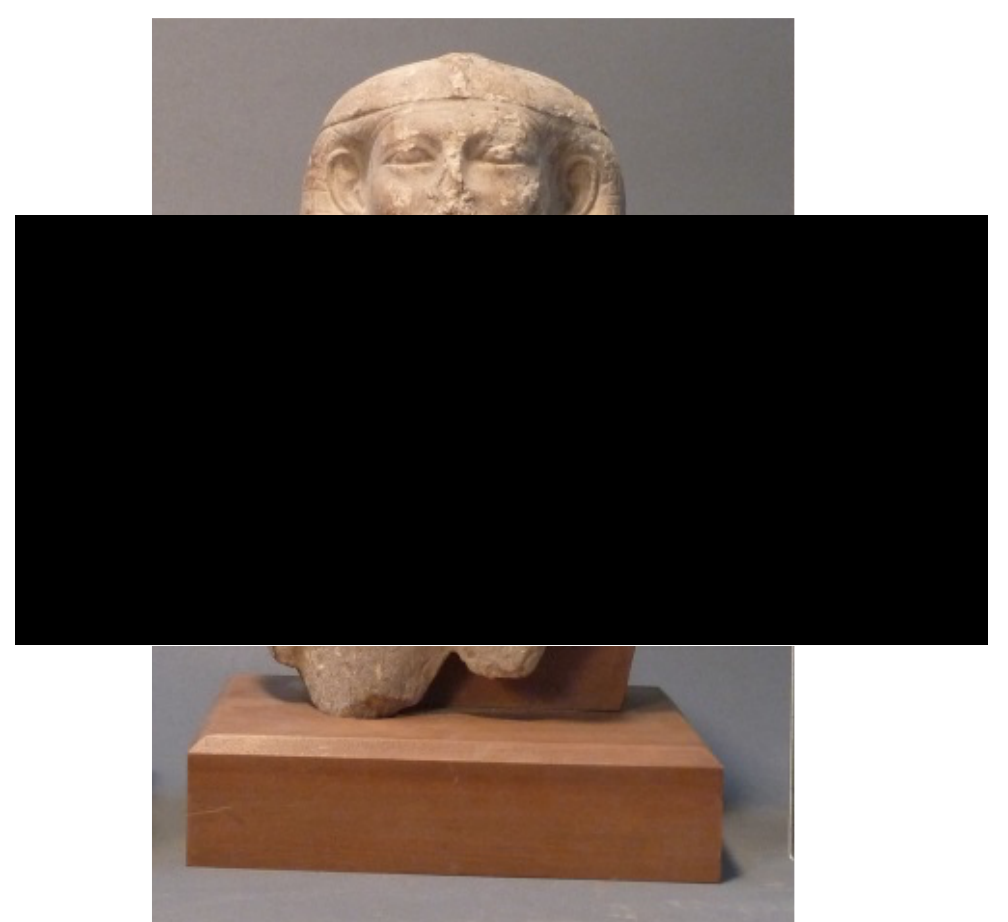

Fig. 4.11 Female-human headed bird, Grand Egyptian Museum 14506.

\section{3 'Severe' Facial Characteristics}

During the Twelfth Dynasty royal women adopted the severe facial characteristics, marking an important change in their iconography and political images. Excluding the non-applicable images within the surviving faces, nine statues of unknown royal women are seen with the severe characteristics (Cat. 1, 3, 4, 10, 11, 21, 24, 38, 67). Two of these unknown women (Cat. 38, 67) are the hybrid forms, sphinx, and female-headed bird. The characteristics vary highly and can include round and pentagonal faces, deep-set eyes, heavy eyebrows and long horizontal eyelids, sharp cheekbones, pronounced supraorbital ridges, deep cut nasio-labial folds, and turned down mouths. The individuality of this style can best be seen on the three statues of Senwosret III located in the British Museum (Fig. 4.2). All three statues are similar, almost seeming identical, except for the fact that the faces are noticeably distinct from each other. This can be seen by the treatments of the mouths, cheeks, and eyelids. ${ }^{533}$ This type of differentiation can also be seen on the statues of royal women. Presently there are no two statues with severe facial characteristics attributed to the same royal woman and catalogue examples (Cat. 1, 3, 4, 10, 11, 21, $24,38,67)$ are obviously similar but stylistically different.

${ }^{533}$ Russmann 2001: 101. 


\subsubsection{Round and pentagon faces with sharp cheekbones and nasolabial folds}

The common round face shape (Fig. 4.12) can be found on the three statues of unknown royal women (Cat. 4, 10, 21). Their faces include fuller cheeks with softly rounded jaws and chins. The other six royal women of the nine listed (Cat. 1, 3, 11, $24,38,67$ ) with severe facial characteristics have pentagonal-shaped faces (Fig. 4.13). Their faces have squared foreheads, broad cheeks, and squared jaws that end in a point at the chin, similar to a pentagon with one angle pointing downwards or simply an upside down traditional pentagon. Being a prominent feature of the severe characteristics both face shapes have sharp cheekbones. The pronounced cheekbones are seen on all nine statues (Cat. 1, 3, 4, 10, 11, 21, 24, 38, 67) and can be observed especially well from the side, as seen on the Berlin bust of an unknown woman (Cat. 1)..$^{534}$

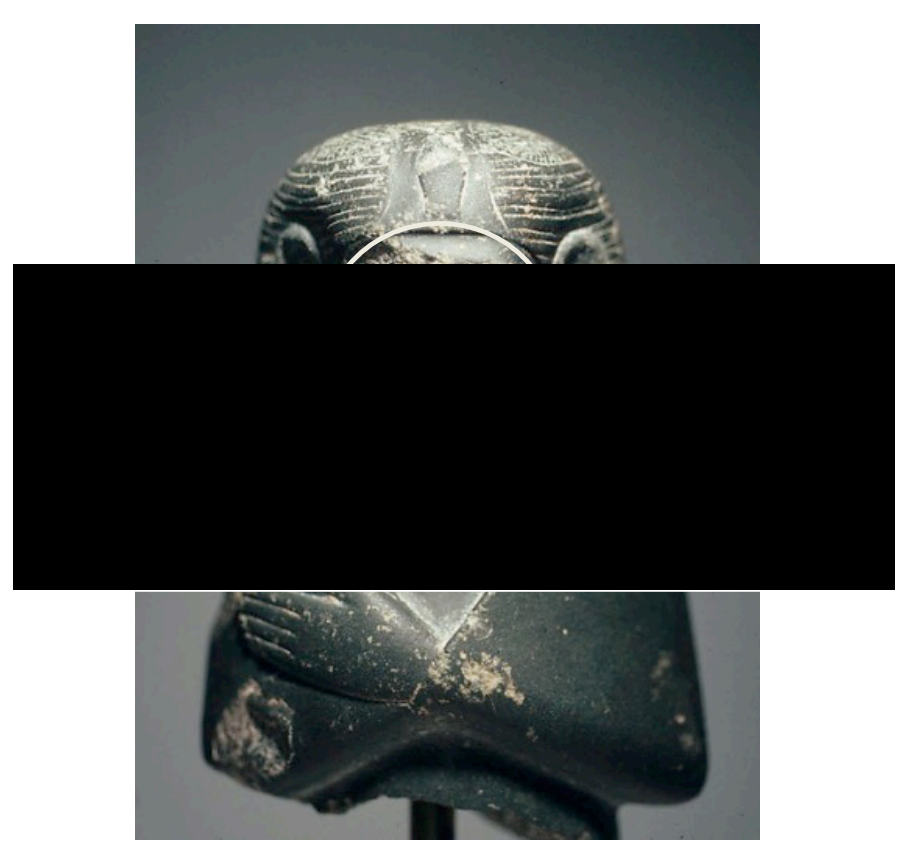

Fig. 4.12 Common round face shape, author's labeling, The Metropolitan Museum of Art New York 65.59 .1

534 This statue possible depicts Sobekneferu, see Chapter 6. 14. 


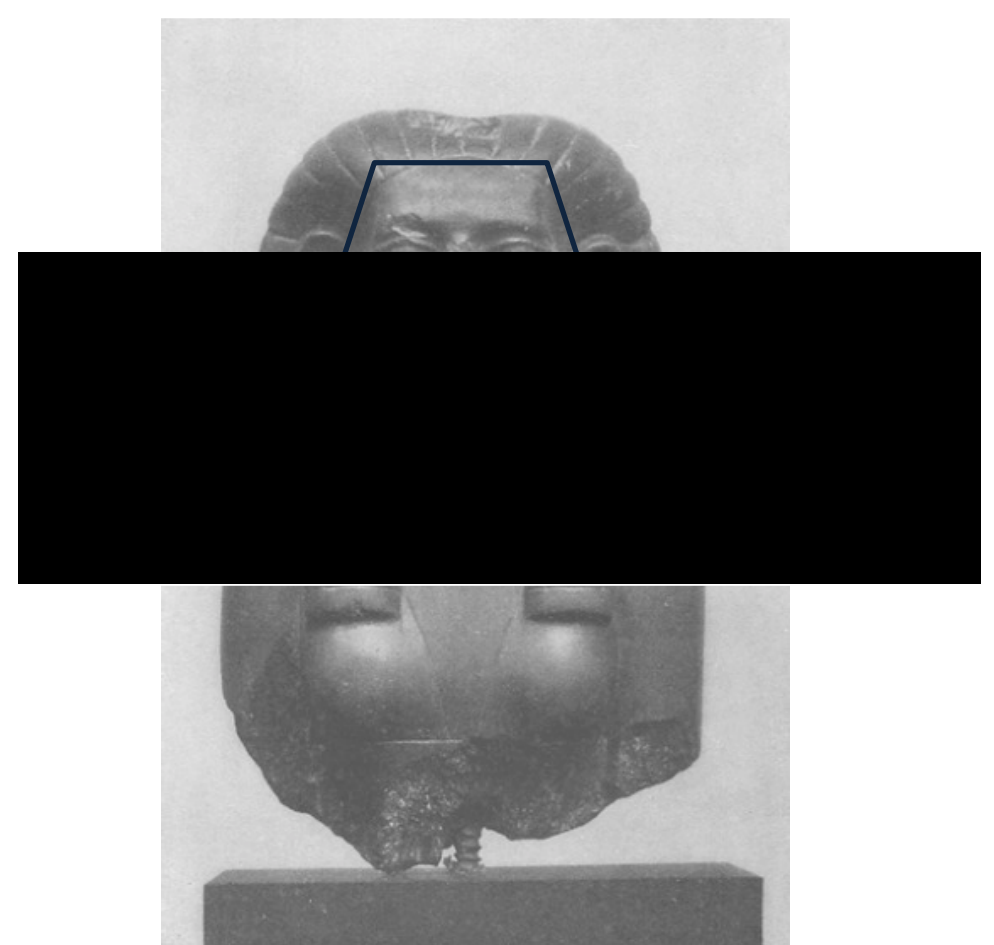

Fig. 4.13 Pentagonal face shape, author's labeling, Stattliche Museen Berlin ÄM 14475.

Due to facial damage only five statues with severe characteristics (Cat. 1, 3, 4, 38, 67) have surviving nasolabial folds, as seen on the statue of an unknown royal woman (Fig. 4.14). The folds create lines from the outside of their noses extending down to the corners of the mouths. They complement the cheekbones by making them look even more pronounced. Along with severe facial characteristics, nasolabial folds were shared among royal women and men. As seen on the Boston sphinx head (Cat. 64), nasolabial folds could also be depicted without the severe characteristics. This further emphasizes that deeply cut or pronounced folds were distinct features of the Twelfth Dynasty and can be clearly seen on the statues of royal women (Cat. 1, 3, 4, 38, 67). 


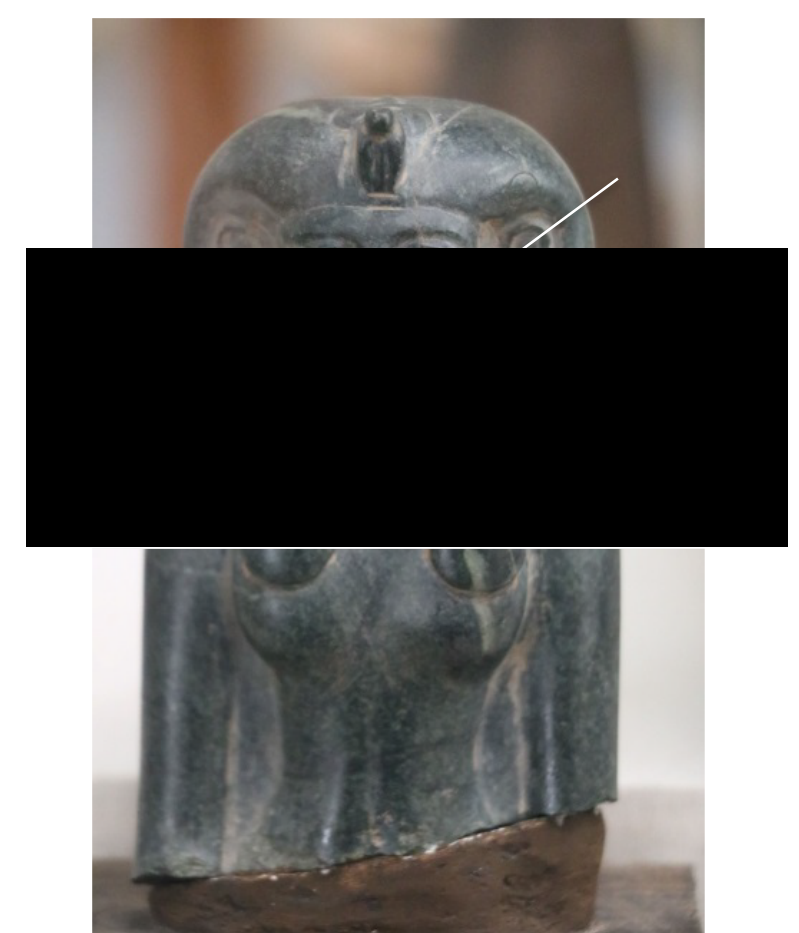

Fig. 4.14 Nasolabial fold, author's photograph and labeling, The Egyptian Museum Cairo JE 39741, M.E. VI.

\subsubsection{Heavy eyelids, eyebrows, and supraorbital ridges}

Since each statue with severe facial characteristics is unique, the eyelids, eyebrows, and supraorbital ridges vary. All nine of the statues of royal women (Cat. 1, 3, 4, 10, $11,21,24,38,67)$ have heavy eyelids that seem to be horizontal. This style of depicting the eyes elongates them horizontally bringing them to a point at the corners. The nine royal women also have naturalistic eyes without cosmetic treatments, which seemed to be favored among royal men as well, as seen on the statue of Senwosret III (Fig. 4.2). The eyebrows of the royal women are also naturalistic and tend to round over their eyes ending just beyond the outside corners.

The supraorbital ridge or eyebrow ridge is the bone that curves above the top of the eye socket. Within the surviving representations of Twelfth Dynasty royal women with severe facial characteristics, four statues have pronounced supraorbital ridges (Cat. 1, 3, 11, 38). When the supraorbital ridges are emphasized, it makes the eyebrows seemed pushed forward as far as the mouth or even farther, as seen on the Brussels bust of an unknown royal woman (Cat. 3) and on the Berlin bust (Cat. 1; Fig. 4.15). The supraorbital ridge is a significant feature among the severe characteristics because the more it is emphasized the more the eye sockets are defined. The combination of the pushed forward eyebrows and the sharp cheekbones gives the statue the look of sunken or deep-set eyes. 


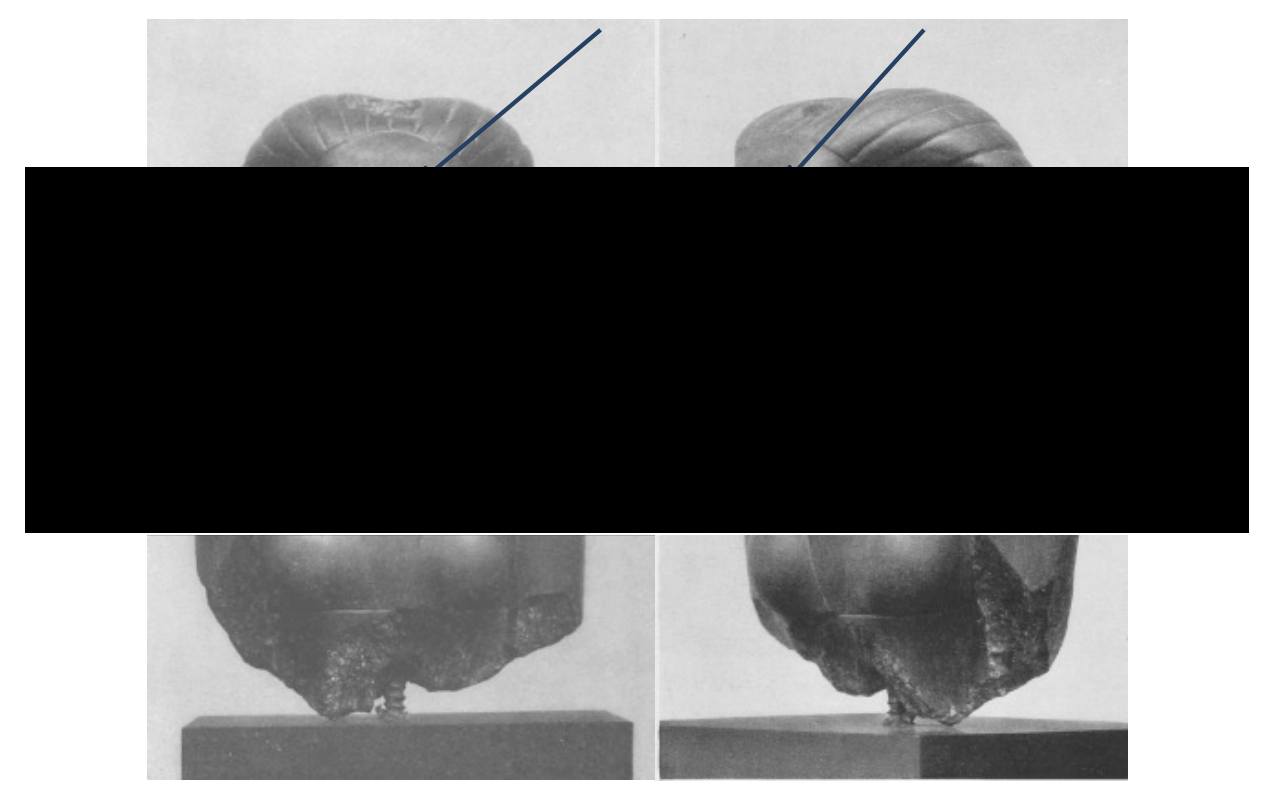

Fig. 4.15 Supraorbital ridge, author's labeling, Staatliche Museen Berlin ÄM 14475.

\subsubsection{Hybrid forms}

Another significant aspect of the severe facial characteristics is that they can be seen on the two hybrid forms, the sphinx pose and female-headed bird. For example, the Bibliotheque Nationale sphinx (Cat. 67) ${ }^{535}$ and Cairo female headed bird (Cat. 38; Fig. 4.11) $)^{536}$ are attributed to the late Twelfth Dynasty based on their facial characteristics. When viewed from the front and right side both hybrid forms are similar. They are represented with vertically striated and horizontally banded Hathoric wigs, severe facial characteristics, pentagonal face shapes, and cheeks that seem broad. During this time, both sphinxes of royal women and men were represented with similar severe facial features. These depictions confirm the political presence of royal women because of the power of the sphinx with the facial characteristics favored by pharaohs. The female-headed bird (Cat. 38) is rare within the art of Twelfth Dynasty royal women but it illustrates the ability of the facial characteristics to be transferred onto different poses. It also shows that royal women being represented with severe facial attributes was relatively common.

\footnotetext{
${ }^{535}$ Fay 1996: Plate 98c-d; Vandier 1958: 223; Ziegler 2008: 317.

536 Vandier 1958: 223.
} 


\subsection{Surviving Uraei}

The upright cobra with an outspread hood placed on the forehead was an iconic feature of Egyptian art. The cobra as royal insignia began as early as the First Dynasty, as presented on a relief of Den, ${ }^{537}$ and lasted well through the Roman rule in Egypt. ${ }^{538}$ The rearing cobra physically resembles the strong offensive and defensive attack style of the serpent. The cobra was the female counterpart to the divine falcon and continually accompanied the pharaoh as a symbol of their rule. ${ }^{539}$ It personified female power, which protected the gods and pharaohs against chaos and enemies. This protection marked the establishment of Egyptian monarchy and the legitimatization of the ruling pharaoh. ${ }^{540}$

While the royal uraeus began in the First Dynasty, it is not until the Fourth Dynasty that a royal woman, Queen Khamerernebty I (Fig. 4.16) is depicted wearing one. She is seen seated below her name and title Mother of the King with a small cobra at her brow. During the Twelfth Dynasty the uraeus becomes standard in the iconography of royal women. In most cases it separates royal from non-royal women, as seen on the statue of an unknown royal woman in the Metropolitan Museum (Cat. 9) and the statue of the non-royal nurse Sitsneferu (Fig. 4.5). The uraeus is also seen on every surviving sculpture of the king's mother, wife, and daughter; except for the reliefs of Queen Khenemetneferhedjet I (Cat. 53), Amenemhat III's wife Aat (Cat. 54), and Amenemhat IV's mother Hetepi (Cat. 56) who are the only women represented wearing the vulture headdress. Other royal women wear the uraeus marking their status as being a part of the royal and political family. Within the catalogue of this thesis the majority of the surviving statues have damaged uraei, along with a small number having the uraeus removed.

\footnotetext{
${ }^{537}$ Ivory label with Den British Museum 55586; Aldred 1980: 30; Johnson 1990: 52.

538 Johnson 1990: 190; Josephson 1992: 123.

539 Shalomi-Hen 2008: 180.

540 Johnson 1990: 6.
} 


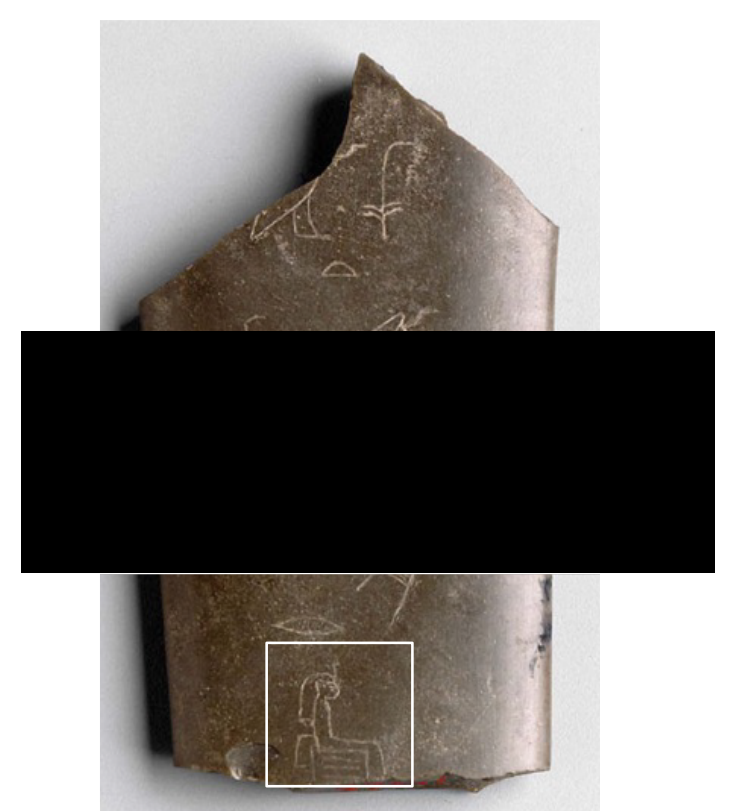

Fig. 4.16 Fragment of a magic knife inscribed for Menkaura's mother Khamerernebty I, Museum of Fine Arts Boston 11.766.

\subsubsection{Uraei designs}

Similar to the configurations of uraei of royal men, those for royal women differ on each statue. Each uraeus is unique to the sculpture but similarities among some royal women can be found. The uraei of Twelfth Dynasty royal women are often broadhooded while lying flat against the forehead and beginning at the wig hairline or a little above. Within the surviving representations, the decoration for the cobra's ventral column was not common or the necks are now too damaged to accurately describe the design. There are also no remains of a royal woman having a uraeus whose tail coils or loops underneath its own body. The Cairo bust of an unknown royal woman (Cat. 4) and the Istanbul bust of an anonymous royal woman (Cat. 5) are the only surviving representations that have full intact uraei. The Cairo bust's uraeus (Cat. 4) has an unprecedented thick body that supports the upright neck of the cobra. It also seems to have a line in the middle of the cobra's neck, possibly a scaled decoration, similar to Nofret as seen on her statue (Cat. 15) or the statue of Queen Khenemetneferhedjet I (Cat. 18). The Istanbul bust of an unknown royal woman (Cat. 5) has a flat and broad uraeus with the cobra's head raising upright on the wig. The obsidian head of an unknown woman (Cat. 21) is the only surviving cobra that seems to have a decoration that does not resemble scaling, but the design is presently unidentified. 


\subsubsection{Tail Curves}

Based on surviving uraei and available photographs the tails of the uraei are usually in the S-shape or tail curved style. Depending on the crown or headdress, the tail can be present or absent. This style comes from the physical characteristic of the cobra when it is in motion, whether moving forward or preparing for attack. While actual cobras are in the S-shape, there is no exact number of tail curves at a set time making the Egyptian artists decide the number of curves for the artwork. From the surviving representations of Twelfth Dynasty royal women's uraei, the minimum number of tail curves is two while the maximum is ten. ${ }^{541}$ Out of eight royal female sphinxes, only on top of two heads can the uraei tail curves be counted. The two sphinxes with countable tail curves have the highest number of curves within the known surviving Twelfth Dynasty uraei tails. The Boston sphinx head (Cat. 64; Fig. 4.17) has seven curves while the Metropolitan Museum of Art sphinx head (Cat. 66) has eight curves. Why these two sphinxes have such high numbers of tail curves is presently unclear, but it is significant to note especially in comparison to other works such as the sphinx of Senwosret III ${ }^{542}$ which has only four tail curves. Due to damage and a lack of head photographs a true comparison of uraei is difficult to conduct, but it can certainly be said there are more differences than similarities between royal men and women uraei.

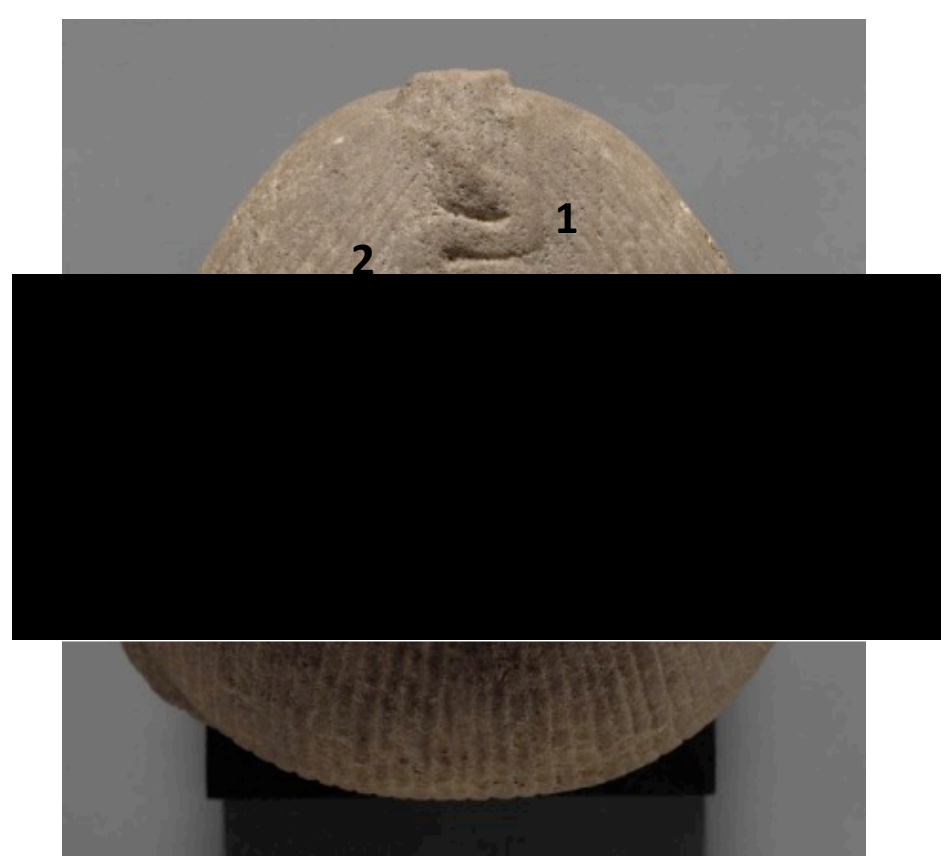

Fig. 4.17 Seven Tail curves, author's labeling, Museum of Fine Arts Boston 2002.609.

${ }^{541}$ Found on the female headed bird, no photo provided by the Egyptian Museum, Cairo.

${ }^{542}$ Sphinx of Senwosret III, The Metropolitan Museum of Art 17.9.2; Hayes 1978: 197. 


\subsection{Wig Type}

Within the surviving images of Twelfth Dynasty royal women four wig types can be seen: the tripartite, Hathoric, rounded/globular, and blunt/bobbed. The tripartite wig can be seen as striated, banned, or smooth. The Hathoric style can be smooth or banned and with vertical or horizontal striations. The rounded wigs have tiered styled curls that are sometimes accompanied by decorated features. The blunt style is described as an even length hairstyle ending above the shoulders and can include hair jewelry.

\subsubsection{Tripartite}

The tripartite wig consists of the hair being parted into three sections with two in the front and one in the back. The style accounts for nearly one third of the royal female representations included in the collection of this thesis and is the most represented out of the four wig types. Over half of the representations with a known wig type are tripartite, making it the most common wig used or best surviving wig type. Within this catalogue the tripartite wig can be seen in different styles and on different poses. As seen on the Boston bust (Cat. 2), the wig is vertically striated and tapers tightly while on the Berlin bust (Cat. 1) her wig is horizontally banned and tapers widely above the breast. On the other hand, the tripartite wig can be presented as smooth with no vertical or horizontal bands, as seen on the Brussels's bust of a queen (Cat. $3)$.

\subsubsection{The Hathoric style}

The second most common wig type is the Hathoric style, which has two frontal lappets of hair that curl, sometimes around a disk, at the bottom imitating the style of the goddess Hathor. ${ }^{543}$ Hathor was the goddess mostly associated with women, and was often depicted wearing this wig along with being represented as a cow or woman with cow ears. ${ }^{544}$ Hathor was directly connected with queenship and kingship, but during the Twelfth Dynasty both royal and non-royal women were depicted wearing the Hathoric style wig. On one level, she was the divine model and religious complement for royal women. On another level, she represented the roles of mother and wife of the pharaoh. ${ }^{545}$ As the divine mother and wife of the living Horus, Hathor was able to connect to royal women through the renewal of kingship

\footnotetext{
${ }^{543}$ Freed 2010: 898; For discussion on the origin of the 'Hathoric curls' see Bouillon 2014: 209-226.

${ }^{544}$ Russmann 2001: 264.

${ }^{545}$ Troy 1986: 53-54.
} 
and through the sharing of the feminine prototype. ${ }^{546}$

The Hathoric style accounts for one sixth of the entire collection and comprises over one third of the four known wig types. Similar to the tripartite style, the Hathoric wig can be seen in different styles and on different poses. The seated statues of Queen Nofret (Cat. 15, 16), the Bibliotheque Nationale sphinx head (Cat. 67), and the female-headed bird (Cat. 38) show the Hathoric wig horizontally banned while also vertically striated. The Hathoric style can also be smooth, as seen on the Cairo bust (Cat. 4), or simply vertically striated, as on the Sotheby's bust (Cat. 11). Out of the three group statues that represent Queens Khenemetneferhedjet I and Khenemetneferhedjet II (Cat. 32, 33, 34) only one has the remains of a Hathoric style wig while one also has the remains of a tripartite wig. Since the two statues (Cat. 33, 34) were found together at Tell el-Muqdam it is a possible that the four depictions may have been represented with the Hathoric wig style. This could conclude that the missing top heads of the three standing women on the group statues (Cat. 33, 34) wore Hathoric wigs and the two from the statue (Cat. 32) found at Tell Nabasha wore tripartite wigs. Although group statues are not common during the Twelfth Dynasty, the Hathoric style may have been the preferred wig type for royal group statues. These depictions can additionally suggest the Hathoric and tripartite wigs were interchangeable on multiple statues made in the same style.

\subsubsection{Rounded style}

The rounded style includes three different versions from the Twelfth Dynasty that are only seen on three separate statues. A head of a royal woman now located in Copenhagen (Cat. 22) shows the rounded wig with horizontal tiers. The seated statue of Queen Khenemetneferhedjet I (Cat. 18) is the only royal woman shown wearing the curled tiered style with lotus flower decorations on top. The lotus blossom is shown open and in a circular form. The third type of rounded wig only remains on one statuette now located in the Metropolitan Museum of Art (Cat. 10). The wig has horizontal tiers and contains vulture decorations flanking the uraeus. These two types of rounded wigs with decorations on the statue of Khenemetneferhedjet and an unknown royal woman $($ Cat. 18,10$)$ are unique for royal women within the Twelfth Dynasty.

${ }^{546}$ Troy 1986: 58, 68. 


\subsubsection{Blunt style}

The fourth wig type is the blunt style, also known as the shoulder length bob, which is only seen on one image from the Twelfth Dynasty. The wooden head of an unknown woman (Cat. 20) has a blunt hair style that has the same length all the way around the head. This style has been previously described as a single mass covering the shoulders. ${ }^{547}$ There are no other surviving examples of Twelfth Dynasty royal women wearing this style on stone sculpture or reliefs, suggesting the blunt wig was reserved for wooden statues. However, because of the wood's organic material, it is possible that preservation does not allow for more surviving examples of the blunt wig type, resulting in representations being unaccounted for.

\subsection{Headgear}

Hair and wig styles were among the most varied means of showing status in ancient Egypt. ${ }^{548}$ Women's hair was often restricted to their positions and the affordability of professional hairdressers as well as royal hairstyles were regularly accompanied with symbols including uraei and crowns. The display of hair was associated with social identities such as age, gender, and status, ${ }^{549}$ and was significant to the context of the scenes' iconography. As for Twelfth Dynasty royal women, status was not directly linked with wig types as much as in some other periods, such as the early Old Kingdom. ${ }^{550}$ All four wig styles — tripartite, Hathoric, rounded/globular, and blunt/bobbed - were shared among non-royal women. During this time, depicting royal status was more centered on the uraeus, titles, and pose. Crowns were not common for Twelfth Dynasty royal women and only one statue of an unknown woman with a bird's body is seen with a diadem (Cat. 38). Instead of crowns or specific royal hairstyles, to project their political status as a member of the ruling family, royal women would combine common wig types with uraei and high-status decorations such as vultures.

\subsubsection{Vulture Headdress}

Besides the fragment of a vulture headdress with a uraeus (Cat. 26) and the heavily damaged head possibly dated to the Twelfth Dynasty, now located in the

\footnotetext{
${ }^{547}$ Robins 1999a: 64.

548 Tassie 2011: 605.

549 Troy 1999: 69.

550 Tassie 2011: 635 .
} 
Metropolitan Museum of Art (Cat. 25), there are no surviving complete sculptures of Twelfth Dynasty royal women wearing a vulture headdress. The reliefs of queens Hepeti (Cat. 56), Aat (Cat. 54), and Khenemetneferhedjet I (Cat. 53) are the only securely dated representations of Twelfth Dynasty royal women with the vulture headdress. Some seated statues are missing the top half leaving no indication of a headdress or headpiece and the knowledge of a headdress being worn is not applicable. It seems the vulture headdress is restricted to reliefs and is only represented in art with the pharaoh's mother and wife. This restriction is proposed because out of the three surviving reliefs only Queen Hetepi who carries the title Mother of the monarch and Queen Aat who carries the title Wife of the Monarch have vulture headdresses; while Princess Neferuptah, the daughter of the pharaoh, only wears a diadem. While no evidence for the title Mother of the Monarch remains for Queen Aat, it can be suggested that she may have been a royal mother due to the fact she wears the vulture headdress.

From the Twelfth Dynasty there are six attested mothers of kings, of which three are known from their titles only and three by their surviving titled images. Queen Neferet I (RW 1), the mother of Amenemhat I, is known from an offering table found near her son's pyramid. ${ }^{551}$ Queen Neferytatenen (RW 2), mother of Senwosret I, was once identified by a titled statue that is now lost ${ }^{552}$ (Cat. 46), and Queen Neferu IV (RW 7), mother of Amenemhat II, is only known from a titled bowl from Lisht. ${ }^{53}$ Royal mothers with surviving images include the three statues of Queen Senet (RW 41; Cat. 17, 28, 36), the intact seated and heavily damaged small group statues of Queen Khenemetneferhedjet (RW 20; Cat. 18, 32, 33, 34,), and the relief of Queen Hetepi (RW 40; Cat. 56). It is unclear if all mothers of the Twelfth Dynasty pharaohs wore vulture headdresses. Additionally, vultures can be found on a statuette of an unknown woman (Cat. 10), uniquely ${ }^{554}$ flaking the uraeus of the royal woman. The two vultures are identical with outstretched wings encircling the tail of the cobra. This particular style of vultures along with late Middle Kingdom facial characteristics, has been suggested to represent Sobekneferu. ${ }^{555}$ However, there are no other surviving images of Sobekneferu wearing a vulture headdress or

\footnotetext{
551 Troy 1986: 157.

552 Josephson and Freed 2007: 138.

553 Troy 1986: 157.

554 Fischer 1996: 118.

555 Fischer 1996: 116.
} 
having the title Mother of the Monarch.

\subsubsection{Diadem type crown}

The Twelfth Dynasty is the first time in Egyptian history the double feather crown or swty feathers is associated with royal women. The swty feather crown of Princess Sithathoryunit is the first example of a royal woman having the two feathers and the first physical example of the 'Double Feather'- Crown. ${ }^{556}$ Different hairstyles and headbands were more common in the iconography of Twelfth Dynasty non-royal women. These include diadems that seem to be non-royal versions of the same crown royal women wore. As shown in rock tomb of Ukhhotep son of Ukhhotep and Henyheryib, non-royal women are seen wearing the double feather crown without uraei on the front (Fig. 4.18).

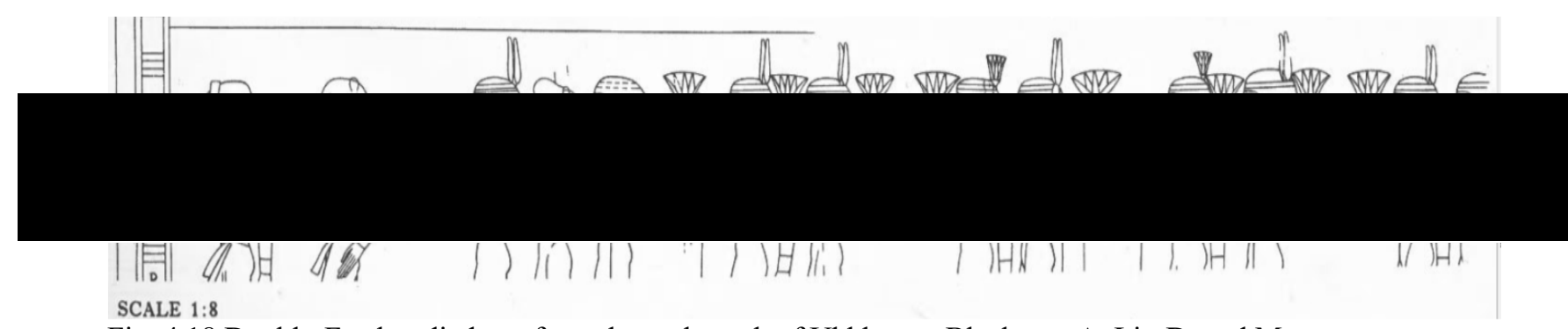

Fig. 4.18 Double-Feather diadems from the rock tomb of Ukhhotep, Blackman A, Litt D, and M Apted 1953: plate X.

The surviving wooden head of a royal woman (Cat. 20) located in the Egyptian Museum Cairo possibly once showed a unique headdress, which is now missing a large central portion of her wig. She may have worn a headpiece with a uraeus marking her royal status or possibly a vulture. The missing headpiece could be similar to the crown of Princess Sithathoryunit (RW 23; Fig. A.39), ${ }^{557}$ a daughter of Senwosret II, which shows a uraeus in the front with the swty feathers in the back. The presence of a vulture for the wooden head (Cat. 20) can also be suggested because a vulture is found on the crown of Princess Khnemet (RW 14; Fig. A.19), a daughter of Amenemhat II. Khnemet's diadem type crown ${ }^{558}$ is the only surviving Twelfth Dynasty physical example of a vulture on a headdress. The diadem shows a full-bodied vulture located at the front with semi-rounded outstretched wings

\footnotetext{
${ }^{556}$ El-Shahawy 2005: 45. The first relief is attested to Sneferu of the Fourth Dynasty, The Egyptian Museum Cairo JE38568.

557 Crown of Sithathoryunit, The Egyptian Museum Cairo JE 44919; Andrews 1990: 104.

558 Andrews 1990: 52.
} 
pointing downwards. This pose is the same as when the vulture lies atop a woman's head as a headdress or crown. It is unclear if Sithathoryunit and Khnemet would have worn the crowns in daily life and from their remaining titled material; they are not wives or mothers of a ruling pharaoh.

\subsection{Ears}

Almost fifty percent of the collection of ears analyzed in this study are nonapplicable due to the lack of preservation or no image available. However, with the one exception of the wooden head now located in Cairo (Cat. 20) every surviving representation of a Twelfth Dynasty royal woman's head shows the ears in front of her wig. The feature of the ears being placed in front of the wig or headdress became an absolute standard in the iconography of Twelfth Dynasty royal women and is seen on all types of representations, poses, and with all wig styles. The surviving ears from Twelfth Dynasty royal women are large to oversize and are shown being slightly pushed forward by their wigs. Their ears are low-set on the head and can be considered realistically shaped due to the rounded tops or helices, which are usually heavily defined and thick (Fig. 4.19). The bottoms of the ears or earlobes are also rounded and are always shown attached to the side of the head. Although their surviving ears have fleshy earlobes, no carved images of earrings exist on the Twelfth Dynasty royal women that are included in this catalogue.

Earrings or earring holes carved into the ears of sculptures were not common until the New Kingdom, ${ }^{559}$ and while it could be possible that depictions of Twelfth Dynasty royal women once contained painted earrings, there is no surviving evidence. The majority of the ear representations show a slight in-turn at the middle of the front of the ear to define the crus of the helix and tragus. This inward turn creates less defined but present conchae and anti-tragi. The feature of the ears that differs the most among the representations is the anti-helix, which can be welldefined as seen on the Berlin bust (Cat. 1) or smoothed down as seen on the Copenhagen head of an unknown woman (Cat. 22).

${ }^{559}$ Russmann 2001: 192. 


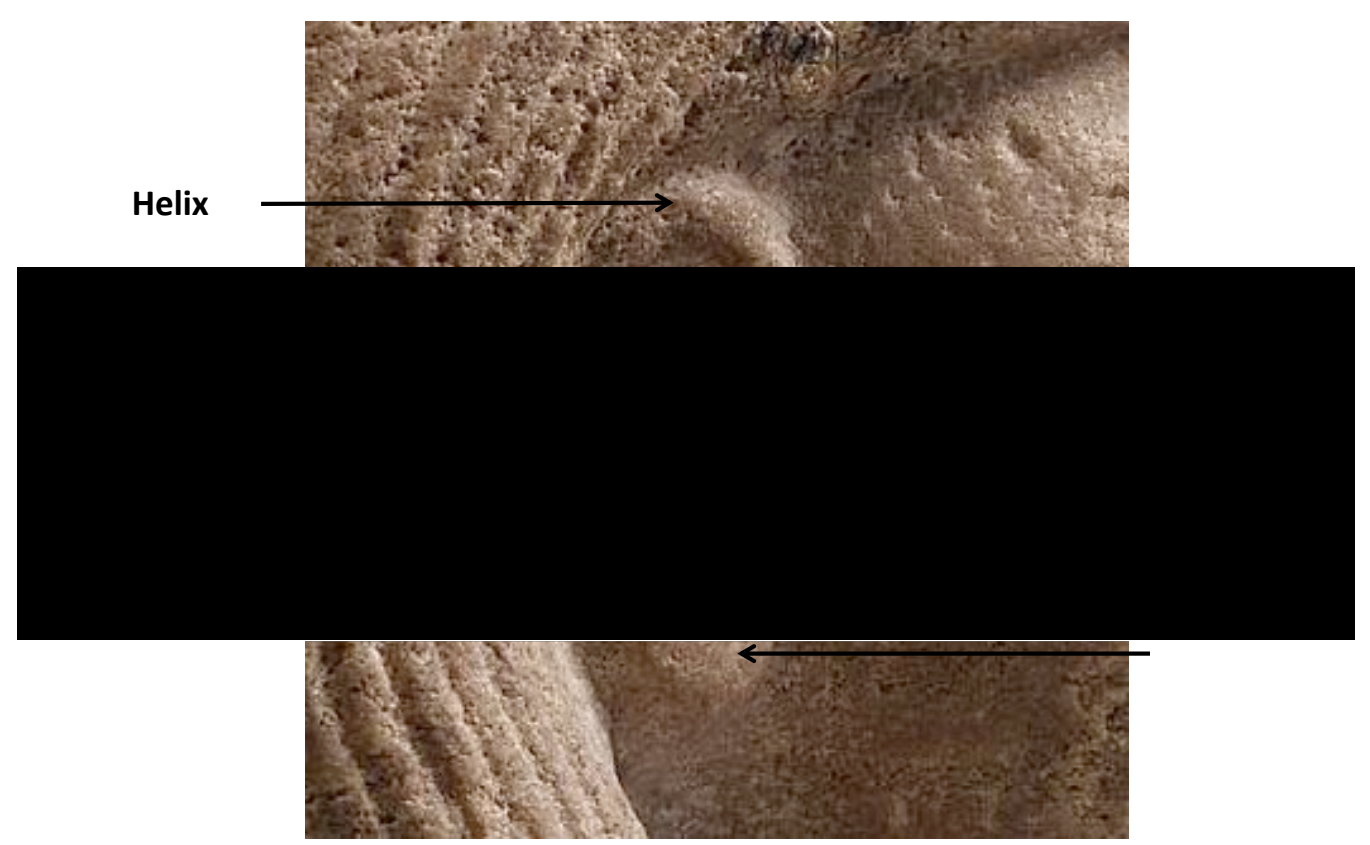

Fig. 4.19 Parts of the ear, author's labeling, Museum of Fine Arts Boston 2002.609.

\subsection{Eyes}

Similar to ears, close to fifty percent of eye representations are non-applicable, but similarities among the surviving images can be seen. Within sculpture the eyes are shown sharply defined, while some are deep and others are shallow set. Out of the known images four statues would have had inlaid eyes (Cat. 15, 16, 20, 65). As for the nine statues of royal female representations that have the Twelfth Dynasty severe facial characteristics (Cat. 1, 3, 4, 10, 11, 21, 24, 38, 67), their eyes are deeply set with heavy eyelids and pronounced eyebrows. These nine statues also have naturalistic eyes instead of cosmetic. The other representations that do not carry the severe characteristics have much lighter eyelids with both naturalistic and cosmetically treated eyes. The naturalistic eye accounts for nearly fifty percent of the known eye images while cosmetic treatments account for the rest. The cosmetic and natural eyes are used on all seated, standing, and sphinx poses. Based on the modern artistic reconstructions, both reliefs of Queen Hetepi (Cat. 56) and Princess Neferuptah (Cat. 55) have cosmetically treated eyes.

\subsection{Dress}

Including the cloak on the Metropolitan Museum of Art statuette (Cat. 10) there are only two types of dress found on Twelfth Dynasty royal women. The cloak found on 
this statuette is seen with sharp corners that stop at the shoulders displaying the wearer's chest. This statuette may be attributed to Sobekneferu, but there are no other parallel representations from the Twelfth Dynasty. ${ }^{560}$ There are at least six examples of Old Kingdom royal women wearing this type of cloak. ${ }^{561}$ Due to another surviving head now in Copenhagen (Cat. 22) that resembles the Metropolitan Museum statuette (Cat. 10) it is assumed by Fischer that royal women in the late Middle Kingdom took part in archaizing style. ${ }^{562}$

The only dress type that is used outside of the cloak is the sheath dress. The sheath dress can be seen on all other surviving representations of Twelfth Dynasty royal females and is seen as an ankle-length garment that fits tightly to the body. The sheath dress is seen on both seated and standing poses, such as the statue of Queen Khenemetneferhedjet (Cat. 18) and the statue of a queen thought to be the wife of Amenemhat III (Cat. 48). ${ }^{563}$ It is accompanied by all wig types and is seen with and without jewelry.

\subsection{Jewelry}

The jewelry of Twelfth Dynasty royal women varies the most out of their features. This may be due to accidental preservation, ancient artistic choices, lack of preserved paint, and modern artistic reconstructions of reliefs. Based on these variables it is almost impossible to construct a complete account of the jewelry seen on the artworks of Twelfth Dynasty royal women. ${ }^{564}$ Within the available images found in the catalogue of this thesis, the majority of the representations do not have any surviving depictions of jewelry as seen on the statues (Cat. 1-6, 9, 10, 11, 17, 27, 28, 31, 32). Five royal women, including two sphinxes, have just broad collars (Cat. 8, $53,56,68,70$ ), and the two statues of Nofret have pectorals and bracelets (Cat. 15, 16). The seated statue of Queen Khenemetneferhedjet I (Cat. 18) and the reconstructed relief of Neferuptah (Cat. 55) are the only representations that have broad collars, bracelets, and anklets. Additionally, the Cairo wooden head (Cat. 20) uniquely has hair jewelry. Although a conclusion cannot be drawn in regard to the

\footnotetext{
${ }^{560}$ Fischer 1996: 118.

561 Tassie 2011: 632 .

562 Fischer 1996: 117-118.

${ }^{563}$ Fay 1996b: 136; Ziegler 2008: 300. A Queen in the Middle Kingdom: a statue thought to be of Amenemhat III's wife, George Ortiz Private Collection.

${ }^{564}$ For this analysis I have included all the jewelry that can be seen on the available images included within the catalogue of this thesis.
} 
jewelry, it is clear that the majority of surviving representations were not adorned with inscribed jewelry. Considering this, one can assume that being depicted with lavish jewelry was not a requirement for Twelfth Dynasty royal female art. ${ }^{565}$

Similar to the previously discussed headgear (see Chapter 4.6), archaeological evidence shows a discrepancy among the representations and what is actually found. During the late Middle Kingdom, objects of daily life, such as jewelry, were the main items in tombs. ${ }^{566}$ It is known that some Twelfth Dynasty royal women were buried with all types of jewelry. These include pectorals, necklaces, collars, crowns, girdles, armlets, bracelets, and amulets. ${ }^{567}$ Furthermore, while most surviving busts are seen without any jewelry, two out of the available six images of sphinxes are seen wearing broad collars. The sphinx of Princess Ita (Cat. 68) and the sphinx of an unknown princess (Cat. 70) are the only two that can be seen wearing neck jewelry. However, they are also the only two sphinxes that have surviving bodies. The other four sphinxes do not have remaining bodies so while it is possible, it cannot be concluded that broad collars or other necklaces were normal for Twelfth Dynasty royal female sphinxes.

\subsection{The royal beard}

Throughout ancient Egyptian history the ruling pharaoh was depicted with a false beard, often called the pharaonic or royal beard, to help express their position in the government. Similar to other iconographic elements, representations of the false beard varied from between Twelfth Dynasty pharaohs. The royal or false beard was not an essential iconographic element when depicting Twelfth Dynasty pharaohs, as shown by multiple inscribed and uninscribed statues (Figs. 4.1, 4.2, 4.3, 4.35, 6.1). Except for the Eighteenth Dynasty Karnak ruler list depicting Sobekneferu (see Chapter 6.6, Fig. 6.11), the false beard is not securely attested on any surviving representations of a Twelfth Dynasty royal woman. Nonetheless, there is one possibility of a false beard depiction found on the royal mother Queen Hetepi (RW 40) from the late Twelfth Dynasty. A false beard for the queen has not been recorded by previous excavators of the temple and is probably assumed by most to be damage from the limestone walls (Cat. 56; Figs. 4.20, 4.21). However, the

\footnotetext{
${ }^{565}$ Fischer 1996: 118.

${ }^{566}$ Grajetzki 2014a: 147.

${ }^{567}$ Winlock 1933: 29-59.
} 
feature is present even if it is unexpected for a royal woman to have and should be discussed.

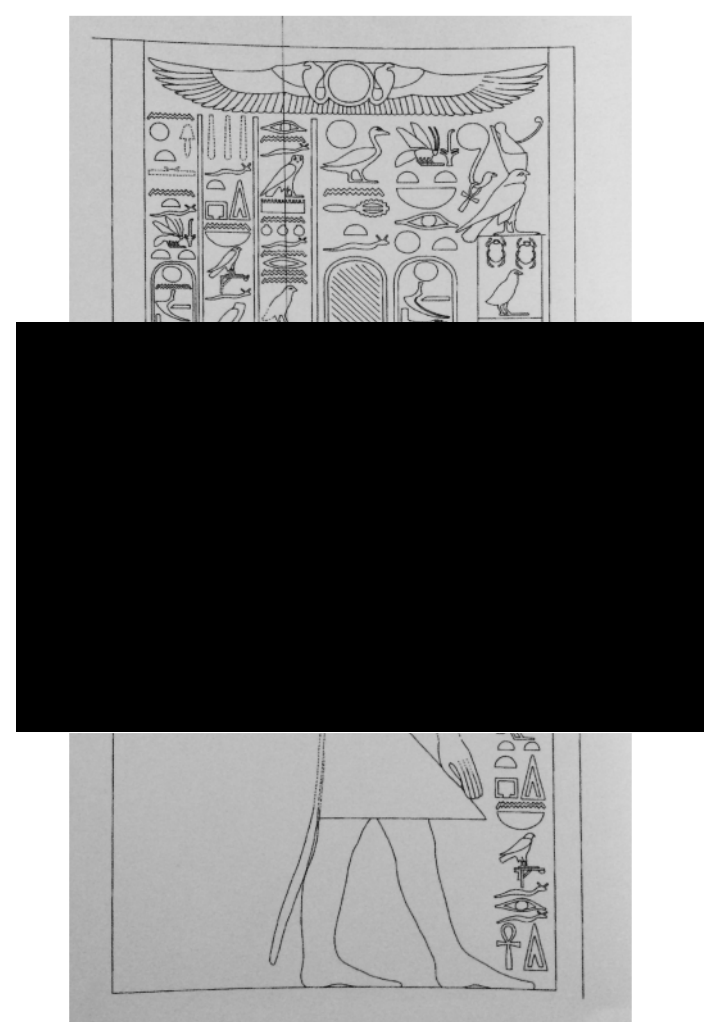

Fig. 4.20, Relief of Queen Hetepi and Amenemhat IV, Bresciani, E. and A Giammarusti 2012, 74

Queen Hetepi was the mother of Amenemhat IV and the royal woman in the political position of queenship during his reign. The only surviving relief of Hetepi is located at the Temple of Medinet Madi in the Fayum. The scene depicts Hetepi following Amenemhat IV into the innermost part of the temple. The scene is relatively wellpreserved with only the bottom half naturally damaged. Upon close examination of Hetepi's face, there is a beard-like feature placed on her chin that is almost identical to that of Amenemhat IV (Figs. 4.21, 4.22, 4.23). The placement of her image inside the Temple of Medinet Madi with Amenemhat III, Neferuptah, and Amenemhat IV demonstrates her exceedingly close relationship to the pharaonic office during the late Twelfth Dynasty. Even with her evident position in the royal family, Hetepi's name is not written within a cartouche in the same manner to that of Neferuptah. While this aids in the theories that Neferuptah was exceptional among Twelfth Dynasty royal women and was the co-regent or intended heir of Amenemhat III, it means Hetepi did not have the 
same political status as Neferuptah who most likely died before Amenemhat IV became pharaoh. The depiction of a false beard on royal women is expected to be accompanying her pharaonic political status similar to that of other male rulers. Consequently, the feature found on Hetepi's face could be argued to not to be representing a beard because while the feature is present she did not carry pharaonic status.

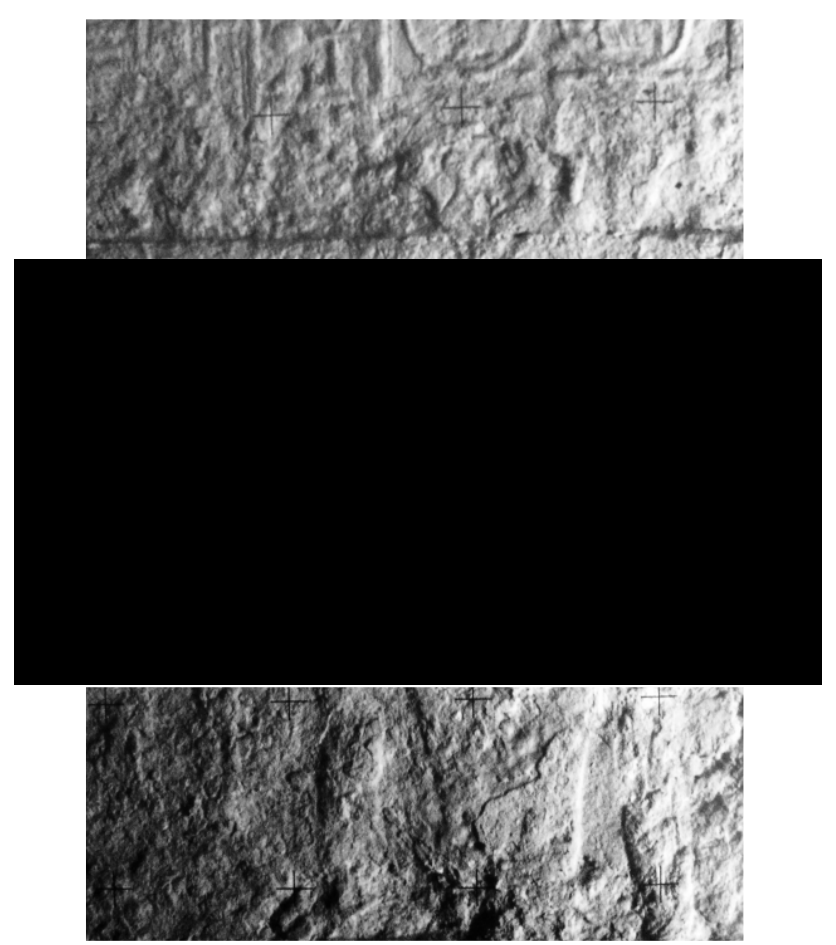

Fig. 4.21 Relief of Queen Hetepi and Amenemhat IV, Bresciani, E. and A Giammarusti 2012, 85.

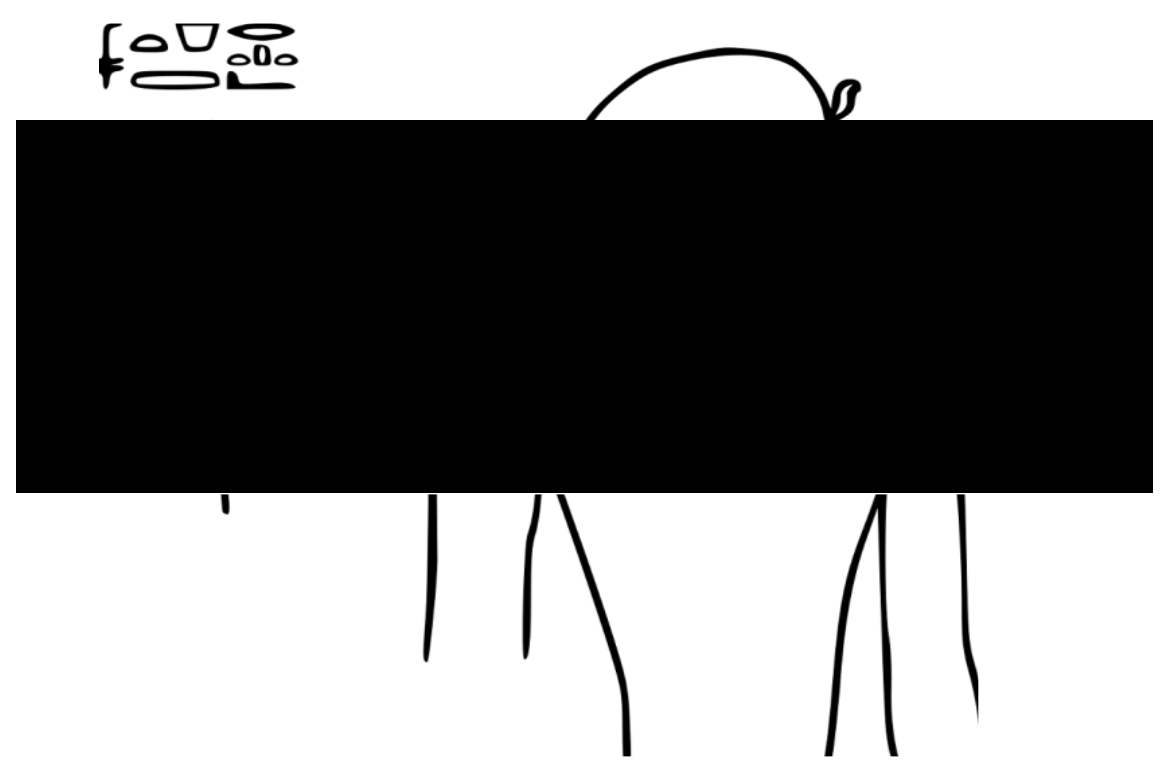

Fig. 4.22 Drawing of Hetepi and Amenemhat IV, illustration by Amber Furmage. 


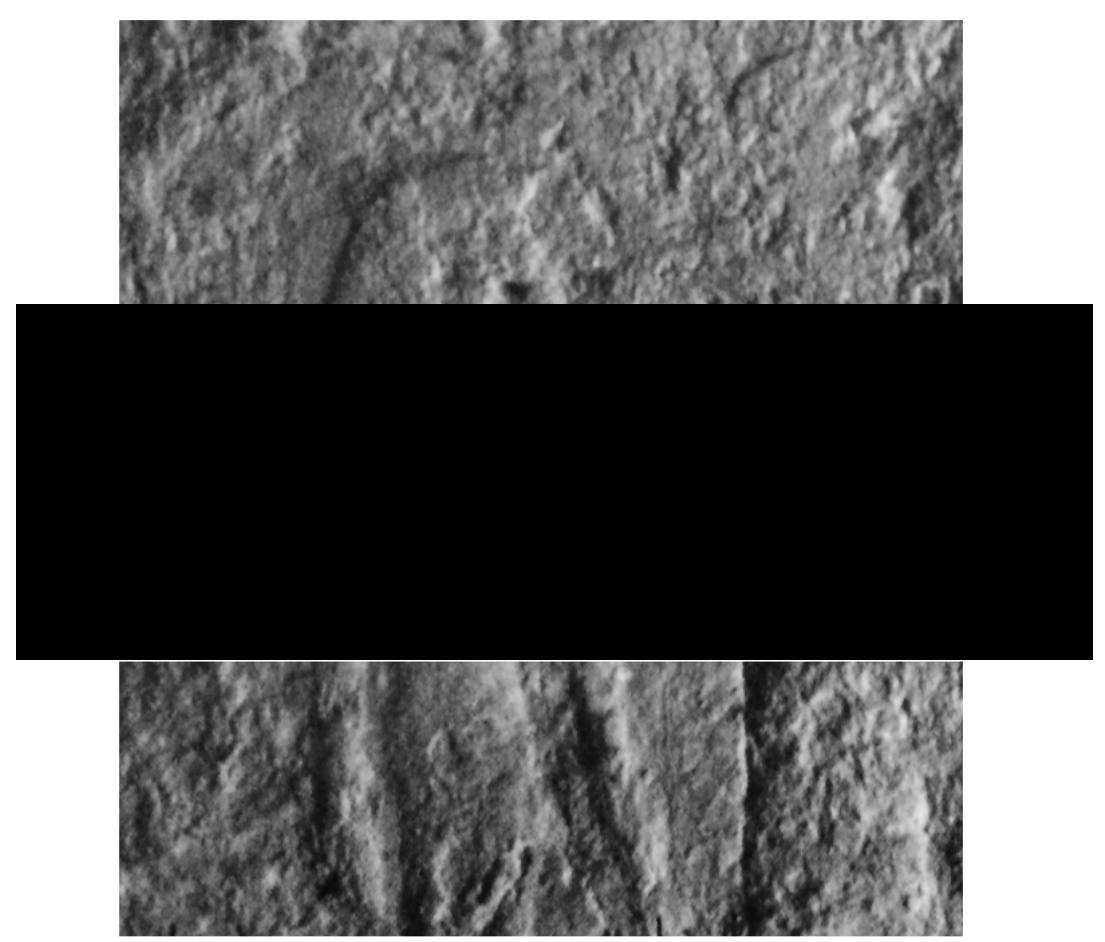

Fig. 4.23 Close up of original relief for Queen Hetepi, Bresciani, E. and A Giammarusti 2012, 85 .

The false beard is first seen on the regent or monarch Khentkaus I from the Fourth Dynasty (see below Chapter 4.13, Fig. 4.45). It is possibly depicted again on a royal female bust, with no surviving inscription, from the Sixth Dynasty (Fig. 4.46). Both Khentkaus I and the unknown royal woman are depicted with the vulture headdress and damaged false beards, whose descriptions are noticeably similar to that of Hetepi's at the Temple of Medinet Madi. Since the three women are royal mothers, with Khentkaus I and Hetepi additionally having certain political status, it can be suggested that false beards were a rare but an effective iconographic element when depicting royal mothers in politically inclined positions. Considering the political roles of royal mothers often merged into that of the pharaonic office, it is also possible that the beard was used as an aspect by artists to express the consolidation of the political roles of royal women.

\subsection{Overview of the iconography of Twelfth Dynasty royal men}

During the Twelfth Dynasty royal men and women shared many iconographic attributes. The royal women are seen in the same poses as royal men including seated, standing, sphinx, and kneeling. This includes one exception, there is only the 
female-headed human-falcon surviving from the Twelfth Dynasty representations. Royal men, especially Senwosret III and Amenemhat III, were also depicted with severe facial characteristics that varied in style. Their uraei includes different numbers of tail curves, and depending on the crown the tail could be absent. ${ }^{568}$ With the exceptions of such depictions as Osiride statues of Senwosret I (Fig. 4.29) and the priestly statues of Amenemhat III (Fig. 4.40, 4.41), the royal men were regularly depicted wearing the nemes-headdress with the shendyt-kilt and pendant. They could be shown wearing different types of headdresses, such as the white crown, nemes, or with particular wigs as seen on the priestly statues of Amenemhat III. Their ears were often prominent features being large to oversize and their eyes could be cosmetically treated or natural. Similar to royal women, the art of Twelfth Dynasty royal men shifted and expanded through the reigns and often certain features could be combined to create styles that relate to each pharaoh.

\subsubsection{Amenemhat I, Senwosret I, Amenemhat II, and Senwosret II}

There are several statues known and possibly dedicated to the first pharaoh of the Twelfth Dynasty, Amenemhat I. ${ }^{569}$ Two are now located in Cairo, the first statue 570 was usurped during the Nineteenth Dynasty, but the name of Amenemhat still survives. The second surviving Cairo statue (Fig. 4.24) depicts Amenemhat I independently seated, with a uraeus, nemes-headdress, and an "active alertness" facial expression. ${ }^{571} \mathrm{He}$ is seen with a slightly smiling mouth, fuller cheeks and cosmetically treated eyes. ${ }^{572}$ This style of representation is reminiscent of the late Eleventh Dynasty characteristics, as seen on the head attributed to Mentuhotep III (Fig. 4.25). These statues have been considered depictions of positivity and optimism for the time period. ${ }^{573} \mathrm{~A}$ heavily restored head attributed to Thutmosis III, now located in the Garstang Museum (Fig. 4.26) is possibly a New Kingdom reworking of a Middle Kingdom statue. The head has a full lower jaw with an upturned mouth and heavy cosmetic lines that resemble those of the late Eleventh and early Twelfth Dynasties. The ears, particularly the right helix, are of Twelfth Dynasty size and are noticeably different styles possibly due to the later reworking

\footnotetext{
${ }^{568}$ For Senwosret III and Amenemaht III uraei see Polz 1995: 241, Fig. 3.

${ }^{569}$ For further discussion see Berman 1985.

570 The Egyptian Museum Cairo 37470; Vandier 1958: PL. LVIII, 171.

571 The Egyptian Museum Cairo JE 60520; Arnold 1991: 30.

572 Aldred 1970: 35.

${ }^{573}$ Wiese 2015: 73; Wildung 1984a: 194.
} 
or refurbishment. It is known Middle Kingdom, especially Twelfth Dynasty sculptures were reused by later rulers in Lower Egypt and the Garstang royal head could be an example of this type of reuse for late Eleventh and early Twelfth Dynasties in Thebes.

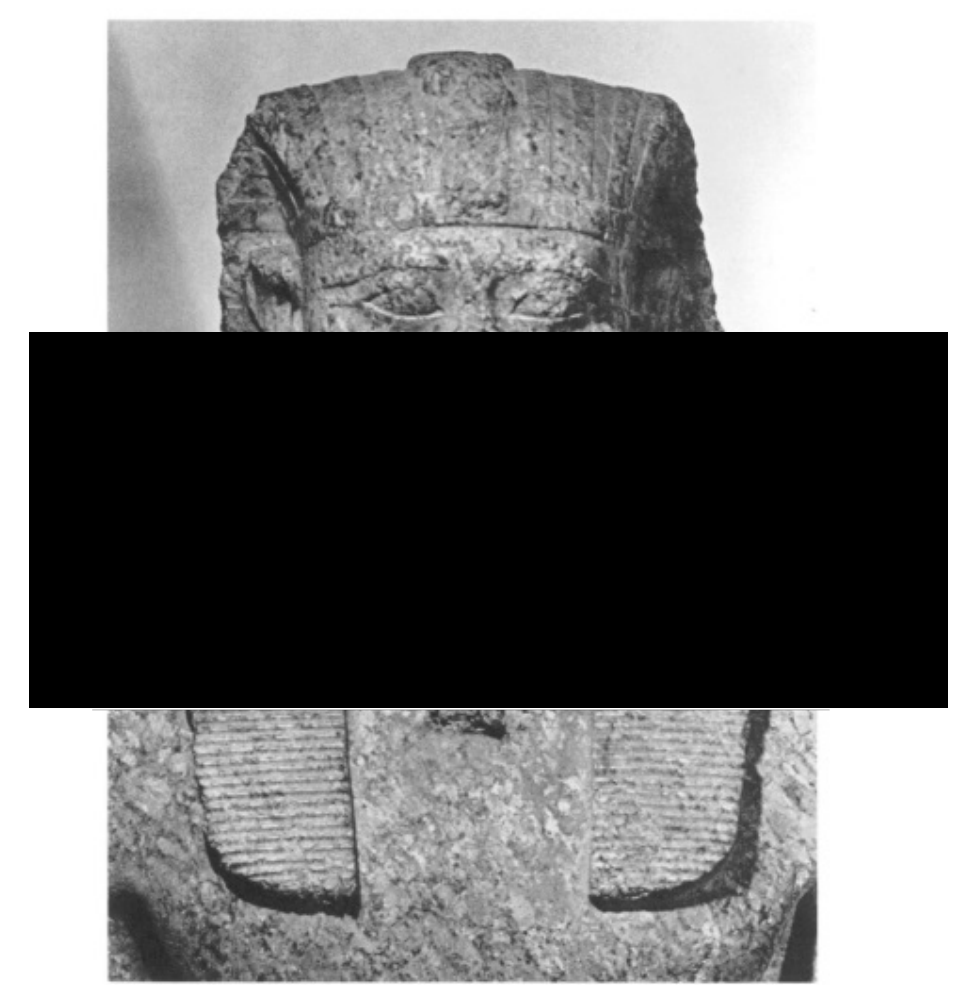

Fig. 4.24 Seated Statue of Amenemhat I, The Egyptian Museum Cairo 60520. 


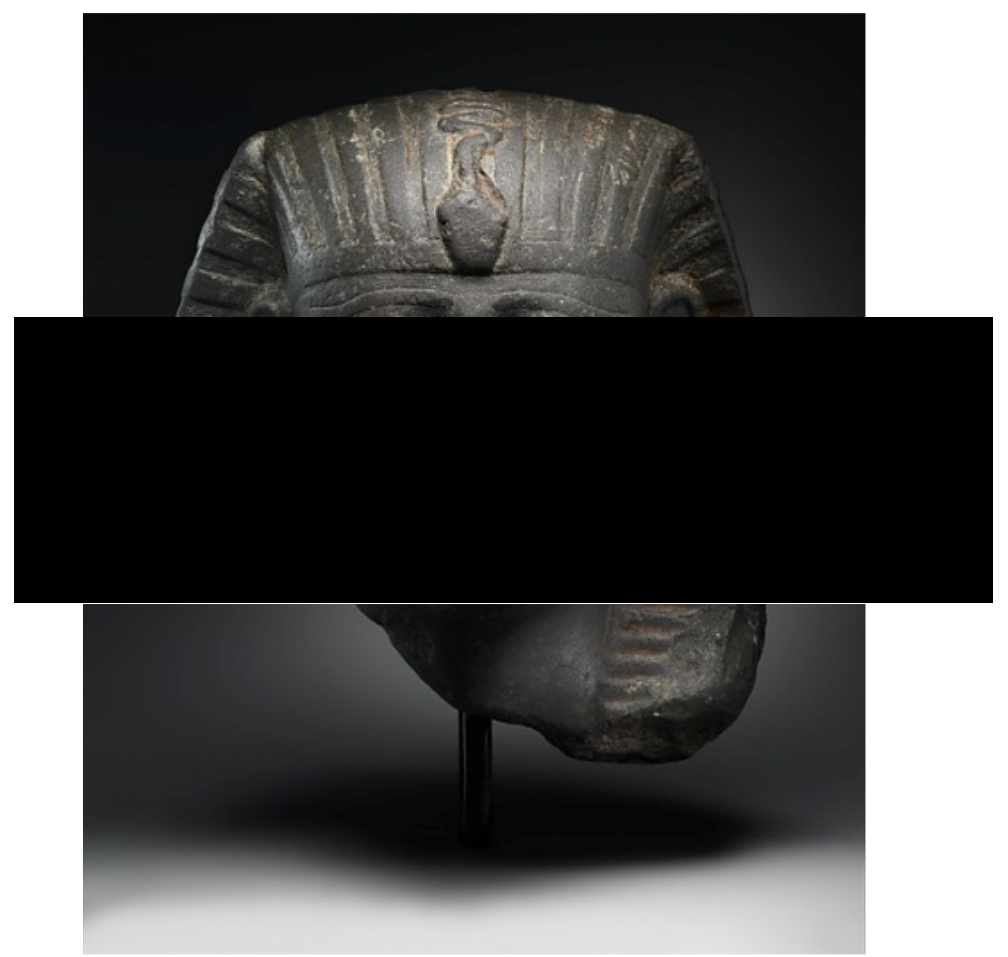

Fig. 4.25 Head of a statue of an early Middle Kingdom ruler attributed to Mentuhotep III, Antikenmuseum Basel und Sammlung Ludwig BSAe III 8397.

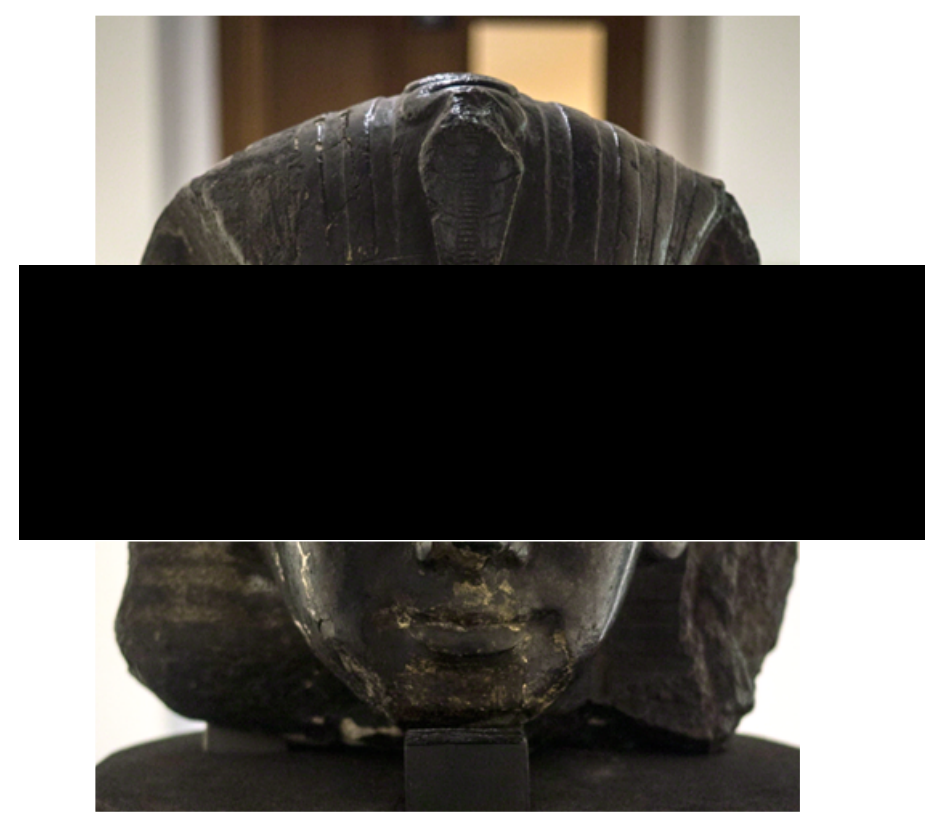

Fig. 4.26 Royal head, The Garstang Museum of Archaeology at the University of Liverpool E.2811.

This style of depicting the pharaoh's face with fuller cheeks and heavy cosmetic lines continued into the reign of his son Senwosret I, as seen on six statues now located in Cairo. ${ }^{574}$ There are at least seventy-three statues known or attributed to the forty-five year reign of Senwosret I. Through his surviving artwork a development of

574 The Egyptian Museum Cairo CG 411, 398, 38230, 384, JE 48851, 38286; Lorand 2011: Figs. 1, 2, 4, 6 7; Lorand 2012: Plates 10.1, 10.2, 11.1, 11.2; 13.1, 13.2. 
style can be seen. ${ }^{575}$ Vandier divided these different styles into 'four schools of art', including the Fayum School (Fig. 4.27), the Delta School (Fig. 4.28), the Memphite School (Fig. 4.29), and the Southern School (Fig. 4.30). ${ }^{576}$ Lorand notes Senwosret I's statues were produced in several 'schools', but there was also an artistic evolution happening during his reign. ${ }^{577}$ From the Fayum School, Senwosret I was depicted with shallow eyes and eyebrows along with a heavily modeled body. In contrast to the Fayum style, the Delta works included his facial features in very high relief with intense eyebrows and cosmetic lines. The Memphite School features prominent cheekbones, horizontal lips, and deep-set eyes ${ }^{578}$ as also seen on British Museum statue EA 44 (Fig. 4.1). The statues Berlin $1205^{579}$ and British Museum EA 44 show Senwosret I as more serious or $\operatorname{sad}^{580}$ and can be suggested to be precursors to the later styles of Senwosret III and Amenemhat III. Senwosret I's statue, British Museum EA 44, is the first representation of the pendant that is worn by the pharaohs of the rest of the Twelfth Dynasty. The representations surviving from the Southern School are the most similar in style with the Eleventh Dynasty (Fig. 4.30). Senwosret I is seen with upturned lips, slightly arched eyebrows with wide cosmetically treated eyes and a rounded face shape.

\footnotetext{
${ }^{575}$ Aldred 1969: 24-25; Hartwig 2015: 200; Lorand 2012: 49.

${ }^{576}$ Vandier 1958 with further discussion by Lorand 2012: 47-52, Plates 10.1-13.2; Aldred 1969: 25 notes there may have been at least two separate schools of sculpture, one working in the style of the Old Kingdom and a second using a more realistic style possibly located in the Delta.

577 Lorand 2012: 52.

${ }^{578}$ Lorand 2012: 48.

${ }^{579}$ Kneeling statue of Senwosret I, Ägyptiches Museen au Berlin 1205; Lorand 2012: Plate 12.1.

${ }^{580}$ Lorand 2012: 48.
} 


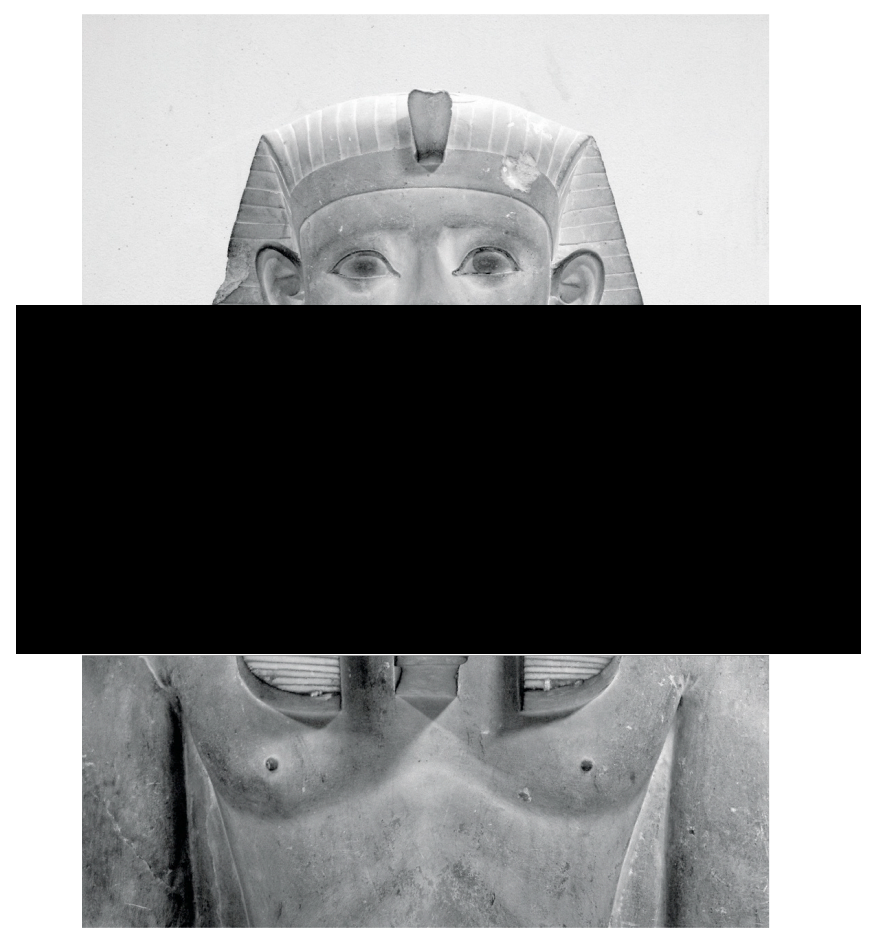

Fig. 4.27 Senwosret I, Fayum School, Egyptian Museum Cairo CG 411.

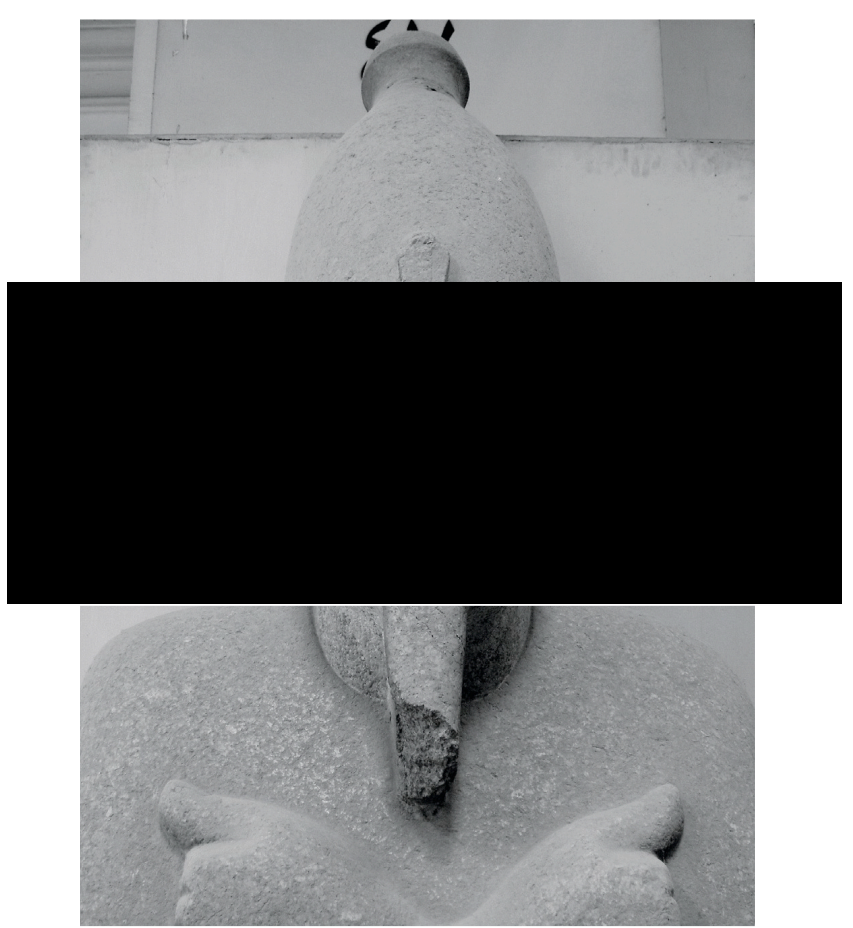

Fig. 4.28 Senwosret I, Delta School, Egyptian Museum Cairo CG 38230. 


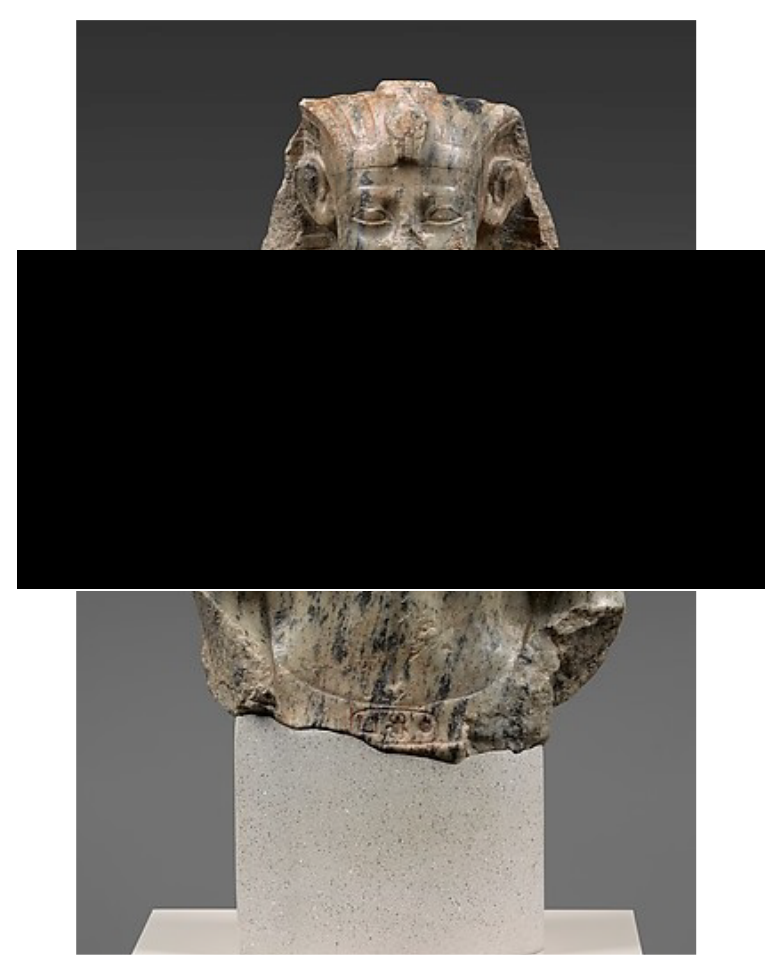

Fig. 4.29 Kneeling statue of Senwosret I, Memphite School, Staatliche Museen zu Berlin, Ägyptisches Museum und Papyrussammlung 1205.

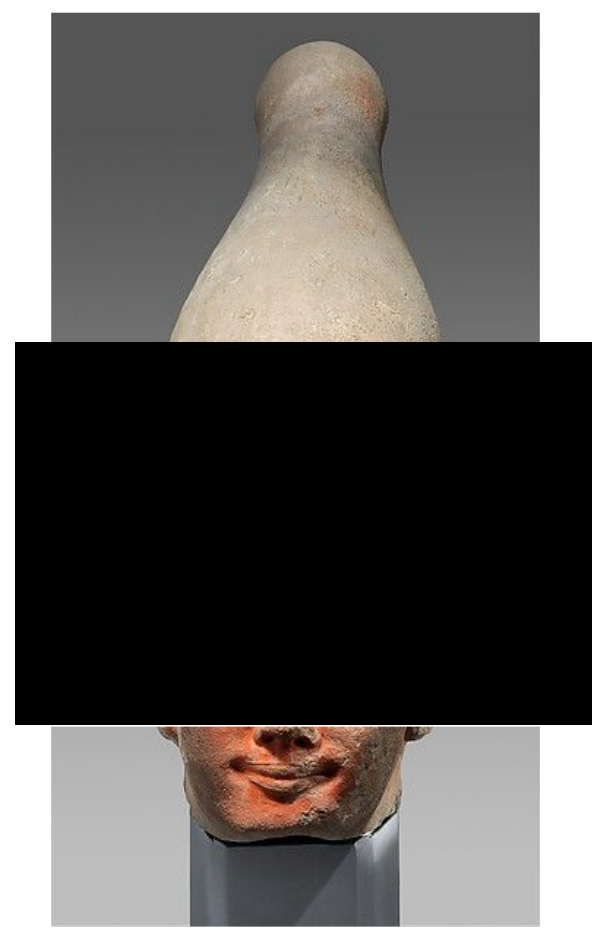

Fig. 4.30 Head of a colossal statue of Senwosret I, Southern School, Medelhavsmuseet, Stockholm MME 1972:017. 
A statue discovered in Sudan that is now located in Boston (Fig. 4.31) has been attributed by the museum to Amenemhat II. ${ }^{581}$ His facial features include lips that are thick and horizontal with emphasized nasolabial folds. He is seen with accentuated cheekbones with cosmetically treated eyes that are slightly lidded.

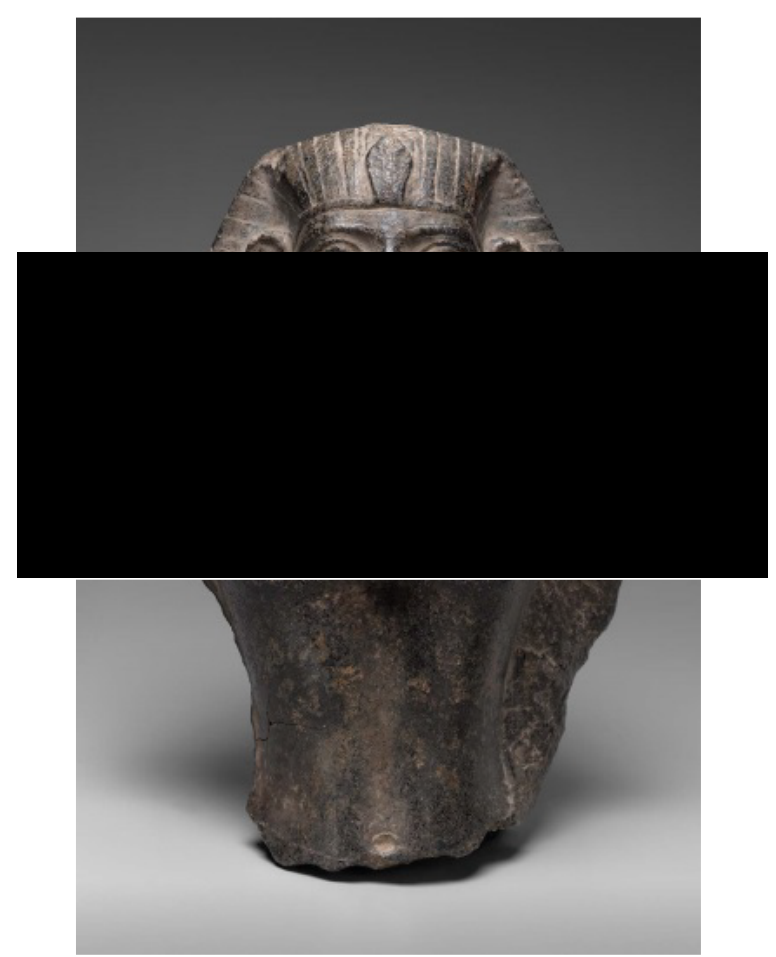

Fig. 4.31 Attributed statuette of Amenemhat II, Museum of Fine Arts Boston 29.1132.

Amenemhat II also has two colossal statues that were reused during the New Kingdom by both Ramses II and Merneptah of the Nineteen Dynasty. Named as the great sphinx of Tanis, the colossal sphinx once included the name of Amenemhat II and was later usurped by Merneptah of the Nineteenth Dynasty and Shoshenq I of the Twenty-Second Dynasty (Fig. 4.32) ${ }^{582}$ The second statue is currently located at the Metropolitan Museum of Art, on loan from the Staatliche Museen zu Berlin, Ägyptisches Museum und Papyrussammlung (7264), and sits at a colossal 3.2m (10ft6in) in height (Fig. 4.33). ${ }^{583}$

\footnotetext{
${ }^{581}$ For more details see the Museum of Fine Arts Boston online catalogue: "Statuette of Anenemhat II" https://www.mfa.org/collections/object/statuette-of-amenemhat-ii-146895.

${ }^{582}$ Arnold 2015b: Fig. 54; For more details see the Musée du Louvre online catalogue: "Great Sphin of Tanis" https://www.louvre.fr/en/oeuvre-notices/great-sphinx-tanis.

${ }^{583}$ Arnold 2015b: cat. 221; For more details see the Metropolitan Museum of Art online catalogue:

"Colossal Seated Statue of a Pharaoh" https://www.metmuseum.org/art/collection/search/590699.
} 


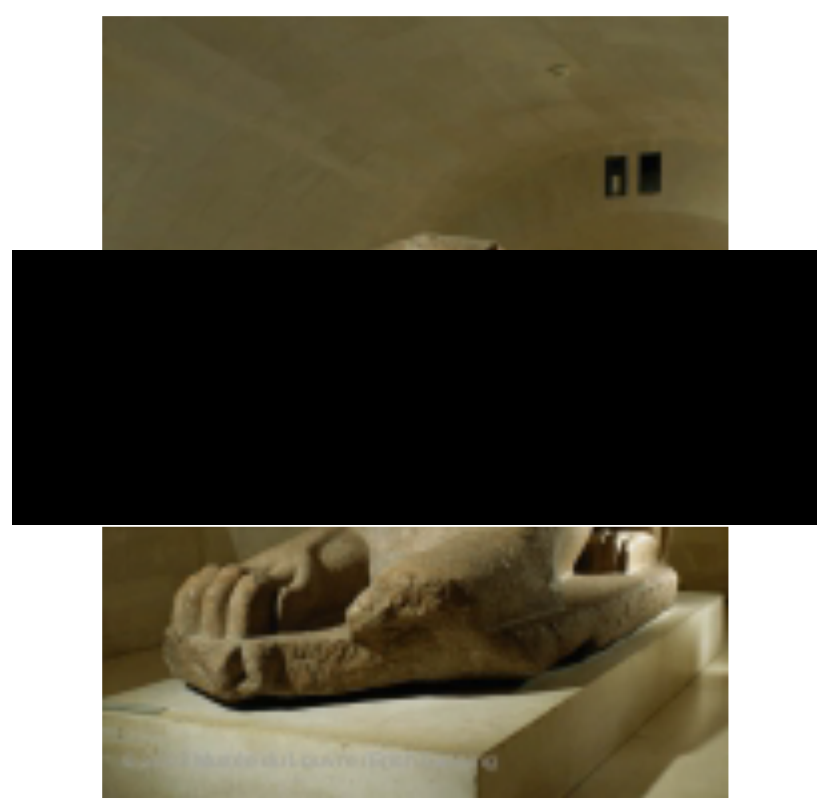

Fig. 4.32 Great Sphinx of Tanis, Musée du Louvre A 23.

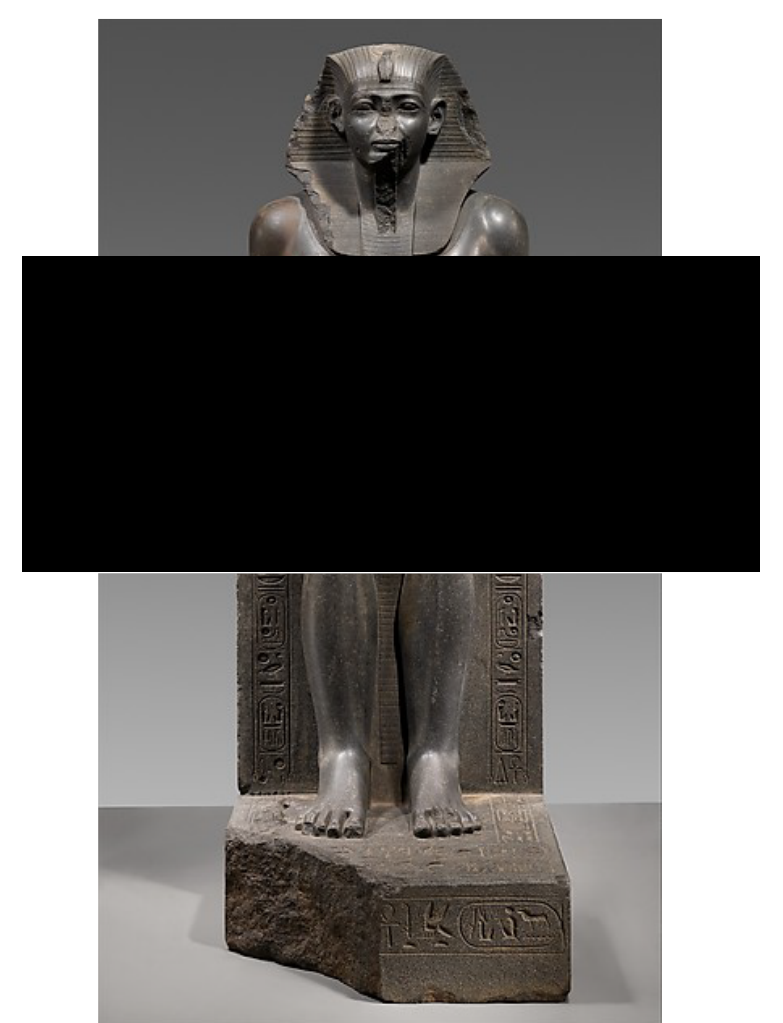

Fig. 4.33 Colossal seated statue of Amenemhat II, Metropolitan Museum of Art New York L.2011.42.

There are presently more statues of royal women (Cat. 2, 9, 15, 16, 18, 23) attributed to the reign of Senwosret II than statues of himself. A surviving bust that likely represents Senwosret II (Fig. 4.34) has similar features to the statuette assigned to Amenemhat II (Fig. 4.31). The bust is considered by Arnold as one of the masterpieces of art from the middle of the Twelfth Dynasty along with the colossal 
seated statue (Fig. 33) and the guadarin figure (MMA 14.3.14-20). ${ }^{584}$ The bust's features include naturalistic eyes that end in sharp points at the inner and outer corners. The eyebrows are naturally modeled and are not in high relief, as seen on Senwosret I, but are more similar to Senwosret III. The cheeks are broad and inwardly defined, emphasizing the space between the cheekbones and the bottom of the eyelids. The lips are horizontal but thinner than what is depicted on Amenemhat II. As noted by Arnold, the torso is expertly modeled with the ribcage pressed forward and the lower abdomen muscles deepened around the navel to depict the pharaoh as if he is breathing. ${ }^{585}$

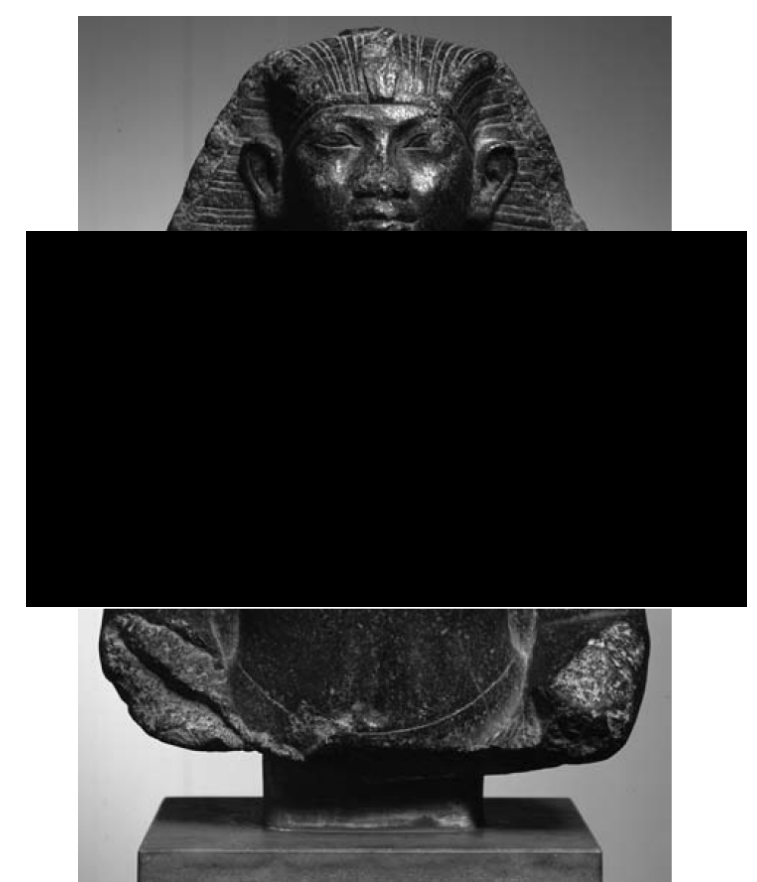

Fig. 4.34 Statue of Senwosret II, NY Carlsberg Glyptotek Copenhagen AEIN 659.

\subsubsection{Senwosret III, Amenemhat III, and Amenemhat IV}

From the surviving representations of the late Twelfth Dynasty male monarchs, there are nearly 200 statues attributed to and inscribed for Senwosret III and Amenemhat III. ${ }^{586}$ Their representations are mostly known because of their facial attributes. The severe facial characteristics (see Chapter 4.3) can be seen on the majority of their surviving artworks, giving the two kings distinct styles within the production of

\footnotetext{
${ }^{584}$ Arnold 2015b: 78.

${ }^{585}$ Arnold 2015b: 78

${ }^{586}$ For further reading, see Aldred 1970; Connor 2014; Connor 2016-2017; Connor and Delvaux 2017; Fay 1996; Freed 2014; Laboury 2016-2017; Polz 1995; Wegner 2007; Wildung 1984a.
} 
Twelfth Dynasty royal art. This was the first time in Egyptian art history that the ruler's face was depicted in a non-ideal style but with a static body type. It has been suggested that these new faces represented the pharaoh as disconsolate or showing their elderly age in which they can be seen as wise rulers. ${ }^{587}$

Senwosret III is arguably the most famous pharaoh with the severe facial characteristics, as seen in the British Museum statues (Fig. 4.2). ${ }^{588}$ His iconographic style is often considered a critical juncture in representing Twelfth Dynasty art and rulership. ${ }^{589}$ An evolution of the severe facial characteristics can be seen during the reign of Senwosret III, and this has caused statues to be placed within the earlier or later parts of his rule. This can be seen on the statue of Senwosret III as a young man, now located at the Musée du Louvre (Fig. 4.35). ${ }^{590}$ This style is followed by the more well-known and prominent features of Senwosret III, such as on the colossal head located in the Nelson-Atkins Museum of Art (Fig. 4.36) and on the sphinx statue from the Metropolitan Museum of Art (Fig. 4.37). Laboury notes on the stela from Senwosret III's Semna fortress now located in Berlin, ${ }^{591}$ Senwosret III states his statues power and for the sake of them fighting rather than old age. ${ }^{592}$

\footnotetext{
${ }^{587}$ Bourriau 1988: 37; Oppenheim 2015: 79; Schoske 2008: 188; For brief discussion on about "realistic" imagery of Senwosret III and Amenemhat III see Hartwig 2015: 200-201.

${ }^{588}$ Statue of Senwosret III, The British Museum, London EA 686.

${ }^{589}$ Freed 2002: 103; Freed 2014: 37-42.

${ }^{590}$ Laboury 2016-2017: 72-73.

${ }^{591}$ Stela from the fortress of Semna, Ägyptisches Museum und Papyrussammlung, Berlin ÄM 1157.

${ }^{592}$ Laboury 2016-2017: 83.
} 


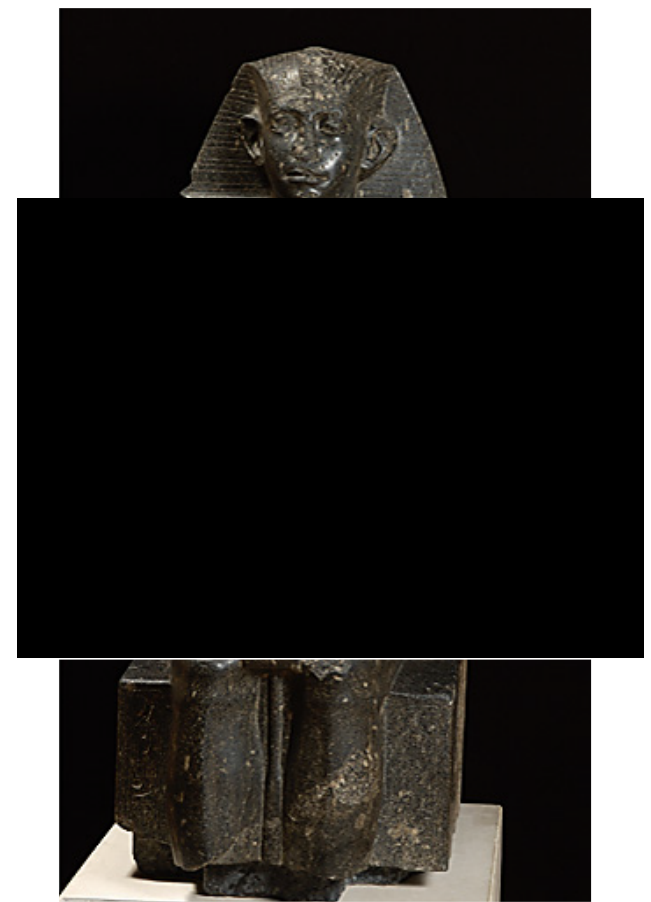

Fig. 4.35 Senwosret as a juvenile, the Musée du Louvre E12960.

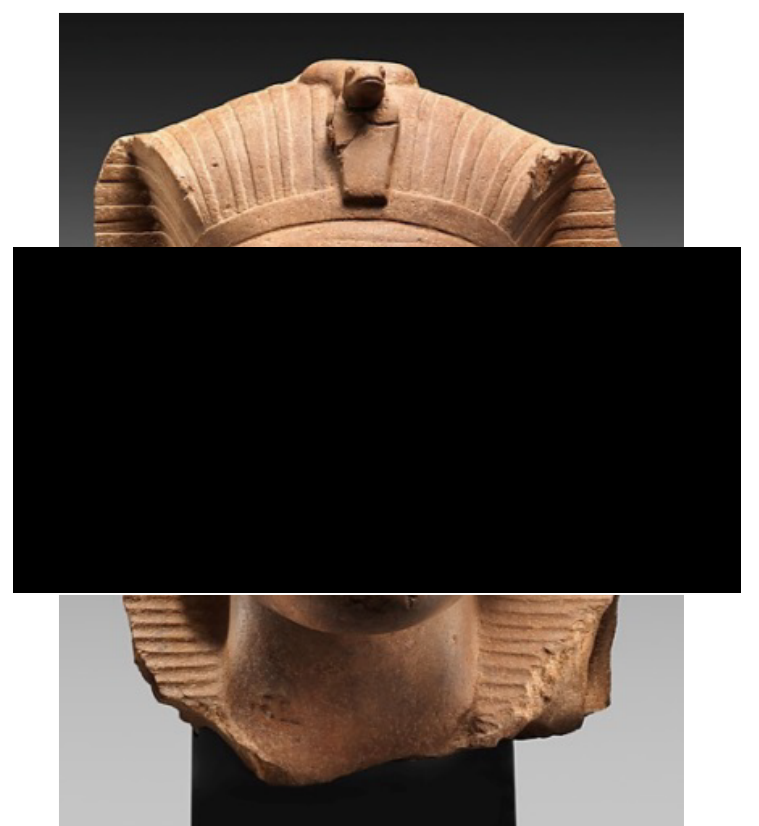

Fig. 4.36 Head of a colossal statue of Senwosret III, The Nelson-Atkins Museum of Art 62-1. 


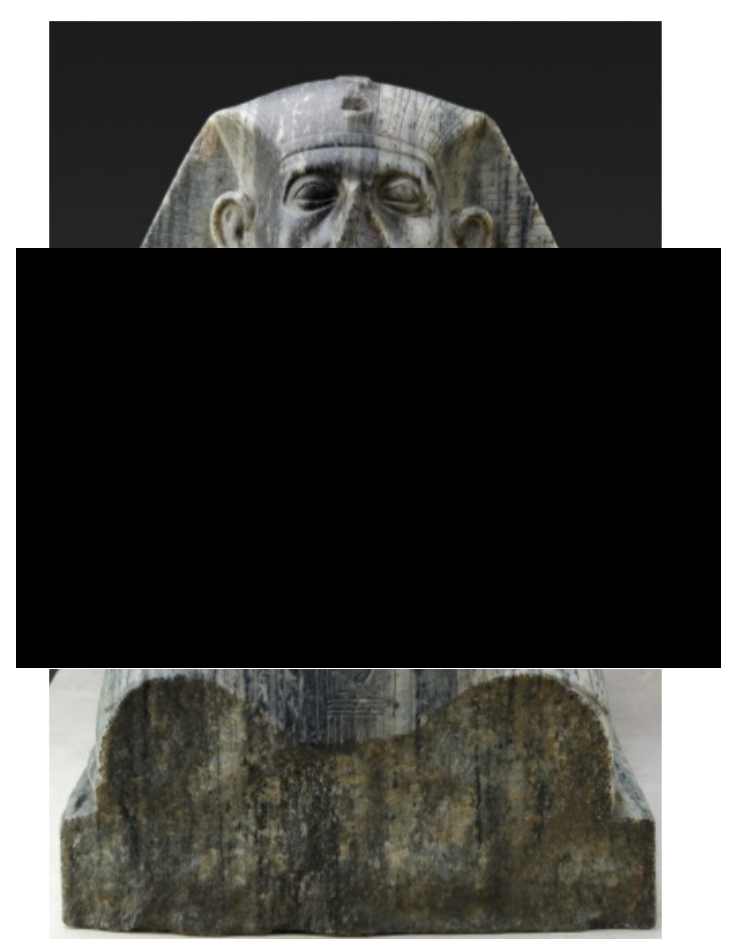

Fig. 4.37 Statue of Senwosret III as a sphinx, Metropolitan Museum of Art New York 17.9.2

Each surviving face is unique and Senwosret III and Amenemhat III are often shown with similar deep-set eyes, heavy eyebrows and lids, sharp cheekbones, deep cut nasio-labial folds, turned down mouths, and with oversized ears. The known faces of Senwosret III and Amenemhat III differ in style and include multiple variations, ${ }^{593}$ making attributions of un-inscribed statues difficult. For example, the bust of Amenemhat III now located in the Metropolitan Museum of Art New York (Fig. 4.38) has been attributed to the Amenemhat III but could reasonably be argued to depict his father Senwosret III. Each pharaoh could be depicted in any variation of the severe facial characteristics. For example, particular artworks show the style fluctuations inscribed statues can have, such as the seated statues of Senwosret III now at the Walters Art Museum, ${ }^{594}$ the Brooklyn Museum, ${ }^{595}$ and the devotional attitudes statues in the British Museum (Fig. 4.2).

\footnotetext{
${ }^{593}$ Polz 1995: 235, plates 48a-d, 50a-d; See also Laboury 2016-2017: 78, Fig. 2 Variations amoung statues of Senwosret III from the same series.

${ }^{594}$ Seated statue of Senwosret III, Walter's Art Gallery Baltimore 22.115; Steindorff 1940: 47.

${ }^{595}$ Senwosret III, Brooklyn Museum 52.1.
} 


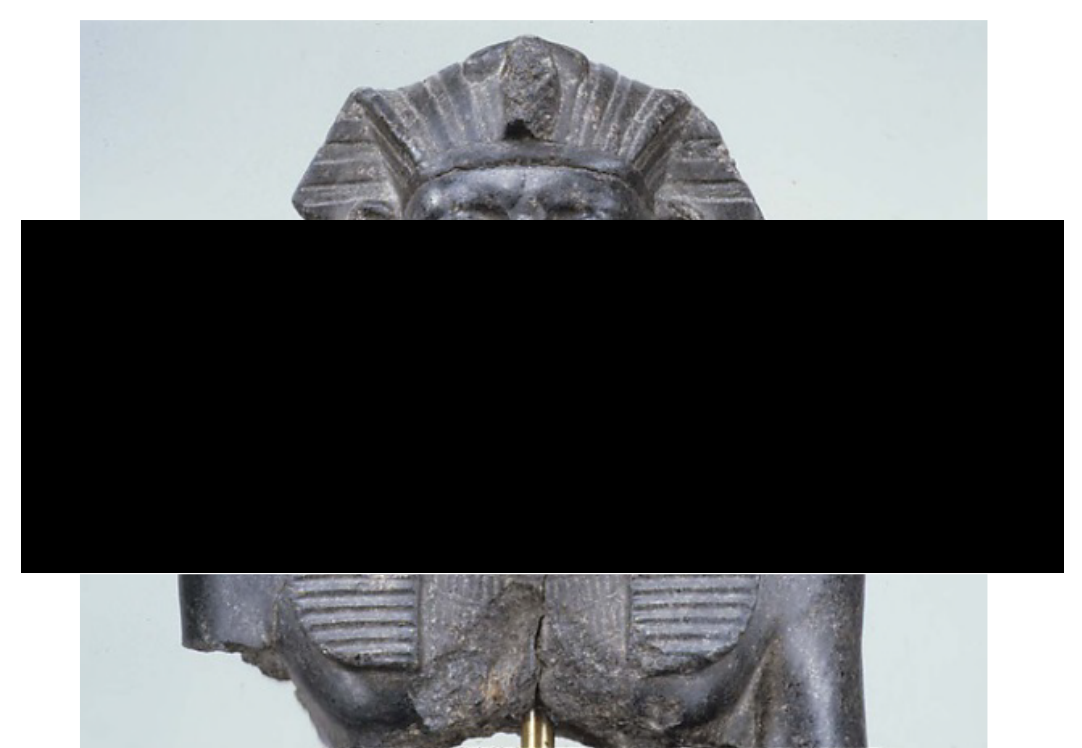

Fig. 4.38 Bust of Amenemhat III, The Metropolitan Museum of Art New York 45.2.6.

Emerging from the surviving artworks inscribed for or attributed to Amenemhat III, there is an obvious diverse style used for his statues (Figs. 4.38, 4.39, 4.40). Amenemhat III was often depicted with naturalistic eyebrows and eyes with the outer corners extending back into sharp points. He is usually represented with a welldefined Cupid's bow and a more upside down pentagonal face shape rather than a square face shape as seen on Senwosret III (Fig. 4.36). Lasting for more than fortysix years, Amenemhat III's reign is the longest of the dynasty and due to the diversity of his representations; his statues cannot be truly categorized into years of his rule, such as early, middle, or late. ${ }^{596}$ Alternately, Amenemhat III's artworks have often been categorized into facial types, such as realistic, idealized, stylized, and young, ${ }^{597}$ as well as traditional or innovative. ${ }^{598}$ Amenemhat III's timeless type of iconography can be seen from the statues now located in the Egyptian Museum in Cairo (Fig. 4.39) and the Fitzwilliam Museum (Fig. 4.40).

\footnotetext{
${ }^{596}$ Aldred 1969: 27; Laboury 2010: 6-7; Laboury 2016-2017: 77; Oppenheim 2015: 85; Polz 1995: 227-254; Russmann 1989: 62.

597 Polz 1995: 230.

${ }^{598}$ Freed 2002: 105, 108.
} 


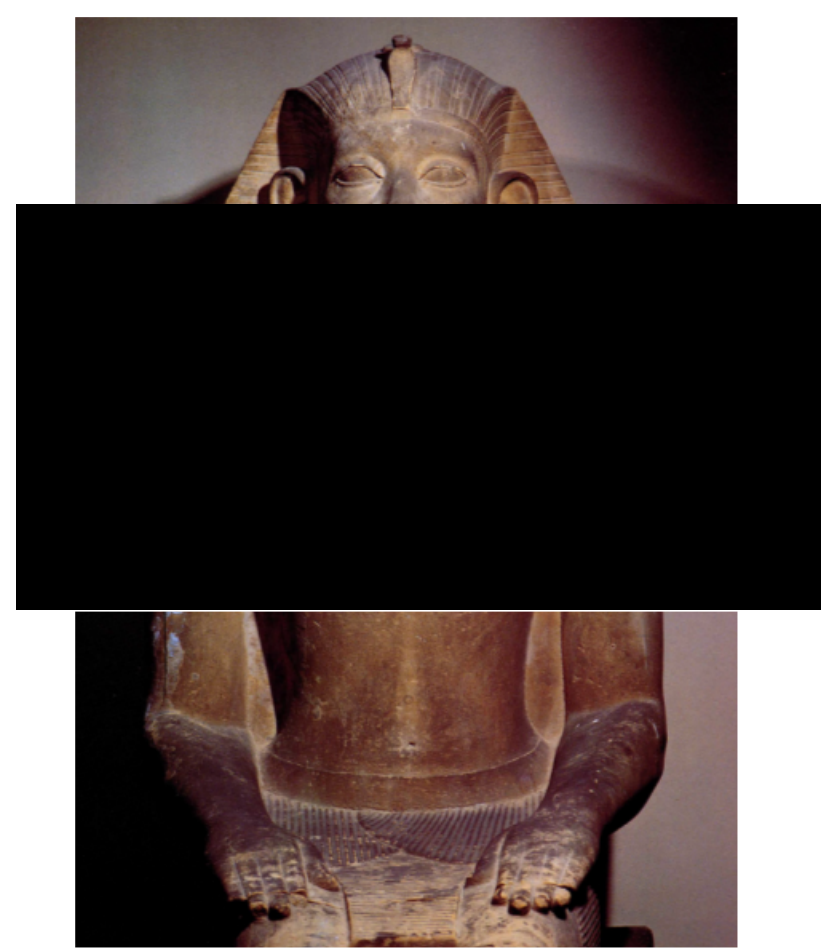

Fig. 4.39 Seated statue of Amenemhat III, Egyptian Museum Cairo CG 385.

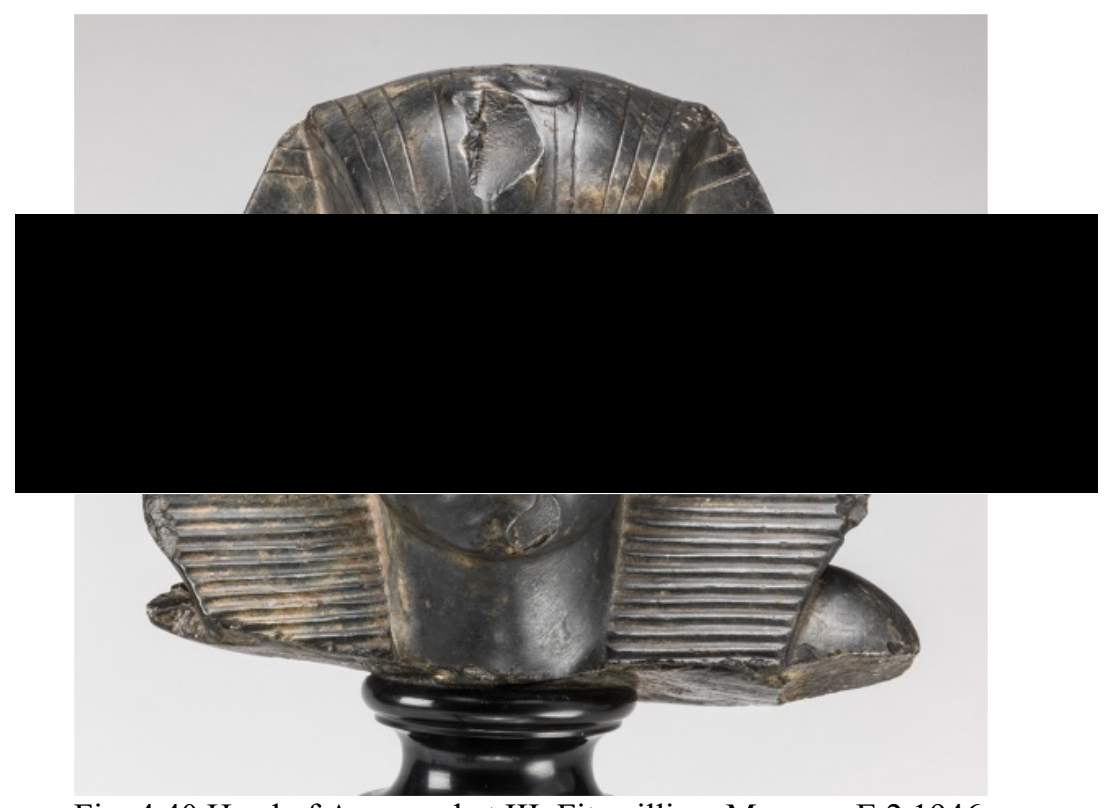

Fig. 4.40 Head of Amenemhat III, Fitzwilliam Museum E.2.1946.

Amenemhat III's surviving artworks and their features are unparalleled from the time period. As a reigning male monarch, he was the first to be depicted with both hands laid flat on this lap, as seen in the Cairo statue (Fig. 4.39) and was also the first to fully represent himself as the high priest of the gods both now located in Cairo (Figs. 4.41, 4.42). The statues of Amenemhat III as priest are unique to Egyptian art history and represent multiple iconographic firsts for a pharaoh. These include the leopard skin attire, the menat necklace, the wig and beard styles, along 
with the falcon headed standards. The dyads themselves and another statue of Amenemhat III with two goddesses holding fish are unique to his reign. ${ }^{599}$ Amenemhat III also commissioned the Biahmu colossi in the Fayum, which were the largest statues in Egypt at the time they were built. ${ }^{600}$

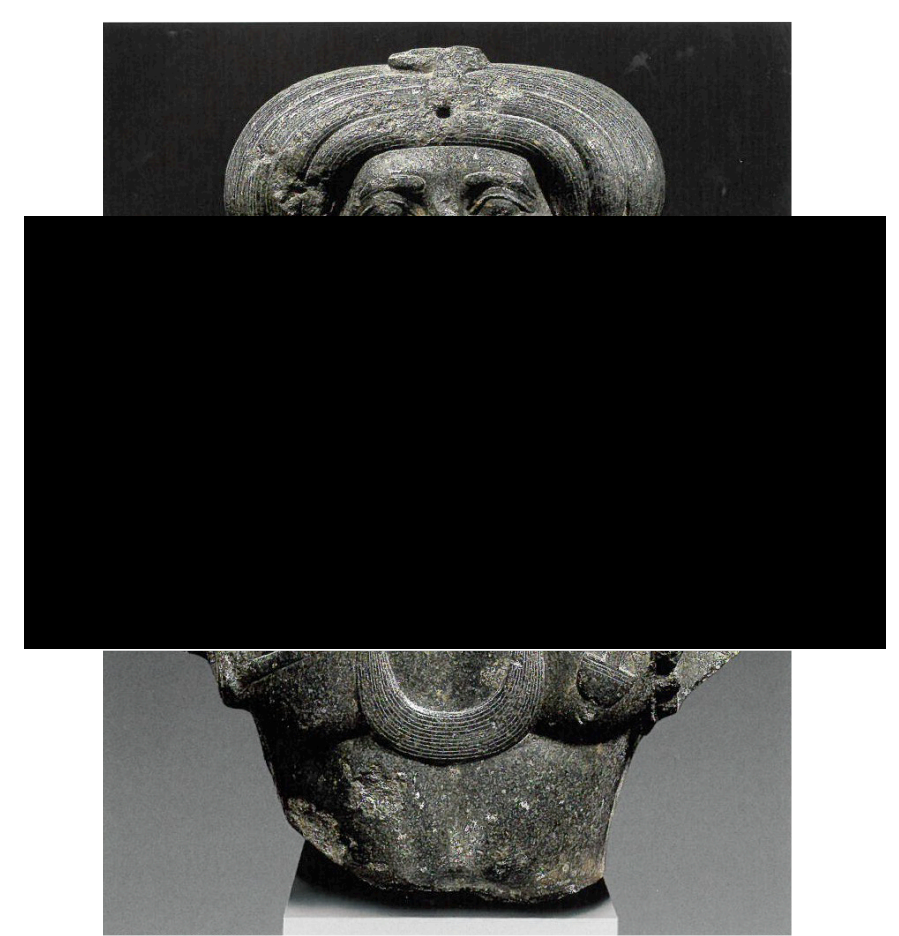

Fig. 4.41 Statue of Amenemhat III as Priest, The Egyptian Museum Cairo JE20001.

${ }^{599}$ Freed 2002: 114-118.

${ }^{600}$ Arnold 2015a: 15-16; Freed 2002: 110-1110; Hartwig 2015: 201; Petrie 1889: 54-55, pl. 26. 

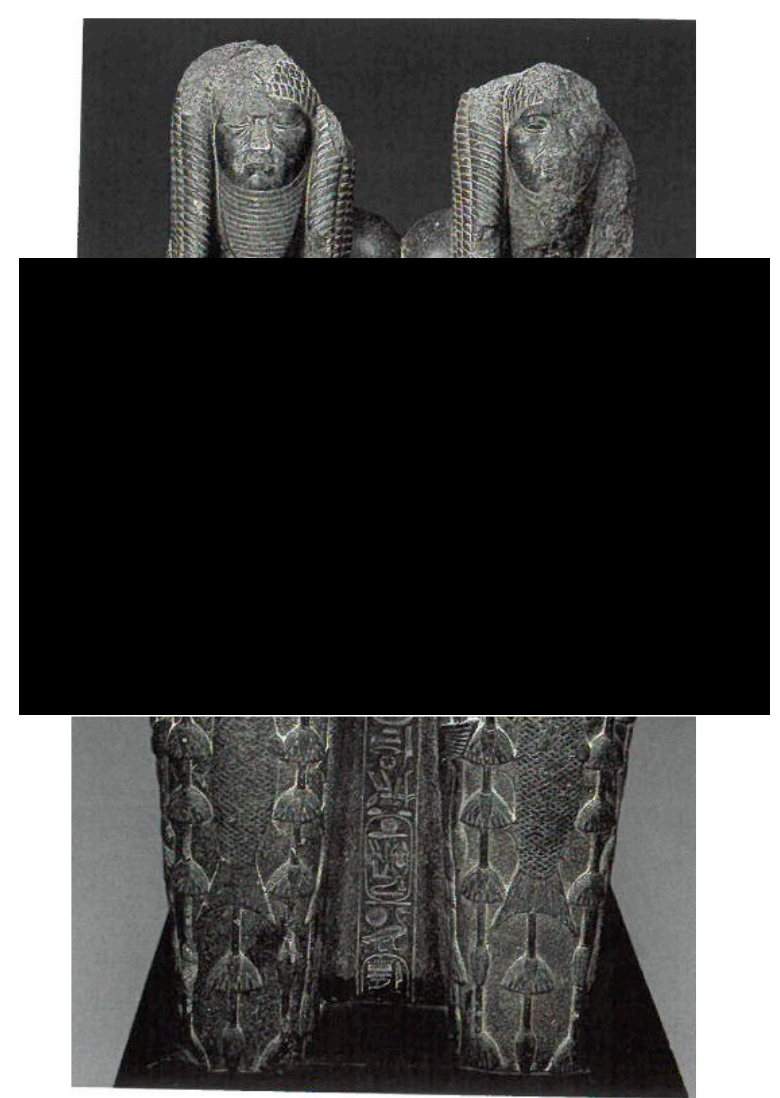

Fig. 4.42 Dyad statue of Amenemhat III, Egyptian Museum Cairo CG 392.

A sphinx statue, presently located at the British Museum EA 58892 was reworked in Ptolemaic times and is currently the only surviving example inscribed for Amenemhat IV (Fig. 4.43). ${ }^{601}$ There is also a small head located in the Metropolitan Museum 08.200.2, ${ }^{602}$ which the museum has attributed to his reign based upon the possibility it may be the head of a statue that would have been placed inside a shrine near the pyramid of Amenemhat I. ${ }^{603}$ The head is depicted with well-defined eyes, natural rounded eyebrows, and pronounced nasolabial folds (Fig. 4.44). Amenemhat IV is securely shown along with his mother Hetepi at the Temple of Medinet Madi (Fig. 4.21), although with no distinctive facial features, which was usual for Twelfth Dynasty reliefs.

${ }^{601}$ Sphinx of Amenemhat IV, British Museum London EA 58892; Strudwick 2006: 98-99.

${ }^{602}$ Published as head of Senwosret III in Aldred 1970: 41 and as Amenemhat III in Wildung 1984a: 208.

${ }^{603}$ For more details see the Metropolitan Museum of Art online catalogue: "Head of a King, possibly Amenemhat IV" https://www.metmuseum.org/art/collection/search/544177. 


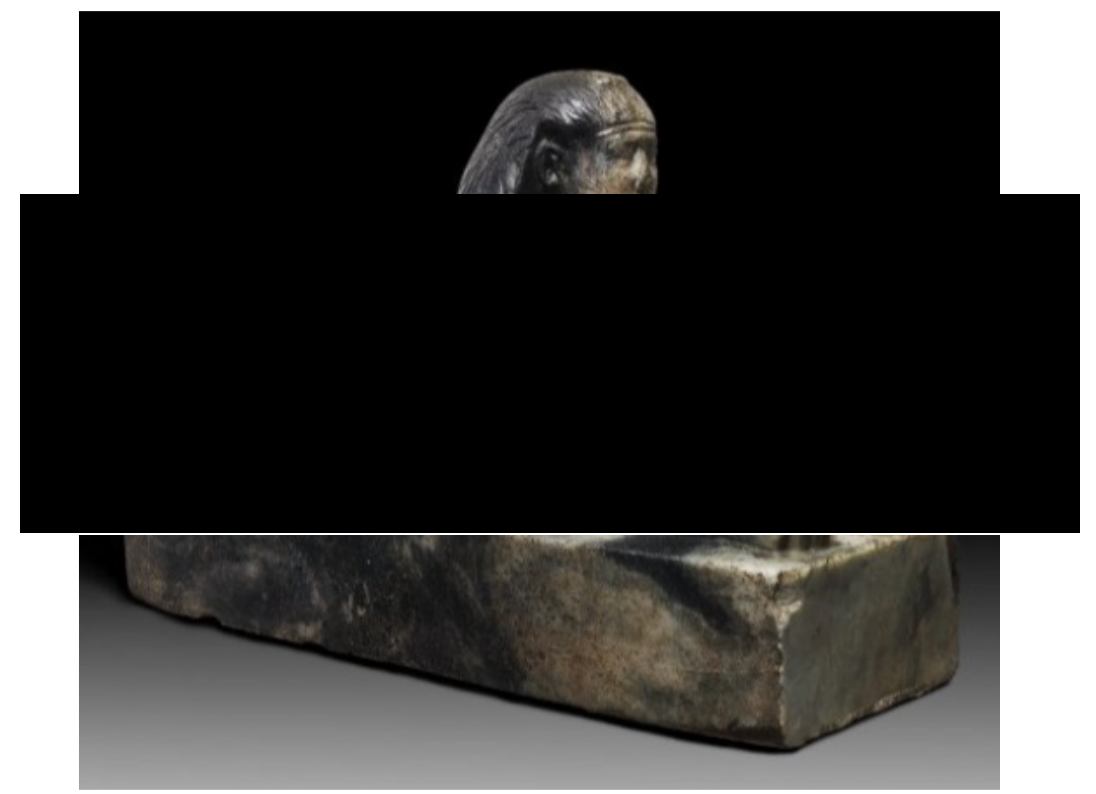

Fig. 4.43 Sphinx of Amenemhat IV, British Museum London EA 58892.

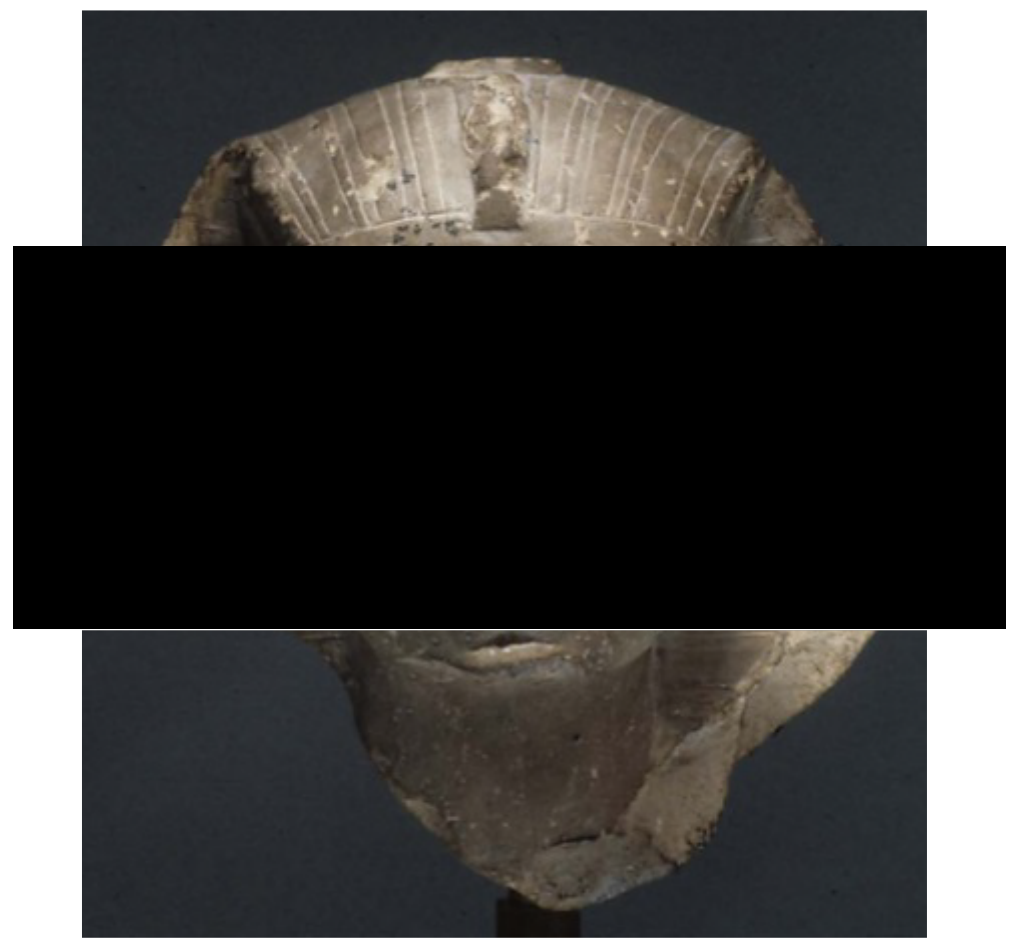

Fig. 4.44 Head of a king, possibly Amenemhat IV, Metropolitan Museum of Art New York 08.200.2. 


\subsection{The iconography of Twelfth Dynasty royal women compared to royal women of the Old Kingdom, Middle Kingdom, and early New Kingdom}

\subsubsection{Old Kingdom through the Eleventh Dynasty}

An artistic shift from the Old Kingdom to the Twelfth Dynasty can be seen in most of the surviving representations of royal women. These noticeable shifts of iconographic attributes are important for the Twelfth Dynasty royal women because they happened along with their changes in governmental positions. From the Old and Middle Kingdoms there are more surviving images of royal men than royal women, but in the late Twelfth Dynasty royal women were represented in the same style as the pharaohs more often than Old Kingdom royal women. For example, certain royal attributes become frequent only in the Twelfth Dynasty such as uraei, independently seated figures, sphinxes, and severe facial characteristics. Although Twelfth Dynasty royal women are the first Egyptian women to be regularly represented with politically associated features, such as the sphinx pose and uraei, it is during the Old Kingdom that some permanent iconographic motifs were introduced. The first representation of a queen wearing the vulture headdress is seen on the head of a queen (Fig. 4.45) attributed to Khamerernebty I, the mother of Khafre from the Fourth Dynasty. As previously mentioned, Khamerernebty I (Fig. 4.16) was also the first royal woman depicted wearing a uraeus.

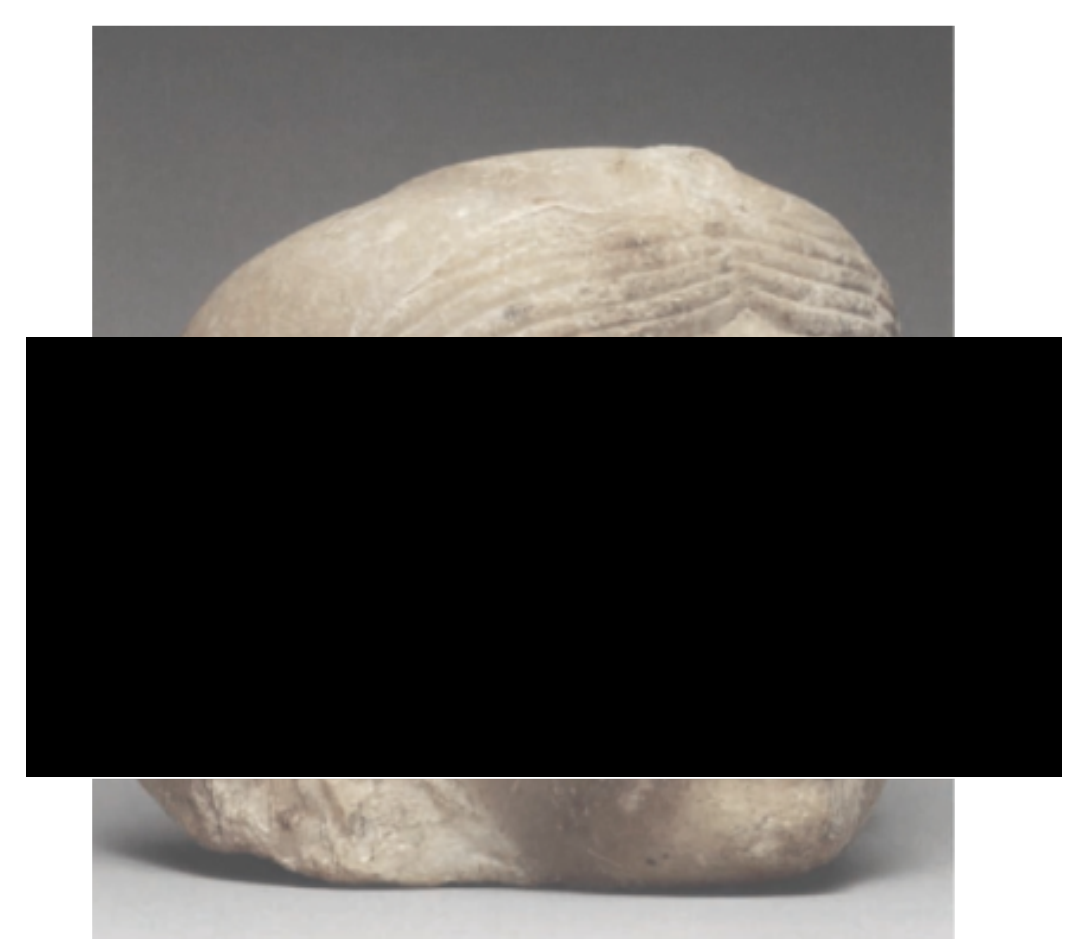

Fig. 4.45 Head of possible queen with vulture crown, Ägyptisches Museum, Universität Leipzig 1965. 
Dated to the end of the Fourth Dynasty and into the beginning of the Fifth Dynasty are the first images of a royal woman wearing pharaonic type regalia such as the royal beard, uraeus, and scepter. Khentkaus I (see Chapter 3.5.2) is also the earliest royal woman to be seen wearing the combination of a vulture headdress with a short beard and holding a small scepter (Fig. 4.46). Through the Fifth Dynasty and by the beginning of the Sixth Dynasty, the vulture headdress had become standardized in the iconography of royal women. ${ }^{604}$ The vulture headdress is seen on different women during this time, ${ }^{605}$ but numerous representations like this are not repeated until the New Kingdom. Other examples, such as seen on Queen Neith ${ }^{606}$ from the late Sixth Dynasty, show the combination of the vulture headdress and uraeus. It has also been suggested that Ankhnesmeyre II wears this headdress combination ${ }^{607}$ on the dyad statue with her son Pepy II. From the Twelfth Dynasty there is three securely dated images of the vulture headdress being worn by queens Hetepi (Cat. 56), Aat (Cat. 54), and Khenemetneferhedjet I (Cat. 53). There is possibly a fourth or fifth but both heads of unknown royal women (Cat. 25, 26) are heavily damaged.

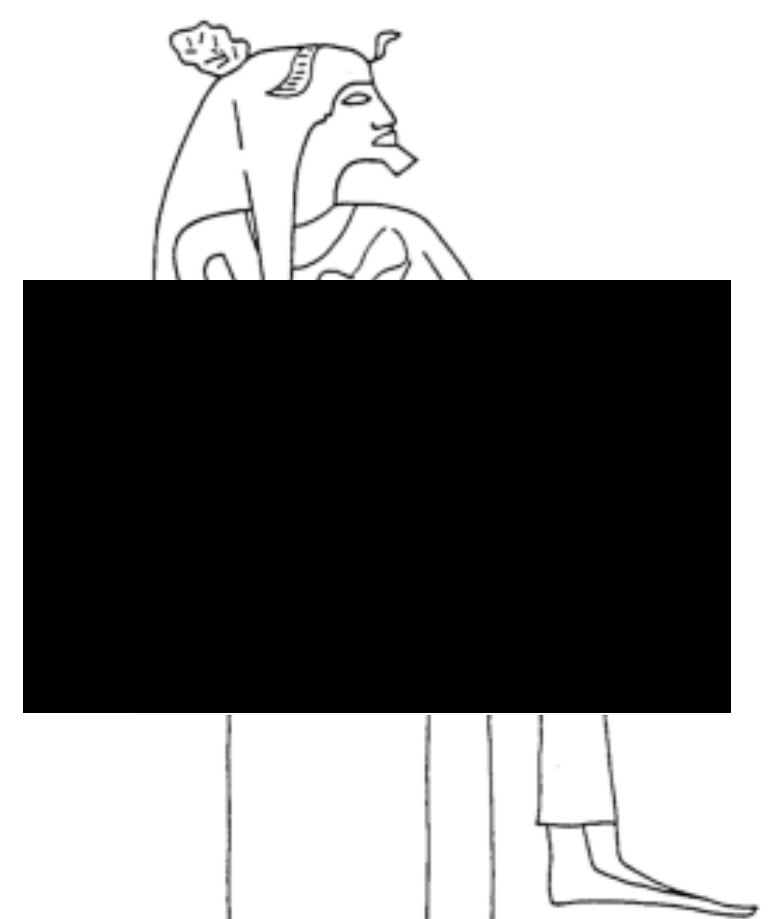

Fig. 4.46 Drawing of Khentkaus I on the southern doorjamb of the granite gate, Verner 2001: fig 85a.

\footnotetext{
${ }^{604}$ Queen Iput in vulture cap stands opposite a goddess, Callender 2011a: 227; Queen Ankhnesmeyre II in a boat with a tiny female figure, Callender 2011a: 261; Pair statue of Ankhnesmeyre II and her son Pepy II, The Brooklyn Museum 39.119; Roehrig 1999: 437-439.

${ }^{605}$ Khamerernebty I; Khentkaus I; Khentkaus II; Iput; Ankhnesmeyre II; Neith.

${ }^{606}$ Block containing the name and head of Queen Neith from her temple, Callender 2011a: 273.

607 Troy 1986: 120.
} 
Stylistically attributed and said to have been found in a Sixth Dynasty tomb, a bust of a queen mother has no surviving inscription and is now located in the Egyptian Museum, Cairo (Fig. 4.47). The bust is adorned with a vulture headdress, suggesting she may have been the mother of a pharaoh, ${ }^{608}$ and possibly the first sculpture of a royal woman wearing a mustache. ${ }^{609}$ Additionally, there are possible traces of a false beard that can be seen on the bust's proper left side. While this statue is not discussed as often as others from the Sixth Dynasty, it could represent a female wearing the appropriate pharaonic regalia similar to Khentkaus I and later Sobekneferu of the Twelfth Dynasty. There are no surviving examples of Sobekneferu having a mustache or false beard, but from previous iconographic descriptions facial hair was not a requirement for the iconography of Twelfth Dynasty female or male monarchs (see above Chapter 4.11). ${ }^{610}$

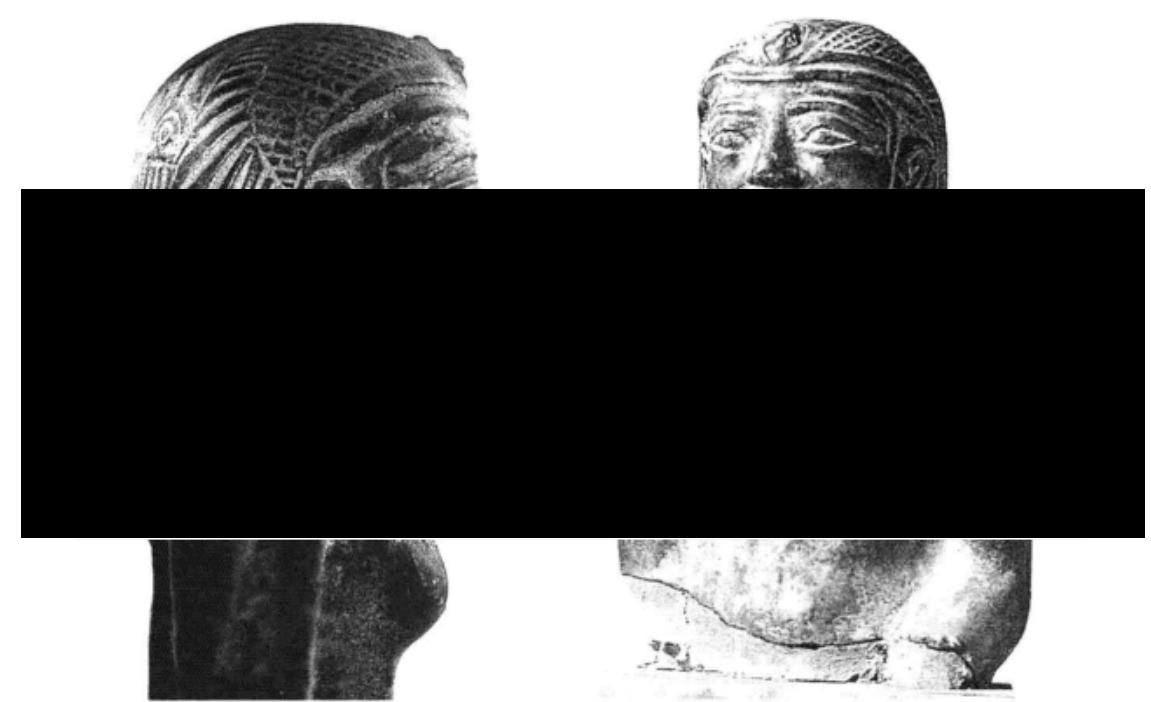

Fig. 4.47 Bust of the mother of a pharaoh, The Egyptian Museum Cairo CG 255.

There is only one known representation of a royal woman from the First Intermediate Period, showing Princess Nebet independently seated while holding a papyrus flower (Fig. 4.48). The original false door is heavily damaged, and the only

\footnotetext{
${ }^{608}$ Fay 1999: 129.

${ }^{609}$ Fay 1999: 102-103.

${ }^{610}$ Sample of Twelfth Dynasty royal statues: Seated statue of Senwosret II, The Egyptian Museum Cairo 432; Young Senwosret III, Musée du Louvre E.12960; Senwosret III, Musée du Louvre E.12961; Senwosret III: Brooklyn Museum 52.1; Seated statue of Amenemhat III, The Egyptian Museum Cairo 385; Egyptian limestone statue of Amenemhat III, The Fitzwilliam Museum E.2.1946; Statuette of Amenemhat III, Musée du Louvre N464; Head of a king, possibly Amenemhat IV, The Metropolitan Museum of Art 08.200.2.
} 
remaining image is a drawing by Habachi. ${ }^{611}$ Although the drawing is not detailed, Nebet's iconography seems similar to the Twelfth Dynasty relief of Neferuptah (Cat. 55). Both princesses wear sheath dresses, broad collars, and headbands. Unlike the Sixth and Twelfth Dynasties, Princess Nebet of the Eighth Dynasty along with the royal women of the Eleventh Dynasty are not represented with royal insignia such as uraei or vulture headdresses. The majority of the images of Eleventh Dynasty royal women are from the finds at Mentuhotep II's Theban mortuary complex. ${ }^{612}$ None of the women wear royal insignia and their iconography seems to be purposely stylized differently from the Sixth Dynasty.

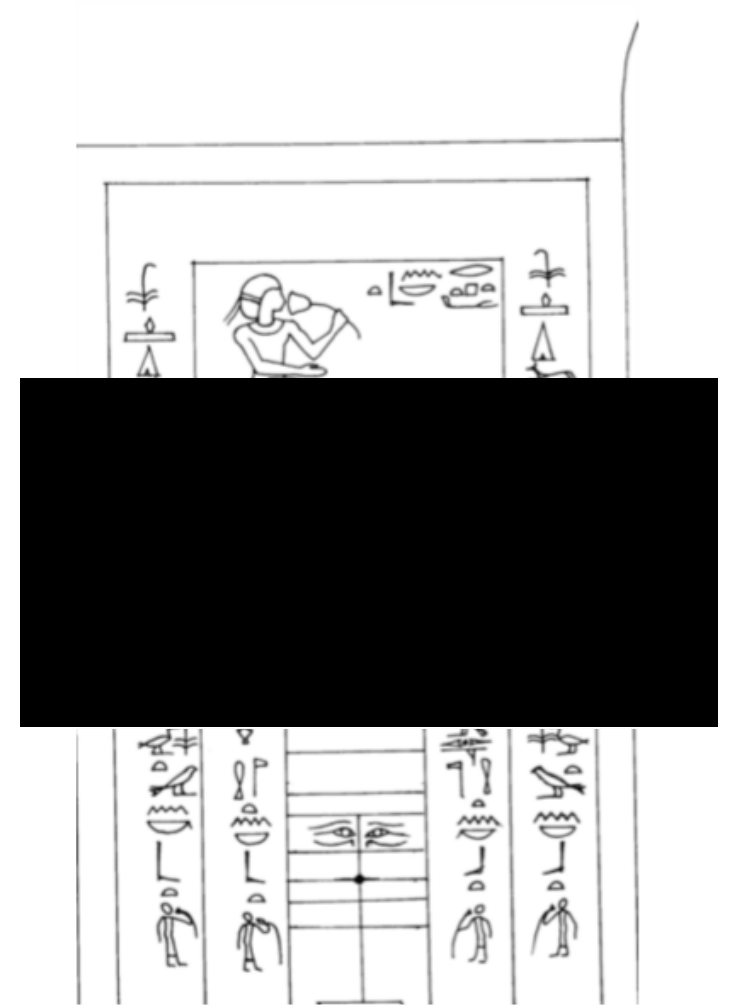

Fig. 4.48 Drawing of the false door of Princess Nebet, present location unknown.

During Amenemhat I's reign at the beginning of the Twelfth Dynasty ${ }^{613}$ a new style of sculpture that was based on Old Kingdom forms was developing. From the Eleventh to the Twelfth Dynasty there was a complete change in the iconography of royal women. The Twelfth Dynasty style seems to continue and build upon that of the Old Kingdom, excluding the Eleventh Dynasty characteristics. Separating themselves from the Fourth through the Eleventh Dynasties, royal women of the

\footnotetext{
${ }^{611}$ Habachi 1983: 208-211.

612 See Arnold 1979.

${ }^{613}$ Arnold and Jánosi 2015: 54.
} 
Twelfth commonly shared politically associated attributes with reigning pharaohs, such as uraei, facial characteristics, and the sphinx pose. This equality of iconography continued to evolve and includes the complete pharaonic regalia of Sobekneferu.

\subsubsection{Thirteenth Dynasty through the Eighteenth Dynasty, ending with Hatshepsut}

Beginning with the Fourth Dynasty, during the reign of Sneferu, the swty feathers were first connected with the pharaonic office ${ }^{614}$ Eight dynasties later during the reign of Senwosret II, the diadem type crown of Princess Sithathoryunit ${ }^{615}$ is the first association of a royal woman with the double feathers. As a meaning of feminine duality, the feathers were often joined with the duality of the cobras from Lower Egypt, the duality of Atum's children Shu and Tefnut, ${ }^{616}$ and with the two horizons in which the renewal of the sun happened. ${ }^{617}$ The šwty feathers are an important example of the equality among iconography that began in the late Middle Kingdom. The šwty feathers were a reference to the iconography of the rulership ${ }^{618}$ and are similar to other characteristics, such as uraei, facial features, and the sphinx pose that displayed the political presence of the royal woman. During the Thirteenth Dynasty, the swty feather crown became standardized in the iconography of royal women ${ }^{619}$ and for the first time a queen is shown with the combinations of the vulture headdress with the modius crown and swty feathers, as seen on Queen Iuhetibu (Fig. 4.49).

\footnotetext{
${ }^{614}$ Relief of Sneferu from Wadi Maghara, The Egyptian Museum Cairo JE 38568; El-Shahawy 2005: 45.

${ }^{615}$ Crown of Sithathoryunit: The Egyptian Museum Cairo JE 44919; Andrews 1990: 104.

616 Troy 1986: 128 .

617 Troy 1986: 127.

618 Callender 1992: 316.

619 Callender 1992: 313.
} 


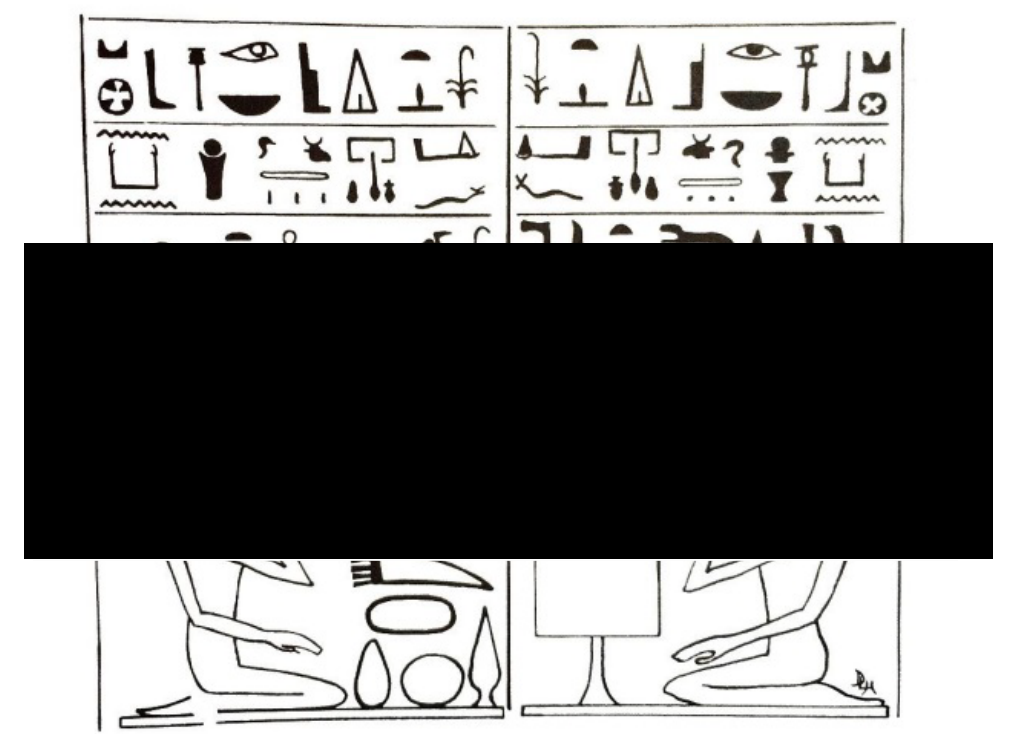

Fig. 4.49 Drawing of Queen Iuhetibu XVII and Dedusobk, the parents of a pharaoh, The Egyptian Museum Cairo; Dodson 2004: 113.

A relief depicting two daughters of Sobekhotep III, princesses Iuhetibu II and Dedetanuq, (Fig. 4.50) show both wearing curled rounded wigs or ibis wigs, similar to Queen Khenemetneferhedjet I of the Twelfth Dynasty. They wear ssd headbands similar to Princess Neferuptah's (Cat. 55), and have uraei on the front of the brow similar to the female headed bird statue (Cat. 38; Fig. 4.11).

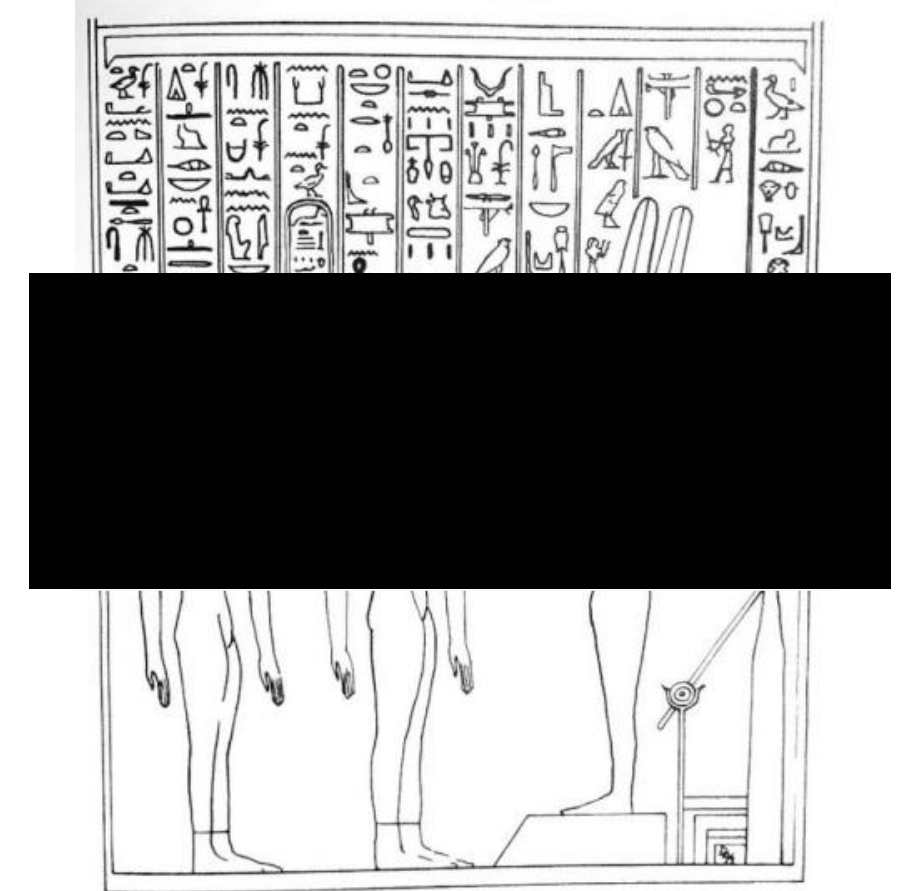

Fig. 4.50 Drawing of the Princesses Iuhetibu II and Dedetanuq standing before Min, Musée du Louvre Paris C8; Dodson 2004: 109. 
There are more surviving relief depictions of Thirteenth Dynasty royal women than statues which is opposite of what has survived from the Twelfth Dynasty. One small sculpture shows Princess Sobeknakht (RW 48; Fig. 4.51) nursing a royal child. ${ }^{620}$ She is seen with a diadem-type crown that has a cobra at the brow, which is again similar to the diadem of Princess Sithathoryunit and the relief diadems of Iuhetibu II and Dedetanuq. Sobeknakht also wears a vertically striated tripartite wig that is pushed back by oversized ears. Similar to Twelfth Dynasty images, she has welldefined naturalistic eyes with heavy upper eyelids. It seems that after the death of Sobekneferu the iconography of Thirteenth Dynasty royal women carried on from the Twelfth Dynasty. Iconographic features associated with administrative and religious roles, such as the uraei and swty feathers, continued to be expanded and royal women were represented with symbols originally held by male monarchs or gods. ${ }^{621}$ By the end of the Thirteenth Dynasty royal women had already acquired features such as uraei, the cartouche, šwty feathers, and the office of ruling Egypt. This accumulation of pharaonic features by royal women continued and extended into the New Kingdom. ${ }^{622}$

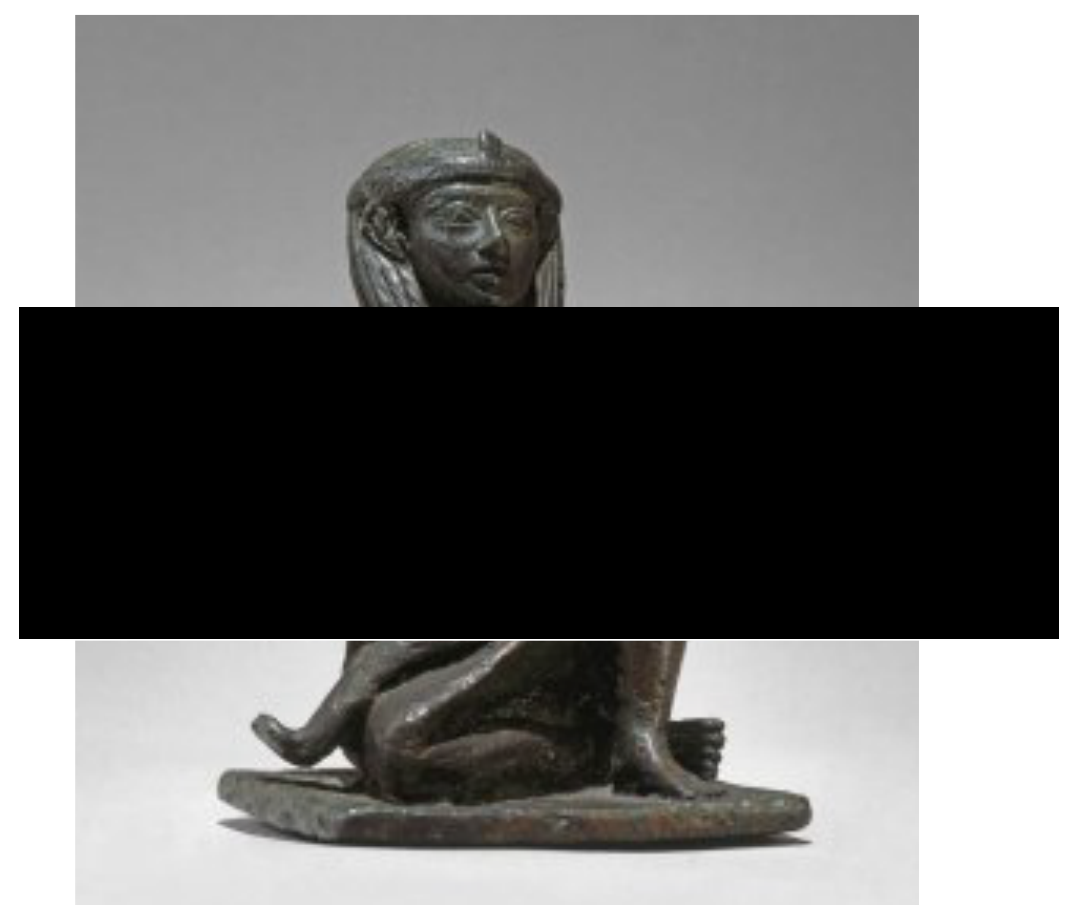

Fig. 4.51 Statue of Princess Sobeknakht nursing a prince, The Brooklyn Museum of Art 43.137.

\footnotetext{
${ }^{620}$ Ziegler 2008: 320-321.

${ }^{621}$ Callender 1992: 326.

622 Troy 1986: 134.
} 
By the late Seventeenth and into the early Eighteenth Dynasty, there is a large change in the iconographic elements used for royal women. Some features stay permanent, such as uraei, sheath dresses, wig types, and vulture headdress. However, other features changed, such as the standardization of the platform crown, smaller ears or wigs that cover the ears completely, and women wearing sleeved dresses. A bust that is tentatively attributed by Russmann to Queen Ahmosenefertari (Fig. 4.52) shows a large vulture covering the majority of the wig that is set in front of her ears. ${ }^{623}$ Her eyes are very shallow set with small eyelids and with no pronounced eyebrows. While the sharply defined facial features are similar to the work presented on Twelfth Dynasty royal women, the actual characteristics are recognizably different and belong to a different time period. ${ }^{624}$

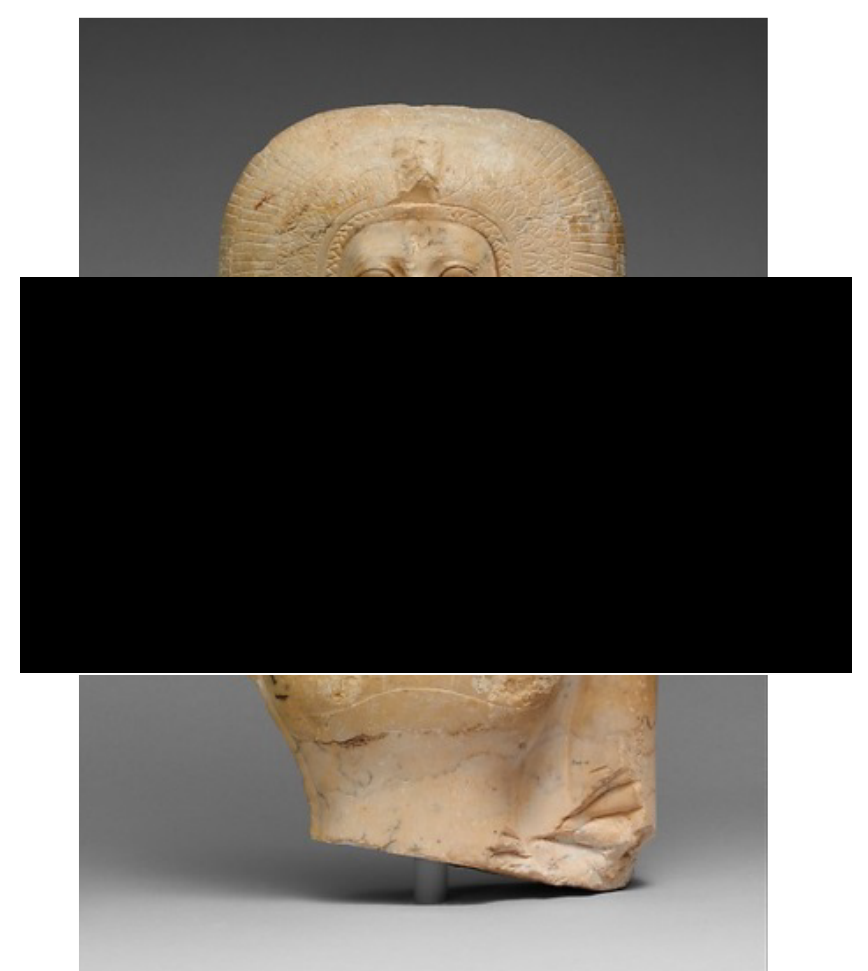

Fig. 4.52 Upper part of the seated statue of a queen, possibly Ahmosenefertari, The Metropolitan Museum of Art New York 16.10.244.

A bust attributed by the Museum of Fine Arts Boston 52.347 to be a very young Hatshepsut before she became pharaoh of Egypt (Fig. 4.53) is one of the early Eighteenth Dynasty statues that resemble the Twelfth Dynasty style. The appearance

\footnotetext{
${ }^{623}$ Russmann 2005: 29; Ziegler 2008: 312, For more details see the Metropolitan Museum of Art online catalogue: https://www.metmuseum.org/art/collection/search/544454.

${ }^{624}$ Russmann 2005: 29-30.
} 
of the bust is quite different from the previously mentioned bust of Ahmosenefertari. The young Hatshepsut is seen with no headdress but with a striated tripartite wig and thick uraeus. Her oversized ears are set in front of the wig and her eyebrows and cosmetic lines are well-defined. However, her shallow eyes, upturned mouth, and diamond face shape sets it apart from the Twelfth Dynasty style.

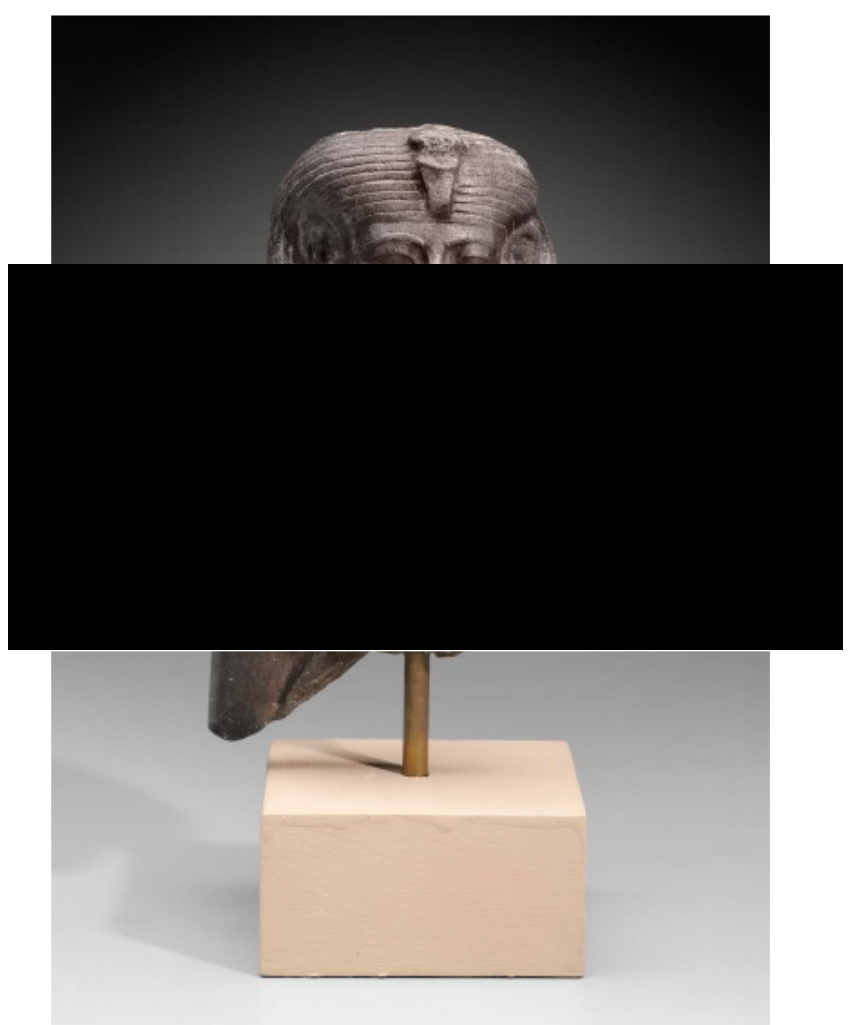

Fig. 4.53 Statue fragment of a young Hatshepsut, Museum of Fine Arts Boston 52.347.

After Hatshepsut adopts full pharaonic iconography, a large similarity between her statuary and the rulers from the Twelfth Dynasty takes place (see Chapter 3.5.5.1). Although her facial features are carved in the Thutmoside style, ${ }^{625}$ some poses and personal adornments resemble late Middle Kingdom representations. Hatshepsut's devotional attitude statues ${ }^{626}$ are a copy of the late Middle Kingdom style. ${ }^{627}$ The female monarch Sobekneferu also copied this pose as seen by her torso (Cat. 58) from her grandfather Senwosret III (Fig. 4.2) and father Amenemhat III (Fig. 4.3). Whether Senwosret III or Sobekneferu inspired Hatshepsut's statues is unknown, but it is possible she saw both rulers in this style. Hatshepsut can also be seen wearing

\footnotetext{
${ }^{625}$ Russmann 2005: 24.

${ }^{626}$ Hatshepsut in devotional attitude, The Metropolitan Museum of Art 28.3.18; Keller 2005: 170.

${ }^{627}$ Keller 2005: 170.
} 
the Twelfth Dynasty tubular chained necklace with a double pouch pendant, ${ }^{628}$ which originated during the reign of Senwosret II and became an item that late Twelfth Dynasty rulers wore. While Hatshepsut's relationship with Sobekneferu's image and her reasoning for emulating the Twelfth Dynasty works is still unclear, certain theories of legitimization can be set forth because of the noticeably copied styles.

\subsection{Discussions}

By the mid-Twelfth Dynasty, Egypt was politically secure, which resulted in their art flourishing. The iconographic expressions of Twelfth Dynasty royal women are one of the most important indicators of their status and political positions. ${ }^{629}$ During this time, royal women were being depicted with the same iconography as pharaohs, suggesting a shift to a more significant role in the political sphere. ${ }^{630}$ While this shift can be considered lesser known than the New Kingdom's Thutmoside style, which has been described as being the most influential style from ancient Egypt ${ }^{631}$ and the Amarna Period's radical change in iconography, ${ }^{632}$ the Twelfth Dynasty evolution in style is highly significant because it is the first time a complete iconographic shift takes place for both the pharaohs and royal women.

Among the four poses that are recorded from the surviving images of Twelfth Dynasty royal women, seated, standing, sphinx, and a female-headed bird, one of the most significant features is that independent statues of royal women are always seated. While the statues of the royal women may have been close in proximity to a king, there are no surviving representations of a rulering monarch and royal woman sharing one throne. Furthermore, in the only surviving relief of a seated Twelfth Dynasty royal woman, Queen Aat (Cat. 54) is seen as independent, in contrast to the other two surviving reliefs where both royal women, Princess Neferuptah (Cat. 55) and Queen Hetetpi (Cat. 56) are standing. On every confirmed group representation of royal women, they are standing but not embracing or touching the ruling pharaoh (Cat. 29, 32, 33, 34, 55, 56). This suggests an absolute representational independence among the royal women from the pharaoh on statues and reliefs found in funerary and religious complexes. Twelfth Dynasty royal women are occasionally shown in

\footnotetext{
${ }^{628}$ Large kneeling statue of Hatshepsut, The Metropolitan Museum of Art 30.3.2; Keller 2005: 168 169.

${ }^{629}$ Callender 1992: 306-307.

${ }^{630}$ Josephson and Freed 2007: 136.

${ }^{631}$ Russmann 2005: 23.

${ }^{632}$ Bahrani 2013: 107.
} 
association with the pharaoh but never in direct contact with him, resulting in the viewer's understanding that the figures are associated together but are independent figures.

Resulting from their elevated political status, ${ }^{633}$ Twelfth Dynasty royal women could be represented in therianthropic forms. The sphinx pose is the third most common representation within the Twelfth Dynasty and the human-headed bird is rare for any gender during this time period. The sphinxes and suggested pharaonic human-falcon show the royal women's political connection with rulership and their close position with the gods and goddesses. If the Cairo statue (Cat. 38) is the first human-headed and falcon bodied statue that represents either Sobekneferu or a deceased royal woman, then it shows that during the Twelfth Dynasty the female monarch's connection with the god Horus was demonstrated in art and that the wellbeing of royal women's souls ${ }^{634}$ were essential. Currently there are no contemporary male parallels, possibility suggesting the political and religious art of royal women was expanding more than the royal men.

While there is no clear explanation for the severe facial characteristics of the late Twelfth Dynasty, it has been suggested Senwosret III and Amenemhat III took on these expressions due to the burden of kingship, ${ }^{635}$ although the facial features are undeniably found on royal women and even non-royal men ${ }^{636}$ and women as shown by nurse Sitsneferu (Fig. 4.5). As established by Laboury, the severe facial characteristics are not limited to representing the person but are expressions of a signifying system ${ }^{637}$ as well as promoting the ideal image of royal power during the dynasty. ${ }^{638}$ Significantly, he notes the physiognomy Senwosret III is known for, originally began on private statuary which would have then influenced royal art. ${ }^{639}$ Presently there is no evidence to say the facial characteristics were a style created by the pharaoh himself and then simply copied by royal women. Because of this, it could also be proposed that royal men and women jointly carried the burden of ruling Egypt. This proposition could be supported due to a previous suggestion that

\footnotetext{
633 Josephson and Freed 2007: 136.

${ }^{634}$ Cooney 1968: 266.

635 Russmann 2001: 104.

${ }^{636}$ Seated cloaked man, The Egyptian Museum Cairo 42041.

${ }^{637}$ Laboury 2003: 64. Translation by Arnold 2015b: 70.

${ }^{638}$ Laboury 2016-2017: 84.

${ }^{639}$ Laboury 2016-2017: 83.
} 
the Bibliotheque Nationale sphinx (Cat. 67) represents Sobekneferu. ${ }^{640}$ Since the Bibliotheque Nationale sphinx (Cat. 67) and the female-headed bird (Cat. 38) are iconographically similar (see Chapter $4.2 .3,4.2 .4$ ), it is possible that both represent Sobekneferu (further discussed in Chapter 6.16). Since all of her inscribed statues have no remaining heads and the surviving sculptures with these facial features have no inscription, it can only be assumed that she was represented with the severe facial characteristics of the Twelfth Dynasty (see Chapter 6).

The uraeus was one of the most important items of the pharaoh's royal insignia $^{641}$ and this iconographical aspect became standard for royal women in the Twelfth Dynasty. Royal women were now always directly associated with the royal and divine protection of the cobra goddess Wadjet. ${ }^{642}$ Their positions as ruling monarchs and their close relationships with the solar eye ${ }^{643}$ were legitimized by the forehead position of the cobra. ${ }^{644}$ This type of legitimization displays the political and religious significance royal women had and how it was demonstrated to the viewers. From the surviving representations of Twelfth Dynasty royal women, their uraei are often broad and thick, although where the uraeus begins on the hairline is not standard. Some statues, such as that in Metropolitan Museum of Art (Cat. 9), have the uraeus beginning on the second line of the wig and not at the first line where the forehead meets the wig. Others have the uraeus begin at the usual first hairline, such as the Cairo bust (Cat. 4). Another aspect of the uraeus that is not standard is the number of tail curves. There is currently no standard average number of tail curves to a specific wig or pose type. Two sphinxes of royal women have the highest numbers of tail curves suggesting sphinxes had a direct affiliation with the political presence of royal women.

The lack of headgear worn can possibly suggest the absence or a diminished hierarchy within royal women, suggesting their roles shifted and advanced, such as princesses wearing uraei in real life, as seen on the diadem of Princess Sithathoryunit. ${ }^{645}$ There are only three confirmed appearances of the vulture headdress, as seen on the reliefs of queens Aat, Hetepi, and Khenemetneferhedjet I

\footnotetext{
${ }^{640}$ Ziegler 2008: 317.

${ }^{641}$ Robins 2008: 121.

642 Johnson 1990: 5.

643 Troy 1986: 71, 121.

644 Johnson 1990: 6.

${ }^{645}$ Robins 2001: 121.
} 
(Cat. 54, 56, 53), and neither woman is in association with each other. Queen Hetepi (Cat. 56) is only seen with her son Amenemhat IV while Queen Aat (Cat. 54) is depicted independently seated. Queen Aat's false door is heavily fragmented and missing most of the right bottom side. When compared to Queen Hetepi's relief with Amenemhat IV, it is possible a male monarch may have been similarly present on the false door for Aat to wear the vulture headdress. Both women are seen wearing the tripartite wig, which is the most common type that has survived.

Even though there are more representations of Twelfth Dynasty royal women with tripartite wigs, the Hathoric style is much more decorated and varied. For example, the three statues of royal women (Cat. 4,11,67) all have wavy striations giving the impression of a thick curly wig, while the Cairo bust (Cat. 4) has a noticeably flat smooth Hathor wig. The Hathor wig is the only style that has horizontal bands or ribbons commonly depicted, ${ }^{646}$ as seen on the statues of Nofret (Cat. 15, 16). The blunt style, as seen on the wooden head now in Cairo (Cat. 20), is the only wig with hair jewelry. The Twelfth Dynasty royal women may have used archaizing and copied styles from the Old Kingdom. ${ }^{647}$ The rounded wigs of the statues (Cat. 10, 18, 22) seem to have taken inspiration from the women of the Old Kingdom. Between the Hathoric style and the rounded wigs, it could be suggested that the wigs were used for expressing variations when the royal female bodies were idealized.

The ears are one of the most noticeable features on representations of Twelfth Dynasty royal women. Their ears are always large to oversized and well-defined. For each royal woman the artist took special interest in their ears, making sure to define and create one of the most prominent features of the style. While most ears of the Twelfth Dynasty seem very similar, the majority of them are unique to that artwork. For example, the busts of the unknown royal women (Cat. 1,9) seem to have similar ears, but they are different in minuscule ways. Both busts have well-defined antihelices, but the Berlin bust's anti-helices (Cat. 1) are much thinner and sharper than the Metropolitan Museum of Art's statue (Cat. 9). Some royal women, such as the Petrie Museum bust (Cat. 6), also have little to no inner ear detailing, while others, such as the Boston sphinx head (Cat. 64), have very detailed inner ear features (Fig.

${ }^{646}$ Ziegler 2001: Cat. 146.

${ }^{647}$ Fischer 1996: 117-118. 
4.19). Why there are so many variations of such a prominent feature is still unknown, although it can be considered that the style created by the artists was to purposefully make the ears similar but not exactly the same.

Similar to wigs and headdresses, the jewelry and dress found on representations of Twelfth Dynasty royal women are not highly diverse. All royal women are seen in sheath dresses, except for the Metropolitan Museum bust (Cat. 10) who wears a cloak. The majority of women either have no jewelry or are wearing jewelry that was introduced in the Old Kingdom, such as broad collars, anklets, and bracelets. Pectorals are introduced into the art, as seen on Nofret (Cat. 15), and in burials of royal women at this time. The pectorals are of the highest quality with names of kings, which show the royal woman's direct connection to the pharaoh. ${ }^{648}$ The surviving jewelry found from Twelfth dynasty royal women's burials are numerous and show their high prestige ${ }^{649}$ and royal status.

Beginning with the Fourth Dynasty, the iconography of royal women constantly evolved and expanded. Royal women continuously acquired iconographic attributes originally used only by male monarchs. ${ }^{650}$ The representations of royal women having political presence rose dramatically during the Twelfth Dynasty ${ }^{651}$ and continued into the New Kingdom. ${ }^{652}$ With these attributes, Twelfth Dynasty royal women could now be represented as more prominent political figures and their artworks conveyed their preferred messages to the viewers. The features such as uraei, the sphinx pose, severe facial characteristics, and šwty feathers demonstrate the royal women's political presence and equal iconography with the ruling monarch.

\footnotetext{
${ }^{648}$ Grajetzki 2014a: 123.

${ }^{649}$ Grajetzki 2014a: 43-66.

${ }^{650}$ Troy 1986: 134.

651 Josephson and Freed 2007: 137.

652 Troy 1986: 134.
} 


\section{Chapter 5: Neferuptah}

\subsection{Introduction}

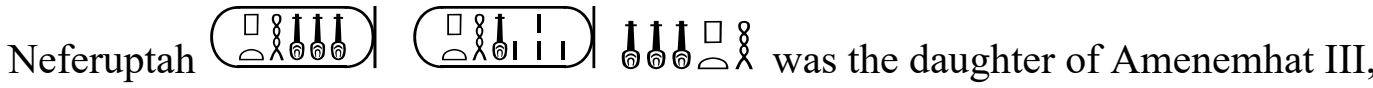
the sixth ruler of the Twelfth Dynasty. She was possibly the half or full sister of Amenemhat IV and Sobekneferu, the seventh and eighth pharaohs of the dynasty. Neferuptah was one of the most politically prominent royal women of the Twelfth Dynasty and was the first princess to have her name written inside a cartouche. It is likely that her tenure in the queenship position and as the presumptive heir to Amenemhat III helped establish the political cohesion of Sobekneferu's sole reign. From Neferuptah's tenure, five secure objects and two burials have survived. These include a relief from the Temple of Medinet Madi (Cat. 55), feet from a seated statue (Cat. 13), a sphinx (Cat. 69), a block of granite (see Chapter 5.5), and a papyrus sheet (see Chapter 5.6). She also has two attested burials located at Hawara. ${ }^{653}$ The first was found within the burial chamber of Amenemhat III and the second is her own personal pyramid. Within this chapter, these artifacts and associated monuments are discussed and are connected with similar Twelfth Dynasty surviving inscriptions and sculptures.

Among Neferuptah, Amenemhat IV, and Sobekneferu, Princess Neferuptah is the only certain royal child of Amenemhat III who was depicted with him. Based on the surviving evidence, both Amenemhat IV and Sobekneferu are securely associated with Amenemhat III only after they took on the political position of pharaoh. Apart from a possible statue (Fig. 5.12) there are no representations that can definitively be identified as Sobekneferu alongside Amenemhat III. In contrast, Neferuptah is depicted along with Amenemhat III in the Temple of Medinet Madi (Cat. 55; Fig. 5.1), which is the only representation of a Twelfth Dynasty royal female in front of the pharaoh. In addition, Neferuptah is the only royal family member to be seen in an active role with Amenemhat III and on multiple occasions she carries the titles szt nswt $n$ ht.f Daughter of the king of his body and $s 3 t n s w t$ mrt.f Daughter of the king whom he loves. These depictions and titles signal her unique and close relationship to Amenemhat III. Neferuptah certainly held a significant place in the royal family of Amenemhat III and in the politics of his reign

\footnotetext{
${ }^{653}$ For an overview of Hawara and the Labyrinth of Amenemhat III see Uphill 2000. For the pyramid of Neferuptah see Uphill 2000: 79-81.
} 
to the extent that it has been suggested that she was the heir to the throne (see section 5.9 and Chapter 7). ${ }^{654}$ These theories can be supported by the fact that Neferuptah, as a princess, was the first recorded royal woman to have her name encircled within a cartouche and the only Twelfth Dynasty princess to be represented with Amenemhat III as well as have a personal pyramid complex.

Neferuptah has funerary objects attested for two different burials, once in her father's Hawara pyramid, then again in her own pyramid located $2 \mathrm{~km}(1.25 \mathrm{mi})$ to the southeast (see below Fig. 5.27). ${ }^{655}$ Although Amenemhat III's burial chamber was originally robbed in ancient times, Neferuptah's own pyramid was never looted. Found within her burial chamber were over thirty items, including her sarcophagus, coffins, and surviving skin (further discussed below in 5.8.2) ${ }^{656}$ In addition to the burial goods found in her undisturbed pyramid at Hawara, this study is the first time all artifacts associated with Neferuptah are analyzed together. Second to Sobekneferu's twenty-five artifacts and associations, Neferuptah's artifacts and burial equipment comprise the largest surviving collection for any royal woman of the Twelfth Dynasty. This chapter examines the tenure of Neferuptah in depth to further clarify her political position in the Egyptian government and what her role in the ruling family was.

\subsection{Relief from the Temple of Medinet Madi (Cat. 55)}

The best-known depiction and only surviving relief of Neferuptah comes from the Temple of Medinet Madi (Cat. 55; Fig. 5.1, 5.2). She is seen standing in front of her father Amenemhat III in an active role playing a Hathoric sistrum for the goddess Renenutet. Her titles include The hereditary princess, very great, great of praise, loved by the universal lord, the daughter of the monarch, of his body, his beloved, Neferuptah who is given eternal life. ${ }^{657}$ This scene of Neferuptah is one of five depicting royal women surviving from the Twelfth Dynasty. Since Neferuptah is depicted in a unique position standing in front of the ruling pharaoh and is the first royal woman shown with a sistrum, ${ }^{658}$ it is important to understand her attire that aids in representing her royal power. From the Twelfth Dynasty there is no other

\footnotetext{
${ }^{654}$ Dodson 2008: 383; Pignattari 2008: 86, 70.

${ }^{655}$ Farag and Iskander 1971; Lehner 1997 182-183; Petrie 1890.

${ }^{656}$ Farag and Iskander 1971.

${ }^{657}$ Pignattari 2008: 58; Valloggia 1969: 110.

${ }^{658}$ Zecchi 2010: 70
} 
surviving relief depiction of a royal woman standing in an active role in front of the king, although others may have existed but have not survived. This is perhaps the result of numerous Twelfth Dynasty temples and their depictions being naturally damaged or destroyed and reused in later times. Neferuptah's surviving depiction indicates she held a significant role in the religious sphere, had closeness with the goddess, and was directly included in her father's pharaonic activities to the extent that she was placed between the pharaoh and the goddess.

An alternative suggestion could be that Neferuptah's depiction was a later addition; however, this seems less likely for various reasons. Farag and Iskander, Pignattari, or Bresciani and Giammarust do not mention this possibility or any change in the wall decoration. The scene is depicted in the innermost part of the temple and was constructed during the reign of Amenemhat III. If Neferuptah was a later addition, it would have had to been added by Amenemhat III after her death. While this is possible, from her surviving titles it is more likely it was commissioned before her death. Additionally, Amenemhat IV is shown in the outer part of the temple with his mother Hetepi which further supports that Amenemhat III was originally represented with a royal woman as well.

Twelfth Dynasty royal women had close connections with specific deities, including Hathor, Sekhmet, Renenutet, Ra, and Sobek. Prior to the New Kingdom, there are few surviving temples and reliefs, making Medinet Madi significant to this study of the late Middle Kingdom. In this temple, two royal women, Hetepi and Neferuptah, participate in activities at the religious site, but Neferuptah is the only one of the two royal women playing a sistrum for the goddess Renenutet. The

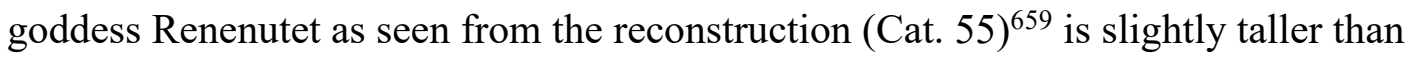
Amenemhat III, making the under life-sized Neferuptah stand up to her father's upper thigh and just above Renenutet's knees. The scene has suffered from heavy natural damage (Fig. 5.2) and for this thesis's analysis, the reconstructions are used (Fig. 5.3, 5.4). In the depiction Neferuptah wears a traditional sheath dress and seems to have a shorter hair style with a diadem type crown or possible headband with flower decorations.

${ }^{659}$ Bresciani and Giammarust 2012: 86. 


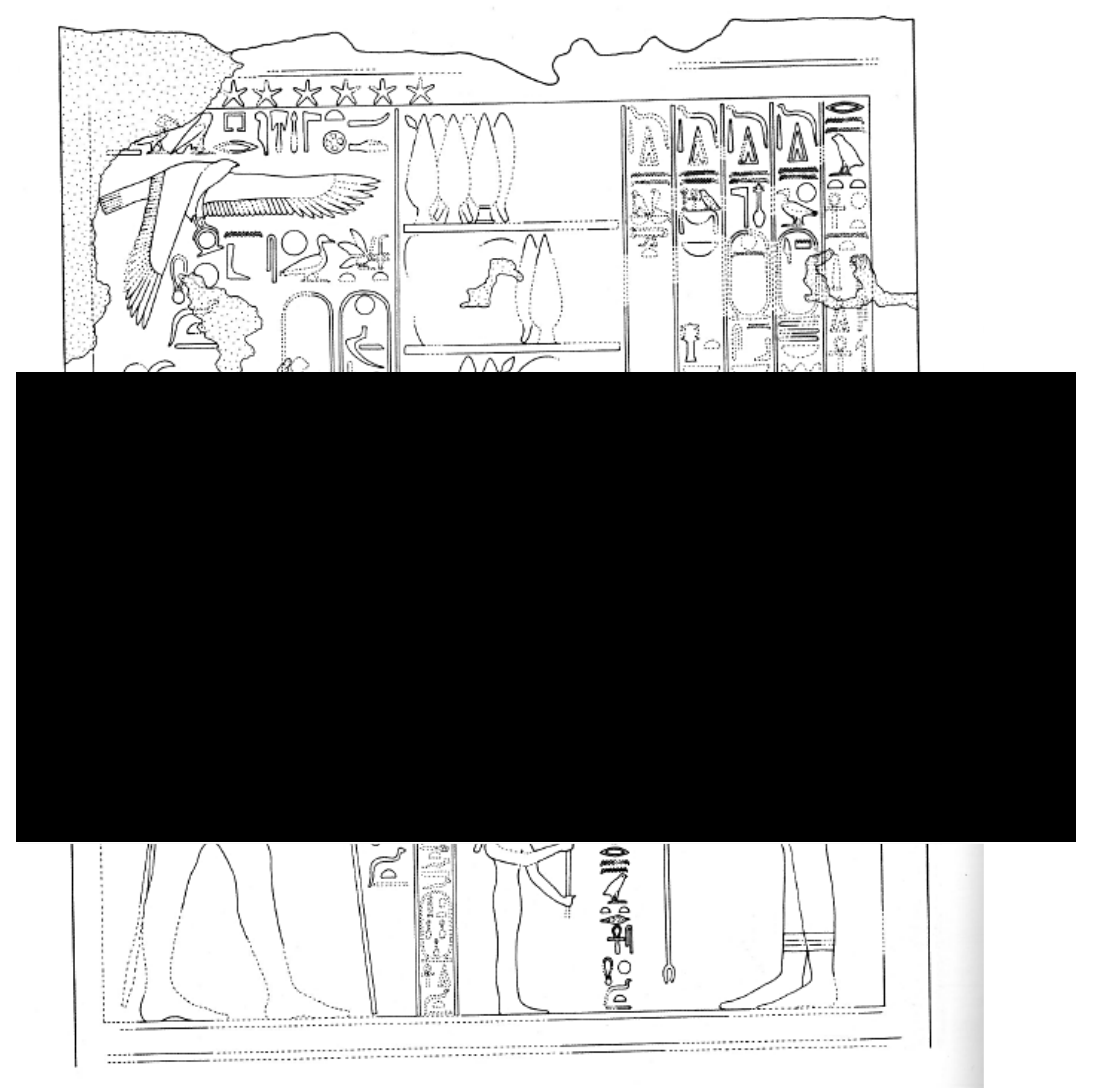

Fig. 5.1 Reconstruction of Princess Neferuptah, Bresciani and Giammarust 2012: 86.

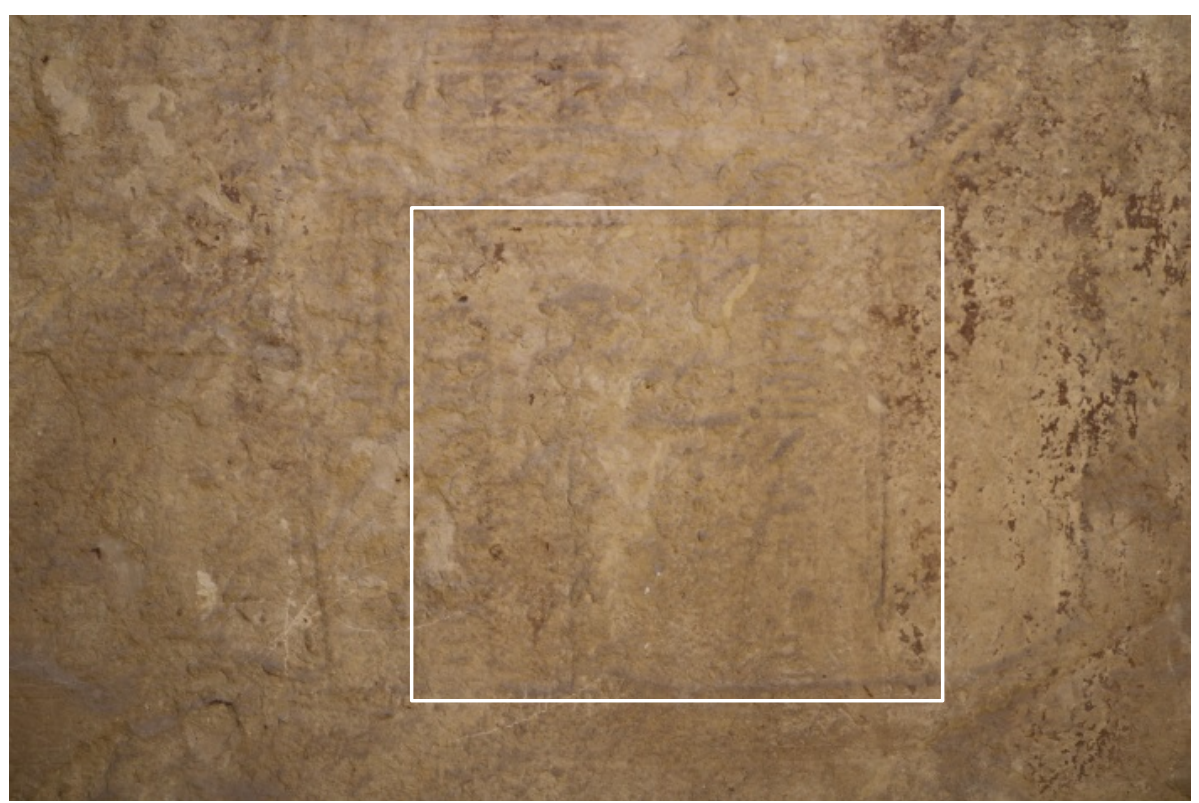

Fig. 5.2 Princess Neferuptah, author's photograph 2016. 
According to Sidky's reconstruction, ${ }^{660}$ Neferuptah wears a banded wavy Hathoric style wig (Fig. 5.3), while in the Bresciani and Giammarust reconstruction ${ }^{661}$ she seems to have a short-rounded wig style (Fig. 5.4). The Hathoric and rounded styles were both common during the late Twelfth Dynasty, with the former being the second most frequent wig type of the dynasty (see Chapter 4.5.2 and 4.5.3). An example of the horizontal bands and vertically wavy striations on a Hathoric style wig can be seen on the bust of an unknown woman (Cat. 11), while the shortrounded style can be found on the seated statue of Queen Khenmetneferhedjet I (Cat. 18), who is possibly Neferuptah's great-grandmother (see Chapter 1.6; Appendix 2). While both hairstyles and wigs can be found on statues, on the other surviving reliefs of Twelfth Dynasty royal women, including queens Hetepi (Cat. 56), Aat (Cat. 54), and Khenemetneferhedjet I (Cat. 53), the tripartite wig is used, which is the most common wig type (see Chapter 4.5.1).

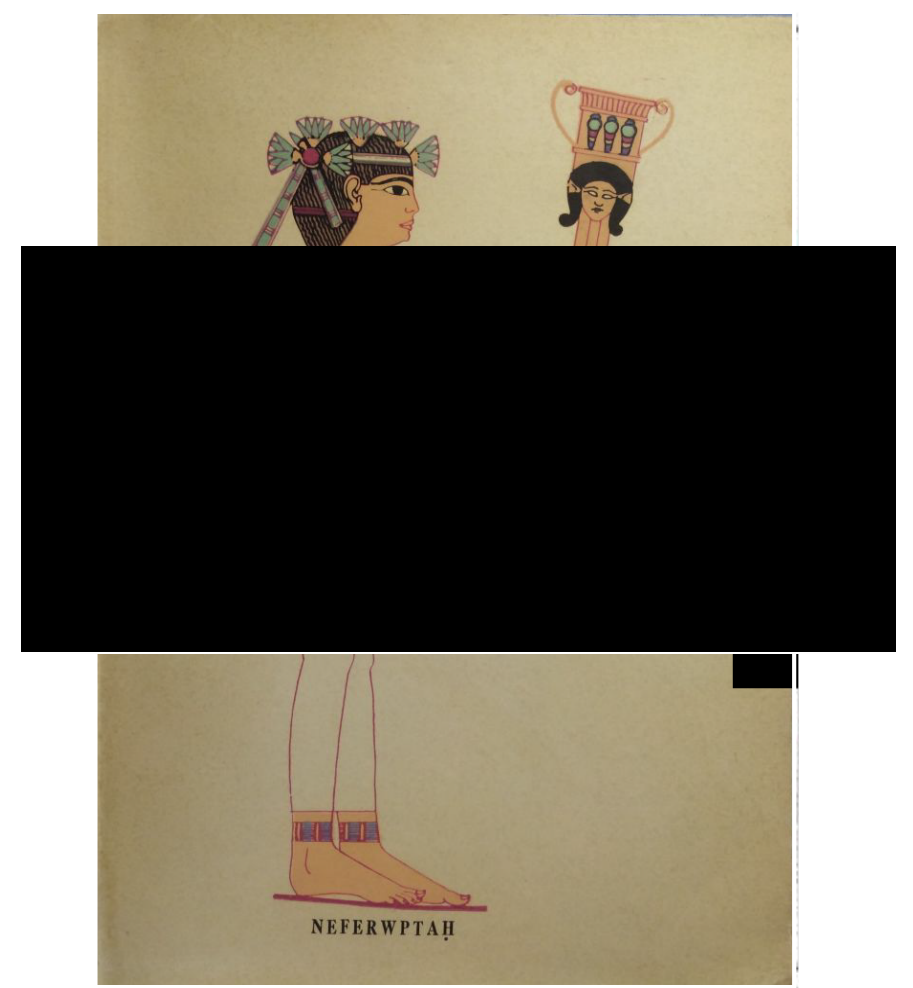

Fig. 5.3 Reconstructions of Princess Neferuptah, Sidky 1971: front cover.

\footnotetext{
660 "Ahmad Sidky, the draftsman in the Department of Antiquities traced the figure of the princess as shown in the scene and was able to restore it in color as shown in the front piece of this book by comparing it with the dress typical of the Middle Kingdom.” Farag and Iskander 1971: 104.

${ }^{661}$ Bresciani and Giammarust 2012: 86.
} 


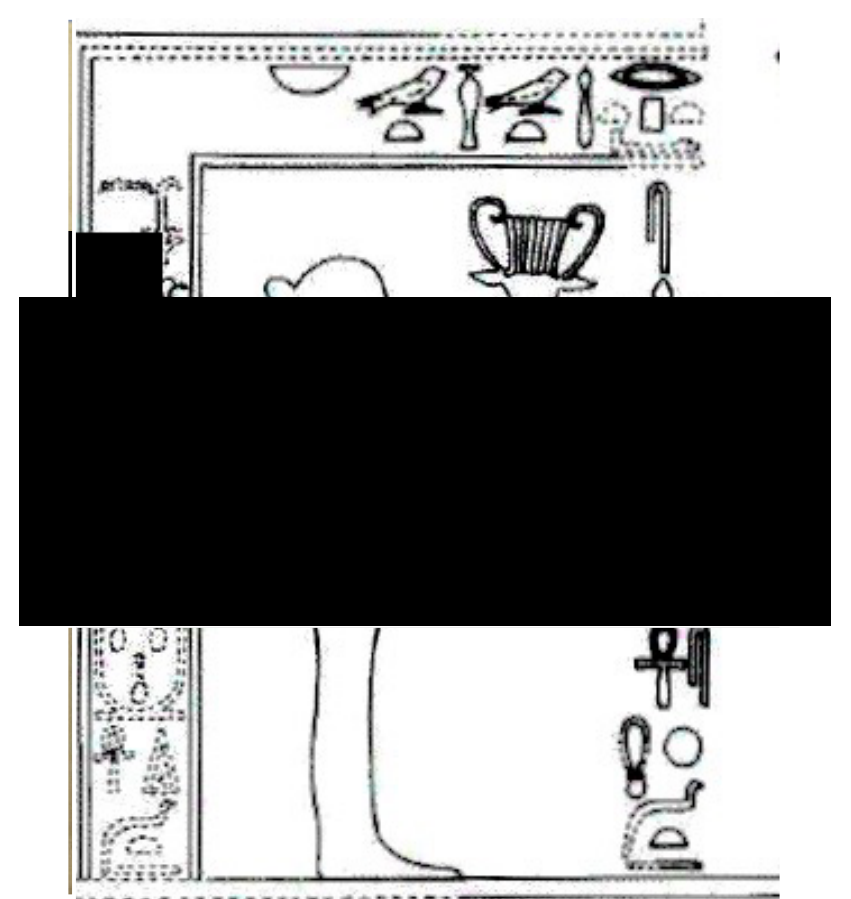

Fig. 5.4 Reconstruction of Princess Neferuptah, Bresciani and Giammarust 2012: 86.

In Bresciani and Giammarust's reconstruction, there is no head gear detailed except for the back streamer and a rounded line at the top of it. In contrast, in Sidky's reconstruction, Neferuptah is wearing a headband with six lotus flowers. In order to determine the most likely reconstruction for Neferuptah's head gear in this relief, it is useful to examine the head pieces worn by other Twelfth and Thirteenth Dynasty royal women. There is no other surviving relief of a Twelfth Dynasty royal woman wearing a diadem type crown and only one statue, the female headed bird of a royal woman with a diadem type crown (Cat. 38; see Chapter 4.2.4). There are four surviving Twelfth Dynasty physical examples of diadem type crowns, the swty feather crown of Princess Sithathoryunit (RW 23), the vulture and golden-wired crowns of Khnemet (RW 14), and the wired circlet of Senebsiti. Sithathoryunit, along with Khnemet, are the known daughters of Senwosret II and Amenemhat II, while Senebsiti is a disputed daughter of Amenemhat I. All three women would have lived before Neferuptah, so it is possible she would have been depicted with a diadem similar in style to the proceeding women.

One clear feature of Neferuptah's diadem type crown is the streamer falling down the back. From this time period it is only seen on the swty-feather crown of Princess Sithathoryunit and then again on the relief reconstruction of the princesses Iuhetibu II and Dedetanuq from the Thirteenth Dynasty (Fig. 4.49). Based on the 
style of the streamer and the missing double feathers in both reconstructions and on the damaged relief, Neferuptah most likely was not depicted wearing a šwty-feather diadem type crown. It is likely that Neferuptah's headgear would be more similar to that of princesses Iuhetibu II and Dedetanuq's of the Thirteenth Dynasty. However, in both reconstructions Neferuptah is not depicted with a uraeus, thus differentiating her from Iuhetibu II and Dedetanuq. Considering Neferuptah's royal cartouche and status as a political figure in the queenship position, a uraeus is expected, but the reconstructions are unclear. Although the relief (Fig. 5.2) has severe damage, a shape can be seen extending out from Neferuptah's forehead, which would explain Sidky's reconstruction of a lotus flower, but it is more likely that it was meant to be uraeus.

The diadems of Senebsiti, Khnemet, and Sithathoryunit have no artistic or relief parallels so it cannot be said whether they were typical for the time. With this stated, there are common features such as gold rosettes, which are seen in the hair jewelry of Senebsiti, on the golden band of Sithathoryunit, and the vulture diadem of Khnemet. Along with the rosettes, other types of floral designs appear on both diadems of Khnemet, including lotuses, papyrus heads, and flowers. ${ }^{662}$ Located on the back of a diadem type crown belonging to Princess Nubhetepikhered of the Thirteenth Dynasty is a disk inlaid with a stone being flanked by two lotus flowers. ${ }^{663}$ Without a surviving streamer, this type of style is certainly similar to that of Iuhetibu II and Dedetanuq's and would be the closest physical example of Neferuptah's diadem type crown. From this evidence it is possible to propose that in the temple relief from Medinet Madi, Neferuptah was depicted wearing a rounded style wig with a diadem type crown that includes a disk with two papyrus flowers, and a streamer on the back with a uraeus in the front.

\subsection{Feet from a seated statue (Cat. 13)}

In 1906, just behind the Irrigation and Antiquities Department rest-house on the island of Elephantine, the lower part of a small grey granite statue of Neferuptah was discovered (Cat. 13). The present location of both the top and lower halves of the statue are unknown and there are no photographs or drawing. It is therefore unclear how Neferuptah would have been originally been depicted. Neferuptah is named daughter of the king of his body with her name in a cartouche, once down the left

\footnotetext{
${ }^{662}$ Diadems of Princess Khnemet, Egyptian Museum Cairo CG 52860; Andrews 1990: 52.

${ }^{663}$ Grajetzki 2014a: 77.
} 
side of the pedestal and again on the right. The inscription includes For the $k a$ of the Hereditary Princess, great one of the hetes-scepter, great of praise, daughter of the king, of his body Neferuptah, possessor of veneration. ${ }^{664}$

Left:

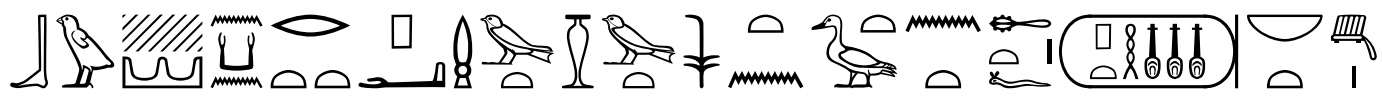

Right:

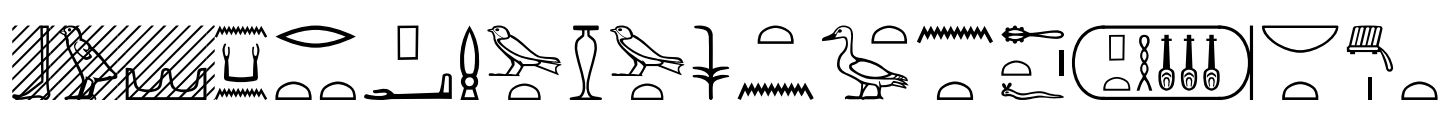

Neferuptah's statue was discovered with four other objects, including a pedestal of Senwosret I, two statues inscribed with the name of Amenhotep III, and a headless statue of a ram from Roman times. ${ }^{665}$ The remaining pedestal and feet appear to have been a part of a seated statue about $1 \mathrm{~m}(3.3 \mathrm{ft})$ tall. Weigall suggested her statue "seemed to have been seated" 666 which indicates that her feet must have been placed together instead of the left foot slightly forward that would have indicated that she was standing.

At an estimated one meter in original height, the statue's size was typical for the Twelfth Dynasty. From the artworks of Twelfth Dynasty royal women that are included in the catalogue of this study, they were represented at both over life-size and under. The over life-sized seated statues of Nofret are $165 \mathrm{~cm}(5 \mathrm{ft} 5 \mathrm{in})$ in height. Queen Khenemetneferhedjet sits a little under a meter high at $77 \mathrm{~cm}(2 \mathrm{ft} 5 \mathrm{in})$ and her feet are seen placed together with her hands laid flat upon her thighs. Unlike Khenemetneferhedjet (Cat. 18), whose inscriptions are placed before her feet, Neferuptah's run down the left and right sides of the pedestals. This type of style is similar to the seated statues of Nofret (Cat. 15, 16) and Sobekneferu (Cat. 59, 60). Although their statues are more numerous, royal men of the Twelfth Dynasty were also represented from large too small. As shown by the statues of Senwosret III and Amenemhat III (Fig. 4.2, 4.3) with the height of $122 \mathrm{~cm}(4 \mathrm{ft})$ and the statue of Amenemhat III ${ }^{667}$ at $21.40 \mathrm{~cm}(8.5 \mathrm{in})$, royal women and men were both depicted in all sizes including large and statuette, suggesting there was no gender restriction on

\footnotetext{
${ }^{664}$ Hieroglyphs from Farag and Iskander 1971: 101; Translation from Pignattari 2008: 57; Valloggia 1969: 109-110.

${ }^{665}$ Weigall 1907: 48.

${ }^{666}$ Weigall 1907: 48.

${ }^{667}$ Statuette of Amenemhat III, Musée du Louvre N464.
} 
the height diversity of statues.

There is a lack of detailed documentation on Neferuptah's seated statue causing her wig type and facial characteristics to be unknown. Based on the context of the artwork, it is possible that Neferuptah would have been represented with the facial features of the late Twelfth Dynasty. During Amenemhat III's reign Neferuptah was in the queenship position and possibly his intended heir, indicating that her iconography would have expressed her position in Egyptian politics. Royal women were often represented with the severe facial characteristics as seen on the statues (Cat. 1, 3, 4, 10, 11, 21, 24, 38, 67; see Chapter 4.3). A bust of an unknown Twelfth Dynasty royal woman (Cat. 4; Fig. 5.5) was found at Elephantine and now resides in the Egyptian Museum, Cairo. Made from serpentine and standing $12 \mathrm{~cm}$ (5in) tall, the bust is only preserved from the waist upwards and may be the closest stylistically and by provenance to the upper part to the lower half of Neferuptah's seated statue. This bust (Cat. 4) can be dated to the late Twelfth Dynasty based upon the lack of jewelry, Hathoric style wig, fleshy ears, lack of cosmetic detailing on her eyes or eyebrows, pointed inner and outer corners of the eyes, and well-defined nasolabial folds. Compared to the other surviving statues of Twelfth Dynasty royal women, this bust has an unprecedented thick uraeus (Fig. 5.6).

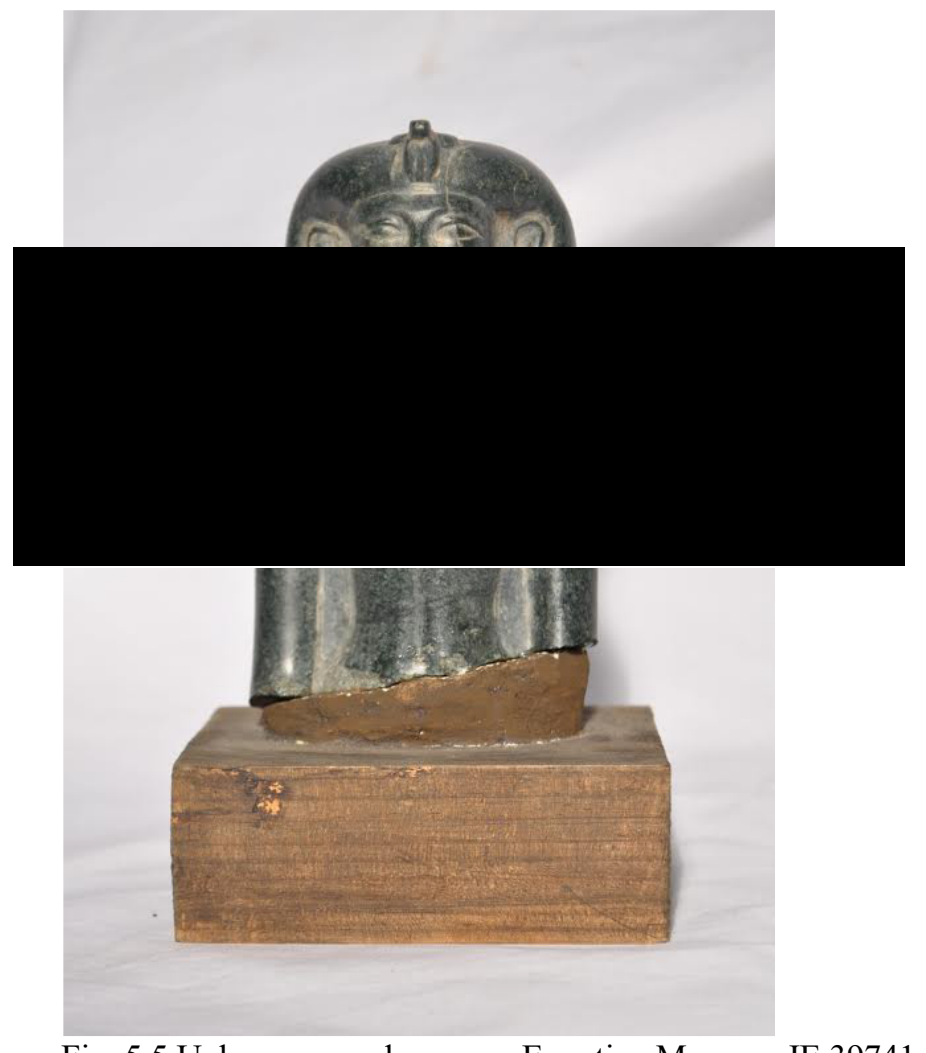

Fig. 5.5 Unknown royal woman, Egyptian Museum JE 39741. 
This is the only surviving example of a thick-bodied uraeus on a royal woman from this time period. This style of uraeus is similar to the one seen on the seated statue of Amenemhat III in Cairo (Fig. 5.7). Both statues have similar characteristics, such as the uraei having thick bodies that support the rearing stature of the cobra with ribbed decorations on the snakes' necks. The eyes and eyebrows of the statue are naturalistic with no surviving cosmetic detailing and their eyes both have pointed inner and outer corners. The noses of Amenemhat III and the unknown royal woman are similarly slender and pointed and both statues have emphasized philtrum columns with cupid bows. All of these features are what is expected for the representation of Neferuptah, thus suggesting that this statue may possibly be a rare depiction of her, which would be similar to her seated statue found on the island of Elephantine.

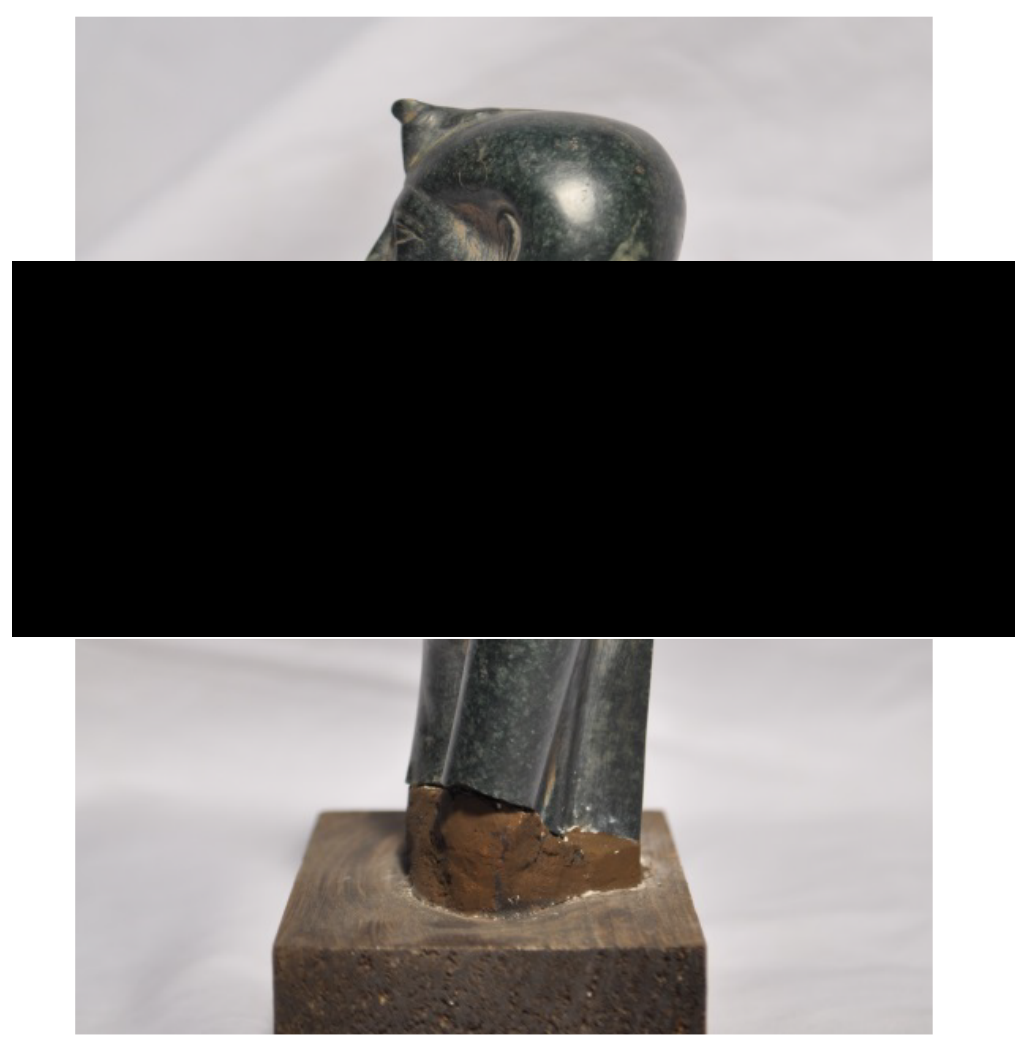

Fig. 5.6 Unknown royal woman, left side, Egyptian Museum JE 39741. 


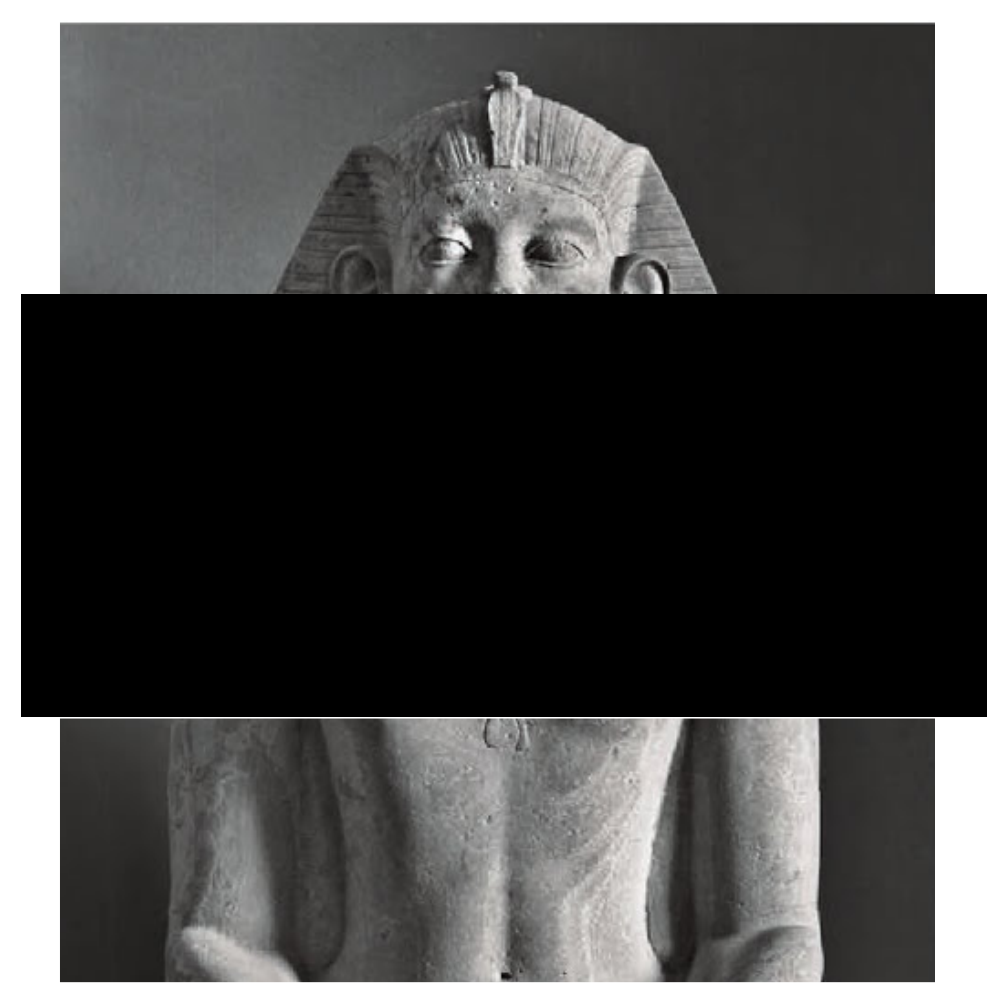

Fig. 5.7 Seated statue of Amenemhat III, Egyptian Museum Cairo CG 385.

\subsection{Sphinx (Cat. 69)}

Out of the known representations for Twelfth Dynasty royal women, there are eight recorded sphinxes (Cat. 62, 64-70). The sphinx of Neferuptah (Cat. 69) was first seen in 1903 by Percy E. Newberry in the shop of a Luxor dealer and the archaeological context, therefore, remains unknown. There is currently no provenance, image, or known location for the sphinx. ${ }^{668}$ Newberry originally described the sphinx as black granite and headless with an inscription incised down the chest and between the paws. ${ }^{669}$ Later, in the same year, Georges Legrain purchased the sphinx of Neferuptah, again saying it was of black granite with a text running down the chest and extending to the end of the paws with her name in a cartouche. ${ }^{670}$ In this dedication text to Amenemhat III, Neferuptah is titled the daughter of the monarch and her name is seen in a cartouche. The inscription reads as:

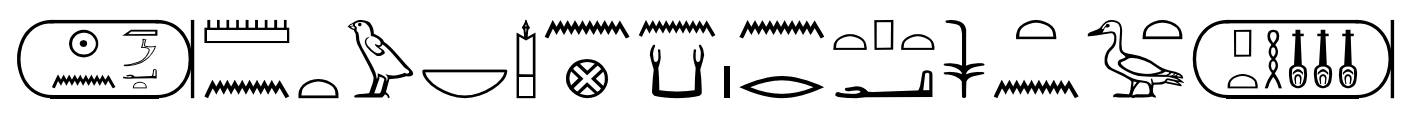

\footnotetext{
${ }^{668}$ Valloggia includes Neferuptah's sphinx as the first monument known from Neferuptah's time as hereditary princess. Valloggia 1969: 109.

${ }_{669}^{6}$ Newberry 1903: 359 .

${ }^{670}$ Legrain 1903: 133.
} 
Ny-Maat-Ra, Montu Lord of 'Iwnw (Heliopolis), for the $k a$ of the hereditary princess, daughter of the king, Neferuptah. ${ }^{671}$ There is no remaining image but Legrain noted the headless sphinx's height is $40 \mathrm{~cm}$ (1 $1 \mathrm{ft} 3 \mathrm{in})$. Not mentioned in either report is evidence for a surviving wig, headdress, jewelry, mane, or tail on the statue. Within her sphinx catalogue, Fay later states that there was probably a Hathoric style wig. ${ }^{672}$

From these eight surviving sphinx representations, one shows many parallels to the description of Neferuptah's sphinx that was sold from the Luxor dealer. The forepart of a headless female sphinx, now located in Vienna (Cat. 70; Fig. 5.8, 5.9), is made of dark granodiorite and is $41.5 \mathrm{~cm}$ (1 $1 \mathrm{ft} 4 \mathrm{in})$ in height. ${ }^{673}$ The sphinx is preserved from the neck to the central part of the lion's body and is wearing a Hathoric style wig with circular disks. Between the wig's curls is a broad collar and across her shoulders is a striated mane. An inscription runs vertically down the chest and appears to end with the cartouche of Amenemhat III. Based upon the descriptions of Newberry, Legrain, and Fay the Vienna sphinx (Cat. 70) could be considered as a candidate for the now missing Neferuptah's sphinx described above, however there are slight differences. With only a $1.5 \mathrm{~cm}$ (1in) difference in height, both being made of dark granite, having inscriptions that include the name of Amenemhat III, and Hathoric style wigs, the sphinxes seem almost identical. Although both sphinxes are not exactly alike they were made during the same reign and possibly for the same woman. The Vienna sphinx (Cat. 70) has a provenance of Memphis, ${ }^{674}$ but it is unclear if this is the actual find spot or, like Neferuptah's sphinx, it was moved or sold by a dealer. The Vienna sphinx also has a slightly different inscription with no other name that can be clearly identified. From the inscription documented by Newberry on Neferuptah's now missing sphinx, her name was inscribed last, which implies it would have been written between the paws. From the elbows to the end of the paws on the Vienna sphinx (Cat. 70), the stone is heavily damaged and is currently illegible. However, it is possible that the Vienna sphinx also had Neferuptah's name between the paws at one time.

\footnotetext{
${ }^{671}$ Hieroglyphs from Farag and Iskander 1971: 101; Translation from Pignattari 2008: 53.

672 Fay 1996: 68.

${ }^{673}$ Fay 1996: 67-68.

${ }^{674}$ Fay 1996: 68, The provenance for the sphinx is listed as Mitrahineh (Memphis).
} 

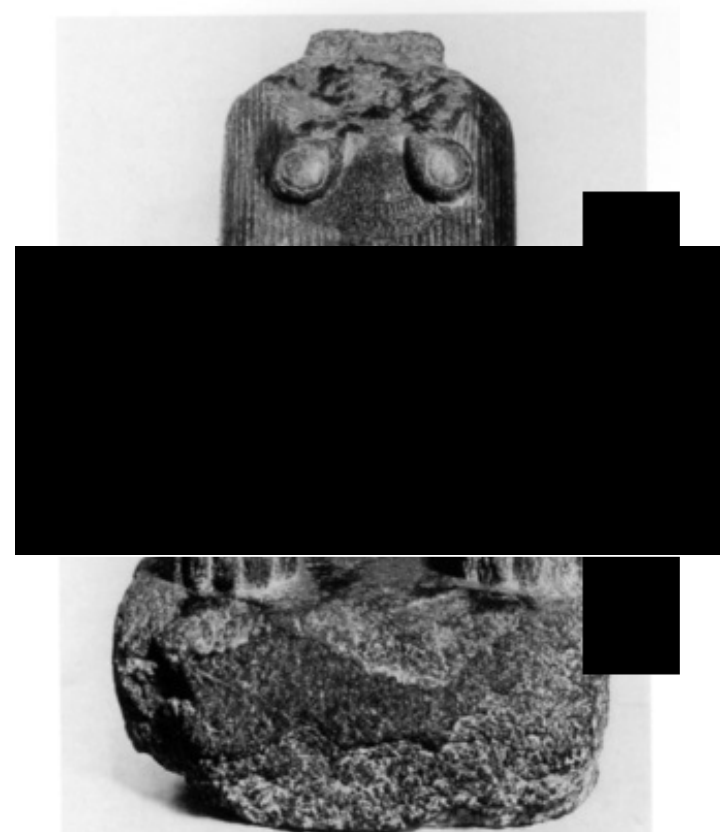

Fig. 5.8 Headless sphinx, Kunsthistorisches Museum Vienna AS 5753.

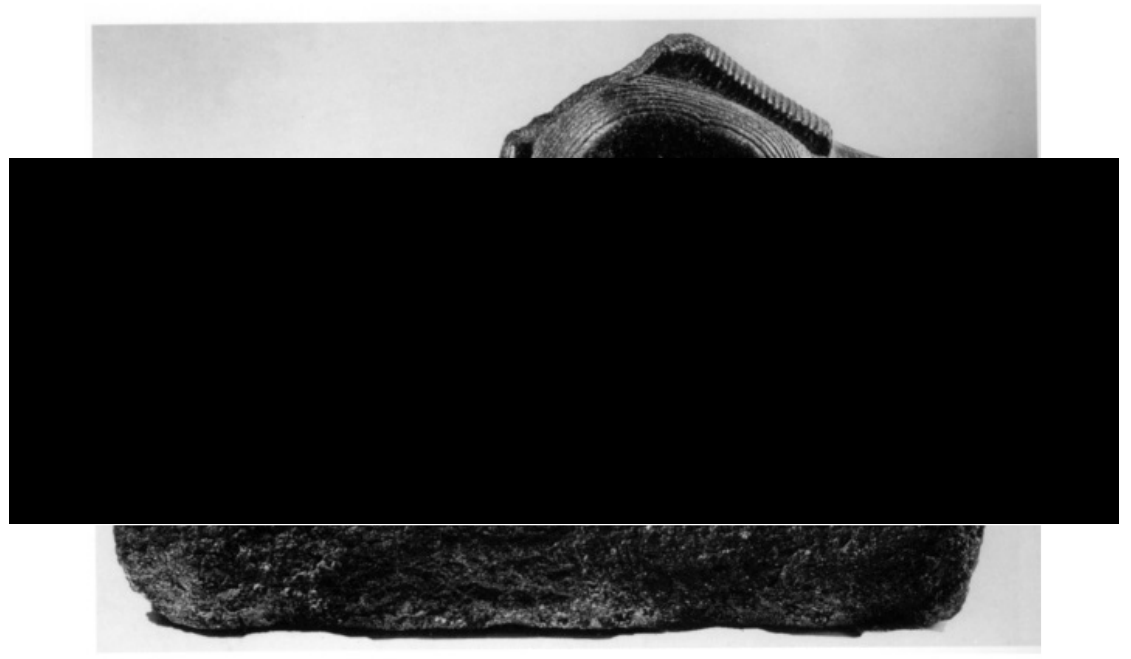

Fig. 5.9 Headless sphinx, Kunsthistorisches Museum Vienna AS 5753.

The fact that these sphinxes are so strikingly similar suggests they were both made for Neferuptah (for previous discussion see Chapter 4.2.3). It is possible that they once stood together pyramid of Neferuptah and were later separated. Twelfth Dynasty artworks were often moved and reused, in ancient and modern times, so it is possible that these two sphinxes were simply taken at some point. Other royal women from the Twelfth Dynasty have multiple known representations such as Queen Khenemetneferhedjet (Cat. 18, 31-34, 39, 40, 53), and Sobekneferu (Cat. 5763) so it is likely that Neferuptah commissioned multiple statues as well. Neferuptah was certainly the most politically relevant royal woman during the reign of 
Amenemhat III and other presently unidentified statues, including the sphinx now located in Vienna could possibly be depictions of her.

\subsection{Block of granite}

A black granite block with the name of Neferuptah was found in the late 1800s in the district of Darb el-Asfar near Gammaliya Street in Cairo and was being used as a mortar. ${ }^{675}$ Georges Daressy first recorded the block in 1888 . He stated the block had a text written twice that included the name of Neferuptah in cartouches. ${ }^{676}$ The two inscriptions title her as the Sister of the God, the King's daughter of his body whom he loves, Neferuptah, may she live eternally. ${ }^{677}$

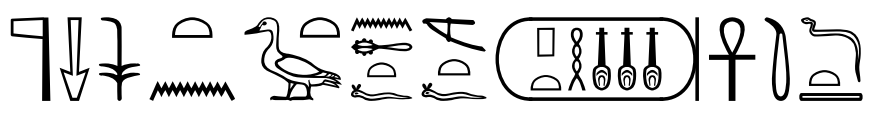

No further details such as size or preservation are given and the current location of the block is unknown. Since the location of the block is unknown the accuracy of the hieroglyphs cannot be confirmed which allows for the possibility that Daressy recorded the inscription incorrectly. There has been some discussion on the title snt nt $\underline{\text { r }}$, sister of the God. Desroches-Noblecourt suggested that the title meant that Neferuptah was not only the sister of Amenemhat III but his favorite wife, ${ }^{678}$ which was later refuted by Valloggia who points out Neferuptah was never a queen. ${ }^{679}$ Sabbahy mentions the only earlier similar title God', which dates to the Old Kingdom, ${ }^{680}$ snt $n \underline{t} r$, which may be an earlier version of the Eighteenth Dynasty title be an error for snt $n s w t$, sister of the king. ${ }^{681}$ Troy includes snt $n t r$ under the sister of the king section within her Titles and Epithets appendix and translates the title as sister of the God. She lists Neferuptah as the only royal woman to carry this title. ${ }^{682}$ In 2008, Pignattari suggests the unique title could be a result of her significant role in

\footnotetext{
${ }^{675}$ Farag and Iskander 1971: 102.

${ }^{676}$ Daressy 1888: 142.

${ }^{677}$ Hieroglyphs from Farag and Iskander 1971: 102; Translation from Pignattari 2008: 55; Valloggia 1969: 110-111.

678 Desroches-Noblecourt 1957: 22, cited in Pignattair 2008: 55.

${ }^{679}$ Valloggia 1969: 111.

${ }^{680}$ Jones 2000: 822 no. 3004; Murray 1908: XXXV; Troy 1986: 181.

${ }^{681}$ Sabbahy 1982: 209.

682 Troy 1982: 194.
} 
governing the country. ${ }^{683}$ This could further suggest Neferuptah's use of the title snt $n \underline{t} r$ was a part of her political status in the queenship position as well as her closeness with the pharaonic office and does not symbolize her kinship with royal male family members.

While snt $n \underline{t} r$ could be a secondary writing for snt $n s w t$, this is unlikely.

From all of the surviving representations of Neferuptah in association with Amenemhat III, she is described as being the daughter of Amenemhat III of his body whom he loves but never his sister. Though she carries the title snt ntr $r$ on the granite block, from what is recorded the snt does not refer to Amenemhat III. If snt ntr is a scribal mistake for sister of the monarch, then another ruler besides Amenemhat III must be sought. The possible nswt could only be describing Amenemhat IV or Sobekneferu who were both rulers after Amenemhat III. However, if the hypothesis is correct that Neferuptah died during her father's reign, the possible $n s w t$ could only be identified as Amenemhat IV if he had a co-regency with Amenemhat III before Neferuptah's death. It is in the Twelfth and Thirteenth Dynasties that snt nswt becomes a standard title for royal women, ${ }^{684}$ so snt $n \underline{t} r$ may be the precursor to snt $n s w t$ and the later $h m t \underline{n t r}$. It is most likely that the snt $n \underline{t} r$ title was given to Neferuptah as another form of $s 3 t n \underline{t} r$ and $h m t n \underline{t} r$ to communicate her political and religious importance. Her use of the cartouche and snt $n \underline{t} r$ both served to emphasize her significant status during her father's reign and her importance to the Egyptian government.

\subsection{Papyrus sheet}

A sheet of papyrus containing Neferuptah's name was found in el-Lahun by Petrie in 1889 and is now located at the Petrie Museum. ${ }^{685}$ The papyrus was found containing the damaged seal of Amenemhat III's cartouche, which securely dated the sheet to his reign (Fig. 5.10, 5.11). ${ }^{686}$ The recto included 1 vertical line and 11 horizontal lines along with the address on the verso. Line 5 on the recto mentions the enclosure of Neferuptah's foundation and includes her name within a cartouche, written as

\footnotetext{
683 Pignattari 2008: 55.

${ }^{684}$ Callender 1992: 107.

${ }^{685}$ Imperfect sheet of papyrus: The Petrie Museum UC32212; Written by the worker Mershenet.

${ }^{686}$ The sheet is $31 \mathrm{~cm}$ ( $1 \mathrm{ft} 4 \mathrm{in}$ ) in height and $18 \mathrm{~cm}$ (7in) wide.
} 


\section{마인}

which is similar to the spelling of Sobekneferu on her papyrus from

Harageh (see Chapter 6.8). Collier and Quirke translate lines 1-8 as following:

The servant of the personal estate Mershenet says: This is a communication to the lord l.p.h. as follows:

the servant-there has taken note of the matter of this document which was brought to the servant-there saying.

'The king's foods have been set from the various grains (-supplies)

of Hetepsenwosret true of voice

the foundations of the King's Daughter Neferuptah true of voice

Atfih:

what is from the districts set as extra-deliveries of this granary to the overseer of the fields? so they should apportion out among them. ${ }^{687}$

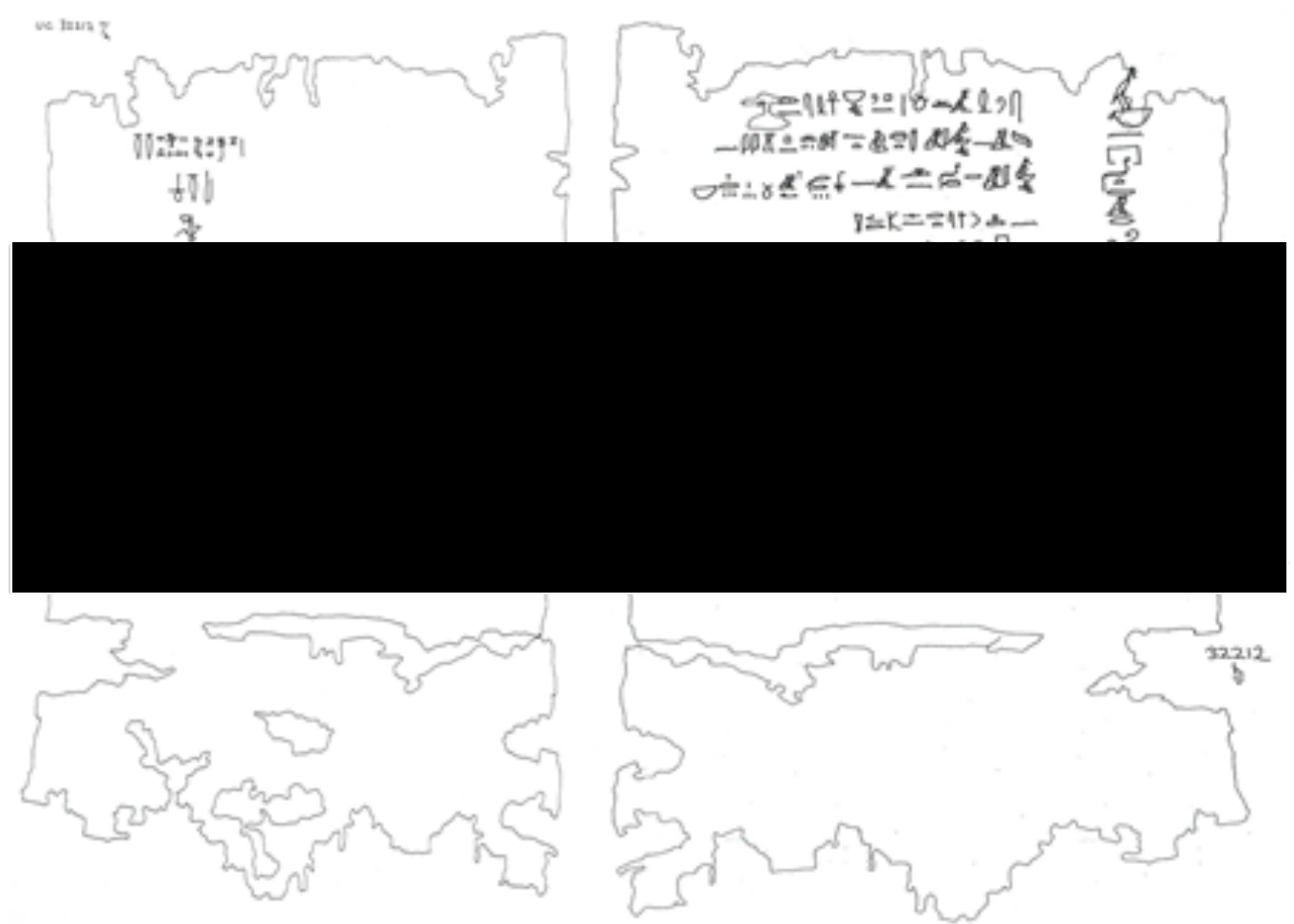

Fig. 5.10 Papyrus: The Petrie Museum UC32212, Collier and Quirke 2002: 138, 140.

${ }^{687}$ Collier and Quirke 2002: 139. 


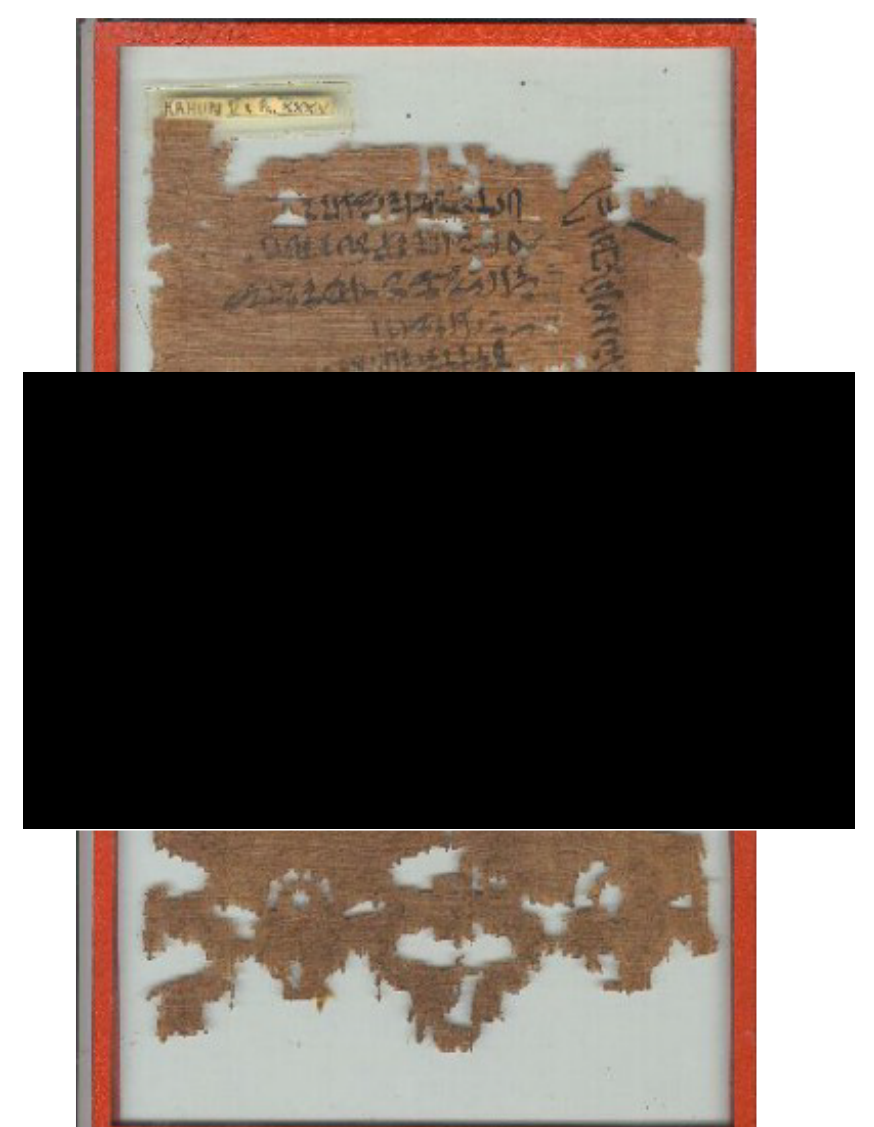

Fig. 5.11 Imperfect sheet of Papyrus: The Petrie Museum UC32212.

The use of the phrase "true of voice", $m 3^{\complement}$ hrrw, in this letter has been the basis for suggesting that Neferuptah died during the reign of her father Amenemhat III.

Proposed by Griffith and later supported by Farag and Iskander who excavated her pyramid, the fact that 'true of voice/deceased/justified' follows Neferuptah's name but not her father's may indicate that he was still alive at her death. Alternatively, $m 3^{\complement}$ hrw does not necessarily mean the person was deceased; it could also suggest the person is "acclaimed as right" 688 or destined to achieve a place of honor in the afterlife. ${ }^{689}$ 'True of voice' or 'Justified' may imply Neferuptah was not yet deceased but was expected to have a continuing high status in her afterlife. ${ }^{690}$ It is attested that $m 3^{e}$ hrw was used during co-regencies of two living pharaohs. ${ }^{691}$ This could have been the situation with Amenemhat III and Neferuptah.

If the death of Neferuptah had already happened before the letter was written, the "foundation" may allude to the completion of her pyramid enclosure. This could

\footnotetext{
${ }^{688}$ Anthes 1954: 23.

${ }^{689}$ Doxey 1998: 1, 91-93, 204.

${ }^{690}$ Farag and Iskander 1971: 105.

${ }^{691}$ Murnane 1977: 271; Wegner 1996: 278.
} 
not have been proposed by Griffith at the time of his publication in $1894^{692}$ since her pyramid would not yet be found for another half a century in 1956. Having had a long reign of about 45 years, Amenemhat III oversaw the construction of two pyramids for himself, one at Dahshur and another at Hawara. Considering this, Neferuptah's pyramid could have been and probably was finished during his lifetime as well. Although Neferuptah's pyramid is substantially smaller than her father's, the dimensions of their base bricks are the same for both pyramids, thus suggesting that they were built around the same time, likely together. ${ }^{693}$ Seen from the activity at Neferuptah's burial complex after her death the surviving papyrus could be further emphasizing her connection with Senwosret II and participation during the reign of Amenemhat III.

\subsection{Amenemhat III in a Sed-festival cloak, flanked by two royal women (Cat.} 29)

A surviving statue of Amenemhat III wrapped in a Sed-festival cloak and flanked by two royal women was found in 1911 at Kom el-Hisn. ${ }^{694}$ This group statue is now housed in the Egyptian Museum Cairo JE 43104 (Cat. 29; Fig. 5.12). The royal woman depicted on the statue's right is preserved from just below the breast down, while the woman on the left is preserved from the hips down. Although parts of the statue's base have survived, the names for both women have not remained. Both royal women are wearing tight fitting sheath dresses with their hands laid flat against their outer thighs. This triad style statue of two royal women, one either side of the pharaoh, is also seen during the reign of Senwosret III (Cat. 32, 33, 34). From surviving representations, the matching size of the three figures on this group statue with Amenemhat III (Fig. 5.12) is not well-attested within the Twelfth Dynasty, although this surviving statue suggests more artworks of this scale may have been made.

\footnotetext{
${ }^{692}$ Griffith 1898: 80.

${ }^{693}$ Base bricks average dimension $=46 \times 24 \times 14 \mathrm{cms}$. Farag and Iskander 1971: 2.

${ }^{694}$ Hirsch 2004: 133, 370 Dok. 333; Stünkel 2015: 95.
} 


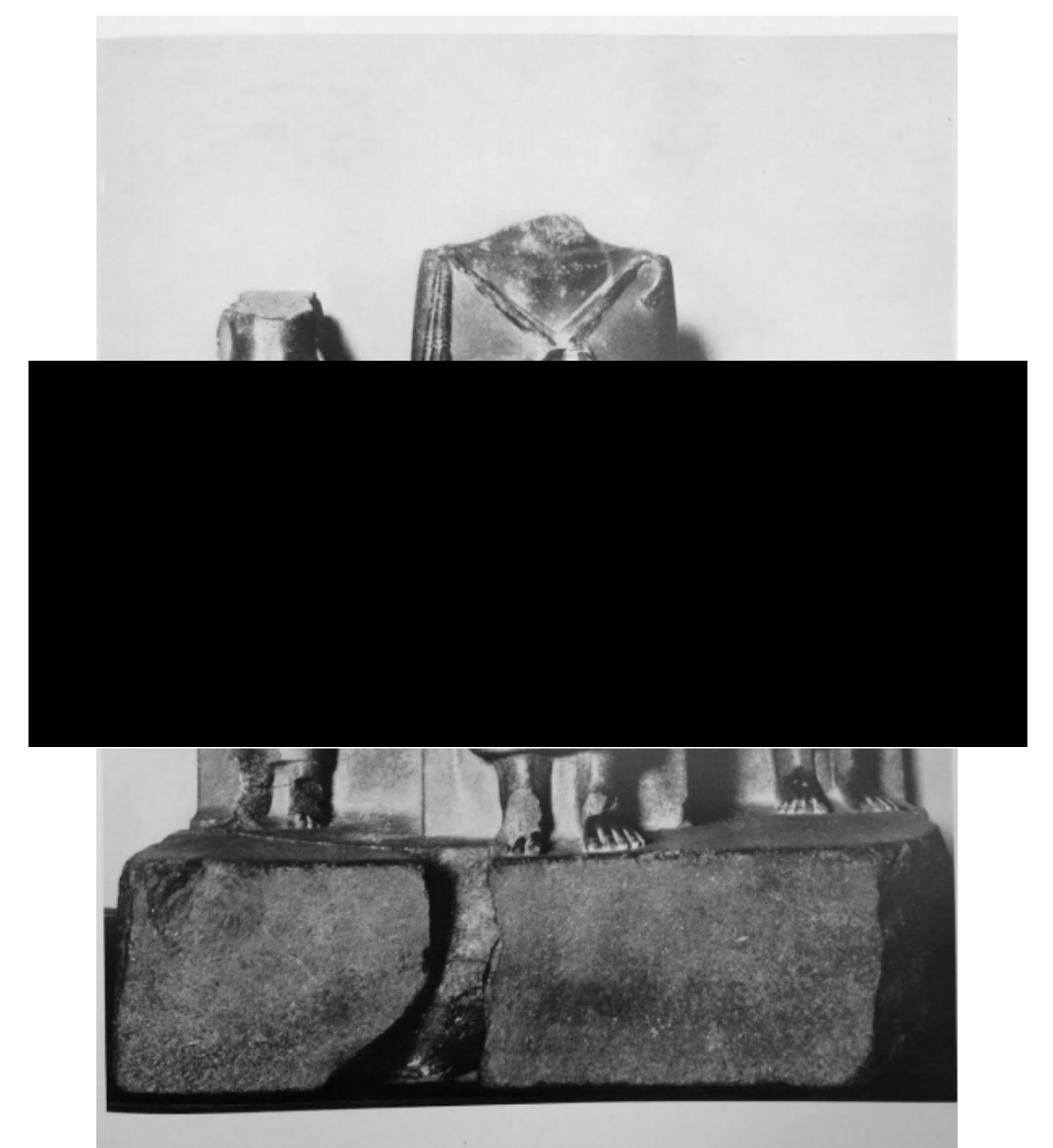

Fig. 5.12 Amenemhat III in a Sed-festival cloak flanked by two women, Egyptian Museum Cairo JE 43104; Stünkel 2015: 95.

The statue is considered the oldest surviving sculptural representation of royal women in the role of rejuvenating the pharaoh during the Sed-festival. ${ }^{695}$ The titles of the royal woman inscribed on the statue's right side are iryt-p't wrt h̆ts wrt hist

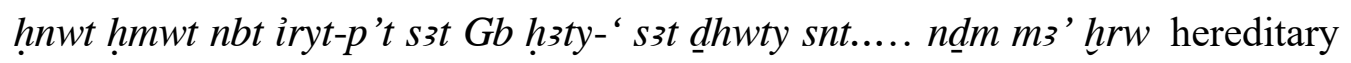
princess, great one of the hetes-scepter, great of praise, lady of all women, hereditary princess, daughter of Geb, nomarch, daughter of Thoth, sister..... pleasant, justified. Surviving from the left side are fragments stating iryt-p't wrt ḥts wrt ḥst ḥnwt ḥmwt $n b t$..... h. $w t h \underline{h r} n b t . .$. ' "nh.ty $\underline{d} t$ hereditary princess, great one of the hetes-scepter, great of praise, lady of all women..... Hathor lady..... may she live forever. ${ }^{696}$ It is possible that one of the royal women shown is Neferuptah, who was a prominent part of Amenemhat III's reign. Neferuptah's relief at Medinet Madi is the only surviving representation of a royal daughter with Amenemhat III. Along with this

${ }^{695}$ Connor and Delvaux 2017: 256; Stünkel 2015: 95; Stela of Seniankhu and Iy, Museum of Fine Arts Boston 13.3844, Leprohon 1985: 13.3844, Found at Sheikh Farag tomb 217, the stela states the "Sed-festival; Regnal year thirty" for the Pharaoh Amenemhat III.

${ }^{696}$ Transliteration by Sabbahy 1982: 210; Payraudeau 2015: 214. 
relief, Neferuptah had multiple other statues made which could have included the triad. Neferuptah's titulary often included titles such as hereditary princess and great of praise, but the titles daughter of Geb and daughter of Thoth are particularly religious and not found elsewhere in her titulary. Within the Temple of Medinet Madi, Neferuptah is shaking a Hathoric sistrum for the goddess Renenutet, which suggests Neferuptah did take part in religious activities alongside her father Amenemhat III and her titulary possibly reflected this.

If Sabbahy is correct in suggesting that both of the royal women represented are princesses instead of a mother and wife, ${ }^{697}$ the statue could then be depicting the princesses Neferuptah and Sobekneferu. Although Sobekneferu has no secure records of her titulary before becoming pharaoh, it can be assumed she was the daughter of Amenemhat III, a view that is supported by her connections to him during her reign. Neferuptah and Sobekneferu were the most prominent royal women linked with Amenemhat III and this statue could be a surviving example of their significance to his reign. Amenemhat III also had other daughters who could possibly be represented on this statue with him. This includes Neithikrety (RW45), who was a Priestess of Hathor and whose statue was discovered in the same context as one of Amenemhat III in the Sinai (Cat. 30; Fig. 6.52) ${ }^{698}$ Considering the surviving titles likely refer to princesses, the probable combinations would be Neferuptah and Neithikrety, or Neferuptah with Sobekneferu (before she became pharaoh).

Another possible candidate for one of the royal women shown is queen Aat (RW 38), who is an attested wife of Amenemhat III. She has no known material outside of her burial at Dahshur in which fragments of a stela (Fig. A.64) and an offering table (Fig. A.65) survive. ${ }^{699}$ From her surviving artifacts, it can be suggested that she was the mother of Neferuptah and, in this case, she could be one of the royal women represented on the statue. Three triad type statues that have survived from the reign of Senwosret III, show Queen Khenemetneferhedjet I, wife of Senwosret II and mother of Senwosret III, on the left along with the wife of Senwosret III, Queen Khenemetneferhedjet II (RW 25) represented on the right (Cat. 32, 33, 34). ${ }^{700}$ If the

\footnotetext{
${ }^{697}$ Sabbahy 1982: 210.

${ }^{698}$ Gardiner and Peet 1955: 105.

${ }^{699}$ For sarcophagus and canopic chest see Arnold 1987: 43-45.

700 Stünkel 2018: 25-27.
} 
Cairo statue of Amenemhat III flanked by two royal women follows this order, it is possible that his mother is represented on the left while his wife is on the right. There is no mother securely attested for Amenemhat III, but if this was a strict order of triad representations, it can be suggested that Queen Khenemetneferhedjet II is on the left and Queen Aat is on the right.

\subsection{Neferuptah's double burial}

Neferuptah is one of the best-known royal women of the Twelfth Dynasty because of her two possible burials at Hawara, one in her father's pyramid and another in her own complex. Amenemhat III's pyramid was plundered in antiquity, but Neferuptah's was never robbed, although it was used as a quarry in ancient times. ${ }^{701}$ Since Petrie's initial excavations of Amenemhat III's Hawara pyramid in 1898, multiple theories concerning Neferuptah's double burial have been compiled. At the time of Petrie's excavation, Neferuptah's own pyramid had not been found and consequently upon finding her burial equipment (see below Chapter 5.8.1) Petrie assumed she had died during her father's lifetime and was buried with him. ${ }^{702}$ After the excavations of her pyramid by Farag and Iskander in 1956, Petrie's theory was further developed. ${ }^{703}$ They suggested that she died during her father's reign and was temporarily placed inside his burial chamber before being transferred to her own pyramid. Nearly forty years after Farag and Iskander's publication, Allen proposed that Amenemhat III had originally planned for Neferuptah to be buried with him but that he must have died first causing the burial chamber to be permanently closed and Neferuptah to be buried in a separate pyramid. ${ }^{704}$ A recent suggestion by Grajetzki is that Neferuptah's double burial was symbolic, representing her connection with Amenemhat III. ${ }^{705}$ Additional to these suggestions, Neferuptah's double burial can be considered a cenotaph, which was a common feature of the late Twelfth Dynasty royal burial customs.

While all four theories can be supported by the evidence that is available, there is no definitive conclusion at this time. If Neferuptah died during her father's

\footnotetext{
${ }^{701}$ Farag and Iskander 1971: 2.

702 Petrie 1890: 17

${ }^{703}$ Farag and Iskander 1971: 105.

${ }^{704}$ Allen 1998: 47; Grajetzki 2014a: 69; Uphill 2000: 80, Uphill suggests both theories can be possible.

${ }^{705}$ Grajetzki 2016: personal communication; Grajetzki 2017: 36, 42.
} 
reign it is possible that Amenemhat III's burial chamber was used as a temporary holding place for her mummy until her pyramid was finished. However, if her and her father's pyramids were contemporary in construction, her mummy may have never been placed into Amenemhat III's. Since Neferuptah's pyramid is comparatively simple she may have been buried quite soon after her death. The construction includes a rectangular burial chamber that had seven immense limestone blocks that formed the roof, which were then covered by the superstructure of the pyramid..$^{706}$ The way the two sarcophagi are situated in Amenemhat III's burial chamber can also substantiate the argument that her mummy was not meant to permanently reside there. The second sarcophagus is almost makeshift on the basis that it is not freestanding and is situated between the king's sarcophagus and the eastern wall. It is made up of only two stone slabs for the head and foot with a lid rested on top and set into the wall. Essentially, the walls of the second sarcophagus were the side of the sarcophagus of Amenemhat III and the walls of the actual tomb (Fig. 5.13). ${ }^{707}$

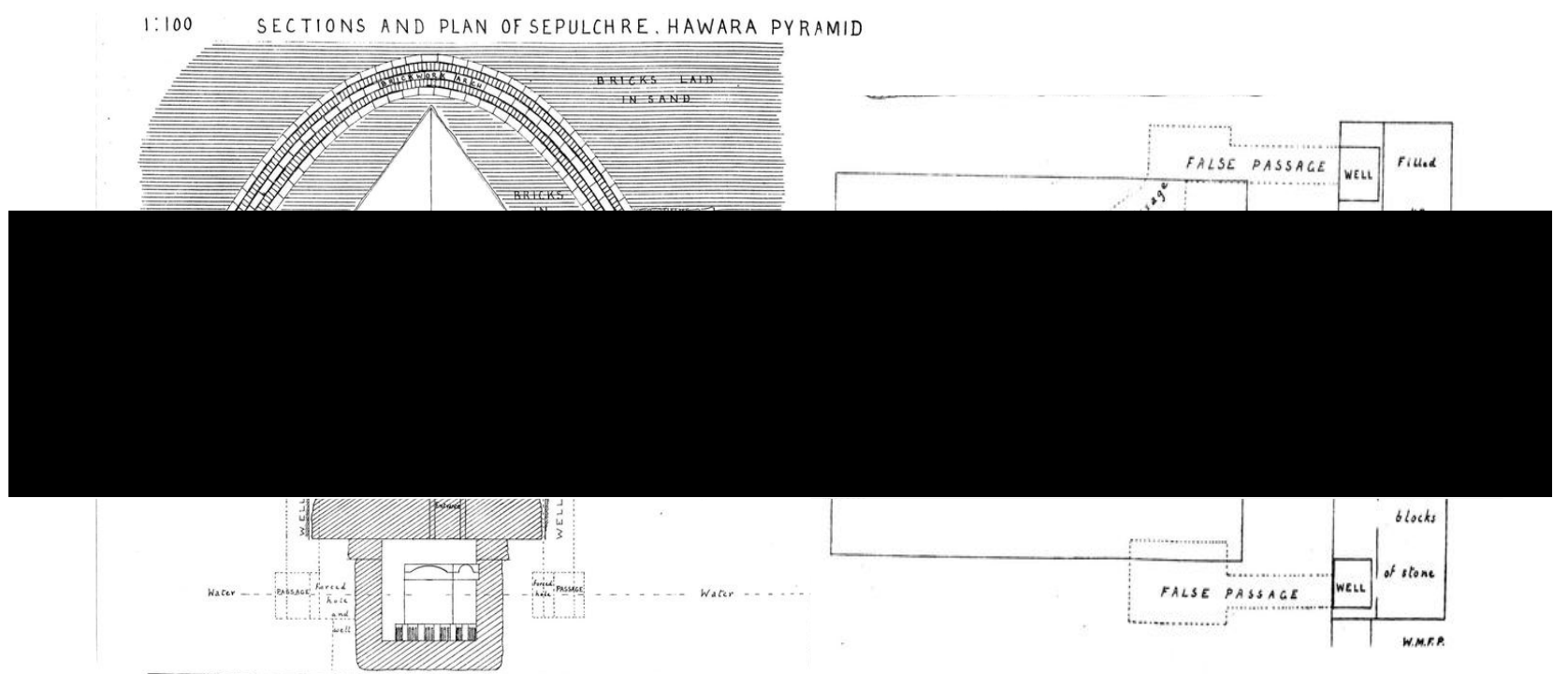

Fig. 5.13 The two sarcophagi in the burial chamber of Amenemhat III, Petrie: 1890: 17.

Neferuptah is the only daughter of Amenemhat III to have a surviving pyramid and an intact burial chamber. This also includes Sobekneferu whose burial has yet to be discovered, although she would have been buried as a pharaoh and not as a princess

\footnotetext{
${ }^{706}$ Farag and Iskander 1971: 3.

${ }^{707}$ Petrie 1890: 17; Grajetzki 2014a: 69
} 
(further discussed in Chapter 6). Although Neferuptah's double burial has been under debate since the excavation of her own pyramid in 1956, a cenotaph for her has not been thoroughly discussed. It is suggested here that her burial equipment found within the pyramid of Amenemhat III was an example of a cenotaph type burial. The royal women Khenemetneferhedjet I (RW 20) and Khenemetneferhedjet II (RW 25) both had cenotaphs at the complex of Senwosret III (Fig. 5.14).

Similarly, it is possible that Neferuptah's double burial was a way of demonstrating her significant position during Amenemhat III's reign.

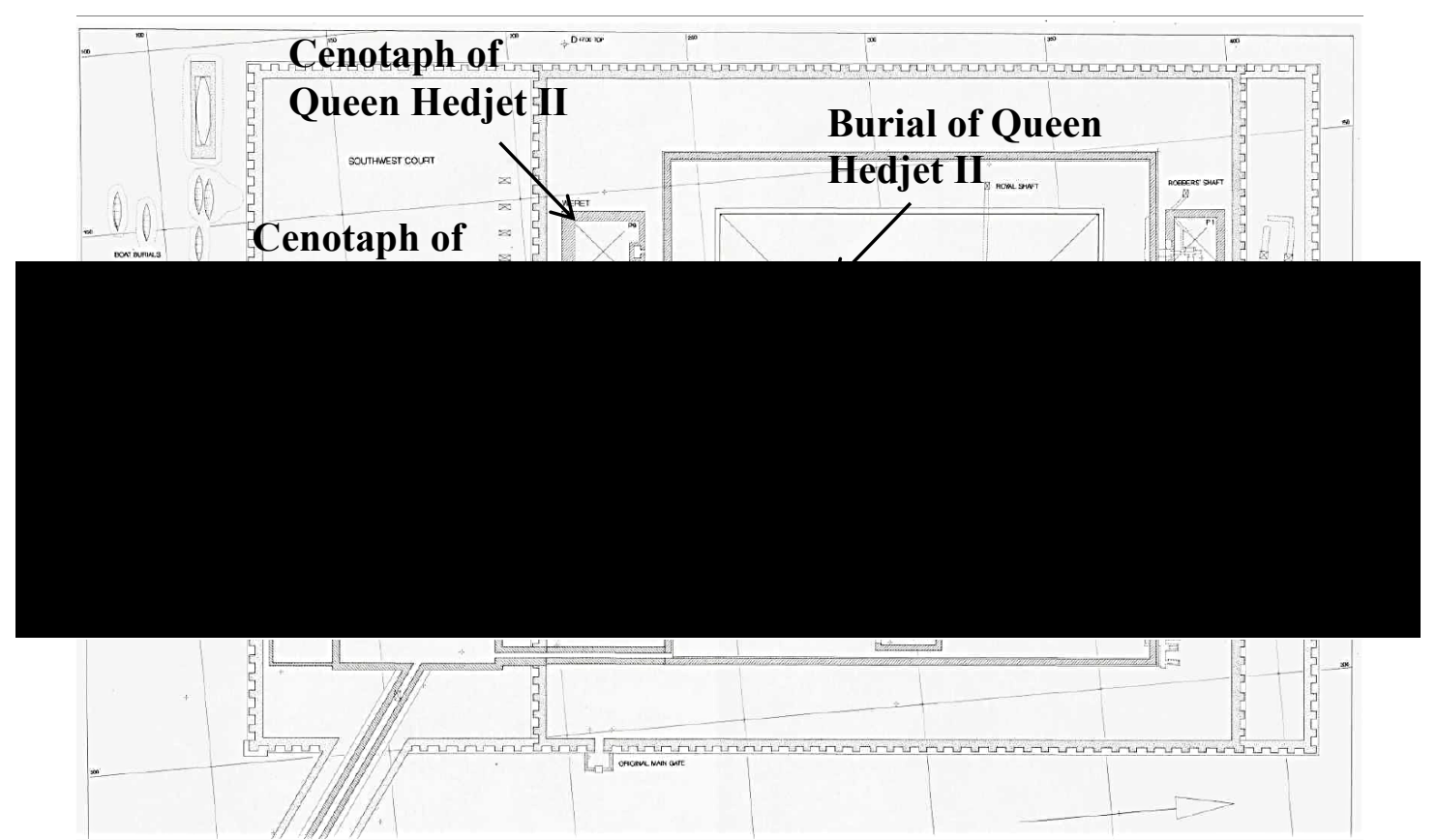

Fig. 5.14 The cenotaphs of queens Hedjet I and Hedjet II and burial of Queen Hedjet II, illustrations by author, Arnold 2002: Plan 1.

It is most likely that Amenemhat III's Dahshur pyramid was also a cenotaph, although there is discussion about the faulty construction of the underground chambers. If this is indeed the case, the cenotaph for Neferuptah would certainly fit the late Twelfth Dynasty burial pattern. ${ }^{708}$ Others who follow this pattern include the cenotaphs and burials of Senwosret III, Queens Khenemetneferhedjet (Hedjet I), Queen Khenemetneferhedjet (Hedjet II), Amenemhat III, and Neferuptah (Table 5.1). In the case of Neferuptah's double burial, the pyramid of Amenemhat III would

708 "The custom of having two burials was evidently not only restricted to kings" Grajetzki 2017: 38, Grajetzki also mentions the possible second burials of the Twelfth Dynasty royal women Neferet (RW 1), Neferu (RW 7), and Khenemetneferhedjet 1 (RW 20) Grajetzki 2017: 39-41. 
have been her cenotaph while her own pyramid was her actual burial place.

\begin{tabular}{|l|l|l|}
\hline \multicolumn{1}{|c|}{ Person } & \multicolumn{1}{|c|}{ Cenotaph } & \multicolumn{1}{c|}{ Burial } \\
\hline Senwosret III & $\begin{array}{l}\text { Pyramid of Senwosret III } \\
\text { and Queen Hedjet II at } \\
\text { Dahshur }\end{array}$ & $\begin{array}{l}\text { Pyramid of Senwosret II } \\
\text { possibly at Abydos }\end{array}$ \\
\hline Queen Hedjet I & $\begin{array}{l}\text { Pyramid of Senwosret III at } \\
\text { Dahshur }\end{array}$ & $\begin{array}{l}\text { Possible monument of } \\
\text { Hedjet I at el-Lahun }\end{array}$ \\
\hline Queen Hedjet II & $\begin{array}{l}\text { Pyramid of Queen Hedjet } \\
\text { II at Dahshur }\end{array}$ & $\begin{array}{l}\text { Pyramid of Senwosret III } \\
\text { and Queen Hedjet II at } \\
\text { Dahshur }\end{array}$ \\
\hline Amenemhat III & $\begin{array}{l}\text { Pyramid of Amenemhat III } \\
\text { and Queen Aat at Dahshur }\end{array}$ & $\begin{array}{l}\text { Pyramid of Amenemhat } \\
\text { III and Neferuptah at } \\
\text { Hawara }\end{array}$ \\
\hline Princess Neferuptah & $\begin{array}{l}\text { Pyramid of Amenemhat III } \\
\text { and at Hawara }\end{array}$ & Pyramid of Neferuptah \\
\hline
\end{tabular}

Table 5.1 Cenotaphs and burials of the late Twelfth Dynasty.

If Neferuptah did die during her father's lifetime and was buried within her own pyramid, Amenemhat III may have continued to use his pyramid as Neferuptah's cenotaph. As noted by Farag, there was no passage to Neferuptah's burial chamber within the pyramid, thus implying that she had died during the completion and her mummy was set inside immediately before the burial was closed. ${ }^{709}$ The surviving evidence demonstrates that Neferuptah was obviously highly important during Amenemhat III's reign. Whether for political, religious, or familial reasons, Neferuptah played a significant role in all three sectors. She was also essential for her father's successful afterlife. The offering tables from her pyramid and her father's (further discussed in Chapter 5.8.1) are noticeably similar, possibly from the same workshop. ${ }^{710}$ It can be suggested that a second set of burial equipment, similar to her own, was made to be left in the well chamber of her father's pyramid to complement her cenotaph burial.

\subsubsection{Burial equipment from the pyramid of Amenemhat III}

During his excavations of Amenemhat III's pyramid at Hawara, Petrie recorded a room that he called the "well chamber" (antechamber), which held alabaster burial equipment for Neferuptah. The equipment included an alabaster table of offerings and eight or nine large alabaster inscribed bowls in the shape of half a trussed duck.

\footnotetext{
${ }^{709}$ Farag and Iskander 1971: 106.

710 The number and type of offerings on the two tables are exactly the same. Grajetzki 2014a: 68 .
} 
Within the burial chamber itself only one large alabaster jar inscribed with Neferuptah's name was recovered. ${ }^{711}$ The alabaster offering table includes all sorts of food, which are inscribed with their descriptions and numbers (Fig. 5.15, 5.16, 5.17). On the offering table Neferuptah's name is not written in a cartouche

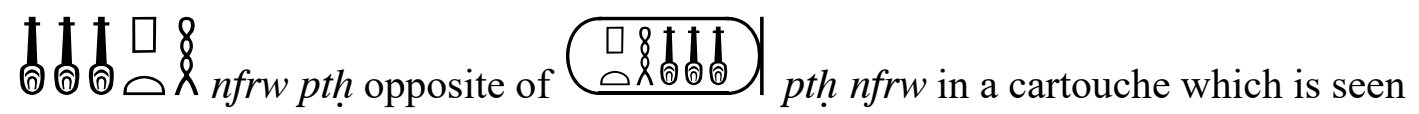
on the offering table found in her own pyramid. The idea of a second princess called Neferuptah can be excluded, although there is no obvious explanation for why her name is written without a cartouche on this offering table. Since the two offering tables from Amenemhat III's and Neferuptah's pyramids are so similar, it can be suggested they were certainly made for the same Neferuptah, but during different times of her life as her political status evolved.

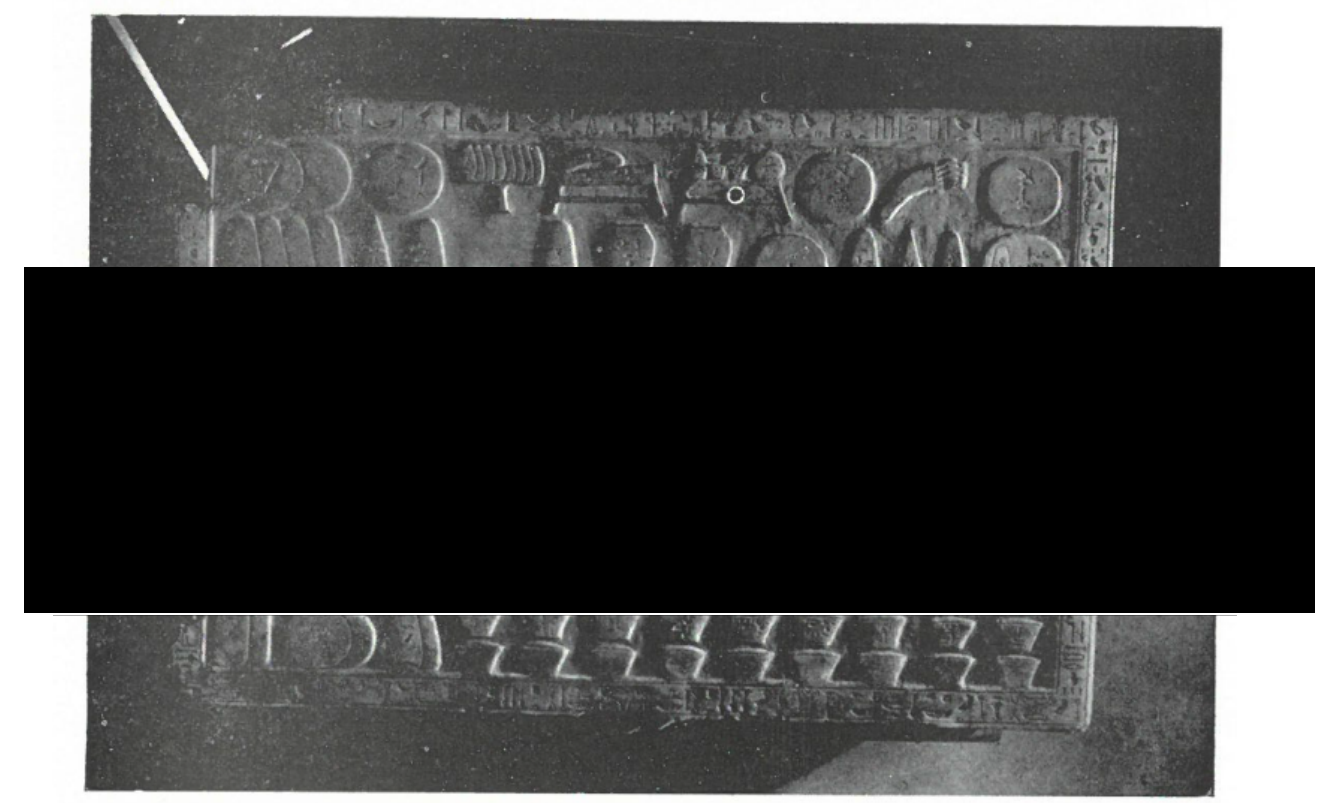

Fig. 5.15 Offering table found in the well chamber, Farag and Iskander 1971: VIIIa.

${ }^{711}$ Petrie 1890: 15-16. 


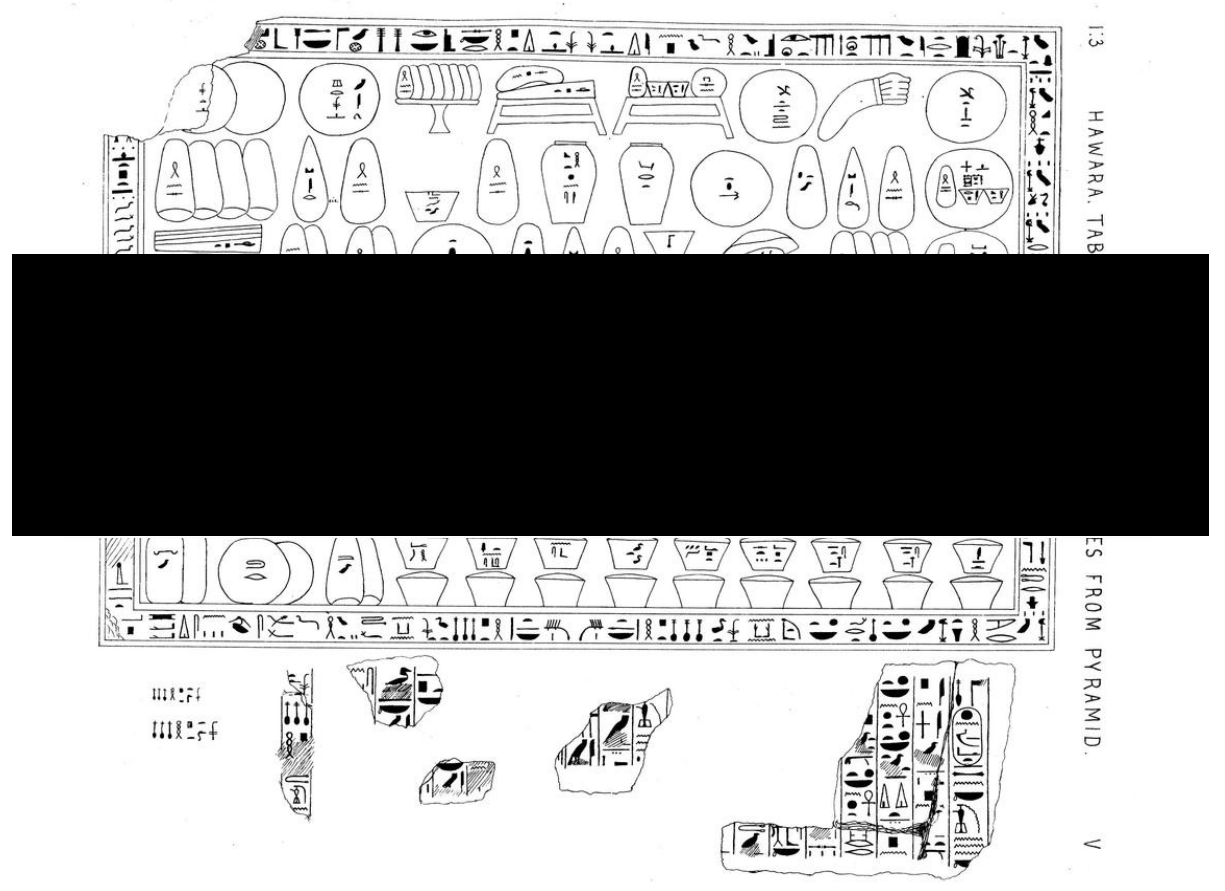

Fig. 5.16 Offering table found in the well chamber along with vase fragments, Farag and Iskander 1971: VIIIb.

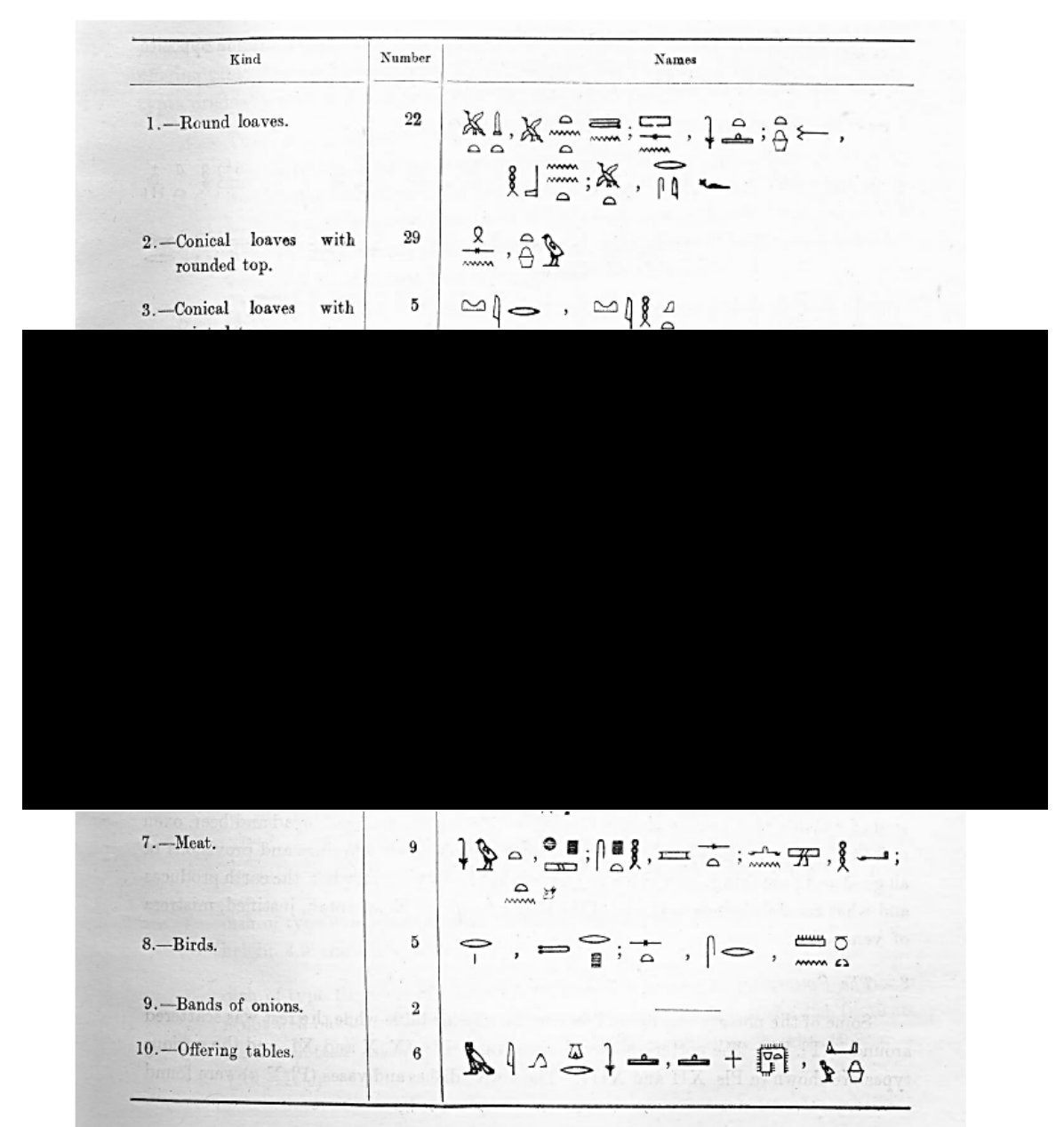

Fig. 5.17 Alabaster offering table with list of offerings, Farag and Iskander 1971: 9. 


\subsubsection{Burial equipment from the pyramid of Neferuptah}

Neferuptah's pyramid was excavated by Nagib Farag and Zaky Iskander in 1956, with their publication being the only source for her pyramid and burial. ${ }^{712}$ In their report, Farag and Iskander described dozens of items found within her chamber, including small amounts of her skin (Table 5.2). Most likely all the burial equipment was taken to the Egyptian Museum, Cairo. Neferuptah's pyramid is located about 2 $\mathrm{km}(1.25 \mathrm{mi})$ south east of her father's Hawara pyramid. The base of the pyramid was $35 \mathrm{~m}$ (114ft8in) long while the superstructure was made of mudbricks with casing stones. The burial chamber was roofed by seven large limestone blocks in their original positions, the largest being $433 \mathrm{~cm}(14 \mathrm{ft})$ in length and the smallest being $390 \mathrm{~cm}$ (12ft8in). After removing the roofing stones with the help of a crane, half of Neferuptah's burial chamber was found to be filled with $116 \mathrm{~cm}$ ( $3 \mathrm{ft} 8 \mathrm{in})$ of infiltration water. The water was pumped out and the chamber itself was measured to be $2.40 \mathrm{~m}$ (7ft9in) in height, $5.10 \mathrm{~m}$ (16ft7in) long, and $1.90 \mathrm{~m}$ (6ft2in) wide. Her chamber was divided into northern and southern parts, which constituted the offerings and burial.

${ }^{712}$ Farag and Iskander 1971. 


\begin{tabular}{|c|c|c|c|}
\hline Coffins & Jewelry & Ceremonial Staves & $\begin{array}{c}\text { Cosmetic } \\
\text { Equipment }\end{array}$ \\
\hline $\begin{array}{l}\text { Remains of the } \\
\text { rectangular coffin }\end{array}$ & Necklace & Mace head & $\begin{array}{l}\text { Small pieces } \\
\text { of white gesso }\end{array}$ \\
\hline $\begin{array}{l}\text { Remains of the } \\
\text { anthropoid coffin }\end{array}$ & Barrel shaped beads & The flail & $\begin{array}{l}\text { Small } \\
\text { alabaster vases }\end{array}$ \\
\hline $\begin{array}{l}\text { Broad collar inlaid in } \\
\text { the anthropoid coffin }\end{array}$ & $\begin{array}{l}\text { Broad collar and } \\
\text { counterpoise }\end{array}$ & Scepters & $\begin{array}{l}\text { Large } \\
\text { alabaster jar }\end{array}$ \\
\hline Sewert Necklace & $\begin{array}{l}\text { Small and large } \\
\text { hawk's heads of gold }\end{array}$ & Other staves & Kohl sticks \\
\hline $\begin{array}{l}\text { Silver locking } \\
\text { elements of the } \\
\text { coffin }\end{array}$ & Bracelets and anklets & $\begin{array}{l}\text { Semi-octagonal piece } \\
\text { of gesso covered } \\
\text { with gold leaf, } \\
\text { possibly used as a } \\
\text { knob of a dagger's } \\
\text { handle }\end{array}$ & \\
\hline $\begin{array}{l}\text { Eye-panel for the } \\
\text { rectangular coffin }\end{array}$ & $\begin{array}{l}\text { Kilt with a crouching } \\
\text { falcon amulet }\end{array}$ & One or more bows & \\
\hline $\begin{array}{l}\text { Panel of carnelian } \\
\text { beadwork }\end{array}$ & $\begin{array}{l}\text { Funerary apron with } \\
\text { faience tail }\end{array}$ & & \\
\hline
\end{tabular}

Table 5.2 Types of items found in Neferuptah's sarcophagus, table by author based upon Farag and Iskander 1971.

The burial equipment consisted of an offering table (Figs. 5.18, 5.19), sixty-nine different types of pottery, and three silver vases. Unlike the offering table found in Amenemhat III's well chamber, this one is made from black granite and has Neferuptah's name in a cartouche. It measures $61 \mathrm{~cm}(2 \mathrm{ft})$ in length, $50 \mathrm{~cm}(1 \mathrm{ft} 6 \mathrm{in})$ wide and $35 \mathrm{~cm}$ ( $1 \mathrm{ft} 1 \mathrm{in})$ height. The front of the offering table has a water channel for libations to be poured. The inscriptions include lists of typical offerings for the $k a$ of Neferuptah. They record thousands of bread and beer, oxen, and fowl, different types of geese, alabaster jars, clothing, incense, and ointments. 


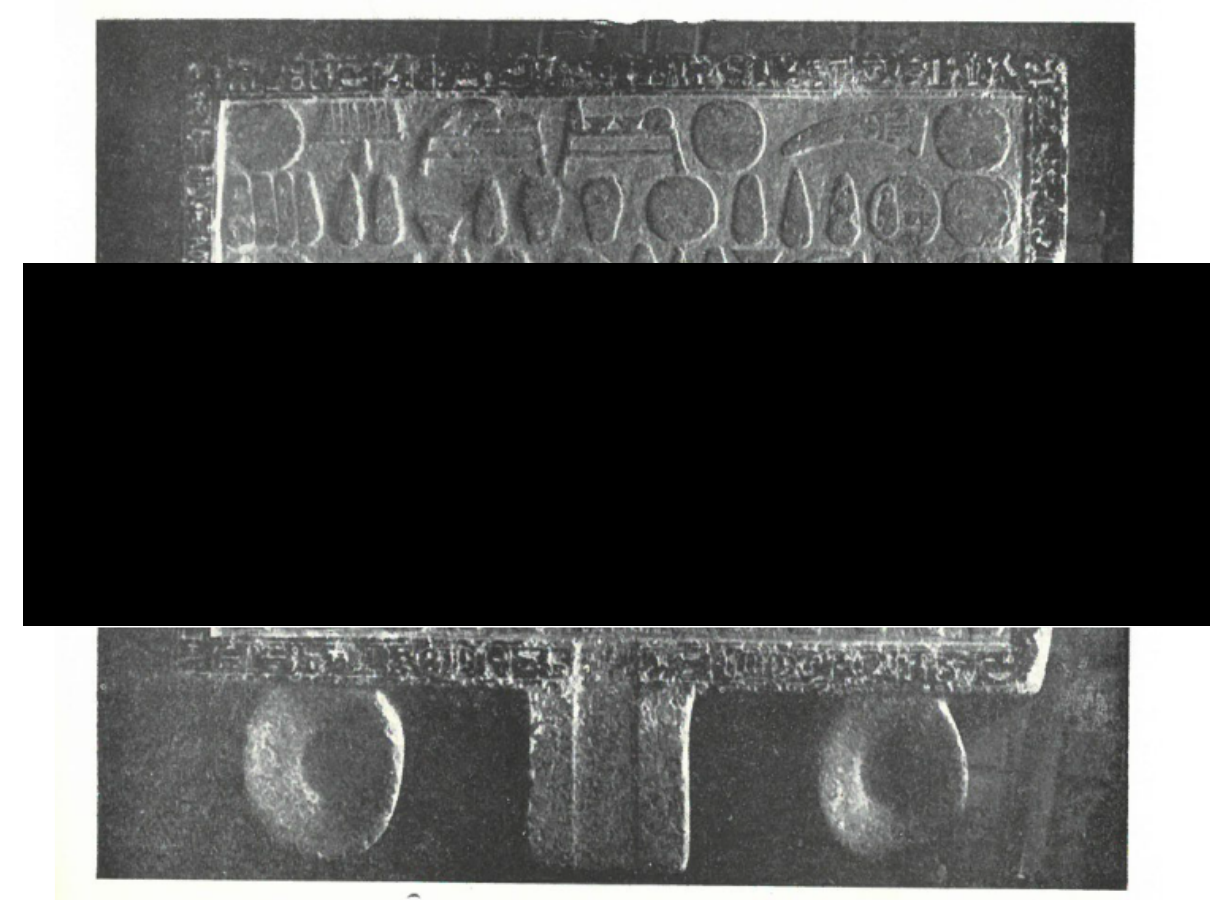

Fig. 5.18 Black granite offering table found in Neferuptah's pyramid, Farag and Iskander 1971: VIa.

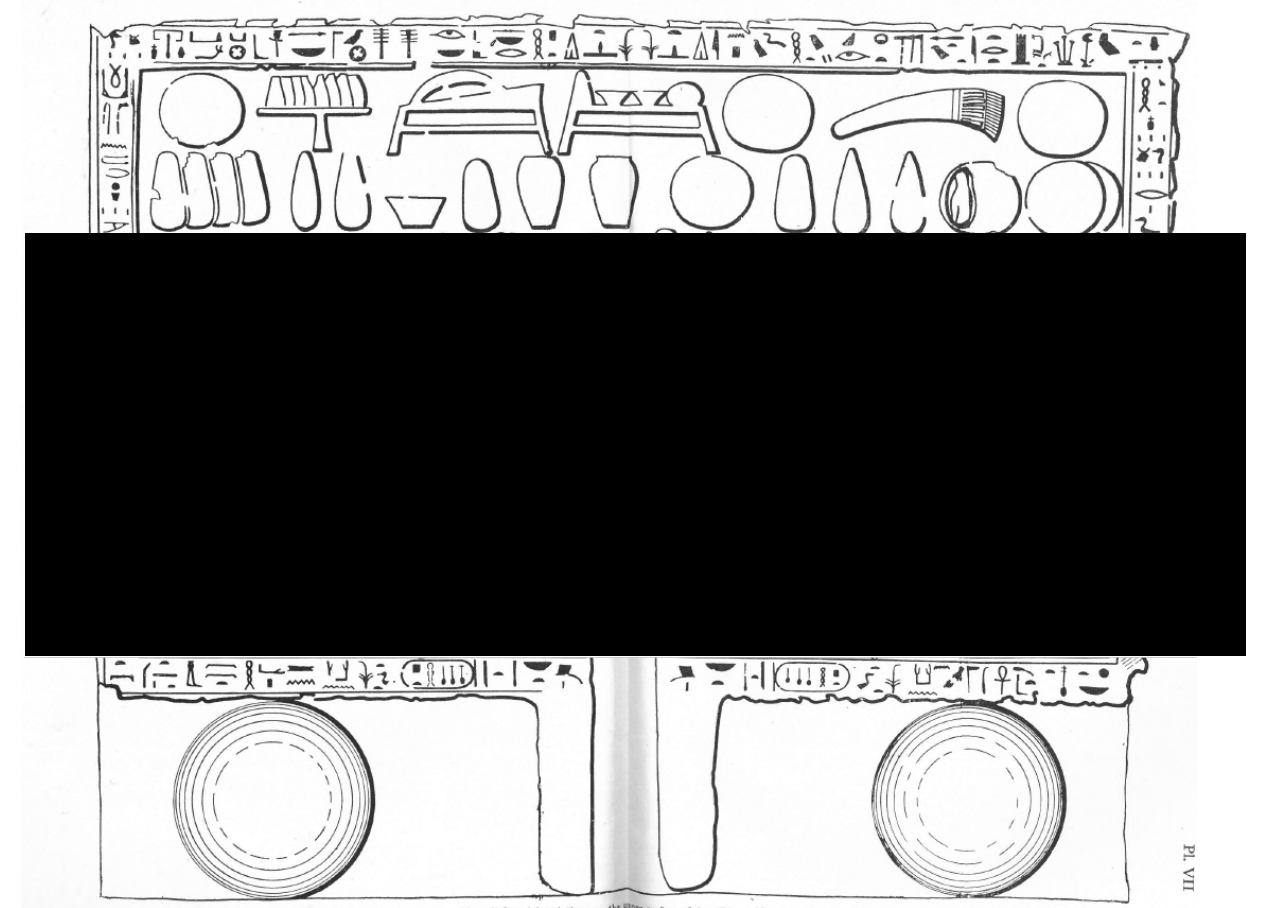

Fig. 5.19 Black granite offering table found in Neferuptah's pyramid, Farag and Iskander 1971: VIb.

Most of the pottery found in Neferuptah's pyramid was damaged and was either found on top of the offering table or on the floor. After some restoration the estimated total number of pots of different types is sixty-nine. These include three rounded-bottom narrow-necked jars with stands, fifty-nine votive dishes and vases along with seven other large pottery dishes. Her red coated pottery is considered a 
rough type which was regular for royal women and was probably used for food offerings. ${ }^{713}$ In contrast to other pottery finds for the burials of Twelfth Dynasty royal women, Neferuptah did not have queens' ware. Queens' ware or Pyramid ware has been described by Susan Allen as a type of pottery first developed during the Twelfth Dynasty, often found in the burials of royals, mostly women. ${ }^{714}$ The type is characterized by a thick red polished coating over the entire surface. The vessels are all small to medium in size and the forms are simple and were used from the reign of Senwosret II until the Thirteenth Dynasty (Fig. 5.20, 5.21).
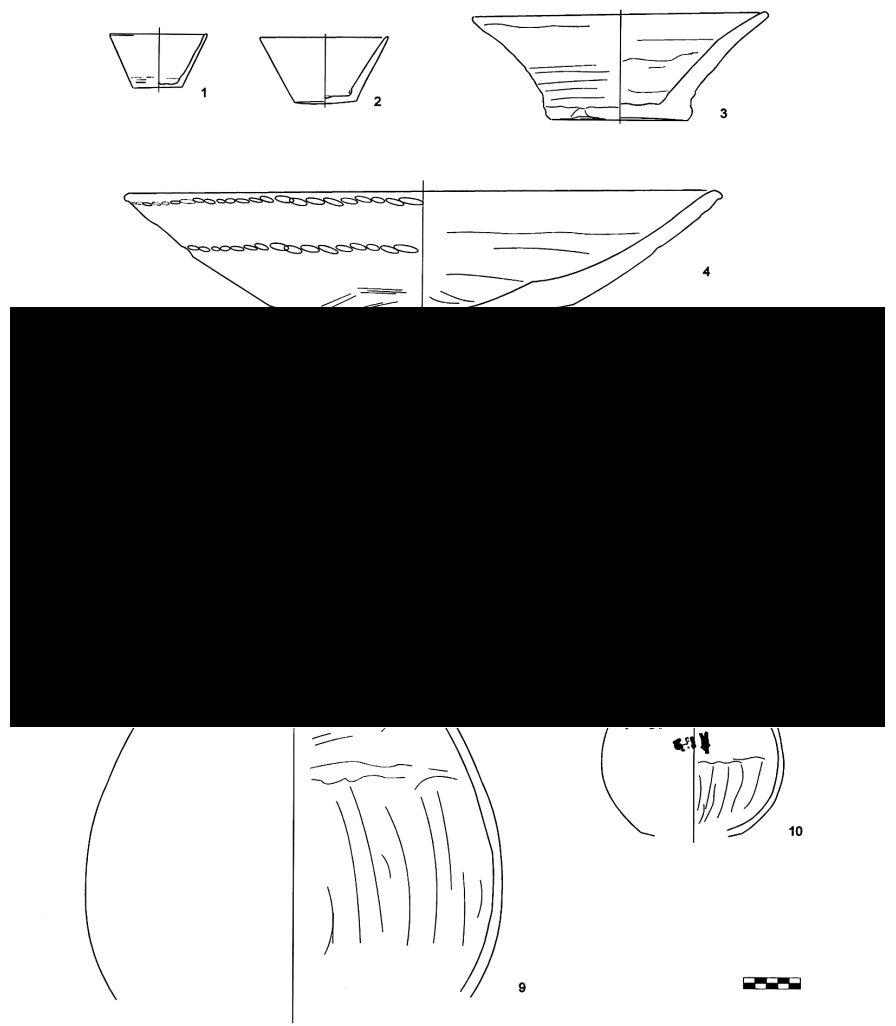

Fig. 20 Pottery types of Queen Khenemetneferhedjet I (RW 20) minimum of 260 vessels, 1. Nile B, plain; 2. Pyramid Ware; 3. Nile $\mathrm{C}$ red coated all over; 4 . Nile $\mathrm{C}$ red band over rim and on interior; 5. Pyramid Ware; 6. Pyramid Ware; 7. Nile B red coated on exterior, 8. Pyramid Ware; 9. Marl C; 10 March C, Allen 1998: 45.

${ }^{713}$ Farag and Iskander 1971: 12.

${ }^{714}$ Allen 1998: 47; Grajetzki 2014a: 35. 


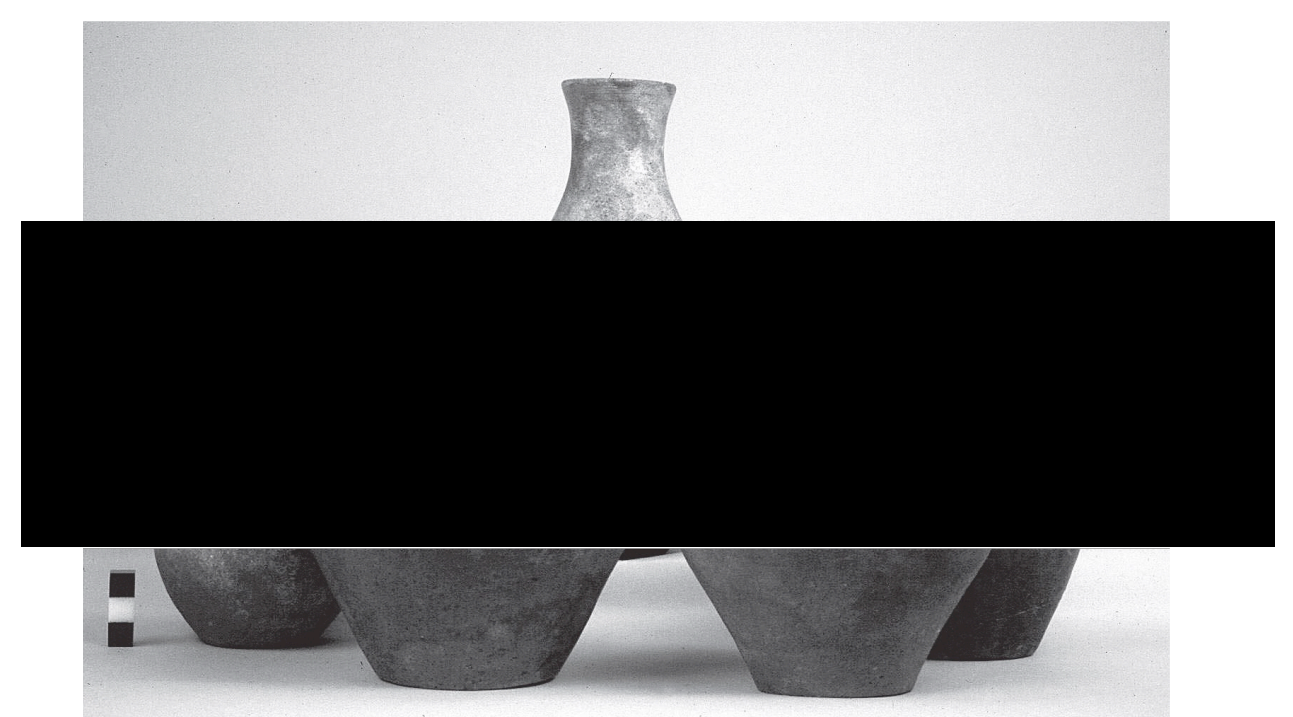

Fig. 21 Queens' ware from the tomb of Queen Khenemetneferhedjet I (RW 20), Allen 2009: 326.

The queens' ware of Princess Nubhetepetkhered is the only known examples for a royal woman from the Thirteenth Dynasty. ${ }^{715}$ The low usage during the Thirteenth Dynasty may explain why Neferuptah did not have this type of ware near the end of the Twelfth Dynasty. Neferuptah's burial did not include queens' ware or common pottery, only her plates and model vessels have parallels from the time period. It could also be suggested that during her life time Neferuptah was perceived as more than a princess or a queen, perhaps the heir to the throne and her burial should consist of a unique collection of pottery.

There were three silver vases discovered in her burial chamber, one that was in the offering section and two with her burial. Two tall silver vases were found on either side of her sarcophagus, along with a smaller vase that resembles later New Kingdom style. ${ }^{716}$ During the Middle Kingdom silver was considered to be a prized material ${ }^{717}$ and could be imported from other countries such as Greece. ${ }^{718}$ Neferuptah's three vases were the first silver set found dating to the Middle Kingdom due to bronze and wood being the usual materials for these vase types. Her heaviest vase, including the lid, weighed $1250 \mathrm{~g}(2.8 \mathrm{lbs})$. They were probably originally set together on a stand, but due to infiltration water two vases shifted sections. The jars are firmly identified as Neferuptah's because of identical inscriptions on the bodies of the vases as, translated by Farag as:

\footnotetext{
715 Allen 1998: 47

${ }^{716}$ Grajetzki 2014a: 67.

${ }^{717}$ Gale and Stos-Gale 1981: 103.

718 Ogden 2000: 170.
} 
A boon which the king gives to Ne-maat-re, Geb, Ptah-Sokar, Osiris Sobek the Fayumite, residing in the Fayum, The Great Ennead of gods and the Small Ennead of gods, that they may give an invocation- offering consisting of bread and beer oxen and fowl, offerings, alabaster, clothing and incense to the hereditary princess, the king's daughter Neferwptah true of voice. ${ }^{719}$

Neferuptah's sarcophagus was found at the south west part of the burial chamber and is now located in the Egyptian Museum, Cairo. The sarcophagus and the lid were both made from a single block of red granite. Her sarcophagus is immense and is the "largest of its type" (rectangular coffin made from a single block of granite). ${ }^{720}$ Her sarcophagus is larger than her father's sarcophagus in his Hawara pyramid (Table 5.3; Fig. 5.22). Both of their sarcophagi have a palace façade decoration at the bottom, but Neferuptah's sarcophagus is made from granite, which was used more often than Amenemhat III's quartzite sandstone. ${ }^{721}$ Her sarcophagus also contains an inscription with her name written inside a cartouche, while Amenemhat III's does not include any phrases. Farag and Iskander translate Neferuptah's sarcophagus inscription as

An offering given by the king to Osiris, lord of life, for the $k a$ of the member of the elite, the great one of the hetes-scepter, the great one of honor, the beloved king's daughter of his body, Neferuptah, true of voice. ${ }^{722}$

\begin{tabular}{|l|l|l|l|l|l|l|}
\hline \multicolumn{1}{|c|}{ Neferuptah } & \multicolumn{2}{c|}{ Length } & \multicolumn{2}{c|}{ Width } & \multicolumn{2}{c|}{ Height with lid } \\
\hline External & $3.06 \mathrm{~m}$ & $10 \mathrm{ft}$ & $1.54 \mathrm{~m}$ & $5 \mathrm{ft}$ & $2.31 \mathrm{~m}$ & $7 \mathrm{ft} 6 \mathrm{in}$ \\
\hline Internal & $2.52 \mathrm{~m}$ & $8 \mathrm{ft} 3 \mathrm{in}$ & $98 \mathrm{~cm}$ & $3 \mathrm{ft} 2 \mathrm{in}$ & & \\
\hline Amenemhat III & \multicolumn{3}{|c|}{ Length } & \multicolumn{2}{c|}{ Width } & \multicolumn{2}{c|}{$\begin{array}{c}\text { Height without } \\
\text { lid }\end{array}$} \\
\hline External & $2.7 \mathrm{~m}$ & $8 \mathrm{ft} 8 \mathrm{in}$ & $1.2 \mathrm{~m}$ & $4 \mathrm{ft}$ & $1 \mathrm{~m}$ & $3 \mathrm{ft} 5 \mathrm{in}$ \\
\hline Internal & $2.2 \mathrm{~m}$ & $7 \mathrm{ft} 3 \mathrm{in}$ & $79 \mathrm{~cm}$ & $2 \mathrm{ft} 6 \mathrm{in}$ & & \\
\hline
\end{tabular}

Table 5.3 Measurements of the sarcophagi of Neferuptah and Amenemhat III sarcophagi by author, based upon Farag and Iskander 1971: 17; Petrie 1890: 17.

\footnotetext{
${ }^{719}$ Farag and Iskander 1971: 12.

${ }^{720}$ Farag and Iskander 1971: 17-24; Grajetzki 2014a: 63.

${ }^{721}$ Aston, Harrell, and Shaw 2000: 53.

${ }^{722}$ Grajetzki 2014a: 63.
} 


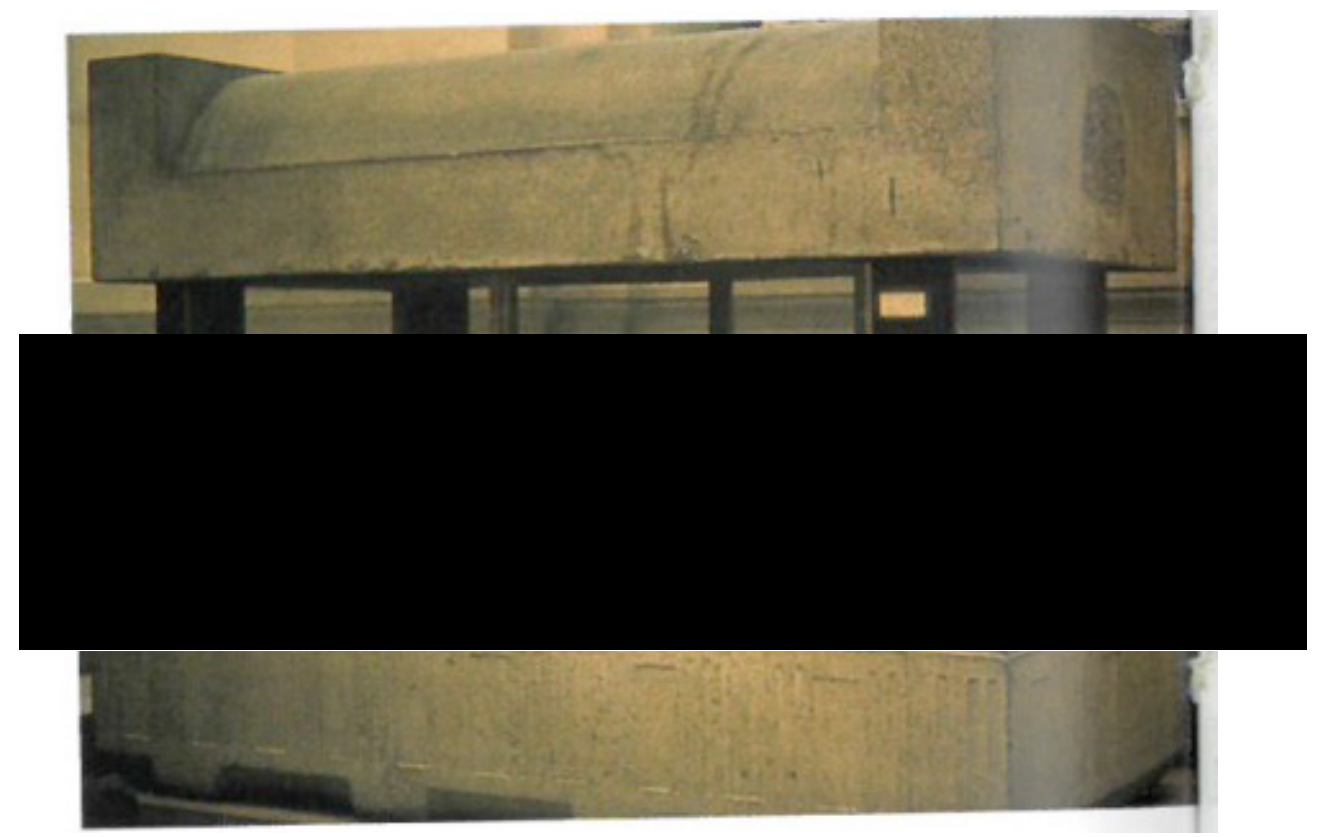

Fig. 5.22 Neferuptah’s granite sarcophagus Egyptian Museum Cairo.

The sarcophagus also contained many items buried with Neferuptah's body. These included two wooden coffins with diverse types of jewelry, staves, and cosmetic equipment. Both wooden coffins were almost completely disintegrated due to the water damage. The surviving inscriptions from Neferuptah's rectangular wooden coffin are heavily fragmented, but Grajetzki notes they are most similar to the great king's wife Hatshepsut of the early Eighteenth Dynasty rather than other coffins from the Middle Kingdom. ${ }^{723}$ The rectangular coffin would have been around $2 \mathrm{~m}$ (6ft6in) long with an inlaid eye panel. Within the few surviving inscriptions Neferuptah's name is found spelled nfrw pth without a cartouche instead of pth $n f r w$ within a cartouche, which is contrary to her sarcophagus. Her anthropoid coffin would have had a broad collar and sewert necklace of a large carnelian bead on the chest. Some original gold leaf was recovered but no inlaid eyes were found for the coffin. $^{724}$

The jewelry has been reconstructed and is located within the Egyptian Museum Cairo. ${ }^{725}$ Neferuptah's necklace would have fitted closely to her neck and is comprised of two strings with fifty-eight carnelian and twenty-nine carnelian beads. Her broad collar is made from two shouldered hawk heads with fifteen rows of beads

\footnotetext{
${ }^{723}$ For full discussion of Neferuptah's middle wooden box see Grajetzki 2005b: 55-61.

${ }^{724}$ Farag and Iskander 1971: 62.

${ }^{725}$ Musuem numbers are currently unknown. For Neferuptah's fly whisk scepter, Egyptian Museum Cairo JE 90200 see Ziegler 2008: 312, cat. 139.
} 
and a falcon-headed counterpoise. There is no other recorded identical Twelfth Dynasty broad collar to Neferuptah's, the closest being that of the Princess Nubhotep's (RW 43). Neferuptah's bracelets were made from alternating strings of carnelian and feldspar while the anklets were made completely of carnelian beads. Originally worn around the abdomen, Neferuptah's kilt displays her closeness with the protection of Horus. ${ }^{726}$ As an amulet attached to the kilt, a crouching falcon would have been situated on the wrappings above the mummification incision on the left side of the body. ${ }^{727}$ A very similar falcon amulet is found on the kilt of Senebtisi, now located in the Metropolitan Museum of Art, New York (Fig 5.23). ${ }^{728}$ Although Senebtisi's royal status and time of death are still disputed, ${ }^{729}$ her kilt is similar to that of Neferuptah's. Princess Neferuptah's funerary kilt would have been worn on top of the linen bandages, and similar to Senebtisi, her kilt would have had a bull's tail. On Neferuptah's kilt each string of beads to the right starts with a lotus flower and each string to the left begins with a papyrus flower symbolizing the protective significance of Upper and Lower Egypt. It is most likely the kilt would have had a name plate of wood or silver. These types of kilts were exclusively for royal women who had the right to wear this style of representing Upper and Lower Egypt. ${ }^{730}$

\footnotetext{
${ }^{726}$ Farag and Iskander 1971: 72.

727 Patch 2015: 239-240.

${ }^{728}$ Garment of Senebtisi: Metropolitan Museum of Art 08.200.29; Falcon amulet of Senebtisi: Metropolitan Museum of Art 08.200.42a.

${ }^{729}$ Grajetzki 2014a: 34-35.

${ }^{730}$ Farag and Iskander 1971: 78.
} 


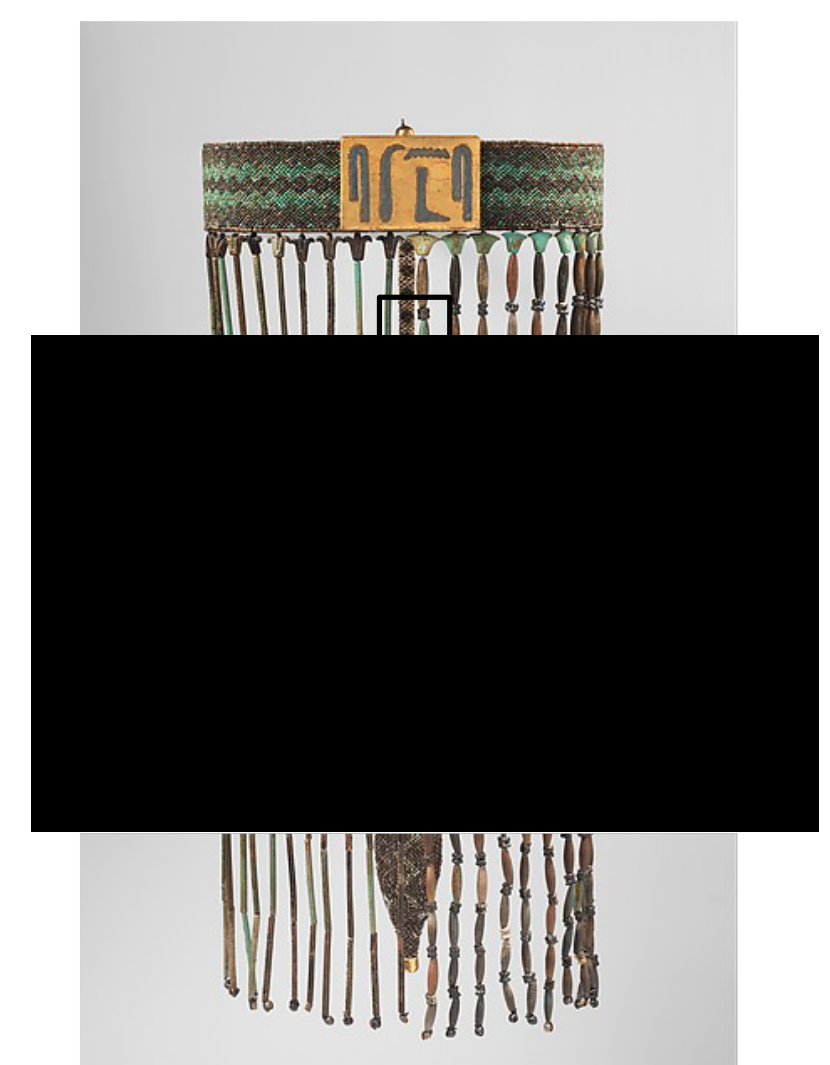

Fig. 5.23 Kilt of Senebtisi, Metropolitan Museum of Art New York 08.200.29.

Neferuptah also had ten cosmetic vases that are unparalleled from the Middle Kingdom. Eight vases contained perfumes and ointments and two others contained green and black kohl. Two kohl sticks made of silver accompanied the kohl vases. At the time of excavation these were the only silver kohl sticks ever discovered. ${ }^{731} \mathrm{~A}$ large alabaster jar was found that once contained a type of medical treatment for eyes. The treatment being partly resin, galena, and common salt, Iskander references Eber's medical papyri 393, 421, 430, and $401^{732}$ and suggests Neferuptah probably had leukoma, which affects the cornea by causing white spots. He further proposed that the Egyptians may have believed Neferuptah needed to continue the medicinal treatment after death, which is why it was included in her burial equipment. ${ }^{733}$

Within her sarcophagus, a set of divine staves were found. Parts of scepters and a flail, a gesso-coated gold leafed dagger knob, one or more bows, and a mace were among the surviving pieces. The wooden handles for the flail and mace head had disintegrated. The surviving flail beads are made from faience, gold, and carnelian and the alabaster mace head is of a pear shape. Among the identifiable

\footnotetext{
${ }^{731}$ Farag and Iskander 1971: 96.

732 Ebell 1937: 68-76.

${ }^{733}$ Farag and Iskander 1971: 96-99, 115.
} 
staves and surviving fragments, Neferuptah was buried with at least a w3s and a d'm scepter. During the Twelfth Dynasty it was commonplace for staves and weapons to be routinely buried with royal women. ${ }^{734}$ They were also buried with scepters resembling those of gods and not goddesses. ${ }^{735}$ The frequent presence of these types of symbols of authority among royal female burials conveys that the equipment was used as indicators for the women's equal place in the afterlife.

\subsection{Neferuptah's political tenure and familial connections}

Neferuptah is the best documented royal child from Amenemhat III's reign. She is one of seven known or strongly presumed daughters of Amenemhat III, which include the princesses Sit..(RW 36), Hathorhotep (RW 42), Nubhotept (RW 43), Sithathor II (RW 44), Neithikrety (RW 45), and Sobekneferu (RW 47). Out of these six daughters, Neferuptah is the only princess to have a surviving burial that is located outside that of the pharaoh's pyramid complex. The burials for Hathorhotep, Sithathor, and Nubhotept are located in the pyramid complex of Amenemhat III at Dahshur. Inscribed canopic jar fragments for Hathorhotep ${ }^{736}$ (Fig. 5.24) and Nubhotep were found within the underground compartments.

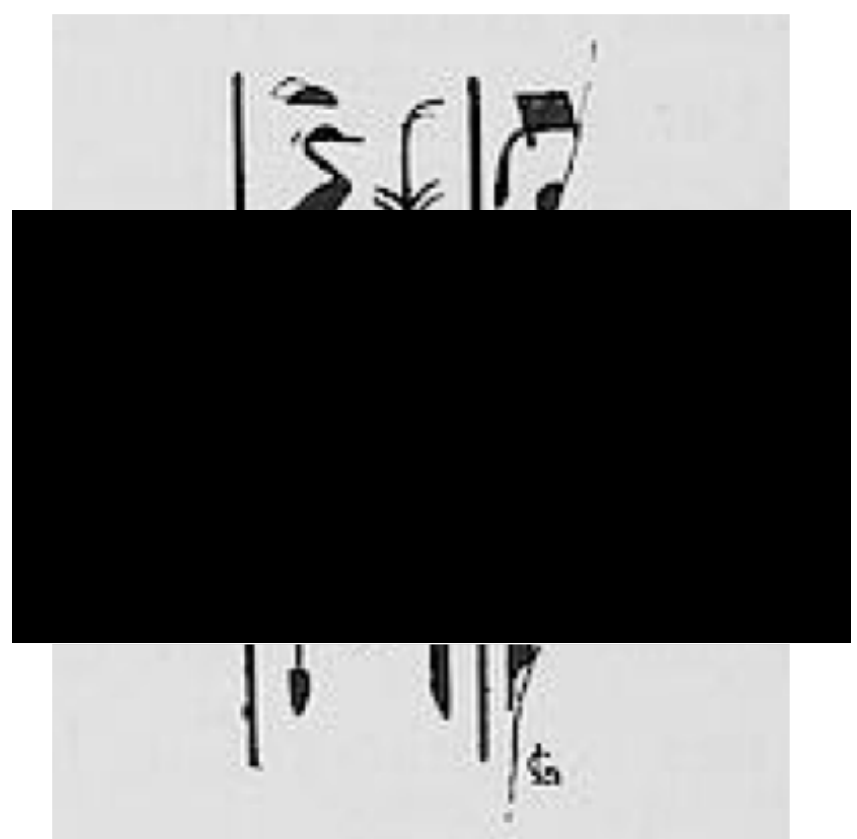

Fig. 5.24 Canopic jar fragment of Hathorhotep, De Morgan 1903: 105.

\footnotetext{
${ }^{734}$ Grajetzki 2014a: 10, 147.

${ }^{735}$ Farag and Iskander 1971: 82.

${ }^{736}$ De Morgan 1903: 105; Grajetzki 2014a: 194; Dodson 2004: 96.
} 
The royal women Sithathoryunit, Ita, Khenmet, Itaweret, and Sathathromeryt also had burial equipment associated with Amenemhat III. This possibly suggests that they were daughters of Senwosret II and Amenemhat II, but that they were also buried during the reign of Amenemhat III. ${ }^{737}$ As a result of this system of burying royal daughters with their equipment one and two generations later, it is possible that a wand and bowl fragment (Figs. 5.25, 5.26) found in the pyramid complex of Senwosret I at Lisht belong to Neferuptah and Sobekneferu of the late Twelfth Dynasty. Neither Neferuptah nor Sobekneferu were buried near Senwosret I, but objects of daily life such as wands and stands could have been placed there as offerings for or by the royal women. The wand and offering stand fragments were found in a "rubbish"738 or "old material"" 739 pile and are thus not in their original context. Twelfth Dynasty royal women shared certain name elements, such as Khenemetneferhedjet, Neferu, and Hathor. It is possible there were two princesses named Neferuptah and Sobekneferu during the reign of Senwosret I and then again in the late Twelfth Dynasty under Amenemhat III. However, it is equally possible and more likely that the wand and offering stand were placed at the Senwosret I's complex during the late Twelfth dynasty and ended up in a fragment heap. ${ }^{740}$

\footnotetext{
${ }^{737}$ Grajetzki 2014a: 46, 49.

738 Hayes 1946: 194.

${ }^{739}$ Arnold 1992: 58.

${ }^{740}$ Arnold 1992: 58; Grajetzki 2014a: 190, 207 note 198; Hayes 1946: 194: Ryholt 1997: 213. Until further information or material is uncovered, both arguments can be supported.
} 


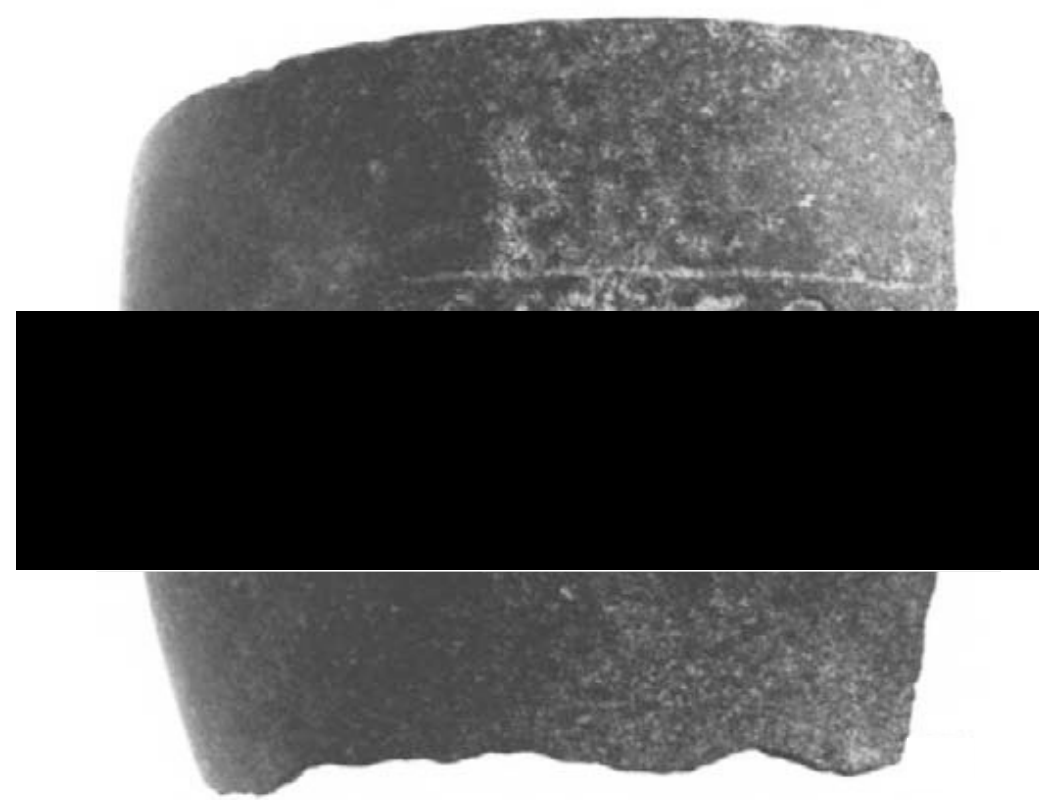

Fig. 5.25 Stone fragments with the name Sobek, probably Sobekneferu, Arnold 1992: pl. 71a, 23.

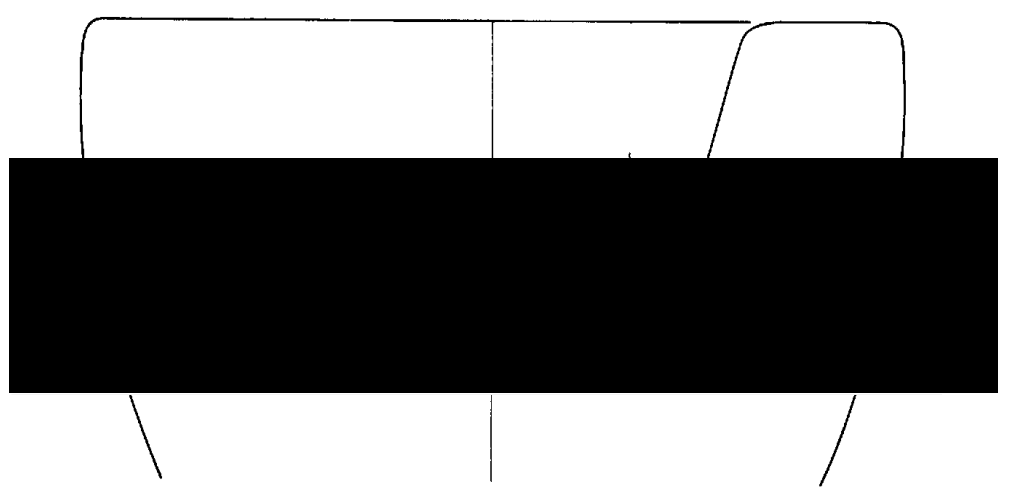

Fig. 5.26 Line drawing of the stone fragment with the name Sobek, probably Sobekneferu, Arnold 1992: pl. 71a, 23.

There is also a fragment of a papyrus, said to be from Dendera, which states: ' $O$

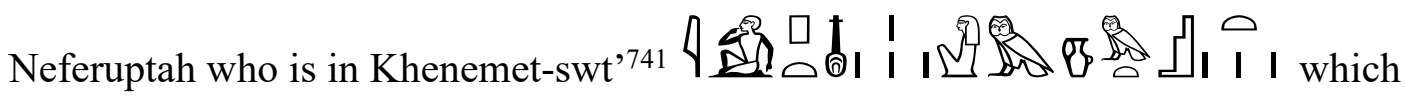

likely refers to the same Neferuptah. On the wand and offering stand fragment neither Neferuptah or Sobekneferu's names are encircled within a cartouche. If these two princesses refer to the Neferuptah and Sobekneferu of the late Twelfth Dynasty, the wand and bowl could only have been placed at the pyramid complex of

\footnotetext{
${ }^{741}$ Hieroglyphs and translation: Farag and Iskander 1971: 104. Although the papyrus includes the area of Senwosret I's pyramid, the provenance of the fragment is insecure.
} 
Senwosret I during their extent as princesses. This could include the time before Neferuptah received her cartouche as a princess and before Sobekneferu became pharaoh. In this case, it would mean Sobekneferu was born during the lifetime of Neferuptah and the offerings were made before either royal woman used the cartouche. Additionally, Princess Sobekneferu, the later Sobekneferu, would have to have been born in the earlier part of Neferuptah's lifetime, suggesting they were close in age. If so, this would support Neferuptah's early death and Sobekneferu's advanced age when in the pharaonic office (see Chapter 6).

As stated above, there is no securely attested mother for Princess Neferuptah. From their burials in Dahshur, queens Aat (RW 38) and Khenemetneferhedjet III (RW 39) $)^{742}$ have been confirmed as wives of Amenemhat III. Another possible wife includes Queen Hetepi, the mother of Amenemhat IV, but there is no definite evidence. From their burial equipment, Queen Aat has been considered the most well-known queen during Amenemhat III's reign. ${ }^{743}$ On nearly sixty percent of the surviving representations for Twelfth Dynasty royal women, the inscription has not survived. From this, it is possible that Queen Aat has additional depictions that have not been identified. From these surviving statues, reliefs, and titulary Queen Aat is not associated with Amenemhat III outside of her burial. This is particularly notable because, similar to Senwosret III, it is likely the wife of Amenemhat III would have been depicted in the political office of queenship (see Chapter 3.2). However, at least in the later part of his reign, his daughter Neferuptah was in this position. This type of royal female encompassing office of queenship is also seen in the reigns of pharaohs Amenemhat III and Sobekneferu. There is no wife attested for Amenemhat IV and in the Temple of Medinet Madi his mother, Queen Hetepi, is represented in the political office of queenship. It can be assumed that Sobekneferu did not have a 'wife' or an accompanying royal woman, but it is also possible her reign did not require a royal woman to be in the political position of queenship anyway (see Chapter 6).

Both queens Aat and Khenemetneferhedjet III may have been wives of Amenemhat III simultaneously, which is seen from the development of the Dahshur pyramid. Despite being decoratively different, the two separate burial chambers were

\footnotetext{
742 Grajetzki 2014a: 193-194.; Strouhal and Klir 2006: 131, Also known as the 'anonymous queen'.

743 Arnold 1987: 43-45; Strouhal and Klir 2006: 145.
} 
established from the beginning of the pyramid construction. ${ }^{744}$ From the analysis of their skeletal remains, Aat and Khenemetneferhedjet died relatively young, possibly in their late twenties, with the latter being the youngest at death. The women were not related to each other, but both would have married Amenemhat III in the earliest part of his reign. ${ }^{745}$ Amenemhat III was in the pharaonic office for forty-six years, meaning both queens Aat and Khenemetneferhedjet died early, possibily half way through his reign. There are no other wives attested for Amenemhat III, which implies that all of his children, including princesses Neferuptah, Hathorhotep, Sithathor, Nubhotept, Neithikrety along with pharaohs Amenemhat IV and Sobekneferu, were born within the first ten to twenty years of his time as ruler. Furthermore, it also suggests Amenemhat III did not remarry in the last half of his forty-six-year reign. It can only be assumed from this that at least during the last twenty to thirty years of his reign, Amenemhat III's daughter would have taken on the political position of queenship.

The daughter of Amenemhat III who would most likely have taken on the political role of queenship is Neferuptah. This assumption is strongly supported by the surviving evidence presented in this chapter, which includes a relief from the Temple of Medinet Madi, the feet from a seated statue, a sphinx, a block of granite, a papyrus sheet, a cenotaph, and her own pyramid at Hawara. Because of her prominent political position during her father's reign, Neferuptah's surviving evidence can be used as the determining factor for her role in politics as the feminine element of the pharaonic office (see Chapter 3.2). It can also be suggested that she was, in fact, the intended heir to the Egyptian throne. It is also possible in Neferuptah's case that the political offices of queenship and crown princess overlapped and complemented each other. In this situation Neferuptah would have doubled her political roles as the divine feminine manifestation of the pharaonic office while maintaining the divine rulership aspects of the intended heir.

Neferuptah was not only depicted in every form available for Twelfth Dynasty royal women, she also received honors beyond those associated with queenship and instead was accorded those usually reserved for pharaonic status. In terms of the political office of queenship, Neferuptah receiving a cartouche as a

\footnotetext{
${ }^{744}$ Arnold 1987: 43-45, 50-52.

${ }^{745}$ Strouhal and Klir 2006: 145.
} 
princess indicates that any royal woman, not just the royal wife, could take on the role of the feminine divine element of the pharaonic office. Before Neferuptah received the cartouche it was only available to ruling pharaohs. Thus, for her to have the cartouche as a princess means that in her position as daughter of the ruler she was near to pharaonic status. This can only further suggest that Neferuptah received the cartouche as the intended heir to the throne. By the New Kingdom it was common for queens to have their names within a catouche without having overt pharaonic status. However, in the Middle Kingdom the situation is more ambiguous. It is possible that at this time a cartouche may have been an indicatior of pharaonic statuses. In either case it certainly indicates a higher status than was the norm.

Neferuptah's position as the intended heir of her father can be further supported by the location and style of her burial. Her cenotaph is comparable to other royal women in the queenship position such as Khenmetneferhedjet I and Khenmetneferhedjet II, but her own pyramid complex is unique within the Twelfth Dynasty. Neferuptah's pyramid is located over a mile away from that of Amenemhat III's complex (Fig. 5.27), yet it remains in the same general region, thus maintaining a link with the pharaoh.

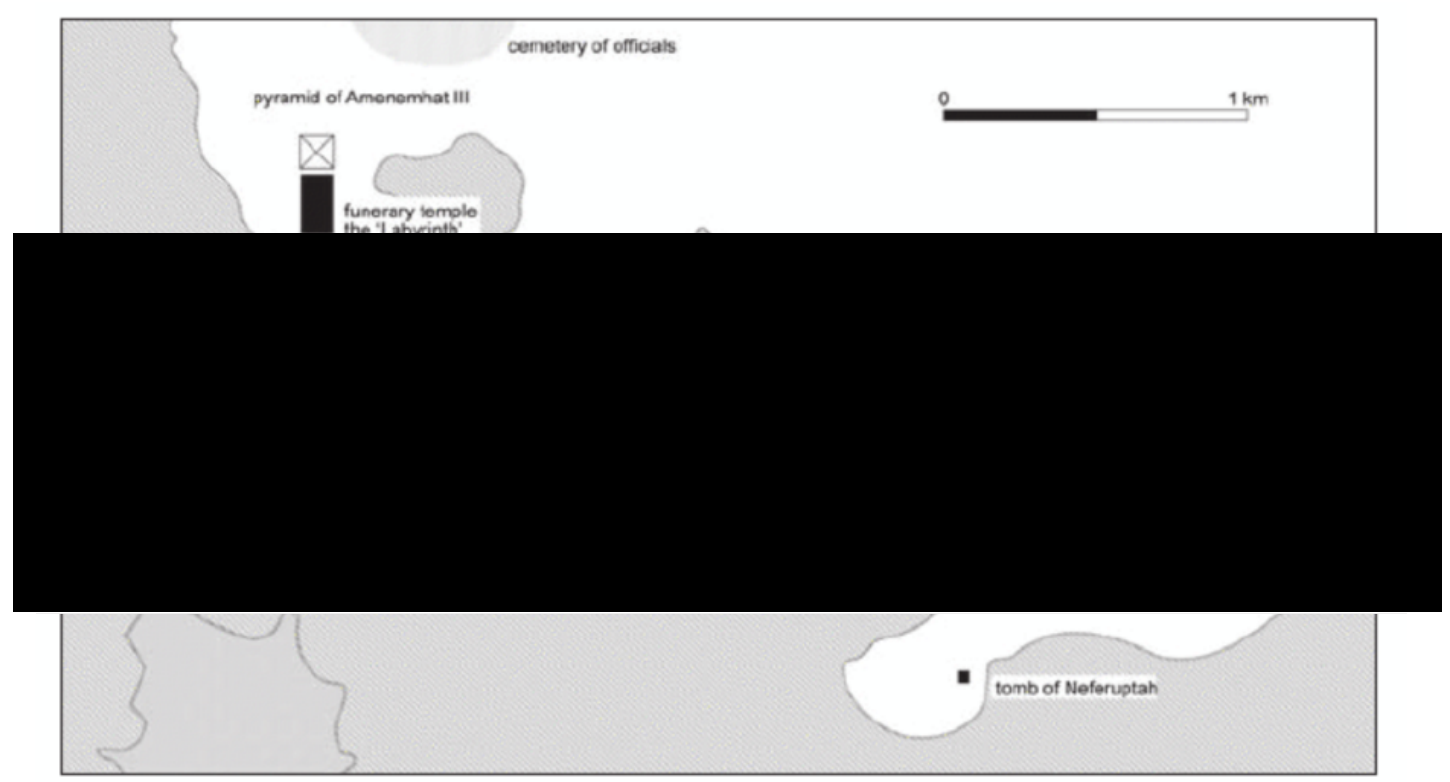

Fig. 5.27 Map of Amenemhat III's and Neferuptah's pyramids, Grajetzki 2014a: 62.

Neferuptah most likely died during the second half of Amenemhat III's reign and while the construction of his Hawara pyramid was ongoing. If the interpretation of the papyrus now located in the Petrie Museum (Fig. 5.10, 5.11) is correct in 
assuming her pyramid was stated to be complete, then her pyramid was started and finished during the reign of Amenemhat III. If her death was unexpected, it is also probable that Amenemhat III chose the location of her pyramid, although it would still have been possible for Neferuptah to choose the location for her complex before dying at a young age. The fact that their pyramids were distinct but constructed nearby is obvious and unique for royal women of Amenemhat III's reign.

\subsection{Discussions}

The surviving objects belonging to Neferuptah discussed in the chapter include three (possibly six) statues, one relief, and one papyrus. Based upon the catalogue of this thesis and an analysis of iconography (see Chapter 4), royal women of the Twelfth Dynasty would have had multiple items inscribed for them, such as statues, temple titulary, and burial goods. Neferuptah's representations in a seated position and as a sphinx were common poses among royal women. This is corroborated by the seated statues of Nofret (Cat. 15, 16) and of the surviving sphinx statues (Cat. 62, 64-70). In addition to Neferuptah and Queen Hetepi being depicted within the Temple of Medinet Madi, a statue of princess Neithikrety was found in the context of the Temple of Hathor at Serabit el-Khadim. ${ }^{746}$ Neithikrety carries the title priestess of Hathor, further emphasizing the royal women's religious roles. Neferuptah was also not the only royal woman to be named in a papyrus. In year 9 of Senwosret III the wooden and stone statues of queens Khenemetneferhedjet I and II are mentioned in a papyrus from el-Lahun (Cat. 39-42). ${ }^{747}$ Also, included within a papyrus is a list of royal children of Senwosret II and Khenemetneferhedjet I are princesses Itakayet (RW 21) and Nefret (RW 22) who are sisters of Senwosret III. ${ }^{748}$

The fact that Neferuptah's name encircled within a cartouche is found on the majority of her surviving objects indicates that a cartouche was commonplace for her titulary. While the reason for her name being written both with and without a cartouche is unknown (as can be the case with male monarchs as well), it can be suggested the artifacts were made during distinct times when her political statues were developing. However, because of her unexpected death all of her prepared

\footnotetext{
${ }^{746}$ Gardiner and Peet 1955: 105.

${ }^{747}$ Kahun Papyurs Berlin 10003; Arnold: 2002: 118; Borchardt 1899: 96; Perdu 1977: 71; Troy 1986: 158.

${ }^{748}$ Arnold 2002: 64; Borchardt 1899: 92; Grajetzki 2014a: 82.
} 
burial equipment, regardless of the cartouche, was used. The second royal woman to have her named encircled within a cartouche was Sobekneferu, suggesting that at this time the cartouche was still associated with ruling status. Princess Neferuptah was the first royal women to have her name written within cartouche, to have the title of sister of the God, and to be shown standing in front of the ruling pharaoh. Among her titles, snt $n \underline{t} r$, found on a block of granite, is not only unique to the Twelfth Dynasty but to all known titles for royal women ${ }^{749}$ (see above Chapter 5.5). The title snt $n \underline{t} r$ is not securely attested on any other inscription for Neferuptah, suggesting that the block of granite found in Cairo was part of a statue with a particular theme similar to the Sed-festival statue of Amenemhat III and two royal women (see Chapter 5.7; Cat. 29; Fig. 5.12). Found on the Sed-festival statue within the surviving titulary of the royal woman is the word snt. The word directly following is damaged but this snt could allude to another example of snt $n \underline{t} r$. If this hypothesis is correct, the royal woman on the right has to be princess Neferuptah since she is the only known royal woman to have carried this title.

Also unique to Twelfth Dynasty representations of royal women is Neferuptah's placement in front of the reigning pharaoh in the relief located at the Temple of Medinet Madi. There are other representations from the New Kingdom that present the royal child in an active role in front of the reigning pharaoh making Neferuptah's relief at Medinet Madi the earliest known depiction of this type. Sety I is seen behind Prince Ramses II giving offerings to Osiris on behalf of their ancestors, which is known as the Abydos king list at the Temple of Sety I (Fig. 5.28). ${ }^{750}$ Similar to his father, Ramses II as pharaoh is shown behind his son Prince Khaemwaset while offering to the god Ptah (Fig. 5.29). ${ }^{751}$ Neferuptah's placement in front of Amenemhat III at the Temple of Medinat Madi is also possibly an indication of her being his heir. There are no other surviving depictions from the Twelfth Dynasty, but this scene is shown in the later Nineteenth Dynasty examples where the crown princes Ramses II and Khaemwaset are standing in front of their fathers while offering to a god. While it seems unclear in some New Kingdom cases whether the

\footnotetext{
${ }^{749}$ Grajetzki 2014a 68-69; Troy 1986: 194.

${ }^{750}$ Redford 1986: 18-20.

${ }^{751}$ Dodson 2004: 168.
} 
child in front is the heir, ${ }^{752}$ there is no earlier surviving representation of this style before the Twelfth Dynasty. This supports that the relief of Princess Neferuptah and Amenemhat III from the Temple of Medinet Madi is the first known depiction of a royal child and the possible heir in front of the reigning pharaoh.

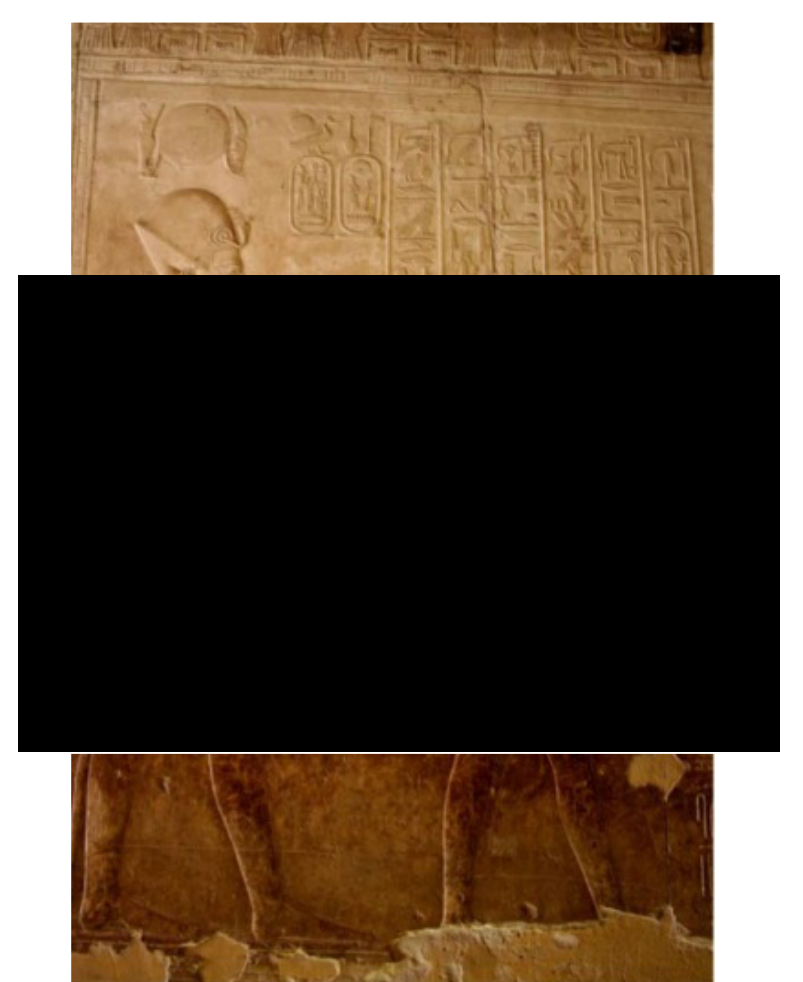

Fig. 5.28 Prince Ramses II in front of Sety I at Abydos, Dodson 2004: 168

${ }^{752}$ During the Eighteenth Dynasty Princess Neferubity is shown in front of her father Thutmose I and mother Ahmose. 


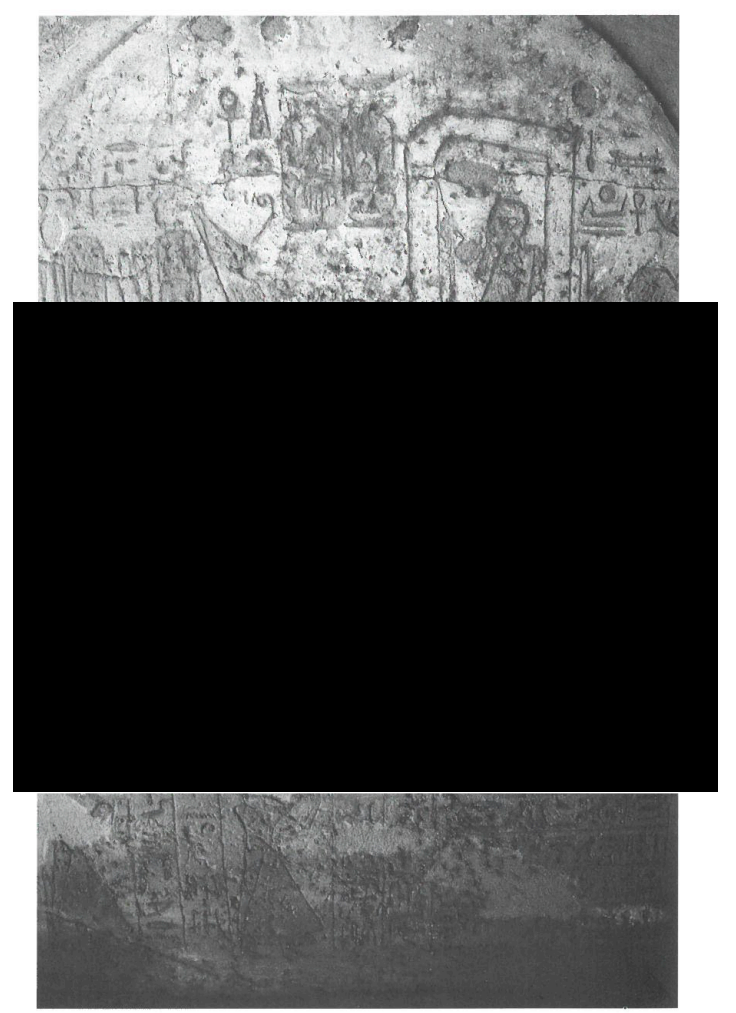

Fig. 5.29 Prince Khaemwaset in front of Ramses II, Queen Isetneferet, and Princess Bintanath. Dodson 2004: 168

Neferuptah held an exceptional political position during Amenemhat III's reign and her surviving depictions, pyramid, and cartouche show her significant status among other Twelfth Dynasty royal family members. As the holder of the political office of queenship, Neferuptah was the divine female manifestation of the pharaonic office, which consisted of her being religiously active with deities and participating in rejuvenation rituals such as the $S e d$-festival. As the intended heir to the throne, she demonstrated pharaonic aspects, such as having her name encircled within a cartouche, standing in front of her father, the reigning pharaoh, and being the only royal child with a cenotaph and an independent pyramid complex. This type of doubling of political offices is further seen during the reign of Sobekneferu when she incorporates both the offices of queenship and of pharaoh. Although Neferuptah may have succumbed to a premature death, her reign as the crown princess of Amenemhat III exemplifies the prominent political positions of royal women of the Twelfth Dynasty and serves as an example of them acquiring pharaonic attributes along with the office itself. 


\section{Chapter 6: Sobekneferu}

\subsection{Introduction}

Sobekneferu ${ }^{753}$ is the first unequivocally attested ancient Egyptian female monarch and royal woman to ascend the throne without the accompaniment of a male family member. Comprehensively examining her time as ruler of Egypt is essential to Middle Kingdom, along with queenship and gender studies. Sobekneferu is considered to be the daughter of Amenemhat III, who was the sixth ruler of the Twelfth Dynasty. ${ }^{754}$ Callender states that she was also the sister or half-sister of Amenemhat IV, ${ }^{755}$ which would also make Sobekneferu the sister or half-sister to Princess Neferuptah. However, there is no surviving evidence to support the theory that she was the wife of Amenemhat IV (see below Chapter 6.19). This would ensure that, through her own right of kinship, Sobekneferu followed her brother and not a husband onto the throne. She also never carried the titles wife or mother of the monarch and has no attested children.

Sobekneferu is also the first female to have full pharaonic titles: ${ }^{756}$

- Horus name: $\odot$ PAी

- Nebty name: $\operatorname{s}_{0}$ now Lady of the Two Lands ${ }^{757}$

- Golden Horus name: 肁

\footnotetext{
${ }^{753}$ Both names Sobekneferu and Neferusobek are considered correct and can be interchangable. Neferusobek: Bryan 1996: 28; Fay 2015: 89; Habachi 1954: 463; Ryholt 1997: 15; Valloggia 1964: 45; von Beckerath: 1997: 189; Sobekneferu: Aufrère 1989; Callender 1998a: 227; Callender 1998b; Callender 2000: 158; Dodson 2004: 92; Dodson 2008: 384; Grajetzki 2006: 61; Leprohon 1996: 170; Leprohon 2013: 60; Murnane 1997: 20; Pignattari 2008: 69; Troy 1986: 159; Zecchi 2001: 143; Zecchi 2010: 84; Ziegler 2008: 317.

${ }^{754}$ Bryan 1996: 29; Callender 1998a: 228; Dodson 2004: 92; Dodson 2008: 384; Grajetzki 2006: 62; Ryholt 1997: 213.

${ }^{755}$ Callender 1998a: 227.

${ }^{756}$ Aufrère 1989: 1-14; Leprohon 1996: 166, 171; Leprohon 2013: 60; Pignattari 2008: 75-77; Valloggia 1964 45-53; von Beckerath 1999: 86-87.

${ }^{757}$ The powerful one may be referring to her father Amenmath III. Leprohon 2013: 60.
} 


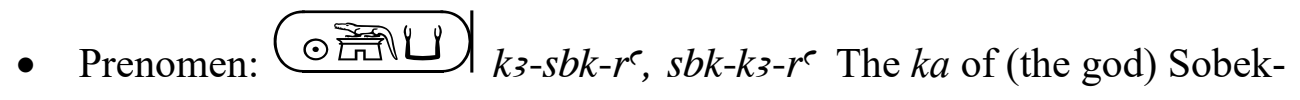
$\mathrm{Ra}^{758}$ The $k a$ of Sobek is $\mathrm{Ra}^{759}$

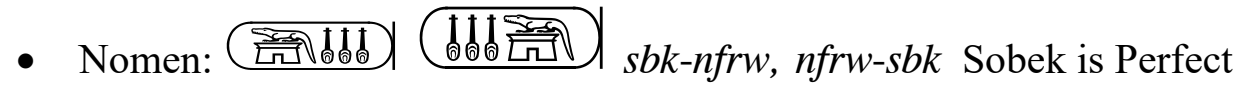

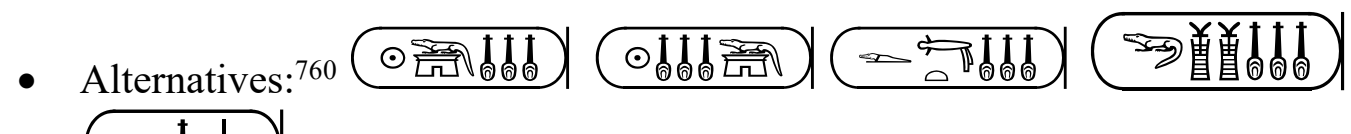

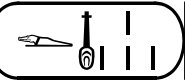

Sobekneferu's position as pharaoh is attested on the Karnak $^{761}$ and Saqqara lists, ${ }^{762}$ the Turin Canon, ${ }^{763}$ and was recorded by Manetho. ${ }^{764}$ The Turin Canon states that her reign lasted three years, ten months, and twenty-four days. ${ }^{765}$ Due to her relatively brief reign, Leprohon suggests she was already older in age when taking the throne and this led to only a four-year rule. ${ }^{766}$ While her reign may be considered brief, during her four years as pharaoh, Sobekneferu was able to accomplish a prevailing amount of projects. Compared with Amenemhat IV's nine-year reign, Sobekneferu has several surviving statues that were commissioned for her and are associated with building projects at Hawara, Herakleopolis Magna, and Tell elDab'a. Sobekneferu is also the only known late Twelfth Dynasty ruler to have a building project and statues located in the Delta, even though Amenemhat III's reign extended to nearly forty-six years and an abundance of artifacts have survived.

As the eighth pharaoh of the Twelfth Dynasty, Sobekneferu is securely known from at least twenty-five artifacts. As a result, her existence as a sole reigning pharaoh cannot be challenged. Even though her time as pharaoh is securely documented from sites in the Fayum and the Delta, her burial complex has not yet been discovered. There are five known images representing Sobekneferu: a torso (Cat. 58), two identical seated statues (Cat. 59, 60), a kneeling statue (Cat. 61), and a

\footnotetext{
${ }^{758}$ Leprohon 1996: 171.

${ }^{759}$ Leprohon 2013: 60.

${ }^{760}$ Aufrère 1989: 13, notes that $n s w t$ bjtj is used with both $s b k-k 3-r^{c}$ and $n f r w$ - sbk-šdty suggesting

Neferu-Sobek Shedyt could be her throne name as well and was mixed with Sobek-ka-ra.

${ }^{761}$ Lepsuis 1853: 425-455; Redford 1986: 29-34.

762 Redford 1986: 21-24.

763 Ryholt 1977: 9-33.

764 Waddell 1948: 68.

765 Ryholt 1997: 15.

${ }^{766}$ Leprohon 1996: 107.
} 
sphinx (Cat. 62). Out of these five representations, neither a head nor facial image securely survives. As described below, there are an additional six statues with no inscriptions, five of which have surviving faces that potentially represent Sobekneferu.

Multiple inscriptions were found at Amenemhat III's burial complex at Hawara. The two significant inscriptions that show Sobekneferu directly identified with him will be discussed below (See chapter 6.4). Several inscriptions naming Sobekneferu as the reigning pharaoh were found at the Temple of Heryshef in Herakleopolis Magna (see Chapter 6.5), thus indicating that she had building projects at the site. She was also named in a Nile level reading from the second cataract at Kumma (see Chapter 6.11). Other artifacts include a papyrus, scarabs, cylinder seals, a bead, a statue base, and a stela (see Chapter 6.7, 6.8, 6.9, 6.10, 6.12, 6.13). This chapter analyzes the surviving evidence from Sobekneferu's reign to provide an overview of how her political power was displayed through her iconography and building projects.

\subsection{Torso of Sobekneferu, Musée du Louvre E27135 (Cat. 58)}

The torso of Sobekneferu (Cat. 58; Fig. 6.1) is made from red sandstone and has a surviving height of $48 \mathrm{~cm}$ (1 $1 \mathrm{ft} 6 \mathrm{in})$, which is only part of its original estimated size of $1.6 \mathrm{~m}$ (5ft2in). ${ }^{767}$ The statue is preserved from just above the hips to the top of the shoulders. Except for the right upper arm, all four limbs and head are missing. From the surviving stance the full statue would have been standing in devotion, a pose made popular by Senwosret III (see Fig. 4.2). The devotional pose includes the hands open with both palms resting on the front of the kilt along with the left foot forward. She wears a sheath dress underneath a nemes headdress and a shendyt-kilt. The tubular chained necklace with a double pouch pendant that was commonly featured on Twelfth Dynasty pharaohs (see Fig. 4.2, 4.33, 4.38) is placed between the front straps of her dress and ends at the bust line.

The neck line of the dress plunges downward to just underneath the breast where it meets the empire style dress line. The kilt sits slightly above her natural waistline, emphasizing the seams of both the dress and the kilt. The kilt consists of

\footnotetext{
${ }^{767}$ Torso of Queen Sobekneferu, Musée du Louvre E27135; Callender 1998a: 233-234; For further detail see Musée du Louvre online catalogue: "Torso of Queen Sobekneferu, last queen of the Twelfth Dynasty" http://cartelen.louvre.fr/cartelen/visite?srv=car_not_frame\&idNotice=23673\&langue=en .
} 
decorated horizontal and vertical bands with a dagger tucked into the right side of the belt. Sobekneferu's status as pharaoh is stated in the middle of the belt directly above the vertical band, identifying her as the daughter of Ra. The inscription reads:

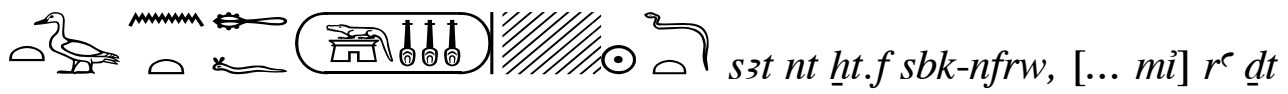

Daughter of his body, Sobekneferu, [...] like Ra forever. ${ }^{768}$ It is unclear if the kilt and dress would have extended downwards towards the ankles or if both articles of clothing stopped above the knees, which would have been the common length for the kilt (Fig. 4.2, 4.3). ${ }^{769}$ It is also possible that the kilt would have ended above the knees allowing for the dress to extend underneath down to the ankles.

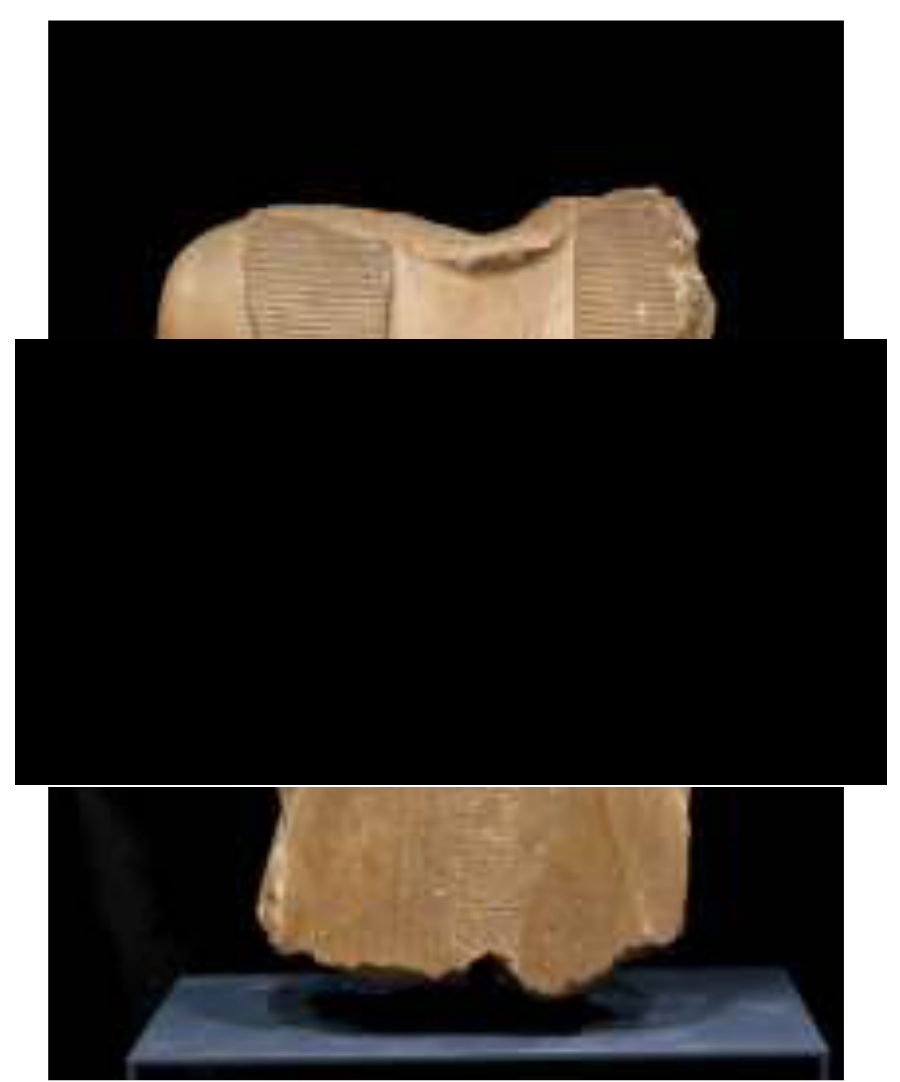

Fig. 6.1 Torso of Sobekneferu, Musée du Louvre E27135.

Sobekneferu's torso is one of the best surviving Twelfth Dynasty examples of how iconography communicates the profound meanings of Egyptian art being intertwined with political power. The statue unmistakably exhibits a female monarch by combining the pharaonic elements of the nemes headdress, kilt, and beaded pendant with the sheath dress. Sobekneferu is presented with female pharaonic regalia

\footnotetext{
768 Translation by Pignattari 2008: 78 .

${ }^{769}$ Statue of Amenemhat III, The Cleveland Museum of Art 1960.56.
} 
because the goal of the statue's iconography is to portray a female in the pharaonic office. At the time this statue was commissioned, Sobekneferu was a de facto female ruler of Egypt and this statue expresses this combination. The viewer would have known exactly what the statue represented and would have received the preferred message no matter the original context the statue stood in. Similar to Amenemhat III and Senwosret III, it can be proposed that multiple devotional attitude statues would have been erected for Sobekneferu, although no other parallel statue for her has been recorded.

\subsection{Statues from Tell el-Dab'a (Cat. 59, 60, 61, 62)}

Four main basalt statues clearly inscribed for Sobekneferu were discovered at Tell el-Dab'a in the years 1885 and $1941 .{ }^{770}$ They include a sphinx (Cat. 62), a kneeling statue (Cat. 61), and two identical seated statues (Cat. 59, 60). All four statues were possibly left on site by the excavating teams, but the current locations for the sphinx, kneeling and two seated statues are unknown. Shown in the map labeled by Habachi (Fig. 6.2), the find spots of Sobekneferu's statues are seen as 8: sphinx; 9: kneeling; 10: seated $a ; 11$ : seated $b$. Her sphinx was discovered in close proximity to the one kneeling and two seated statues which were discovered together.

${ }^{770}$ Habachi 1954: 459-460; Habachi 2001: 33, 169; Naville 1885: 21. 


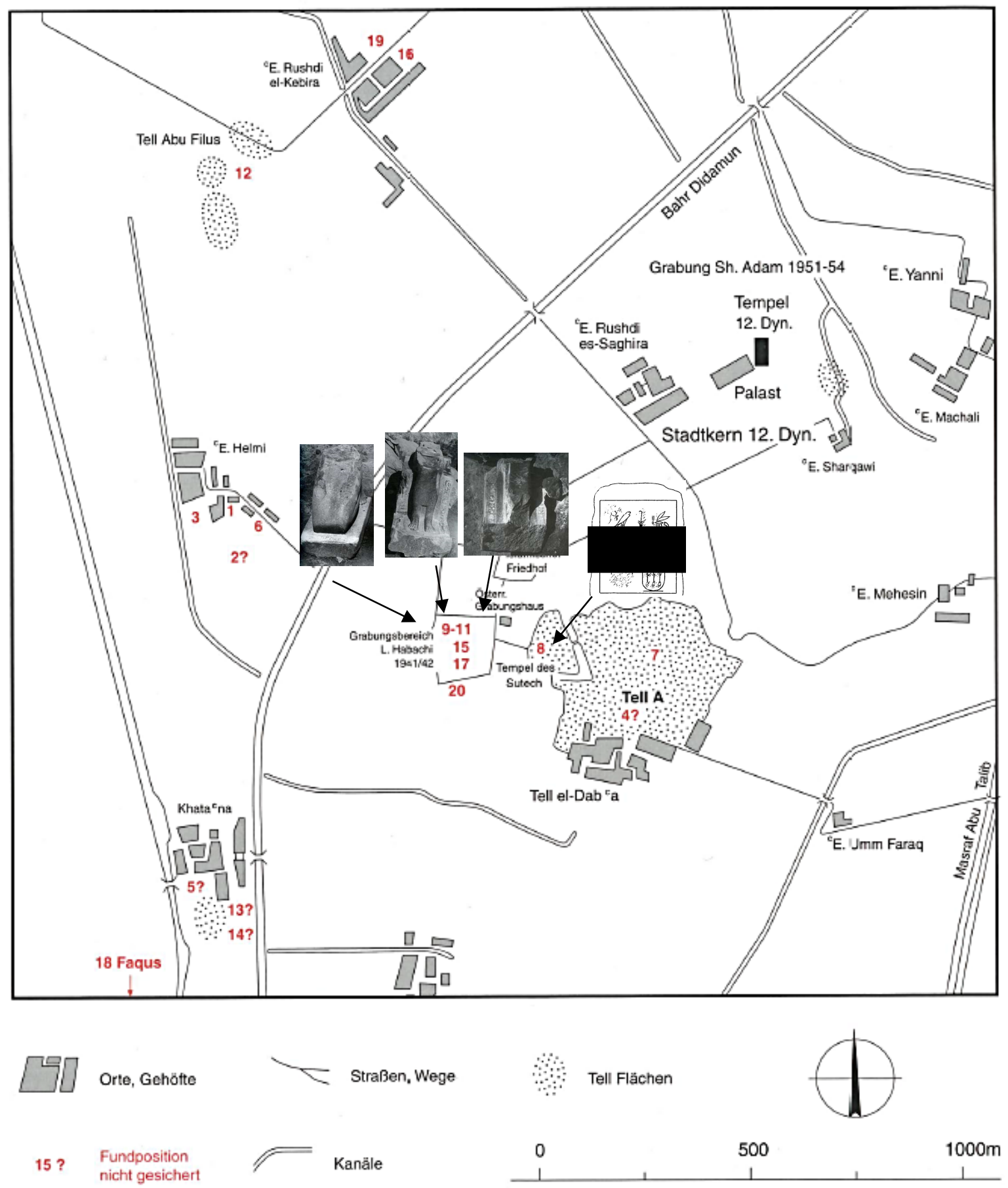

Fig. 6.2 Map of Sobekneferu's statues found at Tell el-Dab'a, Habachi 2001: 154, illustration by author.

These four statues of Sobekneferu were found within or near an enclosure, which supports the belief that she was active in commissioning buildings at Tell el-Dab'a or in the nearby area. Her sphinx was discovered in the center of an enclosure located on the top of a mound. The mound was described by Naville as being on the edge of the desert and on the verge of cultivated land. Within the enclosure itself Naville stated to have found six columns made of limestone, a pavement that 
probably had a granite shrine and no inscription except for a stone and a pottery sherd inscribed for Seti. ${ }^{771}$ Sobekneferu's kneeling and two seated statues were found close to a building dated to the Twelfth Dynasty that was made from thick sun-dried brick walls and also near a Thirteenth Dynasty palace. ${ }^{772}$ From this, Habachi concluded that the statues were found near to their original positions. ${ }^{773}$

It is possible they were taken from a location in the Fayum ${ }^{774}$ or the Ezbet Rushdi settlement that is only $1 \mathrm{~km}$, a half a mile, away from Tell el-Dab'a. Found together with three of Sobekneferu's statues was a statue of Sahornedjhiryotef (Amusahornedjheryotef), ${ }^{775}$ a pharaoh of the Thirteenth Dynasty. Habachi and Bietak suggests that Sahornedjhiryotef was originally her husband or the chief steward of Sobekneferu and took power after her death. ${ }^{776}$ This seems unlikely because Sekhemrekhutawy Amenemhat Sobekhotep I is accepted as the first ruler of the Thirteenth Dynasty and Sahornedjhiryotef as the fifth. ${ }^{777}$ Perhaps during his reign, Sahornedjhiryotef placed Sobekneferu's statues alongside his as a legitimization tactic, showing a connection with the authentic succession line of the Twelfth Dynasty, although this cannot be proven. Since other fragments from statues were also found in the same area, it is possible the statues of Sobekneferu and Sahornedjhiryotef were transported there at different times or all together at a later date.

Sobekneferu's headless basalt sphinx (Cat. 62) was discovered in the center of an enclosure located on top of the largest of three mounds, which were excavated by Naville in $1885 .{ }^{778}$ The remains of her pharaonic nemes headdress and modern graffito were recorded. ${ }^{779}$ The sphinx's heavily damaged inscriptions (Fig. 6.3) contained a barely legible serekh with enough traces remaining to suggest it once stated her Horus name $\odot$ 个A

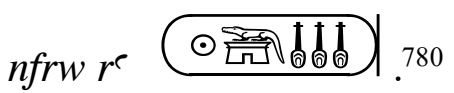

\footnotetext{
${ }^{771}$ Naville 1885: 21.

772 Bietak 1996: 20.

${ }^{773}$ Habachi 1954: 16.

774 Ahrens 2011: 23.

${ }^{775}$ Bietak 1991: 49; Bietak 1996: 30; Habachi 1954: 458-470.

776 Bietak 1996: 30; Habachi 2001: 102.

777 McCormack 2008: 22. Sahornedjhiryotef is listed as Hotepibre Qemau Saharnedjeritef.

778 Naville 1885: 21.

${ }^{779}$ Habachi 2001: 168.

${ }^{780}$ Habachi 1954: 20; Valloggia 1964: 47.
} 


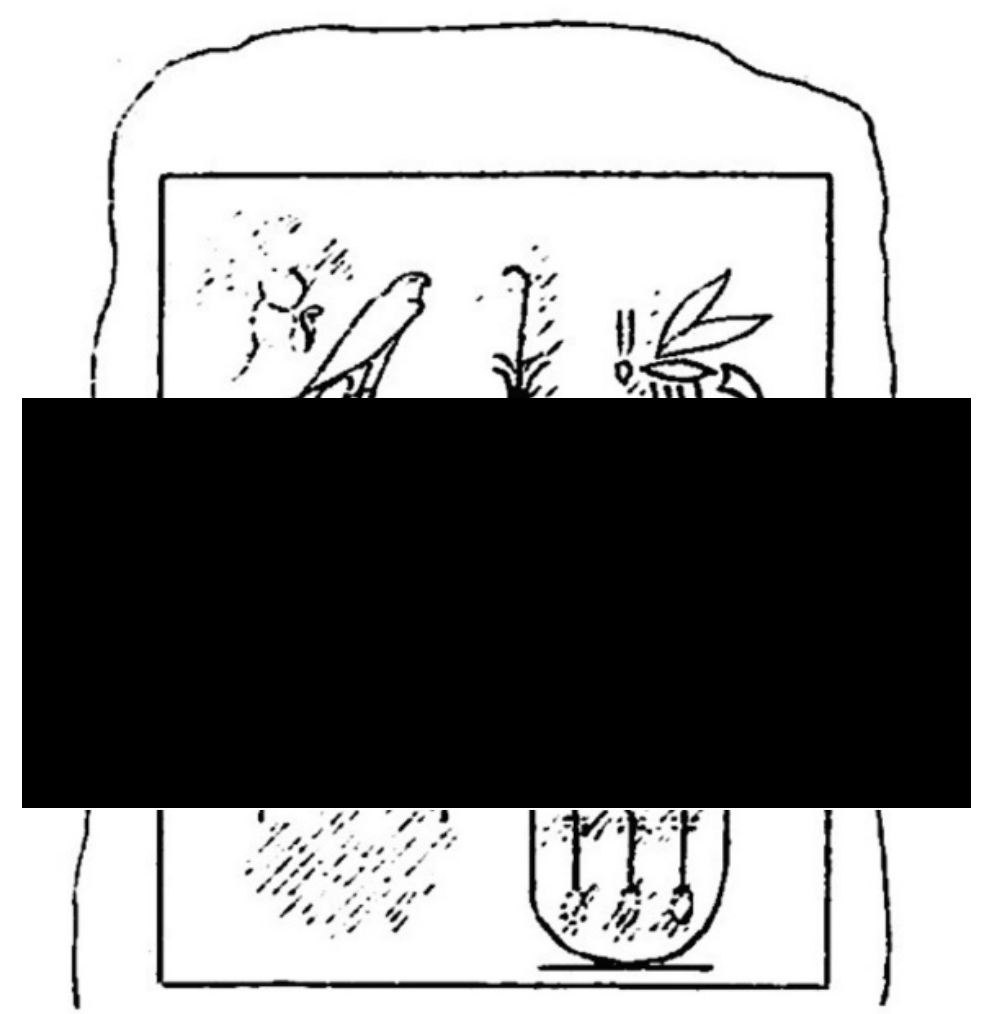

Fig. 6.3 Inscription from the headless sphinx of Sobekneferu, Naville 1885: 21.

Due to the kneeling pose being restricted to rulers, Sobekneferu was the only royal woman of the Twelfth Dynasty to be represented in this pose (Cat. 61; Fig. 6.4) which further indicates that she was considered a legitimate pharaoh. This statue is preserved from the waist down, including the feet with an inscribed base.

Sobekneferu's now missing arms can be seen from their damaged outlines, which show them resting upon her upper thighs. The base has a slightly damaged horizontal inscription, which reads from right to left:

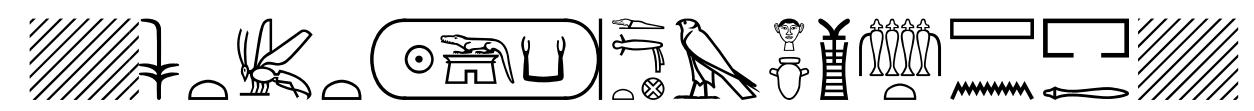

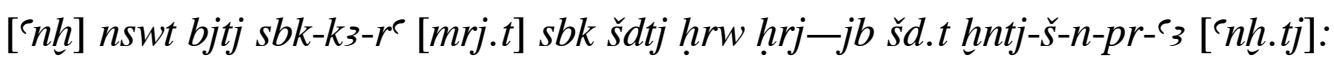

May live the Monarch of Upper and Lower Egypt, Sobek-ka-Ra, beloved of Sobek of the Fayum, the Horus residing in the Fayum, the one of Khenteshe-en-per'a (Garden of the Palace), ${ }^{781}$ may she live. ${ }^{782}$

\footnotetext{
${ }^{781}$ Habachi suggests that Khenteshe-en-per'a (Garden of the Palace) is the palace used by Sobekneferu in the Tell el-Dab'a area which would have been near a lake. Habachi 1954: 459-460 782 Translation by Habachi 1954: 459; Habachi 2001: 168.
} 


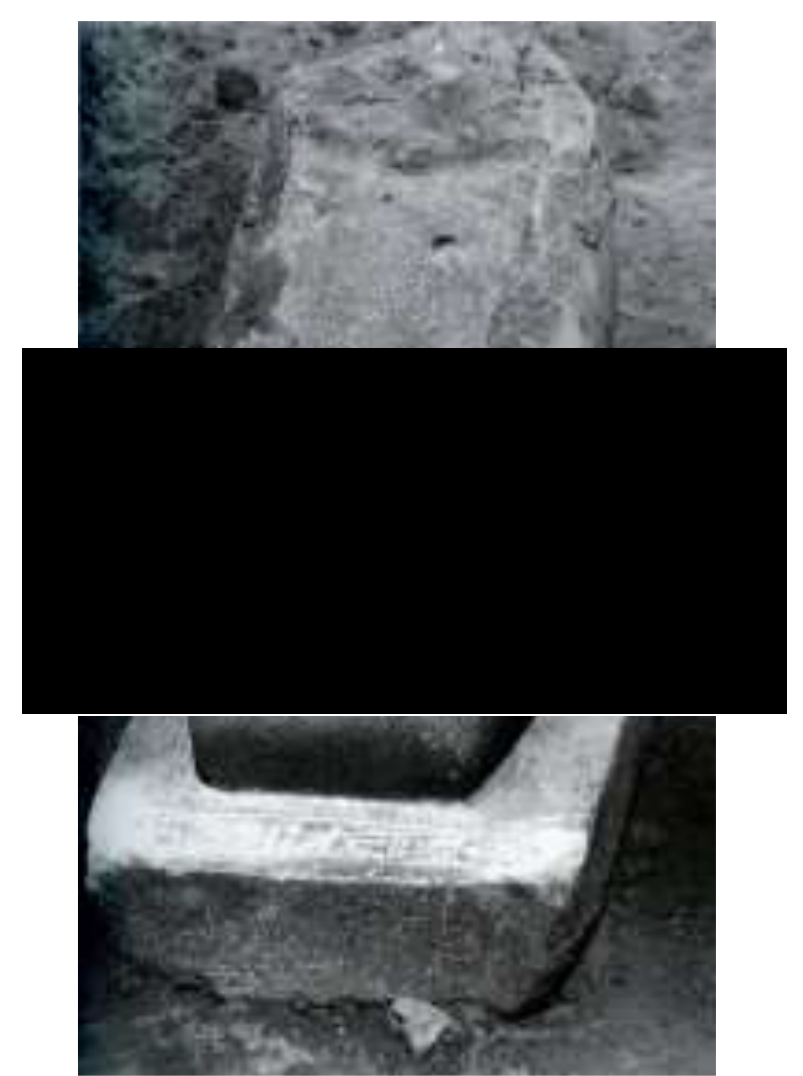

Fig. 6.4 Kneeling statue of Sobekneferu, Habachi 2001: pl. 13.

Two seemingly identical statues of Sobekneferu depict her seated upon a throne (Cat. 59, 60; Fig. 6.5, 6.6). Both statues are preserved from the waist down, with the second seated statue (Cat. 60) missing its base. Sobekneferu's hands would have been laid upon her lap. She wears a sheath dress that ends above her ankles. Beside both right and left legs, the statues are inscribed with two columns of identical texts. At the beginning of both inscriptions is her Horus name: mryt $r^{e}$ Beloved of Ra.

Above the serekh, the Horus hieroglyph is accompanied with the feminine $t$ presenting Sobekneferu as the female Horus (see Chapter 3.4). The reigning pharaoh was the living Horus ${ }^{783}$ and these inscriptions prove that Sobekneferu was the living Horus in female form. The most complete inscription from the two thrones reads as: Left

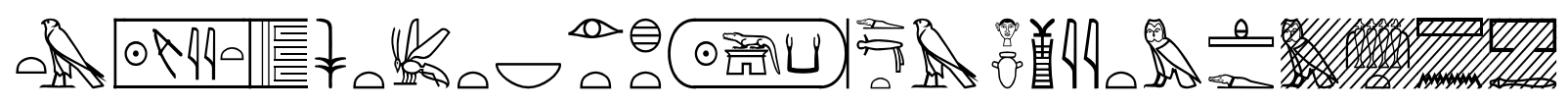
Right:

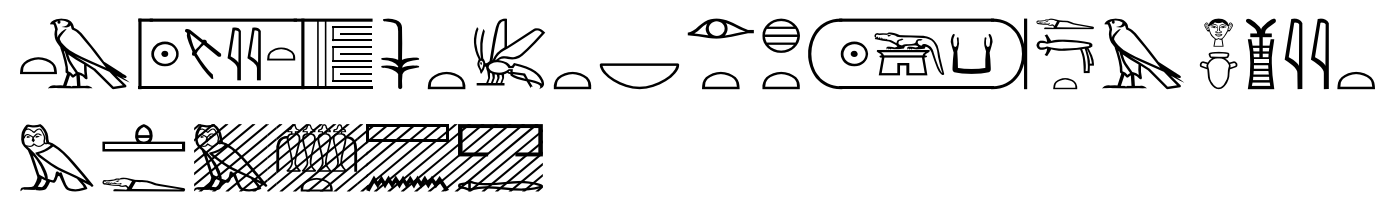

${ }^{783}$ Baines 1995: 9. 


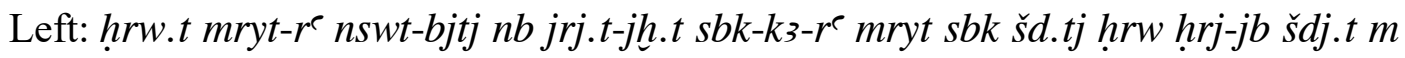

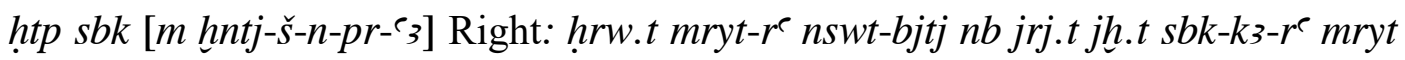

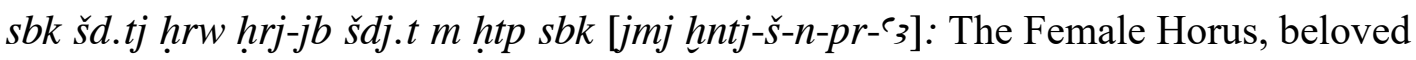
of Ra, the Monarch of Upper and Lower Egypt, Lord of rituals, Sobek-ka-Ra [beloved of] Sobek of the Fayum, the female Horus residing in the Fayum in peace, Sobek who is in Khenteshe-en-per'a (Garden of the Palace). ${ }^{784}$

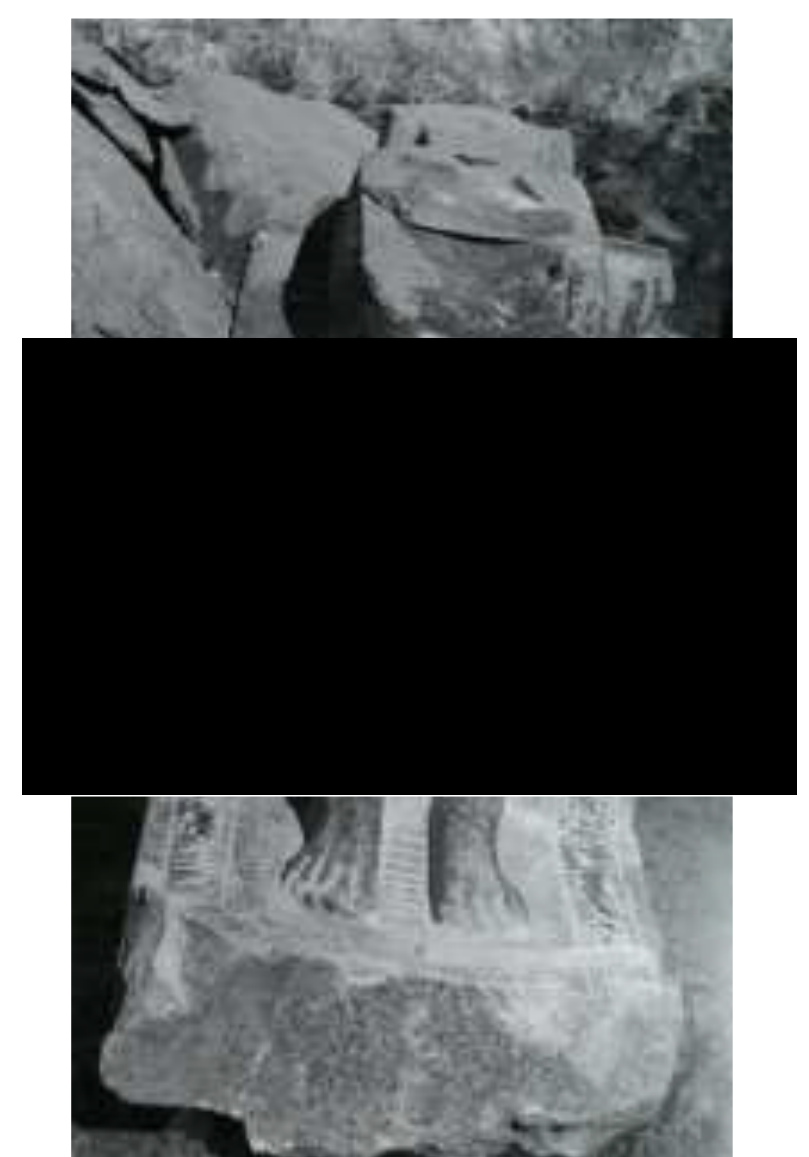

Fig. 6.5 Seated statue of Sobekneferu, Habachi 2001: pl. 15b.

${ }^{784}$ Habachi 1954: 459-460; Habachi 2001: 33; Valloggia 1964: 46. 


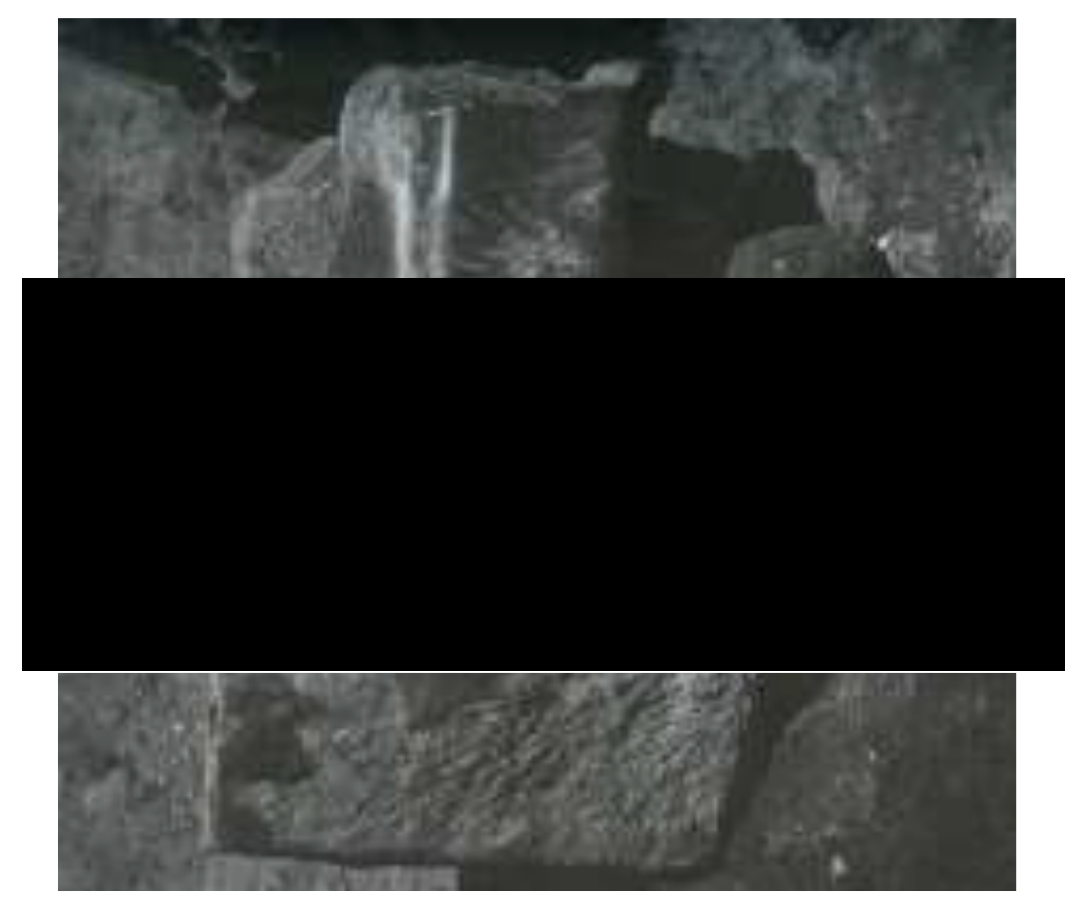

Fig. 6.6 Seated statue of Sobekneferu, Habachi 2001: pl. 14a.

Sobekneferu's feet resting upon the nine bows can clearly be identified on the base of the better-preserved statue (Cat. 59). Since the two depictions would have been identical, the nine bows should be shown on both statues (Cat. 59, 60). The 'Nine Bows' was the usual term used for the traditional enemies of Egypt who were often depicted as rows of bows. ${ }^{785}$ Similar to other pharaohs, Sobekneferu was depicted with the Nine Bows under her feet. The Nine Bows are shown under her feet symbolically indicating that she is crushing and treading upon her enemies. This depiction represents Sobekneferu in one of the main functions of the ruler, as the defender of Egypt. The crushing of the Nine Bows would have representatively shown Sobekneferu as the military commander of Egypt, which may allude to her military presence in foreign lands. While in the pharaonic office, the pharaoh would have been depicted as the unifier of the Two Lands, as well as head of the administration and military. ${ }^{786}$ Sobekneferu would have inherited Egypt's foreign domain from Amenemhat IV, Amenemhat III, and Senwosret III. During the Twelfth Dynasty, Egyptian occupation extended into both Syria and Nubia, ${ }^{787}$ which suggests that during Sobekneferu's reign, Egypt would still have had a presence in these areas. Although less is known about Sobekneferu's activity beyond the Delta,

\footnotetext{
${ }^{785}$ Uphill 1967: 393-420.

786 Arnold 2015b: 68.

${ }^{787}$ Uphill 1967: 407-409.
} 
Egypt's occupation of Nubia and operation of the Semna and Kumma forts was continuous until at least the reign of Sobekhotep IV in the Thirteenth Dynasty. ${ }^{788}$ As pharaoh, she would have continued controlling Egypt's enemies and exhibiting military power in prevailing in conflicts, which could have been expressed in her art.

During the Twelfth Dynasty the area and town of Khata'na was prosperous ${ }^{789}$ and this affluence seems to have lasted through Sobekneferu's reign and into the Thirteenth Dynasty, with Tell el-Dab'a eventually being chosen as the capital for the Hyksos. ${ }^{790}$ Sobekneferu's presence at Tell el-Dab'a is significant to the late Twelfth Dynasty because neither Amenemhat III nor Amenemhat IV had connections with the immediate area. ${ }^{791}$ Similar to Herakleopolis Magna (see below Chapter 6.5) Sobekneferu continued building at sites already established by earlier Twelfth Dynasty rulers. Following Amenemhat I, Senwosret I, Amenemhat II, Senwosret II, and Senwosret III, she would have erected life size statues in the area of Khata'na and commissioned a building project. ${ }^{792}$ Sobekneferu's name on her Tell el-Dab'a statues was also never erased by a different ruler in a later dynasty. Sobekneferu's work at Tell el-Dab'a opens questions about other statues possibly from the Delta that have not been securely ascribed including the human headed bird of a female monarch (Cat. 38; see Chapter 4.2.4, Fig. 4.11) and the 'Hyksos monuments' that have been attributed to the reigns of Senwosret III, Amenemhat III, and Amenemhat IV. ${ }^{793}$ Similar to the possible shrines depicting two pharaohs (see below Chapter 6.17) the sphinxes from Bubastis and Tanis form dyads. If showing a second ruler along with Amenemhat III, they could possibly be representing Sobekneferu especially considering Amenemhat III and Amenemhat IV have no surviving monuments from the area. The sets of dyad sphinxes were reused by a Hyksos ruler, Ramses II, Merenptah, and Psusennes I and moved to Bubastis and Tanis. ${ }^{794}$ It is likely they originally stood in Khata'na or Tell el-Dab'a with other Twelfth Dynasty statues and it is a possibility that Sobekneferu is shown as one of the sphinxes.

\footnotetext{
788 Ryholt 1997: 76-77.

${ }^{789}$ Habachi 2001: 99.

${ }^{790}$ Bietak 1996: 1.

${ }^{791}$ Habachi 2001: 101; Hirsch 2004: 110-146.

792 Habachi 2001: 99-102; Hirsch 2004: 148.

793 Two sets of dyad sphinxes, The Egyptian Museum Cairo, JE 393, JE 394, JE 590, and JE1243. Ahrens 2011: 23-24; For discussion see Engelbach 1923 and Habachi 1978; listed as a double sphinx of Amenemhat III in Hirsch 2004: 396-370, Dok. 332.

${ }^{794}$ Habachi 1978: 91, Fi.g 3.
} 
The previously mentioned triad statue of Amenemhat III flanked by two royal women (Cat. 29; Fig. 5.12) was discovered in Kom el-Hisn located in the Delta. ${ }^{795}$ This may suggest Amenemhat III had a building project in the town, although a temple has not been identified. ${ }^{796}$ Within the aforementioned section (see above Chapter 5.7), among others, Sobekneferu is suggested to be represented as one of the royal women flanking Amenemhat III. Considering Sobekneferu's significant presence in the Delta, this could further support that one of the royal women in the triad statue depicts Sobekneferu before becoming pharaoh. The statue was usurped by Ramses II $^{797}$ and could have been brought to the site of Kom el-Hisn, but similar to other Twelfth Dynasty statues, it may have originally been placed in the Khata'na area. Two other Twelfth Dynasty royal women are also associated with Khata'na, queens Senet and Nofret. Two statues for Queen Senet, who has been suggested to be Sobekneferu's mother (see below Chapter 6.19) where found in the area of Khata'na and Tell Abu el-Filus ${ }^{798}$ (Cat. 28, 36; Fig. 6.46, 6.47). Additionally, Queen Nofret the wife of Senwosret II had two over life size statues most likely taken from Khata'na and placed at Tanis, the same as her husband. ${ }^{799}$ Similarly to Sobekneferu, the names of queens Senet and Nofret were not erased.

\subsection{Inscriptions from Amenemhat III's mortuary complex and Labyrinth at Hawara}

As noted by Petrie, ${ }^{800}$ Sobekneferu's name was found as often as that of Amenemhat at his mortuary complex in Hawara. She is known from at least seven inscriptions from the Hawara complex, which includes fragments of architraves, door posts, columns, and buildings. ${ }^{801}$ Among the red granite columns and blocks discovered is a column fragment, now housed in the Egyptian Museum Cairo (Figs. 6.7, 6.8) ${ }^{802}$ The fragment is inscribed with the names of Amenemhat III and Sobekneferu. Sobekneferu is once again named as the female Horus mryt $r^{e}$, Beloved of Ra. Amenemhat III's Horus falcon is wearing the red and white crown of Upper and

\footnotetext{
795 Hirsch 2004: 133, 370 Dok. 333; Stünkel 2015: 95.

${ }^{796}$ Hirsch 2004: 133.

${ }^{797}$ Hirsch 2004: 370 Dok: 333.

${ }^{798}$ Habachi 2001: 169, Kat. 12-13.

${ }^{799}$ Habachi 2001: 100.

800 Petrie 1894: 197.

${ }^{801}$ Lepsius 1849: 15; Uphill 2000: 29-36 H.24, H.25, H.46, H.57, H.67; Valloggia 1964: 47-49.

${ }^{802}$ Habachi 1954: 464-466, pl. XV.
} 


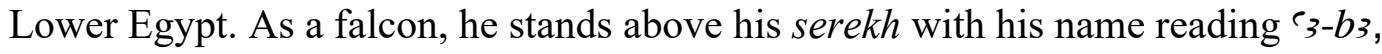
holding the $\underline{d} d$ and ' $n k h$ scepter of power towards the female Horus. Sobekneferu's Horus falcon, marked as female by the $t$-sign before it, faces the scepter and Amenemhat III's Horus falcon. The inscription confirms Sobekneferu as the living female Horus receiving power of ruling Upper and Lower Egypt from Amenemhat III. This not only emphasizes her close connection with Hawara and the deified Amenemhat III, it also displays that her legitimacy as ruler was represented during and after her reign.

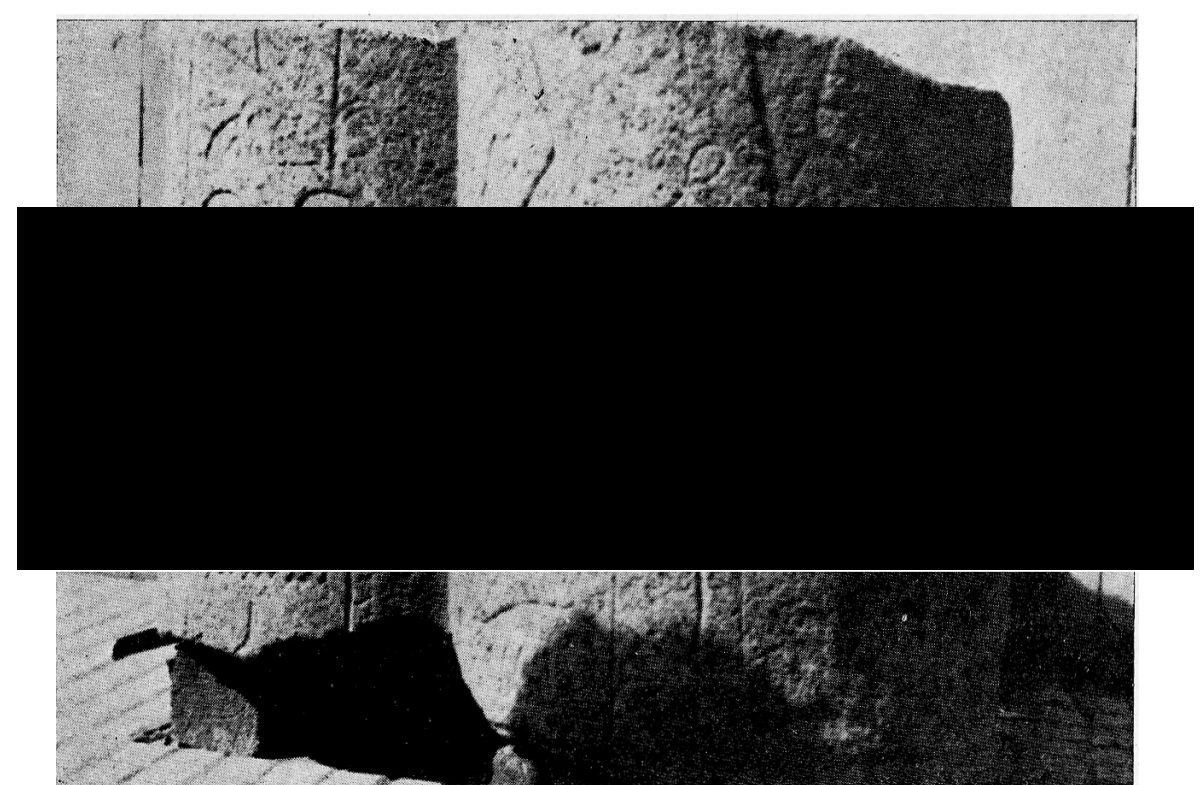

Fig. 6.7 Column fragment for Sobekneferu, Egyptian Museum Cairo, Habachi 1954: XVb. 


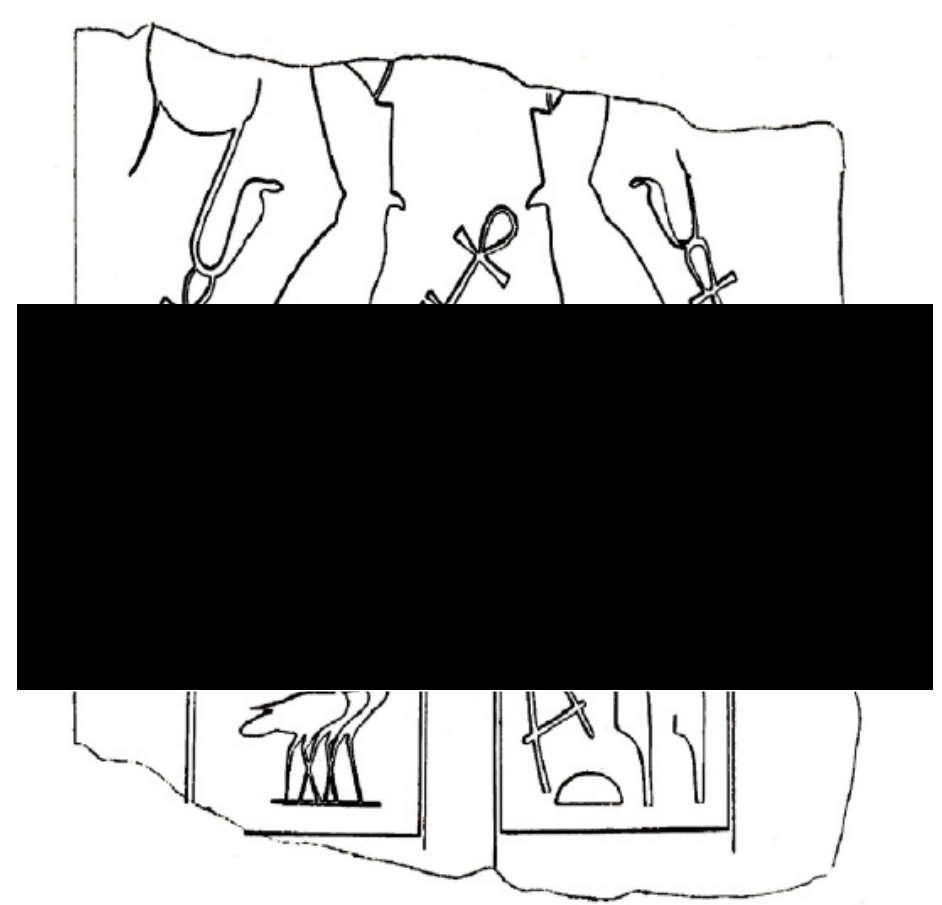

Fig. 6.8 Drawing of column fragment for Sobekneferu, Egyptian Museum Cairo, Habachi 1954: XVa.

A second plaque found by Petrie at the Hawara Labyrinth (Fig. 6.9) is made from limestone and now housed in the Petrie Museum (UC 14337). The plaque is inscribed with the names of Amenemhat III and Sobekneferu and that of the goddess Dehdehet. ${ }^{803}$ From left to right, Amenemhat III's cartouche and Dehdehet's name are facing Sobekneferu's inscription. Sobekneferu is named $s 3 t-r^{\complement}$ Daughter of Ra with her name encircled within a cartouche.

\footnotetext{
${ }^{803}$ Leitz 2002: VII, 597; Pignattari 2008: 73; Valloggia 1964: 49; Uphill 2000: 34, Uphill states that "this is the only known reference to this goddess"; Zecchi 2001: 143-144, suggests that Dehdet is a different spelling for Dehdh, the god of the ninth hour of the Amduat. This would be the oldest inscription for the deity;
} 


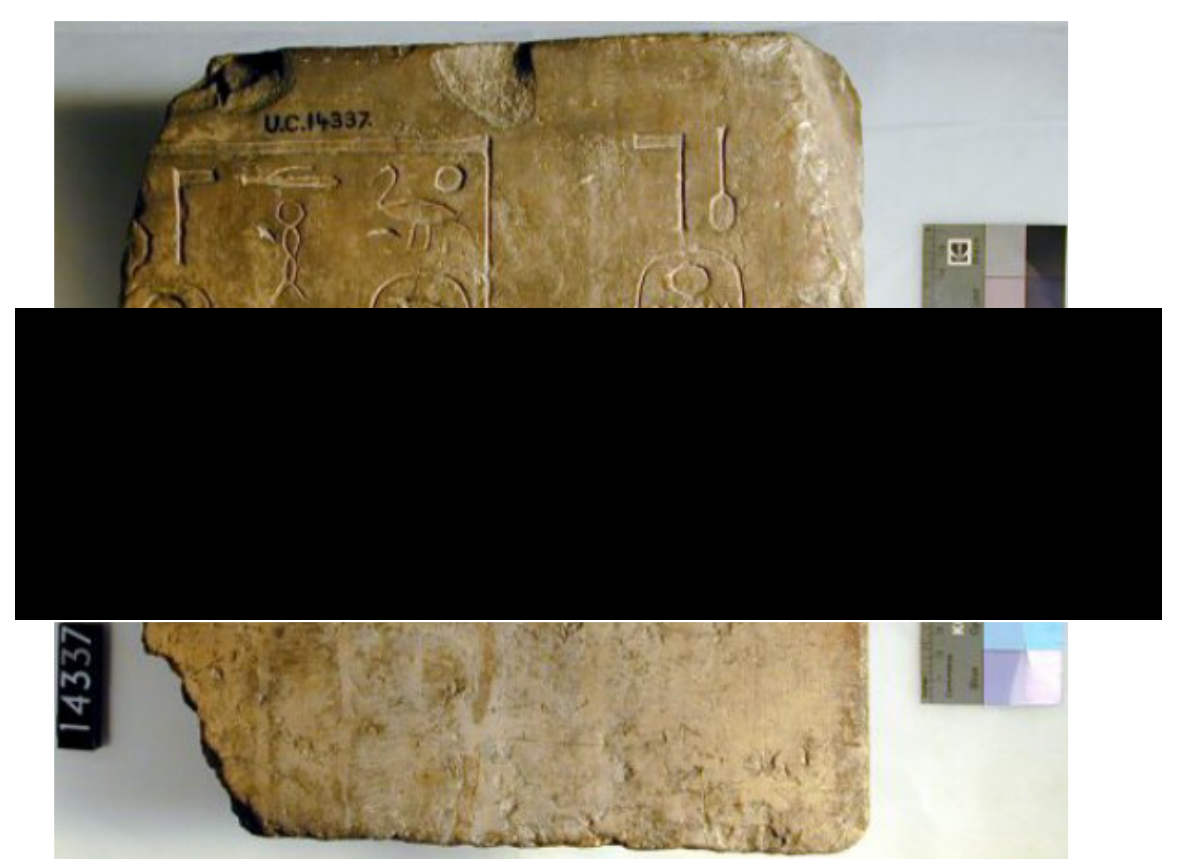

Fig. 6.9 Plaque with inscriptions of Sobekneferu, Amenemhat III and Dehdehet, Petrie Museum UC14337.

Both of these fragments found at Hawara illustrate Sobekneferu's reign and close affiliation with Amenemhat III. These inscriptions also show Sobekneferu's direct connection with Amenemhat III's name and mortuary complex, further supporting that he was Sobekneferu's father. Amenemhat III would have been buried in his pyramid several years before Sobekneferu became pharaoh (for discussion see Chapter 7.4) so she must have continued building at the complex after his death. Petrie commented that Amenemhat IV's name never appeared among the fragments found at Hawara, thus suggesting Sobekneferu finished building the complex rather than her predecessor. ${ }^{804}$ During her reign Sobekneferu commissioned building projects at both Herakleopolis Magna and Tell el-Dab'a, therefore it is likely she would have also completed the mortuary complex of Amenemhat III at Hawara.

${ }^{804}$ Petrie 1894: 197, Uphill 2000: 43, 45. 


\subsection{Surviving architraves from Herakleopolis Magna (Ihnasya el-Medina and the Temple of Kom el-Aqarib)}

Herakleopolis Magna or Ihnasya el-Medina is located near the Fayum and is named for its most significant god, 管的 Herishef, "He who is upon his lake" who was identified with the separate god Osiris. ${ }^{805}$ Herakleopolis Magna was a historically significant site from the First Dynasty and was at its political height as the capital of the Ninth and Tenth Dynasties during the First Intermediate Period. ${ }^{806}$ Herakleopolis Magna's location near the entance of the Fayum made the site geographically important and also why Tweflth Dyansty rulers such as Senwosret III and Sobekneferu may have taken building interest there. ${ }^{807}$ The site has been excavated by the Spanish Archeological Missoin, Museo Arqueológico Nacional, Madrid team under the direction of Carmen Pérez-Die with recent prospection and documention done for the Twelfth Dynasty temple at Kom el-Aqarib. ${ }^{808}$

It is most likely that the Tweflth Dyansty temple was separate from the main Temeple of Herishef and was possibily near the lake of Ihnasya, however due to the heavy reuse of blocks by Ramses II, the complete reconstruction of Twelfth Dynasty buildings is unclear. ${ }^{809}$ In addition to finishing her father's mortuary complex, Sobekneferu further extended her building projects in Egypt. Several architraves inscribed with Sobekneferu's name survive from the site (Fig. 6.10), ${ }^{810}$ including one with the inscription $\odot$ ( Sobek-ka-Ra, daughter of Ra, Neferu-Sobek Shedyt. ${ }^{811}$ Based upon the surviving blocks from the site, it is possible that Sobekneferu commissioned a complete or partial temple during her time as pharaoh. Surviving inscriptions and colossi statue for Senwosret III were found on the site suggesting he also had building projects in the area. ${ }^{812}$ It is likely that during her reign Sobekneferu would have expanded or built a temple next to Senwosret III's. This building project would connect Sobekneferu with the previous ruler, who was possibly her grandfather.

\footnotetext{
${ }^{805}$ Leitz 2002: V, 381-383; Mokhtar 139-191; Naville 1894: 2; Wilkinson 2003: 193.

${ }^{806}$ Mokhtar 1983: 119-120.

${ }^{807}$ Mokhtar 1983: 20, 123; For Senwosret III's building presence at the site see Connor and Delvaux 2017.

${ }^{808}$ For more information on the excavations see Pérez Die 2009, 2015, 2016, 2017.

${ }^{809}$ Connor and Delvaux 2017: 252; Mokhtar 1983: 78-79, 90.

${ }^{810}$ Daressy 1917: 34-35; Mokhtar 1983: 90, pl. VIIIA; Pérez-Díe 2016: 135; Pérez-Díe 2017: 481.

811 Callender 1995: 230, Pignattari 2008: 73; Valloggia 1964: 45-46.

812 Daressy 1917: 35; Pérez-Díe 2017: 481, 484.
} 


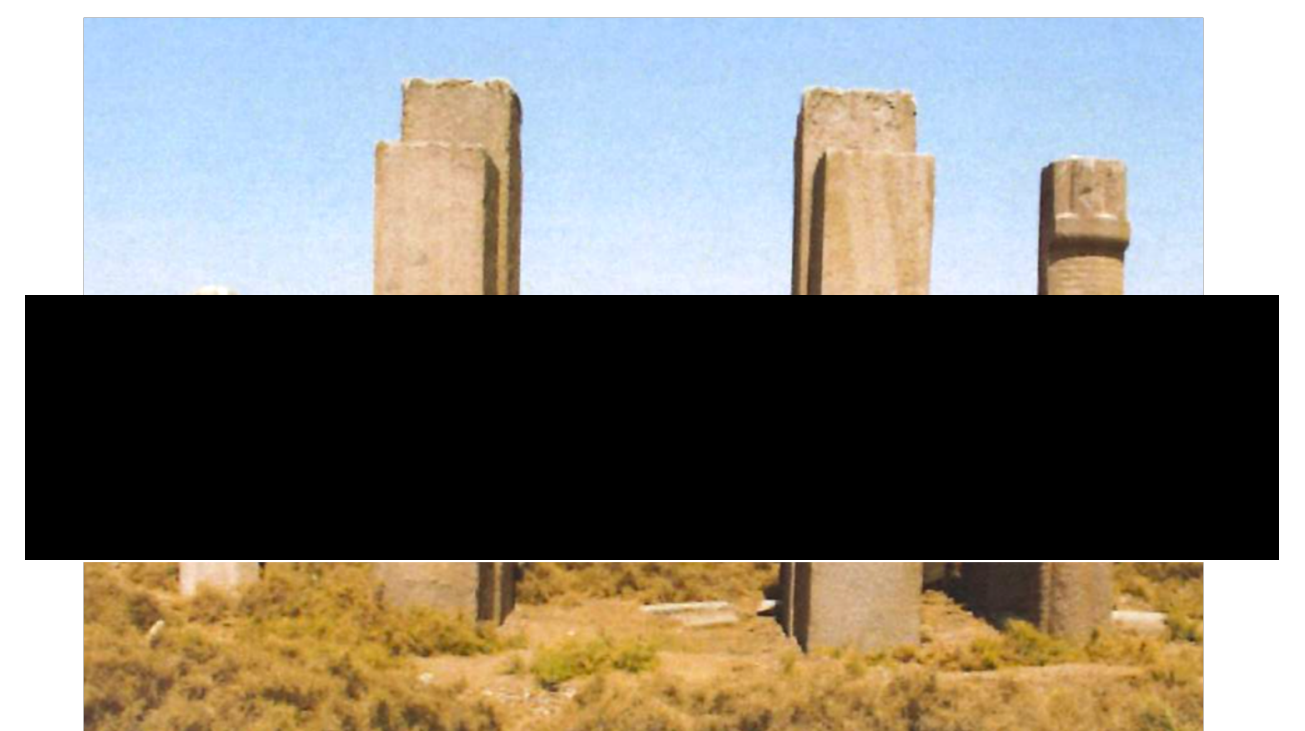

Fig. 6.10 Surviving blocks from the Kom el-Aqareb Temple at Herakleopolis Magana, Perez-Die 2017: 481.

\subsection{Karnak and Saqqara Lists, the Turin Canon, and Manetho}

King or ruler lists are records of the royal successions for people in the ancient Egyptian pharaonic office. This practice of recording pharaohs was prevalent during the Twelfth Dynasty and continued into the New Kingdom. ${ }^{813}$ Sobekneferu's sole reign as Pharaoh of Egypt is recorded on the Karnak ${ }^{814}$ and Saqqara lists, ${ }^{815}$ the Turin Canon, ${ }^{816}$ and by the ancient historian Manetho. ${ }^{817}$ Now located in the Musée du Louvre (E13481), the Karnak ruler list originally named sixty-one pharaohs, but because of damage only thirty-nine names survive. The list was compiled during the reign of Thutmosis III and was located in the Chapel of Ancestors in the Akhmenu festival hall of the Temple of Amun-Ra in Karnak. ${ }^{818}$

Following the numbering of Lepsius, ${ }^{819}$ Sobekneferu is numbered twenty-two and is located on the third row reading right to left (Fig. 6.11). She is seated in second place behind Amenemhat IV and in front of Intef. This surviving representation shows Sobekneferu from the waist downwards with a small portion of her head. She is seated on a throne with her right hand lifted forward and her left hand resting on her lap while holding a bolt of cloth. Sobekneferu wears a kilt that is

\footnotetext{
${ }^{813}$ Redford 1986: 151, 1-2.

${ }^{814}$ Lepsuis 1853: 425-455.

815 Redford 1986: 21-24.

816 Ryholt 1977: 9-33.

${ }^{817}$ Waddell 1948: 68

${ }^{818}$ Chapelle des ancêtres du roi Thoutmosis III, Musée du Louvre Paris E13481; For more information see the Musée du Louvre online catalogue http://cartelfr.louvre.fr/cartelfr/visite? $\mathrm{srv}=$ car not frame\&idNotice=19043. ${ }^{819}$ Lepsuis 1853: 425-455; Valloggia 1964: $\overline{51}-5 \overline{3}$.
} 
belted at her waist with a bull's tail that is pulled forward in front of her legs. Since the bottom half of her iconography is identical to that of the other rulers, it can be assumed she would have worn the nemes headdress with a uraeus, a broad collar, and a royal beard. Like the other rulers listed her titles include her name within a

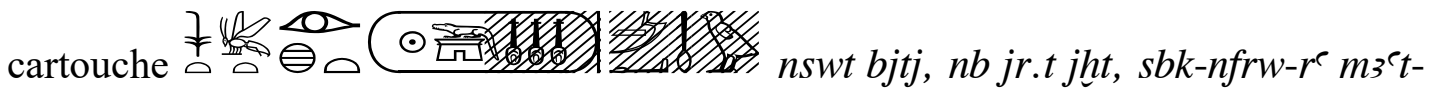
hrw Monarch of Upper and Lower Egypt, Lord of the rituals, Sobek-Neferu-Ra Justified. The fact that Sobekneferu is included within this list of rulers that all have the same titles and iconography, shows her equality among the pharaohs before and after her time period. She is included here as a predecessor of Thutmosis III, which unequivocally confirms her importance as a legitimate reigning pharaoh of the past.

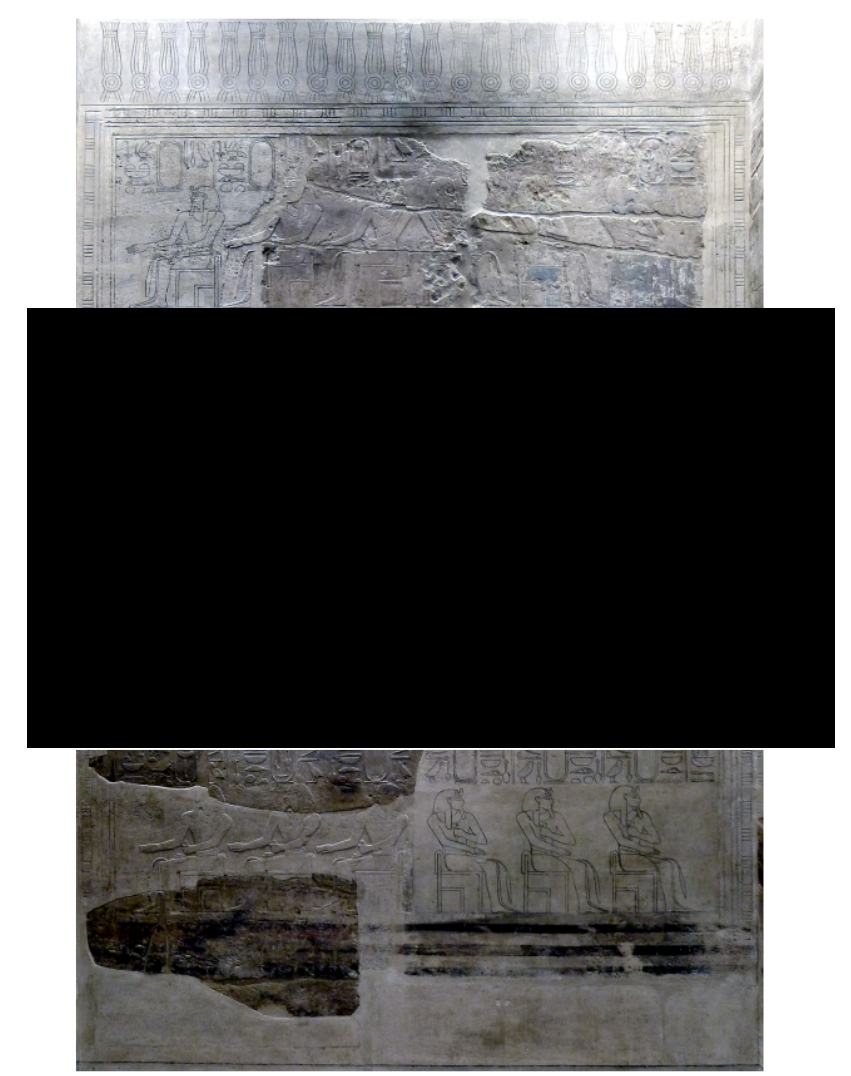

Fig. 6.11 Sobekneferu located on the Karnak ruler list, Musée du Louvre E 13481.

The Saqqara ruler list or Saqqara Tablet is now housed in the Egyptian Museum, Cairo (CG 34516). The list was composed during the reign of Ramses II and found in the tomb of Tjenry in Saqqara. ${ }^{820}$ It originally named fifty-eight rulers but now has forty-seven preserved. The list reads from right to left and Sobekneferu's prenomen,

${ }^{820}$ Mariette 1864: 169; Redford 1986: 21-24; Valloggia 1964: 51-52. 
$s b k-k 3-r^{e}$, is listed twenty-second on the top row (Fig. 6.12). She is named between $m 3^{e}-h r w-r^{c}$, Amenemhat IV, and $n f r-k 3-r^{c}$, Pepi II. Each ruler's prenomen is accompanied with $n s w t$ followed by a seated monarch determinative. Each determinative alternates with the white and red crowns of Upper and Lower Egypt. Sobekneferu is named monarch (red crown) Sobek-ka-Ra justified

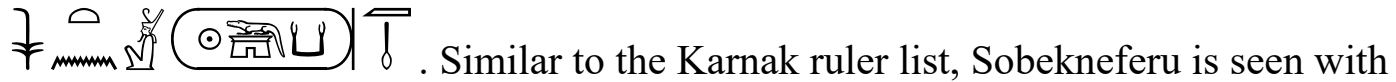
identical titles and with equal importance as the other pharaohs listed. Not only was she recognized as a Twelfth Dynasty pharaoh by later rulers, she was also remembered by the tomb owner and possibly other elite.

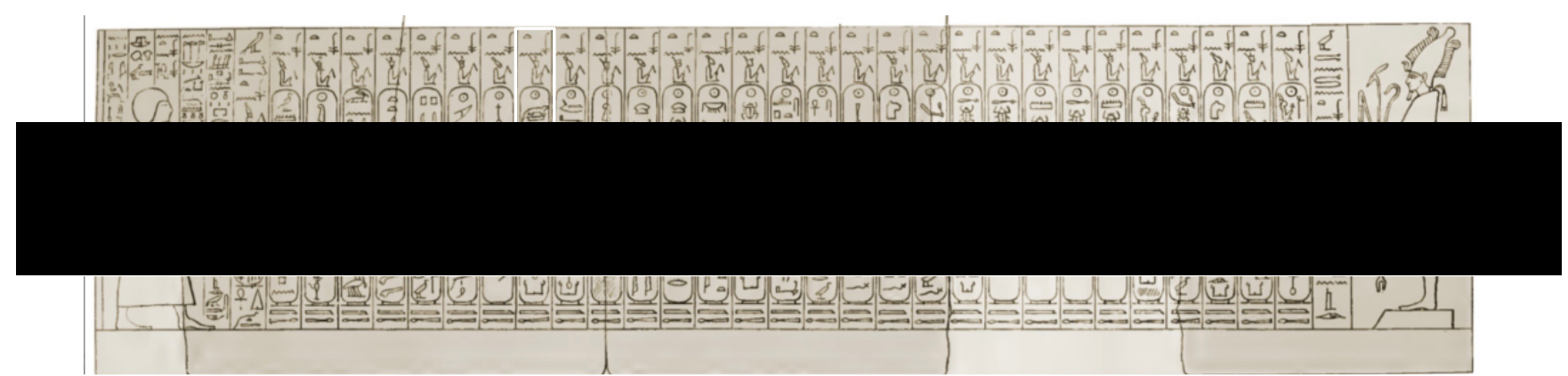

Fig. 6.12 Sobekneferu recorded on the Saqqara list, Mariette 1864: 169.

The Turin Canon is now housed in the Museo Egizio di Torino, Italy (papyrus number 1874) ${ }^{821}$ It is considered by Ryholt as the truest king list prior to the Ptolemaic Period because it records all of the rulers' names along with their reign length. ${ }^{822}$ The list is composed of eleven columns and only has names surviving until the late Seventeenth Dynasty. Because of the papyrus' state of preservation and a tax register written on the reverse dating to the reign of Ramses II, Ryholt suggests the Turin list was created at this time. ${ }^{823}$ Sobekneferu's name and reign length is mentioned within the Twelfth Dynasty section in column seven, line two (Fig. 6.13). She is listed under Amenemhat IV and above the concluding statement that the Twelfth Dynasty consisted of eight rulers: Amenemhat I, Senwosret I, Amenemhat II, Senwosret II, Senwosret III, Amenemhat III, Amenemhat IV, and Sobekneferu. The dynasty lasted for two hundred and thirteen years, one month and seventeen days. Sobekneferu's entry is centrally damaged but what survives states she was the

\footnotetext{
${ }^{821}$ Gardiner 1959.

822 Ryholt 1997: 9; Ryholt 2004: 135.

${ }^{823}$ Ryholt 2004: 135-138.
} 


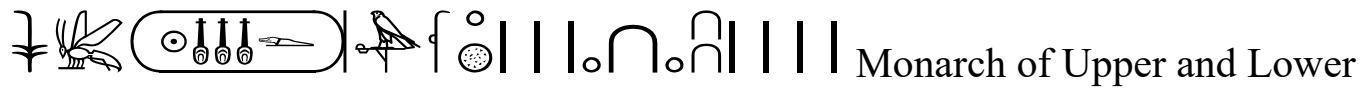

Egypt Sobek-Neferu-Ra, 3 years, 10 months, and 24 days. ${ }^{824}$ This is currently the only surviving ancient Egyptian statement for Sobekneferu's reign length.

Similar to the Karnak and Saqqara lists, the Turin list includes Sobekneferu in an identical way like all the other rulers. As noted by Ryholt, Sobekneferu's gender is not marked, which may have been the result of forgotten information. ${ }^{825}$ His assertion is plausible, but as seen on the Karnak and Saqqara lists her gender is not marked either. On all of her surviving inscriptions her prenomen and nomen are never gender marked. There was not a need to gender mark the Egyptian phrase $n s w t$-bjtj and as monarch her official position was of greater importance than her sex.

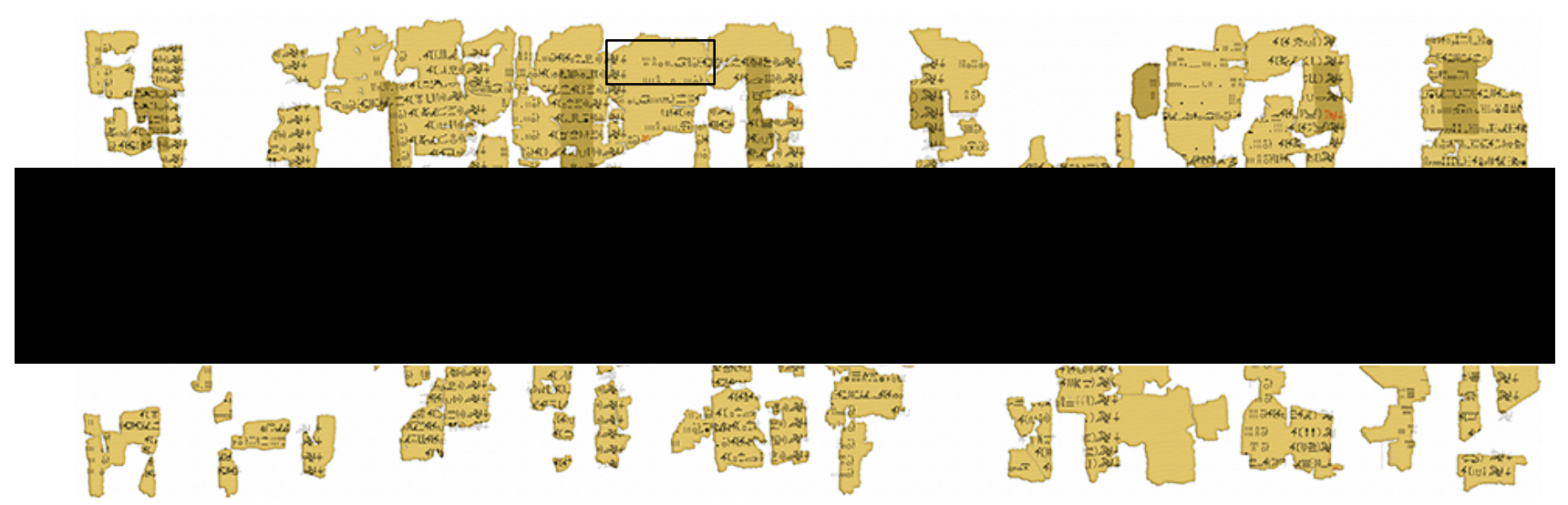

Fig. 6.13 Sobekneferu located on the Turin List, Museo Egizio di Torino 1874.

Manetho wrote his Aegyptiaca during the early Ptolemaic Period and his thirtydynasty division is still used in numbering the dynasties of ancient Egypt. ${ }^{826}$ The list of Twelfth Dynasty rulers can be found at the beginning of Manetho's second book. He included seven pharaohs, placing Amenemhat I between the Eleventh and Twelfth Dynasties, omitting Senwosret II and listing Amenemhat III as two different kings. Although these discrepancies are present for Amenemhat I, Senwosret II, and Amenemhat III, Sobekneferu's entry is presumably accurate. Manetho listed her as Scemiophris, his [Amenemhat IV's] sister who reigned for four years. ${ }^{827}$ This statement of a four-year reign is consistent with what is recorded on the Turin List. Manetho's interpretation also matches the likely case Sobekneferu was Amenemhat

\footnotetext{
${ }^{824}$ Ryholt 1997: 15; Valloggia 1964: 51-52.

${ }^{825}$ Ryholt 2004: 142.

${ }^{826}$ Redford 1986: 231-242.

827 Waddell 1948: 68.
} 
IV's sister and never his wife.

Sobekneferu is listed as a ruler on the Karnak, Saqqara, and Turin lists along with Manetho's Aegyptiaca. These surviving records support the fact that Sobekneferu was a sole reigning pharaoh who controlled Egypt in her own right. Her reign took place after that of Amenemhat IV's and lasted just short of four years. Sobekneferu's reign was recognized and remembered by both royal and non-royal people of later periods. Her time as pharaoh is recorded in these four lists, thus cementing her sole reign and its relevance to later ancient Egyptian rulers and historians.

6.7 Glazed blue cylinder seal BM EA 16581 and Cylinder seal Cairo JE 72663 A glazed blue cylinder seal now located in the British Museum is made of steatite and measures $4.42 \mathrm{~cm}$ (1.5in) in length (Fig. 6.14, 6.15). The inscription of Shedyt on the cylinder seal may suggest the object came from the town of Shedyt ${ }^{828}$ or somewhere in the Fayum. There is also a second, lesser-known cylinder seal inscribed with the name Sobekneferu. Once in the collection of King Fouad, it now resides in the Egyptian Museum Cairo (JE 72663) ${ }^{829}$ From the Naqada II period onwards cylinder seals were used as indications of long-distance trade networks within and beyond Egyptian borders. As a symbol of administrative power cylinder seals continued developing, further enhancing the status of the person mentioned and showing the control of goods through the power of the ruler and the cult centers. ${ }^{830}$ Sobekneferu's reign was continuously promoted and the cylinder seals demonstrate the usage of her name by officials to seal administrative documents or jars of valuable goods. Furthermore, her usage of Sobek of Shedyt on both seals confirm her connection with the god and the location of the Fayum.

\footnotetext{
${ }^{828}$ For full study of Sobek of Shedyt see Zecchi 2010.

${ }^{829}$ Aufrère 1989: 13.

${ }^{830}$ Hill 2016:114-155, 120-121; see also Pittman 1988: 167, "Seals were used through the millennia both as amulets and as tools in the administration of economic and legal matters".
} 


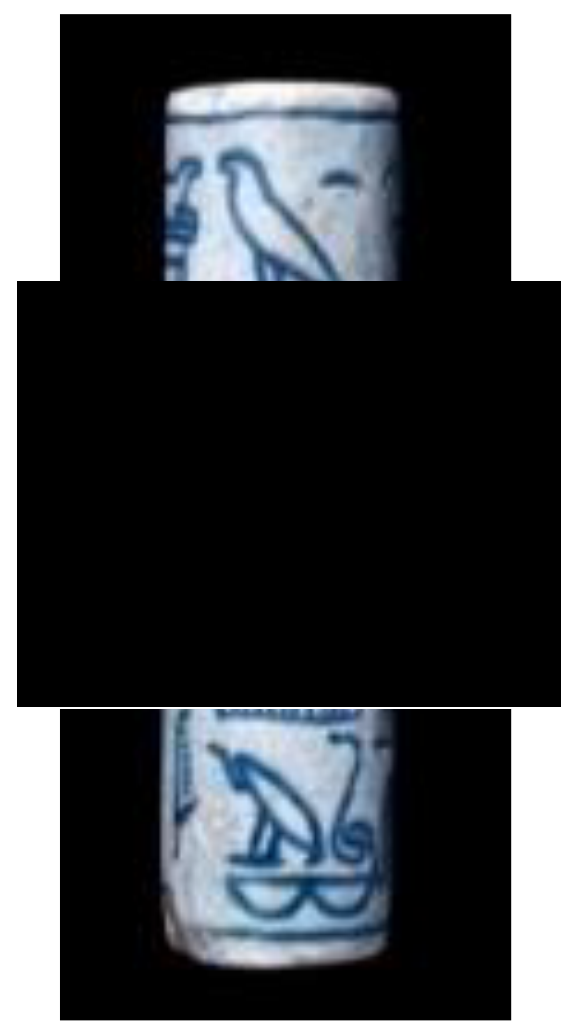

Fig. 6.14 Glazed blue cylinder seal, British Museum London 16581.

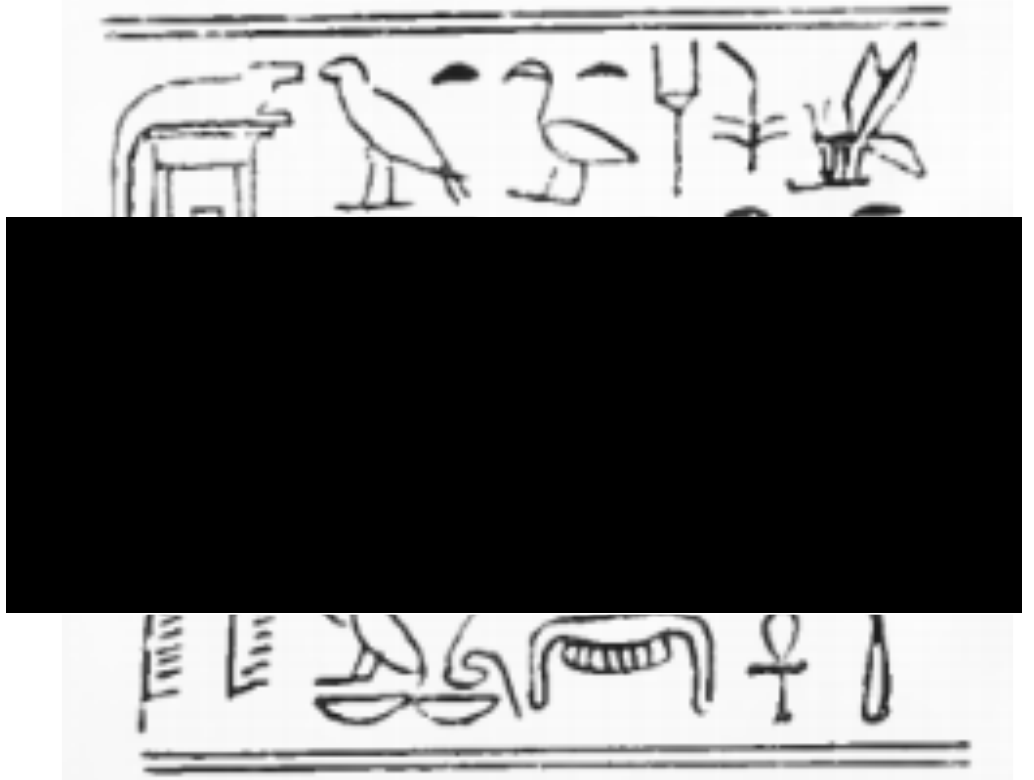

Fig. 6.15 Drawing of glazed blue cylinder seal, British Museum London 16581.

The British Museum cylinder seal displays four of the five royal names for Sobekneferu, which are her Horus, Two Ladies, Golden Horus, and Nomen. The inscription reads: mryt sbk šdty, hrt mryt-re, nbty s3t shmm nbt t3wy, hrr nbw $\underline{d} d t-h^{\complement} w$, nswt bjtj nfrw-sbk-šdty 'nh.ty ${ }^{831}$ Beloved of Sobek of Shedyt, Female Horus,

${ }^{831}$ Callender 1998a: 233; Pignattari 2008: 75; Valloggia 1964: 50. 
beloved of Ra; Two Ladies, daughter of the powerful one Lady of the Two Lands; Golden Horus, stable of Appearance; Monarch of Upper and Lower Egypt, NeferuSobek Shedyt, who lives. ${ }^{832}$ Her Horus name, Beloved of Ra, is unique to the Twelfth Dynasty and her Two Ladies name can either be translated as daughter of the Powerful one Lady of the two lands or the daughter of the powerful one is now the Lady of the Two Lands. Leprohon suggests that in the second translation the powerful one would refer to Amenemhat III ${ }^{833}$ and Sobekneferu may have borrowed componenets of her royal titulary from the pharaohs before her. For example, $t 3 w y$ is also used in Amenemhat IV's Two Ladies name and h్ $h^{\complement} w$ is part of Senwosret III's prenomen. ${ }^{834}$

Having full pharaonic titulary suggests her reign was fully recognized and her titles were used for the sealing of objects. Similar to her seated statues from Tell el-Dab'a and the fragment from Hawara, Sobekneferu's Horus and Two Ladies names on the cylinder seal are marked with $t$. It is noted by Leprohon that given the types of royal names from the Twelfth Dynasty, it is possible the pharaoh played a significant role in titulary decisions. ${ }^{835}$ Among commissioning statues and building projects, Sobekneferu could have constructed her titulary in a way suitable for her reign as a female monarch. Her complete titulary also shows her equality with other pharaohs, which was similar to her iconographic features that presented her as a legitimate ruler.

The Cairo cylinder seal displays an inscription that reads: $n s w t$ bjtj $n f r w-s b k$ $\check{s} d t y$ mry-sbk-šdty nbty sz $r^{e}$, Monarch of Upper and Lower Egypt, Neferu-Sobek Shedyt, beloved of Sobek-Shedyt, Two Ladies, Son of Ra. ${ }^{836}$ It seems this cylinder seal is similar to the one mention above (BM EA 16581), except it stops short of stating her Horus and Golden Horus names. On this seal Sobekneferu uses $s 3$ instead of $s 3 t$ and as Aufrère notes both cylinder seals use nswt bjtj with $n f r w$-sbk-šdty possibly suggesting $n f r w$-sbk-šdty was her throne name that was mixed with $n s w t$ bjtj sbk-k3-r ${ }^{837}$ Since Sobek is named, this could mean that the seal originally had connections with the city of Shedyt in the Fayum, which was most likely

\footnotetext{
832 Pignattari 2008: 75.

${ }^{833}$ Leprohon 1996: 171; Lepohon 2013: 60.

${ }^{834}$ Leprohon 1996: 170-171.

835 Leprohon 1996: 171.

${ }^{836}$ Callender 1995: 232; Pignattari 2008: 76.

837 Aufrère 1989: 13.
} 
Sobekneferu's administrative capital. ${ }^{838}$ Although her royal titulary is not as complete on the Cairo cylinder seal compared to the glazed blue cylinder seal, it further enforces that during her reign multiple pharaonic items were made for Sobekneferu and her titulary was formally recognized.

\subsection{Papyrus from Harageh}

A fragmented papyrus labeled Petrie Museum: UC 32778, found in Harageh by

Engelbach, contains Sobekneferu's name. ${ }^{839}$ The papyrus mentions Sekhem-Sobekneferu twice (Fig. 6.16, 6.17). Translated by Grajetzki, the fragmented letter reads:

[a message to] my lord, may he live, be prosperous and healthy about that he might hear [..

... according what was about ...

... southern district to the ...

... coming South...

... coming... in meeting Sekhem-Sobekneferu

... according to this letter which was brought to the servant there...

... the servant there...

... Senusret, true of voice, take...

... Sekhem-Sobekneferu, true of voice, north of...

$\ldots$ the servant there in the fields according... ${ }^{840}$

\footnotetext{
${ }^{838}$ Pignattari 2008: 79, as seen from her connections with Shedyt as the capital and not a specific temple of Sobek; Zecchi 2010: 86.

${ }^{839}$ Engelbach 1923: 33.

${ }^{840}$ Grajetzki 2004b: 55.
} 


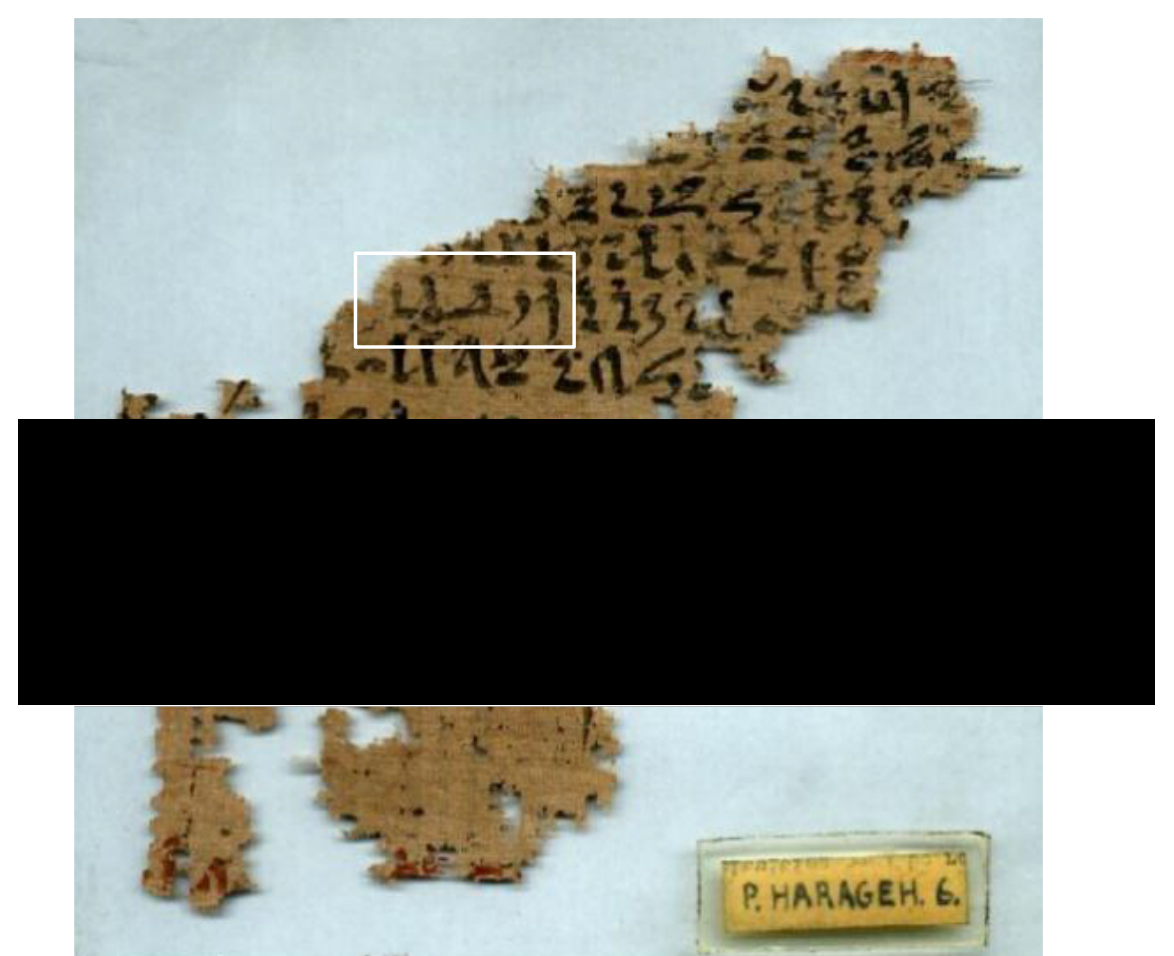

Fig. 6.16 Fragmented papyrus for Sekhem-Sobeknferu, Petrie Museum UC32778; Grajetzki 2004b: 55.

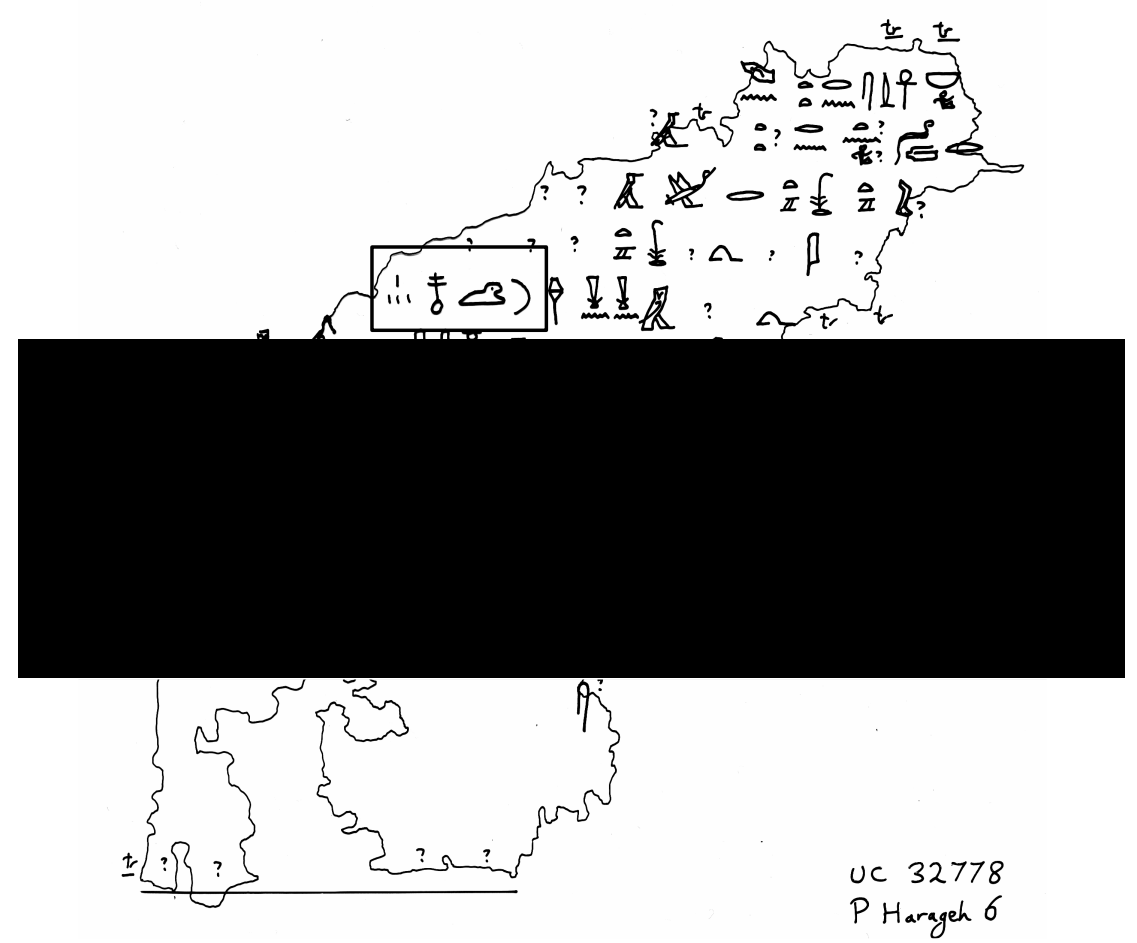

Fig. 6.17 Fragmented papyrus for Sekhem-Sobeknferu, Petrie Museum UC32778; Grajetzki 2004b: 55.

Grajetzki states that Sobekneferu is the latest Middle Kingdom ruler attested for the site of Harageh. He also tentatively suggests that the term Sekhem-Sobekneferu is referring to her pyramid or pyramid temple. ${ }^{841}$ Sekhem-Sobekneferu alluding

${ }^{841}$ Grajetzki 2004b: 55-56; Grajetzki 2006: 63. 
towards the pyramid complex of Sobekneferu is certainly a possibility because no information is preserved in regard to her burial. It is also expected that Sobekneferu's pyramid would have been built in the Fayum, which is where Harageh is located. Grajetzki also notes the surviving "true of voice" and although likely, it is unclear if Sobekneferu was dead at the time the letter was written. Her complex would have been started and seemingly completed during her lifetime, which would result in the complex having already been named. The Petrie Museum also dates the manuscript to the Thirteenth Dynasty ${ }^{842}$ which suggests that the letter was composed after the death of Sobekneferu. This would support the idea that Sekhem-Sobekneferu is her pyramid complex since the area around the burial most likely would have still been in use, similar to that of Amenemhat III and Neferuptah. This could further imply that her pyramid complex was established during and after the Twelfth Dynasty. The letter also proves inscriptions mentioning Sobekneferu existed among the non-royal population and her time in the pharaonic office was documented (see also Chapter 6.13).

\subsection{Bead with an inscription for Sobekneferu}

A bead from the collection of King Farouk has an inscription dedicated to

Sobekneferu. There is currently no image for the bead, which was recorded as being made from green faience that which, over time, had become nearly white. The shape is that of an elongated cylinder, similar to perfume vases. ${ }^{843}$ The bead contains two columns of identical inscriptions engraved opposite of each other (Fig. 6.18). The

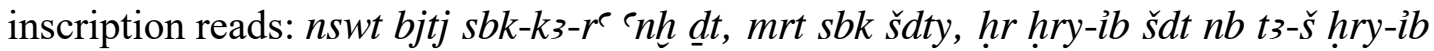
$h^{844}$ Monarch of Upper and Lower Egypt, Sobek-ka-Ra, living forever, beloved of Sobek of Shedyt (Fayum), The Horus residing in Shedyt (Fayum), Lord of the LakeLand residing in the palace. ${ }^{845}$

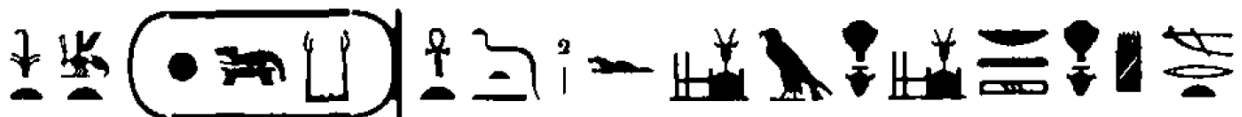

Fig. 6.18 Bead inscription for Sobekneferu, Habachi 1954: 463.

\footnotetext{
${ }^{842}$ For more information see the Petrie Museum online catalogue: http://petriecat.museums.ucl.ac.uk/detail.aspx?parentpriref $=\#$.

${ }^{843}$ Habachi 1954: 463.

844 Pignattari 2008: 79.

${ }^{845}$ Habachi 1954: 463.
} 


\subsection{Green pottery scarab and a Glazed steatite scarab (BM EA 66159)}

Two scarabs, one made of green pottery (Fig. 6.19) and another of steatite (Fig.

6.20), may be attributed to Sobekneferu. The green pottery scarab was originally recorded by Petrie ${ }^{846}$ and was read by Valloggia ${ }^{847}$ as being inscribed with the name of Sobekneferu. Callender notes that the curve of the scarab possibly does not allow

enough space for the crouched crocodile to be above the three nefer signs Without a close examination, conclusions cannot be made; however from Petrie's drawings the surviving traces strongly resemble a crocodile.

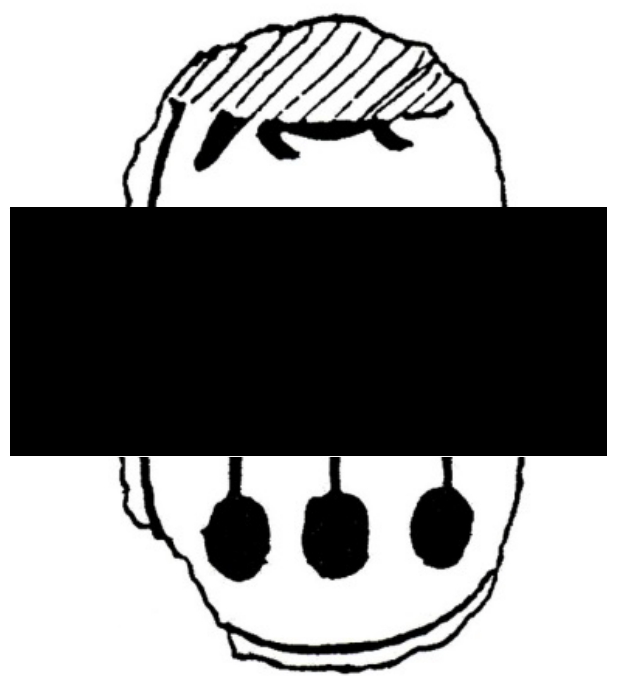

Fig. 6.19 Green pottery scarab, Petrie 1889: no.276; Callender 1998: 231.

The second scarab is housed in the British Museum (BM EA 66159) ${ }^{849}$ and is made of an ivory colored steatite (Fig. 6.20). Sobekneferu's name is seen outside of a cartouche, with $\underline{d} d$ ' $n h$ above and $\underline{d} t$ below her name. From the scarab's lack of cartouche, Callender suggests it may date to the early part of Sobekneferu's reign or possibly the time before her position in the pharaonic office. ${ }^{850}$ However, from the surviving material illustrated in this chapter, Sobekneferu's reign was immediately recognized and the scarab is of a typical style for royals. A surviving scarab for

\footnotetext{
${ }^{846}$ Petrie 1889: no. 276.

${ }^{847}$ Valloggia 1964: 49-50.

${ }^{848}$ Callender 1995: 232-233.

${ }^{849}$ Fore more information see the British Museum online catalogue: "Scarab"

http://www.britishmuseum.org/research/collection_online/collection_object_details.aspx?objectId=14 4829\&partId $=1$ \&searchText $=$ Sobekneferu\&page $=\overline{2}$.

${ }^{850}$ Callender 1995: 233.
} 
Amenemhat IV is similar in style ${ }^{851}$ but to the author's knowledge, this scarab has not been argued to be from the early part of his reign. Additionally, it is relatively common for the name of the pharaoh to be found outside of the cartouche on scarabs in this style. Since the scarabs are so similar it can be assumed both are symbols of Sobekneferu's and Amenemhat IV's positions in the pharaonic office and likely not notions of their reign timeline.

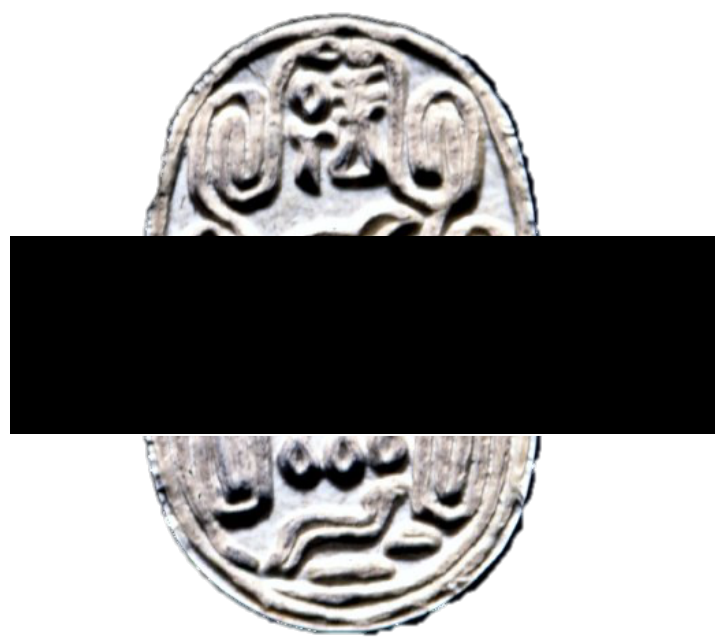

Fig. 6.20 Scarab inscribed for Sobekneferu, British Museum London EA 66159.

\subsection{Nile level reading at the Second Cataract from Kumma, Nubia} A Nile level reading of $1.83 \mathrm{~m}(6 \mathrm{ft})^{852}$ from Kumma was recorded in the third and final year of Sobekneferu's reign (Fig. 6.21). The graffito reads: The level of the Inundation on the third year under the Majesty of the Monarch of Upper and Lower Egypt, Sobekneferu, living forever and eternally. ${ }^{853}$

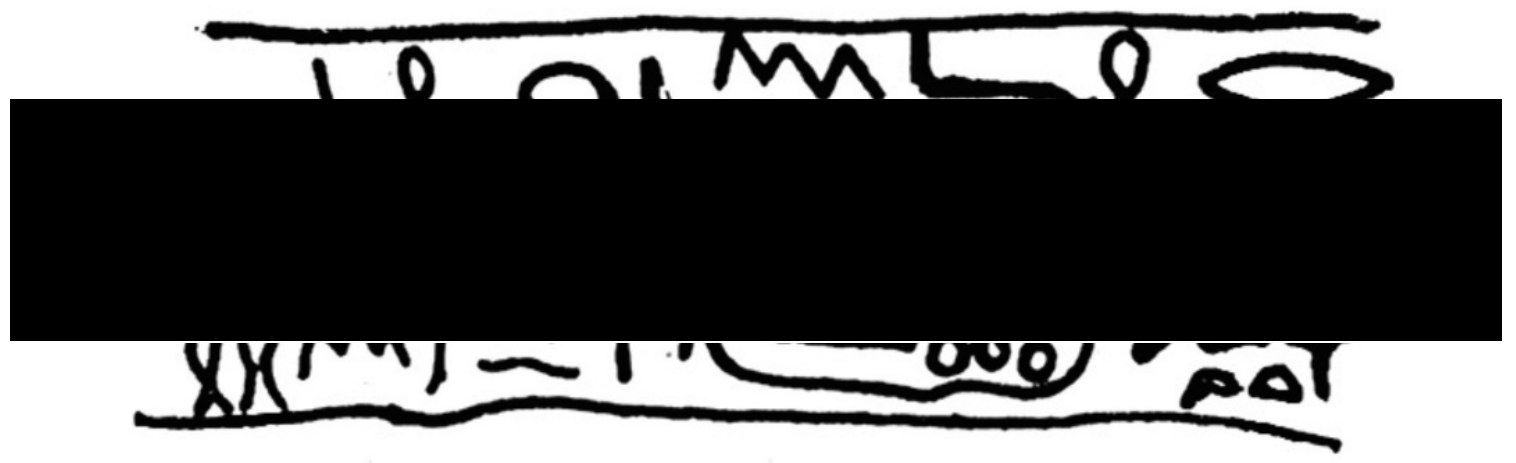

Fig. 6.21 Nile level reading for Sobekneferu located at the Second Cataract from Kumma Nubia, Habachi 1954: P1. XIII C.

\footnotetext{
${ }^{851}$ Scarab of Amenemhat IV, Petrie 1897: 196.

852 Callender 1995: 232, Tallet 2005: 254.

${ }^{853}$ Habachi 1954: 463; Valloggia 1964: 50.
} 
The majority of the Twelfth Dynasty Nile level readings were inscribed with the name of Amenemhat III, which include eighteen recordings in his regnal years 1, 5, $6,7,8,9,13,14,22,23,24,31,32,36,37,40,41$, and $43 .{ }^{854}$ Fourteen of these are found at Kumma, along with Sobekneferu's year 3 inscription. Amenemhat IV also had three Nile level recordings during his fifth, sixth, and seventh regnal years, located at Semna. ${ }^{855}$ In comparison to the high flood recordings of Amenemhat III's Kumma Nile readings, particularly in his regnal years 23 (4.91 m), 30 (5.10 m), 31 $(3.26 \mathrm{~m})$, and $32(4.42 \mathrm{~m}),{ }^{856}$ Callender suggests Sobekneferu's $1.83 \mathrm{~m}$ is a low Nile level reading. ${ }^{857}$ Although it seems Amenemhat III's reign experienced great flooding, some years are recorded as being lower than Sobekneferu's, such as years 5 (0.64 m), $14(1.26 \mathrm{~m}), 40(0.00 \mathrm{~m})$ and $41(0.74 \mathrm{~m}) .{ }^{858}$

Numerous rock inscriptions dated to the Twelfth Dynasty have been found in the area of Buhen near to where Senwosret III's fortress was built. ${ }^{859}$ It can be proposed that after the reign of Amenemhat III, during those of Amenemhat IV and Sobekneferu, there was still a strong Egyptian occupation around the Second Cataract in Nubia. The Nile level reading suggests that during Sobekneferu's reign as pharaoh Egypt was still in control of Nubia and she was recognized and recorded as the ruling figure by an official. Coinciding with her other surviving artifacts and inscriptions, her Nile level recordings were connected with those of Amenemhat III at Kumma instead of Amenemhat IV's at Semna who was the direct ruler before her. Nile level readings are attested for the early rulers of the Thirteenth Dynasty ${ }^{860}$ suggesting the Egyptian occupation of Nubia transferred from Sobekneferu to Sobekhotep without an interruption in the recordings. The Nile level reading proves Sobekneferu was documented as the holder of the pharaonic office by an official as well as future recordings carried throughout her reign and into the Thirteenth Dynasty without disruption.

\footnotetext{
854 Peden 2001: 41.

855 Peden 2001: 42.

856 Putter 1993: 269.

${ }^{857}$ Callender 1995: 232.

858 Putter 1993: 269.

${ }^{859}$ Smith 1972: 54-55; Smith 1976: 61-93.

${ }^{860}$ Peden 2001: 51.
} 


\subsection{Statue base inscribed for Amenemhat III and Sobekneferu (Cat. 57)}

A statue base fragment inscribed with the names of Amenemhat III and Sobekneferu (Cat. 57) is now located at the Ägyptisches Museum und Papyrussammlung, Berlin 38/66. Although the provenance is unknown, the base fragment most likely comes from Hawara. ${ }^{861}$ The fragment is $50 \mathrm{~cm}$ (1 $\left.\mathrm{ft} 8 \mathrm{in}\right)$ in width and is probably made from limestone instead of alabaster as originally described. ${ }^{862}$ The statue base was first recorded by Werner Kaiser as part of the museum's collection (Fig. 6.22). Kaiser notes the importance of Sobekneferu's inscription as pharaoh and that she was one of the few independent female rulers along with Hatshepsut of the Eighteenth Dynasty. ${ }^{863}$ Kaiser, Blom-Böer, and Zecchi all identify the name Sobek of Shedyt on the fragment and briefly describe Sobekneferu's closeness with the god. Zecchi translates the fragment as: Beloved of Sobek of Shedyt - Horus who resides in Shedyt, ruler of the two banks who, in his turn, grants life, stability and power to Sobek-ka-Ra. ${ }^{864}$

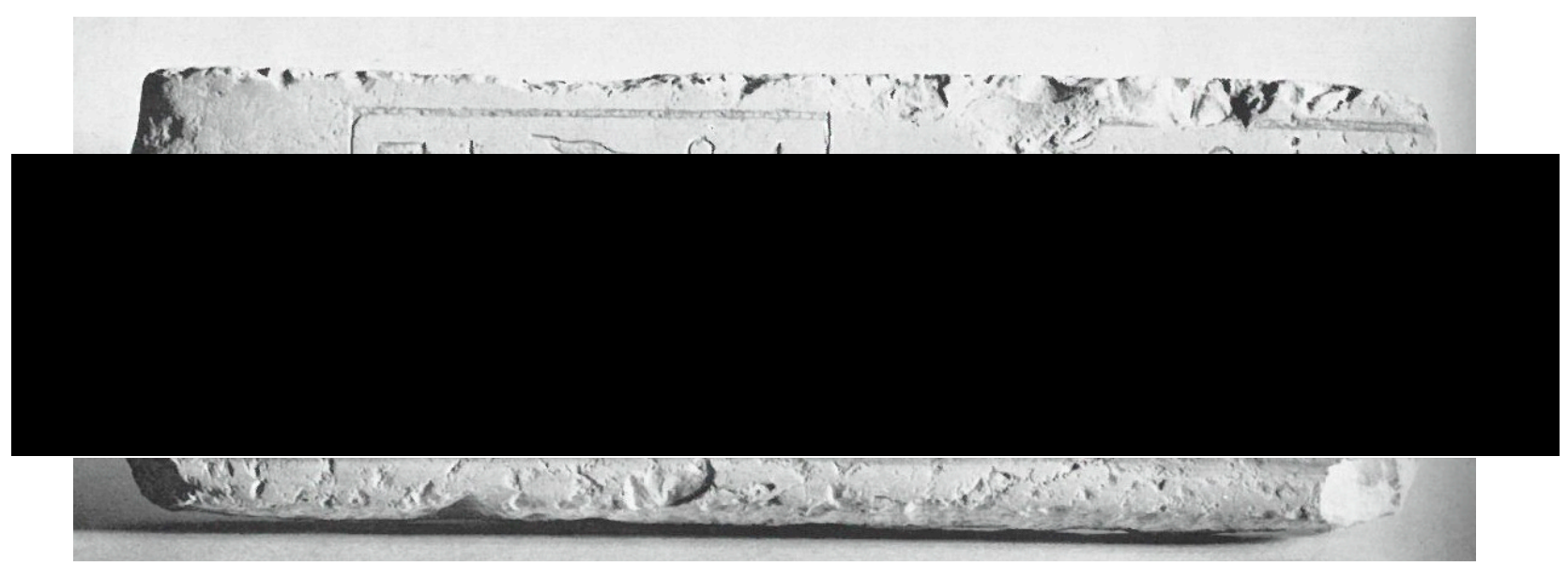

Fig. 6.22 Fragment of statue base inscribed for Sobekneferu (Cat. 57), Kaiser 1967: pl. 428.

\subsection{Stela inscribed with Sobekenferu's name}

A stela found at Abydos dating to the Thirteenth dynasty inscribed with Sobekneferu's name is now located in the Marselles Château Borély with the museum number 223 (Fig. 6.23). ${ }^{865}$ The owner of the stela is Hnms and it is made from limestone measuring $58.5 \mathrm{~cm}$ (1ft1 i in) in height and $42.4 \mathrm{~cm}(1 \mathrm{ft} 5 \mathrm{in})$ in width. The top of the stela is rounded and depicts two jackals on shrines with the stela

\footnotetext{
${ }^{861}$ Kaiser 1967: 42, no. 428; Zecchi 2010: 85, Doc 62.

862 Blom-Böer 2006: 286, no. SG. 27; Kaiser 1967: 42, no. 428.

${ }^{863}$ Kaiser 1967: 42, no. 428.

${ }^{864}$ Zecchi 2010: 85.

${ }^{865}$ Photograph and infromation was provided by Gilles Deckert at the Marselles Château Borély; for publicaitons see Grajetzki 2001: 24, no. 3.8 and Maspero 1890: 114.
} 
divided into two main scenes below. The top two registers include ten of his male and female colleagues including his nephew Jbj-jb. Represented on the stela's lower half is Hmns sitting at an offering table before multiple members of his family. Grajetzki states that the inscription for Amenemhat II and Sobekneferu seem to refer to their cults which means both were still worshipped during the Thirteenth Dynasty. ${ }^{866}$ Initially recorded by Maspero ${ }^{867}$ Grajetzki mentions that the original inscriptions by Maspero are not exact and includes a transliteration of the titles ${ }^{868}$ which can be translated as:

Main person: rh-nswt hnms

Other people:

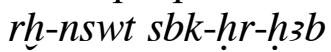

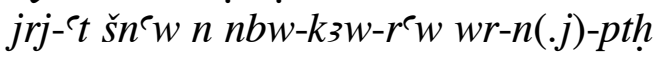

hrj pr $n$ pr- $\varsigma_{3} j b j$

jbhw kзmw

jrj-`t šn ${ }^{\complement} w$ n sbk-nfrw hbjj

jmj-rз wrt $n$ nbwjj pth-wr

jmj-rз $\mathrm{pr}$ jbj-jb

$n f r-h$ tp

ky

snb

tn-nfrt

Main person: The Monarch's acquaintance Hnms

Other people:

The Monarch's acquaintance Sbk-hr-hab

Regional officer for the food production part of the palace of Nbw-Ka-Ra

(Amenemhat II) Wr-nj-Pth ${ }^{869}$

Head of the Great House Jbj

Libationer Kamw

Regional officer for the food production part of the palace of Sobekneferu Hbjj

Section overseer of the goldsmiths Pth-wr ${ }^{870}$

Steward Jbj-jb

Nfr-Htp

Ky

$\mathrm{Snb}$

Tn-nfrt

${ }^{866}$ Grajetzki 2001: 24; Grajetzki 2006: 63.

${ }^{867}$ Maspero 1890: 114.

${ }^{868}$ Grajetzki 2001: 24.

869 "The food production part of the palace called the $\check{s} n$ ` $w$ " Grajetzki 2001: 78.

870 "Section overseer of the goldsmiths" provided by Dr Rita Lucarelli, University of California, Berkeley, Email correspondence. 


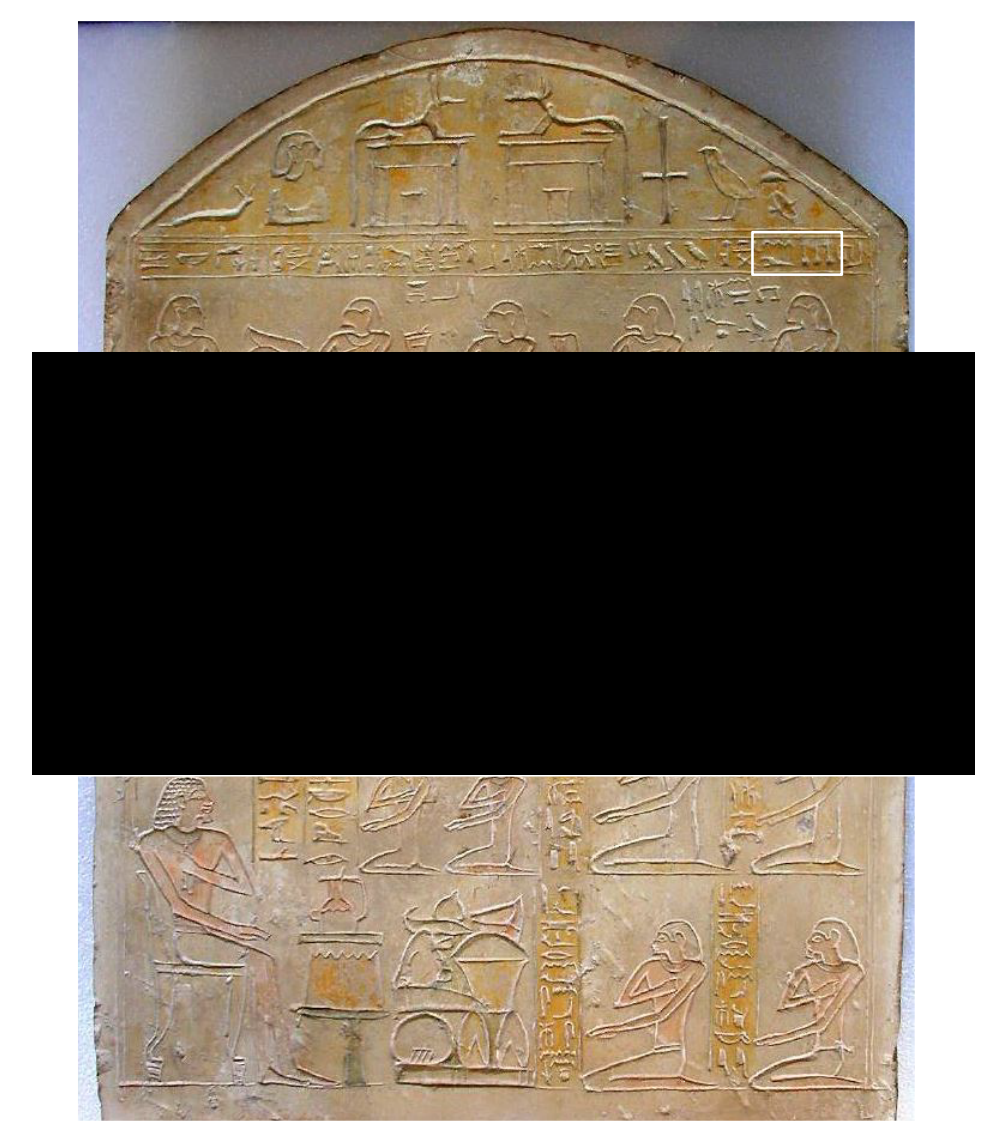

Fig. 6.23 Thirteenth Dynasty Stela with Sobekneferu’s name, Marselles Château Borély 223.

\subsection{Possible statue found at Gezer (Cat. 14)}

The feet and fragmented base of statuette inscribed with the name of a Princess

Sobekneferu was discovered in Tell Gezer, located modern day Israel, by the Hebrew Union College Biblical and Archaeological School on July 9, 1971 (Cat. 14; Fig. 6.24). The statue fragment is $10.2 \mathrm{~cm}$ (4in) long, $11.7 \mathrm{~cm}$ (5in) wide, and $5.6 \mathrm{~cm}$ (2in) high. The inscriptions on the right and left sides would have been identical, which was the prevalent style of Twelfth Dynasty seated statues. The inscriptions can be restored to read: The Monarch's daughter of his body, Sobekneferu, may she live (Fig. 6.25). ${ }^{871}$ Weinstein states that the statuette was probably not originally erected at Gezer during the Twelfth Dynasty because no other Middle Kingdom statues have been found in Palestine. He suggests the statue was brought to Palestine in a later time period, possibly by the Hyksos during the Second Intermediate Period. ${ }^{872}$

\footnotetext{
${ }^{871}$ Weinstein 1974: 49-50.

872 Weinstein 1974: 56.
} 


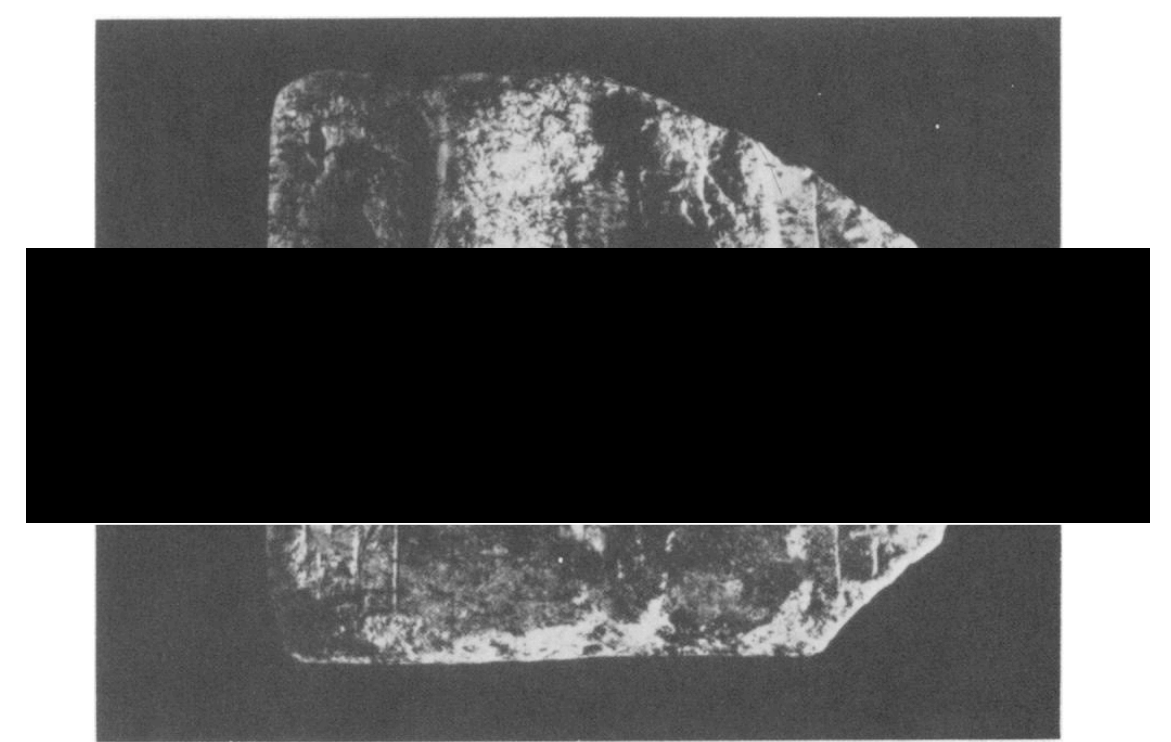

Fig. 6.24 Lower part of Princess Sobekneferu's statue, Weinstein 1974: 49.

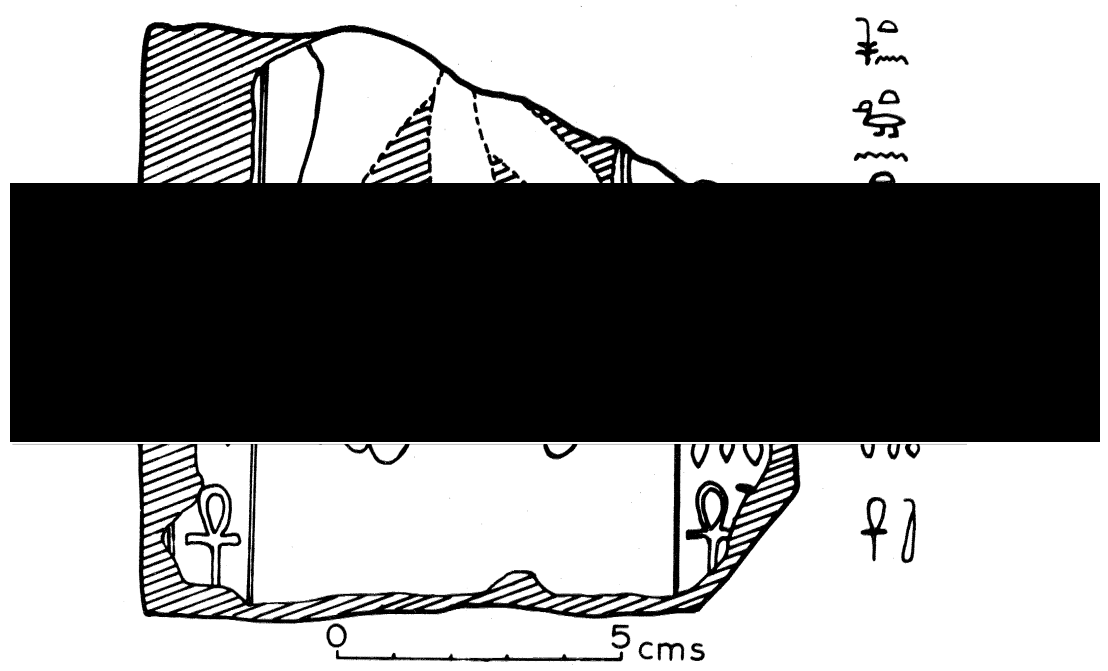

Fig. 6.25 Drawing of the lower part of Princess Sobekneferu's statue, Weinstein 1974: 50.

Although likely, there is no definite answer for the statuette fragment belonging to Sobekneferu because of the aforementioned offering stand fragment found at the pyramid complex of Senwosret I (see Chapter 5.9). Similar to the offering stand, this statuette fragment could possibly be representing Princess Sobekneferu, the daughter of Senwosret I, or Princess Sobekneferu, the daughter of Amenemhat III and the later Sobekneferu as a monarch. ${ }^{873}$ As mentioned above (see Chapter 5.9), there is

${ }^{873}$ Callender 1998a: 228-230; For full discussion, see Weinstein 1974: 50-56. 
the possibility of two princesses named Neferuptah and Sobekneferu during the reign of Senwosret I and then again during the reign of Amenemhat III. In regard to the offering stand fragment (Fig. 5.25, 5.26) and statuette from Gezer (Fig. 6.24, 6.25), they could be inscribed for two different princesses called Sobekneferu or only one. If it is the case that both of these artifacts are attributed to just one Princess Sobekneferu, it is presumably the daughter of Amenemhat III, the later Sobekneferu. This is because Sobekneferu is known from a minimum of twenty-five artifacts and inscriptions from her time in pharaonic office, which makes it more likely statues were commissioned for her as a princess.

\subsection{Possible statuette of a late Middle Kingdom Queen (Cat. 10)} Acquired by the Metropolitan Museum of Art, New York in 1965, a statuette of a royal woman has been attributed to the end of the Twelfth Dynasty or the early Thirteenth Dynasty and possibly represents Sobekneferu (Cat.10; Fig. 6.26). The statue is made of schist and is $16.3 \mathrm{~cm}$ (6.4in) tall without the lower half. ${ }^{874}$ The royal woman is depicted in an outfit that is unique within the Twelfth Dynasty. ${ }^{875}$ She is seen wearing a sharp-cornered cloak with a rounded style wig. Only the left side of her face has been preserved and the remaining features are considered to be severe facial characteristics.

\footnotetext{
${ }^{874}$ Statuette of a Late Middle Kingdom Queen, the Metropolitan Museum of Art New York 65.59.1.

${ }^{875}$ Hetepheres II wears a similar garment during the Old Kingdom. For a detailed photograph and more information see Digital Giza "Hetepheres II (7110-7120), Eastern Cemetery Site: Giza; View: G 7530-7540" http://giza.fas.harvard.edu/ancientpeople/79/intro/.
} 


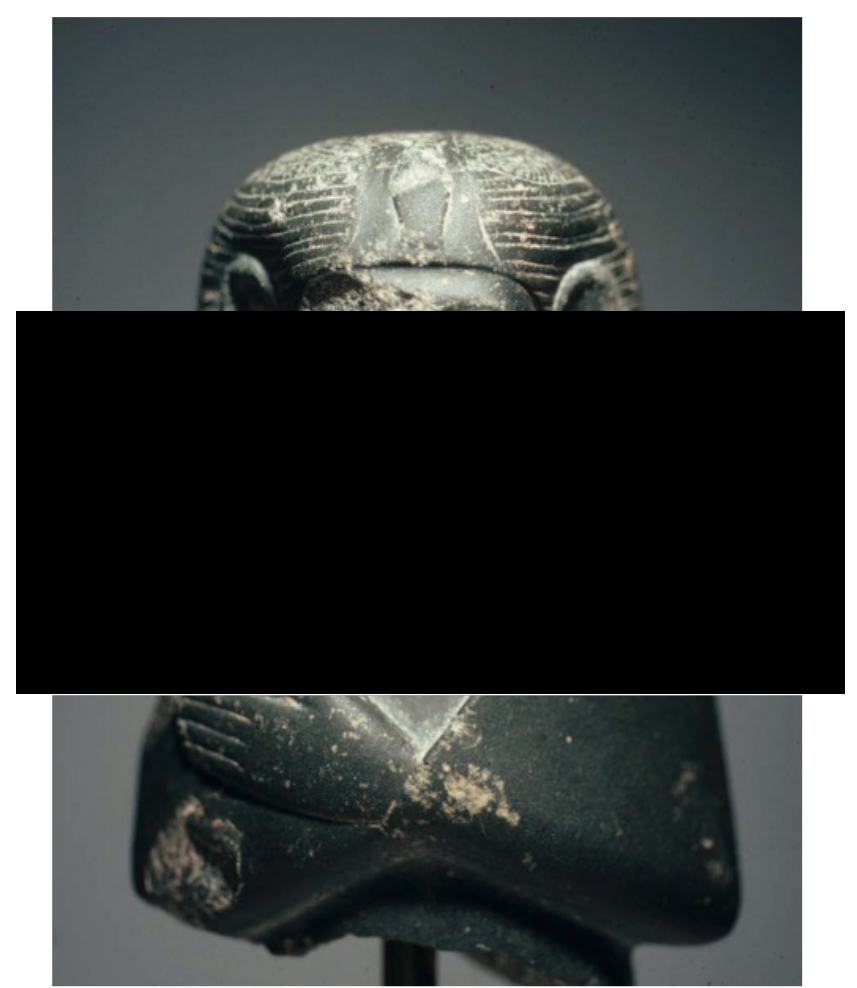

Fig. 6.26 Statuette of a late Middle Kingdom Queen, Metropolitan Museum of Art New York 65.59.1.

The arms of the royal woman are both wrapped under the cloak with only her left hand exposed. During the Middle Kingdom this type of iconographic style with the arms wrapped in a cloak with one or both hands visible is only seen on men. ${ }^{876}$ This particular depiction can be considered a mixture of female and male regalia, which can suggest the statue is a surviving representation of Sobekneferu as ruler. Known from her torso now in the Louvre (Cat. 58; Fig 6.1), Sobekneferu wore female pharaonic regalia, and during the Sed-festival royalty wore cloaks. Sobekneferu ruled for nearly four years, which means she likely did not have a traditional thirty-year celebration, but the festival could symbolize her time before becoming pharaoh or to complement her father Amenemhat III's Sed-festival, which she may have also taken part in (see Chapter 5.7).

The wig is of a rounded or globular style with horizontal striations. Located on top of the head, the design consists of a uraeus with two tail curves flanked by two vultures with outspread wings. Except for the nemes headdress and uraeus, there is no securely known typical headgear or wig of Sobekneferu (see Chapter 6.16, 6.18). As a result, the presence of vultures cannot discount this statuette as a representation of her even though she never carried the title of $m w t$ nswt. The vulture

${ }^{876}$ Fischer 1996: 111. 
headdress is only known from three Twelfth Dynasty two-dimensional reliefs and the vulture decoration found on the Metropolitan Museum statuette should not be considered part of the full vulture headdress. The vulture as a decoration can also be found on the surviving diadem type crown of Princess Khnemet. ${ }^{877}$ The vulture decoration found on the statuette might be another example of the vulture as a decorative head piece, without indicating that the wearer was a royal mother.

The only two possible sculptural representations of the vulture headdress are on fragmented heads now at the Metropolitan Museum of Art (Cat. 25; Fig. 6.27) and from the pyramid complex of Senwosret II (Cat. 26). Only the right side of the Metropolitan Museum of Art head has survived, and short and long feathers for the vulture decoration can be seen. If viewed from behind and above, the vulture can clearly be identified along with the wig being a rounded or globular style wig (Fig. 6.28). The wig is horizontally tiered and similar to the rounded wig found on the statuette of a late Middle Kingdom Queen (Figs. 6.29, 6.30). This further suggests that on Twelfth Dynasty sculpture of royal women, decoration or possible crowns were worn on top of short rounded wigs. In regard to Sobekneferu there is no secure evidence, but it is possible she was depicted in this style as a princess or pharaoh. A rounded wig with a lotus flower decoration on the top of the head is also found on the seated statue of Queen Khenemetneferhedjet I (Cat. 18; Fig. 6.31). This statue shows that this combination type of a rounded wig with decorations flanking a uraeus was a style of the Twelfth Dynasty.

877 Andrews 1990: 52. 


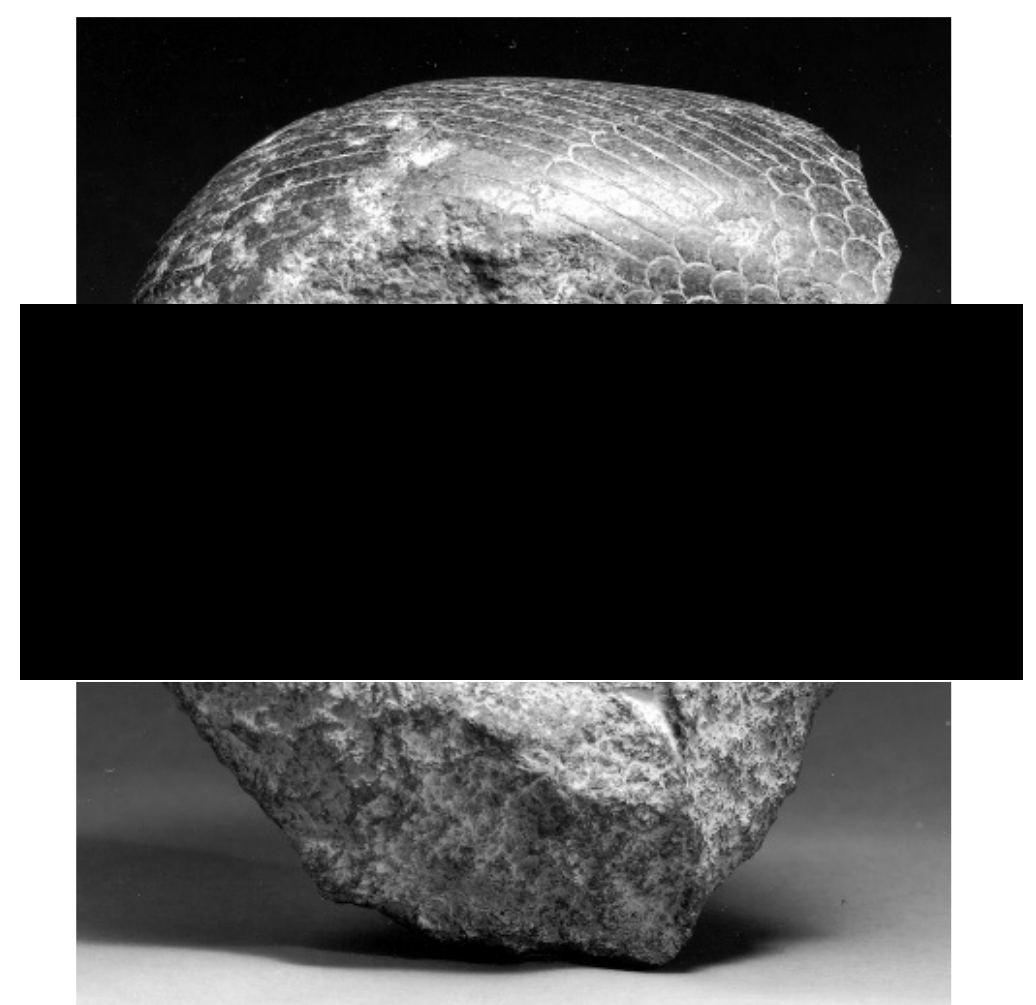

Fig. 6.27 Fragment from the head of Queen's statue, Metropolitan Museum of Art New York 2001.585.

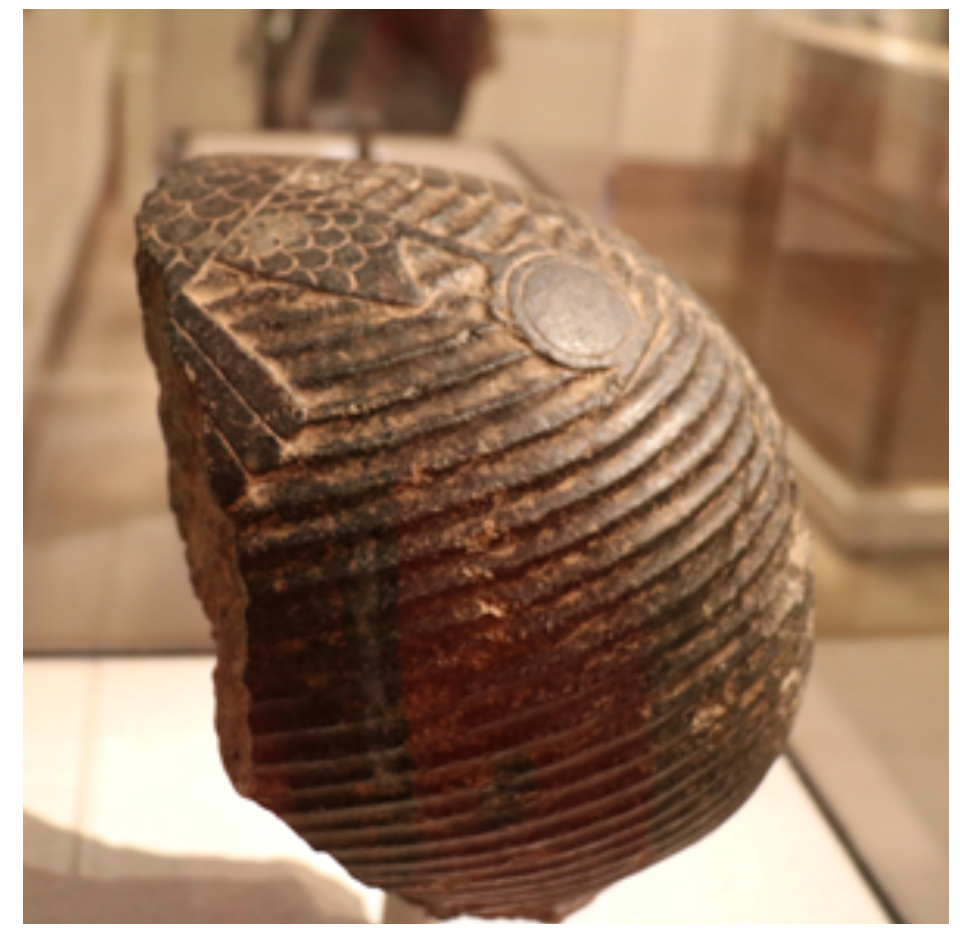

Fig. 6.28 Fragment from the head of Queen's statue, Metropolitan Museum of Art New York 2001.585, authors photograph 2016. 


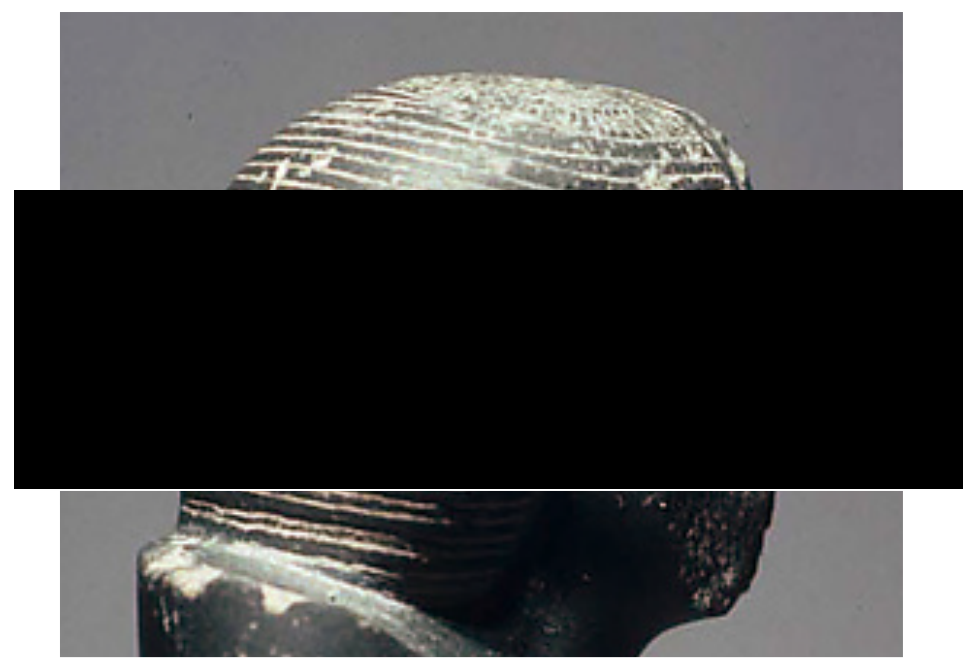

Fig. 6.29 Statuette of a late Middle Kingdom Queen, the Metropolitan Museum of Art New York 65.59.1.

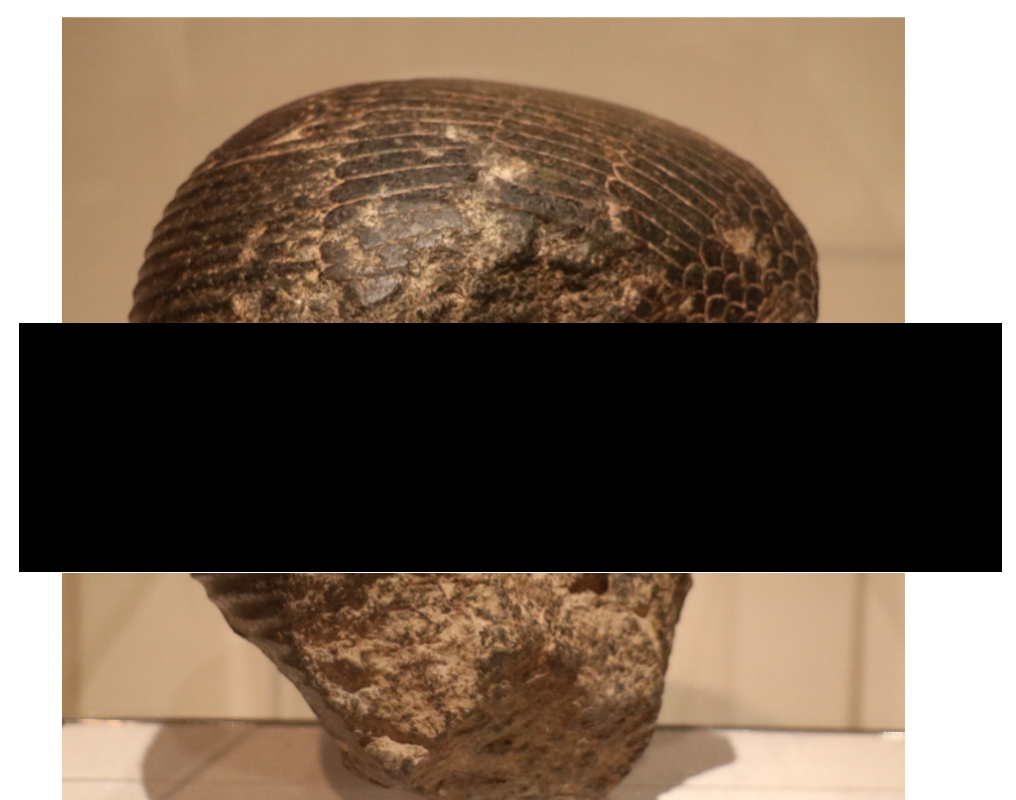

Fig. 6.30 Fragment from the head of Queen's statue, Metropolitan Museum of Art New York 2001.585. 


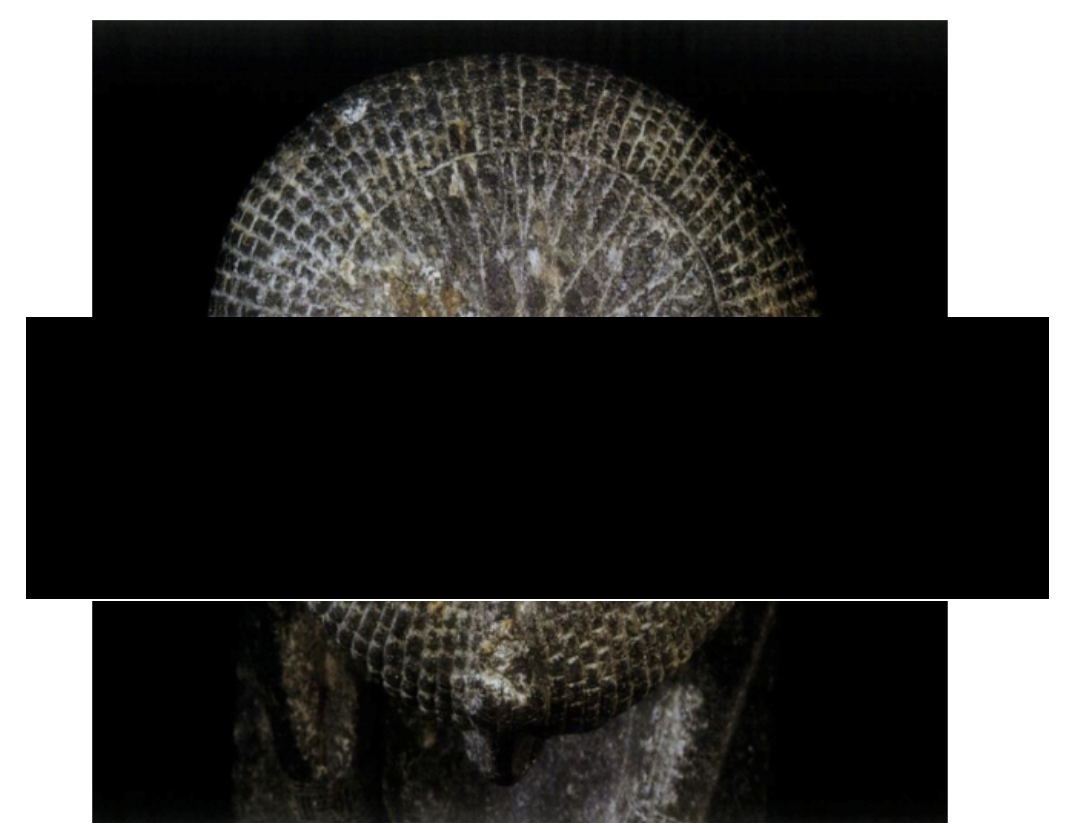

Fig. 6.31 Queen Khenemetneferhedjet I's top of the head decoration, Musée du Louvre E32564.

\subsection{Possible head of a sphinx (Cat. 67)}

A sphinx head made of gneiss, which may have been discovered in Saqqara, was taken to France by Fredric Cailliaud in 1822 . The head was acquired by the cabinet des Médailles in 1824 and is now housed in the Bibliothèque Nationale de France, Paris ${ }^{878}$ The royal woman is seen wearing a Hathoric style wig with vertically striated waves and horizontally banned ribbons (Cat. 67; Fig. 6.32, 6.33). The uraeus is heavily damaged with the remaining piece lying broadly across her forehead and seeming to have multiple tail curves. This sphinx is one of nine statues of Twelfth Dynasty royal women with severe facial characteristics (Cat. 1, 3, 4, 10, 11, 21, 24, 38, 67; see Chapter 4.3). Described as being similar in style to the sculpture of Amenemhat III and representing a daughter of the monarch, Ziegler suggests this sphinx is a depiction of Sobekneferu. ${ }^{879}$

${ }^{878}$ Evers 1929: pl. 76; Legrain 1896 cited in Ziegler 2008: 418; Ziegler 2008: 317.

${ }^{879}$ Ziegler 2008: 317. 


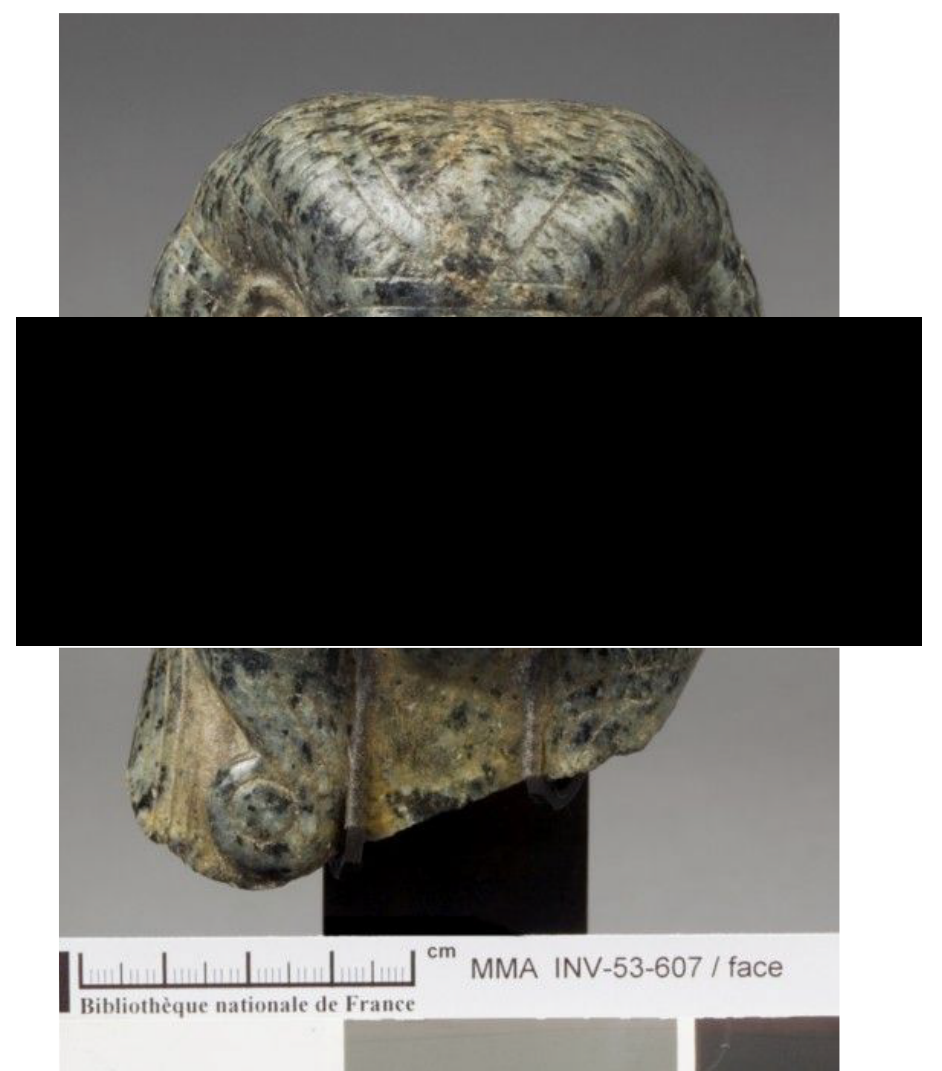

Fig. 6.32 Head of a sphinx, Bibliothèque Nationale Paris 53-607.

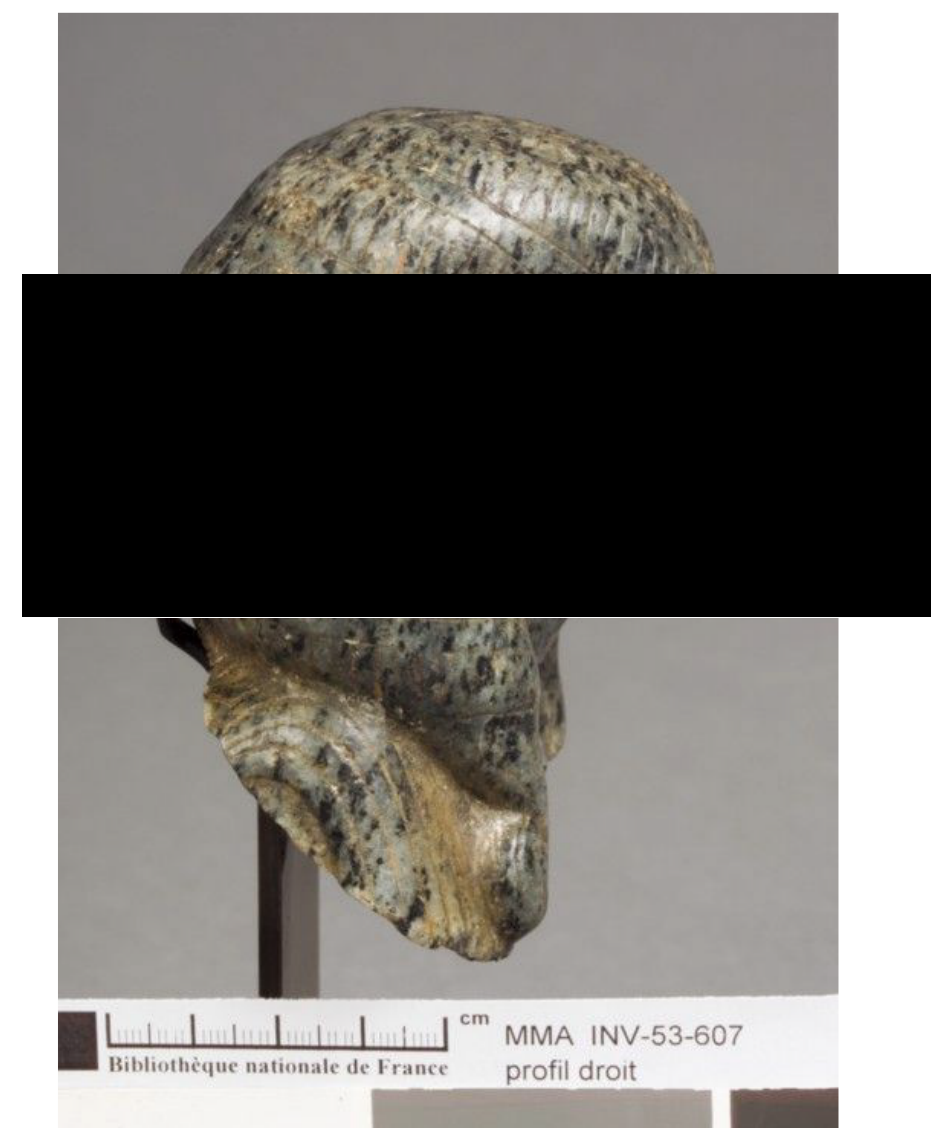

Fig. 6.33 Head of a sphinx, right side, Bibliothèque Nationale Paris 53-607. 
There is no known surviving statue head of Sobekneferu as princess or pharaoh, but there is a surviving bust and lower half that has been suggested to be a depiction of Sobekneferu as ruler (see below Chapter 6.18; Cat. 63). While the Bibliothèque Nationale sphinx could represent multiple Twelfth Dynasty royal women, a persuasive case can be made that it portrays Sobekneferu. This sphinx head of a royal woman has the severe facial characteristics, which would be expected of Sobekneferu as a princess or pharaoh. These characteristics would have been similar to Neferuptah (see Chapter 5.3) and Amenemhat III. The fact that the royal woman depicted is not wearing a nemes headdress is the only argument that can be put forward for the sphinx not representing Sobekneferu. It is possible that the sphinx represents Sobekneferu as a princess before becoming pharaoh. During the Twelfth Dynasty, sphinxes regularly portrayed royal daughters, and in this case the royal daughter could possibly be Princess Sobekneferu.

Two statues that are similar in style to the Bibliothèque Nationale sphinx head (Cat. 67; Fig. 6.32) are the human-headed bird representing a royal woman (Cat. 38; Fig. 6.34) and the bust of an unknown royal woman (Cat. 11; Fig. 6.35). All three statues have severe facial characteristics with the pentagonal face shape, vertically and horizontally striated Hathoric style wigs, and uraei.

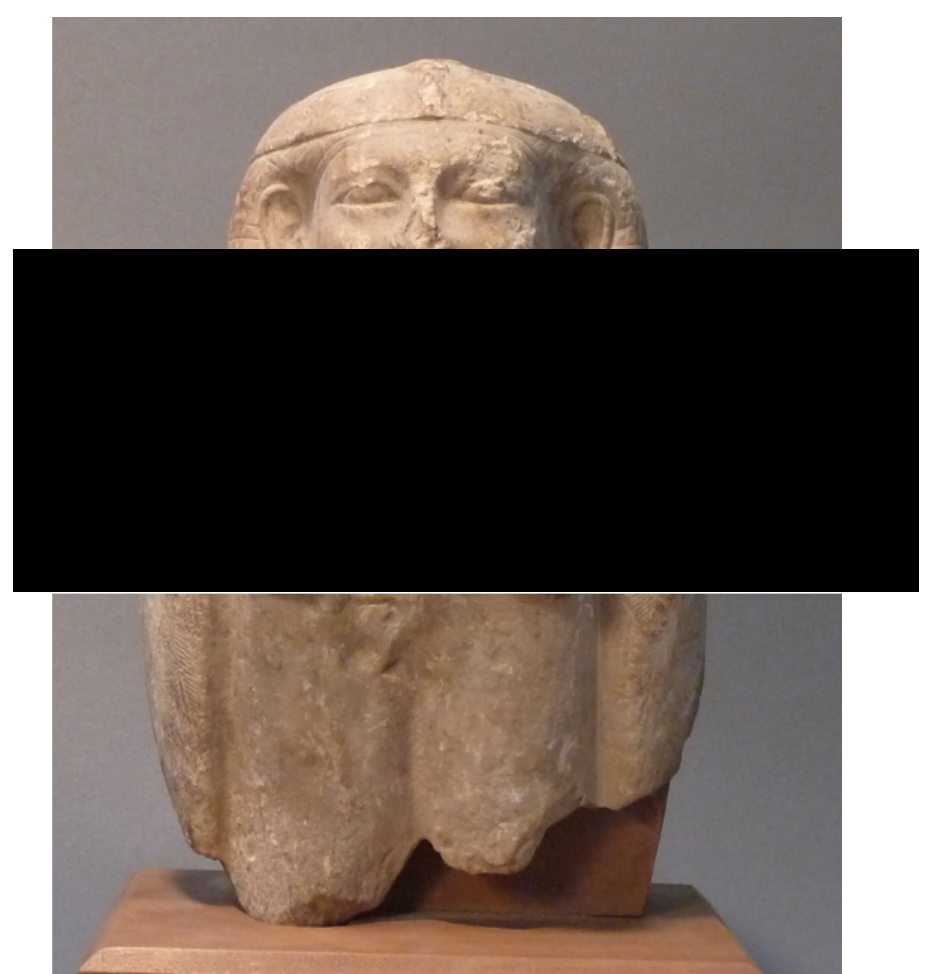

Fig. 6.34 Human-headed bird representing a royal woman, Grand Egyptian Museum 14506. 


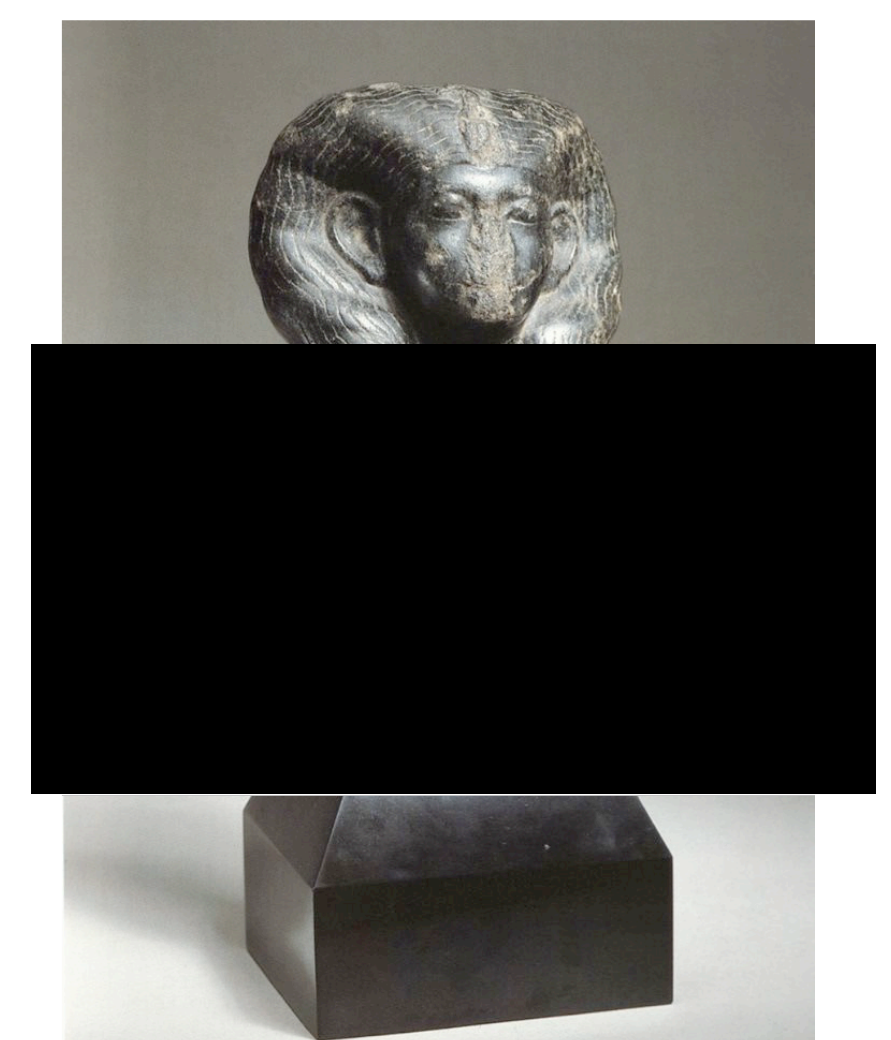

Fig. 6.35 Bust of an unknown royal woman, Sotheby's sales catalogue.

The sphinx and the human-headed bird are also both hybrid forms. As stated above, the sphinx was typical for royal daughters of the Twelfth Dynasty. However, this is the only attested royal female bird from this time period and possibly the earliest pharaonic human-falcon image or $b a$-bird for a royal woman (see Chapter 4.2.4). The royal female-headed bird is wearing a diadem type crown, which was often worn by princesses during the Twelfth Dynasty, in which the argument can be made that the bust likely represents a princess. The Bibliothèque Nationale sphinx (Cat. 67; Fig. 6.32) and the bust of an unknown royal woman (Cat. 11, Fig. 6.35) are strikingly similar in appearance, and if the sphinx is considered to represent Sobekneferu, then the bust could possibly as well. The pharaonic nemes headdress is neither found on the Bibliothèque Nationale sphinx, the human-headed bird, nor the bust of an unknown royal woman, which may suggest that they all represent Sobekneferu as a princess. Although these statues cannot be positively identified as her, they are shown with clear similarities, possibly illustrating a certain artistic style Sobekneferu undertook during her time as both princess and pharaoh. 


\subsection{Possible shrines depicting two pharaohs}

Two large red granite shrines and the fragments of third were found in 1888 by Petrie during his labyrinth excavations near the Hawara pyramid of Amenemhat III. ${ }^{880}$ Upon finding the shrines, Petrie suggested they were found close to their original location and would have been in a row of chapels. Uphill has suggested there were originally more than three shrines, ${ }^{881}$ but from Petrie's findings it can be assumed the three identical shrines were set up in rowed chapels with the largest in the middle. The smaller and more complete of the two known shrines is now located in the Egyptian Museum Cairo (Fig. 6.36) and the larger is located in Ny Carlsberg Glyptotek (Fig. 6.37). The Cairo shrine is $2.16 \mathrm{~m} \mathrm{(7ft)} \mathrm{tall} \mathrm{and} 1.58 \mathrm{~m} \mathrm{(5ft)} \mathrm{wide,}$ while the Glyptotek shrine is $2.5 \mathrm{~m}(8 \mathrm{ft})$ in height and $1.7 \mathrm{~m}(5.5 \mathrm{ft})$ wide.

Both shrines are identical and show two pharaohs, but neither have inscriptions for the people presented. The Cairo shrine (Fig. 6.36) is the most complete except for damage to the face of the pharaoh placed on the viewer's left. The left pharaoh holds the ankh-symbol in both hands, while presenting the ankh in their left hand to the other pharaoh who is passively accepting the symbol of life. The pharaoh who is giving the $a n k h$-symbol is depicted wearing the khat-headdress with a uraeus, and the pharaoh who is receiving the symbol wears the nemesheaddress. Both pharaohs are shown with their left foot forward. ${ }^{882}$

\footnotetext{
${ }^{880}$ Petrie 1889: 30-31.

${ }^{881}$ Uphill 2000: 42, H.3-5.

882 Bagh 2011: 102-103.
} 


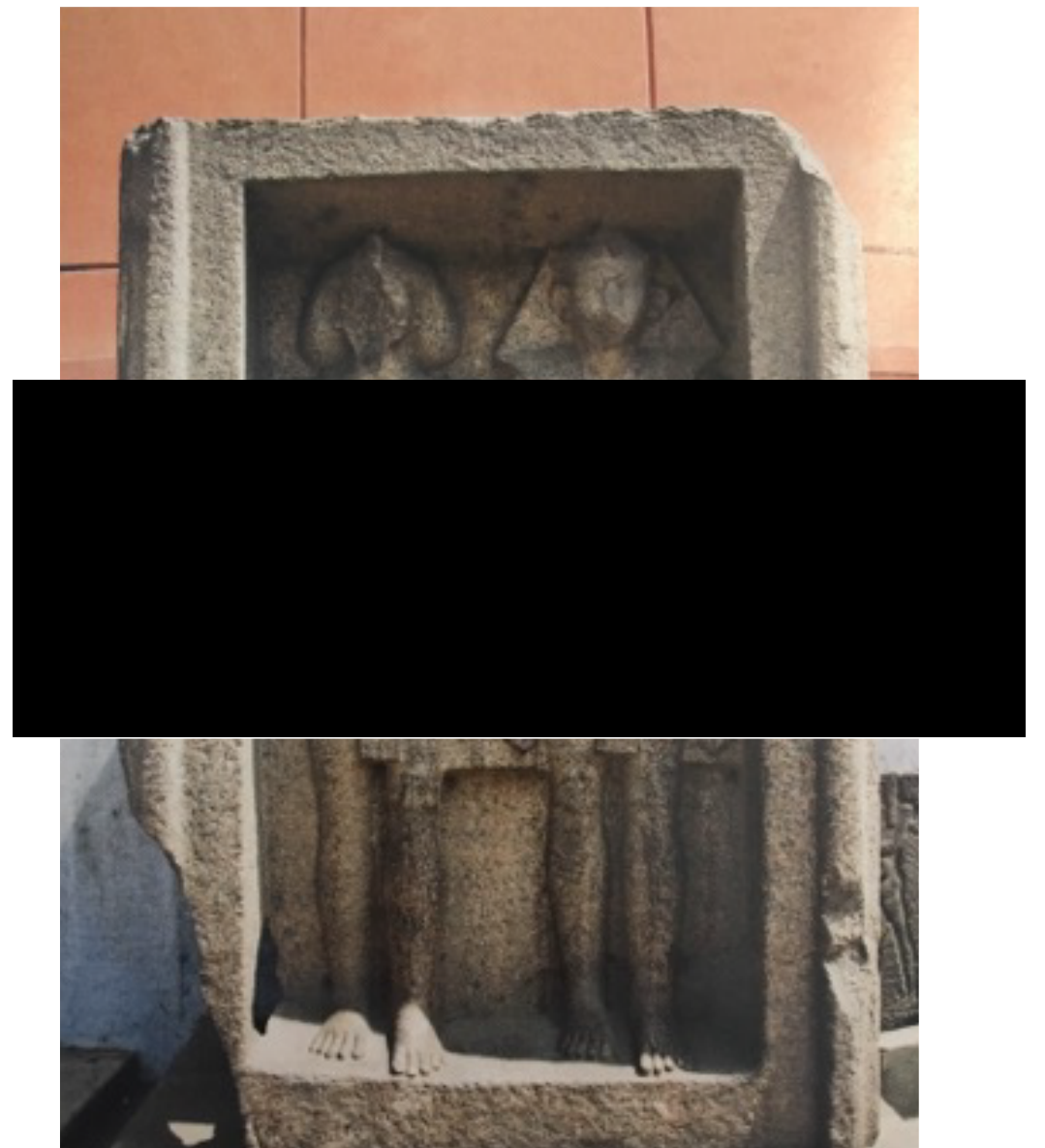

Fig. 6.36 Shrine with two pharaohs, Egyptian Museum Cario JE 43289. 

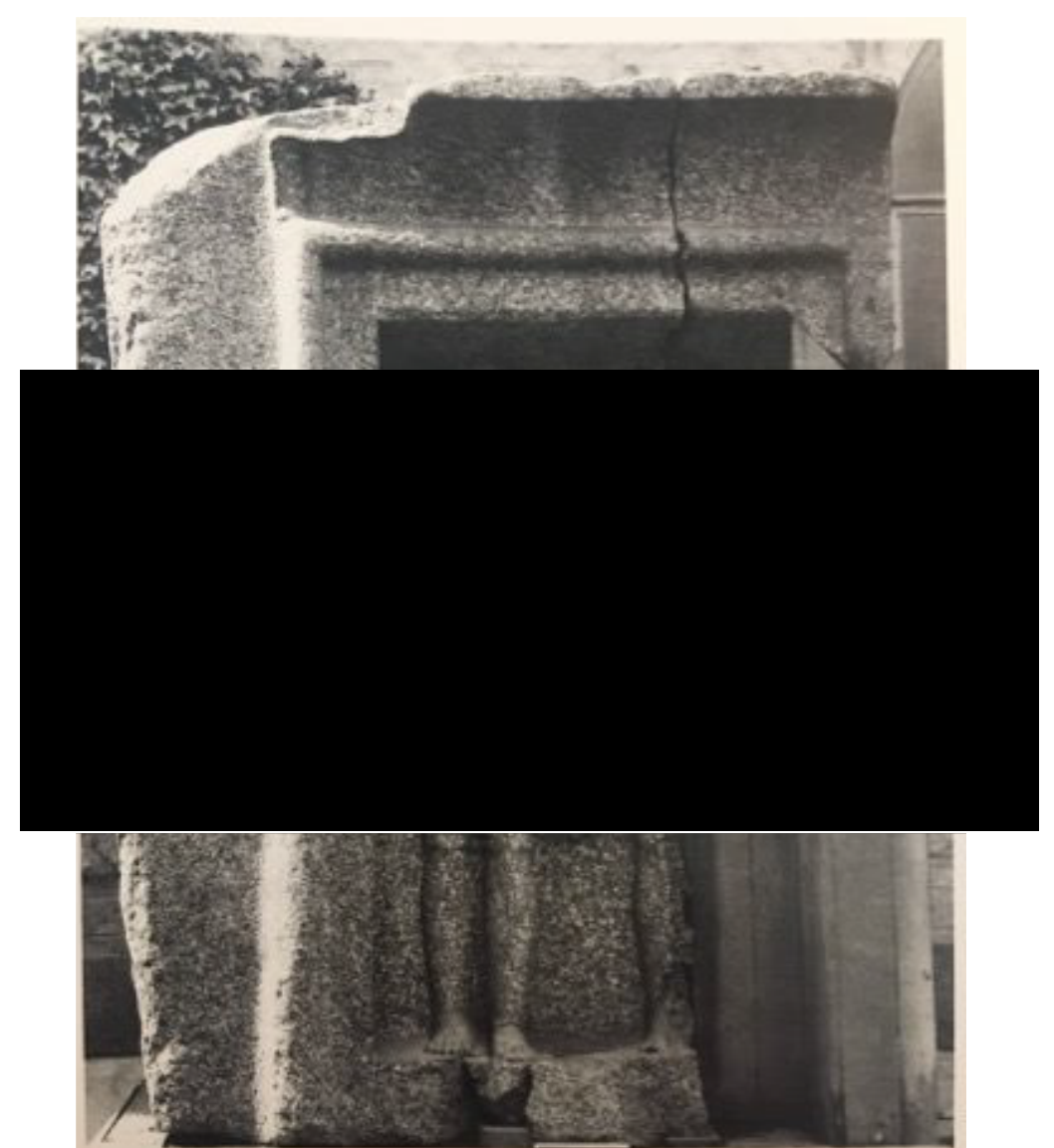

Fig. 6.37 Shrine with two pharaohs, Ny Carlsberg Glyptotek, AEIN 1482.

Since there are no inscriptions found on the shrines, there has been some debate about which two pharaohs are represented. Since the statues were originally discovered in the labyrinth of Amenemhat III's complex, it has been previously suggested the two pharaohs represents himself with Senwosret III, with Amenemhat IV, with a deity giving life to him, Amenemhat III with his $K a$, or a depiction of Amenemhat III as pharaoh twice. ${ }^{883}$ Among these suggestions, none have addressed the possibility the shrines are depicting Amenemhat III and Sobekneferu. Habachi briefly mentions the similarity of the shrines with the papyrus column now located in the Cairo Museum (Fig. 6.38) that shows Amenemhat III's Horus presenting the djed and ankh staff of stability and life with Sobekneferu's female Horus facing it.

Rather, he goes on to state the second figure could depict Amenemhat IV, the son and co-regent of Amenemhat III. ${ }^{884}$ While each suggestion can be considered likely, there is the possibility that the shrines are depicting Amenemhat III and Sobekneferu. As noted by Habachi, the papyrus column with the Horus of

${ }^{883}$ Bagh 2011: 103; Habachi 1978: 88; For brief discussion, see Zecchi 2010: 59-60.
${ }^{884}$ Habachi 1978: 87-88. 
Amenemhat III and Sobekneferu was also found at the labyrinth (see Chapter 6.4) ${ }^{885}$ During her reign, Sobekneferu had a large building presence at Amenemhat III's labyrinth and most likely completed the complex. The papyrus column was discovered among seven other surviving inscriptions for Sobekneferu, which is nearly the amount of surviving for Amenemhat III. No inscriptions for Amenemhat IV were found during Petrie's excavations ${ }^{886}$ which could indicate the second pharaoh receiving life does not represent Amenemhat IV. However, since there are no surviving inscriptions for the shrines, this can only be suggested.

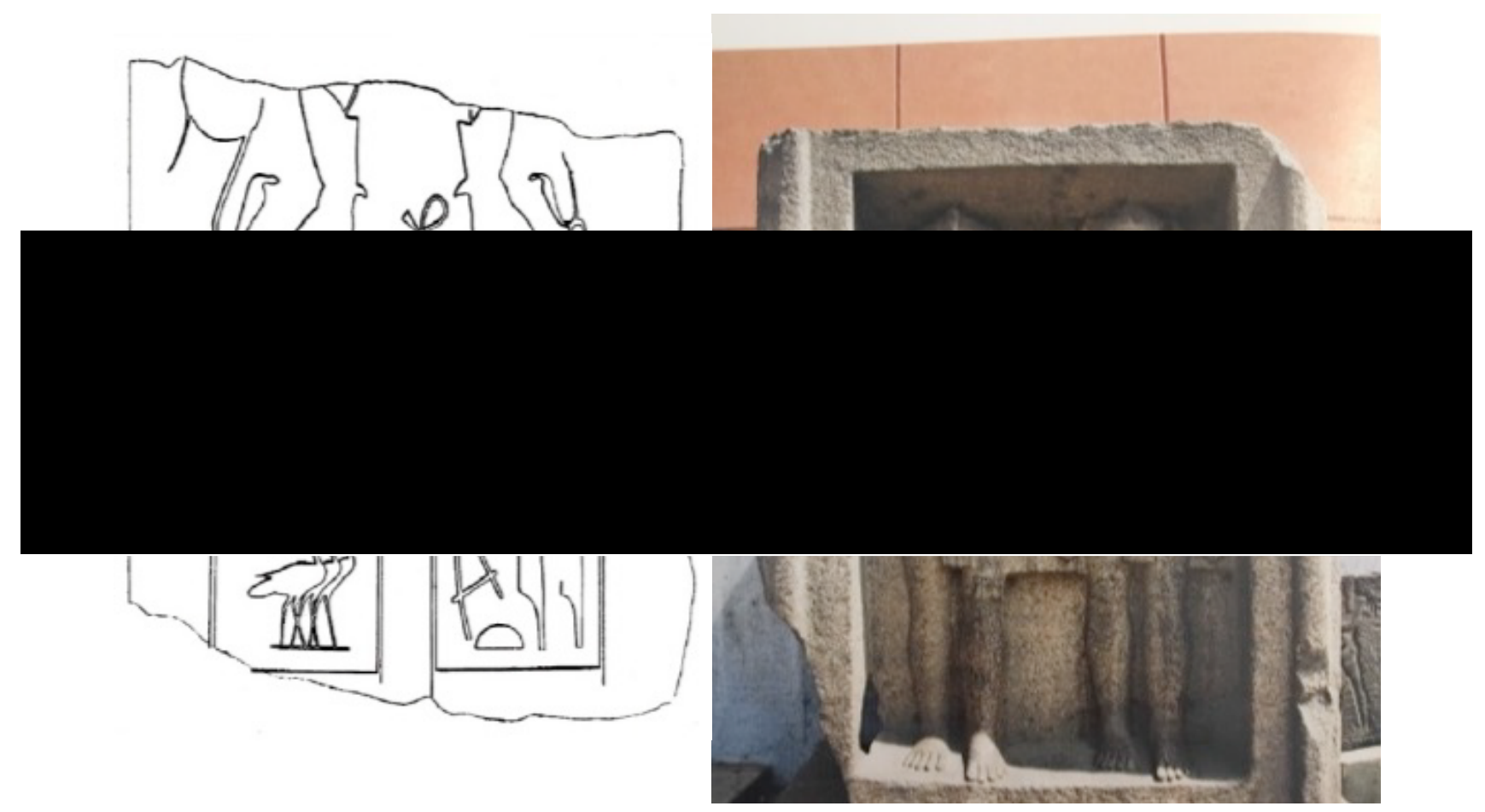

Fig. 6.38 Comparison of column fragment and Cairo shrine, Egyptian Museum Cairo; JE 43289.

The surviving inscription from a papyrus column (see above Chapter 6.4; Fig. 6.8) and the shrine with two pharaohs are similar in many aspects, including the common red granite material used. Multiple red granite columns and blocks inscribed for Sobekneferu were found at the labyrinth, suggesting this material was predominately favored for building at the complex. As pharaoh, Sobekneferu could have commissioned the shrines in the same material as her other columns or continued decorating the parts of the complex, including the shrines, that were originally commissioned by Amenemhat III. In both artifacts, Amenemhat III could be pictured

\footnotetext{
${ }^{885}$ Habachi 1954: 464-466.

${ }^{886}$ Zecchi 2010: 85.
} 
on the viewer's left presenting an object to Sobekneferu who is passively receiving the symbol on the viewer's right. It is most likely Sobekneferu reiterated this type of iconographic style to not only celebrate the cult of Amenemhat III at his complex, but to also emphasize their relationship as the former and current ruler.

The shrines can be considered examples of Sobekneferu's development in the pharaonic office. The two figures of Amenemhat III and Sobekneferu are represented as equal pharaohs, but slight iconographic differences such as Amenemhat III's khatheaddress differs from Sobekneferu's nemes-headdress. On the papyrus column, Amenemhat III and Sobekneferu's Horus birds are equally shown, but Sobekneferu's Horus is noticeably different due to the $t$ hieroglyph. These types of depictions could also mean the resemblance of Amenemhat III and Sobekneferu was an iconographic choice to purposefully present two equal but distinct pharaohs. There are two other similar shrines, which date to the reign of Neferhotep I of the Thirteenth Dynasty. The first of the dyads is now located in the Egyptian Museum Cairo (CG 42022) (87 $^{88}$ and the second more recently discovered is displayed at the Karnak Open Air Museum. ${ }^{888}$ Because of the surviving but incomplete inscription, it is likely the two identical pharaohs presented holding hands are both Neferhotep I. Habachi notes that Neferhotep I's shrine could be an imitation of the Hawara Labyrinth shrines, but they are instead holding hands because Neferhotep I cannot give himself the symbol of life. ${ }^{889}$ This would further support the suggestion that the Hawara shrines depict Amenemhat III with his $K a$, which is seen more often within New Kingdom temples and tombs where the ruler is shown accompanied by their $k a$, usually seen as a double and both are understood to be united. ${ }^{890}$

Within the two shrines, Sobekneferu could possibly be depicted in full pharaonic regalia with an indistinguishable body type from Amenemhat III. If Sobekneferu is represented, she could be seen receiving life while wearing the nemes-headdress and shendyt-kilt with oversized ears and her left foot forward. These depictions would be the only surviving examples of Sobekneferu without a sheath dress as seen on her torso now in Musée du Louvre (Cat. 58; Fig. 6.1) and her

\footnotetext{
${ }^{887}$ Group statue of Neferhotep I, Egyptian Museum Cairo CG 42022. For more information see the IFAO Cachette de Karnak website http://www.ifao.egnet.net/bases/cachette/ck453.

888 Press Release - May 2005: “A Visit to Karnak” http://guardians.net/hawass/Press_Release_0505 Luxor.htm.

${ }^{889}$ Habachi 1978: 89.

${ }^{890}$ Bell 1997: 142, Fig. $53 \mathrm{Ka}$-statue of the divine Amenhotep III-the king followed by the anthropomorphic $k a$ figure at Luxor Temple.
} 
seated statues discovered at Tell el-Dab'a (Cat. 59, 60; Fig. 6.5, 6.6). However, the nemes-headdress and the shendyt-kilt were common features of Sobekneferu's iconography. This type of iconographic transition would be similar to that of Hatshepsut of the Eighteenth Dynasty (see Chapter 3.5.5.1). Sobekneferu's iconography may have developed during her four-year reign in the pharaonic office, although it would have had to evolve much quicker than that of Hatshepsut's. Although rapid iconographic development or exchange is possible, Sobekneferu did not have a co-regent and the act of legitimizing her rule in contrast to someone else's was never needed. From surviving material she also only represented herself with Amenemhat III at his Hawara complex, suggesting her surviving works from the labyrinth symbolizes her formal pharaonic connections with Amenemhat III as well as legitimization for her own reign.

\subsection{A seated statue joined from two parts - Berlin and Boston (Cat. 62)} In 1899 Dr. Deibel bequeathed a bust of a Twelfth Dynasty royal woman to what is now the Staatliche Museen zu Berlin, Germany. Before the original bust was lost during World War II, photographs and a mold was taken (Cat. 1; Fig. 6.39). In a project titled "Neferusobek Project: Part 1", undertaken by Biri Fay, Rita Freed, Thomas Schelper, and Friederike Seyfried, the bust was joined with a seated statue without an inscription discovered at the fortress of Semna in Nubia and now housed in the Museum of Fine Arts in Boston (Cat. 27; Fig. 6.40). The object of the second part of their project is to make a three-dimensional scan providing both museums with a copy of the complete statue and to publish a full report (Fig. 6.41). Within part 1, the authors state:

The subject of the sculpture can now be identified as Queen Neferusobek, the second ruling queen of Egypt who reigned for less than 4 years (1798/971794/93) almost 4000 years ago. The reconstruction is the first complete statue of this female pharaoh and finally provides a face that can with certainty be associated with her name. ${ }^{891}$

${ }^{891}$ Fay, Freed, Schelper, and Seyfried 2015: 89. 


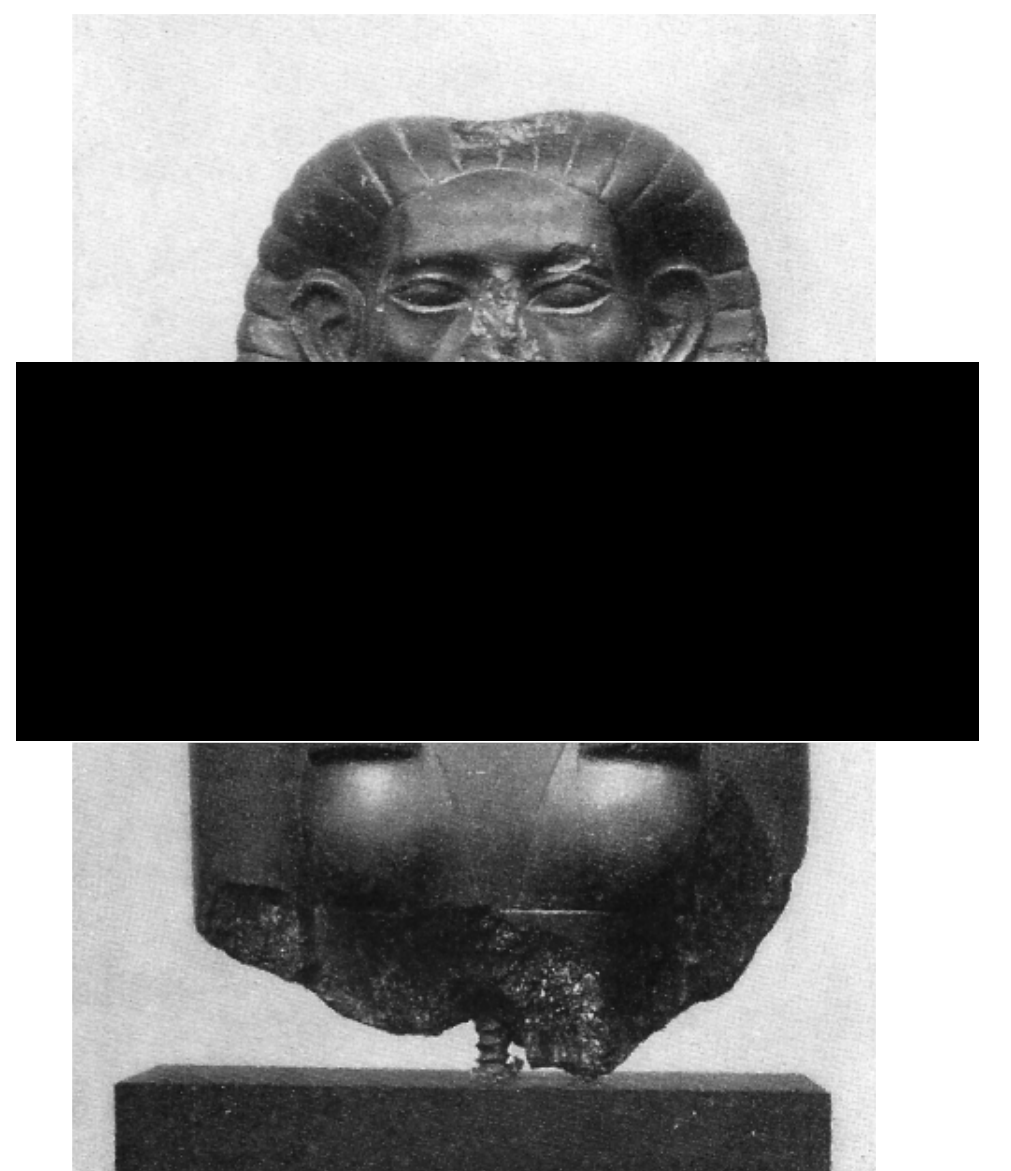

Fig. 6.39 Bust of a royal woman, Staatliche Museen Berlin ÄM 14475.

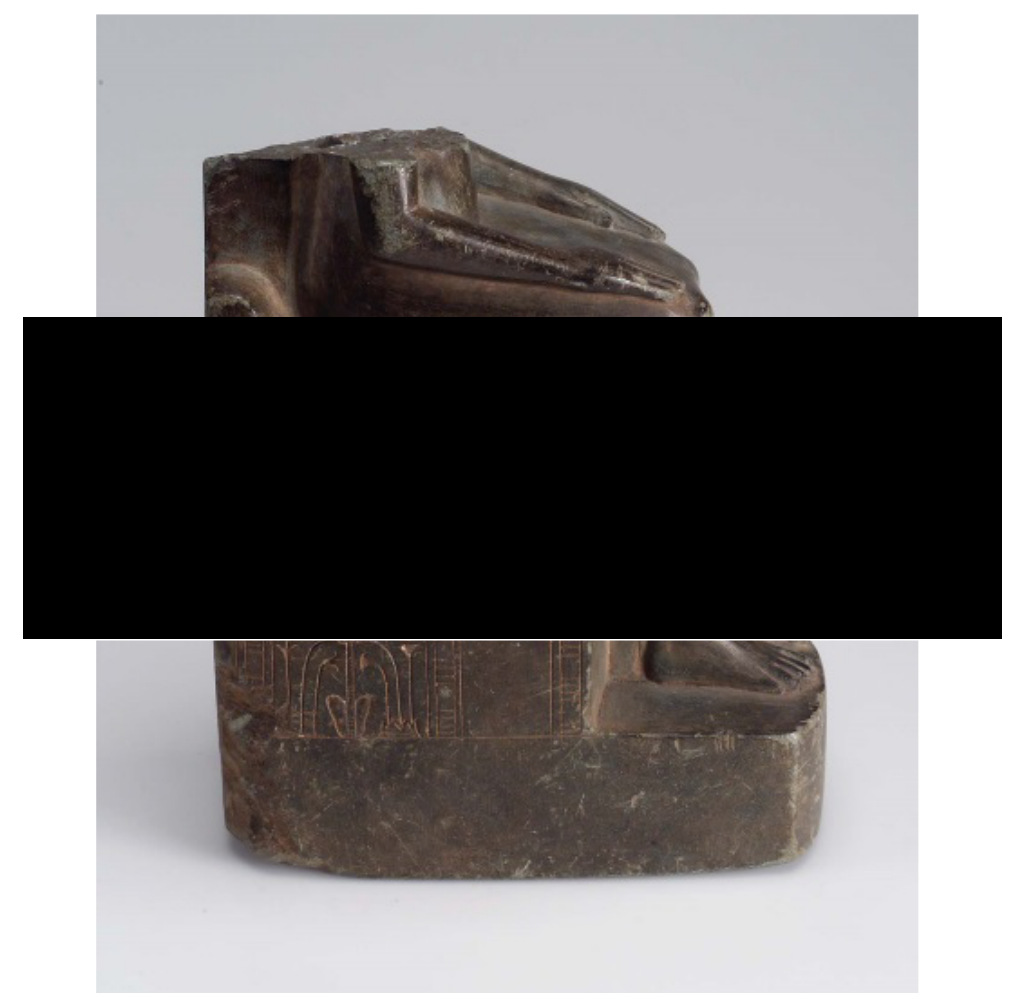

Fig. 6.40 Lower body fragment of a female statue seated on a throne, Boston Museum of Fine Arts 24.742 . 


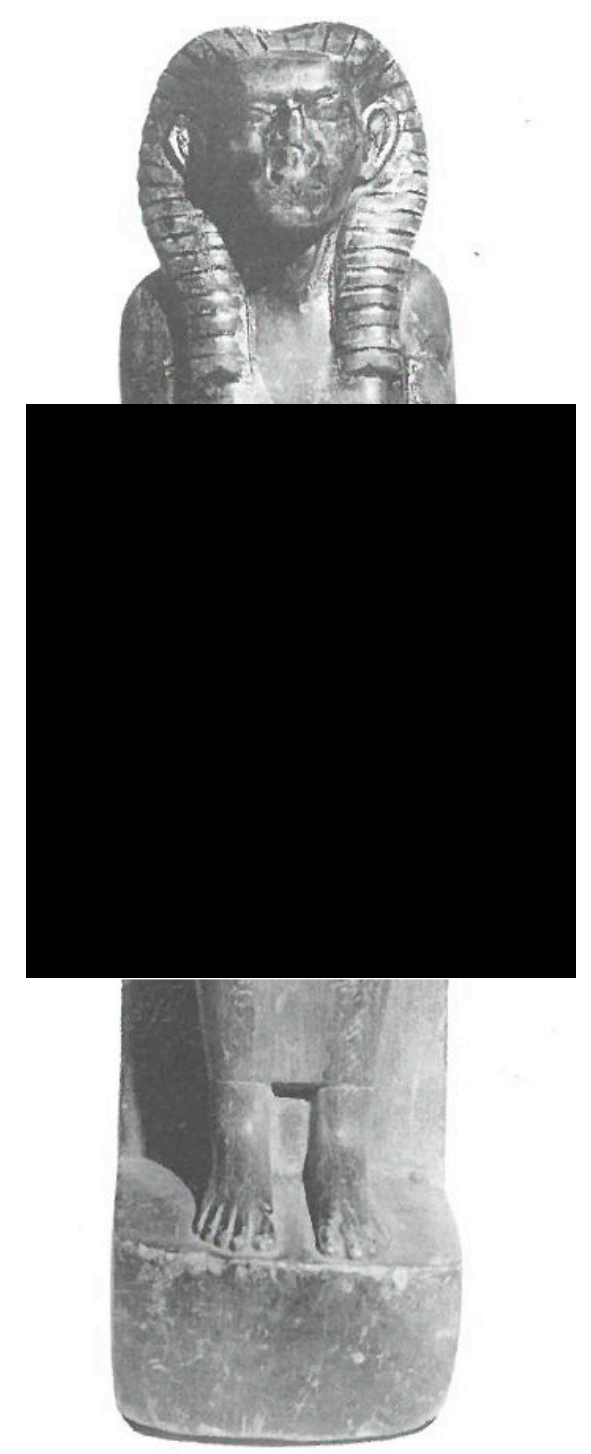

Fig. 6.41 A seated statue of Neferusobek joined by two parts, Fay, Freed, Schelper, and Seyfried 2015: 91.

The face of the Berlin bust has the typical severe facial characteristics of the Twelfth Dynasty and can be considered the most extreme example surviving for royal women. As a ruler of the Twelfth Dynasty and a daughter of Amenemhat III, these extreme facial features were iconographic aspects for Sobekneferu and can be used as evidence that all statues, such as the Bibliothèque Nationale sphinx (Cat. 67), human-headed bird (Cat. 38), the bust of an unknown royal woman (Cat. 11), and now the suggested complete statue, represent Sobekneferu. The Berlin bust has a tripartite wig that is overemphasized behind the ears, resembling that of the Hathoric type wig. The uraeus is completely removed. It is the only example for Twelfth Dynasty royal women where the uraeus has been physically removed from the head of the statue. Like the aforementioned statues (Cat. 11, 38, 67), the Berlin bust is 
again not depicted with a nemes-headdress. Based solely on iconographic considerations, this statue can be regarded as a depiction of Sobekneferu, even if there is no surviving inscription, however Part 2 of the project's final report and art historical analysis is not yet published.

On the two seated statues of Sobekneferu found at Tell el-Dab'a (Cat. 59, 60; Fig. 6.5, 6.6), her titles are extended down both sides of her throne and pedestal with the nine bows under her feet. The two statues are identical and could have been originally displayed together. In comparison with the Sobekneferu's Tell el-Dab'a statues, the style of the bottom half now located in Boston suggests the inscription is unfinished although this is currently unclear. Joined together, the height of the complete seated statue is $35.4 \mathrm{~cm}$ ( $1 \mathrm{ft} 2 \mathrm{in})$ which is significantly smaller than the statues found at Tell el-Dab'a. A similar style in her titulary could be thought to be present but this is not found on the Berlin and Boston complete statue.

Comparatively, the throne on the joined Berlin and Boston statue is slender and would have a small space for Sobekneferu's Horus name to come first, opposite to the Tell el-Dab'a statues. This could suggest a different order in writing for her titulary on this statue, but since there is no inscription any suggestion on her titulary would be unclear.

The majority of known seated statues of Twelfth Dynasty male monarchs depict them wearing a nemes-headdress, and this could also be argued for Sobekneferu's iconography. As seen on her torso (see Fig. 6.1) Sobekneferu was represented with female pharaonic regalia and the joined Berlin and Boston seated statue may be an example of this, but no nemes-headdress is present to coincide with sm3-t3wy symbol. However, it can also be argued that Sobekneferu's typical iconography may have consisted of a Hathoric or overemphasized tripartite wig, as displayed by the Bibliothèque Nationale sphinx (Cat. 67), human-headed bird (Cat. 38), and the bust of an unknown royal woman (Cat. 11).

There is no name inscribed on the statue therefore Fay, Freed, Schelper, and Seyfried use the sm3 t3wy symbol on the side of the throne to conclude the statue is of a ruling pharaoh. ${ }^{892}$ From the combination of the $s m 3$ t3wy symbol and visible sheath dress remaining on the lower half statue from the Museum of Fine Arts, they infer that it is a representation of a ruling female and identify it with Sobekneferu.

${ }^{892}$ Fay, Freed, Schelper, and Seyfried 2015: 89 Footnote 3. 
Due to the lack of preservation and published photographs, the side decorations of Twelfth Dynasty royal women's thrones are not well-known. There is a similar headless seated statuette, dated to a later period, now located in the Egypt Centre Swansea (Figs. 6.42, 6.43). The statue presents a seated royal woman with her right hand rested upon her lap and her right hand clasping a piece of cloth. The sms t3wy symbols are seen on both sides of her throne. The ruling woman is seen wearing a sheath dress, with a broad collar, upper arm bands, bracelets, and anklets. Her sheath dress is accessorized with a striped sash tied around the upper waist and just under the breast to give the look of an empire waist dress similar to that of Sobekneferu's torso (Cat. 58; Fig. 6.1). The inscription located on the back of the throne states "Beloved of the gods who are over the city". ${ }^{893}$ The statue has no known provenance and is dated to the Second Intermediate Period, Seventeenth Dynasty. It has not been attributed to a specific royal woman and if the dating of the Seventeenth Dynasty is correct then the statue could possibly depict the female ruler Ahhotep (see Chapter 3.5.4) or another prominent royal woman of the early New Kingdom. It is possible the style of depicting female rulers with regular pharaonic motifs such as the sm3 t3wy symbols on their thrones began with Sobekneferu and continued into the New Kingdom.

\footnotetext{
${ }^{893}$ Seated royal woman, The Egypt Centre Swansea W848. For more information see the Egypt Centre online catalogue: http://www.egyptcentre.org.uk/index.asp?page $=$ item\&mwsquery $=\{$ Identity\%20number $\}=\{\mathrm{W} 848\}$.
} 


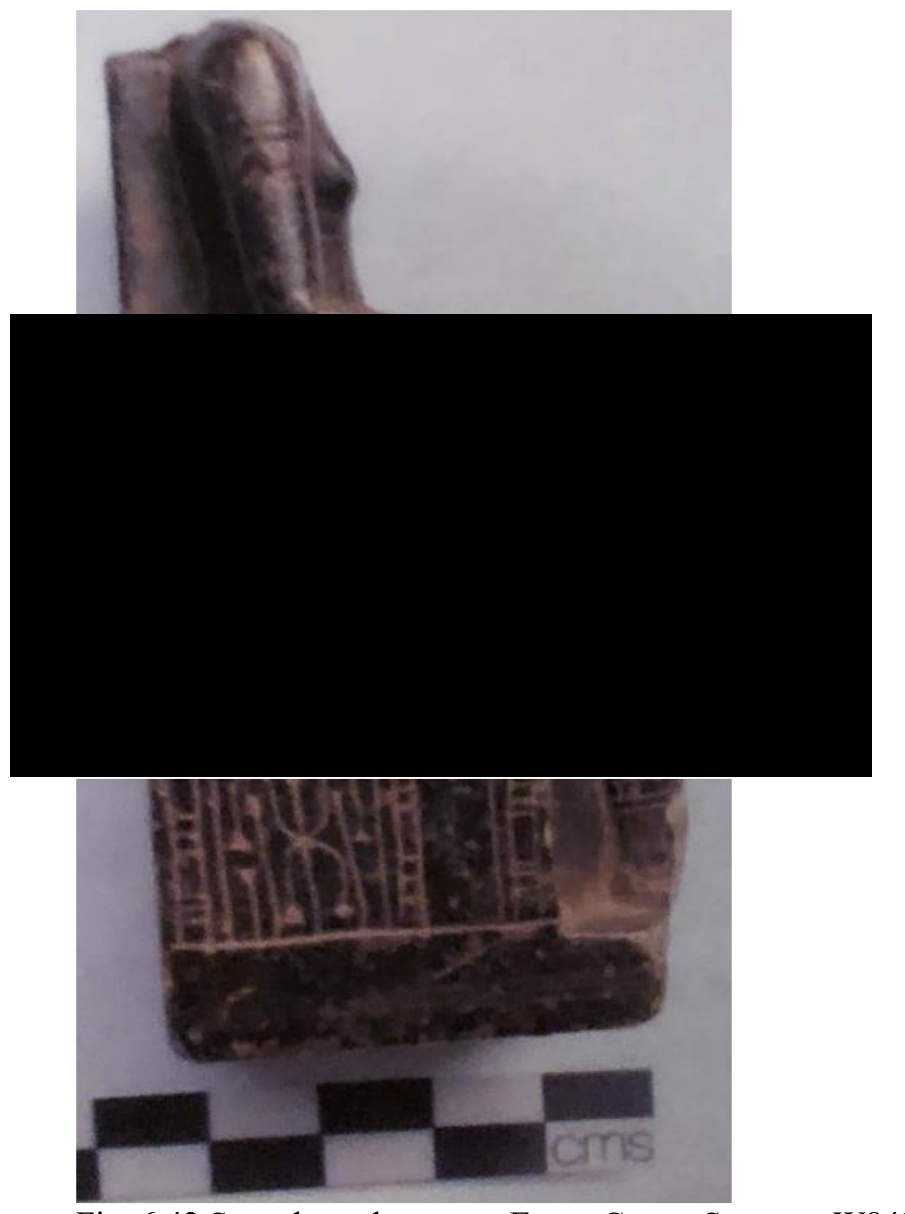

Fig. 6.42 Seated royal woman, Egypt Centre Swansea W848. 


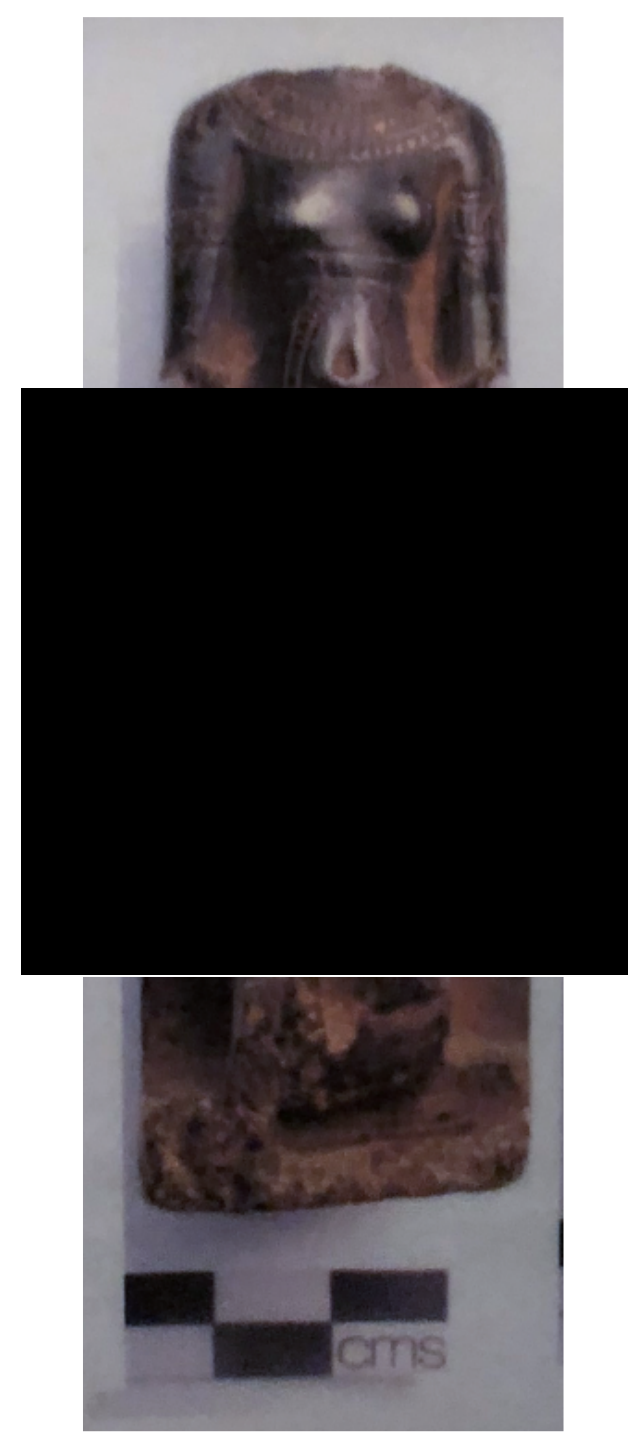

Fig. 6.43 Seated royal woman, Egypt Centre Swansea W848.

\subsection{Sobekneferu's sole reign and familial connections}

The generally accepted first pharaoh of the Thirteenth Dynasty is Sekhemrekhutawy

Amenemhat Sobekhotep I, ${ }^{894}$ who ruled for nearly three years. During his reign, Sobekhotep I made clear connections with the Twelfth Dynasty. For example, his name combines Amen and Sobek. ${ }^{895}$ The name selection could also refer to the previous pharaohs Amenemhat III or Amenemhat IV and Sobekneferu. Sobekneferu was the first ruler to include the god's name Sobek in her throne name and Sobekhotep I of the Thirteenth Dynasty could have been following her titulary style

${ }^{894}$ McCormack 2008: 64-67; Ryholt 1997: 315-321.

895 McCormack 2008: 64-67. 
by referring to the god Sobek. ${ }^{896}$ Nine rulers had the nomen or prenomen Sobekhotep, ${ }^{897}$ which makes it the most common pharaonic name during the Thirteenth Dynasty. An example of this type of referring to an earlier pharaoh using their name can also be seen in the Eighth Dynasty during the First Intermediate Period. Neferkare Pepi-Sonb or Neferkara Khered-Sonb possibly incorporated Pepi II's name into his which would show a connection with the previous ruler and his remarkably long reign. ${ }^{898}$ It has been suggested by Ryholt and McCormack that the pharaohs of the Thirteenth Dynasty we either apart of or purposefully connected themselves with the late Twelfth Dynasty royal family. ${ }^{899}$ From this, the rulers would have been showing a familial connection through their names, which could have included Sobekneferu.

There are no children attested for Amenemhat IV or Sobekneferu, thus making it uncertain if Sobekhotep I was related to either pharaoh. Although generally accepted as the son of Amenemhat IV, ${ }^{900}$ it could also be the case that Sobekhotep I was a brother of Amenemhat IV and Sobekneferu instead of a direct descendent. One suggestion amongst other possibilities is that the late Twelfth Dynasty succession went from Neferuptah (before dying at an early age) Amenemhat IV - Sobekneferu, which was sister - brother - sister. Ryholt also states there is no reason to believe that Amenemhat III had any sons at the time of his death, ${ }^{901}$ but if this is only supported by the fact that Sobekneferu was a woman, then his argument cannot be carried further. Surviving ruler lists make a distinction between the Twelfth and Thirteenth Dynasties; however, this does not necessarily mean a change of family. Sobekneferu is listed as a ruler during the Twelfth Dynasty in the Karnak and Saqqara Lists, the Turin Canon, and was recorded by Manetho. She is omitted from is the Abydos king lists, which also excludes the rulers of the Thirteenth Dynasty and Second Intermediate Period. ${ }^{902}$ This could suggest that the authors of the Abydos King lists saw the Thirteenth Dynasty rulers as descendants of Sobekneferu and excluded them together. However, the reasoning for their omission

\footnotetext{
${ }^{896}$ Aufrère 1989: 12, suggests that Sobekneferu's use of Sobek in both her names Sobekneferu and Neferu-Sobek Shedyt was a new point in the worship of dynastic divinities and Sobekhotep I of the Thirteenth Dynasty continued this tradition.

${ }^{897}$ McCormack 2008: 441, see also Table 6.6: 443.

${ }^{898}$ Ryholt 2000: 94.

${ }^{899}$ McComack 2008: 446; Ryholt 1997: 209-212.

${ }^{900}$ Dodson 2004: 104; Ryholt 1997: 209.

${ }^{901}$ Ryholt 1997: 209.

902 McCormack 2008: 21-22; Redford 1986: 19-20.
} 
together remains unclear and this is seen on the Turin List where there is a distinct separation made between Sobekneferu and the Thirteenth Dynasty. ${ }^{903}$

Sobekneferu also had connections to Hawara, Herakleopolis Magna, along with Khata'na and the surrounding areas, which were settlements used during the Twelfth and Thirteenth Dynasties as well as Tell el-Dab'a before becoming the capital of the Hyksos (Fig. 6.44) ${ }^{904}$ The oldest known structure at the Khata'na site is a colonnaded hall commissioned by Amenemhat I, which was followed by a royal domain and town that were completed by the reign of Senwosret I. ${ }^{905}$ During the reign of Senwosret III, the settlement of Ezbet Rushdi became important to his foreign expeditions to the Sinai and he further expanded the temple of Amenemhat I. ${ }^{906}$ By the late Twelfth Dynasty and early Thirteenth Dynasty the town had become much larger and mainly settled by Canaanites or Syro-Palestinians who lived very similar to the Egyptians, as seen by their ceramics..$^{907}$

903 McCormack 2008: 22; Ryholt 2004: 142.

${ }^{904}$ Ahrens 2011: 22-23; Bietak 1996: 7; Hirsch 2004: 110-146.

905 Bietak 1996: 5, 9.

906 Bietak 1996: 5, 10; Kees 1962: 1-13.

${ }^{907}$ Bader 2011: 44; Bietak 1996: 10. 


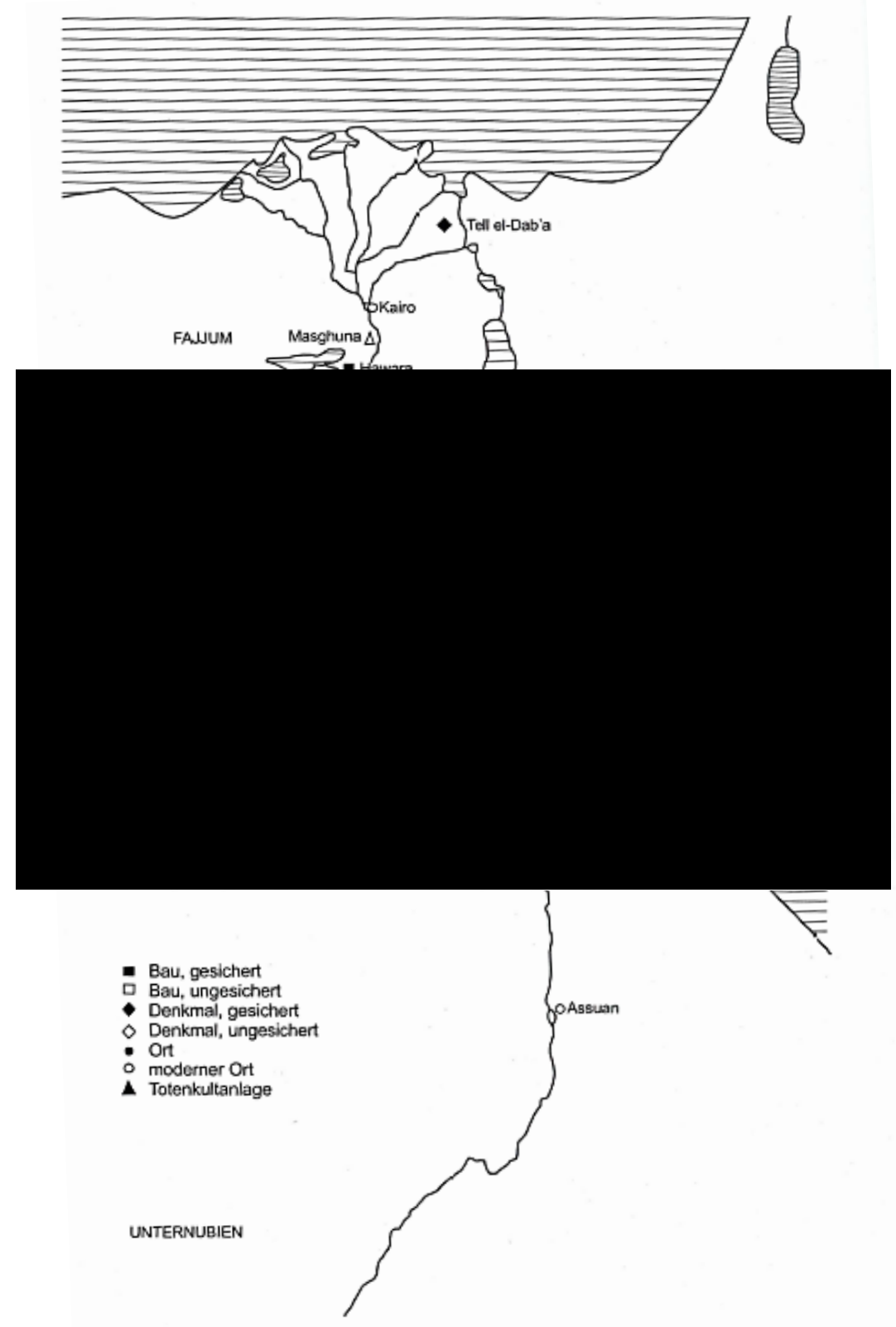

Fig. 6.44 Temple building programme of Sobekneferu, Hirsch 2004: Karte 8.

From the Canaanite burials, it seems military employment was typical among males and from Sinai depictions they commonly participated in expeditions. ${ }^{908}$ A direct association with Twelfth Dynasty royal women and Egyptian born Asiatics working in the Sinai is seen on the seated statue of Princess Neithikerty (Cat. 30), who was a daughter of Amenemhat III and possible sister of Sobekneferu. Princess Neithikerty is inscribed as Her [possibly Hathor] beloved daughter, the hereditary princess, great in favor, great in charm, priestess of Hathor lady of the Turquoise, Neithikerty, true

908 Bietak 1996: 14-19. 
of voice, possessing honor. Additionally, located on the left side of the seat the surviving inscription reads: True acquaintance of the king, his beloved, overseer of all the king's property, god's treasurer, deputy of the chief steward Amenysohenen, conceived of Ituneferu, the Asiatic, possessing honor (Fig. 6.44). ${ }^{909}$

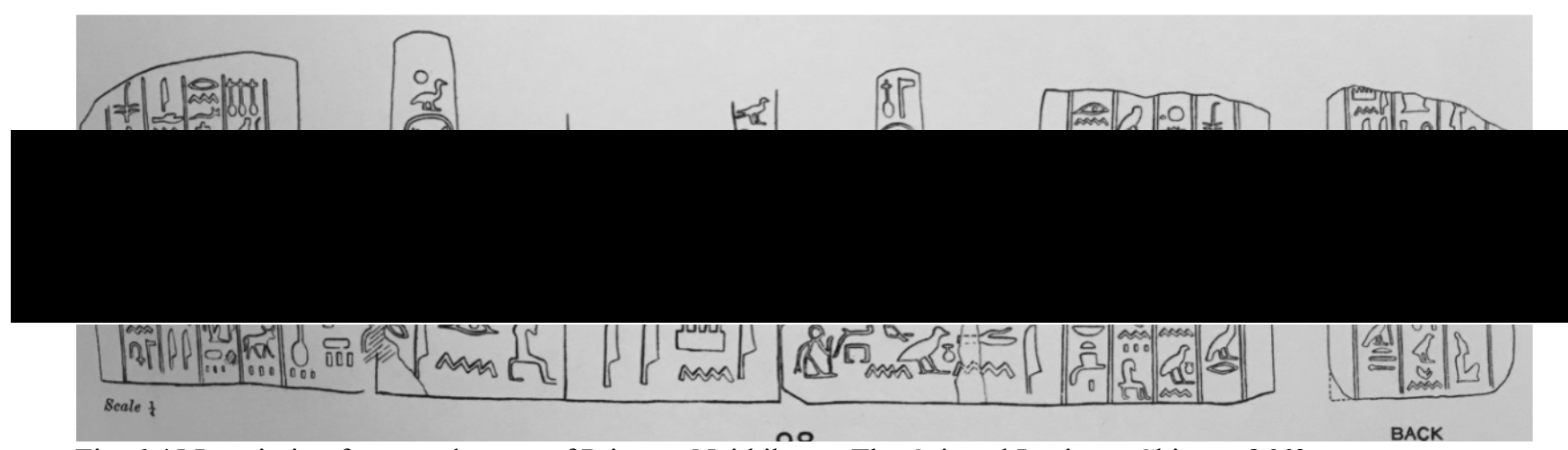

Fig. 6.45 Inscription for seated statue of Princess Neithikerty, The Oriental Institute, Chicago 8663; Gardiner and Peet 1955: XXXIII.

Herakleopolis Magna, or modern Ihnasya el-Medina, is another town with a temple connected with Sobekneferu and the Thirteenth Dynasty. Herakleopolis Magna as a town is known from the Old Kingdom onwards and was an active site during the Twelfth Dynasty. ${ }^{910}$ During the reign of Senwosret III, five monuments were brought by the Officer Khani and were erected to the god Herishef. ${ }^{911}$ The architraves of both pharaohs Senwosret III and Sobekneferu were found among the columns of Ramses II who had reused them. ${ }^{912}$ Naville suggested that in addition to the re-usage the Twelfth Dynasty building may have not survived due to being made from limestone, which does not preserve well in the area. ${ }^{913}$ It seems that Sobekneferu built an independent temple at Herakleopolis Magna, or most likely an expansion to the monuments of Senwosret III. Similar to Ezbet Rushdi near Tell el-Dab'a, both Senwosret III and Sobekneferu built at Herakleopolis Magna and its continual use was carried into the Thirteenth Dynasty.

During her reign, Sobekneferu fulfilled all the requirements for the pharaonic office, and her reign was apparently publicly recognized, accepted, and unproblematic in terms of legitimacy. For Sobekneferu's time to be remarkably

\footnotetext{
909 Gardiner and Peet 1955: 105.

${ }^{910}$ Daressy 1917: 33.

911 Naville 1894: 2.

912 Daressy 1917: 34

913 Naville 1894: 10.
} 
successful and indisputable, it can be argued there was already in place a standardization of obtainable politics for Twelfth Dynasty royal women. This is attested by Sobekneferu and Neferuptah, who was the intended heir for her father Amenemhat III and possibly his coregent. Neferuptah and Sobekneferu represent both obtainable and sustainable politics for Twelfth Dynasty royal women. These types of political positions refer to office of queenship and its extension to the pharaonic office. The sustainability of royal women in the political office of queenship was essential throughout the Twelfth Dynasty. The presence of this position held by a royal woman was indispensable to any male in the pharaonic office. This is seen from the reigns of the pharaohs Amenemhat III and Amenemhat IV when the royal women in the queenship position are the daughter and mother. These reigns confirm a royal female encompassing type of political position was prevalent during the end of the Twelfth Dynasty.

The queenship position extended to the pharaonic office, meaning a royal woman already in this political position could have the opportunity to become regent, co-regent, or pharaoh. Similarly, if a royal daughter was the crown princess she could also become regent, co-regent, or ruling monarch. In the case of Sobekneferu, she was possibly the intended heir and this permitted her to pass over the political position of queenship and directly into the pharaonic office. The duties of the pharaoh were the same for all rulers and this would allow for her reign to be recognized by the public. The only exception found in Sobekneferu's reign is that from her time in the pharaonic office there is no surviving information for a royal woman in the queenship position. This suggests that for male monarchs a royal woman in the office of queenship was necessary, but for female monarchs such as Sobekneferu they could fulfill the governmental functions of both positions and a royal woman in the queenship position may have not been essential.

Similar to Amenemhat III and Neferuptah, there is no securely known mother of Sobekneferu. Amenemhat IV is the only late Twelfth Dynasty ruler for whom a depiction with his mother survives, as attested at the Temple of Medinet Madi (Cat. 56). For Sobekneferu, Roth suggests Queen Senet (RW 41) as her mother. ${ }^{914}$ Two lower halves and a nearly intact seated statue of Queen Senet have been found (Cat. 17, 28, 36; Fig. 6.45, 6.46). On the statues, Senet carries the titles mother of the

914 Roth 2001: 242-245. 
monarch and wife of the monarch. Roth notes that at least one ${ }^{915}$ of the statues of Senet (Cat. 36; Fig. 6.46) was found in Tell Abu el-Filus, which is located in the same area as Tell el-Dab'a and Ezbet Rushdi. Based upon the late Twelfth Dynasty and early Thirteenth Dynasty's activities in this area and the presence of Sobekneferu's four statues, Roth suggest Senet has a connection to Sobekneferu, possibly as her mother. ${ }^{916}$ Senet carried both titles of mother and wife of the monarch, and if she is the mother of Sobekneferu then she is also the wife of Amenemhat III.

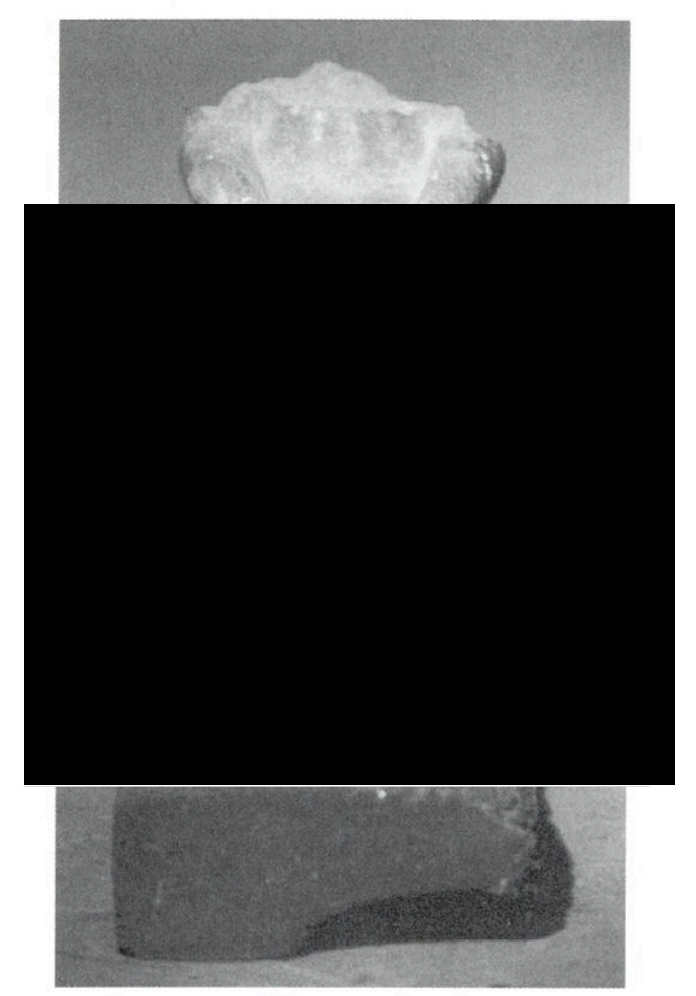

Fig. 6.46 Seated statue of Queen Senet, Egyptian Museum Cairo CG424.

\footnotetext{
${ }^{915}$ Both statues are stated to come from Tell Abu el-Filus and Khata'na by Habachi 2001: 169, Kat. 12-13.

916 Roth 2001: 243-245.
} 


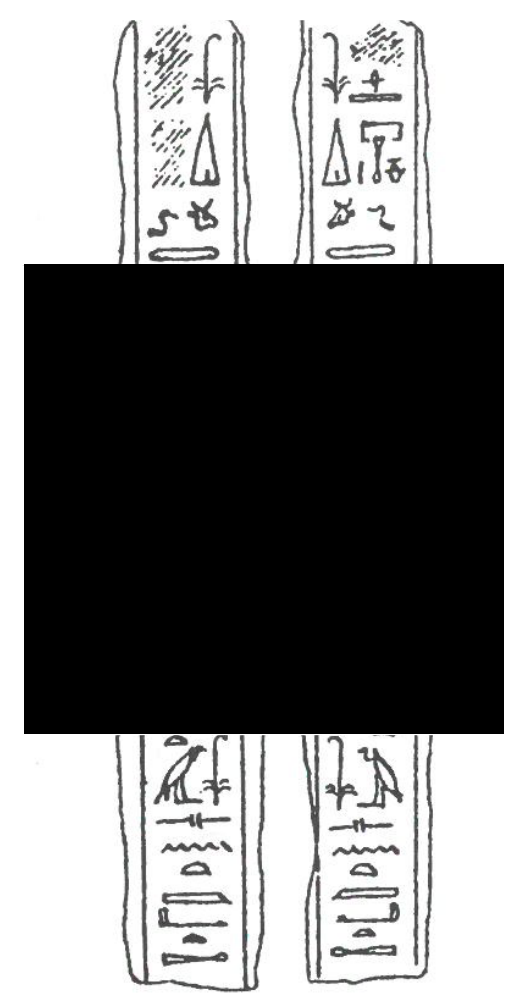

Fig. 6.47 Inscription from seated statue of Queen Senet found at Tell Abu el-Filus, Roth 2001: 582.

Two other wives of Amenemhat III are known, Queen Aat and Queen

Khenemetneferhedjet III. Both of these queens are known from their burials in their Dahshur pyramid and Queen Senet is only attested from her three statues. It seems that there is no surviving evidence that Queen Senet was married or directly associated with Amenemhat III or Aat and Khenemetneferhedjet III. The fact that Senet did not have a burial at Amenemhat III's mortuary complex at Hawara could be due to the fact that as Sobekneferu's mother Senet was possibly buried near to her. It can also be the case that Senet was buried near to Sobekneferu but had a cenotaph similar to queens Khenemetneferhedjet I and II. However, queens Khenemetneferhedjet I and II along with Neferuptah were all in the political office of queenship and for Twelfth Dynasty royal women receiving a cenotaph seems to be a part of this governmental position. This would mean for Queen Senet to have a cenotaph she would have to had been in the office of queenship during the reign of Sobekneferu, but as a pharaoh who happened to be female, Sobekneferu would not necessarily need a royal female present.

During her lifetime Sobekneferu could obtain both political positions of queenship and the pharaonic office. Additionally, Sobekneferu would not have a wife, in the traditional sense, and if it were needed she would partake in the type of 
legitimization that included another royal woman. This would be similar to Amenemhat III with his daughter Neferuptah and Amenemhat IV with his mother Hetepi who were in the queenship position. In this sense, it is possible Queen Senet was the queenship office holder as Sobekneferu's mother. Beyond the fact that Sobekneferu may not have needed an accompanying royal woman, there are two main problems with this theory. Within all depictions and inscriptions of Sobekneferu, her mother is not mentioned or represented. Furthermore, from the surviving titulary of Senet's seated statues, her name is not encircled within a cartouche.

Queen Senet's name not being written inside of a cartouche can lead to two conclusions. Either the statues were created before Neferuptah received her cartouche, or the cartouche was only for her and Sobekneferu. Neferuptah is the first royal woman to receive a cartouche followed by Sobekneferu who was the second. If it is the case, that Senet's statues were commissioned before Neferuptah's first cartouche was established then Senet cannot be the mother of Sobekneferu because she was pharaoh nearly nine years after Amenemhat III's death. This would mean that it is possible Queen Senet was the wife of Senwosret III and the mother of Amenemhat III. However, there is currently no evidence for Senet from either Senwosret III's or Amenemhat III's reigns and it is known that Queen Khenemetneferhedjet II was in the queenship position during Senwosret III's time in the pharaonic office leading to speculate she was Amenemhat III's mother.

The second explanation is that the cartouche was not used for Twelfth Dynasty royal women except for Neferuptah and Sobekneferu. If the three seated statues of Queen Senet were commissioned during the reign of Sobekneferu, the queen mother still did not carry a cartouche. This is also evident for Queen Hetepi (Cat. 56), the mother of Amenemhat IV. Queen Hetepi was in the queenship position during the reign of Amenemhat IV. She is depicted in the Temple of Medinet Madi near Neferuptah but does not have a cartouche. As the mother of Amenemhat IV, Hetepi would have been older than Neferuptah, but her depiction in the Temple of Medinet Madi would have been added after that of Neferuptah's image. Thus, the cartouche did not extend afterwards to Hetepi and was only seen again during the reign of Sobekneferu. This further proves the political position Neferuptah held resembled pharaonic status (see Chapter 5.10) and the cartouche was still reserved for certain royal women. It is possible as the queen mother Senet did not receive a 
cartouche but her representations were obviously significant as the wife and mother of two different pharaohs, one possibly being Sobekneferu.

The majority of Sobekneferu's surviving artifacts represent her not as a coruler, but on her own as an independent pharaoh. The only exception is Amenemhat III with whom she is directly associated. This has been interpreted by Callender as a legitimization tactic to ensure her rule as pharaoh. ${ }^{917}$ From the surviving evidence Sobekneferu only commissioned works directly related to Amenemhat III at his mortuary complex at Hawara, which is one of the five locations Sobekneferu is connected with. Her columns and other fragments from the mortuary complex of Amenemhat III at Hawara (see Chapter 6.4; Figs. 6.7, 6.8, 6.9) are less than a fourth of known representations or inscriptions for Sobekneferu and less than ten percent of known and possible representations or inscriptions. These low percentages suggest that Sobekneferu did not need a legitimization tactic but that she was honoring her father in the appropriate context. This same lack for legitimization outside of Hawara can be extended to the political office of queenship. Sobekneferu may not have needed a royal woman to legitimize her rule and this is why she was never depicted with one, including her mother.

\subsection{Discussions}

Sobekneferu inherited the throne from her brother or half-brother Amenemhat IV while not having a co-regency with him or their father Amenemhat III. She did not share a double ruling date with either Amenemhat III or Amenemhat IV and would have independently reined nearly seven years after Amenemhat III's death. Based upon the evidence, she also never ruled on behalf of a younger male or as a co-regent with a Thirteenth Dynasty pharaoh. ${ }^{918}$ Sobekneferu held a sole reign resulting in her being the first and only royal woman to ascend the throne alone. Her reign was not derived from the death of a husband or a son, and from her surviving artifacts there was an obvious connection to Amenemhat III while ignoring Amenemhat IV. Sobekneferu ruled in her own right and this can be considered the epitome of the political power of Twelfth Dynasty royal women. Escalating past the position of queenship, Sobekneferu's iconography further developed with the original pharaonic

\footnotetext{
917 Callender 1998a: 236. Briefly mentioned by Grajetzki 2006: 62.

918 Murnane 1977: 23.
} 
attributes Neferuptah received during her tenure. It is during Sobekneferu's reign that gender-neutral politics were exhibited. These are established by Sobekneferu legitimizing herself as a female monarch and sole ruler without a male counterpart.

Surviving from Sobekneferu's four regnal years as pharaoh are five statues, at least three construction projects, multiple building fragments, two cylinder seals, a papyrus letter, a bead, two scarabs, a stela, and a Nile level reading from Kumma. During her fairly short reign, Sobekneferu had fulfilled the pharaonic office responsibilities of building structures at Hawara, Herakleopolis Magna, Harageh in the Fayum, and Tell el-Dab'a in the Delta. Her building activities possibly include completing the mortuary complex of Amenemhat III at Hawara, two structures that housed her sculptures near Tell el-Dab'a, a temple or extension at Herakleopolis Magna, and a pyramid complex in the Fayum. Following her father Amenemhat III and her grandfather Senwosret III, Sobekneferu was able to establish herself at these significant sites. During her reign she continued to improve the building projects of the Twelfth Dynasty while securing a personal legacy. There are currently no military campaigns known for Sobekneferu, although her Nile level reading suggests there were still Egyptian officials in Nubia who recognized her reign.

Sobekneferu's iconography is unique to the Twelfth Dynasty and all time periods before her reign. She was the first ruler to outwardly use artistic elements to depict a female monarch. These features include the combination of the shendyt-kilt and sheath dress, the usage of the nine bows, along with her masculine and feminine titles accompanying her images. Her four statues found at Tell el-Dab'a and the devotional style of her torso demonstrate Sobekenferu's pharaonic duties of offering to the gods and controlling the borders of Egypt. Sobekneferu's use of hrt on her Tell el-Dab'a statues and monuments from Amenemhat III's mortuary complex illustrates her pharaonic status as the living female embodiment of the god Horus. The mandatory duties rulers had to perform for the pharaonic position were not restricted to a certain sex and Sobekneferu's iconography expresses these profound meanings that were illustrated for a monarch who happened to be female. Her reign proves that each pharaoh was expected to conduct the same functions and be represented in the same iconography regardless of their gender or sex (for discussion see Chapter 3).

As the eighth pharaoh of the Twelfth Dynasty, Sobekneferu was included in four ruler lists from later dates. After Neferuptah, Sobekneferu was the second royal 
woman to have her name encircled within a cartouche. She was the first to rule without a male counterpart, to be the living female Horus, to have a full five name titulary, and to use the god Sobek's name. Some pharaohs of the Thirteenth Dynasty followed a similar titulary style devoted to Sobek and the Eighteenth Dynasty pharaoh Hatshepsut took inspiration from Sobekneferu's iconography (see Chapter 3.5.5.1). Some of Sobekneferu's surviving names and titles include Monarch of Upper and Lower Egypt, Female Horus, Daughter of Ra, Daughter of the Powerful One, and Lady of the Two Lands. Sobekneferu was able to redefine pharaonic regalia and successfully convey she was a ruling monarch that happened to be female. Her building activities show her power to commission and her inscriptions present her titulary equality with the pharaohs before her. Sobekneferu's inclusion within the Karnak, Saqqara, Turin, and Manetho ruler lists prove her legacy and its recognition during and after her reign. Sobekneferu was able to successfully rule over Egypt without a male counterpart and was distinguished for her pivotal time on the throne. 


\section{Chapter 7: Conclusions}

Twelfth Dynasty royal women held fundamental roles within Egyptian politics. The research presented in this thesis demonstrates that Twelfth Dynasty royal women had power in multiple aspects of Egyptian government. Royal women had opportunities to act as politicians who routinely filled the office of queenship and could, in certain occasions, take on the office of pharaoh. They held influence over the legitimization of the pharaonic office and the rejuvenation of the person holding the position. Using illustrative data, such as regularities and status symbols, this thesis also demonstrates that royal women were represented in multiple iconographic forms and particular characteristics that indicated they were equal to the secular manifestation of the pharaohs. These include the new commonplace use of uraei, the sphinx pose, and severe characteristics, as well as the case of Sobekneferu's full pharaonic regalia. Within this study, the tenure of Neferuptah and reign of Sobekneferu were thoroughly explored to better understand their roles as Twelfth Dynasty female holders of power. The reign of Sobekneferu was well-documented in ancient times and serves as a model for the changing political climate that Twelfth Dynasty royal women were an effective component of. This chapter summarizes the findings of the study, as well as indicating the impact and possible avenues for future research. The research questions are as follows:

1. What are the iconographic regularities and irregularities of the surviving artworks of Twelfth Dynasty royal women and how do these artistic features represent their official positions?

2. What evidence is there to support the hypothesis that Princess Neferuptah was the intended heir to Amenemhat III, and how does this affect the roles and representations of Twelfth Dynasty royal women?

3. There is more surviving evidence from Sobekneferu's reign than is regularly presumed. How do these artifacts demonstrate her political power and how can her sole reign in the dynastic succession of Amenemhat III and Amenemhat IV be interpreted?

Twelfth Dynasty royal women used iconography as a source of showing their status at different stages in their political career. It is also now apparent that Neferuptah had pharaonic attributes, was in the queenship position before her death, and was the intended heir or possible co-regent to her father Amenemhat III. Additionally, 
Sobekneferu ruled independently without a co-regency and was legitimized through her building activities, artworks, and titulary. Each research question is expanded upon below.

\subsection{Redefining female rulership}

To establish the theoretical framework for the study, the operant definitions for Queenship and the Queen was set out. Queenship was part of the pharaonic office and a separate political position from the king. The political occupation of queenship was to be filled by a biological female, such as the royal mother, wife, sister, or daughter of the ruling monarch. In English, a Queen who takes on queenship duties is specified to be the sole ruler of a country or the wife or mother of the king. In Egypt the Queen wife or mother and the Princess daughter or sister could all take on the political role and activities of queenship. Within their lifetime, royal women had the ability to be in one, some, or all the official positions of hmt $n s w t$, $m w t n s w t$, snt $n s w t$, or $s 3 t n s w t$ and take on the political duties of the queenship occupation or fulfill the pharaonic office $n s w t$. While female rulers held the title $n s w t$, there was no title for husband of the nswt. This could be because there was no established political position for royal men as simply kings. From surviving material, certain female monarchs never had a husband associated with them, such as Sobekneferu and others never remarried such as Hatshepsut and Tausret. Royal women could officially hold the two absolute political positions of queenship and monarch, while royal men commonly filled only the pharaonic office and effectively were not needed to legitimize a reign by a female monarch.

Chapter 3 also provides an etymological examination into the word $h r t$, "Female Horus". This title is analyzed in correlation with female rulership since female rulers carried out all aspects of the pharaonic office, including living as the earthly manifestation of the god Horus. hrt is a direct reflection of the office of $n s w t$ and is an example of how the divine aspect of the pharaonic office could be filled by any person no matter their gender or sex. This confirms that the ruling person in the pharaonic office was the living embodiment of Horus and could be either female or male. The pharaonic titles of $n s w t, h r r$, and $h r t$ were directly related to the office and its divine functions. This type of rulership is exemplified during the reigns of the 
female monarchs Sobekneferu, Hatshepsut, and Tausret who all carried the title of hrt Female Hours.

Meretneith, Khentkaus I and II, Ahhotep, Hatshepsut, Neferneferuaten, and Tausret were rulers and monarchs who happened to be females and their unique accessions to the throne show the flexibility of a royal woman becoming $n s w t$. Each ruler could ascend the throne through different processes, and royal women could hold multiple official positions. Due to the structure of the Egyptian pharaonic office, royal women could be princesses, queens, military leaders, as well as the queenship office holder before becoming pharaoh and could rule in any capacity such as sole monarch, regent, and co-regent. Less is known about the earlier female rulers Meretneith and Khentkaus I, and Nitocris's reign is still being debated (see Chapter 3.5). From known evidence, all three rulers did not have the title hmt nswt, which could suggest they were either sole ruling monarchs or regents for their young sons. As the reigning person, they would not carry the title wife hmt nswt because they were the ruler filling the pharaonic office and as regents the female rulers would be able to still carry the title $m w t n s w t$. The later royal women Ahhotep, Nefertiti along with the ruling Hatshepsut and Tausret all are better known from both Egyptian records and modern scholarship. Hatshepsut of the Eighteenth Dynasty is the most well documented royal woman to fill the pharaonic office. It is unclear if she directly modelled her reign after that of Sobekneferu's, although during her reign pharaonic attributes such as iconography and titulary were similar to Sobekneferu of the Twelfth Dynasty.

The analysis of the iconography of Twelfth Dynasty royal women (Chapter 4), along with the tenure of Princess Neferuptah and reign of Sobekneferu (Chapters 5 and 6) exhibit how the redefining of female rulership was needed to further understand the roles of royal women during the dynasty. In regard to Twelfth Dynasty royal women, the political structure of Egypt was expressed through multiple avenues, including titulary, iconography, temples, and mortuary complexes. The propagation of female rulership can be seen through examining these different types of political statements. The iconography of Sobekneferu's torso, now located at the Musée du Louvre (see Chapter 6.2; Cat. 58), demonstrates the Egyptian concept of Twelfth Dynasty female rulership. Sobekneferu is seen in the pharaonic office while being female. The type of iconographic analysis is proven because throughout 
the Twelfth Dynasty monarchs wore nemes-headdresses, shendyt-kilts, and pendent necklaces, while royal women wore sheath dresses with uraei. With this type of iconographic change, the representation of female rulership was revolutionized for the rest of ancient Egyptian history.

Recognizing and understanding these types of governmental activities for royal women are essential to any Egyptological study that intersects with political science. Royal women in both their divine and physical presence legitimized the pharaonic office and for royal women in the pharaonic position, the office was naturally legitimized. The political positions such as the office of queenship, regent, co-regent, and being a governmental representative in the public sector were complementary to the continuous event of royal women becoming pharaoh. These offices also further declared the power dimensions of women as rulers and monarchs, where political power was not defined by dominance but by legitimization.

From limited surviving ancient material, no female monarch was contested during her reign. Female rulership within the political system of Egypt was accepted, and this can be seen from the earliest of pharaonic times. These definitions are presented in this thesis to disconnect the political offices of kingship and queenship, while proving queenship was not simply an aspect of the king but rather a direct part of the pharaonic office. The political role of Queenship is not always straightforward and is not limited to one certain form. To combine all royal women in any political position would immediately release their agency. Each royal woman's accession to the throne was unique and their handling of power was also exclusive to their position within the royal family. This study has accepted and contested previous scholarship to construct these redefinitions, which supply a new framework for queenship and ancient Egyptian female rulership. It is hoped that the redefinitions of this thesis will contribute to a better understanding of Egyptian politics and provide accurate ancient and modern perceptions of female monarchs.

\subsection{The political image of royal women in the Twelfth Dynasty: summaries and findings from the catalogue}

Some Twelfth Dynasty royal women had greater opportunities to play in the government than previously considered. The political acts of royal women were thought to be a part of their time as queen, which was only defined as an aspect of 
kingship. It is rather now apparent that royal women filled the separate political office of queenship. The existence of this independent position was for royal women to function as politicians to legitimize and maintain the pharaonic office. This political mobility of government offices for royal women was shown in their iconography as artistic publicity or propaganda, which shaped the message of female rulership. Having their tenure or reigns produced through this type of political promotion allowed for the viewer, whether human or deity, to understand their occupied position.

A system of analyzing each known Twelfth Dynasty royal female representation through their iconographical forms and iconological meanings has been created for this thesis. This type of art historical analysis is defined as an examination of motifs, attributes, themes, and symbolism. Examples of different iconography for Twelfth Dynasty royal women include the poses, facial characteristics, royal uraei, wigs, headgear, shape of the ears and eyes, dress, as well as jewelry. These iconographic signifiers, along with titles, can communicate to the viewer what government position the royal woman held during the construction of the artwork. Since Twelfth Dynasty royal women could hold multiple positions, their iconography displayed the complexity of female rulership. The variations of the iconographic features of Twelfth Dynasty royal women cement their place in both the public engagement sphere and the private deified sphere. By having themselves presented in multiple forms with a complex range of attributes, Egyptian royal women were able to proclaim their government position. Within the Twelfth Dynasty, royal women used burials and titles to present themselves as being in the political office of queenship, such as Khenemetneferhedjet II (RW25). They were depicted in temples as the crown princess or co-regent (Neferuptah RW46) and were shown fulfilling the pharaonic office (Sobekneferu RW47). This systematic diversity of representations and burial styles emphasizes the uniqueness of each royal woman and further provides a basis for an art historical analysis of the Egyptian Twelfth Dynasty.

An essential aim of this thesis was to identify and collect the first catalogue of all known surviving representations of Twelfth Dynasty royal women. The extensive catalogue allows for an accurate examination of the iconography of Twelfth Dynasty royal women and gives an insight into the number of sculptures and 
reliefs being produced for royal women. Troy's book Patterns of Queenship ${ }^{919}$ was the first publication to list all known Twelfth Dynasty royal women and the artifacts associated with them. Troy originally recorded 41 royal women (see Chapter 1.6), a minimum of 36 artifacts, and 19 statues. Included in this current study is a total of 49 royal women, 62 artifacts, and 70 statues.

The catalogue highlights specific iconographic elements that are associated with royal women and how they showed their different political status and significance to the offices of queenship and pharaoh. These include hybrid poses, severe facial characteristics, headgear, and dress. Twelfth Dynasty royal women were often represented in the sphinx pose similar to the male monarchs (see Chapter 4.2.3). Princes Neferuptah as Amenemhat III's possible heir and Sobekneferu in the pharaonic office were depicted in the sphinx pose as prominent government figures. The human-headed bird representing a royal woman (Cat. 38) could also possibly be a depiction of Sobekneferu (see Chapter 6.16). The statue shows a significant shift in the iconographic innovation of the time period that coincides with Twelfth Dynasty royal women's style of depicting female rulership (see above 7.2). Royal women were represented with the new styles of the dynasty, as seen by the severe facial characteristics, which demonstrates their inclusion in iconographic expansion. Although the sheath dress continues from the Old Kingdom as the primary dress for royal women, the Twelfth Dynasty is the earliest time royal women are regularly portrayed with uraei marking their political status to the public. As stated above (see above 7.2), Sobekneferu's artworks, specifically her torso (Cat. 58), presents to the viewer a person filling the pharaonic office that happened to be biologically female.

The findings from the catalogue are discussed in Chapter 4, which establishes the iconographic regularities and irregularities for Twelfth Dynasty royal women. Chapter 4 provides an introduction to the artistic styles of the Twelfth Dynasty and covers all iconographic shifts. These include such features as the severe facial characteristics (see Chapter 4.3), standardization of the uraeus (see Chapter 4.4), sphinx pose (see Chapter 4.2.3), as well as the introduction of the royal female headed bird statue (see Chapter 4.2.4). Twelfth Dynasty royal women had complete iconographic independence from royal men and were depicted more without them

\footnotetext{
919 As stated in Chapter 1, this record of 41 was the basis for this study and was the highest estimation for the number of royal women during the Twelfth Dynasty, Troy 1986: 157-159.
} 
then with them. This type of independent representation can further support that royal women were commissioning their own artworks. Twelfth Dynasty royal women were also shown with artistic features that expressed royal equality, such as wearing uraei and when becoming sole ruler, Sobekneferu was depicted in full pharaonic regalia (see Chapter 6). This iconographic equality between ruling male monarchs and royal women is also seen with women who were in the political position of queenship. During the Twelfth Dynasty, the art was increasingly displaying the interconnection of the queenship position and the pharaonic office. By achieving this, art work commissioners and artists were able to publicly present royal women in the independent political positions of queenship, co-regency, and the pharaonic office.

The art of royal women during the Twelfth Dynasty differs from that of Old Kingdom and early Eighteenth Dynasty. Their artworks exist as a unique branch of the iconographic evolution that lasted throughout Egyptian history. Twelfth Dynasty royal women changed the dynamic of royal iconography and this can be seen from their depictions in the sphinx pose, the swty feather crown and uraei, developing facial characteristics, and ability to portray female rulership. Twelfth Dynasty royal female rulership was presented to the viewer by illustrating how queenship was an independent element of the pharaonic office and how royal women could hold both offices at separate times. This type of iconographic change is not necessarily an improved style from the Old Kingdom, but rather Twelfth Dynasty expressiveness should be understood as a distinct artistic style that displayed the political climate of the time period.

Although there is an unambiguous difference between Old Kingdom, early Middle Kingdom, and late Middle Kingdom artistic styles, similar iconographic development can be detected for royal women from the Old Kingdom. From the Fourth Dynasty, Khentkaus I used certain iconographic attributes to present herself as a ruler who happened to be female. She was one of the earliest royal women to be depicted with a uraeus and the first to wear a pharaonic beard. A second Old Kingdom example of iconographic innovation for royal women depicts possible pharaonic Regent Ankhnesmeryre II with her son Pepy II (see Chapter 4.13.1). ${ }^{920}$

\footnotetext{
${ }^{920}$ Statue of Queen Ankhnes-meryre II and her son, Pepy II, Brooklyn Museum of Art New York 39.119 .
} 
Ankhnesmeyre II is shown in what is considered a typical style for royal women; she is wearing a sheath dress with a vulture headdress. Pepy II is wearing a pharaonic nemes-headdress and seated sideways on his mother's lap facing in the direction of the viewer's left, which is away from the frontal perspective. Similar to Sobekneferu's torso that is depicting a female in the pharaonic office to the viewer, Ankhnesmeryre II is likely shown as Pepy II's mother and regent. This is applied to the extent that the artwork as a whole is figuratively made of two different statues with two distinct viewing points. As the pharaonic regent, Ankhnesmeryre II is the focal point of the statue and this representation also demonstrates the availability of iconographic attributes for royal women who are holding more than one political office, such as queen and pharaoh.

As stated in Chapter 4, there is no definitive explanation for the severe facial characteristics adopted by royal art during the late Twelfth Dynasty. It can be stated that although the characteristics are made famous by the surviving representations of Senwosret III and Amenemhat III, royal women also took part in this influential artistic style. Other than possibly depicting power, the motive for the characteristics is unclear and there is no surviving evidence that the style was created for a certain sex or gender that would simply be reproduced by the other. The severe characteristics also cannot be considered true portraiture since many royal and nonroyal representations have the features. However, the style can be considered impressions or reflections of the people. It is possible the severe facial characteristics show the "burden of kingship" 921 but again multiple representations include these features that would mean both royal and non-royal people held the burden of ruling the country. All faces with the severe characteristics are different, suggesting this was a style that was changed for each representation. It is further possible the person being portrayed was able to choose the extent of the severity or certain features to include, such as a round or a pentagonal face shape. The choosing of facial types would also coincide with the possible ability of a Twelfth Dynasty royal woman to commission statues, allowing them to decide the complete style of the artwork. Presently, it can only be concluded that these characteristics were specific features that expressed an exceptional artistic time during the Middle Kingdom of ancient Egypt.

${ }^{921}$ Baines 1995: 22; Russmann 2001: 104. 


\subsection{Tenure and possible reign of Neferuptah}

This study includes the first thorough analyses of Neferuptah and Sobekneferu, which is additional to the complete catalogue of surviving representations for all Twelfth Dynasty royal women. This thesis addresses the question of whether Neferuptah was the intended heir to the throne after her father Amenemhat III. From the surviving material, Neferuptah was the intended heir for the pharaonic office, but suffered from an early death during her father's reign. It has been previously suggested that Neferuptah was the intended heir, ${ }^{922}$ and there is currently no publication arguing against this. Through Chapter 5, Neferuptah's iconography, titulary, and tenure are revealed to show her importance to her father and the pharaonic office. Neferuptah is the most prominent royal family member during Amenemhat III's reign, and excluding Sobekneferu, she is the best-documented princess from the Twelfth Dynasty. Princess Neferuptah held the political position of queenship during the mid to late part of her father's rule. During this time Neferuptah also had at least four known relief and sculpture representations, was mentioned in at least one papyrus, and had over seventy items found in her burial. Unlike any other Twelfth Dynasty royal women, she acquired pharaonic attributes such as a cartouche, was depicted in front of her father offering to the Goddess Renenutet, and was buried in an independent pyramid complex.

Neferuptah's younger sister, Sobekneferu, asserted full pharaonic power, which further expanded on the rulership elements of Twelfth Dynasty royal women. Sobekneferu acquired the pharaonic office after Amenemhat IV, who reigned before her. Although all three children - Neferuptah, Amenemhat IV, and Sobekneferu would have been born within the first twenty to thirty years of Amenemhat III's reign, there is no surviving certain record of any of these royal children associated with each other. Their only connection was their associations with Amenemhat III. Both Amenemhat IV and Sobekneferu would have been alive during Neferuptah's time as crown princess and while she was in the queenship position, although were only prominent during their own reigns. It is possible Sobekneferu was depicted before becoming ruler, as seen on a damaged triad statue with Amenemhat III (see Chapter 5.7) as well as on stone fragments from the pyramid of Senwosret I (Figs. $5.25,5.26$ ) and a sphinx found in Gezer (see Chapter 6.14). Alternately, Amenemhat

922 Dodson: 2008: 383; Pignattari 2008: 86, 70. 
IV is only known from his time in the pharaonic office, which to an extent, is expected for royal men. There are two other royal male children known from the Twelfth Dynasty, except for the monarchs taking part in a co-regency. It was standard in the Twelfth Dynasty for princes to be represented with the ruling monarch only beginning with their co-regency and this would have been the same for Amenemhat III and Amenemhat IV. However, there is no double ruling date for Amenemhat III and Amenemhat IV, and a co-regency would have had to take place within the last two years of Amenemhat III's forty-six-year reign. ${ }^{923}$

Furthermore, Neferuptah and Amenemhat IV were not represented in affiliation with each other even though they are both depicted at the Temple of Medinet Madi. Amenemhat IV and his mother Queen Hetepi (Cat. 56) are shown in a scene separated from Amenemhat III and Neferuptah (Cat. 55). Since there is no definitive answer to a co-regency between Amenemhat III and Amenemhat IV, it is possible Amenemhat IV and Hetepi extended the Temple of Medinet Madi at a later point during his reign. Alternatively, if Amenemhat IV's relief was included in the temple during a two-year co-regency with Amenemhat III, Neferuptah did not hold the queenship position during the last two years of Amenemhat III's reign, suggesting she was already dead at this time. This would further support the view that Neferuptah was the intended heir and the accession of Amenemhat IV happened after her death.

\subsection{Clarification of the sole reign of Sobekneferu}

As a result of Amenemhat IV having seven to nine years of a sole reign, a coregency for Amenemhat III and Sobekneferu could not have taken place. ${ }^{924}$ A coregency between Amenemhat IV and Sobekneferu can be discounted as well since there is no surviving record associating the two together. It can also be accepted that Sobekneferu was not Amenemhat IV's wife and that his mother, Hetepi, took on the political position of queenship during his reign. There is currently no wife identified for Amenemhat IV and no definite children. It seems that during the late Twelfth Dynasty, including the second half of Amenemhat III's reign, as well as during those of Amenemhat IV and Sobekneferu, marriages were not a significant part of the

\footnotetext{
923 Parker 1950: 68.

924 Murnane 1977: 229.
} 
monarch's image. ${ }^{925}$ There is currently no known royal woman in the queenship position during Sobekneferu's time in the pharaonic office, thus indicating either that there was not a need for the position or that there were no female family members alive at the time. It is possible for Sobekneferu's reign to have been similar to Amenemhat IV's with her mother fulfilling the office. However, most likely, Sobekneferu did not need another royal woman in the queenship position because as a female monarch she could possess both positions legitimizing her own reign.

Two main ideas have been presented with the accession of Amenemhat IV and Sobekneferu. The first states the Sobekneferu was only able to become monarch because there was no appropriate male heir to the throne, and the second claims Amenemhat IV intervened between the reigns of Amenemhat III and Sobekneferu, thus suggesting she was the true heir rather than Amenemhat IV. ${ }^{926}$ It can be concluded that Sobekneferu held the pharaonic office in her own right and was the true heir, but most likely Amenemhat IV did not maliciously intervene. It is possible Amenemhat IV was next in line to the throne after Neferuptah, which is why his rule came between Amenemhat III and Sobekneferu. A two-year co-regency between Amenemhat IV and Amenemhat III would be similar to the two-year co-regency of Senwosret I and Amenemhat II ${ }^{927}$ and Amenemhat IV's sudden appearance was due to him being a prince. The royal succession line of the late Twelfth Dynasty likely went from Amenemhat III to Neferuptah, who suffered an early death, then Amenemhat IV, who may have had a two-year co-regency with Amenemhat III, and finally to Sobekneferu, who solely reigned for approximately four years.

The joint reign of Amenemhat I and Senwosret I is the earliest securely recorded co-regency from Egypt. ${ }^{928}$ This was followed by the co-regencies of Senwosret I with Amenemhat II, Amenemhat II with Senwosret II, and Senwosret III with Amenemhat III. ${ }^{929}$ The co-regencies between Senwosret II with Senwosret III, and Amenemhat III with Amenemhat IV are highly probable, although still debated. Whether co-regency is certain or not, Twelfth Dynasty monarchs helped legitimize

\footnotetext{
${ }^{925}$ It can be suggested that their wives' names have not survived, however in additional to no names, there are no artifacts, burials, or inscriptions.

${ }^{926}$ An example of this second argument is Dodson's principal line of royal succession running from Amenemhat III to Sobekneferu, while not including Amenemhat IV, Dodson 2004: 92.

927 Murnane 1977: 27-28.

928 Murnane 1977: 1.

929 Wegner 1996: 249-279, 268. Wegner suggests Senwosret III and Amenemhat III had a co-regency for nearly 20 years.
} 
their rule by acknowledging their reign with the previous person. Sobekneferu can be considered the only Twelfth Dynasty ruler who did not depict her association with the directly preceding ruler. Sobekneferu would have commissioned her monuments in this fashion because Amenemhat IV was her brother and not her father. Each Twelfth Dynasty monarch before her combined their reigns, iconography, and titles with the previous ruler who was their father. As ruling monarch, Sobekneferu did exactly this, in that she connected herself with Amenemhat III because the line of succession was from him and not Amenemhat IV. Although a co-regency did not take place between Amenemhat III and Sobekneferu, she clearly followed Twelfth Dynasty style in commissioning monuments that related to their fathers.

Similar to other late Twelfth Dynasty rulers and Amenemhat IV's possible co-regency with Amenemhat III, Neferuptah did not share a double ruling date with Amenemhat III. This would support the view that she was not her father's co-regent, but the occupier of the queenship position and his intended heir. Both Amenemhat IV and Neferuptah's titles were inscribed in association with Amenemhat III. However, Neferuptah is the only one of the three to be depicted with Amenemhat III and is the owner of a pyramid complex directly in conjunction with his. From the surviving evidence, the aspect of the pharaonic office that was available to Amenemhat IV was also applicable to Neferuptah as a princess. It is clear that Neferuptah had the attributes of an intended heir or co-regent, except for full pharaonic titulary, but because of no surviving double ruling dates between her and Amenemhat III, there can be no certain co-regency. Significantly, Sobekneferu did not have a co-regency and undoubtedly ruled as a sole ruler with full pharaonic capabilities. Sobekneferu exhibited legitimate political power, which altered female pharaonic titulary and iconography for the rest of Egyptian history.

\subsection{Impact of research}

The completion of this thesis has an impact on the understanding of Twelfth Dynasty royal women and the Middle Kingdom as a whole. It also further expands the knowledge of queenship along with gender and power studies. By redefining female rulership and examining queenship as an independent element of the pharaonic office, this research validates the Egyptian concept of how gender and power intersected. The pharaonic office was where power, including political and 
influential, was shared between the sexes. The identification of the independent political office of queenship, the reformulation of female rulership, and the first complete catalogue of all known representations of Twelfth Dynasty royal women is unique to this study and propels the developing knowledge of Egyptian royal women.

The catalogue accompanying this thesis fills a void in Middle Kingdom scholarship and removes the disparity of knowledge between Twelfth Dynasty royal men and women. It serves as a database for any further analysis of Twelfth Dynasty royal women and provides the first and only iconographic standard for the artifacts of these women. This study reaches beyond the Twelfth Dynasty catalogue and into Middle Kingdom royal life, including art, politics, rulership, and funerary practices. It not only helps better interpret royal women, but also clarifies how the Egyptians perceived female rulers. The aim of this work is to examine the roles of the royal women in the Twelfth Dynasty, including Princess Neferuptah and Sobekneferu, as well as creating the first complete catalogue for these women. Through this study, it is now possible to appropriately portray royal women along with their roles during the Twelfth Dynasty, and this thesis provides new approaches towards the understanding of female rulership.

\subsection{Future research}

While this thesis will serve as a basis for future Twelfth Dynasty royal women analyses, there will always be new material to add to the understanding of royal women from all time periods. In addition to the information collected in this study, damaged fragments, artifacts with surviving titles, as well as additions to Neferuptah's and Sobekneferu's collections will continue to be added to help further the examination of the Twelfth Dynasty. Furthermore, the interpretations of queenship in ancient Egypt will continue to advance, cultivating new ideas and definitions for the political position. The maintaining of research for the Twelfth Dynasty and royal women of all time periods is essential to Egyptology and this thesis serves as a starting point for future discussions. 


\section{Bibliography}

Ahrens, A. 2011. A "Hyksos Connection"? Thoughts on the Date of Dispatch of Some of the Middle Kingdom Objects Found in the Northern Levant. In Jana Mynářová (ed), Egypt and the Near East- the Crossroads: Proceedings of an International Conference on the Relations of Egypt and the Near East in the Bronze Age, 21-40. Prague: Charles University in Prague.

Aldred, C. 1950. Middle Kingdom Art in Ancient Egypt, 2300-1590 B.C. London: Alec Tiranti.

. 1970. Some Royal Portraits of the Middle Kingdom in Ancient Egypt. $M M J$ 3, 27-50.

Allam, S. 1989. Women as Owners of Immovable in Pharaonic Egypt. In Barbra Lesko (ed), Women's Earliest Records: From Ancient Egypt and Western Asia. Brown Judaic Studies 166, 123-140. Atlanta: Scholars Press.

Allen, J. 1994. Nefertiti and Smenkh-ka-re. GM 141, 7-17.

.2014. Middle Egyptian: An Introduction to the Language and Culture of Hieroglyphs, $3^{\text {rd }}$ edn. Cambridge: Cambridge University Press.

Allen, S. 1998. Queens Ware: Royal Funerary Pottery in the Middle Kingdom. In Cristopher Eyre (ed), Proceedings of the Seventh International Congress of Egyptologists Cambridge, 3-9 September 1995, 39-48. Leuven: Peeters.

Allen, T. 2000. Problems in Egyptology: Ancient Egyptian Kingship. JBS 31, 139148.

Altenmüller, H. 1983. Das Grab der Königin Tausret im Tal der Könige von Theben: erster Vorbericht über die Arbeiten des Archäologischen Instituts der Universität Hamburg im Winter 1982/1983. SAK 10, 1-24

. 2012. A Queen in the Valley of Kings: The Tomb of Tausret. In Richard Wilkinson (ed.), Tausret: Forgotten Queen and Pharaoh of Egypt, 67-91. Oxford: Oxford University Press.

Andrews, C. 1990. Ancient Egyptian Jewellery. London: British Museum Publications.

Andreu-Lanoë, G. and Morfoisse, F. (eds). 2017. Sésostris III et la fin du Moyen Empire: Actes du Colloque des 12-13 Décembre 2014, Louvre-Lens et Palais des Beaux-Arts de Lille. Cahiers de Recherches de l'Institut de Papyrologie et Égyptologie de Lille 31. Lille: Université de Lille.

Angenot, V. 2019. "Neferneferuaten - A Semiotic Outline" Paper presented at the American Research Center in Egypt, Washington D.C. April 12, 2019. 
Anthes, R. 1954. The Original Meaning of $m_{3}{ }^{e}$ hrw. JNES 13 (1), 21-51.

Arnold, Di. 1979. The Temple of Mentuhotep at Deir el-Bahari. New York: The Metropolitan Museum of Art.

. 1987. Der Pyramidenbezirk des Königs Amenemhet III in Dahschur Band 1: die Pyramide. Archäologische Veröffentlichungen 53, Deutsches Archäologisches Institut, Abteilung Kairo. Mainz am Rhein: Philipp von Zabern.

1988. The South Cemeteries of Lisht Volume I: The Pyramid Complex of Senwosret I. New York: The Metropolitan Museum of Art.

1992. The South Cemeteries of Lisht Volume III: The Pyramid Complex of Senwosret I. New York: The Metropolitan Museum of Art.

. 2002. The Pyramid Complex of Senwosret III at Dahshur: Architectural Studies. New York: The Metropolitan Museum of Art.

. 2003. The Encyclopedia of Ancient Egyptian Architecture. Princeton: Princeton University Press.

. 2005. The temple of Hatshepsut at Deir el-Bahri. In Catharine Roehrig, Renée Dreyfus, and Cathleen A. Keller (eds), Hatshepsut: From Queen to Pharaoh, 135-140. New York; New Haven: Metropolitan Museum of Art; Yale University Press.

. 2015a. Architecture: Building for Eternity Across Egypt. In Adela Oppenheim, Dorothea Arnold, Dieter Arnold, and Kei Yamamoto (eds), Ancient Egypt Transformed: The Middle Kingdom, 317-319. New Haven, London: Yale University Press.

. 2015b. Thebes: West Bank. In Adela Oppenheim, Dorothea Arnold, Dieter Arnold, and Kei Yamamoto (eds), Ancient Egypt Transformed: The Middle Kingdom, 317-318. New Haven; London: Yale University Press.

. 2015c. The Fayum. In Oppenheim, Adela, Dorothea Arnold, Dieter Arnold, and Kei Yamamoto (eds), Ancient Egypt Transformed: The Middle Kingdom, 320-321. New Haven; London: Yale University Press.

. 2015d. Dahshur. In Oppenheim, Adela, Dorothea Arnold, Dieter Arnold, and Kei Yamamoto (eds), Ancient Egypt Transformed: The Middle Kingdom, 320-321. New Haven; London: Yale University Press.

Arnold, D. and Peter, J. 2015. The Move to the North: Establishing a New Capital. In Adela Oppenheim, Dorothea Arnold, Dieter Arnold, and Kei Yamamoto (eds), Ancient Egypt Transformed: The Middle Kingdom, 54-57. New Haven; London: Yale University Press. 
Arnold, Do. 1991. Amenemhat I and the Early Twelfth Dynasty at Thebes. MMJ 26, 5-48.

1996. The Royal Women of Amarna: Images of Beauty from Ancient Egypt.

New York: The Metropolitan Museum of Art.

. 2015a. Statues in Their Settings: Encountering the Divine. In Adela

Oppenheim, Dorothea Arnold, Dieter Arnold, and Kei Yamamoto (eds),

Ancient Egypt Transformed: The Middle Kingdom, 17-22. New Haven;

London: Yale University Press.

. 2015b. Pharaoh: Power and Performance. In Adela Oppenheim,

Dorothea Arnold, Dieter Arnold, and Kei Yamamoto (eds), Ancient Egypt

Transformed: The Middle Kingdom, 68-72. New Haven; London: Yale University Press.

Assmann, J. 1984. The Search for God in ancient Egypt. Ithaca; London: Cornell University Press.

. 1996. Preservation and Presentation of Self in Ancient Egyptian Portraiture. In Peter Manuelian (ed), Studies in honor of William Kelly Simpson 1, 55-81. Boston: Deptartment of Ancient Egyptian, Nubian and Near Eastern Art, Museum of Fine Arts

Aston, B. Harrell, J. and Shaw, I. 2000. Stone. In Paul Nicholson, and Ian Shaw (eds), Ancient Egyptian Materials and Technology, 5-77. Cambridge: Cambridge University Press.

Aufrère, S. 1989. Remarques sur la Transmission des Noms Royaux par les Traditions Orale et Écrite. BIFAO 89, 1-14.

Bader, B. 2011. Contacts between Egypt and Syria-Palestine as seen in a grown settlement of the Late Middle Kingdom at Tell el-Daba'a/Egypt. In Jana Mynárová (ed), Egypt and the Near East- the Crossroads: Proceedings of an International Conference on the Relations of Egypt and the Near East in the Bronze Age. 41-72. Prague: Charles University in Prague.

Bahrani, Z. 2013. On the status and purposes of ancient art. In Elizabeth Frood and Angela McDonald (eds), Decorum and experience: essays in ancient culture for John Baines, 103-108. Oxford: Griffith Institute.

Baines, J. 1983. Literacy and Ancient Egyptian Society. Man 18 (3), 572-99.

.1990. Restricted Knowledge, Hierarchy, and Decorum: Modern Perceptions and Ancient Institutions. JARCE 27, 1-23.

.1995. Kingship, Definition of Culture, and Legitimation. In David O'Conner and David Silverman (eds), Ancient Egyptian Kingship, 3-48. Leiden: E.J. Brill. 
Baines, J. and Eyre, C. 1983. Four Notes on Literacy. GM 61, 65-96.

Baines, J and Yoffee N. 1998. Order, Legitimacy, and Wealth in Ancient Egypt and Mesopotamia. In Gary M. Feiman and Joyce Marcus (eds) Archaic States, 199-260. Santa Fe: School of American Research Press.

Bakry, H. 1971. The Discovery of a Statue of Queen Twosre (1262-1194? B.C.) at Madīnet Nașr. RSO 46, 17-26.

Bassir, H. 2013. The Headless Statue of Queen Tausret from Madinet Nasr. In Pearce Paul Creasman (ed), Archaeological research in the Valley of the Kings and ancient Thebes: papers presented in honor of Richard H. Wilkinson, 71-87. Wilkinson Egyptology Series 1. Tucson: University of Arisona Egyptian Expedition.

Baud, M. 2010. The Old Kingdom. In Alan Lloyd (ed), A companion to ancient Egypt 1, 63-80. Chichester: Wiley-Blackwell.

Bell, L. 1997. The New Kingdom "Divine" Temple: The Example of Luxor. In Byron E. Shafer (ed), Temples of Ancient Egypt, 127-184. Ithaca; London: Cornell University Press; I.B. Tauris \& Co Ltd.

Bennett, J. 1969. The Names of the Pyramids of the Twelfth Dynasty. JEA 5, 216.

Berman, L.1985. Amenemhet I. Ph.D. diss. Yale University, New Haven.

Bietak, M. 1991. Egypt and Canaan during the Middle Bronze Age. BASOR 281, 27-72.

1996. Avaris. The Capital of the Hyksos: Recent Excavations at Tell el'Dab'a. London: British Museum Press.

Blackman, A. 1914. The Rock Tombs of Meir: Part 1. The Tomb-Chapel of UkhHotp's Son Senbi. Archaeological Survey of Egypt 22. London: The Egyptian Exploration Society.

. 1915a. The Rock Tombs of Meir: Part 2. The Tomb-Chapel of Senbi's Son Ukh-Hotp. Archaeological Survey of Egypt 23. London: The Egyptian Exploration Society.

. 1915b. The Rock Tombs of Meir: Part 3. The Tomb-Chapel of Ukh-Hotp's Son Ukh-Hotp and Mersi. Archaeological Survey of Egypt 24. London: The Egyptian Exploration Society.

1921. On the Position of Women in the Ancient Egyptian Hierarchy. JEA 7, 8-30.

1924. The Rock Tombs of Meir: Part 4. The Tomb-Chapel of Pepi'onkh the Middle Son of Sebkhotpe and Pekhernefert. Archaeological Survey of Egypt 25. London: The Egyptian Exploration Society. 
Blackman, A. and Apted, M. 1953. The Rock Tombs of Meir Part 6: The TombChapels of Ukhhotpe, Son of Iam, Senbi son of Ukhhotpe, Son of Senbi, and Ukhhotpe, Son of Ukhhotpe and Heny-Hery-Ib. Archaeological Survey of Egypt 29. London: The Egyptian Exploration Society.

Bonnet, C. 2014. An Unusual Architecture of Hatshepsut in Nubia. In José Galán, Betsy Bryan, and Peter Dorman (eds), Creativity and Innovation in the Reign of Hatshepsut: Papers from the Theban Workshop 2010, 427-435. Studies in Ancient Oriental Civilization 69, Occasional proceedings of the Theban Workshop. Chicago: Oriental Institute.

Borchardt, L. 1899. Der zweite Papyrusfund von Kahun und die zeitliche Festlegung des Mittleren Reiches der ägyptischen Geschichte. ZAeS 37, 89-103.

Bouillon, H. 2014. A New Perspective on So-Called 'Hathhoric Curls'. E\&L 24, 209-226.

Bourriau, J. 1988. Pharaohs and Mortals: Egyptian Art in the Middle Kingdom. Cambridge: Fitzwilliam Museum, Cambridge University Press.

. 1991. Patterns of Change in Burial Customs. In Stephen Quirke (ed), Middle Kingdom Studies, 3-20. New Malden, Surry: SIA Publishing.

Bresciani, E. and Giammarusti, A. (eds). 2012. I templi di Medinet Madi nel Fayum. Pisa: PLUS-Pisa University Press.

Brier, B. and Michael, Z. 2000. The Remains of Queen Weret. Chungará 32, 23-26.

Brunton, G. 1914. The British School at Lahun. Ancient Egypt 2, 49-51. . 1920. Lahun I: The Treasure. British School of Archaeology in Egypt and Egyptian Research Account 27 (20th year). London: School of Archaeology in Egypt; Bernard Quaritch.

Bryan, B. 1996. In Women Good and Bad Fortune are on Earth: Status and Roles of Women in Egyptian Culture. In Anne Capel and Glenn Markoe (eds). Mistress of the House, Mistress of Heaven: Women in Ancient Egypt. New York: Hudson Hills.

Breyer, F. 2016. Punt: die Suche nach dem "Gottesland". Culture and History of the Ancient Near East 80. Leiden; Boston: Brill.

Bryce, T. 1990. The death of Niphururiya and its aftermath. JEA 76, 97-105. 2003. Letters of the Great Kings of the Ancient Near East: The Royal Correspondence of the Late Bronze Age. London: Routledge.

Brzostowski, S (ed). 1979. The Temple of Queen Hatshepsut. [Vol. 1]: Results of the Investigations and Conservation Works of the Polish-Egyptian Archaeological Mission 1968-1972. Warsaw: PKZ. 
Callender, V. 1992a. Female Officials in Ancient Egypt and Egyptian Historians. In Barbara Garlick, Suzanne Dixon, and Pauline Allen (eds), Stereotypes of Women in Power: Historical Perspectives and Revisionist Views. 11-35. Westport: Greenwood Press.

. 1992b. The Wives of the Egyptian Kings: Dynasties I-XVII. Ph.D. diss. Macquarie University.

. 1995a. A Note on the Title hnmt nfr hִdt. SAK 22,37-41.

. 1995-1996. Problems in the Reign of Hatshepsut. KMT 6 (4), 16-27, 7980.

. 1998a. Materials for the Reign of Sebekneferu In Christopher Eyre (ed), Proceedings of the Seventh International Congress of Egyptologists, Cambridge 3-9 September 1995. 227-236. Leuven: Peeters.

. 1998b. What Sex was King Sobekneferu and What Do We Know about Her Reign? KMT 9, 24-30.

. 2000. The Middle Kingdom Renaissance (c. 2055-1650 BC). In Ian Shaw (ed) The Oxford History of Ancient Egypt. 131-171. Oxford: Oxford University Press.

. 2004. Queen Tausret and the End of Dynasty 19. SAK 32, 81-104.

. 2008. Queen Tatjet: An Exercise in Chronology. In Hana Vymazalova and Miroslav Barta (eds), Chronology and Archaeology in Ancient Egypt (The Thrid Millennium B.C.) 170-179. Prague: Czech Institute of Egyptology, Faculty of Arts, Charles University in Prague.

. 2011a. In Hathor's Image I: The Wives and Mothers of Egyptian Kings from Dynasties I-VI. Prague: Charles University Faculty of Arts.

. 2011b. Queen Neit-ikrety/Nitokris. In Miroslav Bárta, Filip Coppens, and Jaromír Krejčí (eds), Abusir and Saqqara in the year 2010 1, 246-260.

Prague: Czech Institute of Egyptology, Faculty of Arts, Charles University in Prague.

. 2012. Female Horus: The Life and Reign of Tausret. In Richard Wilkinson (ed), Tausret: Forgotten Queen and Pharaoh of Egypt. 5-24.

Oxford: University Press.

Capel, A. and Markoe, G (eds). 1996. Mistress of the House, Mistress of Heaven: Women in Ancient Egypt. New York: Hudson Hills.

Charron, A. 2009-2010. L'intronisation de Nitocris. ÉAO 56, 43-52.

Coche-Zivie, C. 1972. Nitocris, Rhodopis et la troisième pyramide de Giza. BIFAO 72, 115-138. 
Collier, M. and Quirke, S. 2002. The UCL Lahun Papyri: Letters. BAR International Series 1083. Oxford: Archaeopress.

Conkey, M. 2007. Questioning Theory: Is There a Gender of Theory in Archaeology? JAMT 14, 285-310.

Conkey, M. and Spector, J. 1984. Archaeology and the Study of Gender. AAMT, 7. $1-38$.

Connor, S. 2014. Images du Pouvior en Égypte à la fin du Moyen Empire et à la Deuxième Période Intermédiaire. Ph.D. diss. Univèrsite Libre de Bruxelles.

. 2016-2017. Pierres et Statues. Représentation du Roi et des Particuliers sous Sésostris III. CRIPEL 31, 9-32.

. 2018. Sculpture Workshops: Who, Where, and for Whom? In Gianlucca Miniaci, Juan Carlos Moreno García, Stephen Quirke, and Andréas Stauder (eds), The Arts of Making in Ancient Egypt: Voice, Images, and Objects of Material Producers 2000-1550 BC. Leiden: Sidestone Press.

Connor, S. and Delvaux, L. 2017. Ehnasya (Heracleopolis Magna) et les Colosses en Quartzite de Sésostris III. CdE 92 (184), 247-265.

Cooney, J. 1968. Siren and Ba: Birds of a Feather. BCM 55 (8), 262-271.

Cooney, K. 2008. The Problem of Female Rebirth in New Kingdom Egypt: The Fragmentation of the Female Individual in her Funerary Equipment. In Carolyn Graves-Brown (ed), Sex and Gender in Ancient Egypt: Don your wig for a joyful hour. 1-26. Swansea: Classical Press of Wales.

. 2009. Where Does the Masculine Begin and the Feminine End? The Merging of the Two Genders in Egyptian Coffins during the Ramesside Period. In Bernhard Heininger (ed), Ehrenmord und Emanzipation: die Geschlechterfrage in Ritualen von Parallelgesellschaften, 99-124. Berlin; Münster: Lit. . 2014. The Woman who Would be King: Hatshepsut's Rise to Power in Ancient Egypt. London: Oneworld Publications.

Costin, C. 1996. Exploring the Relationship between Gender and Craft in Complex Societies:Methodological and Theoretical Issues of Gender Attribution. In Rita Wright (ed), Gender and Archaeology. 113-140. Philadelphia: University of Pennsylvania Press.

Creasman, P. 2014. Hatshepsut and the Politics of Punt. ARR 31 (3), 395-405.

D’Amico, F. 1995. Women National Leaders. In Francine D'Amico and Peter Beckman (eds), Women in World Politics: An Introduction, 15-30. London: Bergin and Garvey. 
Daressy, G.1888. Remarques et Notes. $R T$ 10, 139-150.

. 1909. Catalogue Général des Antiquités Egyptiennes du Musée du Caire, n61001-61044, cercueils des cachettes royales. IFAO 3, 274.

1917. Grandes states de Ramsés II d'Héracléopolis. ASAE 17, 33-38.

De Morgan, J. 1894. Fouilles à Dahchour: Mars - Juin. Vienna: Adolphe Holzhausen.

1895-1903. Fouilles à Dahchour, 2 vols. Vienna: Adolphe Holzhausen.

Desjardins, M. 1860. Descritpion des bijoux de la reine Aah-Hotep. Revue Générale de l'Architecture et des Travaux Publics 28, 100-112.

Desroches-Noblecourt, C. 1957. Nouvelles d'Égypte et de Nubie. BSFE 23, 15-31.

Dodson, A. 1988. The Tombs of the Queens of the Middle Kingdom. ZAeS 115, 123136.

. 2000. Great Finds Revisited 10: The Intact Pyramid Burial at Hawara of 12th Dynasty Princess Neferuptah. KMT 11, 40-47.

. 2004. The Complete Royal Families of Ancient Egypt. London: New York: Thames \& Hudson

. 2008. The Book of Egyptian Queens. In Christiane Ziegler (ed), Queens of Egypt: from Hetepheres to Cleopatra, 380-393. Monaco: Grimaldi Forum.

. 2009. Amarna Sunset: Nefertiti, Tutankhamun, Ay, Horemheb, and the Egyptian Counter-reformation. Cairo; New York: American University in Cairo.

. 2015. Were Nefertiti \& Tutankhamen Coregents? In Dennis Forbes (ed), Amarna Letters: Essays on Ancient Egypt ca. 1390-1310 BC Volume V. Weaverville: KMT Communications, LLC.

. 2016. Poisoned Legacy: The Decline and Fall of the Nineteenth Egyptian Dynasty. Cairo and New York: The American University in Cairo Press.

. 2016. The Royal Tombs of Ancient Egypt. Barnsley: Pen \& Sword.

Dorman, P. 2005. Hatshepsut: Princess to Queen to Co-ruler. In Catharine Roehrig, Renée Dreyfus, and Cathleen A. Keller (eds), Hatshepsut: From Queen to Pharaoh, 87-89. New York; New Haven: Metropolitan Museum of Art; Yale University Press.

Doxey, D. 1998. Egyptian Non-royal Epithets in the Middle Kingdom: A Social and Historical Analysis. Probleme der Ägyptologie 12. Leiden: Brill. 
Dreyer, G. 1986. Elephantine VIII: der Tempel der Satet. Die Funde der Frühzeit und des Alten Reiches. Archäologische Veröffentlichungen, Deutsches Archäologisches Institut 39, Abteilung Kairo. Mainz: Zabern.

Dunham, D. 1946. An Egyptian Diadem of the Old Kingdom. BMFA 44. 255, 23-29.

Dziobek, E. 1992. Das Grab des Ineni: Theben Nr. 81. Archäologische Veröffentlichungen, Deutsches Archäologisches Institut, Abteilung Kairo 68. Mainz: Zabern.

Eaton-Krauss, M. 1990. The Coffins of Queen Ahhotep, Consort of Seqeni-en-Re and Mother of Ahmose. CdE 65 (130), 195-205

Ebbell, B. 1937. The Papyrus Ebers: The Greatest Egyptian Medical Document. Copenhagen; London: Levin \& Munksgaard; Oxford University Press.

Edgerton, W. 1942. Chronology of the Twelfth Dynasty. JNES 1 (3), 307-314.

Emery, W. 1949. Great Tombs of the First Dynasty I. Excavations at Saqqara. Cairo: Government Press.

. 1961. Archaic Egypt: Culture and Civilization in Egypt Five Thousand Years Ago. London, New York; Victoria; Toronto; Auckland: Penguin Books.

Engelbach, R. 1923. Harageh. British School of Archaeology in Egypt and Egyptian Research Account 28. London: British School of Archaeology in Egypt; Bernard Quaritch.

Engelstad, E. 2007. Much More than Gender. JAMT 14, 217-234.

Eldamaty, M. 2015. Die Gottesgemahlin des Amun. In Mamdouh Eldamaty, Friedhelm Hoffmann, and Martina Minas-Nerpel (eds), Ägyptische Königinnen vom Neuen Reich bis in die islamische Zeit: Beiträge zur Konferenz in der Kulturabteilung der Botschaft der Arabischen Republik Ägypten in Berlin am 19.01.2013, 67-85. Vaterstetten: Brose .

Eldamaty, H. Hoffmann, F. and Minas-Nerpel, M. 2015. Ägyptische Königinnen vom Neuen Reich bis in die islamische Zeit. Vaterstetten: Patrick Bose.

Evers, H. 1929. Staat aus dem Stein: Denkmäler, Geschichte und Bedeutung der Ägyptischen Plastik während des Mittleren Reichs. München: Bruckmann.

Farag, N. and Iskander, Z. 1971. The Discovery of Neferwptah. Cairo: General Organization for Government Printing Offices.

Faulkner R. 1962. A Concise Dictionary of Middle Egyptian. Oxford: Griffith Institute. 
Fay, B. 1991. Royal Women as Represented in Sculpture during the Old Kingdom Part II: Uninscribed Sculpture. In Christiane Zielger (ed), L'art de l'Ancien Empire Égyptien. 159-186. Paris: Musee du Louvre.

.1996. The Louvre Sphinx and Royal Sculpture from the Reign of Amenemhat II. Mainz am Rhein: Philipp von Zabern .

.1998. Royal Women as Represented in Sculpture during the Old Kingdom. In Nicolas Grimal (ed), Les critères de datation stylistiques à l'ancien empire, 159-186. Le Caire: Institut français d'archéologie orientale.

. 1999. Royal Women as Represented in Sculpture during the Old Kingdom. Part II: Uninscribed Sculptures. In Christiane Ziegler and Nadine Palayret (eds), L'art de l'Ancien Empire égyptien: actes du colloque organisé au musée du Louvre par le Service culturel les 3 et 4 avril 1998, 99-147. Paris: Documentation française.

. Thoughts on the sculpture of Sesostris I and Amenemhat II inspired by the Meket-re Study Day. In Gianluca Miniaci and Wolfram. Grajetzki (eds), The world of Middle Kingdom Egypt (2000-1550 BC): contributions on archaeology, art, religion and other written sources. Volume I, 81-83. London: Golden House Publications.

Fay, B. Freed, R. Schelper, T. and Seyfried, F. 2015. Neferusobek Project: part I. In Gianluca Miniaci and Wolfram Grajetzki (eds), The World of Middle Kingdom Egypt (2000-1550 BC): Contributions on Archaeology, Art, Religion and Other Written Sources. Volume I, 89-91. London: Golden House Publications.

Fechheimer, H.1923. Die Plastik der Ägypter. Berlin: Bruno Cassirer.

Feiman, G. and Marcus, J. (eds). 1998. Archaic States. Santa Fe: School of American Research Press.

Fischer, H. 1996. Varia nova. Egyptian Studies 3. New York: The Metropolitan Museum of Art.

Forbes, D. 1998. Sidebar: Another Sobekneferu? KMT 9, 55.

Freed, R. 1984. The Development of Middle Kingdom Egyptian Relief Sculptural Schools of Late Dynasty XI with an Appendix on the Trends of Early Dynasty XII. Ph.D. diss. New York Universit, New York. . 1996. Stela Workshops of Early Dynasty 12. In Peter Der Manuelian (ed), Studies in Honor of William Kelly Simpson I, 297-336. Boston: Deptartment of Ancient Egyptian, Nubian and Near Eastern Art, Museum of Fine Arts. 
. 2002. Another Look at the Sculpture of Amenemhat III (Pl. XV-XX). RdE 53, 103-136.

2010. Sculpture of the Middle Kingdom. In Alan Lloyd (ed), A Companion to Ancient Egypt Vol. II. 882-912. Chichester; Malden: Blackwell Publishing LTD.

. 2014. Les portraits Royaux de Sésostris III. In Fleur Morfoisse and Guillemette Andreu-Lanoë (eds), Sésostris III: Pharaon de Légende, 34-42. Gand: Snoeck

Freed, R. and Josephson, J. 2009. A Middle Kingdom Masterwork in Boston: MFA 2002.69. In David P. Silverman, William Kelly Simpson, Josef Wegner (eds), Archaism and innovation: Studies in the culture of Middle Kingdom Egypt, 1-15. New Haven: Department of Near Eastern Languages and Civilizations, Yale University; Philadelphia: University of Pennsylvania Museum of Archaeology and Anthropology.

Gabolde, M. 1998. D'Akhenaton à Toutânkhamon. Collection de l'Institut d'Archéologie et d'Histoire de l'Antiquité 3. Lyon: Université Lumière-Lyon 2 .

. Akhenaton: du Mystère à la Lumière. Découvertes Gallimard 478. Paris: Gallimard.

Galán, M. Bryan, B. and Dorman, P. (eds). 2014. Creativity and Innovation in the Reign of Hatshepsut: Papers from the Theban Workshop 2010. Studies in Ancient Oriental Civilization 69, Occasional proceedings of the Theban Workshop. Chicago: Oriental Institute.

Gale, N. and Stos-Gale, Z. 1981. Egyptian Silver. JEA 67, 103-115.

Gardiner, A. 1927. Egyptian Grammar: Being an Introduction to the Study of Hieroglyphs. Oxford: Clarendon Press.

1961. Egypt of the Pharaohs: An Introduction. Oxford: Oxford University Press.

Gardiner, A. and Peet C. 1952. The Inscriptions of Sinai Part I: Introduction and Plates, $2^{\text {nd }}$ edn. Memoir of the Egypt Exploration Society 36. London: Oxford University Press.

. 1955. The Inscriptions of Sinai Part II. Edited and completed by Jaroslav Černý. Memoir of the Egypt Exploration Society 45. London: Oxford University Press.

Gee, J. 2004. Overlooked Evidence for Sesostris III's Foreign Policy. JARCE 41, 61 76. 
Godley, A. 1920. Herodotus. Volumes I-IV. Translated by Godley. Loeb classical library (Herodotus). London: Heinemann Putnam's Sons.

Goedicke, H. 1962. Zur Chronologie der sogenannten "Ersten Zwischenzeit" ZDMG $112,239-254$.

Gero, J. and Conkey, M. (eds). 1991. Engendering Archaeology: Women in Prehistory. Oxford, Cambridge: Basil Blackwell Ltd.

Giddy, L. 2015. Memphis. In Adela Oppenheim, Dorothea Arnold, Dieter Arnold, and Kei Yamamoto (eds), Ancient Egypt Transformed: The Middle Kingdom, 322-323. New Haven; London: Yale University Press.

Grajetzki, W. 2001. Two Treasures of the Late Middle Kingdom. Oxford: Archaeopresss.

. 2002. Zwei Pyramiden der 13. Dynastie bei Mazghuna und die ungeklärte Frage des Bestattungsortes von Amenemhet IV. und Sobeknofru. Sokar 5, 24-27. 2003. Burial Customs in Ancient Egypt: Life and Death for Reach and Poor, around 1800bc. London: Golden House Publications. . 2004a. Das Grab der Königstochter Neferuptah bei Hawara. Sokar 9, 4953.

. 2004b. Harageh, an Egyptian Burial Ground for the Rich, around 1800BC. London: Golden House Publications.

. 2005a. Ancient Egyptian Queens: A Hieroglyphic Dictionary. London: Golden House Publications.

. 2005b. The Coffin of the "King's Daughter" Neferuptah and the Sarcophagus of the "Great King's Wife" Hatshepsut. GM 205, 55-65.

. 2005c. Neues zum Sarg der Neferuptah. Sokar 10, 50-51.

. 2006. The Middle Kingdom of Ancient Egypt: History, Archaeology and Society. London: Gerald Duckworth \& Co.

. 2009. Women and Writing in the Middle Kingdom: Louvre C 187. RdE 60, 209-214.

. 2013a. Late Middle Kingdom. In Willeke Wendrich (ed), UCLA

Encyclopedia of Egyptology. Los Angeles.

http://digital2.library.ucla.edu/viewItem.do?ark=21198/zz002hcnh5. 
. 2013b. Setting a State Anew: The Central Administration from the End of the Old Kingdom to the End of the Middle Kingdom. In Juan MorenoGarcía (ed), Ancient Egyptian Administration. Handbook of Oriental Studies section 1: The Near and Middle East 104, 215-258. Leiden; Boston: Brill.

.2014a. Tomb Treasures of the Late Middle Kingdom: The Archaeology of Female Burials. Pennsylvania: University of Pennsylvania Press.

. 2014b. La Place des Reines et des Princesses. In Fleur Morfoisse and Guillemette Andreu-Lanoë (eds), Sésostris III: Pharaon de Légende, 48-57. Gand: Snoeck.

. 2017. The Two Burials of Neferuptah and Other Second Burials for Royal Women. CCdE 22, 33-42.

Graves-Brown, C. (ed) 2008. Sex and Gender in Ancient Egypt: Don your Wig for a Joyful Hour. Swansea: Classical Press of Wales.

Green, L. 1996. The Royal Women of Amarna: Who was Who. In Dorothea Arnold The Royal Women of Amarna: Images of Beauty from Ancient Egypt, 7-16. New York: The Metropolitan Museum of Art.

Gretchen, R. and Nicole, M. 2000. The State of Gender Studies in Political Science. ANNALS, AAPSS 571, 121-134.

Griffith, F. 1898. The Petrie Papyri. Hieratic Papyri from Kahun and Gurob (Principally of the Middle Kingdom), Volumes I-II. London: Bernard Quaritch.

Grimal, N. 1992. A History of Ancient Egypt. Translated by Ian Shaw. Oxford: Blackwell.

Guégan, I. 2015. Âhhotep, Mère d'Âhmosis. Matériaux pour l'Étude d'une Mère de Roi. Master Archéologie des Mondes Anciens, Université de Strasbourg.

Güterbock, H. 1956a. The Deeds of Suppiluliuma as Told by His Son, Mursili II. JSC 10 (2), 41-68.

Güterbock, H. 1956b. The Deeds of Suppiluliuma as Told by His Son, Mursili II (Continued). JSC 10 (3), 75-98.

Harris, J. 1973. Neferneferuaten. GM 4, 15-17. . Neferneferuaten Regnans. $A O 35,5-13$.

Hartwig, M. 2011. An Examination of Art Historical Method and Theory: A Case Study. In Alexandra Verbovsek, Burkhard Backes, and Catherine Jones (eds), Methodik und Didaktik in der Ägyptologie: Herausforderungen eines kulturwissenschaftlichen Paradigmenwechsels in den Altertumswissenschaften, 313-326. München: Wilhelm Fink. 
Habachi, L. 1954. Habachi - Khatâ'na-Qantir Importance. ASAE 52, 443-562.

. 1978. The So-called Hyksos Monuments Reconsidered: Apropos of the Discovery of a Dyad of Sphinxes. SAK 6, 79-92. . 1983. The Tomb of Princess Nebt of the VIIIth Dynasty Discovered at Qift. SAK 10, 205-213.

. 2001. Tell el-Dab'a I: Tell el-Dab'a and Qantir. The Site and its Connection with Avaris and Piramesse. In Eva-Maria Engel, Peter Jánosi, and Christa Mlinar (eds), Untersuchungen der Zweigstelle Kairo des Österreichischen Archäologischen Institutes 2; Österreichische Akademie der Wissenschaften, Denkschriften der Gesamtakademie 23. Wien: Österreichischen Akademie der Wissenschaften.

Hanning, R. 1995. Großes Handwörterbuch Ägyptisch - Deutsch: Die Sprache der Pharaonen (2800-950 v. Chr.). Hannig-Lexica 1. Kulturgeschichte der antiken Welt 64. Mainz: Philipp von Zabern.

.2006. Ägyptisches Wörterbuch II: Mittleres Reich und Zweite Zwischenzeit. Hannig-Lexica 5. Kulturgeschichte der antiken Welt Bd 112. Mainz: Philipp von Zabern.

Hardwick, T. and Riggs C. 2010. The King as a Falcon: A 'Lost' Statue of Thutmose III Rediscovered and Reunited. MDAIK 66, 107-119.

Hasenmueller, C. 1978. Panofsky, Iconography, and Semiotics. JAAC 36 (3), 289301.

Hayes, W. 1946. Royal Portraits of the Twelfth Dynasty. BMMA 4, 119-124.

1953. Notes on the Government of Egypt in the Late Middle Kingdom. JNES 12 (1), 31-39.

.1973. Egypt: from the Death of Ammenemes III to Seqenenre II. In I. E. S., Edwards, C. J. Gadd, N. G. L. Hammond, and E. Sollberger (eds), The Cambridge Ancient History. Volume II, Part 1: The Middle East and the Aegean region, c. 1800-1380 B.C., 42-76. Cambridge: Cambridge University Press.

1978. The Scepter of Egypt: A Background for the Study of the Egyptian Antiquities in The Metropolitan Museum of Art, From the Earliest Times to the End of the Middle Kingdom. New York: The Metropolitan Museum of Art.

Hays-Gilpin, K. and Whitley, D. (eds). 1998. Reader in Gender Archaeology. London; New York: Routledge. 
Hill, J. 2016. Categories of Control: Development of Cylinder Seal Glyptic within the Context of Egyptian State Formation. In Gwenola Graff and Alejandro Jiménez Serrano (eds), Préhistoires de l'Écriture: Iconographie, Pratiques Graphiques et Émergence de l'Écrit dans l'Égypte Prédynastique, 113-124. Aix-en-Provence: Presses Universitaires de Provence.

Hirsch, E. 2004. Kultpolitik und Tempelbauprogramme der 12. Dynastie: Untersuchungen zu den Göttertempeln im Alten Ägypten. Berlin: Achet Verlag.

Hoch, J. 1997. Middle Egyptian Grammar. The Society for the Study of Egyptian Antiquities: studies 15. Mississauga: Benben

Hornung, E. 1996. Conceptions of God in Ancient Egypt: The One and the Many. Translated by John Baines. Ithaca: Cornell University Press.

Houlihan, P. 1986. The Birds of Ancient Egypt. Cairo: The American University in Cairo Press.

Hussein, K. 1938. L'âge d'or de l'Égypte Ancienne et l'Ombre de la Reine SebekNeferoura: Première Partie. $R C 1$ (5), 379-398.

Ilin-Tomich, A. 2011. A Twelfth Dynasty Stela Workshop Possibily from Saqqara. JEA 97, 117-126.

Iskander, Z. 1965. The Pottery Found in the Tomb of Neferwptah and Its Significance. In Frederick R. Matson (ed), Ceramics and Man. Viking Fund Publications in Anthropology 41, 178-186. Chicago: Aldine Publishing Co.

Johnson, S. 1990. The Cobra Goddess of Ancient Egypt: Predynastic, Early Dynastic and Old Kingdom Periods. Studies in Egyptology. London; New York: Kegan Paul International.

Johnson, J. 1996. The Legal Status of Women in Ancient Egypt. In Anne K. Capel and Glenn E. Markoe (eds), Mistress of the House, Mistress of Heaven: women in ancient Egypt, 175-186. New York: Hudson Hills Press, in association with Cincinnati Art Museum.

1999. Speculations on Middle Kingdom Marriage. In Anthony Leahy (ed), Studies on Ancient Egypt in Honour of H.S. Smith, 13. 169-172. London: Egypt Exploration Society.

Johnson, W. 2015. An Amarna Royal Head at Hanover's Museum August Kestner: Evidence for King Ankhkheperure Neferneferuaten. KMT 26 (3), 22-29.

Jones, D. 2000. An Index of Ancient Egyptian Titles, Epithets and Phrases of the Old Kingdom, Volumes I-II. BAR International Series 866 (1-2). Oxford: Archaeopress. 
Jordan, P. 1998. Riddles of the Sphinx. Photographs by John Ross. Stroud: Sutton Publishing.

Josephson, J. 1992. A Variant Type of the Uraeus in the Late Period. JARCE 29, 123-130.

Josephson, J. and Freed, R. 2007. The Status of the Queen in Dynasty XII. BES 17, 135-143.

Kaiser, W. (ed). 1967. Ägyptisches Museum Berlin: östlicher Stülerbau am Schloss Charlottenburg. Staatliche Museen Preussischer Kulturbesitz. Berlin: Staatliche Museen Berlin. .1986. Zum Siegel mit frühen Königsnamen von Umm-el-Qaab. MDAIK 43, 115-119.

Kamrin, J. 2015. Middle Egypt. In Adela Oppenheim, Dorothea Arnold, Dieter Arnold, and Kei Yamamoto (eds), Ancient Egypt Transformed: The Middle Kingdom, 319. New Haven, London: Yale University Press.

Kawai, N. 2005. Studies in the Reign of Tutankhamun. Ph.D. diss. Johns Hopkins University.

Kees H. 1962. Ein Handelsplatz des Mittleren Reiches im Nordostdelta. MDAIK 18, 1-13.

Keller, C. 2005. The Joint Reign of Hatshepsut and Thutmose III. In Catharine Roehrig, Renée Dreyfus, and Cathleen A. Keller (eds), Hatshepsut: From Queen to Pharaoh, 96-98. New York; New Haven: Metropolitan Museum of Art; Yale University Press.

Kemp, B. 2012. The City of Akhenaten and Nefertiti: Amarna and its People. London: Thames \& Hudson Ltd.

Kirwan, L. 2002. A Classification and Algorithm for Treatment of Breast Ptosis. ASJ, 355-363.

Krauss, R. 1978. Das Ende der Amarnazeit: Beiträge zur Geschichte und Chronologie des Neuen Reiches. Hildesheimer Ägyptologische Beiträge 7. Hildesheim: Gerstenberg.

Krejčí, J. Kytnarová, K. and Odler, M. 2015. Archaeological Excavation of the Mastaba of Queen Khentkaus III (tomb AC 30) in Abusir. PES 15, 28-42

Krzyżanowski, L. (ed). 1980. The Temple of Queen Hatshepsut. Volume II: Results of the Investigations and Conservation Works of the Polish-Egyptian Archaeological Mission 1972-1973. Warsaw: PKZ. 
.1985. The Temple of Queen Hatshepsut. Volume III: Results of

Investigations and Conservation Works of the Polish-Egyptian

Archaeological and Preservation Mission Deir el-Bahari. Warszawa: PKZ.

Krzyżanowski, L. and Mirosław, O. (eds). 1991. The Temple of Queen Hatshepsut.

Volume IV: The Report of the Polish-Egyptian Archaeological and

Preservation Mission Deir el-Bahari 1980-1988. Reports of the research-

conservation missions of PKZ 14. Warsaw: Ateliers for Conservation of

Cultural Property.

Lacau, P. and Chevrier, H.1956-1959. Une chapelle de Sésostris Ier a Karnak. 1-2. Cairo: l'Institut Français d'Archéologie Orientale.

Laboury, D. 2003. Le Portrait Royal sous Séostris III et Amenemhat III: un Défi pour les Historiens de l'Art Égyptien. EAO 30, 55-64.

. 2014. How and why did Hatshepsut invent the image of her royal power? In José Galán, Betsy Bryan, and Peter Dorman (eds), Creativity and innovation in the reign of Hatshepsut: papers from the Theban Workshop 2010, 49-91. Studies in Ancient Oriental Civilization 69, Occasional proceedings of the Theban Workshop. Chicago: Oriental Institute.

. 2016-2017. Senwosret III and the Issue of Portraiture in Ancient Egyptian Art. CRIPEL 31, 71-84.

Leclant, J. and Labrousse, A. 1998. La Nécropole des Reines de Pépy Ier à Saqqâra (1988-1998) (Information). CRAIBL 142 (2), 481-491.

Legrain, G. 1896. Inventaire Méthodique de la Collections d'Antiquités Egyptiennes Conservée au Cabinet des Antiques et Médailles. Paris: handwritten inventory.

. 1903. Second Rapport sur les Travaux Exécutés à Karnk du 31 Octobre 1901 au 15 Mai 1902. ASAE 4, 1-29.

Lehner, M. 1997. The Complete Pyramids. London: Thames \& Hudson.

Leitz, C. (ed). 2002-2003. Lexikon der Ägyptischen Götter und Götterbezeichnungen, Volumes I-VIII. Orientalia Lovaniensia Analecta. Leuven: Peeters.

Leprohon, R. 1996. The Programmatic Use of the Royal Titulary in the Twelfth Dynasty. JARCE 33, 165-171.

2013. The Great Name: Ancient Egyptian Royal Titulary. In Denise M.

Doxey (ed), Writings from the Ancient World 33. Atlanta: Society of Biblical Literature. 
Lepsius, C. 1849-1859. Denkmaeler aus Aegypten und Aethiopien, Volumes I-XII.

Nach den Zeichnungen der von Seiner Majestät dem Koenige von Preussen, Friedrich Wilhelm IV, nach diesen Ländern Gesendeten und in den Jahren 1842-1845 Ausgeführten Wissenschaftlichen Expedition. Berlin: Nicolaische Buchhandlung.

. 1853. Über die Zwölfte Aegyptische Königsdynastie. APAW 1852, 425-455.

Lesko, B. 1978. The Remarkable Women of Ancient Egypt. Berkeley: B.C. Scribe. (ed).1989. Women's Earliest Records: From Ancient Egypt and Western Asia. Atlanta: Scholars Press.

. 1991. Women's Monumental Mark on Ancient Egypt. BA 54, 4-15.

Lloyd, A. 1975-1988. Herodotus, Book II. Études Préliminaires aux Religions Orientales dans l'Empire Romain 43. Leiden: E. J. Brill

Lohwasser, A. 2001. Queenship in Kush: Status, Role and Ideology of Royal Women. JARCE 38, 61-76.

Lorand, D. 2011. La Statuaire Royale de Sésostris Ier: Art et Politique au Début de la Dynastie. BSFE 180, 23-43.

2012. The 'Four Schools of Art' of Senwosret I, Is It Time for a Revision? In Katalin Kothay (ed) Art and Society: Ancient and Modern Contexts of Egyptian Art, Proceedings of the International Conference held at the Museum of Fine Arts, Budapest, 12-15 May 2010, 47-56. Budapest: Museum of fine Arts.

Lovenduski, J. 1981. Toward the Emasculation of Political Science: The Impact on Feminism. In Dale Spender (ed), Men's Studies Modified: The Impact of Feminism on the Academic Disciplines. 83-98. Oxford; New York; Toronto; Sydney; Paris; Frankfurt: Pergamon Press.

2005. Feminizing Politics. Oxford; Malden: Polity Press.

Lurson, B. 2016. A Perfect King: Aspects of Ancient Egyptian Royal Ideology of the New Kingdom. Paris: S.N. Librairie Orientaliste Paul Geuthner S.A.

Lythgoe, A. 1907. The Egyptian Expedition II. BMMA 2, 113-117. . 1909. The Egyptian Expedition II. BMMA 4, 119-123.

.1915a. Excavations at the South Pyramid of Lisht in 1914: Report from the Metropolitan Museum, New York. AncEg (4), 145-153.

. 1915b. The Egyptian Expedition II: Excavations at the South Pyramid of Lisht in 1914: Report from the Metropolitan Museum, New York. BMMA 10, $5-22$. 
Mace, A. 1914. The Egyptian Expedition: Excavations at the North Pyramid of Lisht. BMMA 9 (10), 207-222.

. 1921. The Egyptian Expedition, 1920-1921: I. Excavations at List. BMMA 16 (November), 5-19.

Mace, A. and Winlock, H. 1916. The Tomb of Senebtisi at Lisht, Publications of the Metropolitan Museum of Art Egyptian Expedition, 1. New York: The Metropolitan Museum of Art.

Maragioglio, V. and Rinaldi, C. 1967. L'Architettura delle Piramidi Menfite/ 6, La Grande Fossa di Zauiet el-Aryan, la Piramide di Micerino, il Mastabat Faraun, la Tomba di Khentkaus. Turin: Officine Grafiche Canessa.

.1973. Note complementari sulla tomba di Neferu-Ptah. OrNS 42, 357-369

Mariette, A. 1864. La Table de Saqqarah. $R A r$ 10, 169-186.

Maspero, G. 1890. Monuments Égyptiens du Musée de Marseille. RT 13, 113-126.

Matzker, I. 1986. Die letzten Könige der 12. Dynastie (Ägyptologie). Europäische Hochschulschriften, Reihe 3: Geschichte und ihr Hilfswissenschaften 297. Frankfurt am Main: Peter Lang.

McCarthy, H. 2008. Rules of Decorum and Expression of Gender Fluidity in Tawosret's Tomb. In Carolyn Graves-Brown (ed). Sex and Gender in Ancient Egypt: Don your Wig for a Joyful Hour. 83-114. Swansea: Classical Press of Wales.

McClain, B and Johnson, R. 2013. A Fragment from the Reign of Tausret Reused at Medinet Habu. JARCE 49, 177-186.

McCormack, L. 2008. Dynasty XIII Kingship in Ancient Egypt: A Study of Political Power and Administration through an Investigation of the Toyal Tombs of the Late Middle Kingdom. Ph.D. diss. University of Pennsylvania.

Melville, S.1997. Neo-Assyrian Royal Women and Male Identity: Status as a Social Tool. JAOS 124, 37-55.

Meskell, L. 1999. Archaeologies of Social Life: Age, Sex, Class et cetera in Ancient Egypt. Oxford: Blackwell Publishing.

Millard, A. 1976. The Position of Women in the Family and in Society in Ancient Egypt, with Special Reference to the Middle Kingdom. Ph.D. diss. University College London.

Miniaci, G. \& Grajetzki, W. (eds). 2015. The World of Middle Kingdom Egypt (2000-1550 BC): Contributions on Archaeology, Art, Religion and Other Written Sources. Volume I. London: Golden House Publications. 
2016. (eds). The World of Middle Kingdom Egypt (2000-1550 BC):

Contributions on Archaeology, Art, Religion and Other Written Sources.

Volume II. London: Golden House Publications.

Minas-Nerpel, M. 2015. Arsinoe II. und Berenike II: Frühptolemäische Königinnen im Spannungsfeld zweier Kulturen. In Herausgegeben von Mamdouh Eldamaty, Friedhelm Hoffmann und Martina Minas-Nerpel (eds), Ägyptische Königinnen vom Neuen Reich bis in die islamische Zeit, 87-114. Vaterstetten: Patrick Bose.

Mokhtar, M. 1983. Ihnâsya el-Medina (Herakleopolis Magna): Its Importance and its Role in Pharaonic History. Bibliothèque d'Étude 40. Cairo: Imprimerie de l'Institut français d'archéologie orientale du Caire.

Moore, T. 2011. Petrie's excavation. In Richard Wilkinson (ed), The Temple of Tausret: The University of Arizona Egyptian Expedition Tausret Temple Project, 2004-2011, 6-10. Arizona: University of Arizona Egyptian Expedition.

Moran, W. The Amarna Letters. Baltimore; London: Johns Hopkins University Press.

Morfoisse, F. and Andreu-Lanoë, G. (eds). 2014. Sésostris III: Pharaon de Légende. Gand: Snoeck.

Morris, E. 2010. The Pharaoh and Pharaonic Office. In Alan Lloyd (ed.) A

Companion to Ancient Egypt Volume I. Malden; Oxford; Chichester: WileyBlackwell Publishing.

Moser, S. 2007. On Disciplinary Culture: Archaeology as Fieldwork and its Gendered Associations. JAMT 14, 235-263.

Müller, M. 2015. Iconography and Symbolism. In Melinda Hartwig (ed), A Companion to Ancient Egyptian Art, 78-97. Chichester: Wiley Blackwell.

Murnane, W. 1977. Ancient Egyptian Coregencies. Studies in Ancient Oriental Civilization 40. Chicago: The Oriental Institute of the University of Chicago. . 1997. Three Kingdoms and Thirty-Four Dynasties. In David P. Silverman (ed), Ancient Egypt 20-39. London: Piatkus.

Murray, M. 1908. Index of Names and Titles of the Old Kingdom. British School of Archaeology in Egypt, Studies 1. London: British School of Archaeology; Bernard Quaritch.

Naville, É. 1894. The Temple of Deir el Bahari: Its Plan, its Founders, and its First Explorers. Introductory Memoir. Egypt Exploration Fund 12. London: Egypt Exploration Fund. 
. 1895. The Excavations at Deir el Bahari during the Winter, 189495. Archaeological Report 1894-1895, 33-37. Egypt Exploration Fund 13.

London: Egypt Exploration Fund.

. 1896. Excavations at Deir el Bahari. Archaeological Report 1895-1896, 1-6.

Egypt Exploration Fund 14. London: Egypt Exploration Fund.

. 1907a. Excavations at Deir el Bahari. Archaeological Report 1906-1907, 1-

7. Egypt Exploration Fund 16. London: Egypt Exploration Fund.

. 1907b. The XIth Dynasty Temple at Deir el-Bahari. Part I. Egypt

Exploration Fund 28. London: Egypt Exploration Fund.

. 1910. The XIth Dynasty Temple at Deir el-Bahari. Part II. Egypt

Exploration Fund 28. London: Egypt Exploration Fund.

. 1913. The XIth Dynasty Temple at Deir el-Bahari. Part III. Egypt

Exploration Fund 28. London: Egypt Exploration Fund.

Naville, É. and Hall, H. 1904. Excavations at Deir el Bahari. Archaeological

Report 1903-1904, 1-12. Egypt Exploration Fund 19. London: Egypt

Exploration Fund.

1905. Excavations at Deir el Bahari. Archaeological Report 1904-1905, 1-

10. Egypt Exploration Fund 27. London: Egypt Exploration Fund.

. 1906. Excavations at Deir el Bahari. Archaeological Report 1905-1906, 1-

7. Egypt Exploration Fund 29. London: Egypt Exploration Fund.

Naville, E. Tylor, J. and Griffith, F. 1894. Ahnas el Medineh (Heracleopolis

Magna): With Chapters on Mendes, the Nome of Thoth, and Leontopolis /

The Tomb of Paheri at El Kab. Memoir of the Egypt Exploration Fund 11.

London: Egypt Exploration Fund.

Nelson, S. 1997. Gender in Archaeology: Analyzing Power and Prestige. Walnut

Creek: AltaMira Press, A Division of Sage Publications Inc.

Newberry, P. 1893. The Archaeological Survey of Egypt: Mr. Newberry's Work, 1892-93. Archaeological Report 1892-1893, 9-15.

1903. Extracts from my Notebooks (VII). PSBA 25, 357-362.

. 1943a. Queen Nictocris of the Sixth Dynasty. JEA 29, 51-54.

. 1943b. Co-regencies of Ammenemes III, IV and Sebknofru. JEA 29, 74-75.

Nikolic, I. 1989. Muzej Mimara. Zbirka umjetnina Ante I Witturd Topic. Zagreb: Muzej Mimara. 
Nilsson, M. 2010. The Crown of Arsinoë II: The Creation and Development of an Imagery of Authority. Ph.D. diss. University of Gothenburg, Göteborg.

Nunn, J. 1996. Ancient Egyptian Medicine. London: British Museum Press.

O'Connor, D. 1974. Political Systems and Archaeological Data in Egypt: 2600-1780 B.C. WorldArch 6, 15-38.

O’Conner, D. and Silverman, D. (eds). 1995. Ancient Egyptian Kingship. Probleme der Ägyptologie 9. Leiden: E.J. Brill.

Ogden, J. 2000. Metals. In Paul T. Nicholson, and Ian Shaw (eds), Ancient Egyptian Materials and Technology, 148-176. Cambridge: Cambridge University Press.

Oppenheim, A. 2015. Artists and Workshops: The Complexity of Creation. In Adela Oppenheim, Dorothea Arnold, Dieter Arnold, and Kei Yamamoto (eds), Ancient Egypt Transformed: The Middle Kingdom, 23-27. New Haven; London: Yale University Press.

Oppenheim, A. Arnold, Do. Arnold, Di. and Yamamoto, K. (eds). 2015. Ancient Egypt Transformed: The Middle Kingdom. New Haven, London: Yale University Press.

Panofsky, E. 1939. Studies in Iconology: Humanistic Themes in the Art of the Renaissance. Boulder: Westview Press.

Parker, R. 1950. The Calendars of Ancient Egypt. Studies in Ancient Oriental Civilization 26. Chicago: University of Chicago Press.

Partridge, R. 2002. Fighting Pharaohs: Weapons and Warfare in Ancient Egypt. Manchester: Peartree Publishing.

Patch, D. 2015. Garment of Senebtisi. In Adela Oppenheim, Dorothea Arnold, Dieter Arnold, and Kei Yamamoto (eds), Ancient Egypt Transformed: The Middle Kingdom, 239-240. New York: The Metropolitan Museum of Art.

Pätznick, J. 2017. Meret-Neith: In the Footsteps of the First Woman Pharaoh in History. In Tomorad Mladen and Joanna Popielska-Grzybowska (eds), Egypt 2015: Perspectives of Research: Proceedings of the Seventh European Conference of Egyptologists, 2nd-7th June 2015, Zagreb, Croatia, 289-306 Oxford: Archaeopress.

Pavlov, V. and Khodzhash, S. 1985. Egipetskaîa Plastika Malykh Form. Moskva: Iskusstvo.

Paxton, P. and Hughes, M. 2014. Women, Politics, and Power: A Global Perspective. Los Angeles: SAGE Publications. 
Payraudeau, F. 2015. Considérations sur Quelques Titres des Reines de l'Ancien Empire à l' Époque Ptolémaïque. In Rémi Legros (ed), Cinquante ans d'Éternité: Jubilé de la Mission Archéologique Française de Saqqâra. MAFS V, 209-225. Le Caire: Institut Français d'Archéologie Orientale.

Peden, A. 2001. The Graffiti of Pharaonic Egypt: Scope and Roles of Informal Writings (3100-332 B.C.) Probleme der Ägyptologie 17. Leiden; Boston: Brill.

Pérez Die, C. 2009. Excavaciones de la Misión Arqueológica Española en Heracleópolis Magna: Ehnasya el Medina. In Carmen Pérez Die and Wafaa al- Sadiik (eds), 120 Años de Arqueología Española en Egipto, 54-65, 314321. Madrid: Sociedad Estatal de Conmemoraciones Culturales; Ministerio de Cultura.

. 2015. Ehnasya el Medina (Herakleopolis Magna): Excavations 2004-2007 at the Necropolis of the First Intermediate Period/Early Middle Kingdom. In Panagiotis Kousoulis and Nikolaos Lazaridis (eds), Proceedings of the Tenth International Congress of Egyptologists: University of the Aegean, Rhodes. 22-29 May 2008 1, 393-409. Leuven: Peeters

2016. The Herakleopolis Magna Project (Ehnasya el Medina): Summary and Results of work 2000-2015. Trabajos de Egiptología - Papers on Ancient Egypt 7, 131-160.

. 2017. The Herakleopolis Magna Project: Seasons 2012-2015. In Gloria Rosati and Maria Cristina Guidotti (eds), Proceedings of the XI International Congress of Egyptologists, Florence Egyptian Museum, Florence, 23-30 August 2015, 480-484. Oxford: Archeopress.

Petrie, W. 1889a. Hawara, Biahmu and Arsinoe. London: Field \& Tuer. . 1889b. Historical Scarabs: A Series of Drawings from the Principal Collections Arranged Chronologically. London: Nutt.

1890. Kahun, Gurob and Hawara. London: Kegan Paul, Trench, Trübner, and Co.

.1891. Illahun, Kahun and Gurob: 1889-90. London: William Clowes and Sons.

. 1894. A History of Egypt: From the Earliest Times to the XVIth Dynasty, Volume I. London : Methuen.

. 1900-1901. The Royal Tombs of the First Dynasty, Volumes I-III. Memoir of the Egypt Exploration Fund 18; 21. London: Egypt Exploration Fund; Kegan Paul, Trench, Trübner \& Co.

1901. Diospolis Parva: The Cemeteries of Abadiyeh and Hu 1898-99. With chapters by A. C. Mace. London: Egypt Exploration Fund. 
. 1905. Roman Ehnasya (Herakleopolis Magna). London: The Egypt Exploration Fund.

1905. Ehnasya: 1904. Memoir of the Egypt Exploration Fund 26. London: Egypt Exploration Fund.

Petrie, W. Brunton, G. and Murray, M. 1923. Lahun II. London: British School of Archaeology in Egyptian, Bernard Quaritch.

Phelps, D. and Creasman, P. 2013. The Tausret Temple Project. In Pearce Creasman (ed), Archaeological Research in the Valley of the Kings and Ancient Thebes. Papers Presented in Honor of Richard H. Wilkinson. University of Arizona, Egyptian Egypedition Wilkinson Egyptology Series Volume I. Tucson: The University of Arizona Egyptian Expedition.

Pignattari, S. 2008. Due Donne per il Trono d'Egitto: Neferuptah e Sobekneferu. Piccola Biblioteca di Egittologia 10. Imola: La Mandragor.

Pittman, H. 1988. Seal Impressions. In Ira Spar (ed), Cuniform Texts in the Metropolitan Museum of Art I: Tablets, Cones, and Bricks of the Third and Second Millennia B.C., 167-193. New York: The Metropolitan Museum of Art.

Polz, V. 1995. Die Bildnisse Sesostris' III. und Amenemhets III: Bemerkungen zur Königlichen Rundplastik der Späten 12. Dynastie. MDAIK 51, 227-254.

Putter, T. 1993. Les Inscriptions de Semna et Koumma (Nubie): Niveaux de Crues Exceptionnelles ou d'un lac de Retenue Artificiel du Moyen Empire? SAK 20, 255-288.

Putter, T. and Karlshausen, C. 1992. Les Pierres Utilisees dans la Sculpture et l'Architecture de l'Egypte Pharaonique. Brussels: Connaissanec de l'Egypte Ancienne.

Quirke, S. 1990. The Administration of Egypt in the Late Middle Kingdom: The Hieratic Documents. New Malden; Surry: SIA Publishing. . 2007. Women of Lahun (Egypt 1800 BC). In Sue Hamilton, Ruth D. Whitehouse, and Katherine I. Wright (eds), Archaeology and Women: Ancient and Modern Issues, 246-262. Walnut Creek, CA: Left Coast Press.

. 2010. Ways to Measure Thirteenth Dynasty Royal Power from Inscribed Objects. In Marcel Marée (ed), The Second Intermediate Period (ThirteenthSeventeenth Dynasties): Current Research, Future Prospects, 55-68. Leuven: Peeters.

Redford, D. B. 1986. Pharaonic King-lists, Annals and Day-books: A Contribution to the Study of the Egyptian Sense of History. Mississauga: Benben Publications. 
Reeves, N. and Wilkinson, R. 1996. The Complete Valley of the Kings: Tombs and Treasures of Egypt's Greatest Pharaohs. London: Thames and Hudson.

Ritter, G. and Mellow, N. 2000. The State of Gender Students in Political Science. Annals Am. Acad. Pol. \& Soc. Sci. 571, 121-134.

Roberts, A. 1995. Hathor Rising: The Serpent Power of Ancient Egypt. Totnes: Northgate.

Robins, G. 1982. Ahhotpe I, II and III. GM 56, 71-77

. 1999a. Hair and the Construction of Identity in Ancient Egypt. JARCE 36, 55-69.

. 1999b. The Names of Hatshepsut as King. JEA 85 (3), 103-112.

. 2002a. Women in Ancient Egypt. London: British Museum Press.

. 2002b. Problems Concerning Queens and Queenship in Eighteenth Dynasty Egypt. NIN 3, 25-31.

. 2001. Egyptian Statues. Shire Egyptology 26. Princes Risborough: Shire Publications.

. 2008. Ideal Beauty and Divine Attributes. In Christiane Ziegler

(ed), Queens of Egypt: from Hetepheres to Cleopatra, 118-130. Monaco:

Grimaldi Forum.

Roehrig, C. 1996. Woman's Work: Some Occupations of Nonroyal Women as Depicted in Ancient Egyptian Art. In Anne Capel, and Glenn Markoe (eds), Mistress of the House, Mistress of Heaven: women in ancient Egypt, 13-24. New York: Hudson Hills Press, in association with Cincinnati Art Museum.

1999. Pair Statue of Queen Ankh-nes-meyre II and her Son Pepi II Seated. In Dorothea Arnold (ed), Egyptian Art in the Age of the Pyramids. New York: Metropolitan Museum of Art.

. 2012. Forgotten Treasures: Tausret as Seen in her Monuments. In Richard Wilkinson (ed), Tausret: Forgotten Queen and Pharaoh of Egypt, 48-66. Oxford: Oxford University Press.

Roehrig, C. Dreyfus, R. and Keller, C. (eds). 2005. Hatshepsut, from Queen to Pharaoh. New York: The Metropolitan Museum of Art.

Roth, A. 1999. The Ahhotep Coffins: The Archaeology of an Egyptological Reconstruction. In Emily Teeter and John A. Larson (eds), Gold of Praise: Studies on Ancient Egypt in Honor of Edward F. Wente, 361-377. Chicago: Oriental Institute of the University of Chicago. 
. 2005. Hatshepsut's Mortuary Temple at Deir el Bahri: Architecture as Political Statement. In Catharine Roehrig, Renée Dreyfus, and Cathleen A. Keller (eds), Hatshepsut: From Queen to Pharaoh, 147-151. New York; New Haven: Metropolitan Museum of Art; Yale University Press.

. 2006. Little Women: Gender and Hierarchic Proportion in Old Kingdom Mastaba Chapels. In Miroslav Bárta (ed), The Old Kingdom Art and Archaeology: Proceedings of the Conference held in Prague, May 31 - June 4, 2004, 281-296. Prague: Czech Institute of Egyptology.

Roth, S. 2001. Die Königsmutter des Alten Ägypten von der Frühzeit bis zum Ende der 12. Dynastie. Ägypten und Altes Testament 46. Wiesbaden:

Harrassowitz.

. 2002. Gebieterin aller Länder. Die Rolle der Königlichen Frauen in der Fiktiven und Realen Außenpolitik des Ägyptischen Neuen Reiches. Orbis Biblicus et Orientalis 185. Göttingen: Universitätsverlag; Vandenhoeck \& Ruprecht.

. 2009. Queen. In Elizabeth Frood, Willeke Wendrich (eds), UCLA Encyclopedia of Egyptology, Los Angeles. http://digital2.library.ucla.edu/viewItem.do?ark=21198/zz001nf7cg.

Russmann, E. 1989. Egyptian Sculpture: Cairo and Luxor. Photographs by David Finn. Austin: University of Texas Press.

. 2013. Eternal Egypt: Masterworks of Ancient Art from the British Museum. London: The British Museum Press.

. 2015. Art in Transition: The Rise of the Eighteenth Dynasty and the Emergence of the Thutmoside Style in Sculpture and Relief. In Catharine Roehrig, Renée Dreyfus, and Cathleen A. Keller (eds), Hatshepsut: From Queen to Pharaoh, 23-27. New York; New Haven: Metropolitan Museum of Art; Yale University Press.

Ryholt, K. 1997. The Political Situation in Egypt during the Second Intermediate Period c. 1800-1550 BC. CNI Publications 20. Copenhagen: Museum Tusculanum Press, University of Copenhagen. . 2000. The Late Old Kingdom in the Turin King-list and the Identity of Nitocris. ZAeS 127, 87-100. . 2004. The Turin King-list. AeUL 14, 135-155.

Sabbahy, L. 1982. The Development of the Titulary and Iconography of the Ancient Egyptian Queen from Dynasty one to early Dynasty Eighteen. Ph.D. diss. University of Toronto.

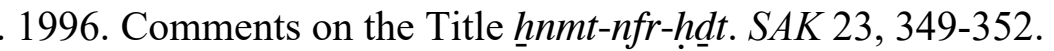


. 2003. The Female Family of Amenemhat II: A Review of the Evidence. In Nicolas Grimal, Amr Kamel, and Cynthia May-Sheikholeslami (eds), Hommages à Fayza Haikal, 239-244. Le Caire: Institut Français d'Archéologie Orientale.

Scalf, F. 2012. The Role of Birds within the Religious Landscape of Ancient Egypt. In Rozenn Bailleul-LeSuer (ed), Between Heaven and Earth: Birds in Ancient Egypt, 33-40. Chicago: The Oriental Institute.

Schaeffer, C. 1932. Les Fouilles de Minet-el-Beida et de Ras-Shamra Troiseme Champagne (Printemps 1931): Rapport Sommaire. Syria 13, 1-27.

Schmitz, B. 1978. Untersuchungen zu Zwei Königinnen der Frühen 18. Dynastie, Ahhotep und Ahmose. CdE 53 (106), 207-221.

Schneider, T. 2006. The Relative Chronology of the Middle Kingdom and the Hyksos period (Dyns. 12-17). In Erik Hornung, Rolf Krauss, and David Warburton (eds), Ancient Egyptian Chronology. 168-196. Leiden: Brill.

Schulz, R. 2015. Hatschepsut: von der Gottesgemahlin zum Pharao. In Mamdouh Eldamaty, Friedhelm Hoffmann, and Martina Minas-Nerpel (eds), Ägyptische Königinnen vom Neuen Reich bis in die Islamische Zeit: Beiträge zur Konferenz in der Kulturabteilung der Botschaft der Arabischen Republik Ägypten in Berlin am 19.01.2013, 7-24. Vaterstetten: Brose.

Seyfried, F. (ed). 2012. In the Light of Amarna: 100 Years of the Nefertiti Discovery. Berlin: Ägyptisches Museum Und Papyrussammlung, Staatliche Museen Zu Berlin

Shalomi-Hen, R. 2008: The Bearded Woman and the Queen. The Formation and Transformation of Female Divine Classifiers. In Carolyn Graves-Brown (ed), Sex and Gender in Ancient Egypt: Don your Wig for a JoyfulHhour. 179-190. Swansea: Classical Press of Wales.

Silverman, D. Simpson, W. and Wegner, J. (eds). 2009. Archaism and Innovation: Studies in the Culture of Middle Kingdom Egypt. New Haven, CT Philadelphia, PA: Department of New Eastern languages and civilizations, Yale University Press; University of Pennsylvania Museum of Archaeology and Anthropology.

Simpson, W. 1974. Polygamy in Egypt in the Middle Kingdom? JEA, 60. 100-105.

. 1956. The Single-dated Monuments of Sesostris I: An Aspect of the Institution of Coregency in the Twelfth Dynasty. JNES 15, 214-219.

. (ed) 2003. The Literature of Ancient Egypt: An Anthology of Stories, Instructions, Stelae, Autobiographies, and Poetry, $3^{\text {rd }}$ ed. New Haven; London: Yale University Press.

Smith, H. 1972. The Rock Inscriptions of Buhen. JEA 58, 43-82. 
. 1976. The Fortress of Buhen: The Inscriptions. Egypt Exploration Society, Excavation Memoir 48. London: Egypt Exploration Society.

Smith, M. 2017. Following Osiris: Perspectives on the Osirian Afterlife from Four Millennia. Oxford: Oxford University Press.

Spender, D. (ed). 1981. Men's Studies Modified: The Impact of Feminism on the Academic Disciplines. Athene Series: An International Collection of Feminist Books. Oxford: Pergamon Press.

Sørensen, M. 2000. Gender Archaeology. Cambridge: Polity Press.

Sourouzian, H. 2005. Features of Early Twelfth Dynasty Royal Sculptures. BEM 2, 103-124.

Squires, J.1999. Gender in Political Theory. Cambridge: Polity Press, Malden: Blackwell Publishers.

Steindorff, G. 1940. A Portrait-statue of Sesostris III. JWAG 3, 42-53.

Strouhal, E. and Klir, P. 2006. The Anthropological Examination of Two Queens from the Pyramid of Amenemhat III at Dahshur. In Miroslav Bárta, Filip Coppens, and Jaromír Krejčí (eds), Abusir and Saqqara in the Year 2005, 133-146. Prague: Czech Institute of Egyptology, Faculty of Arts, Charles University of Prague.

Strudwick, N. 2006. The Translation of Texts of the Old Kingdom. In Miroslav Bárta (ed), The Old Kingdom Art and Archaeology: Proceedings of the Conference held in Prague, May 31 - June 4, 2004, 335-341. Prague: Czech Institute of Egyptology, Faculty of Arts, Charles University in Prague.

Stunkel, I. 2006. The Relief Decoration of the Cult Chapels of Royal Women in the Pyramid Complex of Senusret III at Dahshur. In Miroslav Bárta, Filip Coppens, and Jaromír Krejčí (eds), Abusir and Saqqara in the year 2005, 147-166. Prague: Czech Institute of Egyptology, Faculty of Arts, Charles University of Prague.

. 2015. Royal Women: Ladies of the Two Lands. In Adela Oppenheim, Dorothea Arnold, Dieter Arnold, and Kei Yamamoto (eds), Ancient Egypt Transformed: The Middle Kingdom, 92-95. New Haven, London: Yale University Press.

. 2018. The Decoration of the North Chapel of Khenemetneferhedjet Weret I at Dahshur. Ph.D. diss. Rheinischen Friedrich-Wilhelms-Universität zu Bonn.

Sweeny, D. 2004. Forever Young? The Representations of Older and Ageing Women in Ancient Egyptian art. In JARCE 41, 61-76. 
Szpakowska, K. 2012. Hidden Voices: Unveiling Women in Ancient Egypt. In Sharon L. James, and Sheila Dillon (eds), A Companion to Women in the Ancient World, 25-38. Chichester: Wiley-Blackwell.

Tallet, P. 2005. Sésostris III et la Fin de la XIIe Dynastie. Les Grands Pharaons. Paris: Pygmalion.

Tassie, G. 2011. What your Hair Says about You: Changes in Hairstyles as an Indicator of State Formation Processes. In Renée F. Friedman and Peter N. Fiske (eds), Egypt at its Origins 3: Proceedings of the Third International Conference "Origin of the State: Predynastic and Early Dynastic Egypt", London, 27th July - 1st August 2008, 605-643. Leuven: Peeters.

Teeter, E. 2011. Religion and Ritual in Ancient Egypt. Cambridge: Cambridge University Press.

Tefnin, R.1979. La Statuaire d'Hatshepsout: Portrait Royal et Politique sous la 18 e Dynastie. Monumenta Aegyptiaca 4. Brussels: Fondation Égyptologique Reine Élisabeth.

Thornton, J. 2006. Elite Women in the Kingdom of Kongo: Historical Perspectives on Women's Political Power. JAH 47, 437-460.

Tomashevich, O. 1993. Uraeus, Neith and goddesses of Lower Egypt. In Ėleonora Kormysheva, (ed), Ancient Egypt and Kush: in Memoriam Mikhail A. Korostovtsev, 373-392. Moscow: Nauka.

Troy, L. 1979. Ahhotep - a Source Evaluation. GM 35, 81-91.

. 1986. Patterns of Queenship in Ancient Egyptian Myth and History. Uppsala: Acta Universitatis Upsaliensis.

. 2002. The Ancient Egyptian Queenship as an Icon of the State. NIN 3, 1-24.

.2003. She for Whom All That is Said is Done: The Ancient Egyptian Queen. In Sarah Milledge Nelson (ed) Ancient Queens: Archaeological Explorations. 91-114. California: AltaMira Press, 2003.

. 2008. The Queen as a Female Counterpart of the Pharaoh. In Christiane Ziegler (ed), Queens of Egypt: From Hetepheres to Cleopatra. Monaco: Grimaldi Forum and Paris: Somogy Art Publishers.

Tyldesley, J. 2006. Chronicle of the Queens of Egypt: From Early Dynastic Times to the Death of Cleopatra. London: Thames \& Hudson.

. 2012. Foremost of Women: The Female Pharaohs of Ancient Egypt. In Richard Wilkinson (ed) Tausret: Forgotten Queen and Pharaoh of Egypt. 524. Oxford: University Press.

Uphill, E. 1965-1966. The Nine Bows. JEOL 19, 393-420. 
2000. Pharaoh's Gateway to Eternity: The Hawara Labyrinth of King Amenemhat III. Studies in Egyptology. London; New York: Kegan Paul International.

Van de Mieroop, M. 2011. A History of Ancient Egypt. Blackwell history of the Ancient World. Chichester; Malden: Wiley-Blackwell.

Van Straten, R. 1994. An Introduction to Iconography. Translated by Patricia de Man. London: Psychology Press.

Vandenbeusch, M. Semat, A. and Maitland, M. 2013. Pharaoh: King of Ancient Egypt. Cleveland: Cleveland Museum of Art.

Vandersleyen, C. 1977. Une Stèle de l'an 18 d'Amosis à Hanovre. CdE 52 (104), 223-244. 1980. Les Deux Ahhotep. SAK 8, 237-241.

Vandier, J. 1958. Le Manuel Archeologie Egyptienne Volume III: Les Grandes Epoques: La Statuaire. Paris: Editions A. and J. Picard.

Valloggia, M. 1964. Remarques sur les Noms de la Reine Sébek-Ka-Rê NéferouSébek. RdE 16, 45-53. . 1969. Amenemhat IV et sa Sorégence avec Amenemhat III. RdE 21, 107133.

Verner, M. 1980. Excavations at Abusir: Season 1978/1979 - Preliminary eport. ZAeS 107, 158-169. . 1997. Further Thoughts on the Khentkaus Problem. DE 38, 109-117. . 1999. Khentkaus I, Khentkaus II and the Title mwt nśwt bity nśwt bity (or nśwt bity, mwt nśwt bity). GM 173, 215-218.

. 2001. Archaeological Remarks on the 4th and 5th Dynasty

Chronology. ArOr 69 (3), 363-418.

. 2002. The Pyramids: Their Archaeology and History. Translated from by Steven Rendall. London: Atlantic

. 2011. The "Khentkaus-problem" Reconsidered. In Miroslav Bárta, Filip Coppens, and Jaromír Krejčí (eds), Abusir and Saqqara in the Year 2010, 778-784. Prague: Czech Institute of Egyptology, Faculty of Arts, Charles University in Prague.

. 2015. The Miraculous Rise of the Fifth Dyansty - the Story of Papyrus Westcar and Historical Evidence. PES 15, 86-92. 
Verner, M. and Callender, G. 1997. Image and Reflection: Two Old Kingdom Queens named Khentkaus. KMT 8, 28-35.

Von Beckerath, J. 1962. Queen Twosre as Guardian of Siptah. JEA 48, 70-74.

1997. Chronologie des Pharaonischen Ägypten: die Zeitbestimmung der Ägyptischen Geschichte von der Vorzeit bis 332 v. Chr. Münchner Ägyptologische Studien 46; Münchener Universitätsschriften, Philosophische Faklutät. Mainz: Philipp von Zabern.

Waddell, W. (ed). 1948. Manetho. Translated by F. E. Robbins. Loeb classical library 350. London; Harvard: Heinemann; Harvard University Press.

Warburton, D. 2012. Architecture, Power, and Religion: Hatshepsut, Amun \& Karnak in Context. Beiträge zur Archäologie 7. Wien, Berlin: LIT.

Ward, C. 2000. Sacred and Secular: Ancient Egyptian Ships and Boats. The Archaeological Institute of America, Monographs New Series 5.

Philadelphia: The University Museum, University of Pennsylvania.

Ward, W. Essays on Feminine Titles of the Middle Kingdom and Related Subjects. Beirut: American University of Beirut.

1989. Non-royal Women and their Cccupations in the Middle Kingdom. In Barbra Lesko (ed), Women's Earliest Records: From Ancient Egypt and Western Asia. Brown Judaic Studies, 166. 123-140. Atlanta: Scholars Press.

Wegner, J. 1996. The Nature and Chronology of the Senwosret III-Amenemhat III Regnal Succession: Some Considerations Based on New Evidence from the Mortuary Temple of Senwosret III at Abydos. JNES 55, 249-279.

2017. The Sunshade Chapel of Meritaten from the House-of-Waenre of Akhenaten. University Museum monograph 144. Philadelphia: University of Pennsylvania Museum of Archaeology and Anthropology.

Weigall. A. 1907. A Report on Some Objects Recently Found in Sebakh and Other Diggings. ASAE 8, 39-50.

Weinstein, J. 1974. A Statuette of the Princess Sobeknefru at Tell Gezer. BASOR 213. 49-57.

Wiese, A. Head of a Statue of an Early Middkle Kingdom King. In Adela Oppenheim, Dorothea Arnold, Dieter Arnold, and Kei Yamamoto (eds), Ancient Egypt Transformed: The Middle Kingdom. New Haven, London: Yale University Press.

Wildung, D. 1984a. Sesostris und Amenemhet: Ägypten im Mittleren Reich. Munich: Hirmer. 
(ed). 1984b. Nofret, die Schöne: die Frau im Alten Ägypten: Haus der Kunst München, 15. Dezember 1984-10. Februar 1985: Ägyptisches Museum Berlin, 23. März 1985-2. Juni 1985: Roemer- und Pelizaeus-Museum Hildesheim, 15. Juli 1985-4. November 1985: eine Austellungstournee der Ägyptischen Altertümerverwaltung Kairo / veranstaltet von der Ausstellungsleitung Haus der Kunst München e.V. und der Staatlichen Sammlung Ägyptischer Kunst München. Mainz: P. von Zabern.

Wilfong, T. (ed). 1997. Women and Gender in Ancient Egypt: From prehistory to Late Antiquity: An Exhibition at the Kelsey Museum of Archaeology, 14 March-15 June 1997. Ann Arbor: Kelsey Museum of Archaeology.

Wilkinson, R. 2003. The Complete Gods and Goddesses of Ancient Egypt. London: Thames \& Hudson.

. 2005. The Tausert Temple Project. The Ostracon: ESS 16 (2), 7-12.

. 2006. The Tausret Temple Project and AEF Student Training Grant. Bulletin of the American Research Center in Egypt 190, 5-8.

2010. University of Arizona Egyptian Expedition: Tausret Temple Project. Report for the 2008 season. ASAE 84, 421-428.

. (ed). 2011a. The Temple of Tausret: The University of Arizona Egyptian Expedition Tausret Temple Project, 2004-2011. Tucson: University of Arizona Egyptian Expedition.

2011b. History of the Temple. In Richard Wilkinson (ed), The Temple of Tausret: The University of Arizona Egyptian Expedition Tausret Temple Project, 2004-2011, 160-172. Tucson: University of Arizona Egyptian Expedition.

. 2011c. Introduction. In Richard Wilkinson (ed), The Temple of Tausret: The University of Arizona Egyptian Expedition Tausret Temple Project, 20042011, i-ii. Tucson: University of Arizona Egyptian Expedition.

. 2011d. The UAEE Excavations. In Richard Wilkinson (ed), The Temple of Tausret: The University of Arizona Egyptian Expedition Tausret Temple Project, 2004-2011, 33-52. Tucson: University of Arizona Egyptian Expedition.

2011e. The Tausret Temple Site. In Richard Wilkinson (ed), The Temple of Tausret: The University of Arizona Egyptian Expedition Tausret Temple Project, 2004-2011, 1-5. Tucson: University of Arizona Egyptian Expedition.

. 2011f. Tausret Temple Project. The Ostracon: ESS 22, 3-23.

(ed). 2012a. Tausret: Forgotten Queen and Pharaoh of Egypt. Oxford: Oxford University Press. 
. 2012b. Introduction: The Queen who would be King. In Richard Wilkinson (ed), Tausret: Forgotten Queen and Pharaoh of Egypt, 1-4. Oxford: Oxford University Press.

. 2012c. The "Temple of Millions of Years" of Tausret. In Richard Wilkinson (ed), Tausret: Forgotten Queen and Pharaoh of Egypt, 92-105. Oxford: Oxford University Press.

Wilkinson, T. 2000. Royal Annals of Ancient Egypt: The Palermo Stone and its Associated Fragments. Studies in Egyptology. London: Kegan Pual International.

Williamson, J. 2015. Amarna Period. In Wolfram Grajetzki and Willeke Wendrich (eds.), UCLA Encyclopedia of Egyptology, Los Angeles. http://digital2.library.ucla.edu/viewItem.do?ark=21198/zz002k2h3t

Wilson, J.1941. The Egyptian Middle Kingdom at Megiddo. AJSL, 58. 225-236.

Winlock, H. 1924. The Tombs of the Kings of the Seventeenth Dynasty at Thebes. JEA 10, 217.

. 1933. The Egyptian and Persian Expeditions 1932-1933. BMMA 28 (11.2), 3.

Wylie, A. 1991. Gender Theory and the Archaeology Record: Why is There no Archaeology of Gender? In Joan Gero and Margaret Conkey (eds), Engendering Archaeology: Women and Prehistory, 31-56. Oxford: Blackwell.

Yamamoto, K. 2015. Iconography of the Sledge in Ancient Egyptian Funerary Art. BES 19, 665-674.

Zecchi, M. 2001. Geografia Religiosa del Fayyum: Dalle Origini al IV Secolo a.C. Archeologia e Storia della Civiltà Egiziana e del Vicino Oriente Antico Materiali e Studi 7. Imola: Ed. La Mandragora.

. 2010. Sobek of Shedet: The Crocodile God in the Fayyum in the Dynastic Period. Studi sull'antico Egitto 2. Todi: Tau.

Ziegler, C. (ed). 1991. L'Art de l'Ancien Empire Égyptien: Actes du Colloque Organisé au Musée du Louvre, par le Service Culturel les 3 et 4 Avril 1998. Paris: La Documentation and Musee du Louvre.

. 2001. Une Nouvelle Statue Royale du Moyen Empire au Musée du Louvre: la Reine Khénémet-Nefer-Hedjet-Ouret. Monuments et Mémoires de la Fondation Eugène Piot 80, 11-34.

. 2008. Queens of Egypt: From Hetepheres to Cleopatra. Monaco: Grimaldi Forum and Paris: Somogy Art Publishers. 